\title{
Uloga slobodnog vremena i društvenih mreža u samoprocjeni kvalitete života učenika višeg sekundarnog obrazovanja
}

\section{Rattinger, Marija}

Doctoral thesis / Disertacija

2020

Degree Grantor / Ustanova koja je dodijelila akademski / stručni stupanj: University of Zagreb, University of Zagreb, Faculty of Humanities and Social Sciences / Sveučilište u Zagrebu, Filozofski fakultet

https://doi.org/10.17234/diss.2020.5540

Permanent link / Trajna poveznica: https://urn.nsk.hr/urn:nbn:hr:131:939542

Rights / Prava: In copyright/Zaštićeno autorskim pravom.

Download date / Datum preuzimanja: 2023-04-26

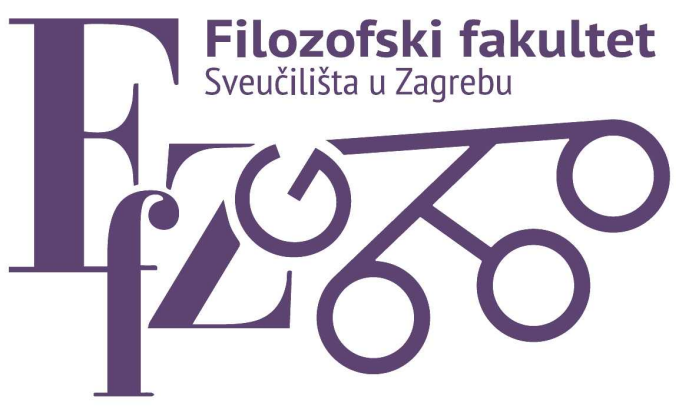

Repository / Repozitorij:

ODRAZ - open repository of the University of Zagreb

Faculty of Humanities and Social Sciences
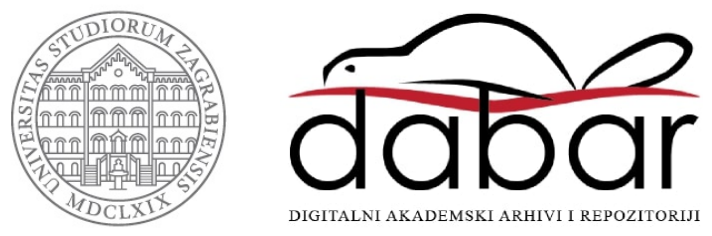


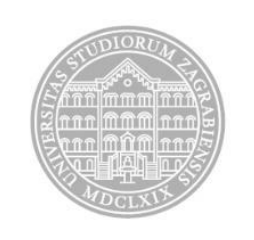

Sveučilište u Zagrebu

Filozofski fakultet

Marija Rattinger

\section{ULOGA SLOBODNOG VREMENA I DRUŠTVENIH MREŽA U SAMOPROCJENI KVALITETE ŽIVOTA UČENIKA VIŠEG SEKUNDARNOG OBRAZOVANJA}

DOKTORSKI RAD

Zagreb, 2020. 


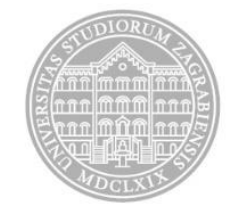

Sveučilište u Zagrebu

Filozofski fakultet

Marija Rattinger

\section{ULOGA SLOBODNOG VREMENA I DRUŠTVENIH MREŽA U SAMOPROCJENI KVALITETE ŽIVOTA UČENIKA VIŠEG SEKUNDARNOG OBRAZOVANJA}

DOKTORSKI RAD

Mentor: doc. dr. sc. Tomislav Topolovčan

Zagreb, 2020. 


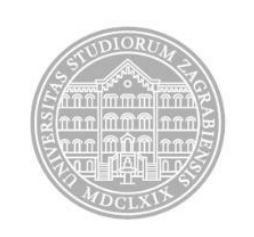

Sveučilište u Zagrebu

University of Zagreb
Faculty of Humanities and Social Sciences

Marija Rattinger

\title{
THE ROLE OF LEISURE TIME AND SOCIAL NETWORKS IN SELF ASSESSMENT OF QUALITY OF LIFE OF STUDENTS IN UPPER SECONDARY EDUCATION
}

\author{
DOCTORAL THESIS
}

Supervisor: Assistant Professor Tomislav Topolovčan, PhD

Zagreb, 2020. 


\section{ZAHVALE}

Za ostvarivanje postavljenih ciljeva, kao i za većinu vrijednih stvari u životu, potrebno je puno rada i upornosti, ali i ljudi koji nas podupiru, bodre i vole.

Stoga, od srca zahvaljujem svom mentoru, doc. dr. sc. Tomislavu Topolovčanu, na sigurnom vodstvu, podršci, ohrabrenju te znanstvenim, stručnim i prijateljskim savjetima tijekom rada na ovoj disertaciji.

Zahvaljujem i članovima Stručnog povjerenstva za obranu rada, jednom od mojih uzora, prof. dr. sc. Nevenu Hrvatiću, na profesionalnom vođenju obrane i svakom savjetu kojeg mi je dao, kao i izv. prof. dr. sc. Goranu Livazoviću.

Najveću zahvalu upućujem svojoj obitelji, kćerima Rei i Lari, a posebno suprugu Dejanu. Bez njihovog razumijevanja i bezgranične ljubavi i podrške ovo ne bi bilo ostvareno.

Volim vas najviše na svijetu!

Marija 


\section{O MENTORU:}

Dr. sc. Tomislav Topolovčan je docent na Učiteljskom fakultetu Sveučilišta u Zagrebu. Na Učiteljskom fakultetu Sveučilišta u Zagrebu je zaposlen 2010. godine. U sklopu učiteljskog studija organizira nastavu iz kolegija: Teorije nastave i obrazovanja, Nastavni kurikulum, Uvod u neurodidaktiku, Metodologija društvenih znanosti te Kvalitativne i kvantitativne metode. U sklopu poslijediplomskog studija doktorskom studiju poučava kolegije Kvalitativne metode istraživanja u obrazovnim znanostima te Digitalne obrazovne tehnologije i multimedijska didaktika. Od 2018. godine je na Učiteljskom fakultetu Sveučilišta u Zagrebu je predstojnik Katedre za pedagogiju i didaktiku. Na Medicinskom fakultetu i Fakultetu za dentalnu medicinu i zdravstvo organizirao je nastavu iz kolegija: Teorija kurikuluma, Didaktika, Metodika nastave zdravstvene njege.

Održao je više predavanja na međunarodnim znanstvenim konferencijama: Oslo (Norveška), Budimpešta (Mađarska), Berlin (Njemačka), Žalec (Slovenija) te na više međunarodnih konferencija u Hrvatskoj. Stručno se usavršavao u sklopu Pestalozzi programa u okviru Vijeća Europe u Strasbourgu (Francuska) i Antalyi (Turska). Bio je suradnika na znanstvenim projektima Nove obrazovne tehnologije i cjeloživotno obrazovanje (2006. - 2013.) i School for Net-generation: Internal Reform of Primary and Secondary School Education (2014. - 2017.). Radi kao član redakcije znanstvenog časopisa Hrvatski časopis za odgoj i obrazovanje.

Znanstveni interesi su mu u području medijske didaktike, istraživanjima kurikuluma, obrazovne neuroznanosti te metodologije istraživanja odgoja i obrazovanja. Objavio je više znanstvenih radova, a ovdje su navedeni radovi koji su vezani uz temu ovog rada:

1. Topolovčan, T. i Matijević, M. (2017). Critical thinking as a dimension of constructivist learning: Some of the characteristics of students of lower secondary education in Croatia. Center for Educational Policy Studies Journal, 7(3), 47-66.

2. Mesić, M. i Topolovčan, T. (2017). Cjeloživotno učenje učitelja u digitalnom dobu: uloga društvenih mreža i ciljnih orijentacija u poslu. Andragški glasnik, 20(1-2), 59-83.

3. Velički, D., Dumačić, M. i Topolovčan, T. (2017). The net-generation, the Internet, and political communication and participation. Croatian Journal of Education, 19(1), 237266.

4. Topolovčan, T., Rajić, V. i Matijević, M. (2017). Konstruktivistička nastava: teorija $i$ empirijska istraživanja: Zagreb: Učiteljski fakultet Sveučilišta u Zagrebu. 
5. Matijević, M. i Topolovčan, T. (2019). Informal learning among teenagers through video games: A qualitative analysis of experience, game modes and didactic benefits. Journal of Elementary Education, 12(1), 1-26. 


\section{SAŽETAK}

Slobodno vrijeme, zajedno sa korištenjem društvenih mreža kao jednim od svojih imanentnih elemenata, može imati značajnu ulogu u kvaliteti života. Stoga je cilj istraživanja bio ispitati obilježja i prediktorsku ulogu slobodnog vremena i upotrebe društvenih mreža u kvaliteti života učenika višeg sekundarnog obrazovanja. Istraživanje je provedeno u na uzorku učenika različitih usmjerenja $(\mathrm{N}=594)$ koji žive u urbanim i ruralnim područjima Zagreba i okolice te je iz tog uzorka intervjuirano 23 učenika. Uz polustrukturirani intervju i utemeljenu teoriju, za prikupljanje podataka preuzeti su odgovarajući instrumenti koji osim demografskih podataka sadrže Skalu aktivnosti u slobodnom vremenu, Skalu stavova o društvenim mrežama i Skalu kvalitete života. Istraživanje je pokazalo da između samoprocjene kvalitete života, dobi, spola, aktivnosti u slobodnom vremenu i stavova o društvenim mrežama postoji pozitivna i statistički značajna korelacija. Najveći utjecaj na kvalitetu života imaju aktivnosti u slobodnom vremenu. Spol je statistički značajan prediktor kvalitete života učenika. Stav o društvenim mrežama nije se pokazao statistički značajnom varijablom, no sudionici kvalitativnog dijela istraživanja smatraju da društvene mreže imaju veliki utjecaj na kvalitetu života. Postoji statistički značajna povezanosti između spola i vremena dnevnog korištenja društvenih mreža.

Rezultati istraživanja doprinose teorijskom (re)definiranju kvalitete života kao složene kategorije koja je determinirana objektivnim i subjektivnim okolnostima u kojima učenici žive i aktivnostima kojima se bave.

Ključne riječi: društvene mreže, kvaliteta života, slobodno vrijeme, učenici višeg sekundarnog obrazovanja 


\section{ABSTRACT (STRUCTURED)}

The title of this thesis contains terms whose importance and complexity necessitated their critical interpretation and analysis of their theoretical sources. This has been accompanied by an empirical study.

Leisure time is not a homogenous behavioural category and there is little consistency in its categorization and definition (Godbey, 2003; Previšić, 2000). However, despite the lack of precision in these numerous definitions, they all concur that the term 'leisure time' indicates the time that remains after all obligations have been completed, and that there are various options for spending that time and various influences affecting how it is spent. During our leisure time we engage in activities that we choose ourselves, which are optional, and exclude time spent in school, time spent doing household chores and time spent at work (Byrne, Nixon, Mayock and Whyte, 2006; Previšić, 2000).

The features of leisure time and characteristics of adolescents imply their manifold mutual interactions, and for this reason leisure time as an everyday phenomenon is often examined through its correlation with adolescents (Ilišin, 2007). The importance of leisure time for the development of children and adolescents is becoming increasingly evident due to the possibilities for socialization and interactions offered by leisure-time activities.

More than any other age group, young people are susceptible to trends (Roberts, 1997), and thus they rapidly accepted the Internet and online social networks and integrated them into all segments of their lives, which also implies the majority of their leisure time. This modernday phenomenon has changed the mode of communication within all factors of socialization, and the entire culture of leisure activities (Tapscott, 2008).

The quality of life of adolescent population is a very complex phenomenon, which can be analysed from various points of view. It consists of numerous and diverse specific features that pertain to various fields of life. The quality of life is determined by certain external factors (economical, physical, environmental, safety-related), the community's social organization, affiliation with a social group, and a number of other circumstances (Bouillet, 2006). Current research into the quality of life encompasses a wide range of disciplines, such as psychology, sociology, economics, politics, marketing, physical planning and medical sciences, but there is still no consensus regarding its precise pedagogical definition.

Research into adolescents' leisure time and their quality of life carried out to date has demonstrated that leisure time has crucial importance for the development of young people, 
who construct their own identities (Larsen, McGraw and Cacioppo, 2001) and their own life styles (Caldwell, Baldwin, Walls and Smith, 2004) in their leisure time, sometimes going beyond the boundaries of conventional society. From this it follows that leisure time is vital to the quality of life (Iso-Ahola, 1980).

With a view to the fact that quality of life of adolescents correlates directly to the way in which they spend their leisure time (Perasović and Bartoluci, 2008; Wang and Kao, 2006), and that the Internet and social networks have become a dominant activity in adolescents' leisure time, the aim of the thesis was to explore the relationship between their leisure-time activities and opinions on social networks, as well as their self-assessment of the quality of their lives.

The first part of the thesis presents some basic features of the age group of higher secondary-school students who are in the developmental stage of adolescence. The main features of early, middle and late adolescence are pointed out, as well as the nature of their interrelations. Today's adolescents are often described as Generation Z (Hamill, 2005); the main characteristics of this generation are presented in this chapter, which relies on knowledge from the fields of developmental psychology, psychology of adolescence and generational theory.

The second part of the thesis discusses the phenomenon of leisure time from the standpoint of sociological and pedagogical analyses, in historical and social contexts. It presents a number of definitions of leisure time, its character and functions. Particular emphasis is placed on adolescents' leisure time and various factors that influence the way they spend it. The relationship between modern technologies and adolescents' leisure time is analysed, together as are the changes in the manner in which adolescents spend their leisure time under the influence of digital technologies, the Internet and social networks.

The third chapter deals with the social network paradigm. It describes the emergence of the Internet - today's most popular medium thanks to its interactive nature and digital background. Background information on the creation of social networks, their evolution and pertinent characteristics is provided. The methods for accessing and use of social networks are described, with particular emphasis on the ways and reasons social networks are used by higher secondary-school students. The chapter also presents recent research on the influence of social networks on adolescents' behaviour. This section relies on media theory, media criticism and media pedagogy.

The fourth chapter consists of an overview of the historical evolution of the quality of life and various ways in which it has been defined. It discusses various theories and models, indicators and possible measures of the quality of life. Particular attention is dedicated to 
adolescents' quality of life, and the relationship between their leisure time and the quality of their lives.

The fifth chapter is the empirical component.

The goal of the study was to examine and explain the features and predictive role of leisure time and social networks in the self-assessment of the quality of life by higher secondary-school students.

The initial assumptions were that the demographic characteristics of the respondents and their leisure-time activities are statistically significant predictors of the students' quality of life, that there is no statistically significant difference in the self-assessment of the quality of life based on gender, domicile and the type of school students attend, and that there is no difference in the frequency of use of social networks based on the students' gender.

The study was conducted on a sample of students specializing in various subjects $(\mathrm{N}=$ 594), who live in both urban and rural communities of Zagreb and its surroundings. Of this sample, 23 students were interviewed. Data were collected using semi-structured interviews and grounded theory, and also using suitable instruments which, besides demographic data, included Leisure Time Scale of Activity, Scale of Opinions on Social Networks and Quality of Life Scale.

The data obtained by the survey were entered in an SPSS file. All types of statistical analyses were conducted using this SPSS file, while the data obtained from the interviews were analysed using the grounded-theory method (Glaser and Strauss, 1967; Strauss and Corbin, 1998).

After presentation of the results, the discussion focuses on significant data and their comparison to results of prior studies. It has been shown that there is a positive and statistically significant correlation between the self-assessment of quality of life, age, gender, leisure-time activities and opinions on social networks. Leisure-time activities have the strongest impact on the quality of life. Gender is also a statistically significant predictor of the students' quality of life. Their social-networks attitude has not proven to be a statistically significant variable in the quantitative component of the study, but participants in the qualitative component of the study were of the opinion social networks had a considerable impact on the quality of life. There is also a statistically significant correlation between gender and time spent daily on social networks.

The final chapter brings the conclusion in which the most important findings are cited and the scientific relevance of this research is underscored. The main conclusion is that self- 
assessment of the quality of life of higher secondary-school students is determined by their satisfaction with their leisure-time activities and their use of social networks as one of the elements of leisure time.

The research results will contribute to a theoretical (re)definition of the quality of life as a complex category determined by objective and subjective circumstances in which students live and activities they engage in.

Key words: leisure time, social networks, quality of life, higher secondary-school students 


\section{SADRŽAJ}

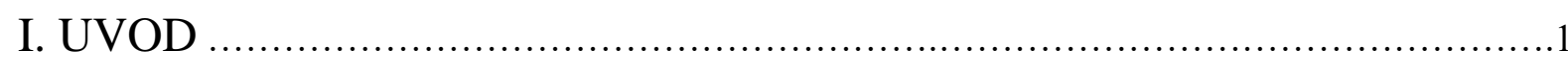

II. METODOLOGIJA TEORIJSKOG ISTRAŽIVANJA ........................5

2. 1. UČENICI VIŠEG SEKUNDARNOG OBRAZOVANJA .................................... 5

2. 2. RAZDOBLJE ADOLESCENCIJE ......................................................... 8

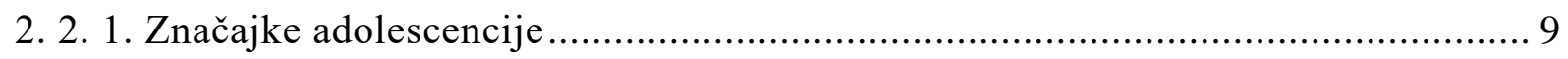

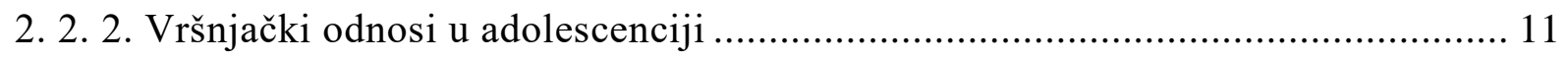

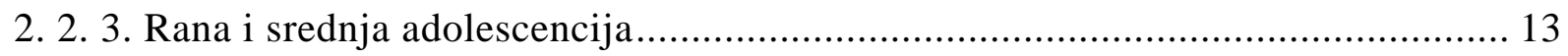

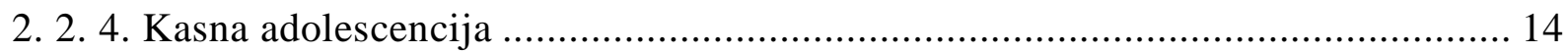

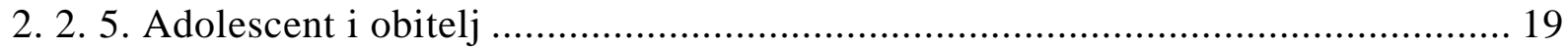

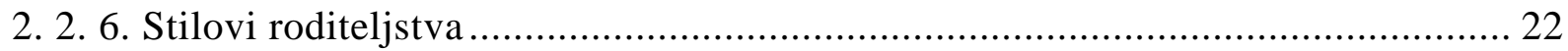

2. 2. 7. Značajke generacija i njihova podjela ........................................................ 28

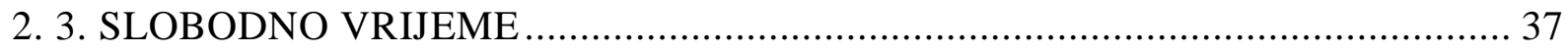

2. 3. 1. Razvoj i pojmovno određenje slobodnog vremena ...................................... 38

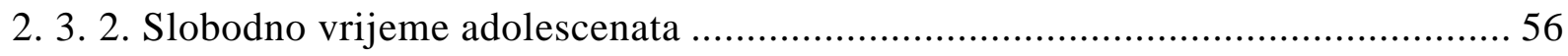

2. 3. 2. 1. Ulica u kontekstu korištenja slobodnog vremena adolescenata ..............65

2. 3. 2. 2. Uloga suvremenih medija u slobodnom vremenu mladih ....................67

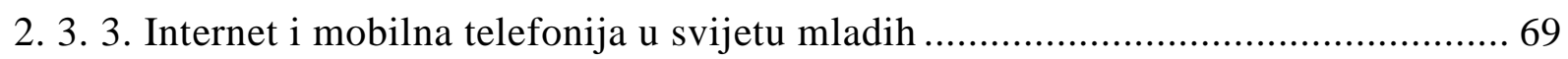

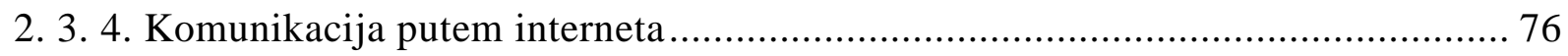

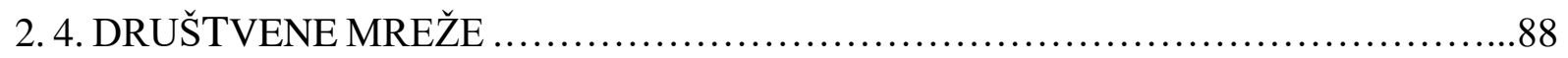

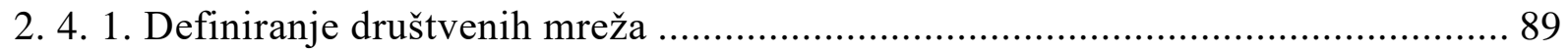

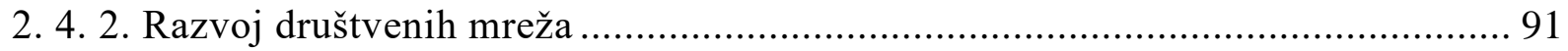

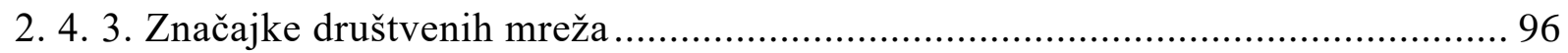

2. 4. 4. Mogućnosti pristupanja društvenoj mreži .............................................. 100

2. 4. 5. Kreiranje identiteta na društvenim mrežama ............................................ 102

2. 4. 6. Razlozi korištenja društvenih mreža među učenicima višeg sekundarnog 
obrazovanja .105

2. 4. 7. Medijski odgoj i uloga društvenih medija u životu mladih .............................. 108

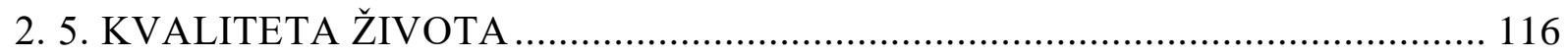

2. 5. 1. Povijesni razvoj koncepta kvalitete života.................................................... 117

2. 5. 2. Definiranje kvalitete života ……………………...................................... 122

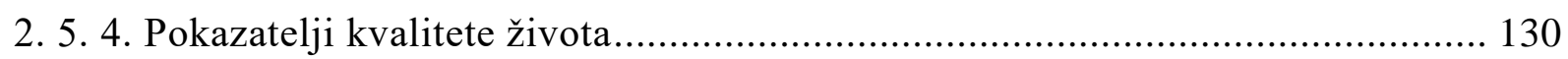

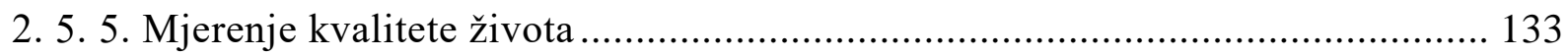

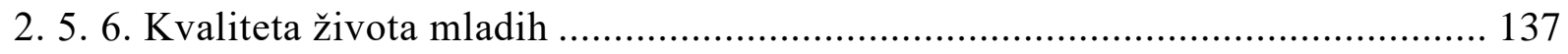

2. 5. 7. Slobodno vrijeme i kvaliteta života mladih ................................................ 141

III. METODOLOGIJA EMPIRIJSKOG ISTRAŽIVANJA ............... 145

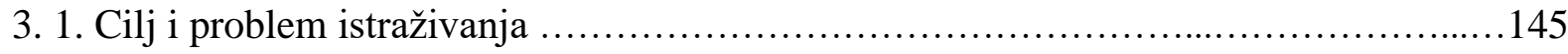

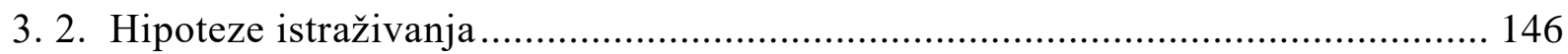

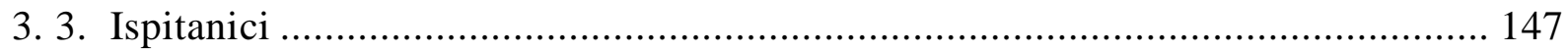

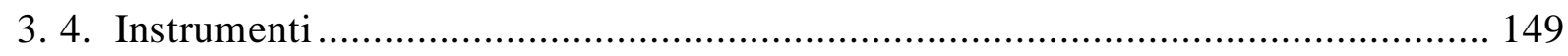

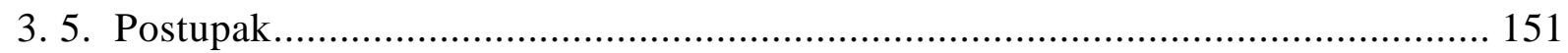

3. 5. 1. Mješoviti istraživački pristup ................................................................. 153

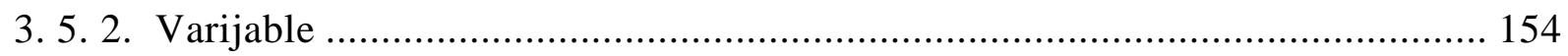

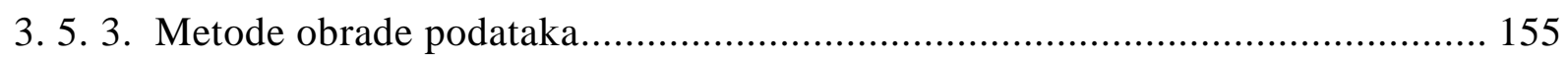

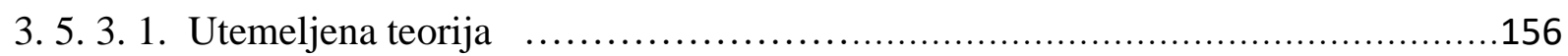

3. 5. 4. Pilot-istraživanje: inicijalna provjera metrijskih obilježja_instrumenata ........... 159

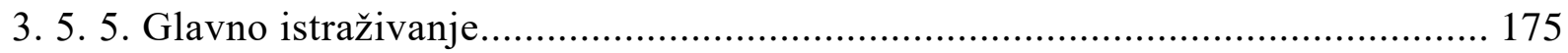

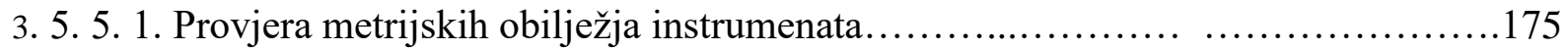

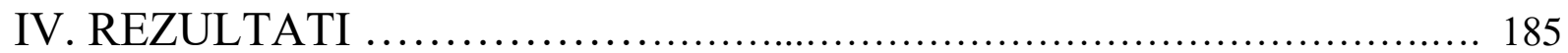

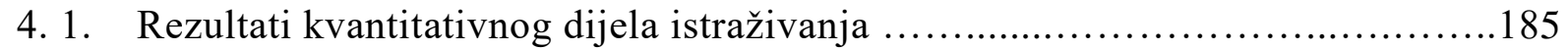

4. 1. 1. Zaključci prema postavljenim hipotezama na osnovu kvantitativnog istraživanja....201

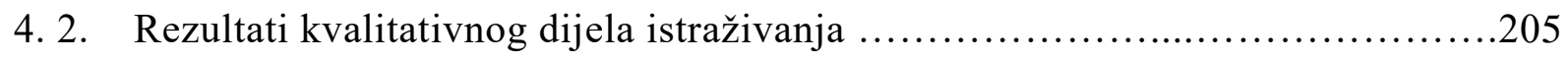


V. RASPRAVA .214

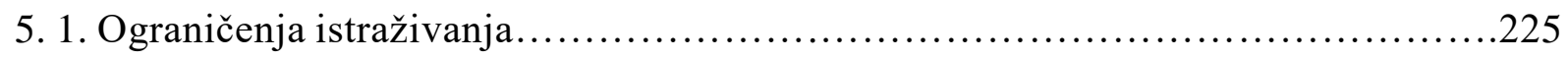

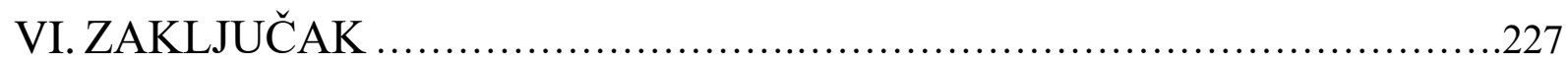

VII. POPIS LITERATURE ...........................................230

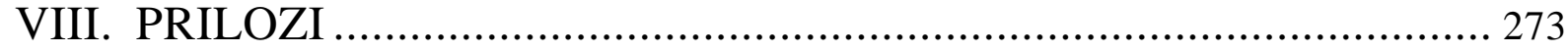

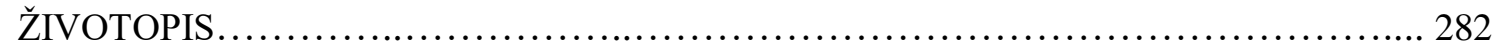




\section{UVOD}

Mladi su važna skupina našeg društva te je kvaliteta njihovog života važna s aspekta ulaganja u budućnost. Važnost tog aspekta potvrđuje činjenica da se kvaliteta života mladih konceptualizira i proučava već nekoliko desetljeća s različitim pristupima u kojima se rijetko raspravlja s direktnom uključenošću samih pripadnika ove dobne skupine.

Danas istraživanja kvalitete života mladih obuhvaćaju široki spektar disciplina. Postala je istaknuti predmet interesa u psihologiji, biometriji, filozofiji, socijalnim znanostima, kliničkoj medicini i zdravstvenoj zaštiti. Sam pojam kvalitete života mijenja se u skladu s promjenama u društvu i ljudskoj svijesti, a u ovisnosti o perspektivi s koje se proučava. Njenim pokazateljima se najčešće smatraju: zdravstveni status, kvaliteta prehrane, kvaliteta obrazovanja, uvjeti rada (zaposlenost), kvaliteta stanovanja, odijevanja i slobodnog vremena te razina socijalne sigurnosti i ljudske slobode (Lay, 1991, prema Bouillet, 2006).

Cilj ovog rada je pridonijeti istraživanjima kvalitete života s pedagoškog aspekta jer ne postoji suglasnost oko preciznog pedagoškog određenja kvalitete života. Rad nastoji ispitati i objasniti obilježja i prediktorsku ulogu korištenja društvenih mreža, kao jednog od elemenata slobodnog vremena, u kvaliteti života učenika višeg sekundarnog obrazovanja. Želi se ispitati i razumjeti učenička iskustva i percepcija značaja upotrebe društvenih mreža u slobodnom vremenu kao jednog od pokazatelja kvalitete njihova života.

Dosadašnja istraživanja kvalitete života mladih pokazuju da je to kompleksni fenomen koji se može analizirati s različitih aspekata. Ona u sebi ujedinjuje različite i brojne specifičnosti koje se odnose na različita područja njihovog života. Određena je izvanjskim uvjetima (materijalnim, fizičkim, sigurnosnim, ekološkim), socijalnom organizacijom društva, pripadnošću pojedinoj društvenoj grupi i brojnim drugim okolnostima (Bouillet, 2006). Kvaliteta života je subjektivan i višedimenzionalan koncept (Wallander i Koot, 2016), obuhvaća subjektivni osjećaj zadovoljstva i objektivne uvjete koji dovode do tog zadovoljstva, a koji se mogu empirijski istraživati (materijalni aspekti, pripadnost određenoj grupi, rasi, konfesiji, sigurnost u radu i sigurnosti materijalnih primanja, socijalna sigurnost, mjesto života sa svim prednostima ili nedostacima, obrazovanost, politički odnosi u zajednici i brojni drugi) (Diener i Lucas, 2002). Pokazalo se da je koncept kvalitete života povezan s fizičkim (npr. zdravljem), individualnim (npr. samopoštovanjem, pozitivnim i negativnim emocijama, stresom) i socijalnim (npr. zadovoljstvo socijalnom podrškom, odnosima s obitelji i vršnjačkim skupinama) dimenzijama (Gaspar, Gaspar Matos, Pais, José, Leal i Ferreira, 2009; Soares i Del 
Prette, 2015). Promicanje kvalitete života kod adolescenata zahtijeva usvajanje ekološke perspektive jer na nju utječu pojedinačni i kontekstualni čimbenici. Svi sustavi u kojima adolescenti žive mogu utjecati na njihove vrijednosti, uvjerenja i stavove, a potom i na kvalitetu života (Schalock, 2004).

Suvremeni kontekst brzih i neočekivanih promjena i uporabe medija stvara veći prostor slobodnog vremena te njegovo kvalitetno korištenje postaje i svojevrsni socio-pedagoški problem (Pehlić, 2014). Mladi su, više nego ostale dobne skupine, osjetljivi na modne trendove (Roberts, 1997), pa su tako online društvene mreže i internet vrlo brzo usvojeni i integrirani u sve segmente njihovog života, a time i u velik dio njihovog slobodnog vremena. Kako koncept vremena ima značajnu ulogu u ljudskom životu, što se posebno uočava u suvremenom društvu u kojem ljudi unatoč činjenici povećanja slobodnog vremena i dalje osjećaju užurbanost i nedostatak vremena (Wang i Kao, 2006), povećanje slobodnog vremena i njegove vitalne funkcije mogu utjecati na zadovoljstvo životom i kvalitetu života suvremenog čovjeka. Dobrobiti fizičkog i psihičkog zdravlja, ideja o povećavanju dobrobiti u nekom području života, kvaliteta i količina uživanja i učvršćivanja zdravlja te povećanju aktivnosti u ostalim aspektima života povezana je sa slobodnim vremenom (Godbey, 2003). Ono ne predstavlja homogenu kategoriju ponašanja i malo je dosljednosti u njegovom kategoriziranju i definiranju (Godbey, 2003; Previšić, 2000), no bez obzira na nepreciznost mnogobrojnih definicija, sve se one slažu da pod pojmom slobodnog vremena podrazumijevamo ono vrijeme koje nam preostaje nakon svih obveza, da postoje različite mogućnosti njegova provođenja i različite mogućnosti utjecaja na način njegova provođenja. U tome se vremenu bavimo aktivnostima koje sami biramo, koje su neobavezne, isključuju vrijeme provedeno u školi, vrijeme provedeno u kućanskim poslovima i na radnome mjestu (Byrne, Nixon, Mayock i Whyte, 2006; Previšić, 2000). U slobodnom se vremenu stvaraju uvjeti koji podupiru individualno iskustvo autonomije, kompetentnosti i povezanosti, što se smatra osnovnim psihološkim potrebama mladih (Ryan i Deci, 2000). Slobodno vrijeme, kao fenomen svakodnevnog života, često se promatra u relaciji spram mladih jer značajke slobodnog vremena i osobine mladih pretpostavljaju njihovu višestruku interakciju (Ilišin, 2007). U sadržajnoj dimenziji slobodnog vremena mladih može se prepoznati njihov životni stil (Caldwell, Baldwin, Walls i Smith, 2004), a pokazalo se da aktivno i smisleno provođenje slobodnog vremena pridonosi razvoju ličnosti u sklopu njihove pozicioniranosti u suvremenom društvu (Mlinarević, Miliša, Proroković, 2007). To je vrijeme integralni dio sistematičnih promjena kod osobe, kognitivnih, psihičkih, socijalnih i psihosocijalnih (Doh, 2010) i sve je više prepoznato kao važan kontekst 
za razvoj djece i adolescenata zbog mogućnosti socijalizacije i međusobne interakcije koju nude aktivnosti u slobodnom vremenu kao i zbog psiholoških, fizičkih i zdravstvenih dobrobiti.

Istraživanja slobodnog vremena i kvalitete života mladih pokazuju da je slobodno vrijeme ključno za razvoj mladog čovjeka $\mathrm{i}$ da oni u sferi slobodnog vremena izgrađuju vlastite identitete (Larsen, McGraw i Cacioppo, 2001), ponekad prelazeći granice konvencionalnog društva. Iz toga je dalje moguće zaključiti da je slobodno vrijeme i način njegova provođenja u izravnoj vezi s pokazateljima kvalitete života (Iso-Ahola, 1999; Perasović i Bertoluci, 2008).

Društvene mreže mladima daju novi, veći prostor za druženje i povezivanje (Car, 2013), ali i mijenjaju način komunikacije unutar svih socijalizacijskih faktora kao i cjelokupnu kulturu provođenja slobodnog vremena (Tapscott, 2008). Time su društveni mediji dobili ključnu ulogu u životima umrežene mladeži. Posredstvom mreže mladi često dopunjuju svoje susrete licem u lice (Boyd, 2004; Car, 2010), a suvremena tehnologija pruža neograničene mogućnosti umrežavanja i komuniciranja. Iako je u porastu broj istraživanja novih medijskih praksi, još uvijek smo u ranim fazama slaganja cjelovite slike o njihovoj ulozi u svakodnevici i kvaliteti života mladih.

Imajući u vidu tu činjenicu i način provođenja slobodnog vremena učenika višeg sekundarnog obrazovanja kao i zastupljenost društvenih mreža u tom vremenu, nezanemariv je korpus istraživanja uloge tih čimbenika u pedagoškom određenju kvalitete njihovog života. Stoga ovaj rad promišlja o dominaciji društvenih mreža u slobodnom vremenu te odnosu slobodnog vremena i društvenih mreža, kao njegovog imanentnog dijela, i samoprocjene kvalitete života učenika višeg sekundarnog obrazovanja.

Rad ispituje odnos između demografskih obilježja, aktivnosti u slobodnom vremenu i samoprocjene kvalitete života učenika te utjecaj spola na samoprocjenu kvalitete života $\mathrm{i}$ učestalost korištenja društvenih mreža. Stoga se polazi od osnovnih karakteristika dobne skupine mladih polaznika višeg sekundarnog obrazovanja koji su u razvojnom dobu adolescencije. Ističu se osnovne značajke rane, srednje, kasne i produžene adolescencije te osobine njihovih međusobnih odnosa. Kako su današnji adolescenti nazvani Generacija Z (Hamill, 2005), uz kratak informativni pregled generacijske podjele, akcent se stavlja na najvažnije osobine generacije kojoj pripadaju. Ovo poglavlje se referira na spoznaje iz područja razvojne psihologije, psihologije adolescencije i generacijske teorije.

$\mathrm{S}$ obzirom na ulogu slobodnog vremena u životu adolescenata u radu se razmatra fenomen slobodnog vremena. Daje se pregled pojave slobodnog vremena sa stajališta sociološke i pedagoške analize, kroz povijesni i društveni kontekst. Prikazane su brojne definicije slobodnog vremena, njegov karakter i funkcije. Nastojala se objasniti distinkcija između slobodnog 
vremena i srodnih pojmova. Poseban se naglasak stavlja na slobodno vrijeme mladih i razne utjecaje na način njegova provođenja. Analiziran je odnos suvremenih tehnologija i slobodnog vremena mladih te promjene koje se događaju u načinu provođenja njihovog slobodnog vremena pod utjecajem digitalnih tehnologija, interneta i društvenih mreža.

Penetracija interneta i društvenih mreža u slobodno vrijeme adolescenata u posljednjim desetljećima inicirala je potrebu uvrštavanje te paradigme u razmatranje kvalitete njihovog života. Opisuje se pojava interneta koji je zbog svoje interaktivnosti i digitalne pozadine najpopularniji medij današnjice. Iznose se činjenice o nastanku društvenih mreža, njihovom razvoju i značajkama. Opisani su načini pristupanja društvenim mrežama i njihovo korištenje s posebnim naglaskom na načine i razloge korištenja društvenih mreža od strane učenika višeg sekundarnog obrazovanja. Prikazana su recentna istraživanja u pogledu utjecaja društvenih mreža na ponašanje adolescenata. Ovo se poglavlje oslanja na teoriju medija, medijsku kritiku i medijsku pedagogiju. Posebna se pozornost poklanja medijskoj pedagogiji i mogućnostima medijskog obrazovanja ove generacije koja svoje slobodno vrijeme provodi u virtualnim zajednicama.

Prikazan je povijesni pregled razvoja kvalitete života i različitih načina njenog definiranja. Raspravlja se o različitim teorijama i modelima, pokazateljima i mogućnostima mjerenja kvalitete života. Posebna je pozornost pridana kvaliteti života mladih i odnosu između slobodnog vremena i kvalitete njihovog života.

Empirijsko istraživanje je provedeno kombinacijom kvantitativnog i kvalitativnog istraživanja kojim su ispitana mišljenja i stavovi učenika višeg sekundarnog obrazovanja o slobodnom vremenu, društvenim mrežama i kvaliteti njihovog života. Donose se rezultati istraživanja i zaključci koji upotpunjuju i proširuju dosadašnja saznanja o ovoj temi. 


\section{METODOLOGIJA TEORIJSKOG ISTRAŽIVANJA}

\section{1. UČENICI VIŠEG SEKUNDARNOG OBRAZOVANJA}

U ovom se radu govori o mladima u razdoblju pohađanja višeg sekundarnog obrazovanja u Republici Hrvatskoj. UNESCO je 1997. prihvatio revidiranu međunarodnu klasifikaciju obrazovanja International Standard Classification of Education - ISCED '97, kao međunarodni standard za prikupljanje i prezentiranje podataka o obrazovanju. Cilj ove klasifikacije bio je za svaki obrazovni sustav u svijetu odrediti razinu i obrazovnu skupinu što omogućuju usporedivost podataka o obrazovanju prema jedinstvenom kriteriju. ISCED je odobren na 35. sjednici Međunarodne konferencije o obrazovanju u Ženevi 1975., a usvojen na 20. sjednici Generalne konferencije UNESCO-a u Parizu 1978. godine. Konačni oblik klasifikacije ISCED '97, prihvaćen je na Generalnoj skupštini UNESCO-a 28. 11. 1997. u Parizu. Druga velika revizija ove klasifikacije provedena je 2011. godine.

Svjesni važnosti prilagodbe statistike Republike Hrvatske, a posebno statistike obrazovanja međunarodnim statistikama, Državni ured za statistiku izradio je Metodologiju Nacionalne standardne klasifikacije obrazovanja - NSKO, koja zadovoljava nacionalne potrebe i u potpunosti je usuglašena s međunarodnom klasifikacijom ISCED, te pruža mogućnost prikupljanja, prikazivanja i predstavljanja podataka o obrazovanju sukladno međunarodnim standardima. Svaki obrazovni program koji je razvrstan po klasifikaciji NSKO, može se razvrstati i po klasifikaciji ISCED. Vremenski raspon između početka i završetka svakog obrazovnog programa zove se trajanje. Jedinica za mjerenje trajanja obrazovnog programa jest godina (iznimno 6 mjeseci). Statistički ljetopis (2005) navodi da NSKO i ISCED imaju dvije glavne ukrižene varijable: položaj programa obrazovanja i područje programa obrazovanja. Prva dimenzija varijable, položaj programa obrazovanja jest razina obrazovanja. Zakon o hrvatskom klasifikacijskom okviru (2018) navodi sljedeće razine obrazovanja, a radi usporedbe, navedene su i klasifikacije ISCED 2011:

Razina 0 - razvoj u ranom djetinjstvu, predškolsko obrazovanje - ISCED 0

Razina 1 - kvalifikacija stečena završenim osnovnim obrazovanjem - ISCED 1 (primarno obrazovanje) i ISCED 2 (niže sekundarno obrazovanje)

Razina 2 - kvalifikacije stečene završetkom strukovnog i umjetničkog obrazovanja - ISCED 
Razina 3 - kvalifikacije stečene završetkom srednjoškolskog obrazovanja u trajanju kraćem od tri godine - ISCED 2/25

Razina 4 (4.1., 4.2.) - kvalifikacije stečene srednjoškolskim obrazovanjem u trajanju tri, četiri i više godina - ISCED 3 (više sekundarno obrazovanje), ISCED 4 (post-sekundarno obrazovanje)

Razina 5 - kvalifikacije stečene završetkom stručnih studija - ISCED 5

Razina 6 - kvalifikacije stečene završetkom preddiplomskih stručnih i sveučilišnih studija ISCED 6

Razina 7. 1. - kvalifikacije stečene završetkom diplomskih studija - ISCED 7

Razina 7. 2. - kvalifikacije stečene završetkom poslijediplomskih specijalističkih studija ISCED 7

Razina 8. 1. - kvalifikacije stečene završetkom poslijediplomskih znanstvenih magistarskih studija - ISCED 8

Razina 8. 2. - kvalifikacije stečene završetkom poslijediplomskih sveučilišnih (doktorskih) studija - ISCED 8

\section{ISCED 3 - više sekundarno obrazovanje - srednje obrazovanje}

Obrazovni programi na ovoj razini nastavak su obrazovanja nakon razine 2 i dijele se na tri podrazine prema usmjerenju. Obrazovanje na ovoj razini nije obvezno, traje najviše pet godina. Programi ove razine osmišljeni su kao priprema za tercijarno obrazovanje ili za pružanje vještina potrebnih za zapošljavanje ili za oboje. Za učenike, ISCED 3 razina započinje nakon 8 do 11 godina obrazovanja od početka ISCED razine 1, što odgovara početku srednjoškolskog obrazovanja prema NSKO klasifikaciji. Učenici obično na ovu razinu dolaze u dobi između 14 i 16 godina. Programi uglavnom završavaju 12 ili 13 godina nakon početka ISCED 1 razine ili početka NSKO 1 razine (ili oko 18-te godine), pri čemu je najčešća kumulativna dužina trajanja programa 12 godina (ISCED 2011, 2012).

Programi na razini ISCED 3 ili srednjeg obrazovanja obično su osmišljeni tako da se učenici pripremaju za visoko obrazovanje ili stječu vještine relevantne za zapošljavanje ili oboje.

Dvije dimenzije razlikuju obrazovne programe na razini ISCED 3:

Orijentacija prema programu i dovršenje razine i pristup višim razinama obrazovanja: 
1. srednje opće obrazovanje i

2. srednje stručno obrazovanje.

Dakle, iz navedenoga je vidljivo da više sekundarno obrazovanje prema ISCED kvalifikaciji označava razdoblje srednjoškolskog obrazovanja u Republici Hrvatskoj.

Učenici višeg sekundarnog obrazovanja su u razvojnom periodu adolescencije. Zbog teme rada, čini se važnim napraviti kratak pregled osobina adolescenata i pregled zadataka na području psihosocijalnog plana koji izravno utječu na provođenje slobodnoga vremena, upotrebe društvenih mreža i kvalitete njihova života. 


\section{2. RAZDOBLJE ADOLESCENCIJE}

Adolescencija (lat. adolescere - mladost, mladenaštvo) se opisuje kao razvojno razdoblje između djetinjstva i odrasle dobi. Ne treba je shvaćati samo kao dobnu kategoriju, već kao razdoblje razvoja, koja ima svoje psihološke osobitosti koje je razlikuju od ostalih životnih razdoblja (Lacković-Grgin, 2006). To je razdoblje u životu čovjeka u kojem dolazi do tjelesnog i psihosocijalnog sazrijevanja, a taj je proces popraćen nizom novih interesa, potreba i problema (Vasta, Haith i Miller, 1998).

Dobna određenja adolescencije su različita, približno obuhvaća razdoblje između desete i dvadeset druge godine (Rudan, 2004). Najččšé započinje između jedanaeste i trinaeste pojavom sekundarnih spolnih karakteristika i traje kroz tinejdžerske godine sve do 18-20 godina, kada završava razvoj odrasle osobe (Kuzman, 2009). Danas se primjećuje produljenje toga doba i do tridesete godine života (Livazović, 2011). Poznati američki psiholog G. Stanley Hall, adolescenciju opisuje kao razdoblje „oluje i stresa“ u kojem mladi prolaze kroz brojne emocionalne i bihevioralne promjene (Arnett, 2006, str. 186).

Encyclopedia Britannica navodi da je adolescencija razdoblje života (prosječno između 12. i 20. godine) za koje su značajne fiziološke promjene, razvoj osobne seksualnosti, napori za izgrađivanje identiteta i progresija od konkretnog $\mathrm{k}$ apstraktnom razmišljanju. Adolescencija se ponekad smatra prijelaznim razdobljem u kojem se mladi počinju odvajati od roditelja, no još nemaju definiranu ulogu u društvu. Često se smatra emocionalno vrlo intenzivnim i nerijetko stresnim razdobljem. To je razdoblje u kojem se događaju intenzivne fizičke, seksualne, emocionalne, psihosocijalne i kognitivne promjene kada se susreću s brojnim promjenama u području mišljenja, osjećaja i odnosa s drugima gdje se adolescent nalazi pred specifičnim razvojnim zadaćama i ciljevima (Graovac, 2010). To oblikuje njihov jedinstven pogled na sebe i druge, kojeg iz perspektive odrasle osobe često nije lako razumjeti. Adolescenti korak po korak napuštaju sigurnost djetinjstva i preuzimaju odgovornosti odraslih (Buljan Flander, 2013; Lewin, 1939). Dolazi do problema izgradnje osobnog identiteta. To je prvi korak prema odrasloj dobi (Levinson, 1986) u kojem se traga za smislom života, a samoaktualizacija je u središtu interesa pojedinca. Erikson (1950) smatra da je adolescencija dob kada mlada osoba počinje stvarati intimne odnose ili pati od osjećaja izolacije.

To je vrlo važno razdoblje zbog procesa koji se u njemu odvijaju i njihovih posljedica (Ilišin, 2007), a od mladih se očekuje da se prilagode svim promjenama koje im se događaju, da se osamostaljuju, da uspostavljaju nove odnose s vršnjacima, da maksimalno iskoriste svoje 
intelektualne sposobnosti, da odaberu svoje buduće zanimanje i još mnogo toga iz čega možemo zaključiti da im slijedi razdoblje preispitivanja sebe i svoga identiteta (Bastašić, 1995).

Tri su razvojne faze adolescentskog razdoblja: rana, srednja i kasna (Rudan, 2004; Vranješević, Trikić, Koruga, Vidović i Dejanović, 2003). Neki autori proširuju podjelu na sljedeće faze: predadolescencija, rana, srednja i kasna adolescencija te postadolescencija ili razdoblje mladenaštva (Graovac, 2010).

Rana adolescencija počinje pubertetom (lat. pubertas - spolna zrelost) i obuhvaća dob između 10 i 14 godina. Srednja obuhvaća dob između 15 i 18 godina, a kasnoj je adolescenciji osobito teško procijeniti kraj, a smješta se u razdoblje između 19. i 22. godine (Rudan, 2004). Kronološka dob ovdje predstavlja samo mjeru, faze su više određene razvojnim obilježjima, duhovnim i tjelesnom sazrijevanjem koje adolescenciju čine specifičnim razdobljem. Razlike $\mathrm{u}$ stajalištima o trajanju pojedinih faza posljedica je raznolikosti kultura i njihovih socijalizacijskih osobitosti. Uzimaju se u obzir procesi odrastanja i sazrijevanja i značenje koje ti procesi imaju za pojedinca i socio-kulturne standarde i očekivanja društva. Kulture koje visoko vrednuju individualizam, sposobnost kritičkog mišljenja i samoaktualizaciju postavljaju šire granice razdoblju adolescencije od kultura koje vrednuju pasivnost, poslušnost i pokoravanje autoritetima (Lacković-Grgin, 2006). Općenito gledajući razdoblje adolescencije posljednjih desetljeća se produžuje. Iako se biološko sazrijevanje događa sve ranije, ekonomska ovisnost se stječe sve kasnije, a to je konačni uvjet za osamostaljivanje i ulazak u svijet odraslih.

\section{2. 1. Značajke adolescencije}

Adolescentni proces obilježen je fizičkim, kognitivnim i psihičkim promjenama. Fizičko sazrijevanje se ogleda u hormonalnim promjenama pubertetskog procesa. Vanjski izgled je u toj dobi vrlo važan, pri čemu se počinju stvarati pozitivni ili negativni stavovi o njemu, ovisno o društvenim normama i kulturnim modelima (Lacković-Grgin, 2006). Osim velikih promjena $\mathrm{u}$ fizičkom izgredu, $\mathrm{u}$ razdoblju adolescencije također dolazi do porasta kognitivnih sposobnosti. Razvija se apstraktno mišljenje, dolazi do prijelaza s konkretno-logičkog na formalno-logičko mišljenje (Ninčević, 2009). Taj napredak u formalnom mišljenju od velikog je značaja jer pretpostavlja upravljanje procesima indukcije, dedukcije, apstrakcije i generalizacije (Lacković-Grgin, 2006). Adolescent na nov način razmišlja o životu i smislu 
postojanja (Ninčević, 2009), dolazi do jačanja kompetencija i potrebe za autonomijom (Klarin, 2006).

Vrijeme adolescencije je i vrijeme psiho-socijalnog sazrijevanja. Mladi počinju oblikovati svoju osobnost, osamostaljuju se od roditelja, izgrađuju odnos s vršnjacima, izgrađuju identitet i socijalno-odgovorno ponašanje. Na regulaciju psihosocijalnog razvoja utječu brojni socijalizacijski čimbenici. Značajnu ulogu u socioemocionalnom razvoju adolescenata imaju tri tipa socijalnih odnosa - s roditeljima, vršnjacima i nastavnicima u školi. Na putu prema zrelosti adolescenti počinju na potpuno nov način doživljavati sebe i svoje fizičke, mentalne i emocionalne sposobnosti, što uključuje i doživljaj vlastite individualnosti i osobne vrijednosti (Rudan, 2004). Za razvoj u odraslu i odgovornu osobu potrebno je ostvariti nekoliko razvojnih zadatka i ciljeva koji obuhvaćaju prihvaćanje vlastitog tijela i brigu o njemu, usvajanje spolne uloge, ostvarivanje zrelih odnosa s vršnjacima oba spola, učenje novih socijalnih vještina, postizanje emocionalne i ekonomske neovisnosti o roditeljima, razvijanje radnog odnosa, priprema za obiteljski život, prihvaćanje društvenih vrijednosti i odgovornosti te etičkih načela prema kojima će se individua ponašati u životu (Havighurst, 1972; LackovićGrgin, 2006).

U adolescenciji raste važnost vršnjačkih skupina. Kroz pripadanje vršnjačkim skupinama, mlade osobe ispunjavaju svoju potrebu za pripadanjem. Istovremeno su podložni raznim pritiscima vršnjaka i priklanjaju se grupnim normama što je izrazito izraženo u ranoj adolescenciji i smanjuje se nakon četrnaeste godine. Skupina vršnjaka ima važnu razvojnu ulogu: unutar ovog okruženja mlada osoba uči vještine koje su temelj prijateljstva i intimnih odnosa u odrasloj dobi i oblikuje svoj identitet. Unatoč velikom utjecaju vršnjaka na svakodnevne izbore vezane uz identitet, obitelj ima snažan utjecaj na temeljna uvjerenja i izbore adolescenata. Adolescenti su više nego ostale dobne skupine skloni rizičnim ponašanjima koja su povezana s konceptom traženja uzbuđenja i potrebe za novim iskustvima. Sklonost traženju uzbuđenja razvija se brže od kognitivnih sustava kontrole ponašanja koji reguliraju te impulse. Istovremeno nisu svjesni posljedica svojih odluka i ponašanja.

Zamijećen je egocentrizam adolescenata (Rosandić, 2018). Adolescenti postaju samosvjesni i potpuno zaokupljeni sami sobom. Oni podrazumijevaju da se drugi ljudi bave onim čime se oni bave, uvjereni su da je ono što je za njih važno podjednako važno i drugim ljudima. Misle da su svi ostali zaokupljeni njima, da ih promatraju, razmišljaju o njima, kao što su oni zaokupljeni sobom (Elkind, 1967). Osoba u fazi adolescencije uvjerena je da nitko ne 
proživljava stvari na način kako se to njoj događa, misli da je ona jedinstvena i da je to što se njoj događa neponovljivo.

\section{2. 2. Vršnjački odnosi u adolescenciji}

Jedan od ključnih razvojnih zadataka u adolescenciji je uspostavljanje kvalitetnih vršnjačkih odnosa. Ta dinamična vršnjačka razmjena u kontekstu intenzivnog razvoja igra bitnu ulogu $\mathrm{u}$ procesu socijalizacije. Kvalitetno uspostavljeni socijalni odnosi rezultiraju zadovoljstvom, odnosno ostvarenjem osnovnih socijalnih potreba - potrebe za pripadanjem i potrebe za intimnošću. U suprotnom, nedostatak na tom planu, dovodi do usamljenosti i socijalne izolacije (Klarin, 2006). Druženja u vršnjačkim skupinama nužna su za zdrav kognitivni i emocionalni razvoj adolescenata (Lacković-Grgin, 2006).

Vršnjačka skupina je posebna mala skupina u kojoj su članovi međusobno emocionalno povezani (Rot, 1983). Ta skupina, pored obitelji i škole, predstavlja važan izvor za učenje socijalnih normi (Lebedina-Manzoni, Lotar i Ricijaš, 2008). Najvažnije vršnjačke skupine su adolescentne vršnjačke skupine (12-18 godina) u kojima dominiraju osjećaji simpatije u međusobnim odnosima članova te zajednička iskustva nastala zajedničkim aktivnostima $u$ slobodnom vremenu (Jeđud i Novak, 2006).

Rot (1983) navodi sljedeće značajke vršnjačkih adolescentnih skupina:

a) postojanje zajedničkih aktivnosti koje se najviše odnose na aktivnosti u slobodnom vremenu

b) adolescentska skupina kao mjesto i prostor za zadovoljenje određenih potreba i želja

c) adolescentske skupine se formiraju na temelju uzajamne privlačnosti članova, te su uspostavljene veze vrlo čvrste

d) ne postoji formalizirana hijerarhija vodstva i moći, postoji više pojedinaca od kojih svaki ima veći udjel u nekoj aktivnosti, karakteristično je stvaranje podskupina

e) očito konformiranje s normama skupine uz istodobno rigidni antikonformizam u odnosu na norme odraslih

Kako bi bio prihvaćen i stekao osjećaj ravnopravnosti u skupini, pojedinac odbacuje prijašnje utjecaje roditelja i škole. Utjecaj drugih vršnjaka postaje dominantan i najintenzivniji je u ranoj adolescenciji, kasnije, postizanjem neovisnosti o roditeljima i oblikovanjem identiteta, njegova dominacija jenjava. Dakle, u razdoblju adolescencije, mijenja se značaj 
vršnjačke skupine, kao i njena struktura: od vezanosti za gomilu, postepeno se prelazi na vezanost za manji broj prijatelja s kojima su sada odnosi intimniji i bliskiji (Brown, Eicher i Petrie, 1986). Promjena strukture skupine znači i promjenu kvalitete prijateljstava $u$ adolescenciji. No, koliko će dominantan biti utjecaj vršnjaka ovisi o osobinama ličnosti pojedinca, njegovom odnosu s prijateljima i kontekstu druženja (Urberg, Luo, Pilgrim i Degirmencioglu, 2003). U kojoj će se mjeri adolescent prilagoditi skupini, određuju osobine samog adolescenta, kao što su: uvjerenja, vrijednosti i stavovi koje nosi iz okoline primarne socijalizacije (obitelj, škola, susjedstvo), čimbenici koji su doprinijeli odabiru specifičnog društva vršnjaka koje ima svoja uvjerenja, vrijednosti i stavovi te neposredno ponašanje vršnjaka u određenom kontekstu (Lebedina-Manzoni, Lotar i Ricijaš, 2008).

Kvalitetni obiteljski i vršnjački odnosi i pozitivna slika o sebi, pridonose društveno poželjnom razvoju i sprječavanju antisocijalnog ponašanja. U traganju za osobnim identitetom, često dolazi do sukoba s okolinom, ponajprije s roditeljima. Adolescenti pružaju otpor prema odraslima, odnosno prema normama i vrijednostima koje im se postavljaju. Često dolazi do poremećaja u ponašanju, češća su rizična ponašanja (Arnett, 1999). To je intenzivno formativno razdoblje, razdoblje izgradnje ljudske osobnosti. Odgojni je moment kao proces izgradnje pozitivnih osobina ličnosti, stavova, pogleda na život i svijet, te karakternih i moralnih, radnih i društvenih vrijednosti, u ovom razdoblju osobito važan i trebao bi biti neizostavan dio svakodnevice mladih (Vukasović, 2000). Razumijevanje razvojnih specifičnosti adolescencije, roditeljima i stručnjacima olakšava tumačenje ponašanja adolescenta, stvara jasnija očekivanja o tome kada pojedino ponašanje prelazi iz okvira onoga što smatramo normalnim i očekivanim te nam daje informaciju kako podržati adolescenta na tom putu (Buljan Flander, 2013). Međutim, odgojna je stvarnost bitno drukčija od potrebnog stanja. Očita je moralna kriza u društvu. Pozornost koja se obraća odgojnoj funkciji škole, obitelji, društva, medija i odgojnoj tematici uopće nije zadovoljavajuća. Zapostavljaju se temeljne ljudske vrijednosti, odlike i potrebe njihova izgrađivanja (Vukasović, 2000). Planski i organizirani utjecaj na mladog čovjeka moraju obuhvatiti sva polja njegova djelovanja.

Vršnjačke interakcije predstavljaju važan socijalizacijski okvir, unutar kojeg adolescenti započinju proces individualizacije s ciljem razvoja i formiranja identiteta (Livazović, 2011). Druženje vršnjaka, okupljenih oko zajedničkih interesa, koje mladi ostvaruju kroz aktivnosti i prostor slobodnog vremena, važna je sfera samoaktualizacije pojedinca. Upravo interesi imaju veliku ulogu u oblikovanju identiteta i u samoaktualizaciji pojedinca i jedan su od čimbenika 
kohezije malih i neformalnih skupina, kao što su vršnjačke skupine koje se prepoznaju kao vrlo važan čimbenik socijalizacije (Jeđud i Novak, 2006).

Kroz slobodno vrijeme, mladi među svojim vršnjacima nalaze istomišljenike, osobe koje dijele interese, imaju iste motive, stajališta i poglede na život (Ropuš-Pavel, 1999, prema Jeđud i Novak, 2006). Vršnjačko okruženje je manje kritično od školskog te ono ima pozitivne učinke na socioemocionalni, profesionalni, fizički, kognitivni i civilni razvoj pojedinca i skupine (Irby i Tolman, 2002). Razvoj adolescenta ovisi o odnosu vremena provedenog s vršnjacima i vremena provedenog s odraslima (Car, 2013). Godbey (2003) mladost opisuje kao početak samostalnosti i slobode i vjerom u sebe, a kulminira u obiteljskom životu gdje radne i obiteljske obveze diktiraju koliko će imati slobodnoga vremena.

\section{2. 3. Rana i srednja adolescencija}

Tijek rane adolescencije kod djevojaka u prosjeku započinje oko dvije godine ranije, s 10,5 a kod dječaka s 12,5 godina (Rudan, 2004). Ranu adolescenciju obilježavaju fizičke promjene s već navedenim pubertetskim znakovima. Događa se ubrzani tjelesni razvoj koji nije istovremeno popraćen i emocionalnim sazrijevanjem (Lacković-Grgin, 2006). Susreću se s brojnim biološkim i fizičkim promjenama, koje uključuju nagli rast, seksualno sazrijevanje, promjene u tjelesnim proporcijama te povećanje snage i izdržljivosti. Razvoj kognitivnih sposobnosti omogućuje mladim adolescentima bolje razumijevanje svijeta oko sebe, razmatranje ideja, mogućnosti i koncepata na sistematičan i logičan način. Razvoj mišljenja uključuje pamćenje, rješavanje problema i donošenje odluka i sposobnost razmišljanja o apstraktnim konceptima. Sada počinju propitkivati stvari i u manjoj mjeri prihvaćaju činjenice kao apsolutnu istinu (Buljan Flander, 2013). Okreću se prema sebi i počinju se oslanjati na vlastito mišljenje i osjećaje.

Više su usmjereni na odnose s vršnjacima, na stvaranje prijateljstva i dijeljenje osjećaja i iskustava. Iako je redoslijed promjena koje se odvijaju relativno predvidljiv, postoje velike individualne razlike u dobi javljanja i tempu kojim se promjene odvijaju. Ranije sazrijevanje osim fizičkih, može imati i socijalne posljedice (Bačkonja, 2014). Adolescente koji sazrijevaju ranije možemo nazvati rizičnom skupinom. Tako djevojčice koje rano sazrijevaju imaju veći rizik za depresiju, zloupotrebu droga, ometajuća ponašanja i poremećaje hranjenja. Dječaci koji kasnije sazrijevaju češće se od svojih vršnjaka mogu susresti s depresijom, konfliktima s 
roditeljima i poteškoćama u školi, a zbog sitnije građe u većem su riziku da postanu žrtve vršnjačkog nasilja (Buljan Flander, 2013).

U srednjoj adolescenciji, potreba za odvajanjem od roditelja i druženje s vršnjacima, postaje još izraženija. To je uočljivo u usmjerenosti adolescenata na istraživanje sebe i upoznavanje vlastitih interesa, dok je u ranoj adolescenciji dominirala prilagodba na tjelesne promjene. Prijateljstva su i dalje značajan čimbenik u socijalnim interakcijama, ali pojavljuje se lojalnosti prema skupini vršnjaka. Ta se lojalnost manifestira kroz slušanje iste vrste glazbe, nošenje određene vrste odjeće, uključivanje u određene sportske ili društvene aktivnosti i dr. (Rudan, 2004). Intimni prijateljski odnosi se mijenjaju te se počinje cijeniti korist koja se očituje u očekivanju adolescenta da prijatelj posjeduje neke korisne vještine za postizanje osobnih ciljeva, potvrđivanje koje se očituje u potvrđivanju njihovih osobnih vrijednosti od strane prijatelja, zatim potpora egu, potpora prijatelja koja potvrđuje ispravnost njihovih odluka te pomaže u izgradnji identiteta. Cijeni se i stimulacija, što znači da su prijateljeve ideje, stavovi i vrijednosti, pomoć u izgradnji svjetonazora i sigurnost koja se očituje u odnosu prijatelja prema njima tako da ih ne povređuju, ne naglašavaju nedostatke i slabosti, a to ih čini sigurnima i brani od osjećaja neadekvatnosti (Lacković-Grgin, 2006). U ovoj fazi nastaju novi odnosi s roditeljima, ali i s ljudima izvan obitelji. Tijekom tog procesa stvaranja novog odnosa s roditeljima, adolescenti često postaju mrzovoljni i izoliraju se ili osamljuju. Prestaju se diviti svojim roditeljima i traže identifikaciju s drugim odraslima i svojim vršnjacima. Srednja je adolescencija značajna po tome što adolescenti šire mrežu poznanstava i zaljubljuju se. Kasnije, iz želje za bliskošću i intimnijim odnosima, javlja se potreba za imanjem partnera/partnerice.

\section{2. 4. Kasna adolescencija}

Razdoblje kasne adolescencije započinje oko 17. godine. U kasnoj adolescenciji mladi postaju svjesni da su osobe i počinju se hvatati u koštac s onim što im donosi budućnost. U ovoj je dobi jedan od najizraženiji razvojnih zadataka ostvarenje dosljednog i stabilnog identiteta. Drugi važan zadatak je profesionalni razvoj i odabir zanimanja. Razvoj profesionalnog identiteta počinje sredinom adolescentskog razdoblja, a nastavlja se u kasnoj adolescenciji. Adolescent postupno odabire svoje zanimanje. Izbor buduće profesije mnogima se čini kao pretežak zadatak stoga im je pri izboru izuzetno važna podrška bliskih osoba, posebno roditelja i stručno profesionalno usmjeravanje. Izbor zanimanja je važan korak na putu prema nezavisnosti i ulasku u svijet odraslih. Među najvažnijim razvojnim zadatcima je i proces 
razvijanja kapaciteta za intimnost. On započinje u kasnoj adolescenciji, a puninu doseže u odrasloj dobi. Prva iskustva intimnosti mladima pružaju prve romantične veze i bliski odnosi s prijateljima (Buljan Flander, 2013).

Doba adolescencije je specifičan prijelazni period kada mladi više nisu zaštićeni kao djeca, a još se ne smatraju odraslima, u nekim situacijama se na njih gleda kao na djecu, a u nekima kao na odrasle, zapravo su oboje i nijedno (Ilišin i Radin, 2002). Adolescencija se može promatrati kao prožimanje dvije vrlo usko povezane faze života, prerastanje djeteta u odraslu osobu (Riera, 2004). Zbog toga su ih se u suvremenom društvu može promatrati kao najranjiviji dio populacije.

Kraj adolescentnog doba vrlo je teško odrediti i samome adolescentu kao i ljudima koji ga okružuju. On uključuje mnoštvo integriranih i sintetiziranih identifikacija i vrlo je neujednačen. Moguće je da adolescent različitim tempom doseže odraslost u različitim područjima života. Područje vlastite primarne obitelji je često posljednje područje u kojemu osjećaju da su dosegnuli odraslost (Rudan, 2004). Posljednjih je desetljeća primijećeno da se faza adolescencije produžuje. Suvremeno društvo sa svojim demografskim, ekonomskim i tehnološkim promjenama mijenja i društveni kontekst odrastanja. Pomicanjem granice završetka obrazovanja, napuštanja doma, ulaska u brak, rođenja prvog djeteta i drugih životnih događaja koji su se smatrali indikatorima odraslosti, nastaje rascjep između razdoblja adolescencije i odrasle dobi. Iako se biološko sazrijevanje događa sve ranije, ekonomska ovisnost, koja je konačni uvjet za osamostaljivanje i ulazak u svijet odraslih, stječe se sve kasnije. Nemogućnost pronalaska posla u struci nakon završetka školovanja, preskupi stanovi, hrana i režije, velika očekivanja, a male mogućnosti, kao i ispodprosječne plaće, dobar dio hrvatske mladeži dovode do situacije da se teško mogu osamostaliti, pa tinejdžerskim životom žive nerijetko i do tridesete godine. Mijenjaju se iskustva mladih u obitelji, društvu vršnjaka, obrazovnim institucijama i na tržištu rada te postavljaju novi izazovi za prijelaz u odraslost. Opaža se tendencija odgađanja sazrijevanja, tzv. produžena adolescencija koja se kod velikog broja mladih produžuje duboko u dvadesete i prema tridesetoj godini života. U medijima i popularnoj kulturi najčešće se koristi izraz „,produžena adolescencija" iako postoje i brojni drugi izrazi kojima se opisuje ova pojava. Adolescente u toj fazi često se naziva „ljudi u dvadesetim godinama kojima treba više vremena da odrastu“. U engleskom govornom području ih nazivaju „,kidults“, „,adultescents“, „,boomerangkids“, „,tresholders“ ili „twixters“ (Extended adolescence, 2012). 
Kidults, adultescents, boomerangkids, tresholders i twixters su nazivi za odrasle osobe koje usvajaju ili vode mladalački stil života, posebno u pitanjima mode, zabave i rekreacije. Zanimaju ih oblici zabave poput računalnih igara, televizijskih programa namijenjenih djeci itd. Često je to naziv i za pojedince sa završenom školom koji su „zapeli“ između djetinjstva i odrasle dobi čemu je uzrok nemogućnost zapošljavanja pa i dalje financijski ovise o roditeljima ili skrbnicima (Urbandictionary). Izraz boomerangkids je pojam koji se u zapadnoj kulturi koristi za opisivanje fenomena odraslog djeteta između osamnaeste i trideset pete godine koje se nakon razdoblja samostalnog života iz ekonomskih razloga vraća kući da bi živjelo s roditeljima. Analiza istraživanja Pew Research Biroa pokazuje da je udio Amerikanaca koji žive u višegeneracijskim obiteljskim domaćinstvima danas najveći, gledano od 1950-ih, značajno se povećao u posljednjih pet godina. Udio 25-godišnjaka do 34-godišnjaka koji žive u višegeneracijskim domaćinstvima bio je najniži u 1980. godini (11\%) i od tada se neprestano povećavao, a posebno od početka recesije 2007. godine. Od tada je ekonomska pozadina mladih jako loša. Mnogi su se zaposlili na radnim mjestima koja zapravo nisu željeli samo da sastave kraj s krajem. Gotovo trećina se vratila u školu, a jednak udio (34\%) odgodio je ili brak, roditeljstvo ili oboje. Ovakva ekonomska situacija je dovela do dugotrajnog ekonomski zavisnog odnosa između roditelja i njihove odrasle djece. Naravno da ima i mladih koji žive u roditeljskom domu iz razloga koji mogu ili ne moraju imati veze sa slabom ekonomijom. U tu kategoriju spadaju mladi u dobi od 18. do 24. godine, od kojih mnogi nisu ni odlazili od kuće (The Boomerang Generation, 2012). Velik dio ove populacije mladih živi bez odgovornosti i uživaju jer roditelji brinu o njima. Razvojni psiholog sa Sveučilišta u Marylandu Jeffrey Arnett i njegovi istomišljenici nazivaju ih twixteri, smatrajući tu fazu pozitivnom i gledaju je kao priliku za mlade kada mogu uživati u zadovoljstvima neodgovornosti, pretraživati dušu te isprobavati i birati životne putove. Također, smatraju da su njeni pripadnici često pogrešno shvaćeni. Ne smatraju ih lijenima, smatraju da je njihovo je ponašanje plod desetljeća američkog bogatstva i socijalnog oslobođenja. Twixteri očekuju lagane prelaske s jednog posla ne drugi i iz mjesta u mjesto dok ne pronađu ono što traže. Stabilna veza između poslodavca i zaposlenika za njih je stvar prošlosti, niti jedan od njih ne osjeća veliku obavezu da vezu učini trajnom. Ne razmišljaju dugoročno o zdravstvenoj zaštiti ili socijalnoj sigurnosti. Zabrinuti su samo za svoju karijeru i trenutno zadovoljstvo. Oni od posla očekuju puno više od plaće. Radi napretka medicine očekuju da će živjeti u svojim 80-ima i duže, pa će im se radni vijek produžiti u skladu s tim te će s odabranom karijerom još dosta dugo živjeti. Twixteri traže smisao i važnost u svom poslu, nešto što će dodati smisao njihovim životima. U njima se nazire idealizam, iako se čine hedonistima. Ono što izgleda kao njihova neprestana hedonistička igra 
je način na koji eksperimentiraju s poslovima, partnerima i osobnostima da bi na kraju naučili to raditi na pravi način. Oni odraslost shvaćaju ozbiljno, godinama pažljivo odabiru pravi put prema tamo. S druge strane povjesničari i ekonomisti to vide drugačije. Oni su zabrinuti i smatraju da twixteri ne odrastaju jer ne mogu. Strahuju da društvo više ne pruža mladima moralnu podlogu i financijsku pomoć kako bi zauzeli dostojno mjesto u svijetu odraslih. Côté, J. sociolog na Sveučilištu u zapadnom Ontariju pojavu produžene adolescencije smatra posljedicom kolapsa na tržištu rada. Da bi mogli konkurirati na tržištu rada mladi se moraju duže školovati, a većina fakulteta ne ide ukorak sa stvarnim svijetom u pripremi studenata za rad te dolazi do problema pri zapošljavanju i zadržavanju radnog mjesta. Pronalaženje karijere i ekonomske i financijske stabilnosti, ljubav i osnivanje obitelji stavlja u drugi plan. To ne znači da oni to ne žele, no odrastanje sa sobom nosi puno odgovornosti pa se odgađanje zapošljavanja i roditeljstva te život s roditeljima čini puno jednostavnijim (Grossman, 2005).

Iako se pojam generacije kidults, adultescents, boomerangkids, tresholders $i$ twixters ponajprije odnosi na američki fenomen i u drugim je zemljama zamijećena slična pojava. U Italiji odraslu djecu koja se vraćaju živjeti s roditeljima identificiraju kao „,bamboccioni” „mamon" ili „mamini dječaci", dok ih Japanci nazivaju „parasaito shinguru", što u prijevodu znači „parazitski samci." U Velikoj Britaniji ih nazivaju kippers (djeca u roditeljskim džepovima koja nagrizaju mirovinske štednje), a u Španjolskoj „generacija ni-ni" (Kenton, 2018).

Sampo generacija, odnosno ,generacija s tri odricanja", novi je naziv za mlade Južnokoreance. Sampo je naziv za generaciju koja ima nestabilne poslove, visoke rate studentskih kredita, nisu dobro pripremljeni za zapošljavanje itd. Odgađaju ljubav, brak i rađanje djece bez ikakvog perspektivnog plana. Sampo je izraz za odustajanje od tri stvari ljubavne veze, braka i djece. Odricanjem od toga mladi izražavaju nezadovoljstvo politikom vlade prema obiteljima, socijalnim pritiscima, ekonomskim problemima poput povećanja troškova života, plaćanja školarine i nepovoljnog stanovanja (Brodie-Hall, 2018). Slična je pojava identificirana u Japanu kao „Satori generacija“. „Satori" je japanska riječ koja je odavno postala globalna, a znači prosvjetljenje. Generacija obuhvaća mlade rođene 1997. godine nadalje, za koje se čini da su postigli osjećaj ,prosvjetljenja“ jer su zadovoljni živjeti u trenutku i usredotočiti se na ono što trenutno imaju. Od malih su nogu bili izloženi širokom rasponu lako dostupnih tehnologija te se jako dobro snalaze s njima. Rado izbjegavaju besmislene sukobe i ne vole trošiti energiju na svađe s drugima. Ne čeznu za materijalnim stvarima i velikim očekivanjima. Radije bi uživali u životu ne opterećujući se školovanjem na prestižnim 
sveučilištima i ne težeći uspješnim karijerama kao što su to činili njihovi roditelji. Zbog ekonomske situacije i velike konkurencije, mnogi ne rade na poslovima s punim radnim vremenom, ali se trude da ih to ne ometa u uživanju u životu. Kad je riječ o postizanju rezultata, važan im je samo konačan rezultat, ne zanima ih način dolaska do njega. Ne vide razloga za istezanje iznad svojih mogućnosti, važnije im je uzeti vremena za odmor i opuštanje. Nastoje prevladati svaku želju, ne žele ništa. Ne voze automobile, ne nose odjeću poznatih robnih marki, ne bave se sportom, ne zanima ih napredovanje u karijeri, ne opterećuju se zaradom većom od dovoljne za pokrivanje osnovnih potreba, ne putuju, ne zaljubljuju se, ne sanjaju o boljem životu, ne prave planove za budućnost. Za razliku od drugih generacija, skloni su se u slobodno vrijeme opuštati u zatvorenim prostorima, u svojim domovima (Hoffman, 2013). Od početka 21. stoljeća sve više mladih Japanaca je postao društveno i kulturno marginalizirano. Nazivaju ih NEET (Not in Employment Education or Training) ili hikikomori (socijalno povučeni / izolirani). Ministarstvo zdravlja, rada i socijalne skrbi definiralo je NEET-se kao „ljude koji nisu zaposleni, ne školuju se, nemaju vlastiti dom i ne traže posao", a hikikomori kao „oni koji nisu ni na poslu ni u školi, nemaju socijalnu interakciju i socijalno su povučeni više od šest mjeseci“. Pretpostavlja se da je uzrok pojave hikikomori generacije nepohađanje škole ili nesigurnost posla. Nakon duge socijalne isključenosti sve je teže ponovno se integrirati u društvo, pa hikikomori sve češće odbijaju ići u školu (Jones, 2006, prema Uchida i Norasakkunkit, 2015). Pojavljuju se slučajevi socijalnog povlačenja na više od desetljeća. Iako postoje razlike u ponašanju NEET-sa i hikikomori-a, postoje i neke zajedničke psihološke tendencije. I jedni i drugi imaju neke simptome autizma (Hoshino, 2011, prema Uchida i Norasakkunkit, 2015), to su mladi ljudi koji izbjegavaju društvene interakcije s drugim ljudima, uključujući i članove svojih obitelji, nisu u mogućnosti osigurati posao ili osjećaj pripadnosti (Brinton, 2011, prema Uchida i Norasakkunkit, 2015). Neki od njih su tzv. freetersi (kombinacija riječi "freelance" i njemačke riječi za "radnik", arbeiter), zaposleni na poslovima na određeno vrijeme ili sa skraćenim radnim vremenom. NEET-si i hikikomori pokazuju tendenciju odstupanja od većinskih kulturnih stavova i vrijednosti. Kao takvi su prepoznati i privukli su svjetsku pozornost. Uočeni su slučajevi NEET-sa ili hikikomori-a u drugim zemljama poput Velike Britanije, Koreje, Italije, Španjolske i Francuske (Pilz, SchumidtAltmann, Eswein, 2013 prema Uchida i Norasakkunkit, 2015), no još uvijek se proučavaju čimbenici koji doprinose takvim psihološkim tendencijama.

Mladi u ovom razdoblju sebe više ne smatraju adolescentima, no istovremeno su svjesni činjenice da nisu u potpunosti ispunili razvojne zadatke koji se smatraju ključnima za postizanje 
odraslosti: preuzimanje odgovornosti za sebe, donošenje neovisnih odluka i financijsku nezavisnost (Buljan Flander, 2013). Taj period odrastanja može sadržavati niz karakteristika koje se međusobno preklapaju i utječu jedna na drugu. One uključuju nemogućnost zapošljavanja, produženo i skuplje institucionalizirano obrazovanje koje bi im trebalo osigurati bolju budućnost, iako u praksi to često nije slučaj, povratak u obiteljski dom nakon školovanja, izvanbračne veze i odgođeno osnivanje vlastite obitelji. Primjećuju se znatne razlike među mladima u načinima odrastanja i odabiru vlastitog životnog puta što je u većoj mjeri uzrokovano socio-ekonomskom nejednakošću, nego njihovom voljom. Karakteristične osobine adolescenata u ovoj fazi sazrijevanja su istraživanje identiteta, isprobavanje mogućnosti u ljubavi i poslu, nestabilnost, samosvijest i osjećaj zatočenosti između adolescencije i odrasle dobi. Sve to ovo razdoblje čini ispunjenim i intenzivnim, ali istovremeno vrlo nestabilnim i potencijalno stresnim.

\section{2. 5. Adolescent i obitelj}

Ne postoji jednoznačno određenje obitelji. Relativno je bogata suvremena literatura u kojoj svaka znanstvena disciplina obitelji pristupa ovisno o području kojim se bavi. Ipak, postoji jedinstveno stajalište da je obitelj temeljna i nezamjenjiva društvena, odnosno socijalna i biološka zajednica čija je zadaća sustavna briga o odgoju. Ona je temeljna institucija društva, primarna, socijalna i ekonomska zajednica koja osim što osigurava preživljavanje svojih članova, brine o sekundarnim ljudskim potrebama vezanim za reprodukciju, njegu, socijalizaciju i pripremu mladih za spremno suočavanje sa životnom stvarnošću kojoj su izloženi (Nimac, 2010). U obitelji se oblikuju moralne norme i vrijednosti, aktivnosti i umijeća i stječu osnove odgoja u svim područjima života (Rosić, 1998). Obitelj je u stalnoj interakciji s društvom (Maleš i Kušević, 2011) i kao dinamičan i promjenjiv sustav, mijenja se zajedno s njim. Upravo te promjene uzrokuju promjene u njezinu tumačenju i definiranju.

Možemo razlikovati nekoliko vrsta obitelji. Jedan od oblika je nuklearna obitelj koju čine roditelji i djeca gdje jedan od roditelja radi, a drugi brine o djeci. Ta je obitelj dugo smatrana univerzalnim obrascem obiteljskog odgoja (Livazović, 2011). Podoblici nuklearne obitelji su: bračna ili izvanbračna zajednica žene i muškarca s biološkim potomstvom, socijalna obitelj koju čini zajednica odraslih bez djece, nepotpuna obitelj u kojoj je jedan roditelj i dijete, adaptivna obitelj koju čini posvojitelj s posvojenim djetetom i obitelj nastala uz medicinsku pomoć koja podrazumijeva bračnu ili izvanbračnu zajednicu s djecom koja biološki ne potječu 
od osoba koji su njihovi roditelji u socijalnom smislu. Svjedoci smo visokom postotku razvoda brakova, izvanbračnih zajednica, migracijama, stilu života i sl. što utječe na promjenu nuklearne obitelji. Suvremenost sve jače utječe na odlike tradicionalne obitelji. Drugi oblik je reorganizirana obitelj. U takav oblik obitelji pripada obitelj koja nastane kada nakon prethodnog braka bivši supružnici zasnivaju novi brak i tako mijenjaju strukturu obitelji te primjeri obitelji zajedničkog življenja tzv. komune i zajednice osoba istog spola, bilo da posvajaju dijete ili ne. Treći oblik je proširena obitelj u kakvu ubrajamo trogeneracijsku obitelj koju čine roditelji, djeca, bake i djedovi, srodničku u kojoj su uz roditelje i djecu i pripadnici iste generacije ujaci, stričevi... te poligamna obitelj u kojoj jedan od supružnika ima više supružnika. Osim navedenih tipova obitelji postoje još neke zajednice koje su česte u današnje vrijeme kao kohabitacija koju čini zajednica dvoje ljudi koji nisu u braku, grupni brakovi, samačka kućanstva itd.

Na promjene u obitelji djeluje više faktora. Jedan od faktora je jačanje bračne veze pri čemu se obitelj shvaća kao mjesto intimnosti i partneri se osamostaljuju od ostale rodbine. Žene danas u braku traže osobnu sreću, a ne materijalnu sigurnost i pozitivnu reputaciju u društvu. Bračni par postaje „norma sam sebi“, što uzrokuje poremećaj ravnoteže, utječe na etičkonormativni aspekt braka i uzrokuje njegovu nestabilnost. Pad nataliteta koji je često shvaćen kao gubitak vrijednosti roditeljstva također je faktor utjecaja. Roditeljstvo je sve više shvaćeno na romantičan način, emocionalno naglašenije, dok žrtvovanje ostaje po strani. Zbog toga se roditelji odlučuju na manji broj djece koju često opterećuju svojim visokim očekivanjima. Odnos roditelja i djece smatra se nečim najvrjednijim, a često oslabljeni bračni odnos i društveni odnosi za posljedicu imaju snažniju povezanost s djecom. Nezanemariv faktor promjena $\mathrm{u}$ obitelji je $\mathrm{i}$ produženi ostanak djece $\mathrm{u}$ roditeljskom domu, odgođeno osamostaljivanje ili produžena adolescencija. Mladi izbjegavaju donošenje konačnih odluka, jer žele biti slobodni i imati mogućnost eksperimentiranja. To s jedne strane može biti pozitivno, dok s druge strane, previše razmišljanja kod donošenja odluka često rezultira odgađanjem, a nerijetko i nedonošenjem istih. Osim problema nezaposlenosti i nemogućnosti pronalaska rješenja po pitanju prostora za stanovanje, utjecaj na to mogu imati roditelji koji su svu svoju energiju i trud ulagali u manji broj djece, pa se teško odvajaju od njih i ne žele da napuštaju roditeljski dom (Nimac, 2010, str. 31). Roditelji različito proživljavaju pojavu produžene adolescencije i ta pojava utječe na cijelu obitelj. Većina je roditelja sretna kad vide da njihova djeca postaju neovisna jer život s odraslom djecom može negativno utjecati na kvalitetu odnosa među roditeljima. U takvim se obiteljima roditelji često osjećaju kao da se nalaze između 
adolescenta i njegove zrelosti. Većina roditelja smatra vrijeme kada je dijete u dobu adolescencije najtežom fazom roditeljstva.

Odnosi između roditelja i djece dugo su se smatrali najznačajnijim čimbenicima socioemocionalnog razvoja djeteta. Adolescencija je najburniji period u čovjekovom životu i razvoju, kako psihički gledano tako i fizički te zahtijeva maksimalnu podršku, pažnju i toleranciju od strane roditelja. S obzirom na to da se javljaju nove potrebe i novi pogled na svijet, roditelji bi trebali biti visoko senzitivni i fleksibilni ako sa svojim djetetom žele ostvariti kontakt bez konflikata gdje će ono moći razviti samopoštovanje i osamostaljivanje. Potrebno je znati uspostaviti tzv. optimalnu distancu i stvoriti takav odnos u kojem dijete može najbolje funkcionirati, uz istovremenu prisutnost težnji za autonomijom i postojanje osjetljivosti na odvajanje. To znači da roditelji budu aktivni i prisutni u djetetovom životu, ali i da mu daju dovoljno prostora da razvije samostalnost, da bi se u budućnosti moglo odvojiti od roditelja (Berk, 2015). U toj fazi djeca i roditelji moraju uspostaviti novu ravnotežu u odnosima, tj. uskladiti adolescentsku potrebu za neovisnošću i roditeljsku potrebu za kontrolom i nadziranjem djece. Najbolje šanse za zdrav psihološki razvoj adolescenti imaju u obiteljima u kojima se potiče njihova neovisnost $\mathrm{i}$ individualnost i u kojima ujedno postoje bliski odnosi između članova obitelji. Stoga bi preventivne aktivnosti trebalo u većoj mjeri usmjeriti na rad s roditeljima čija su djeca na pragu adolescencije.

U periodu srednje, kasne i produžene adolescencije roditelji sve više preuzimaju ulogu menadžera svoje djece koji nalaze informacije, šire socijalne kontakte, pomažu definirati izbore, savjetuju kako izbjeći neuspjeh i kako naći svoj put u nizu mogućih izbora. Tu dolaze do izražaja različiti roditeljski stilovi o kojima ovisi tempo, brzina i intenzitet odrastanja. 


\section{2. 6. Stilovi roditeljstva}

Istraživanjem roditeljskih ponašanja koja se pojavljuju u različitim situacijama identificirano je nekoliko roditeljskih stilova koji stvaraju odgojnu klimu (Berk, 2015). Dvije su temeljne dimenzije roditeljstva - emocionalnost i kontrola (Darling i Steinberg, 1993) pri čemu se emocionalnost odnosi na emocije koje roditelj doživljava i pokazuje u odnosu s djetetom, a nazivaju se još i podrškom, toplinom, osjetljivošću, prihvaćanjem, brigom ili njegovanjem. Na jednom kraju ove dimenzije nalazi emocionalna toplina i prihvaćanje djeteta, a na drugom kraju hladnoća, odbacivanje, udaljenost i neprijateljstvo prema djetetu. Brojna istraživanja pokazuju da je roditeljska emocionalna toplina povezana s prosocijalnim ponašanjem adolescenata, pozitivnim vršnjačkim odnosima i zadovoljstvom u odrasloj dobi, razvojem kompetencija, formiranjem identiteta, akademskim uspjehom i samopoštovanjem (Amato, 1989; Bean, Bush, McKenry i Wilson, 2003). Emocionalna toplina je negativno povezana s brojnim negativnim ponašanjima adolescenata (alkoholizam, poremećaj hranjenja, depresija,...) (Barnes, Reifman, Farrell, \& Dintcheff, 2000; McVey, Pepler, Davis, Flett i Abdolell, 2002; Whitbeck, Conger, i Kao, 1993).

Postupci koje roditelji koriste da bi utjecali i modificirali ponašanje djeteta pripadaju dimenziji kontrole. Na jednom kraju ove bipolarne dimenzije se nalaze roditelji koji prakticiraju čvrstu kontrolu, a na drugom oni koji imaju slabu kontrolu nad djetetovom ponašanjem. Unutar ove dimenzije razlikujemo dvije vrste kontrole - psihološku kontrolu koja se odnosi na roditeljska ponašanja koja uključuju pretjeranu kontrolu djetetovih aktivnosti, sprečavanje samostalnog rješavanja problema, izazivanje osjećaja krivnje ili uskraćivanje ljubavi i bihevioralnu koja je pozitivan oblik roditeljske kontrole, kontrolu (Darling i Steinberg, 1993).

Ovakva su roditeljska ponašanja utjecala na formiranje različitih roditeljskih stilova.

1. Autoritativni (demokratski-dosljedan) odgojni stil je kombinacija emocionalne topline i čvrste kontrole. Autoritativni roditelji postavljaju velike zahtjeve svom djetetu, sukladno njegovoj dobi, određuju granice i kontroliraju, ali mu istovremeno pružaju puno topline i potpore. Takvi roditelji su više savjetnici nego nadzornici ili kontrolori (Čudina-Obradović i Obradović, 2006). Autoritativno roditeljstvo često se opisuje kao pristup usmjeren prema djetetu. Roditelji koji koriste ovaj stil očekuju poštivanje pravila, no pritom omogućuju otvoreni dijalog s djecom o pravilima i ponašanju općenito, otvoreno pokazuju ljubav i prihvaćanje te daju potporu u okvirima zadanih ograničenja. Oni veliku važnost pridaju komunikaciji s 
djetetom, potiču ga na izražavanje svojih misli i osjećaja, dozvoljavaju da samo odlučuje u područjima u kojima je spremno donositi odluke te mu tako postupno daju odgovarajuću autonomiju. Takav odnos roditelja u kojem se pokazuje spremnost prilagođavanja stajalištu djeteta pridonosi lakšem uvažavanju stajališta roditelja od strane djeteta i njegovu poslušnost kad je potrebna (Berk, 2015). Jedna od ključnih navika ovih roditelja je jačanje dobrog ponašanja svoje djece, a ne samo ukazivanje i kažnjavanje nepoželjnih. Ustanovljeno je da ova vrsta roditeljstva stvara zdravo okruženje te pomaže razvoju produktivnog odnosa roditelja i djeteta. Autoritativni stil roditeljstva dovodi do sretne, odgovorne, neovisne, uspješne djece s boljim samopoštovanjem i samopouzdanjem.

2. Autoritarni odgojni stil karakterizira nisko prihvaćanje i uključenost, visoku prisilnu kontrolu te vrlo ograničeno davanje autonomije (Berk, 2015). Roditelji imaju velike zahtjeve i očekivanja prema svojoj djeci bez davanja objašnjenja, uz nedovoljno topline i potpore, često omalovažavaju svoju djecu rugajući im se i kritizirajući ih. Glavni odgojni ciljevi takvog odgoja su postizanje djetetove samokontrole i poslušnosti. Roditelji su usmjereni na postavljanje granica i pravila. U situacijama kada dijete to ne poštuje skloni su kažnjavanju, često i tjelesnom kažnjavanju (Čudina-Obradović i Obradović, 2006). Uglavnom su to poslušna i sposobna djeca, no sklona niskom samopoštovanju, strahu ili stidljivosti, slabijih su socijalnih kompetencija, a nerijetko su i lošeg ponašanja kada su izvan kruga roditeljske skrbi. Postupci i ponašanje autoritarnih roditelja utječu na razvoj agresivnosti i probleme u ponašanju kod djece. Često izražavaju neprijateljstvo prema drugima, a kako bi dobila ono što žele, koriste se silom, baš poput svojih roditelja (Berk, 2015).

3. Permisivan (popustljiv) odgojni stil je stil odgoja u kojem dominira kombinacija emocionalne topline i slabe kontrole. Permisivni su roditelji obično pružaju puno topline, ljubavi i podrške, no ne postavljaju jasne granice, rijetko discipliniraju ili kažnjavaju svoju djecu, a pravila se nedosljedno provode. Ne postavljaju velike zahtjeve prema djetetu i provode slabu kontrolu (Čudina-Obradović i Obradović, 2006). Djetetu se prepušta donošenje odluka, čak i kad ih dijete nije sposobno samo donijeti (Berk,2015). Nedostatak strukture uzrokuje da djeca odrastaju s malo samodiscipline i samokontrole, pretjerano su usmjerena na sebe, nedovoljno razvijenih socijalnih vještina te nerijetko ulaze u sukobe s autoritetima. Prevelika sloboda nije primjeren način odgoja jer uzrokuje nesigurnost djeteta i nesnalaženje u granicama, a time se potiče agresivno i impulzivno ponašanje (Čudina-Obradović i Obradović, 2006). Djeca najčešće razviju osjećaj sreće i dobro raspoloženje, ali samo kada se sve njima podređuje. 
4. Indiferentni ili zanemarujući odgojni stil karakterizira emocionalna hladnoća i slaba kontrola. Indiferentni roditelji djetetu postavljaju male zahtjeve, ne kontroliraju ih, ne pružaju toplinu niti potporu. Iako ispunjavaju osnovne potrebe djeteta, zanemarujući roditelji uglavnom su ravnodušni, ne pokazuju interes za dijete, njegove želje, potrebe, uspjehe i neuspjehe te nemaju vremena $\mathrm{i}$ snage brinuti se za njih. Djeca na ovakav roditeljski odnos reagiraju neprijateljstvom i otporom, a to utječe na loš uspjeh u školi i nemogućnost stjecanja društvenih kompetencija (Čudina-Obradović i Obradović, 2006). U ekstremnim slučajevima ovakvi roditelji mogu čak odbaciti ili u potpunosti zanemariti potrebe svoje djece. Djeca koja imaju negativan odnos sa svojim roditeljem teže formiraju odnose s drugim ljudima, posebice djecom njihove dobi, zahtjevna su i nerijetko neposlušna te imaju slabu mogućnost regulacije emocija.

Jedna od glavnih kritika ove tipologije je kulturološka determiniranost. Danas se mogu identificirati novi roditeljski stilovi koji su, na neki način, kombinacija ranije definiranih stilova, ali imaju i neka svojstva uvjetovana kulturološkim obilježjima suvremenog načina života. Tako su prepoznati stilovi: tigar roditelji (Tiger parents), helikopter roditelji (Helicopter parents), roditelji ralice ili buldožeri (Snowplough or bulldozer parents), roditelji slobodnog kruga (Free-range parents) i povezani ili nježni roditelji (Attachment or gentle parents). Tigar roditelji su identificirani kao roditelji koji svoju djecu usmjeravaju da uspiju prema njihovim uvjetima, vole imati apsolutnu kontrolu nad životom svoje djece i vrše pritisak na njih kako bi ostvarivali njihove želje, odnosno usmjeravaju djecu na put za koji oni misle da je pravi za njih. Očekuju potpunu poslušnost svoje djece i izvrsnost u svemu što rade. Ovaj tip roditeljstva potječe iz azijskih zemalja u kojima je vrlo važno da dijete postigne vrhunske rezultate. Roditelji tigrovi su puni ljubavi i podrške, ali su nepopustljivi i uvijek kažnjavaju dijete kada napravi nešto loše. Kod djeteta pokušavaju probuditi smisao za samokontrolu i disciplinu. Zbog svega toga djeca ih često doživljavaju hladnima, ali prisutnima i znaju da se na njih mogu osloniti. Ovaj je stil roditeljstva identificirala Amy Chua u svojoj knjizi „Battle Hymn of the Tiger Mother“ iz 2011. godine u kojoj navodi da kineski roditelji pokazuju svoju nadmoć i pretpostavljaju da su im djeca dužnici od kojih očekuju da im uzvraćaju poslušnošću, ponašanjem i uspjesima na koje će oni biti ponosni. Kod roditelja tigrova uočavamo osobine autoritativnog i autoritarnog odgojnog stila. Njegova je dobra strana što navodi dijete na više produktivnosti, motiviranosti i odgovornosti te pri radu daje svoj maksimum pri čemu osjećaju stalnu roditeljsku podršku. Zagovornici ove teorije kao najbolje moguće vjeruju da su roditelji kojima je obrazovanje djece na prvom mjestu samo ambiciozni roditelji koji pokušavaju motivirati svoju djecu i naučiti ih da budu vrijedni, uporni i uspješni ljudi. No, stil ima i svoje 
nedostatke koji se očituju u tome da djeca postaju depresivna, tjeskobna s lošim socijalnim vještinama jer nemaju pravo samostalno odlučivati o vlastitom životu i jer ih se usmjerava isključivo na obrazovanje i planiranje karijere (English, 2016). One roditelje koji su prekomjerno uključeni u školovanje svog djeteta te često zovu njegova učitelja, sprječavaju svaki sukob i ne mogu prestati paziti na svog tinejdžera i pustiti ga da odraste, Foster Cline i Jim Fay (1990, prema English, 2016) nazivaju helikopter roditeljima. Oni helikopter roditelje opisuju kao zbunjene jer ne vide razliku između ljubavi i spašavanja djece od samih sebe. Drugi naziv za helikopter roditelje je ,pretjerano roditeljstvo". Ovi se roditelji vjerojatno boje za budućnost svog djeteta jednako kao roditelji tigrovi te možda nemaju povjerenja u njegovu sposobnost snalaženja u svijetu. Smatraju da će svojim stalnim nadzorom uspjeti sačuvati svoje dijete od svakog zla i neuspjeha. Taj je odgojni stil mješavina autoritarne i permisivne tipologije. Njegova je prednost što prezaštitnički nastrojeni roditelji često mogu spasiti dijete ili adolescenta od nepredvidljivih problema. Dok se nedostatkom može istaknuti to što djeci takvih roditelja može nedostajati emocionalna otpornost i neovisnost, što može utjecati na njih u odrasloj dobi. Biti dijete roditelja helikoptera može dovesti do nedostatka samokontrole. Roditeljima ralicama ili buldožerima nazivaju se oni roditelji koji guraju sve prepreke s djetetovog puta. Ne dozvoljavaju da se dijete suoči s problemom, rješavaju ga prije nego li ga ono uoči. Skloni su birati učitelje za svoje dijete i optuživati druge za njihove neuspjehe, podmićivati ljude u djetetovom okruženju za bolje rezultate i sl. Ovaj roditeljski stil je prepoznao i objavio David McCullough 2015. godine radeći kao profesor u srednjoj školi. Iako se u ovome stilu primjećuju aspekti autoritarizma, u smislu očekivanja velikih rezultata, permisivnost je puno više zastupljena. Ovi roditelji mogu pomoći djeci da se osjećaju jako zaštićeno i sigurno, ali mogu potaknuti i osjećaj narcizma. Prednosti i nedostaci su vrlo slični kao kod helikopter roditelja. Svojim pretjerano zaštitničkim odnosom mogu spriječiti neke neugodne situacije, ali može se kod djeteta razviti neopravdana sigurnost, sebeljublje i nedostatak otpornosti i samokontrole. S druge strane susrećemo roditelje koji imaju potpuno povjerenje u svoje dijete i daju mu popunu slobodu (Free-range parents). Ovaj je termin objavila bivša kolumnistica Lenora Skenazy (2009, prema English, 2016) koja se bori protiv percepcije da je svijet opasno mjesto s posebnim naglaskom na omogućavanje djeci da imaju odgovarajuću razinu slobode i odgovornosti za svoju dob, a pritom ih i dalje čuvaju. Pobornici ovoga roditeljskog stila ukazuju na činjenicu da roditelji previše brinu o svemu oko svoje djece, od bakterija do drugih ljudi. Vjeruju da je ovaj stil u skladu s autoritativnim u smislu podučavanja djece da brinu o sebi te da uči djecu biti samostalnima i imati samokontrolu te će moći lakše podnositi pogreške, biti otporniji i preuzeti odgovornost za svoje postupke. U prilog 
ovome stilu ide mišljenje psihologa koji sugeriraju da ovakav odgoj sprječava pojavu anksioznosti kod djece. Povezano roditeljstvo je roditeljska filozofija koja predlaže metode kojima se želi promovirati povezanost roditelja i djeteta ne samo maksimalnom roditeljskom empatijom i obzirnošću, već i stalnom tjelesnom bliskošću i dodirom. Izraz roditeljska povezanost skovao je američki pedijatar William Sears. Roditelji koji koriste ovaj stil drže svoje dijete što je moguće bliže sebi u svakom trenutku. Oni koriste svoje prirodne instinkte i reakcije, a ne sat, kao upute o tome što djetetu treba ponuditi. Sljedbenici ovog stila vjeruju da će djeca sama roditeljima dati do znanja kada su spremna jesti, spavati, spavati sama u krevetu, biti prepuštena njima ili kultivirati novo ponašanje. Roditelji koji koriste ovaj stil vjeruju da su najbolji način za discipliniranje djeteta modeliranje uloga, nagrade za dobro ponašanje, ograničeni izlasci i gubitak privilegija, pritom imajući na umu njegov razvojni stadij. Koriste nježnu, nenasilnu disciplinu koja se temelji na očekivanjima primjerenim dobi. Zagovornici također potiču dojenje kojim se promiče vezivanje majke i djeteta, a pokazalo se da je zdravije i ekonomičniji izbor za mnoge obitelji. Vjerujete se da najranija povezanost djeteta s roditeljima uvjetuje sve kasnije veze koje osoba doživljava. Argument sugerira da je snažna emocionalna i tjelesna povezanosti s barem jednim roditeljem od ključne su važnosti za djetetov osobni razvoj. Roditelji mu pružaju sigurno utočište ljubavi i poštovanja u kojem će se graditi odnosi i iz kojeg dijete može sigurno doživjeti svijet. No, takav roditeljski stil je često naporan i zahtjevan za roditelje jer im postavlja nerealne zahtjeve i obveze, posebno radnim majkama.

Pregledom odgojnih stilova roditelja može se steći uvid da samo kombinacijom različitih stilova možemo udovoljiti odgojnim potrebama adolescenata današnjice. Imajući na umu osobine adolescenata, pozitivne utjecaje dobrog roditeljstva u toj dobi možemo promatrati kroz demokratski odgojni stil koji karakterizira ravnoteža emocionalnog prihvaćanja i jasno postavljene strukture. Davanjem jasnih i konzistentnih smjernica, očekivanja, pravila i povratnih informacija, mladima se pružaju osnove za razvoj kompetencija što rezultira najmanjim brojem problematičnih ishoda. Možemo reći da roditeljski stil koji podupire temeljne psihološke potrebe adolescenata karakterizira podržavanje kapaciteta mladih za samoinicijativu i autonomnost, zainteresiranost roditelja za dijete i aktivnu ulogu u njihovom životu, otvorenost i bliskost te jasno pružanje strukture. Za održavanje dobrog roditeljstva potrebno je nadzirati s kim i gdje se adolescent druži, kvalitetna komunikacija i postavljanje jasnih i određenih pravila ponašanja.

Drugim riječima, kao čimbenici koji predstavljaju najveći rizik za razvoj problematičnog ponašanja kod mladih značajnu ulogu imaju nedostatno nadgledanje djece, nedosljedna 
disciplina, visoka razina konflikata u obitelji, neučinkovita komunikacija i rješavanje problema, nedostatak ulaganja roditelja $\mathrm{u}$ odnos $\mathrm{s}$ djecom te posljedično nisku razinu privrženosti. Prakticiranje autoritarnog odgojnog stila može dovesti do sukoba na relaciji adolescent roditelj. Sukobi rezultiraju prkosnim i odbijajućim ponašanjima adolescenata što smanjuje toplinu i brigu, a jačaju kontrolu i strogost kod roditelja te se odnos sve više narušava. Permisivni ili indiferentni stil roditeljstva dopušta djeci da imaju neovisne živote u koje roditelji imaju malo uvida (Silver, 2018). Indiferentni roditeljski stil, karakteriziran emocionalno hladnim odnosom uz izostanak bilo kakve strukture i pravila, rezultira s više ponašajnih problema i više internaliziranih poremećaja.

Doba adolescencije je specifičan prijelazni period kada mladi više nisu zaštićeni kao djeca, a još se ne smatraju odraslima, u nekim situacijama se na njih gleda kao na djecu, a u nekima kao na odrasle, zapravo su oboje i nijedno (Ilišin i Radin, 2002). Zbog toga su ih se u suvremenom društvu može promatrati kao najranjiviji dio populacije. Porebno im je zadržavanje bliskosti s roditeljima i njihova podrška, ali odnos se mora mijenjati kako bi se postigla simetričnost u području međusobne moći i autoriteta. Podrška roditelja i bliskih odraslih osoba pruža sigurnost pri istraživanju sebe i svijeta, pri izazovima odrastanja. 


\section{2. 7. Značajke generacija i njihova podjela}

Uzrast ispitanika je srednja adolescencija, oni prema Levickaite (2010), pripadaju Generaciji Z. Pripadnici Generacije Z su rođeni poslije 1995., odnosno 1997. godine, a prema Hamill (2005) od 2001. godine. Kako bi se što bolje razumjeli načini funkcioniranja današnjih adolescenata, u nastavku će se posebna pozornost posvetiti ovoj populaciji.

Teoriju generacija postavio je Karl Mannheim 1923. u djelu The Problem of Generation (Mannheim, 1952). Generacija je skupina ljudi koja prolazi kroz iste socio-povijesne uvjete, odrastaju i žive tijekom specifičnih povijesnih događaja, političkih struktura, ideologija i tehničkih dostignuća. Oni imaju izgrađene iste svjetonazore po kojima se razlikuju od drugih generacija. Svjetonazor svake osobe uvjetovan je naslijeđem šire zajednice i oblikovan je individualnim i lokalnim prilikama te istovremeno omogućuje i ograničava životne izbore i socijalna ponašanja (Savage, Colins-Mayo, Mayo i Cray, 2006).

Postavljanje kronoloških granica izazvalo je mnoge polemike među znanstvenicima koji se bave proučavanjem generacija (Walker i Clurman, 1997; Schroer, 2004; Hammill, 2005; Huntley, 2006; Rothberg, 2006; Savage i sur., 2006; Osit, 2008; Freeman, Trower, Tan i Terkla, 2009; Tapcsott, 2009).

Tablica 1

Generacijska podjela (Hammill, 2005, str. 12).

\begin{tabular}{ccccc}
\hline $1922 .-1945$. & $1946 .-1964$. & $1965 .-1980$. & $1981 .-2000$. & $2001 .-$ \\
Veterani, & Baby Boom & Generacija X, & Generacija Y, Gen & Generacija Z \\
Mirna generacija, & generacija & Gen X, Xeri & Y, Millennial, Echo & \\
Tradicionalisti & & & Boomeri &
\end{tabular}

Razlike među generacijama mogu utjecati na sve, uključujući zapošljavanje, izgradnju timova, nošenje s promjenama, motivacijom, upravljanjem, održavanjem i povećanjem produktivnosti rada. Utječu i na međusobnu komunikaciju. Svaka generacija ima različita stajališta, ponašanja, očekivanja, navike i način motivacije (Green, Heather, McKittrick, Naranjo i Ward, 2013).

Danas su jasnije razlike među generacijama nego ikada prije. Svjesni tih razlika moguće je pomoći pojedincima postizati maksimalne učinke, bez obzira na zadatak ili odnose unutar obitelji, među prijateljima i kolegama na radnom mjestu. Dobar posao se temelji na 
razumijevanju drugih (Hammill, 2005). Institucija Mission and Ministry (2010, prema Levickaite, 2010), razlikuje svaku od generacija na tri područja: godine i životna faza (ontološki kriterij), vrijeme i tehnologija (sociološki kriterij), događaji i iskustva (povijesni kriterij).

U nastavku će se iznijeti primjer identifikacije i opisa populacijskih skupina novijega doba koja se općenito (ali ne i univerzalno) slaže s teorijama većine demografa i istraživača (Schroer, 2004).

Veterani, Mirna generacija, Tradicionalisti su nazivi za generaciju koja je sudjelovala u zajedničkom cilju za vrijeme rata. Naglasak je bio na događaju, a ne na njima samima, kao što je to slučaj u novije vrijeme. Kad se rat okončao, ova generacija je imala značajne mogućnosti za zapošljavanje i obrazovanje. Međutim, rast napetosti u Hladnom ratu, potencijal za nuklearni rat i druge prijetnje, dovele su do nemira i nesigurnosti tijekom čitave generacije. Članovi ove generacije cijenili su sigurnost, udobnost te poznate aktivnosti i okruženja.

Baby Boom generacija, Boomeri (1946. - 1964.) su bili optimistični, neovisni, ciljno orijentirani, posao im je bio u središtu života. Na radnom mjestu bili su timski igrači, voljeli su se sastajati, osobno su preferirali komunikacije, cijenili su novac i priznavali ga kao nagradu, željeli su se osjećati vrijednima i potrebnima (Green i sur., 2013). Baby Boomers-i su živjeli u poslijeratnom razdoblju Drugog svjetskog rata, u vrijeme društvene stabilnosti i napretka. Razvodi brakova su bili relativno rijetki, škole su bile sigurne i poslovi osigurani. Bila su normalna pojedinačna kućanstva s jasnom podjelom rada između muškaraca i žena. Bili su rangirani prema svom radnom uspjehu. Ako su naporno radili, bili lojalni i produktivni zaposlenici i slijedili pravila organizacija, ostajali su u svojim radnim organizacijama dokle god su željeli. Bili su nagrađivani za svoje doprinose i na kraju radnog vijeka osigurani odgovarajućom mirovinom (Conrad i Poole, 2005).

Generacija X (1966. - 1976.) - pojam Generacija X prvi put je upotrijebio Douglas Coupland 1991. godine u svom romanu u kojem prikazuje osobe u dvadesetim godinama kao cinične, apatične, nepristojne gubitnike i lijenčine (Filipczak, 1994; Pointdexter i Lasora, 1999). Od tada je pojam Generacija X korišten na televiziji i u tiskanim medijima kako bi se opisale osobe rođene od 1965. do 1981. godine (Green i sur., 2013). Ovakav prikaz Generacije X doveo je do mnogih zabluda oko njihove odanosti prema organizacijama, poštovanju autoriteta, 
pažljivosti, predanosti radu i spremnosti da naporno rade na postizanju svojih ciljeva (Tulgan, 2000). Ova generacija često se naziva ,izgubljenom“ generacijom, smatra se prvom generacijom djece s ključićem oko vrata. $U$ to vrijeme rođeno je puno djece i razvedeno puno brakova. Djeca su često ostavljana sama doma dok su njihovi roditelji radili i to je rezultiralo razvojem njihovog vlastitog stila rješavanja različitih situacijama s malo ili bez roditeljskog nadzora (Keaveney i Young, 1997; Kindrick Patterson, 2007). Poznati su po najnižoj stopi sudjelovanja u glasovanju. Karakterizira ju visoka razina skepticizma (McCready, 2011) i vjerojatno su najobrazovanija generacija. S obrazovanjem i zrelošću stvaraju obitelji s većom razinom opreza i pragmatizma nego njihovi roditelji. Zabrinuti su za sigurnost svojih domova, za financijsku stabilnost i odrastanje djece bez roditelja (McCready, 2011; Schroer, 2004).

Značajke Generacije X su: prilagodljivost, tehnološka pismenost (Zemke, Raines i Filipczak, 2000) i samostalnost (Tulgan, 2000). Neke od njihovih radnih osobina su: kreativnost, poduzetnost, informiranost, fleksibilnost, dobro balansiranje između posla i obitelji i brzina. Pripadnici Generacije X žele raditi u radnim organizacijama u kojima mogu puno doprinositi i gdje će se njihov rad cijeniti (Healey, 1998; Tulgan, 2000). Vole biti u promjenjivom okruženju koje im omogućuje fleksibilnost u radu i u kojem mogu održavati ravnotežu između posla i obiteljskog života koji im je izuzetno važan (Zemke, Raines i Filipczak, 2000). Ne vole da ih se ograničava starim načinom rada kada postoji bolji, brži i učinkovitiji.

Generacija $Y$ - prema Schroer (2004), Generacija Y obuhvaća osobe rođene između 1977. i 1994. godine, a prema Markert (2004) to su osobe rođene između 1986. i 2005. godine, dok Zemke, Raines i Filipczak (2000) u ovu generaciju svrstavaju rođene između 1980. i 2000. godine. Naziva ih se i Milenijalcima, Nintendo generacijom i Internet generacijom.

Pripadnici ove generacije su odrasli u vrijeme sigurnosti, stabilnog gospodarstva i brzog rasta svjetske tehnologije. Općenito govoreći, oni imaju tendenciju biti realistični, zabavni, društveni i samouvjereni (Hammill, 2005). No, iako su urbani, nestrpljivi i idealistični, iskustvo ih je poučilo da budu oprezni (Montana i Petit, 2008). Odrasli su u svijetu tehnologije i vjerojatno ne mogu zamisliti život bez računala, interneta i mobitela (Kindrick i Patterson, 2007). To je tehnološki pismena generacija (Eisner, 2005) i ovisna o tehnologiji. Pristup računalima imali su još u osnovnoj školi i vrlo rano su dobili pristup internetu (Glass, 2007). Istovremeno obavljanje više radnji odjednom je njihova stvarnost (Crumpacker i Crumpacker, 2007). Pripadnici Generacije Y nisu navikli čekati jer su odrasli u vrijeme gospodarskog rasta 
i većinu vremena dobivaju ono što žele (Green i sur., 2013). Neke od njihovih značajki kao zaposlenika, uključuju: multitasking, poduzetnost, ciljnu usmjerenost, timski rad, suradnju i planiranje (Hammill, 2005). U usporedbi s ostalima generacijama, članovi Generacije Y imaju nisku toleranciju za dosadu, ne vole miran i ponavljajući rad. Ova generacija ima veliku mogućnost različitih izbora i sve sebi prilagođavaju te žele i radno mjesto koje im omogućuje isto (Rickles, 2011, prema Green i sur., 2013).

Conrad i Poole (2005) se slažu da je njima sve moguće. Često ih se gleda kao pretjerano ambiciozne managere koji dobro zarađuju i puno troše (Rickles, prema Green i sur., 2013). Pripadnici Generacije Y su poznati kao nevjerojatno sofisticirani, tehnološki znalci, imuni na većinu tradicionalnih marketinških i prodajnih trikova jer su odrasli izloženi svemu tome od ranog djetinjstva.

Mnogi istraživači slažu se da su članovi generacije Y značajno različiti od drugih generacija (Crumpacker i Crumpacker, 2007; Shaw i Fairhurst, 2008; Cogin, 2012; Westerman i Yamamura, 2006). Crumpacker i Crumpacker (2007) iznose da su mnogi članovi ove skupine dobro obrazovani, ali im nedostaju komunikacijske vještine i vještine rješavana problema. Dok su istovremeno stvorili široku mrežu društvenih kontakata i vrlo su druželjubivi, izrazito vjeruju vlastitom krugu prijatelja i poznanika, a međusobno povjerenje smatraju nužnom sastavnicom u svojim privatnim životima (Lammiman i Syrett, 2005). Vrlo vješto balansiraju između posla i privatnog života. Imaju puno više slobodnog vremena od bilo koje prethodne generacije (Schiano, Elliott i Bellotti, 2007). Vole putovati, važan im je napredak u karijeri i žele priznanje za svoj rad (Kyles, 2009, prema Stevens, 2010).

Generacija Y ne vjeruje masovnim medijima, a reagira na glasne i brze vizualne, audio i glazbene sadržaje. Vole programe i poruke koji odražavaju njihov životni stil i vrijednosti, koji moraju uključivati humor i emocije. Videoigre i DVD-e vole više od televizije i filmova. Njihovo odrastanje uz internet, različite talk show i reality programe izgradilo im je stav da je normalno da se istovremeno čuje više glasova i različitih zvukova. Smatraju da svatko može biti zvijezda te osjećaju da nikada ne postoji samo jedan pravi odgovor na bilo koje pitanje. Imaju prirodnu potrebu izazivati i preispitivati rečeno, traže objašnjenja i dokaze. Iznimno su tolerantni, brižni, zahtjevni i pomalo tjeskobni.

Cufaude (2000) sugerira da generacije X i Y predstavljaju razdoblje okarakterizirano velikim promjenama i drastičnim povećanjem fleksibilnosti i izbora. 
Generacija $\boldsymbol{Z}$ - novija istraživanja generacija (Grail Research, 2011; Han, 2007; Knežević, 2010; Levickaitè, 2010; Meister i Willyerd, 2010; Montana i Petit, 2008; Prensky, 2001) govore o novoj generaciji koja je nastala ulaskom u novo tisućljeće i koju autori nazivaju Generacijom Z. Generacija Z je rođena sredinom devedesetih godina i odrasla je s novom tehnologijom (Levickaitè, 2010). Hamill (2005) smatra da su rođeni poslije 2000. Prema tome, u ovu skupinu se svrstavaju i učenici sadašnjeg višeg sekundarnog obrazovanja. Meister i Willyerd (2010) nazivaju ih i „Generacija 2020.“ jer će otprilike sada visokoobrazovani pripadnici ove generacije ući na tržište rada.

Generacija $\mathrm{Z}$ odrasta u potpuno drugačijem povijesnom kontekstu od Milenijalaca, što im je dalo i drukčiji pogled na svijet. Milenijalci, Generacija Y, su bili internetski pioniri. Izumili su Facebook, osvojili su ih pametni telefoni. Dok se ova generacija ne sjeća života bez toga. Pripadnici Generacije Z velike promjene koje su se dogodile u vrijeme Generacije X i Y doživljavaju kao normu. Milenijalci su živjeli u doba gospodarske ekspanzije i bilo je normalno da se poslije završene škole zapošljavaju na željenim radnim mjestima. Generaciju Z oblikovala je recesija (Segran, 2016).

To je internetski i tehnološki osviještena generacija, a njeni pripadnici se razvijaju u osobe koje mogu raditi više zadataka odjednom (eng. multitasking). Uz to, pripadnici Generacije Z brzo prelaze s jednog zadatka na drugi i pridaju više pažnje brzini nego točnosti. Svima su dobro znani kao bežična, hiper-povezana generacija koja je uvijek udaljena nekoliko „klikova mišem“ od svakog djelića znanja (Mission and Minsitry, 2010, prema Levickaitè, 2010, str. 173).

Tri su temeljne osobine Generacije Z (Petrić, 2007):

a) Natprosječne vještine pretraživanja i skeniranja informacija - kada pripadnici Generacije Z otvore internet stranicu oni samo „prolete“ kroz ekran pogledom, skenirajući slike, simbole i natpise što im omogućuje trenutačno odlučiti gdje će kliknuti mišem. Odjednom gledaju u nekoliko različitih zaslona ili monitora i imaju otvorene profile na desecima društvenih mreža, a svoje mobilne telefone ne ispuštaju iz ruku ni dok jedu (Paige, 2017). Prensky (2001) je Generaciju Z nazvao „digitalni urođenici“ (eng. Digital Native) s objašnjenjem da su oni sposobni primati informacije izrazito brzo i paralelno s drugim zadacima te je naglasio da pripadnici ove generacije prednost daju grafici umjesto tekstu i zahtijevaju olakšan pristup svim informacijama. 
b) Simultano obavljanje više zadataka - pripadnici ove generacije bez posebnog smanjenja koncentracije istovremeno uspijevaju pisati domaću zadaću, razgovarati preko chat programa i slušati glazbu.

c) Diskontinuirano $i$ nelinearno učenje - linearan način učenja ide od općeg prema specifičnom, a nelinearna metoda koja se temelji na traženju odgovora na konkretna i precizna pitanja, tipična je za novu generaciju.

Generacija Z radije komunicira porukama (digitalnim razgovorom) nego direktnom osobnom komunikacijom te $\mathrm{u}$ tome vide puno prednosti, poput: nema neugodnih stanki, razmišljanja o položaju tijela, ljepše rečenice, bolje vještine pisanja itd. (Paige, 2017). No, neka istraživanja ipak pokazuju suprotno, da vole i tradicionalne oblike komunikacije (Schawbel, 2014). Implementacija novih tehnologija u živote mladih ljudi, nedostatak komunikacije i stalna užurbanost, dovode do njihovog bržeg osamostaljivanja (Matthews, 2008, prema Knežević, 2010).

Woodrufe (2009) smatra da je Generacija Z psihološki lijena jer više komunicira sa strojevima nego s ljudima te smatra da nije dobro što dvije trećine ove generacije spava manje nego što je preporučeno, a razlog je u tome što njihove spavaće sobe više nisu mjesta za odmor, nego centar njihove mreže. Medijalna dob majke prilikom rođenja prvog djeteta je otprilike 31 . godina što znači da su roditelji ove generacije sada u dobi oko pedeset godina (Levickaitè, 2010), pripadaju Generaciji X koje koja cijeni zaposlenost i rad. Pripadnici Generacije Z odrastaju u obiteljima s manje članova, pri čemu oba roditelja rade (Matthews, 2008, prema Knežević, 2010.) To su djeca koja se sama odgajaju jer su po cijele dane bez prisutnosti roditelja koji nedostatak vremena provedenog s djecom nadomještaju kupovanjem igračaka i novih tehnologija kako bi popunili prazninu koju su stvorili.

Predviđa se da će ova skupina biti više ekološki osviještena od prethodnih generacija i da će ih obilježiti visok stupanj nepovjerenja prema korporacijama zbog čega će biti više skloni mijenjaju posla i/ili karijere (Han, 2007). Budući da mnogi članovi Generacije $Z$ još nisu krenuli u osnovnu školu, nemoguće je donijeti konačne zaključke o njihovim navikama, stilu života i svjetonazoru. No, najstariji od njih su na fakultetima i započinju svoje karijere, pa se počinju nazirati trendovi. Segran (2016) navodi sljedeća zapažanja:

a) U stalnom su pokretu i odbacuju velike robne marke. Trgovci već dugo pažljivo proučavaju Generaciju Z i uočili su njihove sklonosti kao djece i tinejdžera te utvrdili da imaju potpuno različite stavove prema robnim markama od prethodnih generacija. Manje im vjeruju, vrlo su kritični jer odrastaju u vremenu u kojem su informacije uvijek bile dostupne. Online 
recenzije u trenu daju informacije o različitim proizvodima, a blogovi i društvene mreže razotkrivaju tvrtke s lošom korporativnom kulturom ili lošim uvjetima rada. Danas tinejdžeri i mladi nisu naivni, svjesni su da su Instagram, Snapchat, YouTube i druge društvene mreže plaćeni da reklamiraju proizvode (Segran, 2016).

b) Oprezni su potrošači. Pripadnici Generacije Z ne samo da se ističu u pogledu načina na koji se odnose prema robnim markama, već svoj novac troše drugačije. Današnji tinejdžeri i studenti odrasli su slušajući strašne priče o tome koliko je Milenijaca ostalo živjeti kod kuće nakon škole, često opterećeni financijskim dugovanjima. Dakle, oni imaju tendenciju da budu financijski oprezni. Tinejdžeri se više ne oslanjaju na modu kako bi izrazili svoj identitet. Prije su nosili etikete koje su pokazivale isticanje, bunt ili sportski stil. No, internet je umnožio broj odjevnih tvrtki koje mogu odabrati, što je rezultiralo smanjenjem lojalnosti brendovima. Društveni mediji nude osnovu za stvaranje javne osobe što omogućuje i stvaranje vlastitog brenda. Generacija $\mathrm{Z}$ dosta je neutralnija po pitanju rodnosti kada je u pitanju sve - odjeća, stil, razgovor, izbor kupaonica. Istraživanje Lincoln Financial Group (Godfrey, 2016) pokazalo je da pripadnici Generacije Z počinju štedjeti puno ranije nego prethodne generacije. Njihova prva tri prioriteta su zapošljavanje, završavanje fakulteta i štednja novca za godine koje dolaze. Cijene vrijeme provedeno s prijateljima i obitelji, izlaske i putovanja. Većina ih je optimistična u pogledu budućnosti, više od bilo koje druge ispitane generacije (Segran, 2016). Vrlo im je važno dobiti pravu vrijednost za svoj novac. To su primijetile prijevozničke tvrtke koje sve češće nude jeftina putovanja, ali bez suvišnih usluga i dodataka što mladima odgovara jer im je samo važno sigurno stići od jednog do drugog odredišta. Mlađi potrošači žele znati što dobivaju za cijenu, stoga pažnju posvećuju pregledima iskustva drugih ljudi i mogućnosti uštede. Kada je u pitanju tehnologija, Generacija $Z$ pametno pristupa potrošačkoj elektronici, odupiru se privlačenju najnovijih, skupih proizvoda kada postoji stalan dotok novih, jeftinijih opcija. Oni na tehnologiju gledaju kao na alat.

c) Izuzetno kompetitivni $i$ vrlo dobro prihvaćaju različitosti. S obzirom na to da se usredotočuju na financijsku sigurnost, ne čudi da je Generacija Z spremna na sve kada je riječ o zapošljavanju i uspostavi karijere. Osjećali bi se sretni kad bi dobili posao, što je u suprotnosti sa zajedničkom percepcijom Milenijaca koji smatraju da imaju pravo na posao. Generacija Y je najkonkurentnija generacija. Oni su pokrenuli aplikacije kao što je Facebook i započeli dijeljenje svega sa svima, a Generacija $Z$ je potpuno drugačija, oni su vrlo neovisna $i$ kompetitivna generacija. Roditelji su ih naučili da u životu uvijek postoje pobjednici i gubitnici, dok je Milenijcima rečeno da, ako rade zajedno, svatko može biti pobjednik (Segran, 2016). Zadovoljni su sobom, ulažu u svoje karijere, inovativni su i imaju poduzetnički duh. Više su 
motivirani napredovanjem nego novcem (Schawbel, 2014). Spretno pretvaraju svoje hobije u zanimanja. S Googleom nadohvat cijelo vrijeme, uče kako ostvariti vlastite snove. Vrlo rano počinju graditi karijeru. Putem društvenih mreža stvaraju poslovne kontakte još u adolescentskoj dobi (Paige, 2017). Smatraju da za dobro obavljanje posla nije važna starosna dob, nego ideje koje osoba donosi. Na svojim radnim mjestima ne žele biti na marginama, nego u upravljačkim tijelima (Schawbel, 2014).

Iako radno mjesto vide kao bojno polje, vrlo su inkluzivni i tolerantni. Odrasli su sa suvremenim vođama slobodnog svijeta, sa ženama na visokim položajima na svojim radnim mjestima, s gay slavnim osobama kao što su Ellen DeGeneres, Anderson Cooper i Neil Patrick Harris. Generalno, Generacija Z je vrlo tolerantna generacija (Segran, 2016). Čini se da su pripadnici ove generacije puno bolji od drugih generacija jer nisu skloni osuđivanju, ne prave razlike među ljudima, nije im važno što radiš, što voliš ili kako izgledaš. Generacija $Z$ visoko je uključena $u$ aktivističke pokrete, $s$ istinskom namjerom da spasi svijet.

U široj su javnosti često prisutna mišljenja o mladoj generaciji kao generaciji sa smanjenim socijalnom vještinama, sebeljubljivima, egocentričnima, nesamostalnima, neetičnima s poremećenim sustavom vrijednosti. Evidentno je njihovo necijenjenje osobne privatnosti što se manifestira izlaganjem svog privatnog života na fotografijama i video uradcima na online društvenim mrežama. Takve predrasude se stvaraju zbog nedovoljnog poznavanja njihovih stilova života, razmišljanja, stavova i uvjerenja. Dubljim upoznavanjem generacije uviđaju se razlike među pojedincima. Iako pozornost privlače negativna ponašanja koja se ističu u medijima kao nasilje, zlouporaba droga i alkohola, maloljetničke trudnoće i sl. onih koji su čudni, buntovni, opasni, ne može se ne primijetiti one koji su pametni, susretljivi, empatični, kreativni, entuzijastični, puni planova i ideja. Uz sve navdeno, ipak je teško generalizirati i sve pripadnike jedne generacije svrstati u jednu skupinu (Car, 2013).

Društvene promjene utječu na promjene kod mladih. Stjecanje uvida u promjene omogućuju istraživanja njihovih vrijednosti. Vrijednosti podrazumijevaju da je dugotrajno vjerovanje da je određeni način ponašanja ili krajnji cilj egzistencije osobno i društveno preferabilan u odnosu na suprotni ili obrnuti način ponašanja ili krajnji cilj egzistencije (Rokeach, 1973, prema Ilišin, 2011). Istraživanja o vrijednostima uključuju utjecaj dobi, spola, socio-ekonomskog statusa, socijalnog porijekla, obrazovanja, političkih preferencija i religioznosti (Čulig, Fanuko i Jerbić, 1982; Radin, 2002; Schwartz i Huismans, 1995; Schwartz i Rubel, 2005; Ferić, 2009). Pri tome se razmatraju vrijednosti u odnosu na hobije, načine provođenja slobodnog vremena, autoritete, životne strahove i zadovoljstvo životom 
(Bromwick i Swallow, 2001; Thomson i Holland, 2002; Casas, Figuer, Gonzales i Malo, 2007). Tijekom adolescencije, uvjetovano kognitivnim razvojem i povećanjem iskustva, postupno se gradi i mijenja hijerarhija vrijednosti (Simmons i Wadw, 1983, prema Lacković-Grgin, 2006).

Istraživanje vrijednosnih orijentacija mladih u Hrvatskoj pokazalo je da mladi nisu homogena skupina kada se govori o vrijednostima. Najpoželjnije vrijednosti za njih su materijalni položaj, privatnost, samosvojnost i profesionalni uspjeh (Radin, 2002).

Zadatak pedagogije je trajnim odgojnim vrijednostima, konstruktivno integrirati vanjske utjecaje kako bi se konstituirala kao teorija cjeloživotnog učenja i integrativna, formativna i preventivna disciplina (Previšić, 2007). Obrazovni sustav koji postoji više nije pogodan za ove generacije jer one jednostavno ne pripadaju nijednom šablonu koji je vladao u prošlosti (Prensky, 2001). Pri tome je neminovno je uzeti u obzir sve njihove individualne značajke po kojima se razlikuju unatoč odrastanju u istom razdoblju. Sredina i ekonomski status, kao i socijalne prilike, uvelike utječu na razvoj mlade osobe. Velike socijalne promjene u društvu uvijek ostavljaju tragove, pozitivne ili negativne. Samo shvaćajući njihovu dinamiku i utjecaj možemo donositi dobre odluke o njihovom obrazovanju, razvoju njihovih mogućnosti i fizičkom i psihičkom zdravlju. 


\subsection{SLOBODNO VRIJEME}

Koncept vremena ima značajnu ulogu u ljudskome životu. To je osobito uočljivo u suvremenom društvu, u kojem ljudi, unatoč činjenici povećanja slobodnog vremena i dalje osjećaju užurbanost i nedostatak vremena (Wang i Kao, 2006). Ta je činjenica potakla znanstvenike mnogih područja da se upuste u sustavno proučavanje korištenja vremena uopće, a posljednjih desetljeća i slobodnog vremena.

Slobodno vrijeme (eng. leisure) se sagledava kao promjenjiva društvena pojava i moderan fenomen, koji je obilježio gotovo sva područja društvenoga života: od socijalnog, pedagoškog, ekonomskog, političkog, zdravstvenog, komercijalnog i turističkog. Ono postoji od postanka čovjeka, ali tek u industrijskoj civilizaciji dolazi do preciznog razgraničenja radnog i neradnog vremena. Mijenjalo se ovisno o društveno-političkim uvjetima i u odnosu na radne uvjete i položaj. S obzirom na to, u relaciji i interakciji s globalnim društvenim sustavom, njegovo djelovanje obuhvaća različite aspekte suvremenog življenja, rada, razonode i odmora čovjeka. Upravo je zato i predmet interesa većine znanstvenih disciplina kojima je u središtu interesa čovjek (Vidulin-Orbanić, 2008). Istraživanjem slobodnog vremena bave se filozofi, sociolozi, psiholozi, pedagozi i stručnjaci mnogih drugih profila. Za potpuno razumijevanje ovog fenomena nužan je interdisciplinaran pristup.

Postoje mnoge definicije tog složenog pojma koji ne predstavlja homogenu kategoriju ponašanja i malo je dosljednosti u njegovom kategoriziranju i definiranju (Byrne, Nixon, Mayock i Whyte, 2006). Iako je sam pojam slobodnog vremena pojašnjen u mnogim enciklopedijama, monografijama, studijama i udžbenicima, ipak postoje suprotstavljena mišljenja autora pri njegovom određivanju. Razlog tome može se naći u činjenici da suvremene znanosti fenomenu slobodnog vremena pristupaju s različitih stajališta i na različite načine.

Pitanje korištenja slobodnog vremena, njegovog organiziranja i oblikovanja, pitanje je kojim se bavi pedagogija slobodnog vremena te je njena funkcija definirana $u$ Enciklopedijskom rječniku pedagogije (1963). Ona razmatra i proučava prigodne, nenamjerne i neorganizirane utjecaje koji, pored planskih, namjernih i organiziranih odgojnih utjecaja obitelji i škole, djeluju na razvoj i formiranje mladoga čovjeka, a proizlaze iz šire ili uže okoline u kojoj mladi čovjek živi, u vrijeme kada je izvan kruga obiteljskih ili školskih utjecaja, u njegovo slobodno vrijeme. Ona ima zadatak organizirati takve mogućnosti provođenja slobodnog vremena koje će biti dovoljno široke i bogate da zadovolje najrazličitije želje pojedinaca. Mora se truditi oko toga da se u ostvarivanju slobodnog vremena uklone negativni 
i što više pojačaju pozitivni utjecaji za formiranje ličnosti. Također, treba brinuti za utjecaje koji će mladog čovjeka dovesti do toga da doista koristi pružene mogućnosti za vrijedno provođenje slobodnog vremena.

\section{3. 1. Razvoj i pojmovno određenje slobodnog vremena}

Promišljanja o nekom pojmu i problemu te istraživanja o njemu uvijek se javljaju puno ranije nego što se to uokviri u znanstvenu disciplinu. Tako proučavajući povijest, možemo vidjeti da je u svim razdobljima, od postanka čovjeka, postojalo neko vrijeme koje nije imalo obilježja rada, koje je bilo prepušteno pojedincu da sam izabere kako će ga provesti (Krivokapić, 2007). Iako se nerijetko smatra modernom pojavom, slobodno vrijeme zauzima važno mjesto u čovjekovoj povijesti od plemenske zajednice do danas, ne možemo ga pripisati jednoj epohi. Kao sociološka pojava mijenjalo je svoj smisao i funkciju u skladu s razvojem društva i društvenim zbivanjima (Previšić, 2000).

Još su se u doba prvobitnih zajednica, u vrijeme borbe za egzistenciju, rodovi sastajali uvečer oko vatre pričali priče, pjevali pjesme, plesali, obavljali sakralne rituale kojima je bila svrha razvijanje i održavanje zajednice (Božović, 1979). To je bilo vrijeme kada su se javili i oblici kompeticije, inicijacije, nepisani programi tradicije i običaja plemena, vjerski odgoj i oblici rekreacije (Plenković, 2000). U antičko i rimsko doba, slobodno je vrijeme bilo privilegija vladajućih $\mathrm{i}$ bogatih $\mathrm{i}$ oni su ga provodili na javno-kulturnim, umjetničkim i sportskim događanjima koje su im priređivali potlačeni, robovi. Od toga doba ono postaje predmet rasprave.

U staroj Grčkoj se za slobodno vrijeme koristila latinska riječ schole. To se vrijeme odnosilo na dokolicu, a dokolica je u starogrčkom jeziku označavala stvaralaštvo u vremenu izvan obveznog, radnog vremena, dok se danas dokoličarenje izravno povezuje s hedonizmom, dosadom, konzumentskim stilom života te s različitim vrstama ovisnosti o (s)tvarima. Grci su to smatrali sasvim osebujnim vremenom bitka čovjeka koje istom omogućuje nešto takvo kao što je filozofiranje u smislu formalizirano označenog samostalnog i odgovornog mišljenja. Oni su osnivali vježbališta fizičkih, umnih i umjetničkih vještina. Za njih slobodno vrijeme nije bila samo zabava, koristili su ga za aktivnosti pod vodstvom stručnjaka koje dovode do olimpijskog ideala (arte) (de Lisle, 2010). 
Poznati filozofi, Platon, Aristotel i Epikur promišljali su o slobodnom vremenu i smatrali da je to vrijeme koje pruža sreću, ali ne u smislu zabave već jačanja za daljnji rad. Aristotel je u djelu Politika (prema Janković, 1973) istaknuo da slobodno vrijeme može biti opasno ako zemlja ne zna što će s njim, a upravo u tom dijelu vremena on vidi sadržaj života. Vrlo je određen u definiranju dokolice, definira je kao vrijeme i stanje osobite ljudske djelatnosti izvan „,nužnosti i korisnosti“, ali s dodatnim pojašnjenjem prema kojemu su „djelatnosti“ u dokolici one u kojima se radi i stvara nešto lijepo. Ona se ne događa sama po sebi, za sadržajnu i kreativnu dokolicu treba biti osposobljen i pripremljen posebnim, ciljanim odgojem. Smatrao je da s tim ciljem treba odgajati djecu. On dokolicu smatra počelom svih stvari te između zaposlenosti i dokolice treba birati dokolicu (Aristotel, 1988). Zamarovsky arhajske Grke opisuje kao „narod dokoličara“, a dokolica je za njih bila „ideal lijepe dobrote ili kalokagatije, tj. harmoničnog razvitka duha i tijela“ (Polić, 2003, str. 26; Zamarovsky, 1978). Pojam dokolica se pojavljuje i danas, često se slobodno vrijeme zamjenjuje pojmovima dokolica i oslobođeno vrijeme. Teško je razgraničiti trenutke dokolice od slobodnog vremena jer se oni neprestano izmjenjuju.

U svom izvornom značenju dokolica je upravo slobodno vrijeme. Dokolica, slobodno vrijeme, dokonica, dokoličan je onaj koji nije zauzet poslom, koji je besposlen, dokon. U rječnicima postoje i oprečna značenja dokolice. Npr. Anićev Rječnik hrvatskog jezika (1991) određuje dokolicu kao slobodno vrijeme, ali vrijeme u kojem se nešto sadržajno radi, tj. slobodno vrijeme koje je obilježeno, označeno i osmišljeno radom, a ne besposlicom. U istom je smislu dokolicu odredio i Žepić (1961) prijevodom latinske riječi otium kao dokolice koja označava vrijeme predviđeno za određene sadržaje koje pojedinac svojom voljom bira i ostvaruje. Dok je u Rječniku hrvatskog jezika dokolica definirana kao vrijeme kada se ne radi, slobodno vrijeme, besposlica, a dokoličar je čovjek koji živi u dokolici i ima puno slobodnog vremena, odnosno, dokon čovjek (Anić, 2003).

Prema Polić (2005) pogrešno je izjednačavati dokolicu i besposlicu. Oba se termina odnose na vrijeme u kojem čovjek nije zaokupljen poslom, ali besposlicu treba shvatiti kao vrijeme slobode od rada, dok se slobodno vrijeme kao dokolica odnosi na vrijeme slobode za samodjelatnost i za samoostvarenje. Ističe da je slobodno vrijeme slobode u punom i pravom smislu tek kao sloboda za igru i/ili stvaralaštvo, tj. za samodjelatnost koja pretpostavlja i u sebi sadrži i onu slobodu od vanjske prisile i ograničenja. Dokoličiti također znači provoditi vrijeme u dokolici, a jedino tada do izražaja dolazi slobodan izbor pojedinca. To je vrijeme u kojem se 
pojedinac lišen svih obveza, prepušta izboru ovisno o svojoj volji. Time ona predstavlja važan prostor za (su)djelovanje u zdravom razvoju djece i mladih odnosno ključni kontekst za učenje.

Slobodno vrijeme i dokolicu se stavlja u hijerarhijski odnos pa slobodno vrijeme definiramo kao temeljni ili rodni pojam kojem su dokolica i prazno vrijeme niži rodni pojmovi. $\mathrm{U}$ tom kontekstu dokolica gubi svoj pejorativni prizvuk i dobiva funkcionalne oblike razonode i osobnog razvoja. Prazno vrijeme je dio slobodnog vremena koji nije iskorišten ni za odmor, ni za razonodu, ni za osobni razvoj, već ima osobine besciljnog trošenja vremena ili ispunjavanja slobodnog vremena oblicima društveno neprihvatljivog ponašanja (Arbunić, 2002).

Kao što je već rečeno, dokolica se često poistovjećuje sa slobodnim vremenom koje se percipira kao vrijeme u kojemu se čovjek ne mora ciljano usmjeravati prema određenim sadržajima i oblicima kulturnih manifestacija već može jednostavno i opušteno besposličariti. Slobodno vrijeme postaje slobodno u punom smislu tek kad se pojedinac rastereti briga i strahova oko preživljavanja (Marcuse, 1965). Stvaralačka aktivnost u tom značenju nema ključnu ulogu, njezino značenje se pokriva pasivnim odmorom. Prihvatimo li slobodno vrijeme kao prostor čovjekove slobode u kojoj je on najviše prepušten sebi, gotovo je nemoguće analizirati sadržaje koji taj prostor popunjavaju, osmišljavaju i definiraju. Dokolica bi mogla biti jedan od fenomena koji bi se mogao poistovjetiti s konkretnim sadržajima slobodnog vremena pojedinca. Ona nadilazi okvire preostalog slobodnog vremena jer nastaje nakon obaveza koje ne moraju nužno biti vezane uz radno vrijeme. Treba se razvijati u okvirima slobodnog vremena kako bi slobodno vrijeme pojedinca očistila i osmislila (Artić, 2009). Dokolica je rad koji je neoperećen materijalnom proizvodnjom (Despot, 1976). Supek (1996) je vidi kao pledoaje za društveno ili povijesno djelovanje, za ispunjenje života određenim sadržajima. Dokolica predstavlja životni stil koji podrazumijeva potrebu za prostorom osobne slobode, vrednovanje vremena, stvaralaštvo, duhovnost, u osnovi nešto slično idealu aktivnog i kontemplativnog života u duhovnoj i tjelesnoj slobodi (Janeković Römer, 2004). Fenomeni slobodnog vremena i dokolice zahvaćaju duboko i široko područje duhovnog i društvenog života. U svakom slučaju, treba se odmaknuti od pretpostavke u kojoj se slobodno vrijeme poistovjećuje s preostalim vremenom koje zna biti opterećeno iscrpljenošću čovjeka, umorom i bezvoljnošću. Slobodno vrijeme predstavlja sadržajan i slojevit fenomen u čijim okvirima bi se trebala razvijati dokolica, koja bi slobodno vrijeme pojedinca definirala i osmislila. Pri tome bi oba fenomena ostala samostalna, iako ih se može promatrati paralelno, u paru. U dokolici se razvija samosvijest koja utječe na svakodnevno ponašanje pojedinca. Svakom čovjeku ostaje 
mogućnost da se u svom slobodnom vremenu rastereti iscrpljenosti i zamora i da se oslobodi podložnosti kako bi na kraju stvorio okvir uljuđene i smislene dokolice koja bi se prema navedenim značenjima mogla razumijevati kao vrlo izoštrena, suvisla i autonomna samosvijest građanina (Artić 2009). Izbor sadržaja dokolice uvjetovan je subjektivnim i objektivnim čimbenicima (Ilišin, 2003). Subjektivni čimbenici su npr. društveni položaj, obrazovanje, navike, sposobnosti, dok se objektivni čimbenici odnose na socijalnu okolinu: njezino kulturno nasljeđe, ponudu i dostupnost određenih sadržaja.

Rimljani su također uživali u slobodnom vremenu, ali oni ga shvaćaju drukčije od Grka. Za njih je to vrijeme potpuno podređeno osobnim užitcima, igrama, zabavi itd. (de Lisle, 2010). Oni su svoje slobodno vrijeme provodili na javnim mjestima, poput foruma, amfiteatara, stadiona, knjižnica, termi s kupalištima gdje su upražnjavali kulturne, umjetničke, sportske i zabavne sadržaje (Vukasović, 2000).

Kako crkva tijekom feudalnog društvenog uređenja dominira u području filozofije, tako sudjeluje i u raspravama o slobodnom vremenu. Slobodno vrijeme tada smatraju izvorom zla i grijeha dok rad dovodi do milosti Božje. Naravno da se takva filozofija odnosila samo na potlačenu klasu, kmetove, slobodne seljake i zanatlije. Plemstvo i svećenstvo je privilegirano, a kmetovima je crkva uspjela osloboditi nedjelju od rada, kao jedan dan u tjednu za odmor i razonodu. Tako su uz druge blagdane i svečanosti imali oko sedamdeset neradnih dana u godini. Svećenstvo razvija umjetnost, znanost i književnost dok se plemstvo bavilo ratovanjem, a u slobodno vrijeme uživalo u raznim turnirima, lovu i zabavama na dvorovima. Vremenom su kraljevi i plemići postajali mecene pa su njihovi dvorovi postajali središta umjetnosti, glazbe i književnosti. U njihovoj službi su mnogi umjetnici, profesionalci stvarali velika djela.

Humanizam i renesansa donose nova razmatranja te se potiče aktivni odmor u kojem bi ljudi kroz učenje razvijali duh i tijelo. No, iako se proklamirala nova orijentacija čovjekove slobode, ona i dalje ostaje privilegija povlaštenih društvenih slojeva, posebno nove aristokratske inteligencije (Mlinarević, 2006).

Kasnije socijalisti utopisti, Thomas More i Tommaso Campanella, u svojim djelima iznose vizije o idealnoj državnoj zajednici. Posebno mjesto pridaju strukturiranom slobodnom vremenu kao važnom čimbeniku u razvoju ličnosti, vježbanju sposobnosti i učenju, dok ljenčarenje smatraju opasnim. Campanella promiče nužnost aktivnog odmora i razonode (Haralambos i Heald, 1989). Sudeći po tome, slobodno vrijeme ovog dijela povijesti ima obilježja aktivnog odmora, razonode i učenja u svrhu svestranog razvoja ličnosti. 
Tek u 19. stoljeću, razvojem industrijskog društva počinju društvena istraživanja slobodnog vremena. Razvojem manufakture i industrijske proizvodnje vladajuća elita iskorištava kult rada kojeg promiče kršćanstvo i koristi to kao pokretačku snagu proizvodnje u kapitalizmu. Višak rada stvarali su radnici svojim teškim i dugotrajnim radom, a rijetke slobodne dane, nedjelje i blagdane, koristili su za osnovne životne potrebe i neophodan odmor koji im omogućuje nastavak rada. Dok je povlaštena elita uživala u blagodatima njihovog rada i slobodno vrijeme provodila u luksuznim ljetnikovcima i palačama gdje su se odvijale društvene i kulturne djelatnosti (Janković, 1973).

Kraj 19. stoljeća, pun velikih promjena u organizaciji rada, nagovijestio je pojavu nove društvene činjenice koja će se u početku definirati i određivati kroz pojavu rada i preko toga imati značajnu ulogu u kreiranju života pojedinca te imati važan utjecaj na svjetsku kulturu i ekonomiju (Krivokapić, 2007). Osnivanje suvremenih olimpijskih igara i aktualizacija sportova značajno doprinosi demokratizaciji slobodnog vremena u 19. stoljeću.

Godine 1882. u Berlinu je održan Prvi kongres o slobodnom vremenu, a tek dvadesetih i tridesetih godina prošlog stoljeća počinju prva empirijska istraživanja slobodnog vremena $u$ Europi, Americi i Sovjetskom Savezu. Četrdesetih godina dvadesetog stoljeća slobodno vrijeme postaje sociološka disciplina i širom svijeta raste interes za proučavanje dokolice (Martinić, 1977). Za povijesno proučavanje slobodnog vremena posebno je važan rad Richte i sur. (1972, prema Martinić, 1977). Naglašena je sve veća složenost radnih procesa kao posljedica znanstveno-tehničke revolucije. Pri tome se stvaraju uvjeti za oslobađanje čovjekovih potencijala, a to se odražava i na slobodno vrijeme (Mlinarević, 2006)

Veći interes za slobodno vrijeme u znanstvenim se krugovima pojavljuje 20-tih i 30-tih godina 20. stoljeća. Iz tog se razdoblja mogu izdvojiti istraživanja Lind, H. i R. koji su u Middletownu proveli komparativno istraživanje tradicionalne i moderne dokolice. Istraživanje je trajalo deset godina, a pokazalo je da puno ljudi koji počinju participirati u dokolici potpuno nepripremljeno za tu novinu. Tehnološki napredak je donio povećanje materijalnog standarda i bolje životne uvjete, no ništa se nije promijenilo. Čovjek ne može pratiti nagle vanjske promjene čak ni kada imaju pozitivan karakter. Mejovo ispitivanje međuljudskih odnosa razotkrilo je veliki utjecaj koji ponašanje izvan rada ima na sam radni proces. Pozitivna korelacija vodila je poduzimanju konkretnih akcija (Martinić, 1977).

Pedesetih i šezdesetih godina 20. stoljeća u Europi se interes za slobodno vrijeme i dalje povećava. Riesman, Glazer i Revel (1950) ga smatraju sredstvom koje čini razliku među pojedincima, ono je i dalje simbol gornje klase (Veblen, 1966) kao što je to bio slučaj i u antičko 
doba. Neumeyer i Neumeyer (1958) slobodno vrijeme smatraju neobaveznim, ali svima potrebnim vremenom. U sklopu studija o slobodnom vremenu ono je shvaćeno kao komponenta vremena koju karakterizira sloboda i neradne aktivnosti (Godbey, 2003; Kelly, 1999; Neumeyer i Neumeyer, 1958).

Francuska sociološka škola prednjači svojim djelima. Istakli su se Friedman, Dumazedier, Lefargue i drugi. Oni su svojim teorijskim radovima otvorili polje jedne nove discipline, a empirijskim istraživanjima u Francuskoj prikupili su i prikazali dovoljno materijala za dokazivanje važnosti slobodnog vremena i promjena koje ono izaziva u društvu (Krivokapić, 2007). Jedan je od najpoznatijih i najčitanijih filozofa 20. stoljeća Pieper (1963) smatra da je slobodno vrijeme od temeljne važnosti za zajednicu i stvaranje kulture, za stvaranje kulturne svijesti, kulturnog identiteta i prihvaćanja drugih.

Dumazedier (1962) kao jedan od prvih teoretičara slobodnoga vremena, slobodno vrijeme shvaća kao skup aktivnosti kojima se čovjek predaje svojom voljom, radi odmora, razvijanja spoznaja ili društvenog angažiranja (Rosić, 2005). Ističe da je slobodno vrijeme ono vrijeme koje ostaje nakon posla, obiteljskih i drugih obveza, a ključna mu je odrednica sloboda izbora čime će se netko u slobodnom vremenu baviti (Dumazedier, 1967, prema Previšić, 2000). Što implicira da su i neke slobodnom voljom pojedinca odabrane obveze koje mogu biti različitog karaktera, od zabavnih, sportskih do radnih sadržaja, dio njegovog slobodnog vremena. Nakon rada koji čovjeku omogućuje egzistenciju, slobodno vrijeme pruža mogućnost da se ta egzistencija i doživi. Rezultat rada je ekonomska korist, a rezultat slobodnog vremena vidljiv je, prema Dumazedieru (1972), na humanističko-kulturnoj razini gdje dolazi do stvaranja više ljudskih vrijednosti i, još vidljivije, na socijalnoj razini. On slobodno vrijeme promatra usporedno s razvojem tehničke civilizacije. Za njega je slobodno vrijeme, odnosno dokolica, proizvod neprekidnog tehničkog napretka s kojim se ono mijenja i postaje sve značajniji čimbenik u razvoju pojedinca i oblikovanju društva. Definira ga kao slobodu izbora ugodnih aktivnosti, oslobođenje od rada, obitelji i društva.

Naglom industrijalizacijom i ekonomskim jačanjem radničke klase došlo je do postupnog izjednačavanja društvenih slojeva što dovodi do povećanja slobodnog vremena za radnike. Promiče se odmor, kulturna društva i sportske aktivnosti. Do tada je to bio privilegija viših, vladajućih staleža (de Lisle, 2010). Krajem 20. stoljeća, pojavom automehanizacije, industrijalizacije i masovne produkcije ljudi postaju opterećeniji, ali produžuje se slobodno vrijeme i dobiva važnije mjesto u životu (Martinić, 1977; Vukasović, 2000), ukazuje se potreba za rekreacijom (Puntam, 1993). Nakon industrijske revolucije, zapošljavanjem većeg broja 
ljudi, stječu se materijalne i statusne privilegije pa i pravo svakog radnog čovjeka na slobodno vrijeme (Janković, 1973). Dolazi do strogog razgraničavanja radnog i slobodnog vremena, postupnog skraćivanja radnog vremena i povećavanja slobodnog vremena i materijalnog bogatstva. Neosporno je da slobodno vrijeme tada postaje društveni fenomen (Ilišin, 2000). Preteča nastojanja za skraćivanjem radnog vremena bio je engleski socijalist i industrijalac Robert Owen. On je smanjenjem broja radnih sati u tjednu povećao slobodno vrijeme radnika, a tvorničke je prostore uredio kako bi radnici mogli svoje slobodno vrijeme provoditi u zabavi, organiziranim poučnim predavanjima, plesnim i književnim večerima i sl. (Janković, 1973).

U skraćenju radnog vremena i povećanju slobodnog vremena prepoznala se mogućnost povećanja učinkovitosti industrijskog razvoja, a time je slobodno vrijeme umjesto vremena za povećanje slobode postalo vrijeme za realizaciju ciljeva izvan njega samog. Stoga industrijalizacija traži da se i u slobodno vrijeme vrši određena prinuda čime je dovedeno u pitanje ostvarenje slobode u slobodnom vremenu. Za označavanje ukupnog vremena izvan obaveznoga rada Friedman (1959) uvodi termin oslobođeno vrijeme, a slobodno vrijeme definira kao vrijeme u kojem pojedinac svojim izborom teži za vlastitim izrazom i razvojem ako za to ima mogućnosti. On smatra da rad kojim se osoba bavi snažno utječe na izbor slobodnovremenskih aktivnosti. Radnik nezadovoljan svojim radom u slobodno vrijeme traži način za uspostavljanje ravnoteže unutar samoga sebe. Radnik pod takvim pritiskom može u svojim slobodnim satima birati aktivnosti razonode koje se dijele na: trošenje vremena koje podrazumijeva masovni oblik ponašanja pojedinca u tehnološki razvijenoj civilizaciji, a sastoji se od povećanja sve razvijenijih, automatiziranih sredstava za pasivnu rekreaciju i aktivne razonode koja predstavlja aktivan otpor prisili koju radnik osjeća na radnom mjestu.

Nach (1960) također pridaje posebnu pozornost slobodnom vremenu. On ga promatra sa sociološkog i pedagoškog stajališta. Smatra ga vremenom izvan profesionalnih obveza i potreba za hranom i spavanjem, a razumno i korisno korištenje slobodnog vremena vidi kao odlučujući test pojedine civilizacije. Kao i De Grazia (1962), veliča slobodno vrijeme i pridaje mu važnost nazivajući ga utopijskim stanjem bića. Slobodno je vrijeme od temeljne važnosti za stvaranje kulture jer uključuje razvoj kulturne svijesti, kulturnog identiteta i kulturno prihvaćanje drugih (Pieper, 1963).

Prvi pedagog u Hrvatskoj koji je početkom 60-tih godina zvanično uporabio izraz slobodno vrijeme u svom radu Pedagogija slobodnog vremena (1961) bio je Zlatko Pregrad. On u tom radu polazi od stava da su utjecaji i poticaji okoline važni čimbenici u razvoju mlade osobe i da se pedagogija treba baviti i time, a ne samo svjesnim i namjernim odgojnim 
utjecajima. U skladu s tim, Friedmann (prema Janković, 1967) određuje slobodno vrijeme kao ono u kojemu sama ličnost, vršeći svoj izbor, teži za potpunim razvojem ako za to ima sredstava i mogućnosti.

Tijekom 20. stoljeća radno se vrijeme sve više odvaja od vremena nerada koje se i svojim sadržajima i kvalitetom razlikuje od rada i postaje vrijeme odmora zabave i osobnog razvoja (Friedmann i Naville, 1972). Pogrešno bi bilo gledati slobodno vrijeme, tj. dokolicu kao suprotnost radu. Suprotnost na određeni način postoji, ali je treba promatrati u širem smislu, na relaciji između dokolice i obaveza jer je dokolica vrijeme lišeno svih obaveza, radnih, obiteljskih, građanskih itd. Ove obaveze s dokolicom čine slobodno vrijeme jer nekada imaju karakter obveze, a nekada predstavljaju slobodno izabranu aktivnost. Prema Dumazedierovoj definiciji dokolice, prema kojoj je to skup zanimanja kojima se pojedinac može baviti koliko želi, radi odmora, zabave, društvenog angažmana, informiranja ili obrazovanja, oslobođen svih obiteljskih, profesionalnih i društvenih obveza, provedena su mnoga istraživanja od 20. stoljeća nadalje u Francuskoj i cijeloj Europi (Friedmann i Naville, 1972). Martinić (1977) smatra da je Dumazedier prvi uočio snagu slobodnog vremena kao nove društvene datosti kojom je stvoren slobodan prostor za čovjekov razvitak, no smatra da njegovoj analizi nedostaje svestranija kritika. Dok se Božović (1979) u potpunosti slaže sa Dumazedierom da slobodno vrijeme, dokolicu, ne treba poistovjećivati s vremenom slobode jer ono uključuje niz obaveza. To je vrijeme u kojem se zadovoljavaju potrebe koje nisu podmirene u ostalom vremenu. No, prema njegovom mišljenju, podjela vremena na radno, obiteljsko i slobodno vrijeme ne može biti isključiva jer su svi ovi oblici međusobno povezani i ni jedan oblik nema autonomiju, pa i Dumazedier kasnije uviđa tu povezanost (Martinić, 1977).

Neulinger (1974) je u svojim razmatranjima slobodno vrijeme identificirao u odnosu na svoje osnovne komponente koje se odnose na slobodu, intrinzičnu motivaciju, ciljanu orijentaciju i svezu s radom. Kao i Karl Marx, koji je svojom koncepcijom slobodnog vremena utjecao na mišljenje drugih sociologa marksističke i građanske orijentacije, slobodno vrijeme je vrijeme za slobodan razvoj tjelesnih i duhovnih snaga i sposobnosti individue. On ga određuje u odnosu prema kapitalu, prema radu i radnom vremenu, ali ne u smislu antagonističke podjele na radno i slobodno vrijeme, već s obzirom na utjecaj slobodnog vremena na sam prostor rada i radno vrijeme. Osnovna snaga slobodnog vremena prema njemu je u tome što će samosvjesni i kreativni pojedinci svojim potencijalima, koje mogu razvijati izvan radnog vremena, izgraditi model društva po mjeri čovjeka u kojem će biti zadovoljene specifične 
ljudske potrebe. Te će se promjene direktno odraziti i na radno vrijeme u kojem tako oplemenjeni pojedinac doprinosi većoj proizvodnji (Marx, 1974).

Generalno gledano, zapadni sociolozi su se puno manje bavili pojmom slobodnog vremena nego dokolicom. Njihove su koncepcije nailazile na kritike s istoka, ruskih, poljskih i čeških sociologa. Oni im zamjeraju što izjednačavaju slobodno i oslobođeno vrijeme i što pri određenju slobodnog vremena umanjuju vrijednost rada, čak ga suprotstavljaju radu. Veličaju značaj zabave i razonode jer se čovjek tako rehabilitira od rada. Vrijednost dokolice su mjerili prema tome koliko ona može pomoći čovjeku da se oslobodi od utjecaja uobičajenih, rutinskih radnji koje mu nameće rad ili društveni sustav. Važna osobina ruskih shvaćanja je u čvrstoj povezanosti slobodnog vremena s radom u smislu puta kojim se rad mijenja i kojim mu se daje nova dimenzija, više ljudska i stvaralačka. Smatrali su da slobodno vrijeme kroz svoje aktivnosti neminovno mijenja karakter proizvodnog rada, razvija proizvodne snage i mijenja društvo. Mogućnost intelektualnog i kulturnog uzdizanja radničke klase daje socijalističkim društvima izuzetnu vrijednost jer se stvaraju uvjeti za smanjivanje razlika među društvenim slojevima (Koković, 1977).

U sociologiji hrvatskih krajeva, slobodnom se vremenu prišlo kao neobično zanimljivom fenomenu koji se pokazao vrlo važnim utjecajem na život i opća društvena kretanja. Sociolozi su nastojali slobodnom vremenu prići na cjelovit način s težnjom da se obuhvate i shvate uzroci, prouči dinamičan karakter i ispitaju mogućnosti i značajne posljedice ovog fenomena $u$ suvremenom društvu. Pri njihovom se tumačenju mogu uočiti tri osnovne orijentacije. Prema prvoj, slobodno se vrijeme promatra u odnosu prema radu (Farkaš, 2014). Povezanost rada sa slobodnim vremenom ukazuje na dva osnovna pristupa tom fenomenu. Za jedan je pristup dominantna dimenzija vremena kao takvog, a za drugi usredotočenost na kvalitetu provođenja slobodnog vremena (Parker, 1985). Ono je u suprotnosti prema proizvodnom radu, kao vrijeme oslobođeno organiziranog rada. To je ono vrijeme koje se kreće samo iz sebe, vođeno vlastitom voljom, znanjem i moći te postoji autonomno, samosvrsno, ima svrhu u sebi samome i prisebno je vrijeme. Naličje je radnog vremena u kojem se čovjek oporavlja za novi radni dan i ispunjava biološke potrebe (Komar, 2009). Previšić (2000) iznosi da su rad i slobodno vrijeme prirodne i nerazdvojne aktivnosti koje određuju čovjeka kao homo sociusa i ne bi ih trebalo suprotstavljati, nego promatrati komplementarno. Vrijednost slobodnog vremena sastoji se u jačanju društvenog angažmana i svijesti pojedinca i njegovom duhovnom napretku kao preduvjetu kvalitetnijem društvu. Slobodno vrijeme je oslobođeno radnih, ali ne i drugih obaveza, zbog čega se samo uvjetno smatra slobodnim. Druga orijentacija, slobodno vrijeme smatra posebnom 
kvalitetom vremena s dominantnom osobinom samostalnosti u izboru aktivnosti kojima se pojedinac predaje u tom vremenu. To je vrijeme oslobođeno svih vrsta obaveza i može biti iskorišteno za pozitivan razvoj ličnosti, ali i za bezlične aktivnosti koje samo popunjavaju vrijeme. Naglasak je na slobodnom izboru prema željama pojedinca, bez bilo kakve obveze ili nužde, izvan svih profesionalnih, obiteljskih i društvenih obveza. U njemu pojedinac po svojoj volji odabire sadržaje aktivnosti odmora, razonode i stvaralaštva (Potkonjak i Šimleša, 1989). To je vrijeme intime u kojem pojedinac istražuje vlastite potencijale i nadoknađuje sve ono što je prema njegovoj prosudbi nužno ostvariti kako bi se osjećao cjelovitim i kompetentnim (Arbunić, 2002). Čovjek je oslobođen svake obveze s naglaskom da u tom vremenu pokušava razviti svoje sposobnosti (Valjan-Vukić, 2013). Prema trećoj orijentaciji, slobodno vrijeme nema osobnu kvalitetu nego je određeno vanjskim činiteljima koji usmjeravaju njegovo korištenje i oblikuju sadržaje. To je neproduktivno vrijeme koje je u službi kapitala i rada i u njemu se ispunjavaju umjetno izazvane potrebe. Čovjek je potrošač kojim se manipulira i priključen je pasivnoj, inertnoj masi ljudi čija je kreativnost neutralizirana.

Navedene orijentacije predstavljaju jednu od osnovnih razlika u promišljanju o fenomenu slobodnog vremena. Kaplan (1975), u skladu s prvom orijentacijom, identificira slobodno vrijeme kao autonoman napor u službi osobnog rasta i socijalnih interakcija. Ono je dio društvenog sustava unutar kojeg i oko njega su izražena ista životna opredjeljenja kao i u cjelokupnom društvu (Martinić, 1977). Istovremeno pruža različite mogućnost koje pomažu prevladavanju jednoličnosti, uniformiranosti, tromosti i pasivnosti pojedinca i društva te je tako u potpunoj suglasnosti s pronalaženjem smisla same ljudske egzistencije (Božović, 1979).

Slijedom vremena različita se i mnogobrojna promišljanja o slobodnom vremenu u Pedagoškoj enciklopediji (1989) objedinjuju u definiciju slobodnog vremena kao vremena u kojem je pojedinac potpuno slobodan i može ga ispunjavati i oblikovati potpuno samostalno prema svojim željama, a ne prema bilo kakvoj izvanjskoj nuždi ili po nekoj za život nužnoj potrebi. Slobodan je od škole i školskih obveza, slobodan od eventualnih obaveza koje od njega traže roditelji, npr. u vezi s kućanstvom ili kakvim drugim zaduženjima, kada nije okupiran poslovima koje od njega zahtijeva društvo, a koje on nije preuzeo potpuno dobrovoljno. S navedenim se značenjem slobodnog vremena slažu brojni teoretičari (Goodin, Rice, Bittman i Saunders, 2005; Robinson, 1977; Andorka, 1987). To je vrijeme kojemu se radujemo jer smo oslobođeni prisile i bavimo se aktivnostima koje nam pružaju zadovoljstvo. Možemo se i jednostavno opuštati, odmarati bez briga i obveza (Malić i Mužić, 1986). Vezano uz takvo shvaćanje slobodnog vremena, Ragheb i Tate (1993) ističu da slobodno odabrane aktivnosti 
uključuju uživanje, a kako ih odabrati trebalo bi naučiti u obitelji i u odgojno-obrazovnim ustanovama. Škole su institucije u kojima treba podučavati pozitivno korištenje slobodnog vremena.

U 21. stoljeću slobodno vrijeme sa širokom lepezom programa i oblika komuniciranja prerasta u funkcionalnu školu življenja te se povezuje sa školskim sustavom i svim ostalim sustavima kojima pomaže u osuvremenjivanju njihovih specifičnih djelatnosti. Tada slobodno vrijeme poprima vrijednosne značajke. Više nije samo popratna pojava rada, nego postaje poseban fenomen, najvrjedniji oblik ljudskoga života. A kada slobodno vrijeme percipiramo kao korisnost ono mora biti radno osmišljeno i popraćeno te kontrolirano rastom i razvojem društvene zajednice jer bi u protivnom bio upitan osnovni cilj ljudske egzistencije (Plenković, 2000). Također, mladi iz ovih društava slobodno vrijeme u značajnijoj mjeri više provode $u$ različitim strukturiranim aktivnostima poput sporta, umjetnosti itd., a slobodnovremenski angažmani potiču društvene identitete i samoostvarenja, koji utječu na povećanje kvalitete života uopće (Iso-Ahola, 1999).

Kao što je vidljivo iz prethodnog pregleda, tijekom povijesti je bilo mnogo pokušaja određivanja slobodnog vremena, znanstvenici različitih znanstvenih disciplina na različite načine promišljaju o slobodnom vremenu i njegovom značaju, a značaj dolazi od određivanja osobnih, društveno-kulturnih, ekonomskih i ekoloških prednosti koje proizlaze iz njega (Driver i Bruns, 1999). Russell (2002) ukazuje na to da se slobodno u ovome vremenu može shvatiti i kao djelovanje i kao aktivnosti (Argyle, 1996) usmjerene na postizanje stanja uma i „rekreacije duha“. Međutim, Kelly (1996) izlazi izvan vremena i aktivnosti kako bi opisao slobodno vrijeme kao iskustvo, kao posebno egzistencijalno stanje užitka i zadovoljstva. Slobodno vrijeme je socijalna dimenzija, gdje njegov utjecaj u zajednicama i subkulturama olakšava društvenu izgradnju univerzalnih značenja i koristi (Kelly, 1999).

Politika i religija kroz povijest kontroliraju slobodno vrijeme i njegova dužina mijenjala se ovisno o društveno-političkim prilikama u pojedinom razdoblju. Praćenje povijesnog slijeda omogućuje nam shvaćanje sadržaja i utjecaja slobodnog vremena na razvoj čovjeka i shvaćanje uloge slobodnog vremena u suvremenom društvu.

Danas je slobodno vrijeme zasebna društvena kategorija, fenomen društvene svakodnevice i predmet brojnih razmatranja. Rosić (2005) konstatira da slobodno vrijeme više nije dodatak životu već njegov dio te pedagogiju slobodnog vremena izdvaja kao posebnu disciplinu koja se bavi proučavanjem odgojnih utjecaja na mlade u okviru njihovog slobodnog vremena. Većina autora se slaže da slobodno vrijeme ne smije biti vrijeme samo za relaksaciju, 
razonodu, već vrijeme stvaralaštva, osobnog razvoja i ostvarivanja osobnih i društvenih interesa (Janković, 1973; Previšić, 2000; Rosić, 2005; Komar, 2009). To je vrijeme u kojemu čovjeka prepoznajemo kao homo univerzalisa, homo ludensa i homo autokreatora (Shaft, 1989, prema Mlinarević i Gajger, 2010). Slobodno vrijeme se povezuje s dobrobitima za fizičko i psihičko zdravlje, idejom o povećavanju dobrobiti u nekom području svog života, kvalitetom i količinom uživanja i učvršćivanja zdravlja te povećanjem aktivnosti u ostalim aspektima života. Stoga je sudjelovanje u slobodnom vremenu u značajnoj relaciji sa zdravljem i životnim zadovoljstvom jer doprinosi razvoju predanosti, kontrole, prihvaćanja izazova i smanjenju stresnih situacija (Godbey, 2003). Mihovilović (2000) navodi četiri ključne funkcionalne sastavnice slobodnog vremena današnjice: odmor, razonoda, kulturno usavršavanje i razvoj ličnosti. Ističe da je slobodno vrijeme nadopuna radu i razlikuje tradicionalno i suvremeno shvaćanje karaktera slobodnog vremena koje teži oblikovanju i stvaranju harmonične ličnosti i harmoničnog društva. Plenković (1998) to vrijeme smatra vrlo aktivnim i autonomnim ljudskim djelovanjem. Osoba se u tom vremenu ostvaruje kroz razne aktivnosti, igru, hobi i stvaralaštvo. Slobodno bi vrijeme, po njemu, trebalo biti popunjeno aktivnostima koje osiguravaju osnovu kvalitetnijeg života.

Nadalje, aktivnostima u slobodnom vremenu, kao što su ples i aktivnosti koje potiču društvenu participaciju, akumulira se društveni kapital (Urquia, 2005) te uključivanjem zajednice $\mathrm{u}$ aktivnosti slobodnog vremena nastaje demokratsko građanstvo i građanski angažman (Puntam i Gross, 2002), a sudjelovanje u rekreativnim aktivnostima povećava prijenos znanja (Arai i Pedlar, 2003; Jones i Symon, 2001) i utječe na stvaranje društvenih mreža (Inkpen i Tsang, 2005) čime stvara društvenu osobu. Slijedom toga, Glover i Parry (2005) sugeriraju da slobodno vrijeme kroz stvaranje društvenih mreža potiče društvenu produktivnost. Ovo stoljeće obilježava stvaranje veze između rekreacije, demokracije i općeg dobra. Počinje se poticati volonterski rad u zajednici u slobodno vrijeme (Tujillo, 2007).

Slobodno vrijeme kao dio svakodnevnoga života suvremenoga čovjeka u velikoj mjeri oblikuje način života pojedinaca i grupa (Ilišin, Bouillet, Gvozdanović i Potočnik, 2013). To je prostor koji daje mogućnost interakcije u procesima individualizacije, socijalizacije i inkulturacije, prostor samoaktualizacije i ostvarivanja osobnosti, ukupnost vremena, stanja i aktivnosti koje nisu uvjetovane biološkom, socijalnom i profesionalnom nužnošću (Previšić, 2000), a blisko je pojedinčevoj prirodi i njegovim potrebama (Lešnik, 1975). Ima četiri bitna obilježja: slobodu koja je bit samog čovjeka i temelj svih znanosti, stvaralaštvo kroz koje čovjek spoznaje, a zatim i ostvaruje tu slobodu, djelovanje koje smatra prijelaznim oblikom ljudskog 
življenja jer nosi element stvaralaštva i rada te rad koji ima mehanički karakter, a treba ga dovesti u vezu sa stvaralaštvom (Mlinarević, Miliša i Proroković, 2007). Nakon obavljanja neizbježnih aktivnosti, preostalo vrijeme pojedinac može iskoristiti za aktivni odmor, razonodu, pozitivan razvoj, socijalizaciju, humanizaciju i stvaralačko potvrđivanje ličnosti. Upravo ovakvo shvaćanje uloge, svrhe i zadaće slobodnog vremena stvara izazov odgoju, obrazovanju i pedagogiji (Previšić, 2000). Jer, kakogod doživljavali slobodno vrijeme, nužno je osvijestiti važnost njegova kreativnog, aktivnog, smislenog i strukturiranog provođenja (Mlinarević i Gajger, 2010).

Iz navedenih određenja proizlazi da je slobodno vrijeme jedan od nužnih uvjeta razvoja ličnosti i imperativ vremena u kojem je cjeloživotno obrazovanje izvjesna činjenica koja omogućuje da se pojedinac u svom razvoju suoči sa svim onim čimbenicima koje su izvan njegove moći i kontrole, ali i svima onima koji ga čine sretnim i kompetentnim (Mlinarević, 2006). U različitim pokušajima definiranja slobodnog vremena nailazimo na pojmove: dokolica, nerad, neaktivnost, aktivnost, rekreacija, vrijeme za aktivan odmor i razonodu. Ono ne predstavlja homogenu kategoriju i malo je dosljednosti u smislu kako slobodne aktivnosti karakteriziramo i definiramo. No, bez obzira na nepreciznost svih ovih definicija, sve se one slažu u stavu da pod pojmom slobodnog vremena podrazumijevamo ono vrijeme koje nam preostaje nakon svih naših obaveza, da postoje različite mogućnosti njegova provođenja i različite mogućnosti utjecaja na način njegova provođenja. Aktivnosti u tom vremenu su slobodnom voljom izabrane, neobavezne, isključuju vrijeme provedeno u školi, vrijeme provedeno u kućanskim poslovima i na radnome mjestu. Ono uključuje sport, medije i djelatnosti povezane s njima (TV, slušanje glazbe, različite igrice, čitanje), priredbe - glazbene, plesne i društvene uslužne djelatnosti (volonterstvo, crkva itd.) (Byrne, Nixon, Mayock i Whyte, 2006). Značaj slobodnog vremena dolazi od utvrđivanja osobnih, društveno-kulturnih, ekonomskih i ekoloških prednosti (Driver i Bruns, 1999), koje u njemu mogu nastati. To je čovjekovo pravo i privilegij te ga je važnije provoditi nego definirati (Henderson, 2010).

Trujilo (2007) za razumijevanje značenja slobodnog vremena u 21. stoljeću koristi četiri teorijska pristupa. To su: simbolički interakcionizam, društveni kapital, životni ciklus i generacijska teorija. Simbolička interakcionizam otkriva kako se u slobodno vrijeme dijele iskustva i stvaraju značenja i simboli koji postaju opće prihvaćeni. Poznato je da slobodno vrijeme nudi mnoge osobne prednosti, međutim, sa zajedničkim slobodnovremenskim iskustvima moguće je pojavljivanje društvenih i kulturnih prednosti. Tako nastaje društveno kulturni kapital. Simboličko interakcionistička perspektiva bavi se značenjima izgrađenim na 
proživljenim iskustvima i odnosima u svakodnevnom životu. Tako shvaćena neminovno zadire i u područje slobodnog vremena. Ova perspektiva koristi društvene procese interakcije među ljudima temeljene na teoriji Herberta Blumera (1937), simbole komunikacije, interpretaciju iskustava te društveno izgrađivanje sebe. Herbert Blumer je davne 1937. definirao pojam „simbolička interakcija“ kao osebujni i prepoznatljiv karakter interakcije kakva se odvija između ljudskih bića. Ljudska bića interpretiraju ili „definiraju“ radnje jedni drugih, umjesto da samo reagiraju jedni na druge. Njihov „odgovor“ nije izravno djelovanje jednih na druge, nego se temelji na značenju koje im pridaju takve akcije. Dakle, ljudska je interakcija posredovana pomoću simbola, po tumačenju, ili utvrđivanje značenja međusobne akcije. Ovo posredovanje je ekvivalent za umetanje procesa interpretacije između podražaja i odgovora u slučaju ljudskog ponašanja (Blumer, 1978, str. 97). Opće je prihvaćeno među istraživačima slobodnog vremena kao društveno-kulturnog procesa da se u međusobnoj društvenoj interakciji stvaraju zajednička značenja, što je i cilj društvenih interakcija. Dimanche i Samdahl (1994) pokazuju da simbolička značenja i koristi povezane s ugodnim aktivnostima čine osnovu slobodnog vremena. Postoji potreba za sagledavanjem uloge slobodnog vremena u životu ljudi te ono može biti u središtu života, a ne zanemareno.

Ponašanje u slobodnom vremenu može pružati ekonomske koristi u obliku ekonomskog rasta i razvoja, kao i povećane produktivnost osobnog rada i zadovoljstvo poslom (Mannell i Reid, 1999). Dok se pokazalo da neki oblici zabave imaju negativne učinke na okoliš (Kuss, Graefe i Vaske, 1990; Liddle, 1997; Pigram, 1993; Shipp, 1993), neki znanstvenici su dokumentirali pozitivne ekološke prednosti od ponašanja u slobodnom vremenu, poput povećane svijesti o okolišu, očuvanju okoliša i održivom razvoju (Aitchison, 1995; Locke, 1997, prema Tujillo, 2007; Nelson i sur., 1993).

Gledano iz zapadne perspektive, posao, obitelj i slobodno vrijeme predstavljaju tri najvažnija životna stupa i sva tri zahtijevaju uravnotežen dio našeg vremena (Kelly, 1987), ni jedna od ove tri dimenzije ne djeluje samostalno, one djeluju uzajamno i stvaraju osobu, zajednice i kulture. Životni ciklus i generacijska teorija otkrivaju kako skupine mladih utječu na kretanja u popularnoj kulturi i u konačnici utječu na tipove i iznos stvorenog društvenog kapitala što ukazuje na potrebu da se neprestano procjenjuju načini provođenja slobodnog vremena svakog pojedinca (Pepe i Bozkurt, 2010). Promijenjene vrijednosti suvremenog društva razlog su produljenju životnog vijeka i skraćenju radnog vremena te način na koji se troši slobodno vrijeme postaje ključno pitanje. Iako je poželjno da ljudi koriste svoje slobodno 
vrijeme na zdrav i konstruktivan način, često nedostaje planiranih aktivnosti (Zarotis, Katsagolis i Mitrotasios, 2007).

Tijekom slobodnog vremena shvaćenog kao diskrecijskog vremena preostalog nakon sastanka, radnih obveza, kućanskih poslova i ostalih potrebnih dnevnih aktivnosti (Goodin i sur., 2005), osoba ima mogućnost izbora kako ga provesti, hoće li se odmarati, uključivati u društvene interakcije, baviti se slobodnim radom ili jednostavno upuštati u samorefleksiju (Chatzitheochari i Arber, 2012). Slobodno vrijeme najčešće uključuje sudjelovanje u nekoj aktivnosti, bilo sami ili s nekim (Säfvenbom i Samdahl, 1998). Ono pruža priliku za užitak, sreću i samoizražavanje, način na koji ga pojedinac koristi utječe na njihov život u cjelini (Wang i Kao, 2006). Literatura identificira nekoliko prednosti povezanih s uključivanjem u aktivnosti slobodnog vremena. Neke od opće priznatih pogodnosti uključuju da potiče individualni razvoj, osobito među mladima, potiče sudjelovanje zajednice, omogućuje ljudima da eksperimentiraju s različitim ulogama u društvenim situacijama, potiče razvoj interesa i pruža ljudima mogućnost druženja s drugima (Säfvenbom i Samdahl, 1998; Mahoney i Stattin, 2000; Wang i Kao, 2006). Larsen, McGraw i Cacioppo (2001) navode da aktivnosti u slobodno vrijeme poboljšavaju individualnost rast i razvoj i predstavljaju važan dio života, posebno mladih. Caldwell i sur. (2004) smatraju da angažiranje u slobodnim aktivnostima olakšava razvoj samopouzdanja među mladima, jer osigurava sigurno i opušteno okruženje za vrstu učenja koje utječe na životne odluke, čime pridonosi uspješnom odrastanju. Prema Palen i sur. (2011), aktivnosti u kojima pojedinci sudjeluju tijekom svog slobodnog vremena mogu potencijalno pozitivno utjecati na njihov razvoj i zdravlje. Upravljanje vremenom odnosi se na obavljanje određenih ciljanih aktivnosti u cilju postizanja učinkovite uporabe vremena kako bi se olakšala produktivnost i ublažio stres (Claessens, Van Eerde, Rutte i Roe, 2007). Upravljanje vremenom je oblik samoupravljanja i zahtijeva donošenje pravih odluka u pravo vrijeme kako bi se postigao uspjeh. Ne može se stvoriti više vremena, vrijeme je nezavisna kategorija, stoga moramo imati izbor i pristup aktivnostima. Postoje mnoge studije o važnosti i prednostima upravljanja vremenom (Britton i Tesser, 1991; MacCann, Fogarty i Roberts, 2012; Nadinloyi, Hajloo, Garamaleki i Sadeghi, 2013). U posljednjih se nekoliko godina interes za upravljanjem slobodnim vremenom znatno proširio. Freetime management studije uključuju motivaciju za provođenje slobodnog vremena (Baldwin i Caldwell, 2003; Caldwell, Baldwin, Walls i Smith, 2004), stvaranje razlike između diskrecijskog i slobodnog vremena (Goodin, Rice, Bittman i Saunders, 2005). Neorganizirano ili nestrukturirano slobodno vrijeme često je izgubljeno ili se koristi za uključivanje u negativno ponašanje. Pod termin nestrukturiranog provođenja 
slobodnog vremena u dječjoj dobi svrstavamo period igre, a u adolescenciji, u europskim društvima, je to uglavnom period rada, dok u američkom društvu taj dio vremena otpada na razgovor, druženje (često više od dva sata dnevno). Vrijeme provedeno u tome da se „ne radi ništa” (čekanje, razmišljanje, engl. „hanging out”) uglavnom se odnosi na mlade iz postindustrijskih društava. Uočava se suodnos između slobodnog vremena i kvalitete života (Wang i Kao, 2006) i odnos između slobodnog vremena i dosade (Wang, Wu i Huan, 2012).

Koncept upravljanja slobodnim vremenom prvo su razvili Wang i Kao (2006). Prema njihovom konceptu, upravljanje slobodnim vremenom sastoji se od pet čimbenika: postavljanja i evaluacije ciljeva, tehnike, procjene, planiranja i neposrednog dogovora. Postavljanje i evaluacija ciljeva odnose se na sposobnost pojedinca planirati i odrediti prioritete koje treba obaviti tijekom slobodnog vremena. Tehnika se odnosi na sposobnost organiziranja slobodnog vremena i prikupljanja relevantnih informacija prije slobodnog vremena. Planiranje i neposredni odgovor odnosi se na sposobnost pojedinca da odgodi slobodno vrijeme ako ne bude u mogućnosti provesti svoj izvorni plan. Odgojno-obrazovne ustanove i odgajatelji mogu igrati važnu ulogu u pružanju obrazovanja za slobodno vrijeme podržavanjem i poticanjem učenika u boljem planiranju i upravljanju korištenjem svog slobodnog vremena. Način provođenja slobodnog vremena na boljoj osnovi vrlo je važno za adolescente jer će tako naučiti djelovati protiv društvenih i psiholoških problema. U protivnom će ovo razdoblje proći na puno teži način što može rezultirati napuštanjem zajednice i sudjelovanjem u marginaliziranim i ilegalnim skupinama.

U slobodnom vremenu se mogu organizirati razni tečajevi. Cjeloživotne vještine za slobodno vrijeme s ciljem povećanja njegovog pozitivnog korištenja mogu se integrirati u razvoj kurikuluma o korištenju slobodnog vremena. Škole mogu pružiti mogućnosti za slobodno vrijeme i prilike učenicima kako bi im pomogli planirati i konstruktivno upravljati svojim slobodnim vremenom. Povećavajući učenicima slobodne mogućnosti upravljanja, možemo im pružiti važna iskustva koja poboljšavaju njihov individualni razvoj (Klerk i BevanDye, 2014).

U mnogim se znanstvenim radovima o slobodnom vremenu ističe potreba za organiziranom društvenom akcijom na stvaranju uvjeta za njegovo sadržajno provođenje. Međutim, brojni sociolozi upozoravaju na ugroženost slobodnog vremena od pretjerane brige za njegovo provođenje. Kao što je u mnogim definicijama rečeno, slobodno bi vrijeme trebalo predstavljati vrijeme za odmaranje i vraćanje izgubljene snage. Način njegova provođenja treba biti slobodan, prepun mogućnosti iskazivanja vlastitog opredjeljenja, kreativnosti, maštovitosti 
pojedinca i grupa. Način provođenja ovisi o dobi čovjeka, njegovom društvenom statusu, osobnim i društvenim mogućnostima, o općim društveno-političkim odnosima u kojima pojedinac živi. To je vrijeme izazov za brojne utjecaje kojima mogu biti izloženi pojedinci i čitave grupe, usmjereni mimo prihvaćenih normi društvenih odnosa. U kapitalističkim društvima su uz pojavu slobodnog vremena vezane i pojave najrazličitijih ozbiljnih društveno devijantnih oblika ponašanja (bande huligana, odavanje drogi, prostituciji, nasilje, skitnje itd.) (Malić i Mužić, 1986). Pojava slobodnog vremena nije vezana za dob čovjeka pa se može govoriti o slobodnom vremenu i djeteta i odrasla čovjeka, jer svaki od njih ima svoje obaveze primjerene svojim mogućnostima, a svaka dob mora računati i sebi svojstvenim mogućnostima organizacije i provođenja.

Kad govorimo o utjecaju dobi čovjeka na količinu i način provođenja slobodnog vremena, moramo spomenuti da se Generacija y, tzv. digitalna generacija (1970. - 2000., rođeni 1946. 1964.) smatra najučenijom generacijom. Svjesni su održavanja aktivnog života te se to odražava i na njihov način provođenja slobodnog vremena. Dok generacija X (rođeni između 1960. i 1980.) preferira više intrigantna socijalna okupljanja, karakteriziraju ih nestabilnija radna mjesta, česte promjene poslova i želja za odjeljivanjem posla od slobodnog vremena (Delworth, 2010). U životu suvremenog čovjeka slobodno vrijeme ima vitalne funkcije kojima se može procjenjivati kvaliteta i zadovoljstvo životom ljudi neovisno o njihovoj životnoj dobi (Mlinarević, Miliša i Proroković, 2007).

Nemoguće je ne primijetiti društvene dobrobiti slobodnog vremena u vidu smanjenja društvene izolacije, uključenosti u zajednicu, društvene mobilnosti, svijesti o zaštiti okoliša i boljeg pogleda na svijet (Driver, 1990).

Nakon pregleda pojedinih shvaćanja slobodnog vremena, možemo izdvojiti određene karakteristike koje se mogu smatrati općim odrednicama ovoga fenomena (Kačavenda - Radić, 1986, prema Krivokapić, 2007, str. 97):

a) slobodno vrijeme je društveno, povijesno, klasno, ekonomski, kulturno i znanstveno, tehnološki i sl. uvjetovano,

b) slobodno vrijeme predstavlja integralni dio čovjekova vremena, zahvaljujući aktivnostima $u$ tom vremenu čovjek stvara, razvija i određuje svoju suštinu, radnu i individualnu,

c) slobodno vrijeme je vrijednosno obojeno što dolazi do izražaja kroz razne aktivnosti

d) slobodno vrijeme predstavlja (relativnu) slobodu izbora. 
Razmatrane teorije slobodnog vremena se prema Krivokapić (2007) mogu podijeliti u dvije skupine koje se zasnivaju se na analizi suvremene društvene stvarnosti i polaze od istog činjeničnog materijala, ali određenim društvenim momentima daju različite prioritete pa tako tvore i različite perspektive slobodnog vremena. U razvijenim zapadnim zemljama dominira koncept koji je usmjeren na vrijednosti tehnološkog društva. Rad se promatra kao priprema za slobodno vrijeme o kojemu se razmišlja u neodvojivoj korelaciji s vrijednostima većine $\mathrm{u}$ kojima dominira potrošačka dimenzija. Slobodno vrijeme je kvantitativna pojava. Drugi koncept slobodno vrijeme promatra kao prostor razvoja svih ljudskih potencijala, prostor koji mijenja sam rad i ublažava njegov prinudni karakter. Daje više slobode čovjekovoj kreativnosti i stvaralaštvu. To je vrlo idealističan i neobjekivan pristup pa se često pojavljuju nejasnoće pri uviđanju aktualnih društvenih pravaca i tendencija. Sociolozi često pokušavaju približiti ta dva pristupa i oduprijeti se ideološkim utjecajima, iako se sve više osjeća prevladavanje koncepta koji u slobodnom vremenu vidi ostvarenje humanističkih snaga društva. 


\section{3. 2. Slobodno vrijeme adolescenata}

Slobodno je vrijeme integralni dio sistematičnih promjena kod osobe, kognitivnih, psihičkih, socijalnih i psihosocijalnih (Doh, 2010). Ono je jedan je od onih fenomena svakodnevnoga života koji se često promatraju u relaciji spram mladih. Razlog tomu su i značajke slobodnog vremena i značajke mladih, pri čemu se pretpostavlja njihova višestruka interakcija (Ilišin, 2007). U raznim životnim stadijima omjer školskih obveza, obveznog egzistencijalno potrebnog rada, obiteljskih prilika i obveza te količine slobodnog vremena se mijenja što je osobito vidljivo u razdoblju rasta i razvoja (Dumazedier, 1967).

Glavaš (2010) slobodno vrijeme mladih definira kao ono vrijeme koje mladoj osobi preostaje nakon škole, vrijeme kada je osoba oslobođena ne samo školskih nego i obiteljskih zaduženja. To se vrijeme oblikuje prema vlastitim željama, bez ikakve obaveze. Može uključivati čitanje knjiga, odlazak u kino, učenje stranih jezika, igranje igrica i dr. (Hanžek, Holenko, Kojadin, Kolesarić i Morić, 2013).

Istraživanja pokazuju da adolescenti imaju dnevno na raspolaganju 3, 4 sata i više slobodnog vremena. Pokazalo se da se količina slobodnog vremena učenika razlikuje s obzirom na vrstu škole koju pohađaju. Tako je uočljivo da učenici koji pohađaju gimnazije imaju najmanje, a učenici obrtničkih škola najviše slobodnog vremena (Mlinarević, 2006). Opsežno izvješće (Larson i Verma, 1999) pokazuje da većina djece i adolescenata u SAD-u slobodnovremenskih aktivnosti imaju između 40\% i 54\% od radnog vremena, nešto je niži postotak kod europskih adolescenata koji imaju slobodnog vremena oko četiri sata dnevno u dvanaest europskih zemalja.

U postindustrijskim društvima kao značajni čimbenik provođenja slobodnog vremena spominje se media use (gledanje tv-a, slušanje glazbe) (Jeđud i Novak, 2006). Planetarni izum radija, televizije i računala cijeli svijet dovodi u ljudske domove, proširuju repertoar informacijskog posredovanja, a pojam masovne kulture postaje važno područje posredovanja sadržaja u slobodnom vremenu. Danas je slobodno vrijeme adolescenata obilježeno sofisticiranom informacijskom i komunikacijskom tehnologijom, stoga ne čudi brojnost recentnih istraživanja koja pokazuju da mladi većinu slobodnog vremena provode okruženi proizvodima i sadržajima masovne kulture (Ilišin i Radin, 2007; Miliša, Tolić i Vertovšek, 2009). Pokazalo se da je korištenje medija najučestaliji način provođenja njihovog slobodnog vremena (Jeđud i Novak, 2006). Mnoge odgojno-obrazovne teorije upućuju da su mediji, osobito društveni mediji, postali glavni socijalizacijski agens i način provođenja slobodnog 
vremena. Mladi s lakoćom prihvaćaju nove tehnologije informativnog, komunikacijskog i zabavnog sadržaja, pa se može govoriti o afirmaciji digitalne platforme u njihovom slobodnom vremenu. Internet je stvorio revoluciju u komunikaciji i postao najpopularniji masovni medij (Bubaš i Kermek, 2000). Zbog svoje je privlačnosti i reprezentativnosti, online mogućnosti, fonda sadržaja, dvosmjerne komunikacije, fleksibilnosti „u pogledu vremena i prostorne lokacije prilikom slanja i primanja informacija između korisnika i medija“ te „digitalizacije svih oblika informacija“ potisnuo tradicionalne medije (Bubaš i Kermek, 2000, str. 111) i postao sredstvo za zabavu. U usporedbi s njim drugi se oblici i načini provođenja slobodnog vremena čine dosadnim i zastarjelim, a istraživanje (Mlinarević, 2006) pokazuje da nisu zadovoljni ponudom sadržaja i prostora za provođenje slobodnog vremena u svojoj okolini.

Irbi i Tolman (2002) ističu da je slobodno vrijeme prilika za samoizražavanje, relaksaciju, vježbanje samokontrole te razvoj i učenje u drukčijim uvjetima, u kojima ih se manje kritizira nego u školskom ozračju. Naglašavaju da slobodno vrijeme predstavljaju oni sati u danu kad mladi nisu formalno angažirani u školskim, kućanskim ili radnim aktivnostima.

Prema Jeđud i Novak (2006), slobodno vrijeme je prostor za očitovanje problematičnog ponašanja mladih te je nužno u svakoj raspravi i pokušaju unapređivanja slobodnog vremena mladih voditi računa o svim njegovim socijalizacijskim učincima i čimbenicima.

Igranje, odmor i zabavne aktivnosti u slobodno vrijeme važni su u svakom dijelu života, a posebno u doba mladenaštva. Pojam slobodnog vremena najčešće se veže uz rekreaciju, kulturu, sport i odmor (Kooijman, 2002). To je vrijeme kad se mladi razvijaju individualno i u interakciji s drugima (Previšić, 2000). Slobodno vrijeme mladih može biti mehanizam za izgradnju društva, društveni je fenomen koji zahtijeva temeljitije stručne pristupe (Leburić i Relja, 1999).

U oblikovanju identiteta vrlo važno mjesto zauzimaju vršnjačke skupine u kojima su mladi povezani emocionalno i interesno. Vršnjačke skupine biraju svoje aktivnosti prema zajedničkim interesima i uglavnom ih prakticiraju u slobodnom vremenu (Rot, 1983, prema Jeđud, 2007). Učenici višeg sekundarnog obrazovanja se izjašnjavaju da svoje slobodno vrijeme najčešće provode u društvu vršnjaka i članova obitelji (Mlinarević, 2006). Zbog toga odgoj mora obuhvatiti ukupni život mladog čovjeka, njegovo obvezno angažirano vrijeme u školskim i obiteljskim obvezama i slobodno vrijeme koje na njih ima puno veći utjecaj.

Odgojni utjecaj aktivnosti u slobodnom vremenu na mlade vrlo je velik, nerijetko i veći od namjernih i ciljanih utjecaja kroz školski sustav ili druge oblike odgoja i rada. Izborom 
sadržaja, organizacijom provođenja slobodnog vremena, uključivanjem u društveno organizirane oblike provođenja slobodnog vremena, moguće je značajno utjecati na jačanje i razvoj svih fizičkih, intelektualnih, moralnih i estetskih potencijala mladih i zaštiti ih od negativnih utjecaja (Malić i Mužić, 1986). Iz čega proizlazi potreba dobrog organiziranja i sustavnog odgajanja mladeži u slobodnom vremenu koje je postalo najvažnija sredina odgojne stvarnosti te snažno utječe na njezinu koncepciju, organizaciju i učinkovitost. Zbog toga bi prosvjetna i odgojna politika trebala slobodnom vremenu mladih posvetiti puno više pozornosti (Vukasović, 2000) jer slobodne aktivnosti mogu biti izvor pozitivnog napretka, ali i nepovoljnih utjecaja (Mlinarević, 2006). Životno iskustvo i znanstvena istraživanja potvrđuju da su rezultati $\mathrm{u}$ organizaciji i provođenju slobodnog vremena obrnuto proporcionalni s pojavom antisocijalnog ponašanja i antisocijalnih grupacija (Vukasović, 2000).

Mlada osoba ima najviše slobodnog vremena, posebno u razvijenim društvima koja su stvorila uvjete za osjetno produžavanje tzv. socijalne mladosti, kada se zapošljavanje i radne obveze odgađaju za što kasniji period. Otuda i najveća pozornost organizaciji i provođenju slobodnog vremena mladih, gdje je i utjecaj kroz slobodnovremenske sadržaje i organizaciju aktivnosti moguće usmjeriti na svestrani odgoj ličnosti mlada čovjeka (Malić i Mužić, 1986).

Upravo je slobodno vrijeme jedno od onih područja svakodnevnog života mladih u kojem se, poglavito preko uvida u način njegova korištenja, odnosno učestalost obavljanja određenih aktivnosti, mogu detektirati interesi mladih, jer oni ,ispunjavaju i oplemenjuju slobodno vrijeme, pružaju mu sadržaj i daju smisao" (Pantić, 1980, str. 138). Što su interesi mladih raznovrsniji, njihovo je slobodno vrijeme sadržajnije je i bogatije (Ilišin, 2007).

Sadržaji koji se mogu provoditi u slobodnom vremenu ostvaruju se u izuzetno raznolikim aktivnostima. Mladi trebaju imati mogućnost slobodnog biranja djelatnosti prema svojim interesima, željama, sposobnostima i potrebama. Važno je da su one zanimljive, privlačne, da bude vedro raspoloženje, osiguravaju kulturnu razonodu, potiču razvitak sposobnosti, stvaralaštva, da navikavaju mladež na kulturno provođenje slobodnog vremena i na zdrav, osobno i društveno vrijedan i koristan način života (Vukasović, 2000). Slobodno je vrijeme ono područje svakodnevnog života u kojem se mladi najranije osamostaljuju i u kojem je njihova autonomija najveća (Ilišin, Marinović-Bobinac, Radin, 2001, str. 98). Važno je za razvoj ličnosti djece i mladih te pruža bezbroj mogućnosti za zadovoljenje njihovih potreba i interesa. U tome vremenu aktiviraju ona područja svoje osobnosti i kreativnosti koja nisu imali prilike pokazati u ostalim životnim područjima. Kultura i kvaliteta tog vremena ovise o kvalitativnim vrijednostima sadržaja u njemu (Mlinarević, 2006). 
Slobodnovremenske aktivnosti mladih mogu biti strukturirane i organizirane kao i nestrukturirane i neformalne (druženje) (Caldwell i Darling, 1999). Konstruktivno organizirane slobodne aktivnosti nastoje dobro iskoristiti slobodno vrijeme mladih jer tako pružaju vrijedne mogućnosti utjecaja i prakticiranja specifičnih društvenih, fizičkih i intelektualnih vještina koje su potrebne za pripadnost društveno priznatim i cijenjenim skupinama i uspostavljanje društvenih mreža s vršnjacima i odraslima (Byrne i sur., 2006). Njihov izbor i organizacija provođenja ovisi o dobi odgajanika, mjestu obavljanja i cilju koji smo odredili. Tako će se sadržaj aktivnosti u slobodnom vremenu predškolskog djeteta razlikovati od sadržaja aktivnosti učenika osnovne škole ili srednjoškolaca. Sadržaj se mijenja i ovisno o mjestu gdje se te aktivnosti provode (obitelj, predškolska ustanova, škola, društvena organizacija, sportske ili dr. organizacije). Izbor sadržaja ovisit će o mogućnostima pojedine sredine i o postavljenim ciljevima (želimo li utjecati na zdravlje, fizički razvoj, osigurati raznovrsnu rekreaciju ili mogućnosti svestranog razvoja i zadovoljavanja drugih potreba, kao povišenje obrazovanja, sadržajnijeg kulturnog života, zadovoljavanje hobija,..). Organizaciju i provođenje slobodnih aktivnosti mogu preuzeti razne dječje organizacije, organizacije za mlade, društveno-političke i kulturne organizacije. Društvena briga za organiziranje i slobodnog vremena zahtijeva i značajna materijalna sredstva organizatora i sudionika (Malić i Mužić, 1986). Nedostatak novca ograničava nas u načinu provođenja slobodnog vremena (Crawford i Godbey, 1987). Ta činjenica povezuje socijalni i kulturni kontekst života (Henderson, 2010). Istraživanje Roberts i Parsell (1994) otkriva da u Sjevernoj Americi mladi obrazovani pojedinci iz srednje klase i oni iz radničke klase imaju iste težnje za sudjelovanjem u strukturiranim slobodnim aktivnostima, ali si radnička klasa često to ne može priuštiti.

Neorganizirane i nevođene adolescentske aktivnosti u slobodnom vremenu mogu biti suprotne društvenim normama i vrijednostima (Hendry i Kloep, 2003). Takvo provođenje slobodnog vremena mladih može imati negativne posljedice koje proizlaze iz osjećaja dosade, što može rezultirati socijalnim problemima i različitim oblicima delinkvencije. To sugerira da je učinkovito planiranje i upravljanje slobodnim vremenom neophodno za povećanje koristi povezanih s pozitivnim aktivnostima u slobodno vrijeme i izbjegavanjem rizičnih ponašanja.

Mladi često slobodno vrijeme izjednačavaju s neradom što su pokazali i nizozemski i američki ispitanici (12 -18 godina) koji smatraju da je slobodno vrijeme nerad, vrijeme za ne raditi ništa, za zabavu. Oni žele ravnotežu osobnih i društvenih iskustava i smatraju da je psihološka dobrobit najveća korist od slobodnog vremena. Rezultati istraživanja koje je provela Trujillo (2007) pokazuju da mladi imaju dvije domene života, rad i slobodno vrijeme, koje se 
razlikuju po slobodi izbora i elementima zadovoljstva. Smatra se da obitelj i prijatelji ne predstavljaju vlastitu životnu domenu već utječu na obje spomenute domene.

U novije se vrijeme slobodno vrijeme konzumira kao roba, suprotno interaktivnom iskustvu koje utječe na životnu ravnotežu. Zato dolazi do smanjenja sudjelovanja u socijalnim strukturama koje stvaraju društveni kapital. Čini se da je slobodno vrijeme u Americi izgubljeno u konzumerizmu te se razvija ideja ponovnog razvijanja temeljnog stava rekreacijskog pokreta (Putnam, 1993).

Trenutno postoji malo provedenih istraživanja o razlikama obrazaca provođenja slobodnog vremena mladih, pogotovo unutar zapadno europskog konteksta. Međutim za uzorak španjolskih Europljana, Esteve, Martin i Lopez (1999) su utvrdili da su razina truda, socijalne interakcije i način ponašanja temeljne dimenzije značenja zabave. Osim toga, Jung i MoledaZdziech (1998) pokazuju da su se, kao rezultat europske kulturne politike, reforme medija i razvoj medijskih tržišta, postojanje javnih usluga i globalne reklame, zabavne djelatnosti razvile u cijeloj istočnoj Europi uz minimalne promjene i prilagodbe (Tujillo, 2007).

Sve su češće rasprave o promjenama značenja slobodnog vremena u postmodernom društvu, kojima se sugerira da distinkcija između slobodnog vremena i drugih sfera života postaje nejasnija. Pri tome se ukazuje na to da slobodno vrijeme postaje više fragmentirano i individualizirano, da slabe razlike između elitne i masovne kulture, te da se javljaju novi sadržaji i životni stilovi (Rojek, 1995; Scraton, Bramham, 1995; Scheerder i sur., 2005). Kada je riječ o mladima, posebna se pozornost usmjerava na tzv. kultivirano slobodno vrijeme, odnosno na vrijeme koje može potencijalno najviše pridonijeti razvoju ličnosti, a što je vrlo važan element procesa sazrijevanja i stjecanja identiteta. Otuda sadržaji koje mladi koriste u svojem slobodnom vremenu postaju značajna komponenta ukupnog procesa njihove socijalizacije (Ilišin, 2007). Provodeći slobodno vrijeme „viseći okolo“, družeći se s prijateljima ili sami, izgrađuju grupni i osobni identitet (Byrne i sur., 2006). No, primjećuje se da je većina mladih izgubljena u svijetu konzumerizma. Ispitivanje načina provođenja slobodnog vremena pokazuje različite obrasce slobodnovremenskih aktivnosti. Vrste slobodnovremenskih aktivnosti razlikuju se po dobi, spolu i društvenoj klasi. Skoro tri četvrtine adolescenata ima organizirane aktivnosti svaki tjedan, mlađi (12-13 god.) u većem postotku nego stariji (14 -15 god.). Ista studija pokazuje da mlađi uključivanje u strukturirane aktivnosti ne smatraju smanjenjem vremena za opuštenije slobodnovremenske aktivnosti. Autori razlikuju različite dimenzije nestrukturiranih aktivnosti. One uključuju igre vani, ulične sportove, računalne igre i aktivnosti u zatvorenom prostoru, različite računalne aktivnosti. Velika je 
većina muških ispitanika iz višeg društvenog sloja uključena u nestrukturirane aktivnosti, dok mlađi adolescenti iz nižih slojeva sudjeluju u širem spektru aktivnosti. Stariji su više fokusirani na aktivnosti kao slušanje glazbe, razgovori s prijateljima, druženje i gledanje televizije. Dob od 13 godina predstavlja prijelaznu točku za promjene slobodnovremenskih aktivnosti. Taj se prijelaz odnosi na smanjenje sudjelovanja u strukturiranim aktivnostima, posebno kod djevojaka.

Petnaestogodišnjaci u Kanadi najčešće slobodno vrijeme provode u društvenim aktivnostima s prijateljima, što uključuje druženje vani, razgovore putem telefona i zabave. TV im je druga najpopularnija aktivnost, na trećem su mjestu sport i fizičke aktivnosti, slijedi slušanje glazbe, sudjelovanje u glazbenim aktivnostima i igranje različitih igara (Shaw, Caldwell i Kleiber, 1996). George i Chaskin (2004) su proveli istraživanje u Chicagu među četrnaestogodišnjacima i utvrdili da jedna četvrtina učenika sudjeluje u strukturiranim aktivnostima, a mnogo ih više vrijeme provodi u nestrukturiranim aktivnostima kao što je gledanje televizije, igranje kompjutorskih igrica, čitanje i druženje s prijateljima. Međunarodno izvješće na 45 nezavisnih uzoraka (Biddle, Wang, Kavussanu i Spray, 2003) pokazuje da u gledanju televizije većina mladih provodi do 2,5 sati dnevno, video igre igraju oko 30 minuta dnevno. Vikendom se vrijeme gledanja televizije povećava. Možda najsveobuhvatnija longitudinalna studija o slobodnom vremenu adolescenata u Velikoj Britaniji provedena između 1987. i 1991., uključuje preko 9000 mladih od 9 do 20 godina. Cilj joj je bio istražiti mijenjanje aspekata strukturiranog provođenja slobodnovremenskih aktivnosti tijekom adolescencije te ispitati društvene $\mathrm{i}$ individualne čimbenike koji utječu na njihov izbor, nastavak ili odustajanje od njih. Uočene su tri faze promjene u provođenju slobodnog vremena mladih. U ranoj adolescenciji uglavnom biraju organizirane slobodnovremenske aktivnosti, uključujući aktivnosti pod vodstvom odrasle osobe $\mathrm{i}$ sudjelovanje $\mathrm{u}$ sportu. $\mathrm{U}$ srednjoj adolescenciji prevladava val odbijanja sudjelovanja u organiziranim slobodnovremenskim aktivnostima. Najznačajnije mjesto zauzima opušteno druženje s prijateljima na različitim mjestima. Uzorak starijih adolescenata pokazuje potrošački način provođenja slobodnog vremena, odlasci u kina, pabove i klubove, kao dominantan (Hendry, 1993).

$\mathrm{Na}$ izbor načina provođenja slobodnog vremena utječu individualne preferencije, društvene klase i spol. Mladi iz srednje klase vole biti uključeni u aktivnosti organizirane od strane odraslih, vole odlaziti u klubove, manje su angažirani u vršnjački orijentiranim opuštenim aktivnostima. Ekonomski status također utječe na uključenost u slobodnovremenske aktivnosti. Nezaposleni mladi u manjoj mjeri biraju komercijalne forme provođenja slobodnog 
vremena, više preferiraju druženje okolo i sudjelovanje u klubovima za mlade. Istraživanja pokazuju da dečki i djevojke iz viših slojeva društva imaju veći pristup i više mogućnosti za kvalitetnije provođenje slobodnog vremena (Zeijl, DuBois-Reymond i Te Poel, 2001). Slični su i rezultati istraživanja provedenog u Engleskoj (Ridge, 2002) koji pokazuju da djeca i adolescenti iz siromašnijih obitelji puno češće provode vrijeme gledajući televiziju i igrajući se vani s prijateljima ili u pasivnim aktivnostima kao gledanje televizije i slušanje glazbe. Nerijetko uživaju u alkoholu i drogama, česta su rizična ponašanja (Mayock, 2000; Mayock i Byrne, 2004). Gledanje televizije im nije prvi izbor, radije bi radili nešto drugo, ali im je nedostupno. Nekolicina ispitivane djece vrijeme provodi u klubovima za mlade ili strukturiranim aktivnostima s vršnjacima. Potrošačke slobodnovremenske aktivnosti biraju više djevojke nego dečki. Korištenje lokalnog susjedstva kao mjesta provođenja slobodnog vremena je u opadanju i češće je kod dječaka kao i boravak u pabovima.

Istraživanje provedeno u Hrvatskoj (Ilišin i sur., 2013) pokazuje da je „suvremena generacija hrvatske mladeži prvenstveno zainteresirana za fenomene koji nedvojbeno pripadaju sferi privatnosti (prijateljstva, poznanstva, zabava, razonoda, seks, ljubav i putovanja) dok je istodobno interes za sferu javnosti i tzv. velike ideološke teme (politika, vojska, nacija) još manji nego ranije kada je ionako bio na niskoj razini.“(Ilišin i Radin, 2002, str. 298). Najmanje slobodnog vremena, mladi provode čitajući knjige, odlazeći u kino, kazalište, angažiranošću u župi, posjećivanjem izložbi, volontiranjem u humanitarnim udrugama (Dragun, 2012). U stalnoj su potrazi za novim aktivnostima. Ono što bi moglo biti zabrinjavajuće je da većinu svog slobodnog vremena provode na internetu, a najmanje u kulturnim aktivnostima. Opasnost je u tome što je internet elektronički medij koji može doprinijeti razvoju različitih oblika rizičnog ponašanja, kao što su kockanje, klađenje, maltretiranje, maloljetnička prostitucija itd. (Opić i Đuranović, 2014).

Istraživanje koje je proveo Volonterski centar Dubrovnik (2014) također pokazuje da srednjoškolci svoje slobodno vrijeme najviše provode u druženju s prijateljima (79\%), slušanju glazbe $(78 \%)$, surfanju internetom $(75 \%)$, gledanju televizije $(68 \%)$, druženju s članovima obitelji (57\%), u odmaranju i izležavanju (57\%) i pomaganju u kućanskim poslovima (52\%). I u ovom se istraživanju među najslabije zastupljene aktivnosti svrstalo posjećivanje izložbi (4\%), pohađanje tečajeva (4\%), posjećivanje kazališta (5\%), bavljenje izvannastavnim aktivnostima (10\%), igranje igara na sreću (16\%) te volontiranje i sudjelovanje u radu različitih udruga (18\%). 
Postoje razlike prema spolu u načinu provođenja slobodnog vremena, izborima i preferencijama aktivnosti slobodnog vremena adolescenata (Athenstaedt, Mikula i Bredt, 2009; Fitzgerald, Joseph, Hayes i Oregan, 1995; Hilbrecht, Zuzanek i Mannell, 2008; Larson i Verma, 1999; West i Zimmerman, 1987). Mladi muškoga spola preferiraju timski sport više od djevojaka, dok su one češće uključene u pojedinačne sportske, glazbene i dramske aktivnosti (Leversen, Danielsen i Samdal, 2012; Pedersen i Seidman, 2005). I danas možemo govoriti o određenim stereotipima u načinu provođenja slobodnog vremena prema kojima je druženje i kulturne aktivnosti prikladnije za ženski spol, a sportske aktivnosti za muški spol. Istraživanje je pokazalo da djevojke više vremena provode na elektronskim medijima, u kulturnim aktivnostima, druženju, izlascima i opuštajućim aktivnosti, dok dječaci više slobodnog vremena provode baveći se sportskim aktivnostima (Brdar i Lončarić, 2003; Opić i Đuranović, 2014). U Irskoj je provedeno istraživanje o sudjelovanju učenika u sportskim aktivnostima (Fahey, Delaney i Gannon, 2005). Cilj je bio ispitati sudjelovanje učenika drugog stupnja obrazovanja u tri glavna stupa sporta: u okviru nastave tjelesne i zdravstvene kulture u školama, $u$ izvannastavnim aktivnostima i sportovima izvan škole. Studija pokazuje da se muški i ženski ispitanici jako razlikuju po pitanju sudjelovanja u sportskim aktivnostima. Dečki provode više vremena u sportskim aktivnostima nego djevojke. Na sljedećoj razini obrazovanja i njihov broj opada, a gledanje televizije zauzima veći dio dana.

Mnoge životne navike koje stječemo u adolescenciji iskazuju se u odrasloj dobi. Zbog toga je važno proučavati socijalno okruženje u kojem mladi žive $\mathrm{i}$ njihov angažman $u$ strukturiranim i nestrukturiranim aktivnostima u slobodnom vremenu. Slijedom toga, mnoga se istraživanja slobodnovremenskih aktivnosti mladih bave angažmanom u različitim izvannastavnim aktivnostima i dobrobiti koje to donosi. Pokazalo se da konstruktivno organizirane aktivnosti brinu o kvalitetnom korištenju slobodnog vremena mladih i pružaju vrijedne mogućnosti za razvoj i prakticiranje posebnih društvenih, psihičkih i intelektualnih vještina, pripadnost društveno prepoznatljivim i vrijednim grupama i stabilnosti uspostavljenih društvenih odnosa prema vršnjacima i odraslima (Byrne i sur., 2006).

Opsežna studija (Eccles, Barber, Stone i Hunt, 2003) pokazuje da je sudjelovanje u izvannastavnim aktivnostima u školama dugoročan pokazatelj pozitivnog razvoja što, između ostalog, utječe i na smanjenje ranog napuštanja škole. Izvannastavne aktivnosti mogu omogućiti lakše uključivanje $u$ društvo te razvoj individualnih interesa $i$ ostvarivanje dobrih rezultata $i$ postavljenih ciljeva. Kao takve, one mogu biti značajni čimbenici u razvoju anti-socijalnog ponašanja (Mahoney, 2000). Stoga se u istraživanju slobodnog vremena mladih akcent stavlja 
na tzv. kultiviranu dokolicu koja potencijalno najviše pridonosi razvoju ličnosti (Ilišin, 2000). Zbog svoje važnosti u procesu socijalizacije mladih, slobodno je vrijeme nužno promatrati kao „školu života“ (Rojek, 2010). To vrijeme treba biti poligon za poželjne i dugotrajne socijalne učinke jer se učenje zbiva na neformalan način u skladu s interesima mladih (Ilišin i sur., 2013).

Ako slobodno vrijeme shvatimo kao prostor samoaktualizacije i ostvarenja osobnosti, sasvim je razumljiv interes pedagoga za razumijevanjem, istraživanjem i unapređivanjem tog područja odgojnog djelovanja. On proizlazi iz cilja odgoja koji izražava usmjerenost na osobni razvitak učenika, njegovo osposobljavanje za kvalitetno, aktivno i odgovorno življenje. Javlja se potreba odgoja za korištenje slobodnog vremena koje obogaćuje i razvija osobnost te pretpostavlja vrijeme ispunjenja kreativnim djelovanjem i aktivnostima na osobnom razvoju i usavršavanju. Kroz procese identifikacije, interiorizacije i asimilacije koji se događaju u slobodno vrijeme, mladi usvajaju temeljne stavove i oblikuju svoje ponašanje (Mlinarević i Gajger, 2010).

Svakodnevica mladih je obilježena primanjem gotovih sadržaja i poruka, uz iznimku interneta koji je barem djelomično interaktivan, uključuje mogućnost socijalne interakcije i kreativnosti. Postoji praznina unutar dva područja njihovih aktivnosti: u onome koje uključuje elite i intelektualno zahtjevnije kulturne sadržaje. Upravo takve aktivnosti postaju iznimno važne u suvremenom društvu, koje od mladih zahtijevaju kumuliranje različitih znanja i vještina i kulturnog kapitala općenito i u području aktivnosti kojima se razvija društvena odgovornost i osjetljivost za probleme društvene zajednice (Ilišin, 2011).

Slobodno vrijeme se nalazi u središtu rasprave o subkulturama, to je sfera koja se smatra izvorištem subkulturne identifikacije, pa definiranje osnovnih pojmova poput „supkultura“ i „kontrakultura“ prati upravo odnos prema području slobodnog vremena. Mladi predstavljaju specifičnu subpopulaciju unutar ljudskog društva koja zbog svoje oskudnosti iskustva traži intencijalni napor društva kako prostor slobodnog vremena ne bi postao prostor besmisla ili mogućih društveno nepoželjnih ponašanja mladih, a čije posljedice osjeća društvo u cjelini trenutačno kao društvenu opasnost i u budućnosti kao stil življenja. Punkeri, skinheadsi, modsi, nogometni huligani, rockeri i teddy-boysi, u birminghamskim radovima smješteni su u radničku klasu, a njihovo stvaranje stila (kao simbolička solucija na problem) odvija se u sferi slobodnog vremena. Subkulturno djelovanje nazvano je „otporom kroz rituale“(Perasović, 2000, str. 412).

Pod subkulturom unutar adolescentskog svijeta podrazumijevaju se raznovrsne neformalne skupine koje, unutar sfere slobodnog vremena, izgrađuju svoje stilove, više ili manje kompleksne, na osnovi glazbe, imagea, slenga, navijanja na stadionima, sudjelovanja u 
ritualima ili modi, ali s odstupanjima svojeg ponašanja, svojeg simboličkog i vrijednosnog sustava, od onog uže i šire roditeljske kulture. Kontrakultura nastoji zamagliti ili prebrisati granice između sfere slobodnog vremena i sfere rada, škole ili obiteljskog doma. Jedna od prvih dimenzija koja se nameće kao zajednička svim subkulturama jest ona koja govori o slobodnom vremenu. Subkulture nastaju u sferi slobodnog vremena, ali ono što nastaje kao rezultat subkulturalizacije (identitet i simbolička potvrda postojanja ,afektivne zajednice“) izlazi iz sfere slobodnog vremena (Perasović, 2000).

\section{3. 2. 1. Ulica u kontekstu korištenja slobodnog vremena adolescenata}

Istraživanja pokazuju da je korištenje ulice kao mjesta provođenja slobodnog vremena čest izbor djece i mladih, posebno u siromašnijim područjima gdje nedostaje društvenih i rekreacijskih sadržaja (Matthews, Taylor, Percy-Smith i Limb, 2000; Morrow, 2001).

Iako je ulica zastarjelo mjesto za korištenje slobodnog vremena, mnogi autori je vide kao jedinu bazu koju su mladi u stanju zauzeti za sebe. Druženje po ulicama vide kao pružanje otpora odraslima. Brojne studije ističu da odrasli vide mlade na ulicama kao potencijalnu prijetnju za javni red. U novije su vrijeme popularni mediji značajno doprinijeli alarmiranju o ponašanju mladih ljudi koje često prikazuju kao nasilne i destruktivne vandale (Colozzi i Giovannini, 2003).

„Problem mladih“ je identificiran kao problem generacije koja ne odrasta kako bi trebala, žive u određenim zemljopisnim područjima i imaju prepoznatljive društvene karakteristike, npr. nepotpune obitelji (Wyn i White, 1997). Takvo viđenje „problema mladih“ doprinijelo je povećanju zabrane okupljanja i povećanom nadzoru nad javnim prostorima koje mladi koriste kao mjesta okupljanja i sastanaka.

U studiji o učinkovitosti rada s mladima u Velikoj Britaniji utvrđeno je da tinejdžeri najviše vremena provode „viseći okolo“ s prijateljima u dobi srednje adolescencije; 85\% djevojaka i 74\% dječaka provodi više vremena „,viseći okolo“ nego u bilo kojoj drugoj slobodnovremenskoj aktivnosti. Jedni i drugi kao najveći razlog za to navode druženje s prijateljima ,jer nemaju ništa bolje za raditi, a da izađu iz kuće“. Oni „višenje okolo“ vide kao normalan način druženja. Autori zaključuju da nema alternative za druženje što navodi sve više mladih da „vise okolo“ nego što bi to bilo u idealnim okolnostima. Istraživanje je pokazalo i da se značajan dio mladih bavi oblicima ponašanja koji izazivaju policijsku pozornost i 
intervencije. Mladi iznose da vrijeme na ulici provode pijući, pušeći marihuanu, sudjelujući u vandalizmu, većina ih spominje sukobe s policijom. Relativno je mali broj mladih koji su stalni prijestupnici i njihovi prekršaji nisu veliki. Autori su istaknuli pozitivan odnos između sudjelovanja u klubovima mladih i „višenja okolo“. Oni koji su uključeni u klubove mladih manje vremena provode „,viseći okolo“, zaokupljeni su raznim aktivnostima koje ih miču s ulice (Furlong, Cartmel, Powney i Hall, 1997). U europskim su gradovima svi formalno javni prostori privatizirani (Colozzi i Giovannini, 2003). Ova pojava privatiziranja javnih prostora uzrokuje izbacivanje drugih, osobito mladih s tih mjesta. Razvoj i urbanizacija mnogih urbanih sredina pridonio je smanjenju javnih prostora gdje mladi mogu boraviti.

Mnogi mladi ulicu smatraju neovisnim prostorom gdje se mogu ponašati kao odrasli daleko od znatiželjnih očiju. Tinejdžersko „višenje okolo“ predstavlja otpor mladih prema odraslima. Istraživači Colozzi i Giovannini (2003) smatraju da je „višenje okolo“ u društvu prijatelja, unatoč svojim negativnim konotacijama, i dalje poželjna slobodnovremenska aktivnost jer tako mladi stječu i razvijaju socijalne vještine.

Istraživanje provedeno u Irskoj 2005. na više od 2260 ispitanika u dobi od 12 do 18 godina pokazuje da postoje neke gotovo univerzalne aktivnosti adolescentske populacije (gledanje televizije, slušanje glazbe, „višenje okolo“ s prijateljima). Većina mladih smatra da je malo mogućnosti za provođenje slobodnog vremena u njihovim sredinama. Većina mladih iz nižih socioekonomskih slojeva doživjelo je financije kao prepreku za sudjelovanje u nekim aktivnostima. Mladi iz ruralnih sredina imaju poteškoće oko prijevoza do mjesta gdje se neke aktivnosti odvijaju. Autori ističu pozitivnu motivaciju mladih za aktivnosti u slobodnom vremenu, neovisno o spolu, dobi, socio-ekonomskom statusu i geografskim razlikama (Byrne i sur., 2006).

Mladi između 12 i 16 godina iz obitelji slabijeg socio-ekonomskog statusa često se bave nestrukturiranim, slobodnovremenskim aktivnostima, koje ne zahtijevaju dodatno plaćanje, kao što je gledanje televizije, slušanje glazbe i „višenje okolo“ s prijateljima. Istraživanja (Byrne i sur., 2006; Mlinarević i sur., 2007) na uzorku ispitanika od 12 do 18 godina pokazuju iste rezultate. Samo 2 od 25 tinejdžera sudjeluje u nekom obliku organiziranih aktivnosti. Mladi izvan velikih gradova, u manjim sredinama, imaju veća ograničenja i manji raspon ponuđenih aktivnosti (Daly i Leonard, 2002).

Pregled istraživanja načina provođenja slobodnog vremena adolesenata ne razlikuje se prema nacionalnim kriterijima. Na izbor aktivnosti utječu materijalni uvjeti, veličina mjesta življenja, ponuda aktivnosti na lokalnoj razini i uzrast. 
2. 3. 2. 2. Uloga suvremenih medija u slobodnom vremenu mladih

Još je prije više od desetljeća u razvijenim zemljama primijećeno da djeca većinu svog slobodnog vremena provode uz nove medije (de Haan i Huysmans, 2004).

U današnjim visokoindustrijaliziranim i urbaniziranim društvima, kulture i svjetovi su zasićeni različitim medijima koji imaju veliku moć nad suvremenom javnosti i nad privatnim životima ljudi. Neprestano su uključeni u život pojedinca i povećavaju mu domete (Leburić, Quien i Lovrić, 2008). Sloterdijk (2005) medije naziva enciklopedijom cirkusa. Svojom su svestranošću postali centralni element za organizaciju gotovo svih aspekata suvremenog života, stalno se ispreplićući s radnim i društvenim aktivnostima. Imaju svoje mjesto u druženju s prijateljima, društvenim institucijama, kulturnim sustavima ili osobnom razumijevanju svijeta i samoga sebe (Deacon, Pickering, Golding i Murdock, 1999). Govoriti o njima danas znači upravo priznati njihovu sveprisutnost, važnost i mogućnost utjecaja na djecu i odrasle. Međutim, suvremena tehnologija se shvaća kao ostvarenje racionalizacije svijeta, kao pobjeda umjetnog nad prirodnim, kao znak nadmoćnosti izvanjskog objekta nad subjektom (Lemos, 2001).

Teoretičari medija funkcionalističkog stajališta smatraju da mediji zadovoljavaju različite ljudske potrebe kao što su komunikacija, kohezija, socijalna kontrola te kulturalna kontinuiranost u društvu. Ispunjavaju potrebu za nadzorom, osobnim vodičem, odnosima s drugima, oblikovanje identiteta te intervencije i reakcije drugih osoba (Relja i Božić, 2012).

McQuail (prema Relja i Božić, 2012) navodi četiri tipa zadovoljenja koje mediji mogu pružiti:
a) zabava, bijeg iz rutine
b) osobni odnosi, nadomjestak pripadnosti zajednici
c) osobni identitet
d) nadzor, osjećaj da ste uvijek u tijeku s događajima.

Istraživanja slobodnog vremena i mladih su pokazala da je danas slobodno vrijeme učenika višeg sekundarnog obrazovanja obilježeno sofisticiranom informacijskom i komunikacijskom tehnologijom. Oni većinu svog slobodnog vremena provode uz sadržaje masovne kulture (Ilišin i Radin, 2007; Miliša, Tolić i Vertovšek, 2009). Digitalni mediji i online komunikacija postali su sveprisutni dio svakodnevnog života mladih u cijelom svijetu. Društvene mreže, online igre, video stranice i razni digitalni mediji kao iPod i pametni mobilni 
uređaji (smarthphones) postali su dio kulture mladih koji se danas bore za svoju autonomiju kao i generacije prije njih, ali oni komuniciraju, održavaju prijateljstva, igraju se i samoizražavaju kroz nove medije. Međutim, usvajanje novih medija od strane mladih vezano je za dugoročne i sustavne promjene društva i kulture.

Diskurs digitalnih generacija i digitalne mladeži pokazuje da su novi mediji osnažili mlade u propitivanju društvenih normi. Svjedoci smo porasta digitalnih medija kao oblika svakodnevnog izražavanja, cirkulaciju medija i komunikacije u kontekstu umrežene javnosti. Prijateljsko sudjelovanje, druženje i razgovori o pitanjima statusa i pripadnosti lokalnim vršnjačkim skupinama i sudjelovanje u interesnim skupinama događa se u više različitih specijaliziranih mreža znanja. Mladi se neprestano kreću između različitih žanrova sudjelovanja (Ito i sur., 2010).

Razvoj novih tehnologija krajem drugoga tisućljeća potaknuo je komunikacijsku revoluciju koja je započela tijekom 60-tih u SAD-u, što je snažno utjecalo na društvene i kulturne promjene (O'Sullivan, Dutton, Rayner, 1994). Ulazeći u sve segmente ljudskoga života kao sredstva komunikacije koja se baziraju na tehnologiji koja stvara most između komunikatora i primatelja (Dimbleby i Burton, 1998), svojom moći oblikovanja i utjecaja na javne i privatne živote te na brojne društvene, ekonomske, političke, moralne i tehnološke procese, mediji zadovoljavaju potrebu ljudi za informacijama i utječu na formiranje javne sfere i na političko odlučivanje (O'Sullivan i sur., 1994). Služe kao ogledala stvarnosti jer artikuliraju sveukupnu društvenu stvarnost istovremeno oblikujući i specifičan kulturološki kontekst u kojem se sami razvijaju i djeluju. U suvremeno su doba nastale nove kulture čiji su dio novi mediji. Kao takvi u mnogočemu su modificirali načine ponašanja i navike svih korisnika, a posebno tinejdžera koji putem njih održavaju prijateljstva, igraju računalne igrice i slušaju glazbu. Mediji su industriji zabave omogućili da postane aspekt stiliziranja života (Leburić i sur., 2008).

U socijalizacijskom smislu mediji sve više istiskuju školu, obitelj i druge dosadašnje utjecaje i tako utječu na cjelokupno formiranje vrijednosti i stilova ponašanja mlade generacije. Rezultati najnovijih istraživanja u Hrvatskoj i u zemljama Europske unije upozoravaju na činjenicu da se vrijeme mladih provedeno pred ekranima izjednačilo s vremenom boravka $u$ školama. Suvremeni bi se čovjek radije odrekao svega osim TV, računala, mobitela itd. Pomoću njih djeca lako bježe od utjecaja svojih roditelja. Mediji su manipulatori koji umjesto kreativne uporabe slobodnog vremena nude dokoličarenje i prosječnost, banalnost pretvaraju 
u vrlinu, a u dvadeset prvome stoljeću su se usmjerili prema području izmišljene stvarnosti (Miliša, 2006).

\section{3. 3. Internet i mobilna telefonija u svijetu mladih}

Današnji su adolescenti rođeni u tehnološkom svijetu u kojemu je gotovo sve digitalizirano. Koriste mnoštvo različitih tehnologija, često istodobno, vrlo rijetko ih se može vidjeti bez i jednog od suvremenih medija pri ruci. Značajan dokaz povezanosti, integriranja i interaktivnosti unutar novih medija je personalizacija medija putem MP3 playera i mobilnih telefona (2000. godine masovna uporaba mobitela istiskuje fiksne telefone iz uporabe). Mobitel je postao magični predmet (Myerson, 2001). 2006. godine 100\% ispitanika se izjasnilo da ima mobitel. Značaj mobitela kao novih tehnologija nemjerljiv je. Mobilna je komunikacija postala sastavni i nerazdvojni dio poslovne svakodnevice diljem svijeta (Leburić i sur., 2008). Mobilni telefoni i drugi bežični sustavi promijenili su način funkcioniranja komunikacijskog okruženja. Mobitel je postao glavni oblik komunikacije među mladima, postaje glavni oblik elektroničke komunikacije (Relja i Božić, 2012) i broj korisnika je u neprestanom porastu, od njegovih začetaka do danas. Devedesetih je u svijetu bilo jedanaest milijuna mobilnih telefona, a devet godina poslije 400 milijuna. Prema European Information Tehnology Observatory (EITO) krajem 2008. broj korisnika je iznosio 3,9 milijarde, a 2009. 4,4 milijarde. U rezultatima istraživanja iznosi se da $100 \%$ ispitanika posjeduje mobilne telefone, $23 \%$ posjeduje dva mobilna telefona, $3 \% 3$ i više. Kad zazvoni mobitel 6\% ispitanika prekida sve što su do tada radili da bi se javili, a 25\% bi se također javili. Wei i Venhwei (2003) iznose šest oblika zadovoljstva koje omogućuje mobilna telefonija: stjecanje informacija, socijalna korisnost (chat, zabava, komunikacija itd.), privrženost (poboljšanje odnosa s članovima obitelji), izražavanje vlastitog identiteta, mobilnost i dostupnost. Osim toga mobitel im često služi kao modni dodatak i način iskazivanja statusa (Relja i Božić, 2012). Temeljni motivi korištenja mobitela: dostupnost, emancipacija, sigurnost, mikrokoordinacija i korištenje mobitela kao statusnog simbola (Ling, 2000). Istraživanje provedeno u Sjedinjenim Američkim Državama (Lenhart, 2015) pokazuje da $88 \%$ mladih Amerikanaca imaju osobno ili imaju pristup mobilnim telefonima neke vrste, a većina (73\%) ima smarthphone. Oko trećina (30\%) ih ima obični telefon-mobitel, a 15\% ima obje vrste. Tablet ima 62\% djevojčica i 54\% dječaka, bez razlike u rasi i nacionalnosti; 91\% dječaka i 70\% djevojaka ima igraće konzole. Većina mladih ima 
pristup trima ili četirima od pet ponuđenih predmeta (desktop ili prijenosno računalo, smarthphone, osnovni telefon, tablet i igraće konzole).

Sedamdesetih godina dvadesetog stoljeća, izum mikroprocesora označava početak digitalne revolucije, a njen vrhunac počinje 90-tih smještanjem interneta u privatnu sferu. Digitalizacijom je omogućen spoj telekomunikacije i obrade podataka što uvjetuje nastanak oblika komunikacije koja se na značajan način razlikuje od nama poznatih situacija i uzroka usmene ili pisane komunikacije. Došlo je do uspostave globalne mreže čime je informacijsko doba dobilo novi zamah. Rađaju se nove kulturološke forme, kao digitalna TV, internet, elektroničke igre i dr. koje oformljuju nove umrežene zajednice. U tom se procesu neminovno mijenjaju stavovi, načini života i životni stilovi. Internet promovira novu, postmodernu kulturu i njene nove forme. On je osnovna pokretačka snaga informacijskog doba. Omogućuje nove oblike komunikacije, poslovanja i učenja. U cijelom tom tehnologijski razvijenom razdoblju pojavili su se različiti cyber mediji koji su sve popularniji diljem svijeta (Leburić i sur., 2008). Internet za mnoge korisnike i teoretičare predstavlja svijet slobodnih asocijacija, otvorene i permanentne komunikacije koji bez ljudskih aktivnosti ne bi funkcionirao jer kultura interneta, zapravo, odražava kulturu onih koji su ga stvorili (Ristić, 2011).

Nove generacije internet koriste kontinuirano, radi druženja i zabave, to im je način života (Rosen, 2007). Internet im je glavni izvor informacija i zabave i izgubljeni su bez svojih pametnih telefona. Vode brz tempo života u svijetu koji zamagljuje granice između realnog i virtualnog (Carr, 2010). U Americi je 24\% tinejdžera, u dobi od 13 do 17 godina je gotovo stalno online, to se olakšalo dostupnošću pametnih telefona. 92\% izjavljuje da su online svaki dan, uključujući $24 \%$ onih koji kažu da su na internetu neprestano. Više od polovine $(56 \%)$ uključuje se na internet nekoliko puta dnevno, a $12 \%$ jedanput na dan, samo $6 \%$ je online tjedno, a $2 \%$ rjeđe (Lenhart, 2015).

Globalna mreža, internet, u sociološkom smislu ima karakteristike interaktivnosti, multimedijalnosti, hipertekstualnosti, globalizirane komunikacije, komunikacije od mnogih ka mnogima, kooperativne proizvodnja, dekontekstualizacije i derealizacije (Fucks, 2008). Digitalna tehnologija i internet pružaju nove prilike za učenje, omogućuju pojedincima direktnu prodaju ideja, usluga ili proizvoda te pristup informacijama uz zadovoljavanje emocionalnih i psiholoških potreba. Javljaju se tzv. virtualne zajednice utemeljene na zajedničkim interesima. S druge je strane vidljiva pojava otuđenja, najčešće unutar obitelji, kao i mnogo drugih patoloških pojava i ovisnosti o novim tehnologijama, a dolazi do razlika u informatizaciji između bogatih i siromašnih tzv. digitalna podjela. 
Ova, danas široko raširena informacijska struktura, neprestano bilježi porast svojih korisnika u svijetu. Prisutno je stvaralaštvo umjetnika alternative, net-kulturne orijentacije (radionice, seminari, razmjena znanja, vještina itd.). Predstavlja model za fiktivna i idealizirana poimanja slobodnog prostora, neopterećenog moralnim kodeksima (cyber prostora). Ta njegova osobina, koliko god privlačna, stvara i brojne probleme jer informacije postaju dostupne bez obzira na društvena i kulturna ograničenja te politiku nacija i država. Internet razotkriva naličje globalizacije u svakom smislu. On je sudjelujući medij koji inicira simultano sudjelovanje različitih sudionika iz cijeloga svijeta. Postoji različita praksa njegove uporabe i sadržaj komunikacije unutar njega vrlo je različit. Nove informacijsko-komunikacijske tehnologije svojim su se ubrzanim razvojem, personificiranim kroz pojam interneta te prodorom u sfere društvenog i privatnog života ,inficirale“ i sferu kulture, kulturnog djelovanja. Kultura se isprepliće s internetom te nije moguće izbjeći kulturnu dimenziju interneta (Shields, 2001). Prema Castellsu (2003) kulturu interneta čini četveroslojna struktura koja obuhvaća: tehno-meritokratsku kulturu, hakersku kulturu, virtualno-komunikacijsku kulturu i poduzetničku kulturu, a ključna veza među korisnicima interneta je otvorenost i sloboda modificiranja programske potpore. Većina korisnika internetu pristupa instrumentalno, kao oruđu ili izvoru informacija.

Kao skupina, adolescenti internet najviše koriste kao oblik komunikacije. Interpersonalna komunikacija dominantan je oblik korištenja interneta kod svih dobnih skupina, iako on podržava različite usluge od pronalaženja informacija, elektroničke trgovine, do zabave (Stafford i sur. 1999, prema Goby, 2003). Najčešće su to instant poruke (IM), elektronička pošta, blogovi, društvene mreže i stranice za razmjena fotografija i video-igara i virtualnorealnih okruženja itd. Oni različite oblike komunikacije koriste istovremeno, kombinirajući ih (Baym, Zhang i Lin, 2004), a i unutar jednog oblika komunikacije najčešće rade više stvari odjednom, npr. najčešće se koristeći instant poruke istovremeno dopisuju s nekoliko osoba (Boneva, Quinn, Kraut, Kiesler i Shklovski, 2006; Jacobs, 2004; Lewis i Fabos, 2005). Od kako su se umrežena računala smanjila na veličinu iPhonea, korištenje se uvelike povećalo i dobilo novu dimenziju. Povezanost s mrežom postaje neprekinuta. Koristeći računalo kao svog pomoćnika, sve se više oslanjamo na njega u svim životnim situacijama i postajemo ovisni o njegovim uslugama te se odnosi mijenjaju i ono zapravo postaje naš gospodar, iako to ne želimo priznati. Mobilni pristup društvenim mrežama mijenja način korištenja društvenih medija i ostalih online aktivnosti. 91\% tinejdžera koristi internet preko mobilnih uređaja (Lenhart, 2015). Društveno umrežavanje putem interneta, razgovori i slanje tekstualnih poruka čine 
svakodnevicu društvenog života mladih, a time je i važan dio njihove socijalizacije. Pobornici pozitivnog utjecaja tvrde kako mobilna telefonija može biti i društveno korisna, ako razmjena enormnog broja SMS i E-mail poruka koje mladi šalju i primaju implicira pozitivnu sklonost ka komunikaciji i međusobnoj interakciji što $u$ konačnici rezultira socijalizacijom i afirmativnijim društvenim ponašanjem, što nije zanemariva činjenica niti u individualnom, niti u društvenom kontekstu. Ovi mediji nam omogućuju da se, i kada se ne nalazimo fizički zajedno, družimo, komuniciramo, izgrađujemo odnose. Što može imati veliki utjecaj na mlade. Telefonsko druženje i komunikacija ipak se pozitivno odražavaju u mladenačkoj socijalizaciji i njihovom društvenom funkcioniranju (Leburić i sur., 2008). No, život na mreži nije jednak druženju izravnog konteksta i bliskosti koju ono pruža. Ta želja za istovremenom komunikacijom, za informacijama, za seksom, za skrivanjem vlastitih tijela, za maskama i lažnim identitetima pod pseudonimima, za igrama i zajedničkim sudjelovanjem, mikrokretanja koja čine složenost suvremenog života slijevaju se u hladni terminal (Lemos, 2001).

Internet kao interaktivan medij postao je globalno sastajalište na kojemu se ljudi okupljaju i komuniciraju, razgovaraju, ogovaraju, svađaju se, prave važni i koketiraju na Facebook-u, Twiter-u, MySpace-u i drugim socijalnim (i ponekad antisocijalnim) mrežama. Uklanja granice i udaljenosti, približava ljude jedne drugima, daje mogućnost lakog uspostavljanje komunikacije s osobama miljama udaljenim jednih od drugih. Mreža je interaktivna, omogućava povezivanje (linkanje), pretraživa je, multimedijalna i pruža veliku količinu informacija, omogućuje multimedijski informacijski tok. Ona uvodi idealno eksperimentalno oruđe za iznalaženje ideja koje u ovoj novoj formi interaktivnosti nalaze potencijal da postanu pokretač i osnova za dugoročni razvoj svih segmenata kulture (Shields, 2001). Zbog toga nam je izuzetno privlačna. Međutim, kolikogod bila revolucionarna, ne treba je shvaćati kao glavnu i nezamjenjivu, najbolje ju je shvatiti kao posljednju u dugom nizu instrumenata koji doprinose oblikovanju ljudskog uma. Ona ima sposobnost simultanog zaokupljanja svih naših osjetila, osim, za sada, njuha i okusa. Pretvara nas u laboratorijske štakore koji konstantno pritišću poluge kako bi dobili mrvice socijalne ili intelektualne hrane, upravlja našom pažnjom (Carr, 2011). Razne službe oglasnih ploča, pa i sam internet, nude svojim korisnicima mogućnosti igre, formiranje foruma prema interesima, registarski popis podataka, elektroničku poštu i telekonferencije. One su sastajalište pojedinaca. Telekonferencije se pojavljuju kao odjek oglasne ploče, usmjerene su na interakciju između korisnika u stvarnom vremenu. Unutar nje nema emocija izraženih ponašanjem (Argyle i Shields, 1996). 
Za adolescente je internet najtraženiji oblik zabave jer je telefon, televizija, igrača konzola i radio, sve u jednom. Multitasking je njihov stil života (Car, 2010). Oni online rade ono što bi radili i u ostalim oblicima javnog života kojima imaju pristup, a često i ono što bi radili na mjestima kojima, zbog dobne granice nemaju pristup. Nove tehnologije im daju prostor za druženje i povezivanje s prijateljima. Za većinu adolescenata, internet se, uglavnom, koristi za formiranje i održavanje odnosa s postojećim offline prijateljima (Mesch, 2009). Najčešće se druže, natječu za društveni status, predstavljaju se i izlažu rizicima u procjeni granica društvenog svijeta (Peck, 2008). Internet im pruža odličnu okolinu za eksperimentiranje. Tu oni istražuju oblike samoizražavanja, socijalne interakcije, iskušavaju različite uloge i identitete te načine uklapanja u svijet odraslih. Mogu naučiti kako upravljati dojmovima, dobiju povratnu informaciju i vježbaju prilagođavanje zajednici što je ključna socijalna vještina koju stječemo iskustvom (Goffman, 1959). Različita socijalna okruženja, pa o ona online pomažu im da razviju ove vještine.

Većina korisnika interneta, a posebno adolescentska populacija, prihvatila je online mrežu kao prostor u kojemu okuplja obitelj i prijatelje, bez postojanja dobnih i socijalnih granica s relativno visokim stupnjem slobode u izražavanju vlastitih misli i osjećaja (Carr, 2010).

Adolescentima je posebno privlačno što oni na internetu aktivno sudjeluju u stvaranju i distribuciji zabave i informacija. Prvi puta u povijesti čovječanstva mladi su autoritet (jer o digitalnog tehnologiji znaju više od odraslih, od roditelja i učitelja) u području koje je vrlo važno za sveukupno čovječanstvo (Tapsott, 2008) i to ih jako privlači u ovaj virtualni svijet. Korištenje interneta od strane mladih $\mathrm{u}$ adolescentskoj dobi $\mathrm{u}$ neprestanom je porastu. Posvećuju mu sve više vremena, a i raznovrsnost aktivnosti se širi.

Kada se raspravlja o učincima nekog medija uvijek se raspravlja o njegovom sadržaju, postavlja se pitanje jesu li oni dobri ili loši. Entuzijasti hvale mnoštvo novih sadržaja oslobođenih tehnologijom i smatraju to demokratizacijom kulture. Skeptici, pak, osuđuju neizbrušenost sadržaja, smatrajući to zaglupljivanjem kulture (Carr, 2011). Dok neki smatraju (Biškup, 1981; Watson, 2003) da mediji prenose pravila ponašanja u društvo, čuvaju dominantne vrijednosti i kulturne norme te tako utječu na povećanje obrazovanja i stupnja kulture stanovništva, a pritom pružaju i zabavu, drugi im se suprotstavljaju (Tomić, 2007) ističući da su oni uvjetovali pojavu i oblikovanje fizionomije masovnog društva kao nehumanog i otuđenoga, kao društva strojnog komuniciranja. McLuhan i Sarnoff (prema Carr, 2011) ističu da sam medij, ne sadržaj, utječe na naše razmišljanje i djelovanje. Popularni medij oblikuje ono 
što vidimo i kako vidimo. Proizvodi moderne znanosti, općenito, sami po sebi nisu ni dobri ni zli, njihova vrijednost proizlazi iz načina na koji se njima služimo. Svaki novi medij mijenja nas i naš sustav poimanja života i vrijednosti. Mediji nas opskrbljuju materijalom za razmišljanje, ali i oblikuju proces mišljenja, a ljudski je mozak po svojoj prirodi podatan za promjene, njegove se stanice razvijaju i rastu uporabom, a atrofiraju neuporabom. Svaka djelatnost ostavlja trajan otisak na živčanom tkivu. Imajući to u vidu i uzimajući u obzir i internet kao medij i njegove sadržaje, uočljivo je da njegovo korištenje ugrožava sposobnost koncentracije i kontemplacije. Razmišljanje i znanje postaje površno. Miran, usredotočen, neometan, linearni um ustupa mjesto novoj vrsti uma koji želi i treba upijati i izbacivati informacije u kratkim, isprekidanim, često prepletenim naletima, što je brže moguće. Dokazano je da postoji važna povezanost između osjetilno-motoričkog doživljaja materijalnosti pisanog djela kojim se bavimo i kognitivne obrade njegovog tekstualnog sadržaja. Pomakom s papira na ekran ne mijenja se samo način kojim se krećemo pisanim djelom, taj pomak utječe i na stupanj pozornosti koji mu posvećujemo i na razinu udubljivanja u njega. Svijet ekrana se jako razlikuje od svijeta stranice, tu nastupa nov pristup sadržaju, intelektualna etika (Carr, 2011). Medijske konstrukcije stvarnosti značajno utječu na naše viđenje, opažanje i doživljavanje svijeta (Labaš, 2011).

Crumlish (2004) uočava pozitivan trend u digitalnom i online građanskom organiziranju. Primjećuje da se internet koristi za organiziranje dobrotvornih akcija od strane neprofitnih organizacija koje pružaju usluge i mogućnosti za građanski angažman kroz interaktivnu komunikaciju, uključenost $\mathrm{i}$ autonomno sudjelovanje u aktivnostima. Ove aktivnosti dodatno olakšavaju građansku podršku i otvorenost, što su dvije temeljne demokratske prakse. Internet možemo shvatiti kao vrata javnosti (McCaughey i Ayers, 2003) jer se pod utjecajem interaktivnih medija i World Wide Web-a mijenja način života, iskustva i načini provođenja slobodnog vremena i šire se preko društveno-kulturnih granica. Internet je, sa svojim prednostima i nedostatcima, najmasovniji i najanarhičniji medij današnjice (Shields, 2001). On je proizvod društvenih procesa i primjenjuje se u svim područjima ljudske djelatnosti.

Svaka nova tehnologija za sobom vuče manje ili veće društvene promjene, a svako novo tehnološko sredstvo komunikacije prije ili kasnije postaje uzrokom revolucije na koju se može gledati iz dvije perspektive, pozitivne i negativne. Zbog svojih su karakteristika novi mediji neminovno utjecali na niz društvenih promjena. Razvijene medijske tehnologije otvaraju vrata brojnim društvenim devijacijama, ali pozitivna strana im je što homogeniziraju neke društvene skupine, posebno među mladima koji su najbrojniji korisnici. Paradigma informacijske 
tehnologije zasniva se na tome da informacijska tehnologija operira na informacijama, a ne samo prema informacijama, da nove tehnologije utječu na sve segmente društva i da su sustavi mrežno ustrojeni. Informacijska paradigma je, nadalje, zasnovana na fleksibilnosti elemenata, a nove tehnologije konvergiraju u visoko integrirani sustav. Castells (2000) najvećom opasnošću smatra zaostajanje institucionalnoga i društvenoga razvoja za tehnološkim.

Adolescentima je internet osnovno sredstvo komunikacije. On polako ukida sve druge oblike komunikacije, postao je nužnost. Ljudi sve više vremena provode na internetu, čak više nego ispred TV-a, kod mladih često postaje i ovisnost. Mediji, uključujući internet, kultiviraju određene tipove društvenog ponašanja, potiču prijateljstva ili neke posebne interakcije. Možda su to neke nove kulture, u svakom slučaju, riječ je o novim formama društvenih odnosa, koje mogu biti bogatije, humanije i medijski perspektivnije (Leburić i sur., 2008).

Neograničene mogućnosti interneta i pametnih telefona vrlo zavodljivo privlače adolescentsku populaciju koja im prisupa bez ikakvih predrasuda te se ti mediji uvlače u sve pore njihovog života. 


\section{3. 4. Komunikacija putem interneta}

Riječ „komunikacija“, dolazi od latinskog glagola communicare što znači učiniti poznatim, podijeliti, proces u kojem će ono što ja znam doznati i drugi (Markić, 2010). Svaki komunikacijski proces podrazumijeva i određeni odnos među onima koji komuniciraju. Komunikacijski je proces predmet proučavanja posebne znanstvene discipline komunikologije koja se dijeli na (Brajša, 1994): opću komunikologiju, koja se bavi masmedijskom, novinarskom, organizacijskom, javnom, sekundarnom i neizravnom komunikacijom i interpersonalnu, koja se bavi izravnom, primarnom, neposrednom komunikacijom međi ljudima.

Međuljudska je komunikacija iznimno važna za ljudsku egzistenciju. Prvi koji je jednostavno i sveobuhvatno definirao zakonitosti unutar komunikacijskog procesa bio je Paul Wazlawick 1967. (Ajduković i Hudina, 1996).

Kada govorimo o komunikaciji među mladima, među učenicima, mora se istaknuti da se kompetentnost djelovanja u socijalnom, međuučeničkom okruženju očituje u pravilnoj interpretaciji komunikacije drugih učenika. Razina kompetentnosti direktno je povezana s društvenim statusom učenika, pa tako socijalno kompetentniji učenici imaju bolji društveni status (Markić, 2010). Učenička se komunikacija prema Fortmanu (2003) može dijeliti na dvije teorije: teoriju socijalnog identiteta i teoriju komunikacijske akomodacije. Teorija socijalnog identiteta polazi od toga da nedovoljno socijalno kompetentni mladi odvajaju svoj vlastiti identitet od identiteta skupine kojoj pripadaju ili koju simpatiziraju. Slijedom toga mijenja se i njihova komunikacija te počinju komunicirati kao pripadnici određenih skupina. Mladi su članovi većeg broja skupina koje su određene brojnim čimbenicima - dobi, spolom, kulturom, nacionalnosti itd. Svaki se od tih čimbenika u komunikaciji ističe više ili manje, ovisno o sadržaju o kojemu komuniciraju te ovisno o sukomunikatoru (Markić, 2010).

Teorija komunikacijske akomodacije uzima teoriju socijalnog identiteta za temelj u interakciji i komunikaciji između komunikanata. Teorija u svojoj osnovi opisuje i pojašnjava kako pojedinci mijenjaju ili prilagođuju oblike, načine i stilove komuniciranja, ovisno o načinu komuniciranja sugovornika, koristeći određene strategije, metode i postupke kako bi održali ili uspostavili određeni status unutar socijalnog okruženja (Fortman, 2003). Pritom koriste razne tehnike koje uključuju govorne strategije i strategije približavanja, razilaženja i održavanja trenutačnog statusa unutar komunikacijskog procesa (Shepard, Giles i Le Poire, 2001). 
Od početka 20. stoljeća, komunikacijska tehnologija unaprjeđuje oblike komunikacije. Govor, geste, pismo, zvukovi, nastavili su postojati, življi no ikad. Suvremeni oblici komunikacije u mnogome mijenjaju način i zakonitosti komuniciranja. Ovaj oblik komunikacije ne zahtijeva fizičko prisustvo pa rijetko dolazi do bliskih veza. Postoji mogućnost pogrešno shvaćenih i nejasnih poruka, a uviđa se i nedostatak poruka koje proizlaze iz fizičkog kontakta, kao i neverbalnih znakova koji podrazumijevaju intonaciju, pokrete tijela, izraze lica i fizički izgled (Milutinović, 2011).

Kada govorimo o internetski posredovanoj komunikaciji, Bakardijeva (2005) razlikuje racionalistički model internetske komunikacije i posvećenost online zajednicama. U racionalističkom modelu su korisnici fokusirani na pronalaženje informacija, a u drugome je centralna vrijednost druženje, društvenost, interpersonalna komunikacija. Suvremeni mediji donose nove oblike socijalizacije i nove poticaje za društvenost, ali i društvenu izolaciju, prekid društvenih veza u smislu kontakata licem u lice, negativne posljedice i utjecaj na obiteljski život i vrijednosti (Ristić, 2011). Vrijeme provedeno na internetu, bez online komunikacije, predstavlja asocijalnu aktivnost koja sve više dominira nad društvenom aktivnošću licem u lice. Naglim povećanjem uporabe novih oblika komunikacije dolazi do neravnoteže između međuljudske osobne komunikacije i komunikacije putem računala, razvija se u korist drugog, pa možemo reći da je primarno iskustvo ugroženo sekundarnim (Labaš, 2011).

Područje internetski posredovanih komunikacija vrlo je široko polje istraživanja. Iako je sigurno da razvoj digitalne tehnologije utječe na društveno okruženje, teško je istražiti društvene posljedice korištenja i razvoja ove tehnologije (Ristić, 2011).

Pojavom interneta i komunikacije putem njega, pojavljuje se pojam kibernetički prostor ili cyberspace koji je vrsta novog društvenog prostora koji omogućava ubrzanje komunikacije i proširenje određenih aspekata društvenog sustava na globalnom nivou, upućuje na društvenost i oblikuje svakodnevicu korisnika (Jones, 2002). Cyberspace mijenja odnos prostora i vremena, transcendentira fizičke i geografske, a i društvene granice. To je vrsta komunikacije koja se odvija zahvaljujući određenoj tehnologiji. On ima svoje podsustave: virtualne zajednice, cyber kultura i pojedinci koji koriste različite internetske aplikacije i programska rješenja (software), komunikacija globalnih dimenzija (Ristić, 2011).

Komunikacija pomoću interneta ili globalne mreže (online) pripada području cyber kulture. Ona predstavlja samo jedan od tipova komunikacije koju internet omogućuje, a istovremeno je spektar različitih tehno-kulturnih obrazaca koji nastupaju kao posljedica uporabe različitih software-a i aplikacija koje omogućuju kontakte i komunikaciju među 
pojedincima (Castells, 2003). Takva komunikacija podrazumijeva čitanje, pisanje i komunikaciju putem umreženih računala, sinkroniziranu kompjuterski posredovanu komunikaciju u kojoj se komunicira u realnom vremenu zahvaljujući različitim vrstama računalnih programa. Tu ubrajamo i komunikaciju putem e-pošte, čitanje i pisanje dokumenata i njihova distribucija putem web-a. Takav oblik komunikacija povezuje medijski konstruirana tijela u sustav razmjene informacija (Pajić, 2012).

Suvremeni oblici komunikacije omogućuju anonimnost što oslobađa i introvertiranije osobe da se upuste $\mathrm{u}$ odnose $\mathrm{s}$ drugima. Tako često dolazi do toga da ne komuniciraju osobe nego umjetno stvoreni identiteti. Osobnost je fluidna i prolazna jer pojedinac može sam odabrati svoj način samoprezentacije. Komuniciraju osobe koje su predstavljene pseudonimima, oslobođene utega individualnosti. Može se smatrati da je takva osoba sjedinjena s drugim virtualnim pojavama cyber prostora (Lemos, 2001). Pogodnosti pseudonima su što omogućuju naglašavanje aspekata osobnosti koje se drže neprimjerenim u izravnom kontaktu.

U takvoj komunikaciji neminovno dolazi do formiranja novih pravila, pravila igre koje su sudionici dužni poštovati jer u protivnom, operator može isključiti nekoga iz elektroničkog komunikacijskog prostora radi kršenja interno dogovorenih konvencija (Krämer, 2012). U toj se virtualnoj stvarnosti odvija nepostojeći svijet simuliranog događaja. Današnja virtualna stvarnost pokazuje i omogućuje da događaji ne postoje samo na računalu pomoću kojeg se iskustveno komunicira već sami postaju iskustvo (Koković, 2007). Često se autor, vrijeme, mjesto ili fizička lokacija s koje se šalje informacija gube, pa možemo reći da internet doprinosi dekontekstualizaciji informacija (Fuchs, 2008). Takav oblik komunikacije neminovno izaziva određene posljedice u domenama izgradnje identiteta, svakodnevnih aktivnosti, potrošnje, socijalizacije, itd. (Ristić, 2011).

Kada govorimo o socijalizacijskim posljedicama online komunikacije, potrebno je identificirati načine na koje se odvija komunikacija. Pri tome treba imati na umu da su vrijeme i mjesto, tj. društveni kontekst korištenja interneta izuzetno značajni čimbenici u tome procesu. Ovakav oblik komunikacije ne mijenja u velikoj mjeri strukturu svakodnevice iako doprinosi raznolikosti sadržaja svakodnevnih aktivnosti (Bakardijeva, 2005). Kao dodatak društvenim aktivnostima, omogućuje odvijanje društvenih aktivnosti i komunikacije na drukčiji način, koristeći druga sredstva.

Mladima je taj oblik komunikacije izuzetno privlačan jer je komunikacija putem interneta (online komunikacija) produžetak društvene komunikacije osobnim kontaktom, lice u lice (Boyd, 2014) i drugim sredstvima. Idu na mrežu da bi čavrljali s prijateljima, da bi „ubijali 
dosadu“, da bi vidjeli „što ima“ i slijedili trendove. Time se mjesto druženja promijenilo, ali su osnovni sadržaji druženja ostali isti.

Ova vrsta komunikacije može biti sinkrona i asinkrona i omogućuje korištenje određene programske podrške i primjenjivog programa koji omogućuje vidljivost teksta, zvuka ili zvučno-vizualnog načina komunikacije (Ristić, 2011) što je mladima vrlo primamljivo.

Wittel (2001) pojam umrežene društvenosti suprotstavlja pojmu zajednice. Tvrdi da umrežena društvenost nastaje na temelju razvoja komunikacijskih i transportnih tehnologija te da nije dovoljno usredotočiti se na mreže kao takve već na procese njihovog nastanka. Najvažnijim obilježjima umrežene društvene stvarnosti ističe individualizaciju, nastanak kratkotrajnih odnosa, fokusiranje na informacije umjesto na narative, spajanje rada i igre te porast značenja tehnologije.

Programske podrške imaju društvenu dimenziju jer predstavljaju proizvod društvenih procesa. Pojam društvenih software-a obuhvaća različit spektar aplikacija (blogovi, liste, društvene mreže i dr.), a zajednička im je karakteristika da omogućuju ne samo komunikaciju među pojedincima već i suradnju među većim brojem, grupama ljudi što im daje sociološku dimenziju i dinamiku (Ristić, 2011). Oni su nastali i razvijaju se zahvaljujući ljudskoj komunikaciji i interakciji. Predstavljaju određenu vrstu znanja i mogu imati različite primjene u društvenom životu ili društvenim podsustavima (ekonomiji, politici i kulturi). Njihove aplikacije mogu se promatrati kao društvene činjenice jer predstavljaju objektivne izraze društvene kulture, egzistiraju nezavisno o korisniku (Fuchs, 2008). Karakter i značaj društvenih software-a mijenja se velikom brzinom, postaje dobra osnova za online komunikaciju i razvoj novih obrazaca društvenosti. Iako je primijećeno da internet i online komunikacija imaju pozitivne učinke na društvenu interakciju, potrebno je kontinuirano ispitivati u kojoj se mjeri to ostvaruje.

Komunikacija se odvija tako da se poruke koje potječu s istog mjesta istovremeno šire i vrše utjecaj daleko izvan tradicionalnih ,zajednica neposrednog kontakta“ i državno sankcioniranih javnih sfera, bez ograničavajućih svojstava konteksta, sankcija od društva i moralnih arbitara (Shields, 2001). U grupama za diskusiju poruke se mogu poslati od automatiziranih, anonimnih poštanskih službi u inozemstvu te se zatim šire nazad prema području u kojem autor živi.

Tehnologija se često smatra uzrokom razdvajanja jer se stvara virtualni socijalni svijet, virtualna interakcija i osjećaj virtualnog postojanja. Istovremeno dolazi do prekretnice 
socijalnih uređenja i tehnoloških sposobnosti, širi se životni svijet, računalni svijet preoblikuje konvencije i rutine svakodnevnog života. Internet stvara krizu granica između zbiljskog i virtualnog, između tijela i tehnologije, između osjećaja osobnosti i osjećaja prema promjenjivim ulogama. Da bismo održali razliku između života na mreži i života izvan nje, nužno je sačuvati razliku između socijalne interakcije unutar skupine na mreži i socijalne interakcije neposrednim kontaktom. Oba su načina komuniciranja vrsta socijalne interakcije (Shields, 2001), ali pomućene su granice između stvarne zbilje i virtualne zbilje (Bromberg, 2001).

Internet je dio svakodnevnoga života, dio najbanalnijih aspekata socijalne interakcije. Iskustva koja svakodnevno proživljavamo sadržaj su komunikacije putem interneta i bliska su njegovoj uporabi. Emocije i obične trivijalnosti koje čine svakodnevni život, predstavljaju mogućnosti za kontakt, mogućnosti da ljudi sebe učine osjetilno prisutnim za druge, preobražavajući se iz odsutnih i apstraktnih računalnih adresa u angažirane sugovornike (Argyle i Shields, 2011). Na internetu pojedinac nije sam, nego dio veće skupine koja se širi više nego što bi pojedinac mogao zamisliti. Svuda se dodirujemo u prolazu, korisnici se predstavljaju jedni drugima, razgovaraju otvoreno i čine što žele (Shields, 2001). Mreža je posredovana svakodnevnim životom.

Istraživanja o porukama unutar računalnih konferencija ukazuju na to da je tijek misli nalik struji svijesti, ali među korisnicima postoji snažna želja za tjelesnim. U mnogim se slučajevima dogodilo da novi korisnici napuštaju sustav ako ne sudjeluju u događajima odnosno osobnim susretima licem u lice koji ih zbližuju unutar socijalnog okvira. Tjelesni susreti uzrokuju povećanu potrebu za uporabom emotikona i izraza u zagradama jer tragovi sjećanja, dozvani od strane tijela kao i sami dijelovi tijela, omogućuju da iskustvo doživljavamo tjelesnim dijelom naše osobnosti i svim drugim višestrukim slojevima koji nas konstituiraju na načine koji ne zahtijevaju fizičku prisutnost (Argyle i Shields, 2011).

Tehnologija predstavlja primjer neprekidne motivacije da se promijeni koncepcija prostora. Na njen razvoj utječe želja obestjelovljene, otuđene subjektivnosti za transcendencijom tjelesnih granica. Ta kibernetički ostvarena transcendencija predstavlja sredstvo za spajanje hiperindividualizirane moderne svijesti u veću cjelinu. Virtualna je stvarnost spoj vizualne komunikacije i mehanizama koji omogućuju strojevima da čitaju ljudske geste. Time virtualizacija predstavlja materijalizaciju društva, a ne vodi njegovom rastakanju. Digitalne predstave društvenih institucija čine vidljivim ono što se u stvarnosti događa u društvu (Latour, 1998). 
Kolektivne utopijske fantazije na internetu proizvele su očaravajuće igre virtualne stvarnosti poznate kao MUD-ovi (Multi-User Dungeon), tj. tamnice za više korisnika, cyber mjesta na koja dolazi puno ljudi, a mnogi od njih danima ne izlaze. Mnogi imaju problem sa samokontrolom na MUD-ovima. Oni su lijek protiv usamljenosti i depresije, mjesta za izražavanje alternativnih identiteta i osobnosti. Stvara se iluzija moći (Bromberg, 2001).

Prednost cyber prostorvremena je što tamo možemo ostvariti svaku svoju fantaziju a možemo ostati anonimni. Ljudi se povezuju zbog zajedničkih interesa, a ne zbog svoje fizičke lokacije. Taj je prostor prostran, nema gužve, a svaki korisnik koji se osjeća skučeno može pokrenuti novu Usenet grupu za diskusiju. Tu je svaki okoliš virtualan, a ljudi se u njemu sastaju da bi pričali o temi koja ih zanima, nema središnje pozornice. Cyber prostorovrijeme je decentralizirajuće. Ono nam obećava oslobođenje od okova prostora, vremena i materijalnosti. Osigurava nam de se ne moramo opterećivati prisustvom drugih. Ono je bijeg iz geografske uokvirenosti u beskrajnu, zavodljivu, halucinogenu matricu podataka koja brzo i lako stvara ovisnost. S druge strane taj prostor smanjuje opseg i kvalitetu ljudskih susreta. Žitelji informacijskog doba rado se igraju osobnim identitetima. Što više miješamo sebe s našom virtualnom osobnošću to se više pretvaramo u strojeve. Pri radu na računalu djelić našega uma postaje dio računala (Turkle, 2012). Naša lica postaju zasloni, naše oči prozori koji uspostavljaju susjedstvo puno povjerenja. Izbacuje se osobna i privatna komunikacija licem u lice. Naša etička svijest slabi, postajemo slobodniji, a javlja se i prostakluk (Heim, 1993).

Internet nas spaja usmeno i pismeno. Ljudi su društveniji u uvjetima u kojima imaju veću kontrolu nad predstavljanjem sebe u svakodnevnom životu. Mreže su populistički mediji, a odnosi na njima imitiraju i posreduju stvarni život, a temeljna paradigma mreže nije kontrola nego širenje. Virtualna je stvarnost slična znanstvenoj fantastici ili kulturi droga. Interaktivna iskustva umreženih igara mogu imati podjednake učinke kao droga, a dostupnija su (Bromberg, 2001).

Razgovor putem interneta, naročito $M U D$-ovi, obavljaju za korisnika četiri socijalne funkcije (Bromberg, 2001):

a) Izolirani pojedinci u interaktivnoj komunikaciji mogu naći utjehu. Iako postoje saznanja da to obećanje povezanosti kao posljedicu može imati još veću izolaciju iz fizičkog okoliša.

b) Pruža mogućnosti igranja s identitetom. Korisnici mogu mijenjati identitete kako im odgovara, istražuju alternativne i poželjne identitete. Igrači istraživanjem unutar MUD-ova i skupina za razgovor mogu steći uvid u vlastiti identitet. 
c) Erotska privlačnost. Fantazija i mašta često se koriste s računalno-posredovanom simulacijom kako bi se ispunile zajedničke fantazije o erotičnoj fantaziji.

d) Ovladavanje računalnim okolišem također se pokazuje kao privlačna strana virtualne komunikacije. U virtualnoj zajednici kombinacija računalnih i verbalnih vještina znači visok status i prestiž.

Ekspanzija interneta otvorila je nove mogućnosti kroz superbrze i suvremene načine komuniciranja, s druge strane, otvorila je mnoge, zasad nerješive probleme s područja etike, od pornografije, neprimjerenih informacija, grubosti i okrutnosti do vulgarnosti (Ružić, 2008). Pravila dobrog ponašanja na mreži zahtijevaju da se poruke šalju u što ograničenijoj mjeri, da se ista poruka ne šalje više puta u različite grupe, da se ne ponavljaju, da nije dozvoljeno slanje tuđih radova bez njihovog dopuštenja, da su poruke prikladne za Usernet i određenu grupu, da se poruke ne smiju koristiti u komercijalne svrhe, te da se ne smiju slati ako je pošiljatelj uznemiren, ljut ili pod utjecajem opojnih sredstava (Horton i Spafford, 1993). No, elektronički okoliš postavlja mnoge probleme vezane uz nadziranje informacija i premošćivanje službenih kanala (Regan Shade, 2001).

Što više vremena provodimo online, više se navikavamo na obrasce ponašanja koji najčešće uključuju pričanje bez razmišljanja ili osuđivanje bez empatije. Tehnologiji se često okrećemo zbog nesigurnosti u odnosu prema drugima i straha od prisutnosti, u potrazi za načinom da istovremeno održavamo veze i od njih se štitimo. Sve više očekujemo od tehnologije, a manje jedni od drugih (Turkle, 2012). Kao da smo čvrsto odlučili pripisati ljudske osobine predmetima i ne brine nas činjenica što jedni prema drugima postupamo kao prema stvarima. Pri tome nam se tehnologija nameće kao tvorac istine, nudi nam zamjene koje potiskuju ono stvarno.

Iako internet podržava velik broj različitih usluga, dominantni način njegove uporabe je interpersonalna komunikacija. Mail i instant poruke zauzimaju vodeće mjesto u vremenu provedenom na internetu. Istraživanje koje je 2000. godine proveo National Geographic Society pokazuje da je najčešća aktivnost na internetu socijalna, odvija se preko elektroničke pošte i chata (Goby, 2003). Ljude prvenstveno provlači međusobna komunikacija (Putnam, 2000), a novi mediji za mrežno povezivanje nude strojno posredovane međuljudske odnose. To njihovo svojstvo doprinosi sve većoj popularnost. Uvode neke nove prakse, vrijednosti i razmišljanja o interpersonalnim odnosima i, u slučaju adolescenata, samostalnosti, a odrasli trebaju razmišljati o smislu svega toga (Manago, 2015). 
Mlade privlači pomisao na tehnološko zajedništvo. Očekuje se da mreža brani od usamljenosti i održava intenzitet veza. Tehnologija omogućuje stvaranje granice između prisutnosti i samoće (poruke, sms i sl.). Primijećeno je da tinejdžeri izbjegavaju telefonske razgovore, u strahu da se ne „otkriju previše“, radije šalju sms poruke. Oni smatraju da ono što se odvija u realnom vremenu oduzima previše vremena. No, postavlja se pitanje: obezvrjeđuje li virtualna prisutnost naš doživljaj druge vrste prisutnosti i uopće doživljaj susreta bilo koje vrste (Turkle, 2012).

Tehnologija ima osobinu koja se ljudima sviđa, omogućuje da s lakoćom komuniciramo i da se isključimo u trenutku kada nam to odgovara, što je pri fizičkim susretima jako teško. Prakticiranje takve komunikacije dovodi do razmišljanja spajaju li nas brojne mogućnosti društvenog umrežavanja ili nas razdvajaju (Turkle, 2012). Mogućnost slanja sms poruka nudi pravu dozu kontrole. Te poruke drže ljude ni preblizu ni predaleko, na idealnoj udaljenosti. Često kibernetička prisutnost prelazi u kibernetičku samoću. Bez naših se smartphone-a osjećamo isključeno, bespomoćno. Virtualne prostori nam nude veze s upitnom dozom bliskosti. Danas se lako postiže da osoba nikada ne bude sama i da uvijek ima intenzitet veze pod kontrolom. Zahvaljujući mobilnoj telefoniji sve nas se može „staviti na čekanje“.

Zbog svih svojih obilježja, društveni su mediji dobili ključnu ulogu u životima umrežene mladeži. Danas socijalizaciju mladih mnogo više oblikuju vršnjaci nego odrasli, a i najbolji je način socijalnog učenja kroz interakciju s vršnjacima. Segregacija prema dobi dovela je do razvoja distinktivne kulture mladih, u kojoj mladi oblikuju stavove i vrijednosti koji se razlikuju (ili su čak u suprotnosti) od onih koje propagiraju odrasli. Posredstvo elektroničkih medija donosi velike promjene u međusobnoj komunikaciji. Otkriva se sve, nema više tajni (Car, 2013). Znatiželja je zamijenjena cinizmom i arogancijom, a djeca dobivaju odgovore na pitanja koja nisu postavila (Postman, 1982).

Kako bi izbjegli institucionalne, socijalne i tehničke barijere koje im ograničavaju druženje, adolescenti koriste svoje načine kojima uspijevaju zaobići te barijere koje im odrasli autoriteti postavljaju. Lako pronalaze vrijeme da budu s prijateljima, integrirajući medije u svoja neformalna druženja. Nove tehnologije im omogućuju da kreiraju svoj privatni i javni prostor dok su fizički u kontroliranim prostorima od strane odraslih (Car, 2013). Sustav za slanje privatnih poruka služi kao privatni prostor dok društvene mreže pružaju javnu komponentu. Online grade okruženja koja podupiru njihovu socijalizaciju. Umrežena javnost je za njih postala suvremen način stvaranja socijalnih interakcija. Mnogi od njih izabiru druženje s prijateljima online radi izbjegavanja raznih socijalnih i kulturnih ograničenja. Osim 
toga, takva je komunikacija neprestano dostupna, s bilo koje lokacije, trajna je te može biti sačuvana ili ispisana. Uključuje napredne multimedijalne sastavnice i „virtualnu publiku“ (Larsen, 2007; Subrahmanyam i Greenfield, 2008; Valkenburg i Peter, 2008).

Društvene su mreže postale popularne među adolescentima zato što je to jedino mjesto na kojem adolescent nije pod stalnim nadzorom odraslih i kreira ga sam prema svojim potrebama i željama (Car, 2010). Iako im omogućuju komunikaciju i sudjelovanje u online zajednicama, društveni mediji nisu ni prvi ni jedini alati socijalne interakcije među tinejdžerima. Iako u manjoj mjeri, i dalje se koriste alati kao što su e-mail, instant poruke i online forumi. Kao kulturni fenomen, društveni mediji su preoblikovani u informacijske i komunikacijske eko-sustave (Boyd, 2014).

Uspostavljanje interpersonalnih odnosa jedan je od najvažnijih razvojnih zadataka adolescencije. Socijalne vještine temelj su svih odnosa, a one se razvijaju na tri načina potpomognuta tehnologijom: promatranjem, podukom i vježbom. Tehnologija omogućuje mnogobrojnije i češće prigode za njihovo uvježbavanje (Osit, 2008).

Osnovne poveznice online komunikacije i socijalnih odnosa učenika čine odrastanje u kompleksnom, dinamičnom i interaktivnom svijetu, s mogućnošću multitaskinga, balansirajući između različitih poslova, kultura i uloga (Thomas, 2007). Život u online zajednicama povezan je i stapa se sa životom u offline zajednicama. Ono što se radi online, slično je onome što se radi offline. U online zajednicama mladi prezentiraju svoju ljutnju, tugu, želju za popularnošću, ljubavne i seksualne nedoumice koje doživljavaju offline. U suvremenoj kulturi mladih mediji i online zajednice važan su socijalizacijski agens.

Online prijateljstva najčešće se temelje na zajedničkim interesima, vrijednostima, stavovima i uvjerenjima. Današnji tinejdžeri konstantno komuniciraju putem mreže. Obično šalju ili primaju poruku svakih par minuta, sve dok su budni. Zanimaju se za ono što se događa u životu njihovih prijatelja, a istovremeno žive u nevjerojatnom strahu da će, ako prestanu slati poruke, postati nevidljivi, ispasti iz igre.

Turkle (2012) uočava da tinejdžeri doslovno spavaju sa svojim telefonima. Čak i kada nisu uz njih znaju kada vibrira, poput fantomskog uda. Oni odrastaju očekujući neprekidnu povezanost, trajno priključenje. Sklapaju prijateljstva na društvenim mrežama, a često se kasnije pitaju jesu li uopće bili s prijateljima. Komuniciraju cijeli dan, ali nisu sigurni jesu li se uopće našli s nekim, druženje ih pomalo zbunjuje. Neprekidnim druženjem na mreži na neki način se osjećaju slobodni, a s druge strane sputani. Često koriste mreže za ispitivanje 
identiteta. Simulacija im stavlja na raspolaganje novi prostor. Pokušavaju se predstaviti, ali im profil na kraju djeluje tuđi i nerijetko odgovaraju nekoj zamišljenoj osobi kakva bi željeli biti. Nije neobično da provodeći dosta vremena u svom virtualno stvorenom životu ili u igranju uloga, izjave kako se osjećaju više svojima s identitetom stvorenim na mreži nego u fizičkoj stvarnosti.

Neki smatraju svoj život na mreži boljim od ičega do tada poznatog. Brzo kretanje mrežom pretvara se u osjećaj trajne prisutnosti na više mjesta odjednom. Ta višezadaćnost je prerasla u vrlinu i svako se njeno preispitivanje počelo smatrati čudnim. Mlade se hvali zbog sposobnosti da istovremeno obavljaju više zadataka. Stručnjaci su višezadaćnost proglasili vještinom za uspješan rad i učenje u digitalnoj kulturi. No, kada psiholozi proučavaju višezadaćnost ne nailaze na priču o novoj razini učinkovitosti i novim sposobnostima, naprotiv, takve osobe ne ostvaruju dobre rezultate niti u jednoj aktivnosti kojom se istovremeno bave. Uočeno je da studenti koji tijekom predavanja drže otvorena prijenosna računala ne postižu jednako dobre rezultate kao ostali. Tinejdžeri su najskloniji multitaskingu, njima je normalno da ih pri pisanju zadaće prekine poruka na Facebook-u ili sms-u. Dok se istovremeno se upravo oni žale da njihovi roditelji ne podižu pogled s mobitela tijekom obiteljskog objeda i da nose mobitele na sportska natjecanja u školi (Turkle, 2012).

Teško je imati na umu što je uistinu važno uz toliku buku neprekidne komunikacije. Ta nam je komunikacija donijela olakšanje, ali nas je na kraju ubacila u petu brzinu, stavila na pokretnu traku, a to nije isto što i produktivnost. Poruke se razmjenjuju bez prestanka, u nedogled, često bez ikakvih zaključaka. Dvosmjerna osobina online tehnologija kao što su email, oglasne ploče i chat sobe zahtijevaju aktivne korisnike.

Umreženi život utječe na sve ostale aspekte odrastanja. Adolescenti trebaju razvijati empatiju, preispitivati vlastite vrijednosti i identitet, nositi se s različitim osjećajima i naučiti ih pokazivati. Elektronički mediji pružaju jednaku priliku ekstrovertiranijima i introvertiranima.

Svijet brzih odgovora koji pokreće sms poruke ne omogućuje samopromišljanje i ne pridonosi njegovu razvoju. Dolazi do pretjeranoga pojednostavljivanja predstavljanja i samog razgovora što uzrokuje nedostatak udubljivanja u temu i interesa za osjećaje sugovornika i vrlo se lako gubi iz vida ono što je važno. Pri ovakvoj vrsti komunikacije ne vidimo kako naše riječi djeluju na druge. Na mreži ljudi propuštaju govor tijela, intonaciju glasa. Neverbalna komunikacija nije uključena i osoba ne može komunikaciju prilagoditi inicijalnim reakcijama sugovornika. 
Iako, s druge strane, možemo reći i da tehnologija potiče razvoj emocija jer daje priliku za formiranje misli i slanje drugima da je prokomentiraju. Razvoj prisutnosti tradicionalno je podrazumijevao privatnost i bliskost, a danas nismo sigurni kada će naša privatnost procuriti u javnost. Mediji najčešće prikazuju današnju mladež kao naraštaj kojemu nije stalo do privatnosti, ali to nije točno. Točno je da ni učenici, ni studenti ne razumiju pravila: Promatra li te netko? Tko? Je li praćenje zakonito? Ne razumiju uvjete korištenja društvenih mreža ili gmail-a, ne znaju na koji oblik zaštite imaju pravo (Turkle, 2012). E. Schmidt, izvršni direktor Google-a, izjavio je da ako postoji nešto što ne želite da itko dozna, možda to uopće ne biste trebali raditi.

Utjecaj mreže na mladež je paradoksalan. Neprestano su u kontaktu, a sve više su fizički odvojeni, pa i odvojenost danas dobiva drugu definiciju. Umreženost pospješuje igru s identitetom, ali je istovremeno teže ostaviti prošlost jer na internetu sve ostaje zauvijek. Ipak, anonimnost interneta omogućuje izgradnju online identiteta, odvojenih i drukčijih od stvarnih identiteta. Mladi žele eksperimentirati s vlastitim identitetom, za što mreža pruža dosta prostora, i pripadati skupini, ali povezanost donosi nove komplikacije i ponekad je teško pobjeći zahtjevima novoga okruženja (Turkle, 2012).

Adolescenti nisu više pod velikim pritiskom da razviju samostalnost kakvu smo nekoć povezivali s odrastanjem. Samostalnost adolescenata ne svodi se samo na odvajanje od roditelja, nego i odvajanje jednih od drugih, a oni se ne žele odvajati jedni od drugih, žele biti povezani, neprestano pišu poruke. Korištenje telefona svodi se na najmanju mjeru. Pišući poruke imaju osjećaj da su na sigurnoj udaljenosti. Tu pronalaze mjesto na koje se mogu sakriti, povući određene crte i sviđa im se mogućnost biranja s kim će biti na mreži. Stasaju novi naraštaji koji se drže dalje od vlastitih osjećaja i podalje od ljudi koji bi im mogli pomoći. Mreža pruža mogućnost susretanja puno novih ljudi, ali ih se doživljava kao povremene pojave, kao nešto što se može staviti na čekanje u slučaju da naiđe netko bolji. Te veze ne zbližavaju u pravom pogledu, ali nas zaokupljaju. Mladi nemaju više prijatelja nego prije unatoč mnoštvu „prijatelja“ na društvenim mrežama. Mreža pruža mogućnost biti „sami zajedno“ (Turkle, 2012).

Koliko god se mladi saživjeli s novom tehnologijom, ipak izražavaju osjećaj nostalgije za svijetom u kojem im se neće automatski uzimati podatci kao trošak sudjelovanja $\mathrm{u}$ umreženome životu (Turkle, 2012). U provedenom istraživanju (Rattinger, 2016) ustanovljeno je da $89 \%$ tinejdžera daje prednost druženju licem u lice i da im u slobodnom vremenu nedostaje druženja s prijateljima offline. Parks i Floyd (1996) okrivaju da se trećina ispitanika nakon 
upoznavanja online, kasnije susreću s prijateljima offline. Odnosi koji počinju na mreži rijetko tamo i ostaju. 


\subsection{DRUŠTVENE MREŽE}

Pojam društvene mreže odnosi se na sveukupnost društvenih odnosa koji okružuju pojedince. Društvene mreže su odnosi među ljudima koji mogu služiti i mnogim drugim funkcijama osim pružanja društvene podrške. One potiču stvaranje određenih resursa i normi koje nazivamo društvenim kapitalom (Ferlander, 2007). Struktura društvenih mreža može imati karakteristike specifičnih odnosa između pojedinaca i drugih ljudi u mreži i karakteristike mreže kao cjeline (House, Umberson i Landis, 1988; Izrael, 1982).

Iako se društvene mreže i društveno umrežavanje često koriste kao sinonimi razlika među njima postoji jer umrežavanje naglašava iniciranje i pokretanje odnosa među osobama, često među onima koje se ne poznaju. To nisu novi koncepti, već u različitim oblicima postoje oduvijek. Društvene mreže i društveno umrežavanje predstavlja jednostavan čin održavanja i/ili ojačavanja postojećeg kruga prijatelja i/ili poznanika te širenje njihova kruga (Kušić, 2010, str. 103).

Iako je stvaranje društvenih mreža i društveno umrežavanje moguće u stvarnom, realnom svijetu (npr. u četvrti, školi, učeničkom domu itd.), navedeni koncepti preneseni su u online okruženje čime online društvene mreže i društveno umrežavanje postaje vrlo popularno među mladima. Stvaranje online društvenih mreža i društveno umrežavanje omogućeno je putem društvenog softvera i internetskih stranica-servisa koji omogućuju samoprezentaciju, stvaranje, gledanje, korištenje liste prijatelja, pisanje komentara, slanje privatnih poruka, dijeljenje slika, videa, kreiranje grupa i drugih multimedijalnih sadržaja (Kušić, 2010).

Istraživanja društvenih mreža u neprestanom su porastu. Istraživački pristupi potječu iz različitih disciplina i smatraju se osobito korisnim za poboljšanje razumijevanja čimbenika koji utječu na usvajanje i korištenje društvenih mreža. Znanstvenici iz različitih područja pokušavaju razumjeti praksu, implikacije, kulture i značenje web stranica kao i angažman njihovih korisnika. 


\section{4. 1. Definiranje društvenih mreža}

Društvena mreža se može definirati kao skup sudionika i skup veza koje predstavljaju neki odnos ili nedostatak odnosa među sudionicima (Brass, Butterfield i Skaggs, 1998). Korisnici društvenih mreža (ljudi, organizacije ili drugi društveni subjekti) povezani su skupom odnosa, kao što su prijateljstvo, pripadnost, financijske razmjene, trgovinski odnosi ili razmjena informacija. Mogu biti orijentirane prema raznolikoj publici, privući ljude različitih zajedničkih interesa ili prema različitim rasnim, seksualnim, vjerskim ili nacionalnim identitetima, podjelama i sklonostima (Boyd i Ellison, 2007).

Možemo ih shvatiti kao relativno stabilne skupove između društvenih aktera (pojedinca, grupa, organizacija) koji uključuju razmjenu različitih resursa (materijalnih, usluga, informacija, vrijednosti, shvaćanja, normi, praksi i sl.) i posreduju određenu strukturu. Kao interaktivni društveni mediji pružaju korisnicima mogućnost stvaranja vlastitih web stranica, tema, grupa, foto galerija i online prijatelja uz visok stupanj međusobne povezanosti svih elemenata društvene mreže i brigu za samostalno određivanje stupnja privatnosti pojedinca (Vasić, 2010).

Online društvene mreže možemo definirati kao uslugu temeljenu na webu koja omogućuje pojedincima da (Boyd i Ellison, 2007, str. 211):

a) izgrade javni ili polujavni profil unutar omeđenog sustava

b) artikuliraju listu drugih korisnika s kojima dijele vezu

c) gledaju i koriste vlastiti popis veza i popise veza drugih unutar sustava

Uz pojam „društvenih mreža“ (eng. social network), u javnom diskursu pojavljuje se i pojam „društvenog umrežavanja“ (eng. social networking) te se ta dva pojma često koriste kao sinonimi, iako među njima postoji razlika. „Umrežavanje“ naglašava iniciranje i pokretanje odnosa, najčešće između osoba koje se ne poznaju. Iako je umrežavanje moguće na online društvenim mrežama, to nije njihova primarna praksa niti je to ono što ih razlikuje od drugih oblika računalno posredovane komunikacije. Ono što online društvene mreže čini posebnima je što pojedincima omogućuju da artikuliraju i učine vidljivima svoje postojeće društvene mreže, a ne da upoznaju nepoznate osobe. Na mnogim online društvenim mrežama, sudionici se nužno ne „umrežavaju“ odnosno ne upoznaju nove osobe već prvenstveno komuniciraju s osobama koje su već dio njihove šire offline društvene mreže. 
Društvene mreže su, za razliku od ostalih oblika računalno posredovane komunikacije, primarno organizirane oko ljudi, a ne oko interesa (Boyd i Ellison, 2007). Osnovna im je zadaća održati postojeća prijateljstva i stvarati nova (Sheldon, 2008). One su vrsta internetskog servisa, koji se najčešće javlja u obliku platforme, prozora ili web-stranice. To je internetski prostor, koji služi za međusobno povezivanje korisnika, zbližavanje i upoznavanje s novim ljudima. Izuzetno su zanimljive mladima, ali i svim drugim generacijama korisnika interneta. Većina korisnika služi se društvenim mrežama zbog jednostavnog uspostavljanja kontakta, grupiranja po osobnim interesima, dijeljenja fotografija te masovnog komuniciranja. No, nekima su društvene mreže korisne i u poslovnom smislu (Grbavac i Grbavac, 2014).

U posljednjih nekoliko godina pokrenute su stotine društvenih mreža, omogućujući korisnicima da se međusobno povezuju (Ellison, Steinfield i Lampe 2007). Obično je vrlo jednostavno postati korisnik neke mreže. To zahtijeva samo registraciju, naznačujući ime i adresu $e$-pošte, uglavnom besplatno. Nakon što dovrši kreiranje svoje profilne stranice, koja može sadržavati različite (osobne) pojedinosti, kao i slike i videozapise, korisnik se može početi povezivati s drugim članovima platforme. Jedinstveni aspekt društvenih mreža je to što pružaju ne samo priliku za upoznavanje novih ljudi i uspostavljanje veza, nego i činjenicu da je prijateljska mreža korisnika otkrivena i djelomično vidljiva za druge članove (Boyd, 2007).

Iako su granice između različitih vrsta mreža nejasne, možemo uočiti njihove osnovne orijentacije. Mogu biti orijentirane na prijateljstvo, kao što je Facebook, karijere ili poslovne orijentacije, kao što su XING, LinkedIn i prema inicijativama odnosa, prema romantici, kao što je Match.com ili mogu biti usmjerene na povezivanje osoba sa zajedničkim interesima poput glazbe ili životinja, poput MySpacea.

Postojanje i generiranje sadržaja društvenih mreža osiguravaju njihovi korisnici koji impliciraju da je samoobjavljivanje i aktivno sudjelovanje centralni mehanizam funkcioniranja. Ako korisnici ne otkrivaju informacije, umrežavanje se ne može odvijati. Dakle, temeljna ideja društvenih mreža je da korisnici mogu samostalno djelovati otvaranjem svog korisničkog profila (Zaglia, 2013). Stvaranje i korištenje već postojećih i novih odnosa s drugim korisnicima postaje središnji motiv za korištenja društvenih mreža (Heidemann i sur., 2012). Društvene mreže nude usluge i alate kojima se korisnici mogu povezivati, komunicirati s ostalim korisnicima mreže - prijateljima, poznanicima, kolegama i ostalima. No, iako dopuštaju povezivanje s prijateljima, Web 2.0 okruženja i društvene mreže također omogućuju anonimnost, olakšavaju pružanje lažnih ili obmanjujućih informacija i skrivanje ili ometanje verifikacijskih mehanizama (Grabner-Kräuter i Bitter, 2015). 


\section{4. 2. Razvoj društvenih mreža}

Novi oblici društvenih mreža kombiniraju osobine i komponente ranije postojećih oblika društveno-mrežnih sustava, ali iza profila, prijatelja, komentara i privatnih poruka, društvene mreže se uvelike razlikuju po svojim značajkama i korisničkim bazama (Boyd i Ellison, 2007).

Jedna od najranije nastalih online društvenih mreža bile su Bulletin Board Systems u 1980-ima koje su omogućavale korisnicima objavljivati javne poruke, slati i primati privatne poruke, igrati igrice te dijeliti programe (Rosen, 2007). Nakon toga su nastale stranice čija je svrha bila druženje i upoznavanje, ali i danas postoji veliki broj društvenih mreža s raznim namjenama.

U početku su online društvene stranice pokušavale spajati ljude na neki način povezane od ranih školskih dana. Stranica Classmates.com se pokazala kao vrlo dobar način za virtualno okupljanje te kao takva je postala popularna u Sjedinjenim Američkim državama. Korisnici ove društvene mreže nisu mogli stvarati svoje profile, ali je mreža omogućavala lociranje davno izgubljenih prijatelja što je privuklo jako puno ljudi, registrirano je više od 40 milijuna računa dnevno (Taprial i Kanwar, 2012).

Zatim su se pojavile stranice koje su omogućavale korisnicima kreiranje vlastitih profila (eng. profile) koji je zapravo web stranica s osnovnim informacijama (eng. basic info) koje uključuju datum rođenja, mjesto stanovanja, status veze (samac, u vezi, u braku i sl.), religijsko opredjeljenje, političko opredjeljenje, interese, citate, podatke o obrazovanju i zanimanju, te rubriku „o meni“. Prva takva društvena mreža, SixDegrees.com pokrenuta je 1997. godine. Osim stvaranja profila, mreža je dozvolila stvaranje popisa prijatelja i od 1998. surfanje listom prijatelja. Te su mogućnosti postojale i ranije, ali sada su prvi puta kombinirane. Funkcionirala je tako da je osoba registrirana na stranici mogla izlistati do deset prijatelja, ti prijatelji su se i sami mogli registrirati i izlistati deset svojih prijatelja i tako dalje. Bila je temeljena na teoriji da ni jedna osoba nije odvojena od druge s više od šest stupnjeva, odnosno šest osoba (Taprial i Kanwar, 2012). Stranica se koristila za traženje poslova, stanova, starih prijatelja (Boyd i Ellison, 2007). Svaka od navedenih značajki već je postojala u nekom obliku i prije, ali ova je mreža prva kombinirala te značajke. Ta se mreža promovirala kao sredstvo povezivanja ljudi putem poruka. Mreža je privukla milijune korisnika, ali nije mogla održati održivo poslovanje te je 2000. godine ugašena. Njezin osnivač vjeruje da je mreža bila ispred svog vremena (Boyd i Ellison, 2008). 
Neki istraživači tvrde da povijest društvenih mreža seže mnogo ranije, u 1978. godinu kada su M. Turoff i S. R. Hiltz na Institutu za tehnologiju u New Jerseyju izradili Elektronički sustav razmjene informacija (eng. The Electric information Exchange System, EIES) (Acar, 2008). Taj je sustav omogućavao korisnicima da si međusobno šalju e-mail-ove, da gledaju oglasnu ploču i koriste poslužitelja za popise (Hiltz i Turoff, 1978, 1993; Wasserman i Faust, 1994).

Od 1997. do 2001. raste broj alata za podržavanje raznih kombinacija profila i javno prikazivanje prijatelja. AsianAvenue, MiGente i BlackPlanet dopustili su stvaranje osobnih, profesionalnih profila i profila za upoznavanje. Korisnici su mogli identificirati prijatelje na osobnim profilima bez traženja njihove suglasnosti.

Sljedeći veći korak u društvenim mrežama počeo je 2001. godine kada nastaje Ryze.com, 2001. čiji osnivač Adrian Scot navodi da je prvi uveo stranicu svojim prijateljima, članovima San Francisco poslovne i tehnološke komunikacije, poduzetnicima koji su kasnije investirali u buduće društvene mreže (Scott, 2007. prema Boyd i Elison, 2007). Ta je platforma čvrsto isprepletena s Tribe.net, Linkedln i Frendster, osobno i profesionalno. Ryze.com je imao za cilj ojačati poslovne veze korisnika, a vjerovalo se da korisnici mogu biti podrška jedni drugima bez natjecanja (Festa, 2003; Boyd i Ellison, 2008). Nikada nije ostvario masovnu popularnost.

Friendster.com nastaje 2002. kao dopuna Ryse-u. Dizajniran je radi konkurencije stranici za upoznavanje Mach.com (Cohen, 2003), a svrha mu je bila da spaja prijatelje prijatelja pod pretpostavkom da bi oni bili bolji romantični prijatelji od potpunih stranaca (Boyd i Elison, 2007). Stekao je sljedbenike među blogerima, pripadnicima Burning Man arts festivala i homoseksualcima (Boyd, 2004). Do ljeta 2003. neki glazbeni sastavi, bendovi, iz San Francisca shvatili su da se preko ove stranice mogu približiti obožavateljima i promovirati se. Tako je došlo do širenja na globalnoj sceni. Tvorcima Friendstera to se nije sviđalo te zabranjuju takvu praksu i brišu profile bendova. Naišao je na tehničke i socijalne poteškoće i barijere. Tada je počelo masovno prikupljanje prijatelja, a počinju se pojavljivati i lažni profili tzv. „Fakesters“. Eksponencijalni rast uzrokovao je kolaps u društvenim kontekstima jer su korisnici suočavali svoje prijatelje, šefove, bivše kolege i sl. i to je uzrokovalo puno komplikacija te su Friendsteru počeli ograničavati mogućnosti. Ograničeno je gledanje profila ljudi koji su više od četiri stupnja udaljeni (prijatelji prijateljevog prijatelja). Mreža je imala oko 300000 korisnika, ali dolazi do tehničkih poteškoća i društvenog sudaranja te urušavanja povjerenja korisnika $u$ stranicu (Boyd, 2006b). Stranica postoji i danas i ima oko 75 milijuna registriranih korisnika, a 
najpopularnija je u Aziji (Filipini, Singapur, Malezija i Indonezija) gdje je dvostruko veća od bilo koje druge društvene stranice (Goldberg, 2007).

Stranica Ryze.com još uvijek postoji, ali nikada nije stekla masovnu popularnost, Tibe.net je prerastao u bazu strastvenih korisnika, Linkedln je postao moćan poslovni servis, a Friendster je postao najznačajniji, iako je, kako Chafkin (2007) navodi, jedno od najvećih razočaranja u povijesti interneta.

Od 2003. do danas pokrenute su mnoge društvene mreže. Dogster, mreža koja pomaže u povezivanju stranaca sa zajedničkim interesima, Care2 pomaže susrete aktivista, Couchsurfing omogućuje virtualna putovanja, MyChurch povezuje članove crkvenih zajednica,... Zbog njihovog masovnog pojavljivanja Clay Shirky (2003) osmislio je novi pojam YASNS (Yet Another Social Networking Service).

Godine 2003. pojavljuje se i MySpace.com (Lapinski, 2006), mreža koja vrlo brzo raste, oslanja se na Friendster-ove otuđene korisnike. Osniva je nekoliko zaposlenika tvrtke eUniverse iz Santa Monike, koji su odlučili iskoristiti njegove najpopularnije značajke. Dopušta korisnicima personaliziranje stranice i redovito se usavršava prema potražnji i potrebama korisnika (Boyd, 2006b). Prvi korisnici bili su upravo njegovi osnivači, a 2004. dolazi do masovnog uključivanja tinejdžera na MySpace jer je omogućeno uključivanje maloljetnika. Pozvao je bendove i tako vrlo brzo privukao pozornost rock glazbenika iz Los Angelesa. Glazba je „kulturno ljepilo“ među mladima, te kako su bendovi počeli oglašavati svoju prisutnost na MySpaceu, privukli su i velik broj svojih obožavatelja (Boyd, 2007). U SAD-u obožavatelji moraju biti stariji od 21 godinu da bi bili na mjestima gdje bendovi sviraju, a mlađa publika su strastveni potrošači glazbe i glazbene kulture. Kada su saznali da njihovi omiljeni bendovi imaju profil na MySpaceu počeli su se informirati o tome. Mogli su besplatno slušati i preuzimati glazbu, uživali su pišući slavnim glazbenicima koji su im rado odgovarali. Pojavio se simbiotski odnos između bendova i fanova. Bendovi su okupljali fanove, a fanovi se povezuju s bendovima i međusobno. MySpace je postao glavno mjesto za dijeljenje glazbe, videa i slika (Rosen, 2007). S obzirom na stupanj aktivnosti mladih u glazbenim subkulturama ne čudi da je MySpace okupio mlade obožavatelje. Mladi sudionici su vrlo brzo okupljali mnoštvo istomišljenika u svoju popularnu online zajednicu. Adolescenti i tinejdžeri vole mogućnost vizualizacije svog društvenog svijeta kroz mrežne zbirke profila. Mlađi sudionici vrlo brzo usvajaju različite strategije sudjelovanja od starijih sudionika. Dok su mnogi odrasli pronašli vrijednosti umrežavanja u socijalizaciji sa strancima, tinejdžeri su više fokusirani na druženje s ljudima koje poznaju i popularnim osobama iz javnog života (Boyd, 2007). 
Do sredine 2005. MySpace je bio popularno odredište za učenike srednjih škola širom SAD-a dok su mladi iz drugih zemalja bili na raznim drugim mrežama. Svaka je mreža stekla većinu svojih korisnika u određenom dijelu svijeta. Friendster na pacifičkim otocima, Orkut u Brazilu i u Indoneziji (Madhavan, 2007). Mixi u Japanu, LunarStorm u Švedskoj, Hyves u Nizozemskoj, Grono u Poljskoj, Hi5 u Latinskoj i Južnoj Americi i Europi, Bepo u Velikoj Britaniji, Novom Zelandu i Australiji, Cyworld je popularan u Korei (Ewers, 2006, prema Boyd i Ellison, 2007).

Kineska mreža QQ s mogućnošću trenutne razmjene poruka postala je veliki hit u svijetu kada je omogućila stvaranje profila i vidljive prijatelje (McLeod, 2006, prema Boyd i Ellison, 2007).

U SAD-u alati za blogove sa značajkama društvenih mreža poput Xange, LifeJournala i Wox-a privlače široku publiku. Skyrock je popularan u Francuskoj, Windows Live Spaces mreža je popularna diljem svijeta, u Meksiku, Italiji i Španjolskoj. Društveno organizirane mreže traže široku publiku, a profesionalne kao Linkedln stavljaju naglasak na poslovne ljude. Sve one služe za dijeljenje medija, fotografija, za slušanje glazbe i gledanje videa.

Facebook se pojavljuje 2004. kao akademska mreža dizajnirana s namjerom podupiranja studentskih mreža, no već se sljedeće godine proširuje na srednjoškolce, a potom na sve stanovništvo starije od 13 godina. Kreirao ga je Mark Zuckerberg kako bi zamijenio klasični razredni imenik kakvog dobiju studenti pri upoznavanju s novim fakultetom. U osnivanju Facebook.com mreže su sudjelovali Eduard Saverin, Dustin Moskovitz i Chris Hughes. Glavno sjedište mu je u Palo Altu u Kaliforniji. Broj korisnika ove stranice u stalnom je porastu, 2008. godine Facebook je imao 67 milijuna aktivnih korisnika, više od polovine korisnika posjećuju mrežu svaki dan, prosječno su oko 20 minuta dnevno na stranicama (Park, Kee i Valenzuela, 2009), 2011. stranica broji više od 800 milijuna aktivnih korisnika širom svijeta (Statistic, Facebook, 2019), a danas u cijelom svijetu ima više od 2,45 milijardi mjesečnih aktivnih Facebook korisnika. Prema Park i sur. (2009) četiri su osnovna motiva za sudjelovanje na Facebook-u: druženje, zabava, samopotvrđivanje i informiranje.

Većina društvenih mreža služi podržavanju postojećih društvenih odnosa. Ellison i sur. (2007) ukazuju da i Facebook podržava postojeće odnose offline, ti su odnosi ponekad slabi, ali obično postoji neka poveznica među osobama. 91\% američkih tinejdžera društvene mreže koristi upravo za povezivanje s offline prijateljima (Lenhart i Madden, 2007). Omogućuje stvaranje i personalizaciju profila ugradnjom aplikacija. Facebook je osobito popularan i koristan modul koji omogućuje forme na temelju zajedničkih interesa i djelovanja. 
Društvene mreže i „umrežena javnost“ podržavaju društvenost baš kao i javni prostori.

MySpace i Facebook i ostale društvene mreže omogućuju mladima druženje s prijateljima čak i kada nisu u mogućnosti okupiti se u neposrednoj situaciji (Boyd, 2008). Tinejdžeri su društvene mreže pretvorili u mjesto sastajanja, druženja i razmjene informacija. Tamo rade sve što rade i pri susretima licem u lice (Boyd, 2014).

Google se neuspješno pokušavao probiti na scenu društvenih mreža s projektima kao što su Google Wave, Buzz and Talk. Predstavljen je i Google Plus (Google +), koji je vrlo sličan Facebooku s nekim dodatnim značajkama kao što su „krugovi“ prijatelja te se mogu pozivati i dodavati prijatelji ili stranci s kojima dijelimo zajedničke interese ili hobije (Taprial i Kanwar, 2012).

Od 2000-ih godina dogodio veliki broj promjena u načinu na koji se koristio internet, a označile su ih dolazak Web-a 2.0 i njegove zamjene Web 1.0. Internet više nije bio mjesto gdje su korisnici odlazili kako bi konzumirali sadržaj i informacije kao što je to bio slučaj u prošlosti, postao je mjesto gdje se sudjelovalo, dinamični prostor oblikovan akcijama i doprinosima korisnika (Seargeant i Tagg, 2014).

Web 2.0 ima posebnosti: jednostavan je za upotrebu, olakšava socijalnost te osigurava korisnicima besplatno objavljivanje i učitavanje sadržaja u raznim oblicima (Lovink, 2011). Sve je to dovelo do brojnih promjena u načinu na koje su ljudi doživljavali društvenu organizaciju u online svijetu. Online interakcije i komunikacija se počela fokusirati na one koji se već poznaju u stvarnom svijetu, ali dobivena je i mogućnost za stvaranje i širenje društvenih veza i organiziranje oko zajedničkih interesa. Internet se počinje shvaćati kao alat za prezentiranje i promoviranje osobnih identiteta (Jones i Hafner, 2012) kao i prostor za samoprezentaciju u najboljem svjetlu.

Nagli uspon interneta obilježava nekoliko osobina i transformacija. Prva se odnosi na integraciju prethodnih medijskih oblika kao što su televizija, radio, tisak i sl., u jedinstvenu platformu. Druga na mogućnost interaktivnosti sa sadržajem. Treća podrazumijeva povećanje mogućnosti interakcije s drugim korisnicima na mreži. Nastojanja za udovoljavanjem zahtjevima za interaktivnijom i horizontalnijom komunikacijom sa sadržajima interneta i s ostalim korisnicima dovela su do stvaranja posebnih medijskih platformi među kojima su i društvene mreže (Krolo, 2015). 
Razvoj i ekspanzija aktivnosti vezanih za društvene mreže posljedica je brzog razvoja tehnologije koja je cijenom i jednostavnošću uporabe postala pristupačna prosječnom korisniku.

\section{4. 3. Značajke društvenih mreža}

Društvene mreže sve više privlače pozornost akademskih istraživača jer su od svoje su pojave privukle milijune korisnika među kojima je mnoštvo onih kojima je to postala svakodnevna praksa (Boyd i Ellison, 2007).

Postoje dva različita pristupa izučavanju mreža: prvi je ukorijenjen u sociologiji i teoriji organizacije i uključuje mreže kao analitičko sredstvo za osvjetljavanje društvenih odnosa, drugi je više interdisciplinaran i shvaća mreže kao posebnu vrstu logike organiziranja, kao način upravljanja odnosima između društvenih aktera. Oba pristupa sadrže niz zajedničkih karakteristika koje bi u budućnosti trebalo dosljedno razvijati u cilju koherentnijeg i konzistentnijeg pristupa izučavanju mreža (Powell i Smith-Doerr, 1994).

Danas postoji stotinu različitih društvenih mreža s različitim tehnološkim mogućnostima koje podržavaju različite interese i načine korištenja. Iako su njihove tehnološke mogućnosti slične, kulture koje se javljaju oko njih su različite. Većina web stranica podržava postojeće društvene mreže i pomažu povezivanje na temelju različitih interesa, političkih uvjerenja i aktivnosti (Boyd i Ellison, 2007), a razlikuju se prema svojim osobinama i korisničkim bazama, te stupnju uključivanja novih informacija i sredstava komunikacije kao što su mobilne komunikacije, blogovi i dijeljenje foto i video uradaka te po svrsi, izgledu, korisnicima i brojnim drugim karakteristikama.

Servisi za online društvene mreže prvenstveno se organiziraju oko ljudi, a ne oko interesa, kao što je to slučaj kod internetskih stranica (Boyd i Elison, 2008).

Odnosi između aktera jedne mreže imaju različite forme i sadržaje. Forma se može mijenjati prema intenzitetu, snazi, stupnju formalizma itd., a prema sadržaju se mogu ispitivati sasvim različiti odnosi između aktera: srodnički, prijateljski, interesno povezivanje, odnosi moći,... koji mogu biti višestruki i po formi i po sadržaju. Društvene mreže mogu posredovati u različitim društvenim događajima i političkim angažmanima. Neke studije upućuju da se društvene mreže više koriste u političke svrhe nego za zabavu. One jačaju društvene kontakte. 
Prethodne studije su pokazale da su zadovoljstvo životom i društveno povjerenje značajni čimbenici koji utječu na odnos između društvenih mreža i korisnika te političke i građanske uključenosti (Park i sur., 2009).

Zajedničke osobine svim društvenim mrežama su: ideja prijatelja koji prate što objavljujemo i sudjeluju u tome, postavljanje fotografija ili drugog sadržaja kojima ostvarujemo interakciju s drugima, stvaranje novih ili održavanje starih prijateljstava i mnoge druge osobine koje određuju suštinu i postojanje društvenih mreža.

Dijeljenje je jedna od osnovnih karakteristika društvenih mreža. One se temelje na pretpostavci korisničkog sudjelovanja i dijeljenja, što predstavlja radikalan pomak od tradicionalno medijski stvorenog sadržaja i kontrole prema korisnički proizvedenom sadržaju i utjecaju (Motion, Heath i Leitch, 2016). Sve veći utjecaj imaju društvene mreže koje svojim karakteristikama i mogućnostima pružaju korisnicima mogućnost stvaranja vlastitog sadržaja i prostora na internetu. Ljudi su na različite načine motivirani za dijeljenje sadržaja na društvenim mrežama. Neki od razloga su: objavljivanje zabavnih sadržaja prijateljima, samopredstavljanje drugima, kontaktiranje i ostvarivanje veza, osjećaj samoispunjenosti, širenje obavijesti (Mooney, 2015).

Sredinom 2000. godina, sa sve većim pristupom internetu i porastom društvenih medija, pogotovo MySpacea, Facebooka i Twittera, dijeljenje informacija i povezivanje s prijateljima online je postao integralni dio života za mnoge ljude, a pogotovo za adolescente koji su u najvećoj mjeri prihvatili razne alate za komunikaciju i dijeljenje informacija o privatnom životu, a sve u svrhu poboljšanja prikaza svog identiteta i ostvarivanja boljih socijalnih odnosa (Boyd, 2014).

Pojavom društvenih mreža pojavljuje se pojam umrežena javnost (eng. networked publics). Teško je definirati javnost. Kao pridjev, obično se koristi u suprotnosti s privatnim. Kao lokacija, javnost su mjesta koja su dostupna svima (ili odraslima). Javnost se često podrazumijeva kao nepoznata publika koja može svjedočiti nečemu. Javnost se odnosi na zbroj ljudi koji se međusobno ne poznaju, ali dijele identitet, uključenost, konsenzus oko zajedničkog interesa. Javnost je vrlo slična publici, oboje se odnosi na grupu sa zajedničkim interesima i zajedničkim pogledom na svijet (Boyd, 2007). Javni prikaz veza ključna je komponenta društvenih mreža. Kada govorimo o društvenim mrežama misli se na javnost koja je nastala uz pomoć umreženih tehnologija i pomoću njih je simultano prostorno konstruirana. To je imaginarna zajednica koja nastaje povezivanjem ljudi, tehnologije i prakse, preustrojene mrežne tehnologije koje istodobno čine i prostor imaginarnih zajednica koje su rezultat 
miješanja ljudi, tehnologije i praktičnog djelovanja. U prostornom smislu ona ljudima daje mogućnost okupljanja, povezivanja i druženja, a tehnologije imaju funkciju javnih centara ili parkova. Umrežena javnosti ima različite karakteristike od tradicionalnih fizičkih boravaka na javnim prostorima. Društvene mreže omogućuju javnosti ili publici da se okupi u isto vrijeme na jednome mjestu, u prostoru gdje se odvija razgovor. Same društvene mreže su javnost (Boyd, 2007). Na web stranicama možemo razlikovati javne i privatne profile gdje javni znači da je vidljiv svima, a privatni da je samo za prijatelje. Vrste javnosti koje se okupljaju na društvenoj mreži i vrste javnosti koje takve stranice podržavaju prilagođeni su za posredovanje prirodne interakcije. Zato je važno te stranice gledati kao opću, a ne samo umreženu javnost. Iako se ovaj drugi termin koristi za označavanje društvenih, kulturnih i tehnoloških dostignuća koja su pratila sve veću prisutnost digitalno umreženih medija. Radi se o prostorima i publici koji su povezani kroz tehnološke mjere (internet, mobilne mreže i sl.). Umrežena javnost je vrsta posredovane javnosti gdje mreža posreduje interakcije između članova javnosti. Razvoj posredovane javnosti omogućuju mediji svih vrsta (Boyd, 2007). Razlog za razlikovanje umrežene javnosti od posredovane $\mathrm{i}$ neposredovane javnosti ima veze $\mathrm{s}$ temeljnim arhitektonskim razlikama koje utječu na društvene interakcije. U posredovanom okruženju, granice i publika u određenoj javnosti su strukturalno definirane. Pristup vizualnim i slušnim informacijama ograničen je fizički jer zidovi i druge prepreke ometaju vidljivost. Publika je ograničena na one prisutne u ograničenom geografskom radijusu u određenom trenutku. Posredovanje tehnologijom, televizijom, radiom i novinama mijenja sve, mijenja razinu javnosti. Potencijalna publika je pod utjecajem posredovane tehnologije.

Umrežena javnost dodaje još jednu osobinu, a to je mogućnost pretraživanja povećavajući sva ostala svojstva. Osnovnu podjelu između neposredovane i umrežene javnosti čini (Boyd, 2007, str. 9):

a) postojanost - za razliku od prolazne kvalitete govora u neposrednoj javnosti, umrežene komunikacije bilježe se za budućnost što omogućuje asinkronu komunikaciju koja produbljuje duljinu postojanja svakog govornog čina

b) pretraživost - budući da je izražavanje zabilježeno i identitet utvrđen tekstom, pretraživanje i otkrivanje su alati koji pomažu u pronalaženju sadržaja; kada ljudi ne mogu pronaći geografske koordinate neke osobe u neposredovanom okruženju, pronalaženje nečijeg digitalnog identiteta online postiže se jednim pritiskom tipke

c) repliciranje - prepričavanje može biti pogrešno, loše interpretirano, dok umrežena javnost izražavanje može kopirati s jednog mjesta na drugo bez ikakvih promjena 
d) nevidljiva publika - dok u neposrednom prostoru možemo vidjeti većinu ljudi koji mogu čuti naš glas, u umreženoj javnosti je to gotovo nemoguće, tamo nas puno više ljudi može čuti što dodatno komplicira ostala tri svojstva jer se ekspresija može čuti u nekom drugom vremenu i na drugom mjestu.

Ukratko, posredovana javnost se može sastojati od svih ljudi na svim prostorima i u svim vremenima. No, u stvarnosti se to ne događa čak ni kada se to želi. Ipak, ograničene snage umrežene javnosti su geografski i vremenski manje od ograničene neposredne javnosti jer ljudi nisu navikli na druženje pred nepoznatom publikom i kontekstom, interakcija u umreženoj javnosti često frustrira nove članove jer se događa da ih netko pogrešno interpretira.

Tinejdžeri provode puno vremena na društvenim mrežama jer im je dosadno, otvaraju profile za zabavu i društveni voajerizam u kojem im prolazi vrijeme i pruža uvid u društvo (Boyd, 2007, 2014)

Kao društvene tvorevine, društvene mreže stvaraju umreženu publiku koja omogućuje pojedincu da vidi sebe dijelom šire zajednice. One pridonose neovisnosti, osjećaju društvene povezanosti i samopromocije (Turkle, 2012). Ta osobina društvenih mreža je jedan od glavnih razloga zašto adolescenti vole društvene mreže. Umrežena javnost im pruža priliku za pronalaženje svog mjesta u društvu. Tu ostvaruju svoju vječnu želju za društvenim vezama i autonomijom, ono što još nisu u mogućnosti u offline životu. Oni žele biti dio svijeta, biti povezani s ljudima i imati slobodu kretanja, za razliku od mnogih odraslih koji imaju strah od umreženih tehnologija zbog opreza pri sudjelovanju tinejdžera u javnom životu, njihovog druženja u parkovima i drugim centrima njihova okupljanja. Društvene medijske usluge kao Facebook i Twitter pružaju mogućnost sudjelovanja u javnom životu, a to je mladima važnije od zabrinutosti odraslih.

Ideja umrežene javnosti identificira način na koji se osobno (kulturne forme i značenja kao što su obiteljski albumi i druge uspomene) i javno (novine, kino, televiziju i sl.) spaja kroz digitalnu tehnologiju. Većina online zajednica mogu se podijeliti u kategorije: informacijske (,kako do“ informacija), profesionalne koje pomažu izgradnji karijere, napretku u profesiji i obrazovne (suradnja studenata međusobno i suradnja s profesorima) te zabavne (Vasić, 2010).

Da bismo društvene mreže konstruirali kao umrežene javnosti, potrebne su nam četiri karakteristike: profili, lista prijatelja, alati za komentiranje te statusi za izvještavanje (Chambers, 2013, prema Boyd, 2014). Ono što je značajno za ove mogućnosti je značajka 
javnosti - prijatelji javno komuniciraju, profili su javno dostupni i komentari su javno vidljivi (Boyd, 2007).

\section{4. 4. Mogućnosti pristupanja društvenoj mreži}

Tinejdžeri za neku društvenu mrežu obično saznaju preko svojih prijatelja koji ih pozovu da se pridruže. Nakon odluke da se pristupi nekoj društvenoj mreži najprije postoji nekoliko koraka kako bi se registrirali kao korisnik. Slijedi stvaranje profila. Stvaranje profila može se smatrati obredom inicijacije za korisnike društvenih medija te prvi korak prema mikropublicitetu (Quinn i Papacharissi, 2014).

Društvene mreže se temelje na profilima, individualnim ili grupnim domaćim stranicama, koje nude opis svakog člana. Njihovu važnost najbolje opisuje Sundén (2003) kada ističe da su profili stranice društvenih mreža na kojima se bilježi postojanje. Osim teksta, slika i video zapisa nastalih od strane članova, stranica sadrži i komentare drugih članova i javni popis ljudi koji je identificiran kao ,prijatelji“ na mreži. Zbog populariziranja stila tih stranica na kojima je nastao, profil često sadrži materijal tipičan za web stranice, kao demografske podatke (godine, spol, lokaciju itd.), ukuse (interese, omiljene bendove itd.), fotografije i otvoren opis osoba koje žele upoznati. Profili se izrađuju ispunjavanjem obrasca na stranici čija je forma dizajnirana za kontrolu i raspored sadržaja. Tinejdžeri često gledaju druge profile svojih prijatelja na mreži i tako provode jako puno vremena. Preko tuđih profila se informiraju koje su vrste samoprezentacije društveno prikladne te ih to vodi u kreiranju vlastitog profila. Iako su profili izgrađeni kroz niz generičkih oblika ima i dovoljno mjesta za osobno izražavanje. Izbor fotografija i osobni odgovori pojedinca na generička pitanja omogućuju slanje smislenih samoprezentacija (Boyd, 2007).

MySpace je slučajno ostavio otvorenu mogućnost i prihvatio forme HTML (HyperText Markup Language, što znači prezentacijski jezik za izradu web stranica) i CSS (Cascading Style Sheets) koda. Zahvaljujući tome sudionici su mogli mijenjati izgled svojih profila. Kopiranjem i lijepljenjem kodova s drugih stranica, mijenjaju svoje pozadine, video, slike, boje teksta i na druge načine utječu na profile u eksploziji animiranog kaosa koji zapravo sliči tinejdžerskoj sobi. Tinejdžeri u početku provode bezbrojne sata u kreiranju svog profila. Kroz taj proces oni se druže na mreži, uče tehnološke i društvene kodove. Tehnološke informacije im daju početni kapital za rad na profilu, a interpretacija i evaluacija su određene društvenim normama. Njihovi 
profili postaju mehanizmi pomoću kojih šalju informacije o sebi i svojim ukusima i afinitetima (Boyd, 2007).

Vidljivost profila ovisi o lokaciji i korisnikovom nahođenju. Neke stranice dopuštaju privatnost, a neke su potpuno javne. MySpace, npr. omogućuje da samo „prijatelji“ vide profil i postavlja to kao zadano za one koji imaju 14 ili 15 godina, dok je Facebook u začetku davao pristup profilu samo ljudima iz iste škole.

Nakon kreiranja profila, sudionici su zamoljeni da pozovu svoje prijatelje na stranicu prikupljanjem e-mail adresa. Alternativno, mogu gledati tuđe profile i dodavati te ljude na listu „prijatelja“. Većina stranica zahtijeva dvosmjernu potvrdu prijateljstva. Pojam „prijatelj“ na mreži može zavarati, jer to ne označava prijateljstvo u pravom smislu riječi, razlozi koji ljude povezuju su različiti (Boyd, 2006).

Većina društvenih mreža zahtijeva odobrenje dvaju osoba za povezivanje u svojstvu prijatelja. Kada ga još netko prikaže kao prijatelja njegov odnos je uključen u javno povezivanje sa svim profilima. Ti zasloni obično uključuju fotografije i nadimke koji povezuju taj profil. Klikom na poveznice prijatelji mogu surfati mrežom od prijatelja do prijatelja (Boyd, 2007).

Društvene mreže jedinstvenima čini javni prikaz veza, što omogućuju pojedincima da se artikuliraju i učine vidljivima svoje društvene mreže. To može dovesti do veza između pojedinaca koje inače ne postoje (Haythornthwaite, 2005), ali to nije cilj, takva spajanja su najčešća između latentnih veza koje dijele neku offline vezu (Kušić, 2010).

Osim sadržaja kojima članovi kreiraju vlastite profile, stranice obično imaju dio posvećen komentarima prijatelja. Na Friendster-u je to pod nazivom „komentari“, na Facebook-u -“zid“. Friendster je ovu opciju uključio potaknut potrebom ljudi da pišu komentare svojim prijateljima koje svi mogu čitati. Prvi korisnici su koristili ovu opciju za pisanje jedne poruke o osobi zastupljenoj u profilu, a vremenom, uzajamno motivirani ljudi, pišu sve kreativnije komentare stvarajući oblik razgovora koji je posebno popularan među korisnicima igrica na Friendster-u. Kako su se tinejdžeri počeli družiti na Friendster-u, tako su koristili ovaj odjeljak za dopisivanje s vlasnikom profila, iako su izjave bile javne. Tada je MySpace uveo istu mogućnost i takvo dopisivanje i komentiranje postaje vrlo popularno među mlađom populacijom sudionika.

Nekim se društvenim mrežama može pristupiti samo ako se prethodno registriramo kao korisnici, dok je kod drugih za pristup potreban samo nadimak (eng. nickname). Najčešće korisnici ne mogu komunicirati sa svim članovima koji se nalaze na mreži, već samo s onima 
koje imaju registrirane među svojim kontaktima (eng. contacts). Osim standardnog načina čavrljanja, korisnici mogu komunicirati i preko video snimki, što olakšava komunikaciju koja je moguća između dva ili više korisnika.

Servisi društvenih mreža stalno se dorađuju i poboljšavaju, dajući nove mogućnosti korisnicima, a neprestano se pojavljuju i nove društvene mreže s novim mogućnostima.

\section{4. 5. Kreiranje identiteta na društvenim mrežama}

Adolescenti internetom ostvaruju važne razvojne zadatke, kao što je formiranje identiteta, socijalne interakcije i razvoj autonomije.

$\mathrm{U}$ svakodnevnim interakcijama tijelo služi kao stranica pokazivanja identiteta $\mathrm{u}$ predstavljanju ljudima, tijelom šaljemo informacije o sebi. To činimo pokretom, govorom, odjećom, mimikom. Nastojimo se prezentirati, no naša prezentacija nije uvijek protumačena onako kako smo željeli. Tek po reakcijama okoline vidimo koliko smo uspješno prenijeli ono što smo željeli. Ovaj se proces naziva upravljanje dojmom (Goffman 1956, prema Boyd, 2007).

Upravljanje dojmom je dio procesa u kojem ljudi traže definiranje situacije kroz svoje ponašanje. Upravljanje dojmovima je važna društvena vještina koja se usavršava iskustvom. Vremenom naučimo shvaćati pojedine situacije, tuđe reakcije i steknemo vještinu uspješne samoprezentacije. Proces tumačenja društvenih znakova i reagiranja na njih osnova je uključivanja u društvo, socijalizacije. Taj proces počinje u obiteljskom domu, od malena, ali posebno je značajan u tinejdžersko doba, kod uključivanja u širu društvenu zajednicu. To je važan dio odrastanja i odvija se do punoljetnosti. Ni za koga se ne može reći da je potpuno ovladao upravljanjem dojmovima, ali tinejdžeri su zreli za stjecanje iskustava za razvoj ove vještine (Boyd, 2007).

U posredovanim okruženjima kao što su društvene mreže, tijela nisu odmah vidljiva $i$ vještine za interpretaciju i upravljanje dojmovima razlikuju se od onih u neposrednom kontaktu. Društvene mreže možemo promatrati kao oblik digitalnog tijela čije postojanje pojedinci sami upisuju. Tekst, slike, audio i video pružaju vrijedna sredstva za prikazivanje prisutnosti, način artikulacije vrlo je važan u pružanju informacija o sebi (Sundén, 2003). Taj proces samorefleksivnost čini eksplicitnom, a ona je potrebna za razvijanje identiteta (Giddens, 1991). 
Prije pojave društvenih mreža identiteti su se razmatrali u kontekstu anonimnosti i nisu bili vezani uz offline identitete. Rane virtualne zajednice nudile su slobodu izraza u anonimnosti. Danas, posredstvom društvenih mreža, osobe mogu objavljivati informacije o sebi, dijeliti ih s drugim članovima te komunicirati s njima.

Obično je društveni život na društvenim mrežama nastavak ili nadogradnja offline odnosa, no ni to nije isključivo. Na Facebooku je norma korištenje pravih imena i prezimena. Dio te norme je bio i prihvaćanje zahtjeva za prijateljstvo od osoba koje se upoznalo offline. Međutim s rastućom popularnosti Facebooka, neka su se pravila korištenja promijenila i neki su novi korisnici izabrali ne koristiti svoja prava imena (Shafie, Nayanb i Osmanc, 2012). No, nekorištenje pravog imena na Facebooku ne prikriva identitet korisnika. Vrlo je lako odrediti tko se krije iza pseudonima pomoću pregledavanja fotografija, praćenja objava i pregledavanja kontakata koje osoba ima. Čest je slučaj da korisnici koji ne upotrebljavaju svoje pravo ime na Facebooku sve ostale informacije točno popune. Njihov je identitet time izmijenjen, ali nije sakriven.

Istraživanje Ellison i sur. (2007) pokazalo je kako se ljudi na društvenim mrežama ponašaju drugačije nego u anonimnim okruženjima. Pokazalo se da samoreprezentacija varira ovisno o prirodi okruženja (Mehdizadeh, 2010). Slika o sebi koja se projicira na društvenim mrežama dalekosežna je i putem veza i kontakata koje korisnik posjeduje predstavljena umreženoj javnosti, a nerijetko utječe i na percepciju izvan konteksta virtualnih zajednica. No, online su osobe u prednosti jer su u stanju pažljivo birati informacije kojima će se predstavljati.

Tinejdžeri stvaraju profile kojima se prezentiraju svojim prijateljima koji ih interpretiraju. Ono što prezentiraju može i ne mora odgovarati njihovim offline identitetima. Njihova primarna publika su njihovi vršnjaci i offline prijatelji i poznanici te su skloni predstavljati se tako da budu dobro prihvaćeni s njihove strane. Opća želja tinejdžera je biti dobro prihvaćenima od strane svojih vršnjaka zato se nastoje što bolje prikazati na mreži. Društvene hijerarhije prisutne u offline svijetu prisutne su i na mreži, iako postoji mogućnost drukčijeg ponašanja online. Pojedinca definira doživljaj publike. Poželjna obilježja osobe jasno su definirana od strane pojedinaca i vršnjaka. Tinejdžeri promatraju i osluškuju zamišljenu publiku jer ona pruža potreban način dokazivanja njihove prisutnosti. Veličina i raznolikost zamišljene publike ovisi o pojedincu. Zamišljajući publiku, bez obzira na njenu točnu količinu, tinejdžeri mogu odrediti društvenu situaciju što im je potrebno za izgradnju profila. Vrlo je složena veza između tinejdžerskog offline i online društvenog svijeta, ali publika stvara vezu između njih i omogućuje njihovo spajanje. No, njihova publika online ne mora biti ona koju oni 
pretpostavljaju (Boyd, 2007). Umrežena javnost gotovo da ne omogućuje privatnost, ali tinejdžeri je pokušavaju stvoriti (Lauritano-Werner, 2006).

Prethodna su istraživanja pokazala kako online okolina može izmijeniti identitete, pa pojedinci objavljuju više informacija o sebi nego putem drugih medija komunikacije (Christofides, Emily, Muise i Desmarais, 2009; Gibbs, Ellison i Heino, 2006).

Tinejdžeri često pri izgradnji profila stavljaju neistinite ključne identifikacijske podatke kao što su dob, spol i mjesto kako bi se zaštitili. To nailazi na odobravanje od strane roditelja, no roditelji ne uviđaju da oni to rade da bi se zaštitili od njihovog uvida u profil. Ipak, literatura pokazuje da su identiteti proizvedeni online na mrežama poput Facebooka realistični i iskreni (Hew, 2011) jer korisnici shvaćaju kako će objavljivanje netočnih ili lažnih informacija naići na neodobravanje prijatelja.

Popularnost društvenih mreža među učenicima, tinejdžerima uzrokuje brisanje granica između njihovih online i offline identiteta. Nesigurnost, samopromocija i samopercepcija često utječu na njihov online identitet. Proučavani su tekstualni online identiteti i upravljanje vizualnim dojmom kroz ispitivanje korisnikovog izbora korisničkog imena, jezika i profilnih fotografija na Facebook profilu. Pokazalo se da se online identiteti i vizualne reprezentacije rekonstruiraju na temelju vrijednosti koje se vezuju uz percepciju njihovih vršnjaka, socijalnih veza i popularnosti. Profili sadrže fotografije i informacije koje predstavljaju njihove stvarne identitete te projekcije svog idealnog sebstva kao online identiteta (Shafie i sur., 2012). To dokazuje da je upravljanje vizualnim dojmovima na društvenim mrežama pod utjecajem vršnjaka i povezano je sa slikom idealnog sebstva. Slike koje su izabrane za profilne fotografije predstavljaju željene predodžbe korisnika (Tufekci, 2008).

Internetski prostor pruža nezamislive mogućnosti za ispitivanje vlastitog identiteta kroz stvaranje i isprobavanje njegovih različitih oblika i učinaka koje takvi alternativni identiteti imaju. Taj prostor možemo nazvati svojevrsnim laboratorijem za proučavanje identiteta. To je postalo važno mjesto za konstruiranje sebe, što je karakteristika postmoderne egzistencije (Turkle, 1999).

Mreža pruža mogućnost uključivanje postavke privatnosti kojom su u stanju odabrati tko može vidjeti neki sadržaj na njihovom profilu, a tko ne. Često postoji nepovezanost između želje za privatnošću i ponašanja mladih na društvenim mrežama (Acquisti i Gross, 2006). Oni često nisu svjesni javne prirode interneta. 
Zbog široke publike, u koju su uključeni i njihovi roditelji i odgojitelji, tinejdžeri se često suočavaju s pitanjem - što je prikladno na društvenim mrežama? Teško je istovremeno biti dobro prihvaćen od strane vršnjaka i zadovoljiti kriterije svojih roditelja. Većina odraslih želi da djeca cijene njihove vrijednosti, ali to je rijetko tako. Društvene kategorija i načini pregovaranja su ključni elementi tinejdžerskog života. Ponašanja koja su nagrađena statusom među vršnjacima obično nisu prihvaćena od odraslih (Boyd, 2007).

\section{4. 6. Razlozi korištenja društvenih mreža među učenicima višeg sekundarnog obrazovanja}

Sve veća popularnost društvenih mreža, društvenih servisa i sličnih oblika međusobnog druženja osoba u virtualnom svijetu sasvim očekivano dovodi do sve veće količine vremena koje provode na istima.

Teško je mjeriti imaju li mladi danas više ili manje vremena od prijašnjih generacija. Tinejdžeri danas provode više vremena u školi, a u večernjim satima se očekuje da budu kod kuće i da uče. Dom je često prostor s puno pravila postavljenih od strane odraslih, a imaju i vrlo mali pristup javnim prostorima. Javnost je puna strukturalnih i društvenih barijera za njih, kako se oni ne bi uključivali. Sprječava ih se da borave na ulicama, na parkiralištima i sličnim mjestima. Sva ta ograničenja mladima otežavaju socijalizaciju u društvo u cjelini. Njihova se socijalna interakcija odvija u privatnim okruženjima, a da bi odrasli potrebni su im i izazovi javnosti (Boyd, 2007). Internet im je omogućio radikalne promjene u izgradnji i decentralizaciji javnosti. Online pristup mladima pruža novu društvenu domenu. Posebnost interneta je u tome što omogućuje sudjelovanje u nereguliranoj javnosti dok se nalaze u reguliranim prostorima kao što je dom i škola. Roditelji ih, naravno, žele kontrolirati i na ovim prostorima što pak mlade motivira da se skrivaju. Umrežena javnost im osigurava prostor relativne autonomije, prostor u kojem se mogu upustiti u učenje i izgradnju statusa izvan dosega odraslih. Društveni mediji mladima omogućuju da budu u središtu javnosti koja im je često nedostupna. Facebook, Twitter i MySpace nisu samo novi javni prostori, oni su u mnogim slučajevima jedini ,javni“ prostori u kojima se tinejdžeri lako mogu nalaziti sa svojim vršnjacima. Većina onih koji su „ovisni““ o svojim telefonima ili računalima zapravo su usmjereni na ostanak u kontaktu s prijateljima. Tinejdžerska zaokupljenost svojim prijateljima u skladu je s njihovom željom za 
ulaskom u javne prostore koji su dostupni samo odraslima. Oni na mreži rade upravo ono što bi radili na javnom mjestu - druže se, bore se za društveni status, rade na samoprezentaciji, riskiraju kako bi pomicali granice u društvenom svijetu (Boyd, 2007). Svakodnevno više puta provjeravaju novosti svojih prijatelja, pregledavaju slike, preslušavaju pjesme, ažuriraju svoj profil.

Javnost igra ključnu ulogu u razvoju individualnosti, u javnosti se oblikuje društveni identitet (Fraser, 1992). Učenje društvenih pravila se uči kroz sudjelovanje i aktivnost, a ne kroz učenje teorije. Kako odrasli ograničavaju tinejdžerima sudjelovanje u javnosti, tinejdžeri su objeručke prihvatili internet jer posredstvom njega i društvenih mreža stvaraju javni život dostupan nezamislivo širokoj javnosti. Rado se uključuju u online zajednice jer ih privlači mogućnost geografskog raspršenja, mogućnost biti u različito vrijeme na različitim mjestima, ali s istim interesima, $\mathrm{u}$ istom virtualnom prostoru, $\mathrm{s}$ istim pravilima i osjećajem pripadnosti. Oslobođeni ograničenja povezanih s offline osobnošću i društvenih uloga. Virtualni prostor otvara mogućnost za igru identiteta. Ljudsko tijelo postaje privremeno suspendirano, nebitno. Stvara se novi oblik komunikacije gdje nije potreban odnos licem u lice, a mogući su susreti s drugima. Takvi virtualni odnosi često su intimniji, bogatiji i više oslobađajući od offline odnosa jer se temelje na istinskim zajedničkim interesima, a ne na tjelesnoj privlačnosti (Mesch, 2009). Često žele biti s prijateljima pod vlastitim uvjetima, bez nadzora odraslih, u javnosti. Paradoksalno, umrežena javnost im dopušta određenu mjeru privatnosti i autonomije koja nije moguća kod kuće, gdje ih nadziru roditelji, braća i sestre. Iako mnogi odrasli misle drugačije, angažman tinejdžera s javnom životu putem društvenih medija nije odbacivanje privatnosti. Međutim, njihova želja za privatnošću ne umanjuje njihovu želju za sudjelovanjem u javnosti (Boyd, 2007).

Mladi su u svakodnevnim pregovorima oko prijateljstva, popularnosti i romansi, uče o stavovima i vrijednostima svojih vršnjaka kroz ispitivanje društvenih normi i očekivanja. Sve se to odvija u vršnjačkoj javnosti koja je u velikoj mjeri odvojena od odraslih. Pri tome razvijaju zajedničke norme online javnosti, uključujući predstavljanje sebe na online profilima, norme za prikazivanje vršnjačkih mreža i odnosa na internetu, rangiranje odnosa na društvenoj mreži kao i razvoj novih žanrova pisane komunikacije (Ito i sur., 2010). Tako se u proučavanju izražavanja mladih i online komunikacije može identificirati niz praksi koje su dokaz postojanja nove medijske pismenosti. Prijateljsko druženje i boravak u interesnim skupinama potiče stvaranje različitih žanrova nove medijske pismenosti. Oni neprestano testiraju granice novih 
medija i medijskog izražavanja, razvijaju široki spektar stručnih i posebnih formi novih medijskih pismenosti.

Prilikom druženja online, mladi eksperimentiraju s utvrđenim pravilima i normama korištenja medijske tehnologije i izražavanja putem nje i često eksperimentiraju sa svojim identitetima. Nerijetko koriste specijalizirani rječnik i ezoterično znanje i razvijaju nove eksperimentalne žanrove za korištenje i uređivanje autorskih digitalnih medija. To uključuje osobne amaterske medije koji cirkuliraju online, kao fotografije, video blogovi, web stripovi, kao i izvedeni radovi kao fan fiction, fan art, modovi, kombiniranje podataka, rekombiniranje (Ito i sur., 2010). Upravo se u tome uviđa njihovo aktivno stvaranje nove medijske pismenosti.

Nema sumnje da neki razviju nezdravi odnos s tehnologijom. Većina tinejdžera nije ovisno o društvenim medijima. Oni su, prije svega, ovisni jedni drugima, njihov je cilj družiti se s vršnjacima. Kad su tinejdžeri u interakciji s drugima, oni sudjeluju u informalnom učenju, razvijanju osjećaja prema drugima, izgrađuju holističko razumijevanje društvenog svijeta. Društveni mediji su za mlade postali prilika za osjećaj djelovanja gdje imaju privid društvene moći (Boyd, 2007).

Prema istraživanju (Lenhart, 2015), tinejdžeri su oduševljeni korisnici društvenih medija. Njih 76\% koristi društvene medije, $81 \%$ koristi web stranice, $89 \%$ ih koristi barem jedno od ponuđenih mreža (Facebook, Twitter, Instagram, Snapchat, Tumblr, Google+ i Vine), 71\% američkih tinejdžera koristi više od jedne mrežne platforme, 71\% koristi Facebook. Dječaci su češći posjetitelji Facebook-a nego djevojčice (45\%/36\%) dok djevojke češće od dječaka koriste Instagram (23\% / 17\%). Stariji tinejdžeri (15 - 17 godina) češće koriste Snapchat i Twitter, a mlađi (13 -14) Instagram, 33\% koristi mobilnu aplikaciju Kik ili WhatsApp, Online Pinboards (Pinterest i Polyvore) koristi 22\% tinejdžera, većinom djevojaka (33\%), dječaka (11\%), 47\% tinejdžera komunicira s drugima putem video veze (Skype, ooVo, FaceTime i Omegle) ili chata. 


\section{4. 7. Medijski odgoj i uloga društvenih medija u životu mladih}

Pri razmišljanju o utjecaju društvenih medija na mlade osobe ne smijemo zanemariti istraživanja komunikacijskih procesa među njima, upoznati načine njihove komunikacije $\mathrm{i}$ sadržaje o kojima razgovaraju. Evidentno je da oni komuniciraju na različite načine, interpersonalno, a sve više posredstvom medija, putem foruma i sl. (Markić, 2010). Računalno posredovana komunikacija preuzima vodeće mjesto. Svjedoci smo velikim promjenama koje se upravo zbivaju, ali dugoročne implikacije društvenosti u umreženoj javnosti još uvijek nisu poznate.

Iako se strahuje da su u online svijetu narušene društvene norme, ne nailazi se na više mladih koji su uključeni u neka rizična ponašanja nego što je slučaj u offline kontekstu (Ito i sur., 2010). Ito i sur. (2010) ne vide potrebu za strahom od pada kulturnih vrijednosti, te smatraju da nije potrebno postavljati stroga i složena pravila i ograničenja pri korištenju interneta.

Međutim, pokazalo se da je igranje nasilnih video igara direktno je povezano s lošim ponašanjem. Za većinu postoji strategija kojom roditelji utječu na strukturu dječje medijske ekologije, no informiranje i javne rasprave o tim pitanjima više je nego dovoljno za osiguravanje sigurnosti njihove djece.

Tinejdžeri Google vide kao središte digitalnog informacijskog svemira, iako slabo razumiju informacije do kojih tamo dolaze, a pogotovo nedostaje svijest o tome kako na njih utječe ono što vide. Oni nekritički vjeruju Google-u, baš kao i većina odraslih. Potrebno je raditi na razvijanju sposobnosti koje omogućuju razumijevanje i osnaživanje mladih za mudro korištenje postojećih alata. Iako istraživanje koje je proveo Pew Report \& American Life Project (2001) pokazuje da 64\% tinejdžera vjeruje da znaju više od svojih roditelja o online komunikaciji, a čak se i 66\% roditelja složilo s tom činjenicom (Lenhart i Madden, 2007).

Iako se temeljne društvene vrijednosti mogu dijeliti intergeneracijski, stvarni oblik vršnjačke komunikacije jako se razlikuje između generacija. Neki roditelji nemaju ni osnovna znanja o komunikaciji na internetu. Dok mogućnost i sposobnost mladih da budu u stalnom kontaktu sa svojim vršnjacima doprinosi učenju vršnjačke socijalizacije, to može dodatno oslabiti sudjelovanje odraslih u tim okruženjima. Jednostavnim pomakom s kućnog telefona na mobilni znači da su roditelji izgubili kontakte s prijateljima svoje djece koje su do tada imali. 
Upravo kombinacija djeteta koje je vrlo aktivno na internetu i roditelja koji je izvan svih medija stvara rizičnu situaciju (Ito i sur., 2010).

Roditelji su se više orijentirali na određivanje pravila koja se tiču sadržaja, a manje je pravila koja se tiču vremena provedenog uz medije. Nešto su stroža pravila s mlađom djecom. Tinejdžere istovremeno idealiziraju i demoniziraju, istodobno ih se plaše i pokušavaju ih na neki način zaštititi (Carr, 2010).

Odrasli i mladi moraju razvijati medijsku pismenost i tehnološke sposobnosti da budu aktivni sudionici u informacijskom društvu. Učenje je cjeloživotni proces. Djeca i odrasli moraju biti na istoj strani po pitanju normi i učenja pismenosti. No, mladi su razvili različit način korištenja medija od njihovih roditelja, mediji su ih socijalizirali. Oni puno lakše barataju medijima nego odrasli (Labaš, 2011).

Roditelji trebaju uvažavati socijalnu interakciju među mladima i razumjeti njenu složenost i priznati da su njihova znanja respektabilna. Kada roditelji prihvate da se njihove vrijednosti prenose stalnom vršnjačkom komunikacijom i komunikacijom sa svojom djecom, tada će nove medijske prakse postati njihove zajedničke, a ne mjesta tjeskobe i napetosti.

Važno je prepoznati različite žanrovske konvencije nove medijske pismenosti mladih prije razvijanja obrazovnih programa $u$ tom prostoru. Osobito kada se odnose na učenje i pismenost koja proizlazi iz neformalnih vršnjačkih praksi. Također, moramo biti svjesni da su norme i standardi smješteni duboko u ulaganju i identitetu kulturnih i društvenih svjetova djece i mladih (Ito i sur., 2010).

Danas je nemoguće razmatrati bilo kakve aspekte života mladih izvan konteksta utjecaja medija, oni sve više istiskuju druge agense socijalizacije mladih i utječu na formiranje životnih stilova (Miliša, 2006). Sudjelovanje u umreženoj javnosti je u žarištu pozornosti tinejdžera. Oni internet i društvene mreže smatraju najvažnijim medijem (Gospodnetić i Morić, 2015). Najviše ih zanimaju društveni online odnosi, a veliki dio angažmana je usmjeren na društvene, komercijalne i zabavne sadržaje koji nisu dozvoljeni u obrazovnim institucijama. Oni aktivno sudjeluju u stvaranju medijskih sadržaja otvaranjem i pisanjem blogova, snimanjem video sadržaja, sudjelovanjem u društvenim i političkim aktivnostima.

Sudjelovanje u online komunikaciji i video igre postali su središte društvenosti mladih, a nedostatak razumijevanja odraslih za sudjelovanje mladih u popularnoj zajedničkoj kulturi stvorilo je nove prepreke za djecu koja nemaju pristup internetu kod kuće dok su u školama ograničeni na korištenje interneta u informativne svrhe. Korištenje medija za svakodnevno 
druženje danas je važna osnova za stjecanje prijateljstva i grupiranje prema interesima. Suvremeni društveni mediji postaju glavna institucija vršnjačke kulture tinejdžera diljem svijeta (Ito i sur., 2010). Novi društveni mediji mladima omogućuju socijalizaciju koja označava specifičan aspekt razvojnog procesa, a možemo je promatrati kao masovnu komunikaciju i prema masovnoj komunikaciji. Mladi su vrlo aktivni u procesu socijalizacije masovnog komuniciranja jer im dopušta da se medijima koriste za sebe, da se nauče njima služiti i da razviju sposobnost njihova dekodiranja. Adolescenti su aktivni i samopouzdani korisnici medijske tehnologije, ali često nisu dovoljno oprezni (Buckinghan, 2000). Pri razmišljanju o utjecaju na mlade osobe ne smijemo zanemariti istraživanja komunikacijskih procesa među njima, upoznati načine njihove komunikacije i sadržaje o kojima razgovaraju (Markić, 2010).

Godine 2005. prvi se puta naglašava pitanje sigurnosti na društvenim mrežama jer je uočeno niz seksualnih interakcija između odraslih i maloljetnika. Iako su neki smatrali da su problemi preuveličani (Bahney, 2006), pa se uvodi pojam „moralna panika“. Raste i potreba za razvojem medijske kulture i medijskog odgoja, posebno u procesu odgoja i obrazovanja (Labaš, 2011). Medijska kultura je nositelj simboličkih vrijednosti, ona koristi slike, zvuke i predstave koje formiraju sadržaje svakodnevnog života, dominiraju slobodnim vremenom, oblikuju politička gledišta, društveno ponašanje, građa koju donose oblikuje identitet ljudi (Kellner, 2003). Sve kulturno se prenosi komunikacijom, a svaka komunikacija kulturom, posebno medijskom kulturom. Medijski odgoj podrazumijeva usvajanje medijskih kompetencija i bez njega medijska kultura ne može razvijati temeljne kompetencije. Važna načela za razvoj suvremene škole u sklopu medijske kulture i odgoja za medije su: inovacija, integracija, interaktivnost, doživljaj i internacionalizacija. Kao takvu, medijsku pedagogiju treba shvatiti kao opći pedagoški zadatak. Medijski odgoj s medijskom kulturom nadilazi i medijsku pismenost.

Medijski odgoj, prema zadatku medijske pedagogije, ima za funkciju interpretirati sve razine $\mathrm{i}$ aspekte medijskog društva i pojedinačnog medija koji su nužni za razvij mlade generacije. On se bavi usvajanjem medijske pismenosti i ovladavanjem medijskim kompetencijama. Jedan od njegovih glavnih ciljeva je prepoznavanje manipulacijskog i/ili odgojnog djelovanja, razlučiti fikciju od stvarnosti, prepoznati polivalentnost medijskih sadržaja i formi (Miliša, Tolić i Vertovšek, 2009). Važnost medijske kompetencije je u razvoju medijski posredovane komunikacije i interakcije kao obilježja suvremenoga društva. Opći je cilj njenoga razvoja omogućiti pojedincu društveno prihvatljiva i razvojno svrhovita medijska 
iskustva. Međuodnosom komunikacijske, medijske i socijalne kompetencije, njihovim prožimanjem i razvojem pojedinac gradi vlastiti okvir društvenog i individualno prilagođenoga djelovanja. Medijska je kompetencija dio socijalne i kulturološke kompetencije, a središnje mjesto u izgradnji mogućnosti shvaćanja, vrednovanja i djelovanja u odnosu s medijima zauzima identitet. Utjecaj medija na pojedinu osobu ovisi o individualnom stanju te osobe, značenju koji pridaje određenomu sadržaju te snazi konvencionalnih obiteljsko-društvenih veza i odnosa u kojima se nalazi (Livazović, 2010).

Medijska pedagogija stvara nove vizije i koncepte te razvija nove metode kako bi mladi znali koristiti medije jer oni, osim socijalne, imaju i integracijsku dimenziju (Miliša i Tolić, 2009). Razvoj medijskog obrazovanja pospješuje način komunikacije (Baacke, 2007).

Tvorci obrazovnih praksi moraju shvatiti da samo sudjelovanje u digitalnom dobu za srednjoškolce znači više nego biti u stanju pristupiti online informacijama jer to podrazumijeva mogućnost sudjelovanja u društvenim i rekreacijskim aktivnostima online što zahtijeva kulturni pomak i određenu otvorenost za eksperimentiranje i društveno istraživanje koje uglavnom nije obilježje obrazovnih institucija.

Kada pogledamo praksu podrške interesa, vidimo djecu koja razvijaju više specijaliziranih oblika stručnosti i okupljaju se u grupe znanja (znanstvene grupe). To su grupe koje vide vrijednost subkulturnog kapitala koji nije široko dostupan u vodećoj kulturi, to nisu prakse koje pripadaju osnovnoj pismenosti, nestandardne su. Tu vidimo da mladi samostalnim učenjem pomoću novih medija mogu ostvarivati različite načine sudjelovanja u različitim domenama društva. Žanrovi sudjelovanja mogu se generalizirati u širokom rasponu kulturnih i znanstvenih domena. Kako tehničke i medijske vještine postaju dominantnije, djeca koja su povezana s više specijaliziranih grupa natjecat će se u razlikovanju s još više specijaliziranih formi znanja koja testiraju granice virtuoznosti. Fokus politike i obrazovanja ne treba biti samo na specifičnim sadržajima ili vještinama, nego na žanrovima sudjelovanja. Sudjelovanje mladih u umreženoj javnosti sugerira neke nove načine razmišljanja o ulozi formalnog obrazovanja. Treba težiti različitosti, a ne standardizaciji kako bi se djeci omogućio pristup različitim interesnim zajednicama u kojima odrasli mogu imati važnu ulogu uzora i sudionika koji za razliku od učitelja u formalnom obrazovanju i formalnim okruženjima, sudjeluju kao strastveni hobisti i kreatori te ih mladi vide kao iskusne kolege, a ne kao autoritete. Tako oni imaju velike mogućnosti u uspostavljenju društvenih normi. Osim javnosti kojom dominiraju interesi odraslih treba stvoriti javnost koja uključuje sadržaje dostupne mladima i djeci jer oni imaju svoju ulogu, prisutni su, imaju prijatelje i suradnike na putu odrastanja u digitalno doba (Ito i 
sur., 2010). Društvene mreže su dragocjena prigoda za rast i sudjelovanje, za razmjenu sadržaja i životnih stavova ako se shvaćaju i doživljavaju na pravilan način, ako ih se razborito procjenjuje i koristi. One su mjesta susreta i kontakata s prijateljima, mjesta na kojem se čitaju vijesti, kupuju knjige, ulaznice, karte, razmjenjuju ideje i interesi (Labaš, 2011).

Mladi sve više postaju robovi masovnih komunikacija, ovisnici o internetu, a vrlo je često prisutna pojava socijalne potištenosti i izoliranosti pojedinaca (Miliša, 2006). Umreženi nam život istovremeno omogućuje skrivanje jednih od drugih iako smo zapravo vezani jedni s drugima. Usamljeni pojedinci na mreži nalaze društvo i zanimaciju, no previše vremena provedenog u takvim aktivnostima može uskratiti prednosti samoće (Turkle, 2012).

Medijska kompetencija podrazumijeva stjecanje vještina, znanja i upućenosti pri sprječavanju medijske manipulacije (Tolić, 2009), to je kulturna tehnika i ključna vještina, sposobnost kretanja u svijetu medija na kritičan, refleksivan i nezavisan način, s osjećajem odgovornosti (Labaš, 2011). Stjecanje medijskih kompetencija je glavni cilj medijskog odgoja, a prvi korak u tome je stjecanje medijske pismenosti. Medijska pismenost podrazumijeva funkcionalnu pismenost, tj. razumijevanje onoga što je napisano, vizualnu pismenost, razumijevanje vizualnih detalja i računalnu pismenost (Tolić, 2009).

Brojni autori se bave konceptima razvoja medijske kompetencije (Aufenanger, 1999; Baacke, 1997; Fromme, Kommer, Mansel, Treumann, 1999; Groebel, 2001; Kron i Sofos, 2003; Livingstone, 2005; Pöttinger, Schill i Thiele, 2004; Schorb, 1995; Sűss, 2004) i svaki od njih medijsku kompetenciju promatra ovisno o svom osobnom profilu. U svim teorijskim razmatranjima medijske kompetencije uključuju izbor ili odabir sadržaja, uporabu (aktivna, pasivna, interaktivna), vrednovanje, kritiku $\mathrm{i}$ prosudbu te stvaralaštvo (neovisnost $\mathrm{i}$ kreativnost). Pritom neke definicije ideju medijske kompetencije ostavljaju u okviru općeg koncepta kompetencija, a neke naglašavaju specifičnosti odnosa s medijima. Iako oba koncepta imaju gotovo jedinstveno izvorište, jasno ukazuju na teškoće oblikovanja univerzalne definicije (Livazović, 2010).

Medijska pedagogija postavlja strategiju djelovanja koja se odvija u području medijske didaktike, a bazira se na dijalogu, razmišljanju i djelovanju (Uldrijan, 2011). Uviđa se da nije dovoljno vladati računalom igrajući igrice, pretraživati željene pojmove i vladati tehničkim znanjima, potrebna je poduka o odnosima koji vladaju virtualnim svijetom (Labaš, 2011). Iako mladi vrlo suvereno koriste nove tehnologije održavajući društvene odnose, čest je slučaj da oni koji su rođeni u digitalno doba nemaju razvijenu svijest o razlici između stvarnog i virtualnog svijeta (Parsi, Cantelmi, Orlando, 2009). Za takvu mladež ne postoje razlike između 
online i offline svijeta, zato su vrlo iskreni na internetu i računalno posredovanoj komunikaciji i lako ostavljaju podatke na internetu. Djevojčice adolescentske dobi imaju želju za potvrđivanjem svog fizičkog izgleda pa često razmjenjuju fotografije na rubu pornografskih i zavodnički se ponašaju (Labaš, 2011). Prijeti opasnost da se internet pretvori u paralelan svijet, mjesto otuđenja, umjesto u priliku za uspostavljanje boljih međuljudskih odnosa. Christakis i Fowler (2010, str. 24-33) ističu šest pravila života koja vladaju pri korištenju društvenih mreža a kojih mladi često nisu svjesni:

a) mreže oblikujemo sami

b) naše mreže nas oblikuju

c) pod utjecajem smo svojih prijatelja

d) pod utjecajem smo prijateljevih prijatelja

e) mreža ima vlastiti život

f) nikad ne znamo tko stoji iza mreža koje nas umrežuju i tko upravlja našim osobnim podacima.

Medijski odgoj je neophodan i treba ga usmjeravati na upoznavanje medijskog jezika i na širenje kritičkog i svjesnog korištenja digitalnih medija. Adolescenti su vrlo vješto koriste digitalne medije, ali nedovoljno razmišljaju o onome što im je na raspolaganju u tom okruženju i o posljedicama neodgovornog korištenja svih tih mogućnosti. Stoga je potrebno promicati medijski odgoj na svim razinama društva i pri tome treba uvoditi kontrolu, a ne zabrane jer je korištenje interneta danas neminovnost za uključenje u život na svim razinama (Labaš, 2011).

Postoje različiti pristupi internetu, od zaštitničkog pa sve do liberalnog i antiprohibicionističkog i potičućeg na medijsko opismenjavanje i odgoj. Na antropološkoj se razini uočava da novi mediji i digitalne tehnologije mogu štetiti međuljudskim odnosima $i$ neposrednoj interpersonalnoj komunikaciji. Na kognitivnoj razini se uočava problem pretjerane informiranosti ili zagušenja informacijama koje se često brkaju sa znanjem pri čemu je vidljiv gubitak specifične težine informacija (Rivotella, 2008). Pedagogija se mora izboriti za svoje mjesto u društvu kako bi ostvarila ulogu koja joj je inherentna, kako bi upravo ona nudila hipoteze i analize u mogućem odgojnom pristupu medijima, jer se ona bavi odgojem (Labaš, 2011).

Rivotella (2008) izražava veću zabrinutost, ističe dva pedagoška pristupa odgoju za medije: inkulturacijski i kritički pristup, koji se očituju kroz dva stava (liberalni i integrirajući). Inkulturacijska metoda ili pristup u prvi plan ističe da je maloljetnike potrebno zaštititi od 
medija, posebno od interneta. Odgoj zamišlja kao neutralizaciju utjecaja medija na adolescenta. Taj pristup podrazumijeva preventivnu cenzuru internetskih stranica kako bi se djecu i adolescente, koje se smatra slabima, naivnima i pasivnima, zaštitilo od neželjenih sadržaja. Kritička pedagogija medija se suprotstavlja inkulturacijskom pristupu. Odbacuje sliku djeteta kao pasivnog subjekta, kao nekoga tko se ne zna braniti. Ona u žarište svog interesa stavlja jasno saznanje da mediji nisu prozor u svijet, nego govor pomoću kojeg se izgrađuje slika koja nije stvarnost, nego konstruirana stvarnost. Rizik i izazov medija prisutni su upravo u ovakvom kritičkom pristupu i kritičkoj pedagogiji koja u prvi plan stavlja ideju odgoja za korištenje i konzumiranje ili potrošnju medija uz stalno kritičko prosuđivanje. Kod liberalnog i liberalističkog pristupa, antiprohibicionističkog, nije problem što smije biti pristupačno na internetu, a što ne, nego u tome gdje je granica iznad koje pristupačnost zadire u prava drugoga.

Primijećeno je da mladi u Hrvatskoj imaju tehničke vještine potrebne za korištenje interneta, ali slabo je razvijena sposobnost kritičkog razumijevanja sadržaja. Velik je postotak onih koji su neoprezni prilikom komuniciranja na internetu s nepoznatim osobama (65\%) (Gospodnetić i Morić, 2015).

Djeca, a pogotovo adolescenti, puno suverenije vladaju digitalnim medijima nego roditelji i odgojitelji. Prijeko je potrebno da i odrasli steknu osnove medijske pismenosti kako bi mogli pratiti djecu i mlade te kreirati pedagogiju dogovora i sporazuma koja roditelju i odgajatelju dopušta potvrdu njihova prava na odgojnu nesimetriju i otvara put promicanju odgovornosti djece putem dijaloga (Labaš, 2011).

Kao društvo moramo shvatiti kako naučiti mlade snalaženju u društvenim postojećim strukturama jer će se s tim suočiti kada odrastu čak i ako im sada ograničimo pristup. Iako društvene mreže kompliciraju naše živote jer naš društveni život čini vidljivim javnosti, umjesto zaustavljanja i reguliranja njihove uporabe trebamo nastojati razumjeti tinejdžere i pomoći im snalaziti se u umreženoj javnosti (Boyd, 2007).

Društveni život mladih odvija se preklapanjem online i offline komunikacije, što dovodi do neprekinute komunikacije među vršnjacima. Iz toga se može nametnuti mišljenje sa su mladi socijalno preopterećeni i da se izlažu opasnosti kontakata sa strancima. Iako, istraživanje provedeno u SAD-u pokazuje da $91 \%$ mladih koristi web stranice da bi bili u kontaktu s prijateljima s kojima se često viđaju, $82 \%$ da bi kontaktirali s onima s kojima se rijetko viđaju, 72\% za planiranje s prijateljima, a 10\% „prijatelja“ su im stranci (Mesch, 2009). 
Tehnologija stvara promjene u načinu poimanja privatnog i javnog prostora. Zamagljuje se granica između tih prostora. Kako raste korištenje interneta, tako raste i zabrinutost za sigurnost djece i mladih. Tu je prostor za medijsku pedagogiju koju treba shvatiti kao opći pedagoški zadatak, a ne samo kao isključivi dodatak. 


\subsection{KVALITETA ŽIVOTA}

Budući da je ,život“ proces u kojemu svi sudjelujemo, mnogo je razmišljanja i istraživanja o toj temi. Već je nekoliko desetljeća socijalna i znanstvena paradigma. Posljednjih deset godina posebna se pažnja posvećuje pitanju što čini osobnu kvalitetu života. To je pitanje $\mathrm{u}$ fokusu interesa brojnih istraživača, a brojni su i razlozi za to. Jedan od razloga je to što je u porastu broj osoba treće životne dobi i pojavljuje se potreba za reorganizacijom skrbi i zdravstvene pomoći za te osobe. Zatim, medicinske znanosti uspijevaju produljiti životni vijek ali to nije nužno popraćeno kvalitetom života. Jedan od razloga je i to što globalizacija svijeta povećava natjecanja među državama na raznim područjima pa tako i oko ispitivanja kvalitete života njihovih građana (Smith, 2000).

Kvaliteta života je velika, važna, interdisciplinarna i kompleksna tema, koja je zanimljiva za svakog istraživača, filozofa, liječnika, sociologa, ekologa, pravnika, ekonomista, svećenika i svih drugih koji proučavaju čovjeka i njegov radni i duhovni život (Holjevac, 2006, str. 153). To je temeljna tema u filozofiji, medicini, vjeri, ekonomiji i politici. Neki znanstvenici polaze od toga da se ocjena kvalitete vlastitog života događa po vrlo subjektivnim kriterijima. Drugi govore o tome da je ocjena kvalitete života pojedinca u velikoj mjeri ovisna o individualnom temperamentu.

Pojam kvalitete života se mijenjao i mijenja se ovisno o promjenama u društvu i promjenama u ljudskoj svijesti. To je složen i multipolarni koncept jer mora uključiti svaki aspekt života (Wang i Kao, 2006).

Hrvatska enciklopedija (2018) kvalitetu života definira kao pojam koji se koristi u različitim strukama u različitome značenju: u ekonomiji označava tzv. životni standard, odnosno ukupnost materijalnih i društvenih uvjeta koji omogućuju određeni način života, u medicini najčešće označava stupanj sačuvanih funkcija bolesnika, u psihološkom smislu kvaliteta života individualna je procjena vlastitoga zadovoljstva načinom života, njegovim tijekom, uvjetima, perspektivama te mogućnostima i ograničenjima. Ta procjena, utemeljena na individualnome iskustvu, očekivanjima, težnjama i vrijednosnom sustavu pojedinca, određena je i psihofiziološkim sklopom karakteristika pojedinca. 


\section{5. 1. Povijesni razvoj koncepta kvalitete života}

Povijesno gledajući, definicije i mjerenja kvalitete života uvelike su se razlikovale i mijenjale. Iz sfere ekonomskih istraživanja kvaliteta života je s vremenom postala predmet interesa socioloških pa i psiholoških istraživanja. Pojam kvaliteta života prvi put je koristio Arthur Cecil Pigou 1920. godine. Predsjednik SAD-a John F. Kennedy ga je kasnije koristio u svojim govorima o stanju nacije. Izraz je postao popularan od 1970. godine.

Budući da je ,život“" ono što svi sada vode, bilo je mnogo istraga o ovoj temi. Međutim, kvaliteta života je složen i višepolarni koncept jer mora uključivati svaki aspekt života. Kvaliteta života vezana uz zdravlje bila je jedna od tema u posljednjih nekoliko desetljeća. Obrađeni aspekti života variraju od studije do studije, ali mogu uključivati ne samo opće zdravlje, fizičke i emocionalne funkcije, već i društveno blagostanje, samoprocjenu zadovoljstva životom i tako dalje (Fayers i Machin, 2000).

Korijene kvalitete života možemo pronaći još u doba antičke Grčke. Za Aristotela je kvaliteta života etička tema. Njegova socijalna etika i ideja savršenog života uključivale su individualne i društvene koncepte kvalitete života. On kvalitetu života čovjeka sagledava kroz tri aspekta: zadovoljstvo (osjećanje), čast (način života), bogatstvo (vanjsko i unutarnje). On je u svojim djelima često spominjao koncepte „,dobrog života“ i „,blagostanja“. Smatrao je zdravlje uvjetom za dobar život čovjeka. Ako čovjek ima određeni cilj, onda je kvaliteta ovisna o postizanju tog cilja ili općenito ako se može otkriti razlog postojanja i življenja onda možemo i definirati nivo kvalitete života kroz dostizanje (ostvarenje) tog razloga (cilja). Poistovjećivao je kvalitetu života s konceptom sreće, kada sve dobro funkcionira i duša je zadovoljena (Wang i Kao, 2006). Aristotel je smatrao da se bez znanja o poimanju kvalitete života svakog pojedinca ne može govoriti o kvaliteti života države (Smith, 2000).

Kasnije se razvoj ideje kvalitete života proširuje na područje ekonomije. Na području ekonomije se na kvalitetu života gleda kao na životni standard, ona se procjenjuje na temelju bruto društvenog proizvoda. Postavljaju se pitanja „Kolika su primanja u obitelji?“ i „Jeste li zaposleni?“. Odgovorima na ta pitanja dobivala se slika ekonomske kvalitete života ljudi.

S druge strane, u sociološkim se kontekstima govori da korištenje slobodnog vremena pridonosi društvu i pojedincu. Sociologija se ovim područjem počinje baviti u okviru zadovoljenja čovjekovih potreba. Postavlja se pitanje „U kojoj su mjeri zadovoljene vaše životne potrebe?“ (Mujkić i Vuletić, 2002). 
U drugoj polovini prošloga stoljeća se pojavila potreba za razmatranjem odvajanja subjektivnih i objektivnih pokazatelja kvalitete života. U objektivne komponente uvršteni su normativni pokazatelji stvarnosti, a subjektivne su mjere ukazivale na razlike pojedinaca $\mathrm{u}$ opažanju stvarnih uvjeta života (Vuletić i Misajon, 2011).

Psihologija se, pak, počinje baviti pitanjem u kolikoj je mjeri pojedinac zadovoljan svojim životom u cjelini (Martinis, 2005). Psiholozi i zdravstveni djelatnici proučavaju kvalitetu života sa stajališta pojedinca. Oni često kvalitetu života dovode u vezu sa zdravljem. Postoje brojni instrumenti kojima se zahvaća i mjeri konstrukt kvalitete života povezan $\mathrm{s}$ domenom zdravlja.

Šezdesetih se godina nastavlja razvoj značajki kvalitete i to uglavnom subjektivnih. Glavni cilj mjerenja kvalitete života postaje usmjerenost na pojedinca. Smatra se da je kvaliteta života psihološke prirode i vrsta općenitog stava prema vlastitom životu i njegovim područjima. To je subjektivno doživljavanje vlastitog života određeno objektivnim okolnostima u kojima osoba živi, ali i karakteristikama osobnosti koje utječu na samodoživljaj (Mujkić i Vuletić, 2002).

Razdvajanje objektivnih i subjektivnih komponenti kvalitete života 70-tih godina je dovelo do pretpostavke da kod različitih ljudi jednake životne okolnosti rezultiraju razlikama u zadovoljstvu. Objektivne mjere bili su normativni pokazatelji stvarnosti, dok se subjektivnim mjerama ukazalo na razlike pojedinaca u opažanju stvarnih uvjeta života. Subjektivni pokazatelji mjere subjektivnu kvalitetu života nekog pojedinca, odnosno predstavljaju individualnu procjenu objektivnog stanja okoline i vlastita života (Slavuj, 2012). Temelj subjektivnih pokazatelja čine mjerenja psiholoških stanja pojedinca, odnosno njegovih vrijednosti, vjerovanja, stavova, zadovoljstva i sreće.

U to je vrijeme pitanje psihologa koji je ispitivao kvalitetu života glasilo: „U kojoj ste mjeri zadovoljni kvalitetom svog života u cjelini?“. Za ekologe je kvaliteta života ovisna prvenstveno o očuvanosti prirodne sredine. Nutricionisti zastupaju zdravu prehranu kao važan činitelj kvalitetnog života, a sociolozi se bave društvenim odnosima među različitim grupama ljudi. Menadžeri su usmjereni na kvalitetu života u radnoj organizaciji na koju utječu radni uvjeti i odnosi na radu.

Početkom osamdesetih godina prošlog stoljeća u svim se znanostima, od ekonomije, ekologije, sociologije do epidemiologije, počela dovoditi u pitanje nekoliko stoljeća stara paradigma rasta i razvoja, napretka (Kirin, 1991). Na socijalnom se planu ta dogma očitovala 
kao porast prosocijalnih indikatora. U početku su samo marginalne i alternativne ekološke, mirovne, duhovne, zdravstvene i socijalne skupine počele zastupati ideju kvalitete života, no brzo se ta ideja preselila u znanost o radu, jeziku i životu (Orešković, 1994).

Brojni autori upozoravaju na poteškoće u definiranju tog pojma. S jedne se strane ističe objektivnost i mjerljivost, a s druge strane subjektivnost i nemjerljivost. Osnovna poteškoća je u tome što objašnjenje nastanka i održanja života još uvijek nije konzistentno i znanstveno utemeljeno. Razmatranje kvalitete života možemo podijeliti u dva koncepta koji se poklapaju s dva vremenska razdoblja. Prvi koncept čine oni pristupi koji kvalitetu života istražuju samo kod bolesnika, bave se utjecajem bolesti na kvalitetu života. Tek od početka devedesetih godina počinju se razvijati koncepti mjerenja kvalitete života zdravih ljudi. Velik je utjecaj na razvoj takvih pristupa imala konferencija u Alma Ati 1978. godine kada je ideja o kvaliteti života dobila značajno mjesto u dokumentima World Health Organization (WHO, 1993).

U medicini je za procjenu kvalitete života identificirano pet različitih skupina argumenata (Elund i Tancredi, 1990). Prvu skupinu čine shvaćanja kvalitete života kao ispunjenja osobnih ciljeva, što potiče iz eudemoničke filozofije tarih Grka koja je u modernoj interpretaciji zastupljena konceptom samoaktualizacije (Maslow, 1968). Ta ideja glasi - budi sve što možeš biti.

Drugu skupinu čine shvaćanja kvalitete života kao mogućnost vođenja „,normalnog života“، Teorija normalizacije ima ulogu sprječavanja sekundarne devijantnosti. Pokret za normalizaciju, krajem devedesetih prerasta u pokret za povećanje kvalitete života. Pojam „,normalizacija“ izvedenica je pojma „normalan“. Njime se u 19. stoljeću izjednačavao prototip škole prema kojem su se kasnije vršile reforme školstva (tzv. École normale) i ono stanje organizma koje smatramo zdravim. Proces je u pravnoj sferi nazvan „normiranje“, a u socijalnoj i medicinskoj „normalizacija“(Canquilhem, 1987).

Treću skupinu čine shvaćanja kvalitete života kao socijalne korisnosti. Kvaliteta života se izjednačava sa sposobnošću vođenja socijalno korisnog života što podrazumijeva produktivnost u nacionalnoj ekonomiji i sposobnosti obnašanja uloga majke, oca, učitelja, građanina itd. Individualistička definicija kvalitete života podrazumijeva da je jedinka životom koji joj je podaren neponovljiva i različita od bilo koje druge (Orešković, 1994).

Moslow je (1954) napravio klasifikaciju osnovnih ljudskih potreba na pet razina: fiziološke potrebe (hrana, voda, spavanje, sklonište itd.), sigurnost pojedinca i obitelji, potrebe pripadanja i ljubavi, potrebe za neovisnošću i slobodom, potrebe za ljepotom i znanjem kao 
vrijednostima po sebi. On smatra da se sve potrebe realiziraju u okviru potrebe za samoaktualizacijom koja može biti podržana ili onemogućena tipom društva u kojem pojedinac živi.

Danas je jasno da je kvaliteta života sveukupno blagostanje na koje utječu objektivni pokazatelji, a veliki udio ima i subjektivna percepcija te vrednovanje tjelesnog, materijalnog, socijalnog i emotivnog blagostanja, osobni razvoj i svrhovita aktivnost. Sve spomenuto pod utjecajem je osobnih vrijednosti pojedinca (Felce i Perry, 1993, prema Vuletić, 2004). Krizmanić i Kolesarić (1989) definiraju kvalitetu života kao subjektivno doživljavanje vlastitog života određenog objektivnim okolnostima u kojima osoba živi, značajkama ličnosti koje utječu na doživljavanje realnosti i njenog specifičnog životnog iskustva. Postoji slaganje među istraživačima da pojam kvalitete života podrazumijeva kombinaciju objektivnih i subjektivnih varijabli. Opažena je slaba povezanost između čovjekovog subjektivnog osjećaja zadovoljstva životom kao i vlastite procjene kvalitete života i objektivnih životnih uvjeta (Cummins, 1995). Objektivni i subjektivni čimbenici nisu linearno povezani jer u situaciji loših socijalnih uvjeta života, poboljšanjem uvjeta povećat će se i subjektivna percepcija zadovoljstva životom, ali na određenom nivou ta se povezanost gubi (Cummins, 1995, 2000). Ako su zadovoljene osnovne životne potrebe pojedinca, povećanje materijalnog bogatstva neće značajno utjecati na subjektivnu mjeru kvalitete života. No, neka istraživanja potvrđuju povezanost između subjektivne kvalitete života, vanjskih događaja i ličnosti (Vuletić, 2013) i idu u prilog teoriji da u objašnjavanju kvalitete života pojedinca važnu ulogu imaju vanjski i unutarnji čimbenici.

Pri dosadašnjim mjerenjima kvalitete života zapravo se mjerilo subjektivno zadovoljstvo životom u cjelini ili njegovim pojedinim aspektima (Cummins, 2000). Kvaliteta života se odražava u homeostazi (Cummins i sur., 2003). Homeostatički sustav je sličan ravnoteži koja se javlja kod krvnog tlaka ili tjelesne temperature, koje se u normalnim okolnostima zadržavaju na optimalnoj razini za funkcioniranje organizma. Slično je i s kvalitetom života gdje interakcija okolnih uvjeta i psiholoških osobina pojedinca određuje subjektivnu procjenu kvalitete života. Kao čimbenici koji utječu na (samo)procjenu kvalitete života ističu se neke osobine ličnosti kao ekstraverzija, neuroticizam, optimizam i lokus kontrole. Subjektivna percepcija kvalitete života u svakodnevnom životu dosta je stabilna te se u prosjeku procjenjuje kao $3 / 4$ maksimalne vrijednosti. Do narušavanja te ravnoteže dolazi ako dođe do promjena u okolnim uvjetima ili nekoj od psiholoških varijabli pojedinca. Međutim, brojna istraživanja pokazuju da ljudi imaju tendenciju i u takvim situacijama pronaći ravnotežu. 
Dakle, kvaliteta života (eng. quality of life) uključuje:

a) životno zadovoljstvo, koje je subjektivno i može fluktuirati

b) multidimenzionalne čimbenike koji uključuju sve - od fizičkog zdravlja, psihološkog stanja, razine neovisnosti, obitelji, obrazovanja, bogatstva, vjerskih uvjerenja, osjećaja optimizma, lokalnih usluga i prijevoza, zapošljavanja, društvenih veza, stanovanja i prirodne okoline

c) kulturne perspektive, vrijednosti, osobna očekivanja i ciljeve koje očekujemo od života.

Ne smije se zanemariti duhovna dimenzija kvalitete života. Ona je jako važna, ali ju je teško mjeriti i ocjenjivati (zadovoljstvo, vjera, ljepota, moralne vrijednosti, ljudski odnosi i dr.) (Holjevac, 2006).

Općenito, kvaliteta života (eng. Quality of life, $Q o L$ ili $Q O L$ ) je percipirana kvaliteta svakodnevnog života pojedinca, odnosno procjene njihove dobrobiti ili nedostatka. To uključuje sve emocionalne, društvene i fizičke aspekte života pojedinca. U zdravstvenoj skrbi, kvaliteta života povezana sa zdravljem (HRQoL) je procjena načina na koji bi se bolest, nesposobnost ili poremećaj tijekom vremena mogao utjecati na blagostanje pojedinca.

Dokaz da kvaliteta života dobiva sve veći značaj je osnivanje centara za istraživanje kvalitete života u Njemačkoj 1994., u Kanadi Ministarstvo zdravstva provodi nacionalnu studiju kvalitete. U Ujedinjenom Kraljevstvu su istraživanja društvenih znanosti sve više pod utjecajem države kako bi se poboljšala kvaliteta života unutar britanskog stanovništva. Pokrenuto je više projekata Vijeća za ekonomska i društvena istraživanja (Economic and Social Research Council - ESRC) kojima se prikupljaju podaci o kvaliteti života i pomaže podizanju kvalitete života (Smith, 2000). 


\section{5. 2. Definiranje kvalitete života}

Koncept kvalitete života je vrlo istraživan koncept u različitim znanstvenim područjima, no ne postoji opće prihvaćena definicija tog koncepta. Različite operacionalizacije koncepta $u$ istraživačkom smislu donose probleme u komparabilnosti dobivenih rezultata (Kovčo-Vukadin, 2016).

Pojam „kvaliteta života“ često se koristi za opisivanje zdravstvenog statusa, tjelesnog funkcioniranja, simptoma psihosocijalne prilagodbe, dobrog stanja, životnog zadovoljstva ili sreće te se, zbog značenja navedenih termina u svakodnevnom životu, često koristi bez eksplicitne definicije (Ferrans i sur., 2005).

Theofilou (2013) dio problema definiranja termina nalazi u pomicanju znanstvenog područja bavljenja (od objektivnih ekonomskih pokazatelja do subjektivnog doživljaja vlastitog života) i njegovog sinonimnog korištenja s nekim drugim pojmovima (poput dobrobiti - eng. well-being i životnog zadovoljstva - eng. life satisfaction).

Različita shvaćanja pojma kvalitete kroz povijest doprinijela su bogatstvu današnjih pristupa i definicija kvalitete života (Orešković, 1994). Kvalitetu života nemoguće je jednoznačno i sigurno definirati i ne postoji slaganje oko definiranja tog pojma niti univerzalno prihvaćen standard mjerenja. S obzirom na to da ne postoji jedna, univerzalno prihvaćena definicija kvalitete života, ovdje će biti navedene neke od najcitiranijih.

Često se izjednačava s pojmovima subjektivnog blagostanja, zadovoljstva životom, subjektivnom kvalitetom (Penezić, 1999; Vuletić, 1999; Schilling, 2003, prema Leutar i Lovreković, 2010). Različiti autori pri definiranju kvalitete života uključuju različite aspekte (Fayers i Machin, 2000). Oni uključuju ne samo opći zdravstveni status, fizičke i emocionalne funkcije, nego i društveno blagostanje, samoprocjenu zadovoljstva životom i tako dalje. Zbog raznolikosti definicije i mjerenja, Svjetska zdravstvena organizacija razvila je skalu za mjerenje kvalitete života. Ona obuhvaća percepciju položaja u životu pojedinca u kontekstu kultura i vrijednosnih sustava u kojem žive i u odnosu na njih, ciljeva, očekivanja, standarda i zbrinutosti.

Percepcija kvalitete života pojedinca određuje se unutar višedimenzionalnog koncepta.

Različite znanstvene discipline definiraju kvalitetu života u sklopu svojih perspektiva učenja. Primjerice, za ekonomiste kvaliteta života shvaćena je kao životni standard objektivno mjerljiv pokazateljima kao što su visina dohotka, stupanj zaposlenosti, BDP i dr. Za psihologe, kvaliteta života je subjektivni doživljaj zadovoljstva vlastitim životom, a za sociologe kvaliteta 
društvenih odnosa. Na svjetskoj razini najčešće se upotrebljava definicija Svjetske zdravstvene organizacije (SZO) koja definira kvalitetu života kao percepciju pojedinaca o njihovoj poziciji u životu u kontekstu kulture i vrijednosnih sustava u kojima žive i u odnosu na njihove ciljeve, očekivanja, standarde i druge stvari koje ih se tiču. To je široki raspon koncepta, koji uključuje na kompleksan način fizičko zdravlje osoba, psihološko stanje, razinu neovisnosti, društvene odnose, osobna uvjerenja i odnos prema istaknutim značajkama okoline (Measuring Quality of Life, 1997; Szabo, 1996, WHOQOL grupa, 1995, 1996, 1998,1998b).

Kvaliteta života je osobna percepcija životne stvarnosti u pogledu vrijednosnih sustava u kojima netko živi, a s obzirom na očekivanja, vlastite ciljeve i standarde (Leutar i Lovreković, 2010).

Autori Felce i Perry (1995, prema Mujkić i Vuletić, 2002) daju jednu od najopćenitijih i najsveobuhvatnijih definicija kvalitete života. Oni je definiraju kao opće blagostanje koje uključuje objektivne čimbenike i subjektivno vrednovanje fizičkog, materijalnog, socijalnog i emotivnog blagostanja, a sve se vrednuje kroz osobni skup vrijednosti.

Allardt (1976) definira kvalitetu života kao zadovoljenost socijalnih i osobnih potreba uz subjektivnu percepciju tog zadovoljstva.

Kvaliteta života je općenito dobro stanje pojedinca i njegove okoline, društva u kojem se kreće (Dhamo i Kocollari, 2014). Najčešća definicija kvalitete života koju susrećemo u stranoj literaturi je autora Lawtona (1991) koji kvalitetu opisuje kao višedimenzionalnu procjenu sustava pojedinac - okolina u prošlom, sadašnjem i budućem vremenu od strane interpersonalnih i društveno-normativnih kriterija (Blane i Netuveli, 2008).

Petz (2005) kvalitetu života definira kao kompleksan proces evaluacije zadovoljstva životom unutar okruženja u kojem pojedinac živi. Izvori zadovoljstva i nezadovoljstva svakog pojedinca su brojni i različiti, a objektivne okolnosti u kojima živi mogu ih značajno uvećati ili smanjiti.

Prema Poredoš (2002) kvaliteta života se shvaća kao ono što je pojedincu važno iz bilo kojeg razloga. Što nam ukazuje na to da je kvaliteta za svaku osobu posebno određena i pojedinac sam određuje što je za njega kvaliteta.

Browne i sur. (1994) kvalitetu života definiraju kao stalnu interakciju utjecaja vanjskih uvjeta na život pojedinca i subjektivne percepcije tih uvjeta. 
Cummins (1997) ističe da je kvaliteta života u isto vrijeme objektivna i subjektivna pri čemu je i objektivnost i subjektivnost sastavljena od sedam domena: materijalnog blagostanja, zdravlja, produktivnosti, intimnosti, sigurnosti, blagostanja zajednice i emocionalnog blagostanja. Objektivna komponenta uključuje kulturalno relevantne mjere objektivnog blagostanja (Best i Cummins, 2000). Robert Cummins osnivač je međunarodne skupine znanstvenika i istraživača „International Well - Being Group“, koja zastupa shvaćanje da je kvaliteta života multidimenzionalan konstrukt kojeg čine: životni standard, zdravlje, produktivnost, mogućnost ostvarivanja bliskih kontakata, sigurnost, pripadanja zajednici te osjećaj sigurnosti u budućnost (Cummins, 1997). Zadovoljavanje potreba te ostvarivanja interesa, vlastitih izbora, vrijednosti i težnji na različitim područjima i u različitim razdobljima života podrazumijevaju navedeni pojam. Sve navedene domene subjektivne kvalitete života su pod utjecajem pojedinčevog sustava vrijednosti (Vuletić, 2004; Brajković, Godan i Godan, 2008).

Prema Krizmanić i Kolesarić (1989), kvaliteta života je prvenstveno psihološka kategorija koja ne proizlazi iz zadovoljavanja osnovnih potreba, već iz ukupne psihološke strukture pojedinca u interakciji s fizičkom i socijalnom okolinom u kojoj živi i temelji se na subjektivnoj procjeni. Oni kvalitetu života definiraju kao subjektivno doživljavanje vlastitog života određeno objektivnim okolnostima u kojima osoba živi, karakteristikama ličnosti koje utječu na doživljavanje realnosti i njenog specifičnog životnog iskustva. Objektivna poimanja kvalitete ovisna su o kulturološkom okruženju i definiranju blagostanja, dok subjektivne domene, mjere važnost kvalitete za pojedinca (Podgorelec, 2003). Iz čega proizlazi da se koncept kvalitete života sastoji od objektivnog i subjektivnog aspekta. Subjektivni indikatori kvalitete života ovise o osobinama ličnosti pojedinca, dok objektivne indikatore čine materijalne prilike, stambeni uvjeti, organizacija zdravstvene zaštite, socijalna skrb, stopa smrtnosti i slično (Žganec, Rusac i Laklija, 2007). Subjektivna se dobrobit često upotrebljava kao sinonim za sreću (Diener i Ryan, 2009). Diener i Diener (1996) sreću definiraju kao subjektivno vrednovanje života koji je ispunjen ugodnim emocijama. Ta subjektivna dobrobit prema Diener (1984) ima tri osnovne značajke:

a) subjektivna je i ovisi o iskustvu pojedinca,

b) uključuje pozitivne čimbenike, a ne samo odsustvo negativnih čimbenika,

c) predstavlja ukupnu procjenu različitih aspekata života pojedinca, s naglaskom na subjektivnoj evaluaciji života. 
Prema Pavot i Diener (2013) subjektivna dobrobit obuhvaća tri aspekta: pozitivne afekte, negativne afekte i zadovoljstvo životom, koji se grupiraju u dvije komponente: kognitivnu i emocionalnu. Zadovoljstvo životom predstavlja kognitivnu komponentu subjektivne dobrobiti (Diener, 1996). Kognitivna komponenta pri tome obuhvaća dva aspekta procjene dobrobiti iz perspektive pojedinca: globalni osjećaj zadovoljstva životom koji podrazumijeva širu, kognitivno utemeljenu evaluaciju pojedinca o kvaliteti života u cjelini i zadovoljstvo pojedinim područjima života koji podrazumijeva evaluaciju specifičnih aspekata života. Iako su specifične komponente zadovoljstva životom međusobno usko povezane, kada se ispituju zasebno, daju jedinstven doprinos objašnjenju globalnog osjećaja zadovoljstva životom (Pavot i Diener, 2003). Tako pojedina osoba može izraziti zadovoljstvo u većini životnih područja, ali ako je nezadovoljna samo u jednom području to može rezultirati ukupnim nezadovoljstvom (Rijavec, Miljković i Brdar, 2008). Stoga je važno razmatrati sveukupnu procjenu nečijeg života, a ne samo po pojedinim aspektima (Pavot i Diener, 1993). Prema Bradburnu (1969) zadovoljstvo proizlazi iz ravnoteže pozitivnih i negativnih osjećaja. Nadalje, Penezićevi rezultati (1996) upućuju na to kako najveći dio subjektivnog osjećaja dobrobiti objašnjava zadovoljstvo životom.

U Kanadi, Socijalno vijeće za razvoj definira kvalitetu života kao proizvod međuigre društvenih, zdravstvenih, ekonomskih i ekoloških uvjeta koji utječu na ljudski i socijalni razvoj (Smith, 2000). Različiti termini koji se kao sinonimi koriste prilikom mjerenja osobne kvalitete života, kao npr. subjektivna dobrobit, sreća, zadovoljstvo životom, subjektivna kvaliteta života ili samo kvaliteta života, nemaju isto značenje i ne odnose se nužno na iste pojmove.

Kvaliteta života temelji na općem zadovoljstvu, pozitivnim i negativnim osjećajima te zadovoljstvu pojedinim područjima života (Linnakylä i Brunell, 1996; Williams i Roey, 1996). Ovisno o profesiji, kvaliteta života se fokusira na određenu dimenziju kvalitete života. Tako je za liječnika kvaliteta života zdravlje, za ekologa zaštićena priroda (čista voda, zrak, zemlja, flora i fauna), za filozofa moral i ljudske vrijednosti, za sociologa društveni odnosi i komunikacija, za svećenika vjera, za ekonomista materijalno blagostanje itd. Sve navedene dimenzije zajedno čine ukupnu kvalitetu života, što ponovno dokazuje složenost tog pojma.

U akademskoj i popularnoj literaturi termini kvalitete života, sreće, zadovoljstva životom i prosperiteta često se sinonimno koriste $\mathrm{s}$ terminom dobrobiti, premda istraživanja i rječnici sugeriraju kako postoje razlike u tim terminima (Eger i Maridal, 2015). Sreća se često koristi za opisivanje trenutnih ugodnih emocija, dok se zadovoljstvo životom koristi za dugoročnu kognitivnu evaluaciju života u cijelosti, kao dublja sreća. Prosperitet se često koristi u 
raspravama o ekonomskim uvjetima. Veenhoven (1996), koji se smatra osnivačem studija sreće, smatra kako termin dobrobiti treba biti korišten za označavanje generalne kvalitete života. On smatra da je dobrobit (eng. well-being) stupanj u kojem pojedinac procjenjuje svoj cijeli život kroz njegovu kvalitetu. Dakle, jedan od pristupa koji u sebi objedinjuje i uži koncept subjektivne dobrobiti je pojam kvalitete života. To predstavlja stupanj u kojem pojedinac voli život onakav kakav živi (Veenhoven, 1993).

Imajući u vidu sve rečeno, možemo zaključiti da se kvaliteta života temelji na općem zadovoljstvu, pozitivnim i negativnim osjećajima te zadovoljstvu pojedinim područjima života (Linnakylä i Brunell, 1996; Williams i Roey, 1996).

U različitim pokušajima konceptualiziranja kvalitete života, nastala je definicija koja kvalitetu života opisuje kao kompleksan, sintetički doživljaj zadovoljstva ili nezadovoljstva životom, koji nastaje trajnom evaluacijom i reevaluacijom življenja pojedinaca. Ta evaluacija se odnosi na područja poput: posla, socijalne aktivnosti, međuljudskih odnosa i čuvstvenih veza (Krizmanić, 1992).

Kao što ističe i Kovčo-Vukadin (2016), može se konstatirati kako je koncept kvalitete života izuzetno interesantan istraživački koncept u različitim znanstvenim područjima i disciplinama te kako u smislu konceptualizacije i operacionalizacije istraživačkih nacrta postoje velike različitosti. 


\section{5. 3. Teorije i modeli kvalitete života}

Definiranje pojma zadovoljstva životom pomaže nam u razumijevanju njegovog značenja i određenja, no nedostaje ideja o tome kako nastaje izvor i koncept zadovoljstva životom. Stoga je mnoštvo autora razvilo vlastita poimanja i teorijska određenja fenomena kvalitete života.

Brajković i Vuletić (2011) navode šest subjektivnih teorija kvalitete života:

a) teorija višestrukih nesrazmjera

b) teorija krajnjih točaka

c) teorija ugode i bola

d) teorija aktiviteta

e) teorija homeostaze

f) asocijacionističke teorije

Prema teoriji višestrukih nesrazmjera autora Michalosa (Diener, 1984) kvaliteta je shvaćena kao stalno procjenjivanje onoga što smo postigli u usporedbi s onim što želimo postići i uspoređivanje vlastitih postignuća s postignućima drugih ljudi. Zadovoljstvo i nezadovoljstvo nastaje kao rezultat tih usporedbi. Također, važan je nivo očekivanog zadovoljstva koji će direktno motivirati postupke za postizanje i održavanje zadovoljstva pojedinca. Ova teorija podrazumijeva da na sve razlike između ostvarenog i neostvarenog direktno utječe dob, spol, obrazovanje, kulturalna pripadnost, prihodi, samopoštovanje i socijalna potpora.

Teorija krajnjih točaka polazi od pretpostavke da se kvaliteta života podiže zadovoljavanjem osnovnih potreba i ciljeva. Autor Wilson (1967) govori o tome kako zadovoljavanje potreba dovodi do sreće, a konstantno nezadovoljavanje potreba dovodi do osjećaja nesreće i nezadovoljstva. Ovakav pristup možemo usporediti s Maslowljevom teorijom potreba (motiva) koja potrebe svrstava u skupine hijerarhijskim redoslijedom. Prema ovoj teoriji najprije se moraju zadovoljiti osnovne potrebe kako bi se kasnije mogle zadovoljiti i potrebe višega reda.

Teorija ugode i bola također govori o zadovoljavanju potreba osoba koje je usko povezano s osjećajem ugode ili bola. Drugim riječima, autor Diener (1984) tvrdi kako ljudi nakon što zadovolje određenu potrebu mogu osjetiti zadovoljstvo ili nezadovoljstvo (bol) radi istog. Kada organizam nije zadovoljio potrebu i teži za njom, govorimo o stanju deprivacije. 
Zadovoljavanjem te potrebe dolazi do poništavanja stanja deprivacije i stvaranja osjećaja zadovoljstva.

Teorija aktiviteta polazi od pretpostavke da je ključ zadovoljstva neke osobe u njenoj aktivnosti. Sama aktivnost će pojedincu donijeti više sreće neko krajnji cilj te aktivnosti. No, za neke osobe prezahtjevne aktivnosti dovode do stanja anksioznosti, a one prelake do dosade i osjećaja beskorisnosti.

Teorija homeostaze potječe od autora Roberta A. Cumminsa (1995, prema Brajković i Vuletić, 2011). Autor Cumminis je u svojim istraživanjima uvidio da ljudi subjektivno zadovoljstvo životom na ljestvici uglavnom procjenjuju pozitivnim dijelom skale i zaključio da ljudi svoju kvalitetu života uglavnom održavaju u ravnoteži (homeostazi). Takvo tumačenje može se povezati s tjelesnim karakteristikama ljudskog organizma koji konstantno funkcionira tako da održava konstantu krvnog tlaka i tjelesne temperature. Tako održava idealne okolnosti za funkcioniranje (Cummins, 2000, prema Brajković i Vuletić, 2011). Na takav način opisuje i kvalitetu života. Naime, u svakodnevnom životu subjektivna percepcija kvalitete života je stabilna, a do narušavanja ravnoteže dolazi ako dođe do promjena u okolnim uvjetima kao npr. bolesti. Međutim, ljudi teže pronalasku ravnoteže i vraćaju se u homeostazu. U prilog ovoj teoriji idu različita istraživanja koja pokazuju da se subjektivna kvaliteta života održava na pozitivnoj razini.

Asocijacionističke teorije polaze od ideje mreže pozitivnih asocijacija koje izazivaju osjećaj ugode i zadovoljstva. Asocijacije su djelom naučene sposobnosti da se reagira na pozitivne načine. Tako pojedinac razvija određene vrste atribucija koje se učvršćuju na osnovi događaja. Nedostatak ove teorije je u tome što se zadovoljstvo promatra kroz nužno postojanje asocijacionističkih mreža kao alata za postizanje sreće.

Osim navedenih teorija kvalitete života, razvijeni su i različiti modeli strukturiranja fenomena kvalitete života. Iako postoji veći broj modela, ipak se najčešće spominju sljedeća tri (Penezić, 2006):

a) Top-down model - deduktivni model

b) Bottom-up model - induktivni model

c) Dinamički model ravnoteže

Top-down model ili model „odozgo prema dolje“ razvili su Feist, Bodner, Jacobs, Miles i Tan (1995). Taj model govori da ljudi interpretiraju život i vlastitu kvalitetu života na 
pozitivne i negativne načine. Ta procjena života općenito se može podijeliti na manje dijelove zadovoljstva ili nezadovoljstva životom. Iz tog se razloga model naziva „odozgo prema dolje“.

Drugi model je obrnutog tumačenja od prvog modela i naziva se „odozdo prema gore“. Prema njemu, opći osjećaj zadovoljstva stvara se na osnovi zbrajanja zadovoljstva u različitim životnim područjima kao primjerice brak, posao i zdravlje (Fiest i sur., 1995). U ovom modelu važniju ulogu igraju objektivne okolnosti, a ne subjektivna percepcija kao kod prvog modela. To nam govori da zadovoljstvo određenim domenama života može pridonijeti ukupnom zadovoljstvu.

Treći je model, model dinamičke ravnoteže autora Headey i Wearing (1989, prema Brajković i Vuletić, 2011) koji uključuje utjecaj različitih dimenzija osobnosti na procjenu zadovoljstva. Kako osim dimenzija osobnosti, u zadovoljstvu životom važnu ulogu imaju i objektivni i subjektivni pokazatelji zadovoljstva životom, model dinamičke ravnoteže opisuje međusobnu povezanost i ravnotežu između stanja objektivne i subjektivne dobrobiti, a dimenzije osobnosti promatra kao osnovne prediktore zadovoljstva životom.

Možemo uočiti da je veliki broj teorija i modela kvalitete života rezultirao boljim shvaćanjem same ideje kvalitete života i uloge pojedinca u kreiranju iste. 


\section{5. 4. Pokazatelji kvalitete života}

Kroz povijest razvoja pokazatelja kvalitete života, pojavila su se dva temeljna pristupa konceptualizacije kvalitete života: skandinavski i američki.

Skandinavski pristup naglašava objektivne indikatore razine življenja ili kvalitete života društva kao cjeline, a američki subjektivne indikatore kvalitete (Lučev i Tadinac, 2008).

Felce (1996) izdvaja šest dimenzija kvalitete: tjelesno blagostanje, materijalno blagostanje, socijalno blagostanje, produktivno blagostanje, emocionalno i građansko. Za razliku od njega, Schalock (2004) dimenzije kvalitete širi na čak osam područja: tjelesno, materijalno, pripadanje zajednici, emocionalno, građanska prava, međuljudski odnosi, osobni razvoj i samoopredjeljenje.

Uz navedene pokazatelje, valja istaknuti one Svjetske zdravstvene organizacije (SZO) (1995). Naime, SZO je pokrenula izradu instrumenta za ispitivanje kvalitete života koji bi trebao biti primjenjiv u različitim kulturama i zemljama različitih stupnjeva razvoja. U ispitivanju opće kvalitete života najčešće se primjenjuje upravo upitnik Svjetske zdravstvene organizacije koji kvalitetu života svrstava u sljedeća područja: tjelesno zdravlje, okruženje, socijalni kontakti, psihološko zdravlje, nezavisnost i vjeroispovijest.

Internetska publikacija Eurostat pruža nedavne statistike o kvaliteti života u Europskoj uniji (EU). Publikacija prikazuje detaljnu analizu $8+1$ dimenzija koja se statistički može mjeriti kako bi predstavljala različite komplementarne aspekte kvalitete života, nadopunjavajući indikator koji se tradicionalno koristi kao mjera ekonomskog i društvenog razvoja, bruto domaćeg proizvoda (BDP). Oni navode sljedeće dimenzije kvalitete života: materijalni životni uvjeti, produktivna ili glavna djelatnost zdravlje, obrazovanje, slobodno vrijeme i društvene interakcije, ekonomska i fizička sigurnost, upravljanje i temeljna prava, prirodno i životno okruženje i ukupni doživljaj života. Osam od tih dimenzija odnosi se na funkcionalne sposobnosti koje građani trebaju imati na raspolaganju kako bi učinkovito nastavili svoje samoodređeno dobro, prema vlastitim vrijednostima i prioritetima. Posljednja dimenzija odnosi se na osobno postignuće zadovoljstva i dobrobiti života. O'Boyle (1994) ističe individualnu prirodu kvalitete života.

Pokazateljima kvalitete života najčešće se smatraju: zdravstveni status, kvaliteta prehrane, kvaliteta obrazovanja, uvjeti rada (zaposlenost), kvaliteta stanovanja, odijevanja i 
slobodnog vremena, te razina socijalne sigurnosti i ljudske slobode (Lay, 1991, prema Bouillet, 2006).

Prema Holjevac (2006) elementi kvalitete života mogu se svesti na tri velika područja:

a) zdravlje i fizička forma

b) život u obitelji i široj zajednici

c) zaposlenje i napredovanje

Složenija podjela ljudskih potreba obuhvaća devet kategorija: održanje života, zaštićenost, osjećajnost, razumijevanje, sudjelovanje, slobodno vrijeme, kreativnost, identitet i sloboda. Bilo bi jako teško mjeriti i ocjenjivati sve te kategorije potreba, što otežava objektivnost kod definiranja stvarne ukupne kvalitete života pojedinca i društva (Holjevac, 2006).

Generalno gledano, koncept kvalitete života odnosi se na sveukupnu dobrobit unutar društva, a usmjeren je na to da omogući svakom članu društva da ostvari svoje ciljeve. To znači da se kvaliteta života mjeri preko različitih ekonomskih, ali i neekonomskih pokazatelja. Pristup kvaliteti života oslanja se ne samo na indikatore materijalnog životnog standarda (pokazatelji dohodovne nejednakosti, realnog dohotka, stope siromaštva), već i na različite subjektivne čimbenike koji utječu na ljudski život, kao što su: društveni odnosi, sigurnost, mentalno zdravlje, kvaliteta prirodne sredine, dokolica, kulturni resursi i sl.

Kvaliteta života je i subjektivna i objektivna kategorija i usko je povezana s čovjekovim zadovoljstvom ili nezadovoljstvo vlastitim životom. Svaka osoba prosuđuje i ocjenjuje razinu svog zadovoljstva ili nezadovoljstva životom odnosno svoju kvalitetu života.

Znanstvenici Odsjeka za istraživanja kvalitete života Sveučilišta u Torontu na svojim mrežnim stranicama navode konceptualni model koji je razvio Centar za promociju zdravlja Sveučilišta u Torontu ${ }^{1}$. Prema njihovoj definiciji kvaliteta života je ,stupanj do kojeg osoba uživa značajne mogućnosti svog života“. Mogućnosti rezultiraju iz prilika i ograničenja koje svaka osoba ima u svom životu i reflektira interakciju osobnih i okolinskih čimbenika. Uživanje u ovom konceptu ima dvije komponente: iskustvo zadovoljstva posjedovanja ili postignuća nekih obilježja. Kako se navodi u dokumentu pod nazivom „The Quality of Life Model“, ovaj konceptualni okvir ima tri životne domene, od kojih svaka ima tri subdomene. Prva životna

\footnotetext{
${ }^{1}$ http://sites.utoronto.ca/qol/
} 
domena je postojanje (eng. being) koja se odnosi na ono što osoba jest. Ta domena se sastoji od sljedeće tri subdomene s pripadajućim dimenzijama (The Quality of Life Model) ${ }^{2}$ :

a) fizičko postojanje (eng. physical being) - fizičko zdravlje, osobna higijena, prehrana, vježbanje, dotjerivanje i odijevanje i opći fizički izgled

b) psihološko postojanje (eng. psychological being) - psihičko zdravlje i prilagodba, kognicije, osjećaji i samopoštovanje, samokonceptualizacija i samokontrola

c) duhovno postojanje (eng. spiritual being) - osobne vrijednosti, osobni standardi ponašanja i duhovna uvjerenja.

Druga životna domena je pripadanje (eng. belonging) i odnosi se na povezanost osobe s okruženjem. Strukturirana je kroz sljedeće subdomene i dimenzije (The Quality of Life Model):

a) fizičko pripadanje (eng. physical belonging) - obitelj, radno mjesto/ škola, susjedstvo i zajednica

b) socijalno pripadanje (eng. social belonging) - intimne osobe, obitelj, prijatelji, suradnici te susjedstvo i zajednica

c) pripadanje zajednici (eng. community belonging) - adekvatna primanja, zdravstvene i socijalne službe, zapošljavanje, obrazovni programi, rekreacijski programi te događaji i aktivnosti u zajednici.

Treća životna domena je postignuće (eng. becoming) koja se odnosi na postignuće osobnih ciljeva, nada i aspiracija. Ima sljedeće subdomene i dimenzije (The Quality of Life Model):

a) praktično postignuće (eng. practical becoming) - kućne aktivnosti, plaćeni posao, školske ili volonterske aktivnosti te zadovoljenje zdravstvenih ili društvenih potreba

b) postignuće u slobodnom vremenu (eng. leisure becoming) - aktivnosti koje promoviraju opuštanje i smanjenje stresa

c) postignuće razvoja (eng. growth becoming) - aktivnosti koje promoviraju održavanje ili unaprjeđenje znanja i vještina te prilagodba na promjene.

Stupanj osobne kvalitete života u životnim domenama i njihovim subdomenama određen je s dva čimbenika - značajem (eng. importance) i uživanjem (eng. enjoyment). Tako se kvaliteta života sastoji od relativnog značaja ili značenja koji se pridaje svakoj pojedinoj dimenziji i stupnjem uživanja svake pojedine dimenzije (Kovčo-Vukadin, 2016).

\footnotetext{
${ }^{2}$ http://sites.utoronto.ca/qol/qol model.htm (pristupljeno 23. 1. 2019.)
} 
Kvaliteta života mjeri se osobnim zadovoljstvom životom, a ono se može promatrati kao globalna procjena, ali i kao zadovoljstvo različitim područjima kao što su zdravlje, posao, dokolica, socijalni i obiteljski odnosi. Pojedinci procjenjuju koliko su zadovoljni pojedinim područjem, a katkad i koliko im je svako to područje važno ili koliko im se sviđa život s obzirom na pojedino područje (Diener, 2006).

\section{5. 5. Mjerenje kvalitete života}

Kao što se iz ranijih definicija može naslutiti, kvalitetu života nije jednostavno opisati, a još manje mjeriti. Kako bi nešto bilo mjerljivo, mora biti u određenom pogledu kvantificirano i jasno definirano. Ako se osvrnemo na povijest mjerenja kvalitete života, mogu se izdvojiti dva osnovna pristupa: subjektivnost i multidimenzionalnost. Subjektivnost opisuje kvalitetu života iz perspektive pojedinca, a multidimenzionalnost je dio psihometrijske tradicije mjerenja zdravstvenog statusa koja procjenjuje različite dimenzija života pojedinca (Mujkić i Vuletić, 2002).

Schalock (2004) ukazuje na složenu prirodu kvalitete života i mjerenje kvalitete života predstavlja pluralističkim pristupom. On smatra da se kvaliteta života može mjeriti istodobno iz objektivne i subjektivne perspektive uzimajući u obzir vanjske utjecaje. Osim toga, navedena trodijelna podjela nadilazi nedostatke pojedinih istraživačkih metoda i daje bolje rezultate istraživanja (Aranđelović, Ilić i Milić, 2010).

Tehnike mjerenja kvalitete života su najčešće osmišljene i provjerene unutar određenog kulturnog konteksta. Domene mjerenja kvalitete života moguće je podijeliti u tri skupine (Martinis, 2005):

Prva skupina su upitnici koji pokrivaju veći dio područja kvalitete života i opisujemo ih kao višedimenzionalne upitnike. Takav upitnik je usmjeren na prikupljanje podataka zdravih i bolesnih osoba te pokriva područje demografskih i kulturnih razlika ljudi. Neki od instrumenata ove skupine jesu: profil učinka bolesti (Bergner i sur., 1981), SF-36 (Ware, 1993) i Upitnik kvalitete života Svjetske zdravstvene organizacije (The World Health Organization Quality of Life Instrument- WHOQOL, 1996).

Drugu skupinu čine upitnici vezani uz točno određene bolesti, a upotrebljavaju se kod pacijenata sa sličnim zdravstvenim problemima. Najčešće tegobe koje se ispituju su rak, artritis, 
dijabetes, srčane bolesti i dr. Instrumenti kojima se ispituju su: Skala za mjerenje utjecaja oboljenja od artritisa (Meenan, Gertman i Mason, 1980); Skala Europske organizacije za liječenje oboljelih od raka (Aaronson i sur., 1993) i brojne druge skale.

Posljednju skupinu instrumenata čine mjere pojedinačnih domena kvalitete života, poput tjelesnog funkcioniranja i psihičkog zdravlja. Primjer ove vrste upitnika je Beckov inventar depresivnosti (Beck, Ward, Mendelson, Mock i Erbaugh, 1961).

Od navedenih upitnika, najčešće je korišten upitnik Svjetske zdravstvene organizacije WHOQOL koji je osmišljen kako bi mjerio kvalitetu života osoba različite dobi: mladih, zrelih i starijih osoba.

Autori Mujkić i Vuletić (2002) govore o nedostacima postojećih metoda prikupljanja podataka o kvaliteti života. Oni tvrde da mnoge ljestvice koje ispituju kvalitetu života zapravo ne dozvoljavaju ispitanicima slobodan izbor odgovora. Takvi nedostaci su česta pojava kod upitnika koji su standardizirani na uzorcima različitim od populacije koja se ispituje. Iz tih su razloga određeni autori više skloni korištenju intervjua kao metode prikupljanja podataka. Intervjuom je moguće prikupiti podatke koji su značajni za područje ispitivanja, a u isto vrijeme ne ograničavaju količinu informacija od strane ispitanika.

Kritiku postojećim mjerenjima kvalitete života je dao i Olweny (1992) koji je kvalitetu života definirao kao osobno vrednovanje stvarnog i očekivanog stila života. Autor predlaže mjerenje kvalitete života usmjereno na pojedinca kako bi se prevladala ograničenja $u$ međukulturalnim analizama. Dakle, ispitanik ima mogućnost da sam identificira područja života koja su njemu važna i da procjeni u kojoj mjeri to područje predstavlja kvalitetu njegova života.

Bowling (1995) također ističe da u procjenjivanju kvalitete života sudioniku treba biti dana mogućnost da identificira područja života koja su njemu važna i u kojoj mjeri.

Mjerenje kvalitete života može se usredotočiti na:

a) razinu zadovoljstvo koje osoba doživljava u odnosu na domene i pokazatelje kvalitete života (subjektivna komponenta) ili

b) cilj kojeg čine pokazatelji životnog iskustva i okolnosti vezane uz te domene i pokazatelje (objektivna komponenta).

Najčešće se istražuje zadovoljstvo jer ima brojne prednosti (Cummins, 1996; 1998). Omogućuje procjenu relativne važnosti svake pojedinačne domene kvalitete života i procjenu 
vrijednosti odgovarajućih domena. Glavni nedostaci korištenja samo zadovoljstva kao zavisne varijable kvalitete života su: uočena niska korelacija između subjektivnih i objektivnih mjera kvalitete života, stabilnost tijekom vremena, tendencija pružanja samo općeg mjerenja percipiranog blagostanja i nedostatak mogućnosti provjere . Dakle, potrebne su i subjektivne i objektivne mjere kvalitete života, a njihova relativna težina ovisit će o predviđenoj upotrebi (Schalock i Felce, 2004).

Shvatimo li kvalitetu života kao doživljaj zadovoljstva životom (u cijelosti ili pojedinim njegovim aspektima) određen individualnim iskustvom, aspiracijama, željama i vrijednostima pojedinca, njegovim kognitivnim i konativnim karakteristikama te objektivnim uvjetima $\mathrm{u}$ kojima pojedinac živi (Gojčeta, Joković-Turalija i Mejovšek, 2005) tada subjektivnim pristupom kvaliteti života, gdje težište stavljamo na doživljaj zadovoljstva načinom života i njegovim uvjetima te mogućnostima i ograničenjima koje život nameće, pojedinac može procijeniti svoju kvalitetu života na osnovi doživljaja uspješnosti u različitim životnim ulogama (Krizmanić i Kolesarić, 1989; Pastuović, 1993; Pastuović, Kolesarić i Krizmanić, 1995). Zadovoljstvo životom promatrano kroz globalnu, kognitivnu prosudbu vlastitog života (Pavot, Diener, Colvin i Sandvik, 1991), smatra se važnim pokazateljem psihološkog blagostanja (Huebner, Valois, Paxton, Drane, 2005). Kako bi se promicalo psihološko blagostanje i osigurao zdrav razvoj postoje neke osnovne potrebe koje treba zadovoljiti (Deci i Ryan, 2000). Prema teoriji samoodređenja to su psihološke potrebe za kompetencijom, povezanošću i autonomijom. Pretpostavlja da su te potrebe univerzalne za sve ljude i kulture u svim područjima i aspektima života osobe (Deci i Ryan, 1985; Ryan i Deci, 2000).

Pri mjerenju kvalitete života treba se voditi načelima koja bi trebala voditi mjerenje u skladu s trenutnim interesom za koncept kvalitete života kao senzibilizirajućeg pojma, društvenog konstrukta i jedinstvene teme (Schalock i sur,. 2002). Tri su razloga za ovakav interes. Prvi je razlog uvjerenje da znanstveni, medicinski i tehnološki napredci sami ne mogu rezultirati poboljšanim samopoimanjem života osobe. Obitelj, zajednica i društvena dobrobit izvire iz složenih kombinacija ovih napredaka i vrijednosti, percepcije i uvjeta okoliša. Drugi razlog odražava činjenicu da koncept kvalitete života predstavlja sljedeći logičan korak normalizacijskog pokreta koji je naglasio doprinos svakog pojedinca u životu zajednice. Treći razlog povećanog interesa za koncept kvalitete života i njegovo mjerenje je pojačano osnaživanje sudionika u pokretima za građanska prava i naglašavanje planiranja usmjerenih na osobe, osobne vrijednosti i samoodređenje (Verdugo, Schalock, Keith i Stancliffe, 2005). 
Godine 2002., međunarodno priznati istraživači koji rade na području kvalitete života i njegovih mjerenja, objavili su niz dogovorenih načela vezanih uz mjerenje kvalitete života (Schalock i sur., 2002). Ta su načela naknadno ocjenjivana od strane dodatne skupine stručnjaka koji rade na međunarodnoj razini. Kao rezultat toga o društvenoj provjeri valjanosti raspravljano je na okruglom stolu u Sydneyu, 2004. godine te je rasprava donijela četiri načela mjerenja kvalitete života:

a) mjerenje kvalitete života uključuje stupanj vrednovanja životnog iskustva

b) mjerenje kvalitete života određuje područja koja pridonose punom i sadržajnom životu

c) mjerenje kvalitete života razmatra kontekste fizičkog, društvenog i kulturnog okoliša koji su ljudima važni

d) mjerenje kvalitete života uključuje mjerenja iskustva koja su zajednička svim ljudima i ona koja su jedinstvene za svakog pojedinca

Može se ustvrditi da je kvaliteta života vrlo kompleksna kategorija, složen fenomen koji ovisi o puno različitih čimbenika, određen je prvenstveno pojedinačnom subjektivnom percepcijom i subjektivnim doživljajem sebe i svoje sredine (Lorger i Barić, 2012), pristup u istraživanjima trebao bi biti usmjeren na pojedinca koji subjektivno procjenjuje vlastitu kvalitetu života, odnosno osobno zadovoljstvo životom. 


\section{5. 6. Kvaliteta života mladih}

Kvaliteta života mladih kompleksni je fenomen i može se analizirati s različitih aspekata, ona u sebi ujedinjuje različite i brojne specifičnosti koje se odnose na različita područja života. Određena je izvanjskim uvjetima (materijalnim, fizičkim, sigurnosnim, ekološkim), socijalnom organizacijom društva, pripadnošću pojedinoj društvenoj grupi i brojnim drugim okolnostima (Bouillet, 2006). Kvaliteta života mladih, kao i opće populacije, obuhvaća subjektivni osjećaj zadovoljstva i objektivne uvjete koji dovode do tog zadovoljstva, a koji se mogu empirijski istraživati (materijalni aspekti, pripadnost određenoj grupi, rasi, konfesiji, sigurnost u radu i sigurnosti materijalnih primanja, socijalna sigurnost, mjesto života sa svim prednostima ili nedostacima, obrazovanost, politički odnosi u zajednici i brojni drugi) (Diener i Lucas, 2000). Može se postaviti pitanje, zašto zadovoljavanje ljudskih potreba, počevši od ranog djetinjstva, odrastanja i aktivnog uključivanja u društvo, pa sve do školovanja i nakon toga, nailazi na niz poteškoća?

Neprestano smo u potrazi za odgovorom na ovo pitanje kao i na niz drugih pitanja koja kritički pozivaju mladu osobu na razmišljanje o vlastitom životu i svom zadovoljstvu životom. Teoretičari „kulture narcizma“ tvrde kako mladi uživaju u kaosu informacija i ideja, te da u negaciji stvaraju nove trendove. Opisuje ih se kao skupinu koja ne poštuje nikakva načela jer su za njih red i racionalnost neka vrsta zatvora. Za njih stvarnost postaje otvorena proizvoljnoj mogućnosti formiranja i željama za promjenjivošću (Fatović, 2009).

Iako ih se gleda kao problematičnu skupinu, oni sebi, prije stupanja u društvo odraslih postavljaju temeljno pitanje, hoće li društvo uvažiti njihove želje i planove te hoće li oni moći dati osobni pečat radu, zanimanju ili različitim životnim ulogama. Danas se ta pitanja često zamjenjuju pitanjem, slaže li se društvo sa slikom koju pojedinac ima o samom sebi i svom mjestu u društvu. Nažalost, to dokazuje mnoge probleme mladih u društvu danas, ali i ono što mladi traže, a to su promjene.

Razdoblje pohađanja višeg sekundarnog obrazovanja, podudara se s krajem adolescencije i početkom doba odraslosti. To je period života koji obilježavaju mnoge biopsihosocijalne promjene (Cherquiari, 2004). Obilježavaju ga i nedoumice, promišljanja, formiranje stavova i donošenje odluka kao što je izbor fakulteta, karijere, tijeka životnog puta (Assis i Oliveira, 2010). 
Učenici se razlikuju prema svojoj sposobnosti prilagodbe i integracije, nivou znanja, sposobnosti učenja i socijalizacije (Soares i Del Prette, 2015), ali i po samoprocjeni svoje kvalitete života.

Školsko okruženje u tom periodu obilježeno je iskustvima koja zahtijevaju veću mobilizaciju kognitivnih sposobnosti, autonomiju, odgovornost i socijalizaciju, što može učenike izložiti potencijalno stresnim situacijama (Bublitz, Guido, Freitas, Lopes, 2012).

Ranjivost i psihička patnja značajnog su dio ovog dijela života učenika. Treba uzeti u obzir da, s obzirom na nedostatak vještina upravljanja stresom, zajedno sa zahtjevima škole i mogućnostima, upravo to može doprinijeti pojavi nezdravih obrazaca ponašanja (Oliveira, Padovani, 2014) što neosporno utječe na kvalitetu života njih samih i ljudi u njihovom okruženju. Istraživanje provedeno u Kanadi na oko 18000 ispitanika pokazalo je da fizički aktivno provođenje slobodnog vremena povezano sa smanjenjem stresa, većim samopouzdanjem, smanjenjem anksioznosti te pomaže u održavanju zdravlja i opće dobrobiti (Norris, Douglas i Cochrane, 1992; Lasheras, Aznar, Merino i Lopez, 2001). Bavljenje sportskim aktivnostima učenicima može omogućiti usredotočenost na druge sadržaje u svrhu smanjenja stresa i napetosti (Brdar i Lončarić, 2004). Postoji pozitivna korelacije između sudjelovanja u organiziranim aktivnostima u slobodnom vremenu i školskog uspjeha (Eccles, Barber, Stone i Hunt 2003; Fredricks i Eccles 2006, 2008; Gilman 2001), a školski uspjeh povezujemo s osobnim zadovoljstvom.

Različiti načini provođenja slobodnog vremena utječu na različite načine suočavanja $\mathrm{s}$ akademskim stresom (Brdar i Lončarić, 2004), a stres smanjuje osjećaj zadovoljstva, ali načini suočavanja sa stresom u velikoj su mjeri povezani s osobinama ličnosti (Lazarus, 1990).

Postoje mnoge studije koje istražuju kvalitetu života učenika, odnosno, utjecaje na njihovu kvalitetu života (Pilcher, 1998; Makinen i Pychyl, 2001; Cha, 2003; Smith i sur., 2004; Vaez, Kristenson and Laflamme, 2004; Chow, 2005; Ng, 2005). Vaez i sur. (2004) pronašli su pozitivan odnos između samoprocjene kvalitete života i zdravlja studenata. Cha (2003) uočava suodnos između subjektivne dobrobiti i osobina ličnosti, kao što su samopoštovanje i optimizam. Pilcher (1998) je provela istraživanje kako dnevni događaji utječu na životno zadovoljstvo među učenicima.

Jedna skupina istraživanja se fokusira na razvoj mjera posebno prilagođenih za dobrobit učeničke populacije mladih (npr. Witmer i Sweeney, 1992; Roberts i Clifton, 1992; Royal i Rossi, 1993; Disch, Harlow, Campbell i Dougan, 2000; Cohen, Clifton i Roberts, 2001; 
Maggino i Schifini D'Andrea, 2003). Ove se studije usredotočuju na opću kvalitetu života učenika. Cohen i sur. (2001) su koristili Bloomovu taksonomiju (Bloom i sur., 1956, 1971) kako bi razvili sustav mjerenja kvalitete života učenika. Bloomova taksonomija uključuje šest dimenzija poznatih kao znanje, razumijevanje, primjena, analiza, sinteza i evaluacija. Ostali mjerni instrumenti razvijeni za učenike uključuju procjenu uživanja u životu (Witmer i Sweeney, 1992) i zadovoljstvo životom (Disch i sur., 2000). Korišteni mjerni instrument za mjerenje zadovoljstva učenika uključuje 16 dimenzija kategoriziranih u pet glavnih životnih zadaća: duhovnost, samoregulacija, rad, rekreacija i slobodno vrijeme, prijateljstvo i ljubav (prepoznavanje društvene međuovisnosti). Disch i sur. (2000) mjerenje temelje na 10 dimenzija koje su direktno povezane s problemima učenika kao što su droga i alkohol, potrošnja, društveno i seksualno ponašanje, korištenje vremena, potrošačka i financijska pitanja, tjelesna i duševna pitanja, multikulturalizam, stil učenja, pitanja u vezi s karijerom i zapošljavanjem, zločin i pitanja nasilja i životna pitanja. Maggino i Schifini D'Andrea (2003) uključuju tri dimenzije: motivaciju prema učenju, školski uspjeh i zadovoljstvo u pojedinim životnim područjima. Motivacija za školovanje odnosi se na očekivanja za budućnost, motivaciju za učenje i samoevaluaciju u odnosu na školska postignuća (što je pozitivnija samoprocjena veća je motivacija za učenje).

Kvaliteta školskoga života se definira kao skup pozitivnih i negativnih iskustava u školi te ostalih osjećaja povezanih sa specifičnim područjima i posljedicama života u školi (Leonard, 2002). Jedan od prvih modela istraživanja kvalitete školskoga života predložili su Epstein i McPartland (1976). U njihovu se izvornom modelu kvaliteta školskoga života temelji na trima dimenzijama učeničkih reakcija: općem zadovoljstvu školom, predanosti školskim obvezama i reakcijama na nastavnike. Ovi su autori razvili i skalu za mjerenje opisanih dimenzija kvalitete školskoga života, a istraživanja u školskom okruženju potvrdila su valjanost njihova modela (Epstein i McPartland, 1976; Johnson i Johnson, 1993).

Williams i Batten (1981, prema Pang, 1999) razvili su model u kojem se učeničko vrednovanje kvalitete školskoga života temelji na doživljaju opće dobrobiti i osjećajima vezanima uz specifična područja školskoga života. Utvrđena je i činjenica da zadovoljstvo školskim životom i uspjesima u školi utječe na kvalitetu života učenika.

Zadovoljstvo životom mladih možemo promatrati kao dio šireg koncepta subjektivnog zadovoljstva koje uključuje zadovoljstvo životom, kao kognitivnu komponentu, te pozitivne i negativne afekte, kao afektivnu komponentu. Zadovoljstvo životom je mjera kognitivne komponente subjektivne dobrobiti s obzirom na to da se odnosi na procjenu zadovoljstva 
životom (Kovčo-Vukadin, 2016). Subjektivna dobrobit uključuje doživljavanje ugodnih emocija, nisku razinu negativnih raspoloženja i visok stupanj zadovoljstva životom (Diener, Lucas i Oishi, 2002). Diener (2006) smatra kako je subjektivna dobrobit krovni pojam koji obuhvaća različite procjene koje ljudi donose o svojim životima, događajima, svojim tijelima i umovima i okolnostima u kojima žive te da iako se radi o subjektivnoj procjeni, manifestacije te procjene možemo promatrati objektivno kroz verbalno i neverbalno ponašanje, djela, biologiju, pozornost i pamćenje. Osjećaj blagostanja je subjektivan i ovisi o iskustvu svake pojedine osobe. On uključuje pozitivne čimbenike i odsutnost negativnih čimbenika i predstavlja ukupnu procjenu svih aspekata života pojedinca, s naglašenom subjektivnom evaluacijom života (Diener, 1984).

Rijavec (2007) povezuje zadovoljstvo životom mladih s njihovom sposobnošću odabira pravih smjernica za dosezanje određenih ciljeva. Gojčeta, Jakovina, Oreb i Pinjatela (2008) kvalitetu života adolescenata povezuju s doživljajem njihovog subjektivnog zadovoljstva životom pri čemu se kao bitan čimbenik subjektivnog zadovoljstva čini mogućnost podudaranja realnog načina života sa željenim. Kaliterna-Lipovčan i Prizmić-Larsen (2006) navode kako je za subjektivno zadovoljstvo važan obiteljski život i odnosi s prijateljima. Slično razmišljaju i Bratko i Sabol (2006) kada povezuju zadovoljstvo u pojedinim segmentima života s općim zadovoljstvom pri čemu je dobrobit povezana s doživljavanjem pozitivnih osjećaja. 


\section{5. 7. Slobodno vrijeme i kvaliteta života mladih}

Kada se mjeri zadovoljstvo pojedinim područjima života učenika višeg sekundarnog obrazovanja, to uključuje ocjene zadovoljstva u deset životnih područja: prijateljstvo, slobodno vrijeme, obiteljski odnosi, osobno zdravlje, obiteljsko zdravlje, fakultet, obitelj, financijska situacija, sveučilišna karijera, osobna financijska situacija i prijateljstvo.

Slobodno vrijeme samo može obuhvatiti većinu tih područja. Ono je svojevrsni poligon za vježbanje mnogih životnih vještina čijim posjedovanjem možemo utjecati na kvalitetu svog života i života osoba u svojoj okolini. Mladi se u slobodnom vremenu suočavaju sa sukobima i njihovim rješavanjem, uče tolerantno i demokratsko ponašanje, uzajamno poštovanje i razvijaju socijalne i komunikacijske vještine (Opić i Đuranović, 2014). U slobodnom vremenu stvaraju se prilike za samoizražavanje, opuštanje, vježbanje samokontrole, samorazvoja i učenja (Irby i Tolman, 2002). Povezanost slobodnog vremena i kvalitete života vidimo i u tome što pozitivne učinke slobodnog vremena adolescenata: socio-emocionalni razvoj i angažman koji podrazumijeva održavanje prijateljstva, druženje i zabava, profesionalni razvoj i angažman u smislu razvijanja vještina potrebnih za zapošljavanje, razumijevanje i postizanje profesionalne karijere, fizički razvoj i angažman, kognitivni razvoj i angažman koji podrazumijeva razvoj kritičkog mišljenja i rješavanja problema i civilni razvoj i angažman s osobnim utjecajem na društveno okruženje i odgovornost prema drugima (Opić i Đuranović, 2014), možemo direktno povezati s kvalitetom života pojedinca i zajednice. Socijalno i emocionalno razvijen pojedinac s jasnom vizijom svog profesionalnog i društvenog razvoja i svijesti o potrebnom osobnom angažmanu u ostvarivanju zadanih ciljeva zadovoljava preduvjete za kvalitetan život.

Različiti autori fenomen kvalitete života opisuju na različite načine. Perasović i Bartoluci (2008) kvalitetu života povezuju uz slobodno vrijeme mladih ljudi koje smatraju važnim čimbenikom u autonomiji i odrastanju mladog čovjeka, odnosno za izgrađivanje njihova osobnog identiteta i životnih stilova.

Kvaliteta života mladih je kompleksan, jedinstven doživljaj zadovoljstva, odnosno nezadovoljstva pojedinca životom što ovisi o uspješnosti zadovoljenja njegovih potreba (Pastuović, Krizmanić i Kolesarić, 1991; Krizmanić i Kolesarić, 1989). Njihovu kvalitetu života ne čini samo jedan segment već je riječ o složenom konstruktu čiju razinu zadovoljstva definira niz važnih segmenata (Lorger i Barić, 2012, str. 392). Osnovni konstrukt doživljaja kvalitete života mladih čine: subjektivno zadovoljstvo, razina opće i emocionalne dobrobiti, osjećaj sreće, obitelj i socijalno okruženje, a sve su to koncepti koji se ostvaruju kroz slobodno vrijeme. 
Ranija istraživanja (Auguštanec, 2008; Berger i Motl, 2001; Bisegger, Cloetta, Rueden i Abel, 2005; Bratković i Rozman, 2007; Gojčeta, Joković-Turalija i Mejovšek, 2004; Krizmanić i Kolesarić, 1989; Lučev, 2007.; Ravens-Sieberer i sur., 2008) opisuju složenost konstrukta kvalitete života i utjecaj različitih elemenata na doživljaj kvalitete življenja. Istraživanja su također pokazala da je kvalitetu života moguće promatrati kroz slobodno vrijeme u kojem se razvija autonomija važna za odrastanje i oblikovanje životnih stilova (Lorger i Barić, 2012; Perasović i Bartoluci, 2008), kroz subjektivnu procjenu zdravlja i tjelesne forme (Borić, Ivelj, Leko, Bojanić i Roić, 2007; Bramm i sur., 2010; Heimer i Rakovac, 2005; Klassen, Miller i Fine, 2004; Lorger i Barić, 2012; Rajmil i sur., 2009), kroz važnost obiteljskog života i odnosa s prijateljima (Dowda, Dishman, Pfeiffer i Pate, 2007; Fredericks i Eccles, 2005; KaliternaLipovčan i Prizmić -Larsen, 2006; Lorger i Barić, 2012), važnost obitelji, standarda života, osjećaja zdravlja (Brajša-Žganec i Kaliterna-Lipovčan, 2006), važnost razine obrazovanja (Pastuović, 2006), važnost subjektivnog osjećaja sreće i psihološke dobrobiti i izostanak neugodnih emocija i raspoloženja (Berger i Motl, 2001; Lorger i Barić, 2012; Rolim, Thiago, Segato i Andrade, 2007).

Kroz različita područja istraživanja pokušavaju se povezati subjektivni osjećaj dobrobiti S različitim karakteristikama fizičkog i psihičkog funkcioniranja pojedinca. Pokazalo se da utjecaj na subjektivan osjećaj dobrobiti imaju: zdravlje, posao, materijalno stanje, socijalno sudjelovanje, spol, bračno stanje, inteligencija, nivo obrazovanja i samopoštovanje. Pojedini autori subjektivni opći osjećaj zadovoljstva životom povezuju sa samopoimanjem. Smatraju da je opće zadovoljstvo pod utjecajem zadovoljstva u pet područja života: u obitelji, zdravlju, poslu, društvu i slobodnom vremenu (Lacković-Grgin, 1994).

U sociološkim se terminima govori da korištenje slobodnog vremena pridonosi društvu i pojedincu (Warn, 1999). Poznato je da aktivnosti u slobodnom vremenu, koje imaju važno mjesto u individualnim i društvenim uvjetima, zauzimaju značajnu ulogu u povećanju kvalitete života, kao i suočavanje s fizičkim i psihološkim problemima (Hamer, Karageorghis i Vlachopoulos, 2002).

Studija o preliminarnim učincima programa obrazovanja za slobodno vrijeme radi promicanja zdravih načina provođenja slobodnog vremena među adolescentima u srednjim školama (Caldwell i sur., 2004) pokazuje da učenici koji su sudjelovali u sportskim aktivnostima i boravili u prirodi imaju bolje sposobnosti restrukturiranja dosadnih situacija u nešto zanimljivo, sudjeluju u višim razinama odlučivanja, pokazuju inicijativu, imaju razvijenu svijest o zajednici i pokazuju nove interese za sport i rekreaciju. U studiji o čimbenicima koji 
utječu na opću dobrobit koju su proveli Lee, McCormick i Bryan (2004), utvrđeno je da je slobodno vrijeme predskazivač dobrobiti. Sudjelovanje u slobodnom vremenu tijekom adolescencije povezano s niskom razinom depresivnog raspoloženja i tjeskobe (Larson, Wilson, Bradford Brown, Furstenberg i Verma, 2002) te agresivnošću, antisocijalnim ponašanjem i kriminalom (Rhodes i Spencer, 2005).

Adolescenti sudjelovanjem $\mathrm{u}$ aktivnostima u slobodnom vremenu mogu zadovoljiti osnovne psihološke potrebe (Leversen i sur., 2012), potrebe za kompetencijom, povezanošću i autonomijom. Potreba za kompetencijom podrazumijeva osjećaj djelotvornosti u interakciji s okolinom, priliku za korištenje svojih sposobnosti i upravljanje izazovnim zadacima (Deci i Ryan, 1985; Ryan i Deci, 2000; White 1959). Mladi u slobodno vrijeme imaju priliku razvijati svoje vještine, biti izloženi raznim izazovima i osjećati se dobro.

Zadovoljavanjem potrebe za kompetencijom pojedinci su psihološki nagrađeni i osjećaju se sposobno. Potreba za povezanošću usko je povezana s potrebom za kompetencijom jer su podrška i priznanje bliskih osoba važan čimbenik osjećaja kompetentnosti adolescenata (Fredricks i sur., 2002). Osjećaj povezanosti s drugima uključuje povezivanje i brigu za druge i osjećaj uključenosti u društveni svijet općenito (Baumeister i Leary, 1995). U adolescenciji s opadanjem privrženosti roditeljima, za opću psihološku dobrobit postaju sve važniji odnosi s vršnjacima i drugim odraslim osobama. Aktivnosti u slobodnom vremenu mogu stvarati uvjete prilagođene razvojnim potrebama adolescenata za društvenom povezanošću. U tim aktivnostima oni imaju priliku biti s drugim ljudima, surađivati s njima, osjećati se poštovanima i voljenima.

Kada se govori o autonomiji, podrazumijevaju se nastojanja ljudi da osjećaju kako su odabrane aktivnosti u skladu s njihovim intrinzičnim interesima te da samostalno doprinose određivanju vlastitog ponašanja (Deci i Ryan, 1985). Pretpostavlja se da je za adolescente sudjelovanje u slobodnim aktivnostima dobrovoljno, samoinicijativno i da su aktivnosti birane prema njihovim vlastitim interesima, iako društvene i kulturne vrijednosti i mogućnosti mogu utjecati na izbor.

U nekoliko se istraživanja pokazalo da je sudjelovanje u aktivnostima u slobodno vrijeme povezano s dobrobiti i mentalnim zdravljem (Casey, Ripke i Huston, 2005; Fletcher, Nickerson i Wright, 2003; Larson, 2000), a povezano je i sa zadovoljavanjem potrebe za razvojem kompetencija, povezanosti i autonomije. Međutim, zadovoljenje ovih triju psiholoških potreba u slobodnovremenskim aktivnostima ovisi o opsegu uključenosti adolescenata u aktivnosti (Hansen i Larson, 2007; Marsh i Kleitman, 2002). 
Nekoliko istraživanja se bavilo zadovoljstvom psiholoških potreba djece i adolescenata fokusirajući se na specifična okruženja, kao što su škola i obiteljsko okruženje (Veronneau, Koestner, Abela,2005; Milyavskaya i sur., 2009; Sheldon, Abad, Omoile, 2009). Cilj im je bio ispitati doprinos osjećaja kompetencije, povezanosti i autonomije općoj dobrobiti. Došli su do zaključka da su u domeni škole i obitelji sve tri potrebe povezane s dobrobiti, a posebno je važna psihološka potreba za kompetencijom.

Pawelko i Magafas (1997) istražili su i potvrdili da su vještina upravljanja slobodnim vremenom i dobar izbor slobodnih aktivnosti čimbenici koji doprinose dobrobiti i kvaliteti života adolescenata. Kako slobodno vrijeme igra sve važniju ulogu u našem životu, način na koji ga koristimo postaje nezaobilazno javno pitanje modernog društva (Wang i Kao, 2006).

S obzirom na to da sudjelovanje $\mathrm{u}$ aktivnostima u slobodno vrijeme predstavlja važan dio života adolescenata, važno je bolje razumjeti kako takvo sudjelovanje kroz zadovoljenje specifičnih potreba, može pridonijeti životnom zadovoljstvu mladih. Ovim se radom nastojalo proširiti prethodna saznanja o povezanosti zadovoljavanja psiholoških potreba adolescenata $i$ opće dobrobiti koja utječe na povećanje zadovoljstva životom. Također se nastoji proučiti povezanost između zadovoljavanja potreba, uočenih pozitivnih ishoda sudjelovanja adolescenata u slobodnim aktivnostima i percepcija uloge društvenih mreža. Bolje razumijevanje takvih odnosa može se koristiti kao osnova za razvoj pristupa u organiziranju aktivnosti za mlade u slobodnom vremenu i razvoju medijskih kompetencija kako bi se osiguralo da one doprinose razvoju i kvaliteti života mladih na najbolji mogući način. 


\section{METODOLOGIJA EMPIRIJSKOG ISTRAŽIVANJA}

Kvaliteta života učenika višeg sekundarnog obrazovanja kompleksni je fenomen koji se može analizirati s različitih aspekata. Obuhvaća subjektivni osjećaj zadovoljstva i objektivne uvjete koji dovode do tog zadovoljstva, a koji obuhvaćaju kvalitetu prehrane, kvalitetu obrazovanja, zdravstveni status, radne uvjete, kvalitetu stanovanja, odijevanja i slobodnog vremena i brojne druge činitelje (Bouillet, 2006). Ovim je istraživanjem obuhvaćeno slobodno vrijeme učenika koje ne predstavlja istoznačan i pedagoški osmišljen prostor, niti po stilovima, niti po ponašanju u tom vremenu, a zajedno s korištenjem društvenih mreža kao jednim od svojih imanentnih elemenata, može imati značajnu ulogu u kvaliteti života.

\section{1. Cilj i problem istraživanja}

Cilj istraživanja bio je ispitati i objasniti obilježja i prediktorsku ulogu korištenja društvenih mreža i načina provođenja slobodnog vremena u kvaliteti života učenika višeg sekundarnog obrazovanja. Također, želi se razumjeti učenička iskustva i percepcija značaja upotrebe društvenih mreža u slobodnom vremenu kao jednog od pokazatelja kvalitete njihova života.

Zadatci istraživanja:

- utvrditi sociodemografska obilježja ispitanika,

- utvrditi dnevno raspoloživu količinu slobodnog vremena učenika višeg sekundarnog obrazovanja,

- ispitati u kojoj mjeri ispitanici koriste društvene mreže,

- ispitati na koje načine koriste društvene mreže,

- ispitati kakav je odnos između demografskih obilježja učenika višeg sekundarnog obrazovanja i samoprocjene kvalitete života,

- ispitati odnos između aktivnosti kojima se bave u slobodno vrijeme i samoprocjene kvalitete njihovog života.

Problem: Ispitati kakva su učenička iskustva i percepcija upotrebe društvenih mreža kao elementa slobodnog vremena u razumijevanju i objašnjenju vlastite kvalitete života. 


\section{2. Hipoteze istraživanja}

H1: Demografska obilježja, aktivnosti u slobodnom vremenu i stavovi o društvenim mrežama su statistički značajni prediktori kvalitete života učenika višeg sekundarnog obrazovanja.

$\mathrm{H} 2$ : Ne postoji statistički značajna razlika u samoprocjeni kvalitete života s obzirom na sociodemografska obilježja ispitanika.

H3: Ne postoji statistički značajna razlika u aktivnostima slobodnog vremena s obzirom na sociodemografska obilježja ispitanika.

H4: Ne postoji statistički značajna razlika u učestalosti korištenja društvenih mreža s obzirom na spol učenika.

H5: Ne postoji statistički značajna razlika u stavovima o društvenim mrežama s obzirom na sociodemografska obilježja ispitanika. 


\section{3. Ispitanici}

Istraživanje je provedeno u urbanim i ruralnim područjima na području Grada Zagreba i Zagrebačke županije, na uzorku od 594 ispitanika, tijekom svibnja i lipnja 2018. godine. U kvantitativnom dijelu istraživanja je sudjelovalo 224 ispitanika muškog spola i 370 ispitanika ženskog spola (38\% i 62\%). Prosječna dob ispitanika je $16.5 \pm 1.11$ godina, dok je medijan 17.

Od ukupnog broja ispitanika, većina ih živi u gradu (430 učenika, 72\%), a 164 živi u seoskim sredinama (28\%). Smatralo se zanimljivim uzeti u obzir ispitanike iz ruralnih i urbanih područja radi usporedbe mogućnosti i navika provođenja slobodnog vremena, stavova prema drušvenim mrežama i samoprocjene kvalitete života u različitim područjima.

Tablica 2

Broj ispitanika prema dobi $(N=594)^{3}$

\begin{tabular}{cc}
\hline $\begin{array}{c}\text { Dob } \\
\text { učenika }\end{array}$ & $\begin{array}{c}\text { Broj } \\
\text { uč. }\end{array}$ \\
\hline 14 godina & 3 \\
15 godina & 154 \\
16 godina & 124 \\
17 godina & 208 \\
18 godina & 92 \\
19 godina & 13 \\
Ukupno & $\mathbf{5 9 4}$ \\
\hline Napomena: AS $=16.5, \mathrm{M}=17, \mathrm{SD}=1.1$
\end{tabular}

S obzirom na vrstu srednje škole koju ispitanici pohađaju, najviše je gimnazijalaca (267, $45 \%$ ), potom polaznika ekonomske škole (114 učenika, 19\%). Po brojnosti slijede polaznici Škole za modu i dizajn (77 učenika, 13\%), strojarski tehničari (23 učenika, 4\%) itd.

Za potrebe inferencijalne statističke analize škole su podijeljene u dvije grupe:

a) gimnazije - koje pohađa 267 ispitanika (45\%), te

b) strukovne škole - koje pohađa 327 ispitanika (55\%).

\footnotetext{
${ }^{3}$ Napomena: podaci o ispitanicima se odnose na oba spola premda je uvijek u tabelama (zbog kratkoće izražavanja) iskazano samo u muškom rodu
} 
Prema općem uspjehu ispitanika u prethodnom razredu, u istraživanju je sudjelovalo najviše vrlo dobrih učenika (49\%) koliko iznosi i medijan. Prosječna je ocjena 4.03 \pm .75 .165$ (28\%) je odličnih učenika, dobar opći uspjeh je imao 131 učenik (22\%), tri je učenika dovoljnim uspjehom (.5\%) i 3 s nedovoljnim (.5\%).

Anketnim upitnikom je obuhvaćen cijeli uzorak, dok je dobrovoljnim pristankom učenika odabrano 23 sudionika za intervjuiranje. Intervjuiranje je provedeno metodom grupnog intervjua s tri skupine, u tri škole.

Od ukupnog broja sudionika grupnog intervjua bilo je dvanaest ispitanika ženskog i jedanaest muškog spola. Četvero je pohađalo četvrti razred, četvero treći, devet drugi i sedam prvi razred. Jedanaest učenika pohađa gimnaziju, a dvanaest ih je strukovnih usmjerenja. I kvalitativnim dijelom istraživanja su obuhvaćeni i učenici urbanih i ruralnih područja. Sudjelovalo je deset učenika koji žive u selu i trinaest koji žive u gradu.

U prvoj skupini je sudjelovalo sedam ispitanika, pet ženskoga i dva muškog spola, četvero učenika je pohađalo četvrti razred, a troje drugi razred višeg sekundarnog obrazovanja, gimnazijskog usmjerenja, petero živi u gradu, a dvoje u selu. U drugoj skupini je također sudjelovalo sedam ispitanika, četvero ženskog i troje muškoga spola, troje učenika je pohađalo drugi, a četvero treći razred. Skupinu su činili učenici gimnazije i strukovne škole, četvero živi u selu, a troje u gradu. Treća skupina je formirana od devet ispitanika, tri ženskog i šest muškog spola, troje je pohađalo prvi, a šestero drugi razred gimnazije i strukovnih škola, petero živi u gradu, a četvero u selu. 


\section{4. Instrumenti}

Za potrebe ovog istraživanja korišten je anketni upitnik (Prilog 1) se sastoji od dijela o demografskim podacima te tri skale. Demografski podaci o ispitanicima koji su se prikupljali odnose se na: spol, dob, razred, mjesto škole, opći uspjeh, posjedovanje i učestalost upotrebe pojedinih društvenih mreža (,Koje društvene mreže koristiš?“ “, ,Koliko često koristiš društvene mreže? 1) jedan sat tjedno, do 5) tri i više sati dnevno“, „Za što najčešće koristiš društvene mreže?").

Podaci o slobodnom vremenu prikupljani su Skalom aktivnosti u slobodnom vremenu, podaci o procjeni društvenih mreža prikupljani su Skalom stavova o društvenim mrežama, a podaci o kvaliteti života prikupljani su Skalom kvalitete života.

Skala aktivnosti u slobodnom vremenu (engl. Leisure time activity) od Deci i Ryan (1989) sastoji se od dvadeset jedne tvrdnje Likertove skale od pet stupnjeva (od 1= uopće se ne slažem do $5=$ u potpunosti se slažem) koje čine tri latentna faktora: Autonomija sa sedam tvrdnji, Kompetencija sa šest i Povezanost s osam tvrdnji. Skala aktivnosti u slobodnom vremenu razvijena je za HBSC (engl. Health Behaviour in School-aged Children) studiju. Validacija ovih triju faktora provedena je u studiji na 431 bugarskih i 128 američkih radnika (Deci, Ryan, Gagnè, Leone, Usunov \& Kornazheva, 2001). Cronbach's alpha za cijelu skalu bugarskog uzorka bio je .83, za podskale Kompetencije, Povezanosti i Autonomije .81, .57 i .62. Na američkom uzorku je Cronbach's alpha za cijelu skalu bio 1.89 , a za podskale Kompetencije, Povezanosti i Autonomije .73, .84 i .79.

Skala stavova o društvenim mrežama je modificirana Skala stavova o internetu (engl. Internet attitudes scale) od Tsai, Lin i Tsai (2001). Sastoji se od ukupno osamnaest manifestnih tvrdnji Likertove skale od pet stupnjeva ( $1=\mathrm{u}$ potpunosti se ne odnosi na mene do $5=\mathrm{u}$ potpunosti se odnosi na mene) koje čine četiri latentna faktora: Korist s pet tvrdnji, Afektivna procjena s pet tvrdnji, Kontrola s pet i Namjera korištenja s tri tvrdnje. Skala je razvijena za potrebe istraživanja stavova o internetu. Podatci istraživanja prikupljeni su od 753 srednjoškolca iz Tajvana. Koeficijenti pouzdanosti bili su adekvatni za prva tri potkategorije: $82, .71$ i .68 i za cijelu skalu .81 , dok je za četvrtu potkategoriju alfa bila relativno niska (.49), no test interkorelacijske marice na četiri faktora je pokazao da su sve korelacije dosegle značajnu razinu od .01 te na koherentan način mjere stav ispitanika.

Skala kvalitete života (engl. Quality of life scale) od Wang i Kao (2011) sastoji se od devetnaest tvrdnji Likertove skale od pet stupnjeva od (1= uopće se ne slažem do $5=\mathrm{u}$ 
potpunosti se slažem) koje čine četiri latentna faktora: Fizički s četiri tvrdnje, Psihološki sa sedam, Društveni s pet i Okolina s tri tvrdnje. Skalu je razvila Svjetska zdravstvena organizacija. Na podatcima dobivenim istraživanjem koje je provedeno na Tajvanu specificirano je četverofaktorsko rješenje koje je činilo $52.12 \%$ varijance, dok je ukupna pouzdanost od .92 pokazala visoku unutarnju konzistentnost.

Za korištenje skala dobivena su dopuštenja autora te su s engleskog na hrvatski jezik prevedene povratnim prevođenjem.

U kvalitativnom dijelu istraživanja podatci su prikupljani metodom grupnog polustrukturiranog intervjua. Ispitana su iskustava i percepcije slobodnog vremena i društvenih mreža u kvaliteti života pitanjima:

Što je slobodno vrijeme?

Kako provodiš svoje slobodno vrijeme?

Koristiš li društvene mreže?

Koliko vremena dnevno provodiš koristeći društvene mreže?

Za što najčešće koristiš društvene mreže?

Što je kvaliteta života?

Što utječe na kvalitetu života?

Kako procjenjuješ kvalitetu svog života?

Uz glavna pitanja, postavljana su i dodatna pitanja za pojašnjenja danih odgovora. 


\section{5. Postupak}

Istraživanje je provedeno u skladu s Etičkim kodeksom istraživanja s djecom (2003) i uz odobrenje Etičkog povjerenstva Odsjeka za pedagogiju Filozofskog fakulteta Sveučilišta u Zagrebu.

Prije provođenja istraživanja zatraženo je odobrenje Ministarstva znanosti i obrazovanja RH za provođenje istraživanja u srednjim školama u Gradu Zagrebu i Zagrebačkoj županiji.

Nakon odobrenja Etičkog povjerenstva i Ministarstva znanosti i obrazovanja upućen je dopis ravnateljima škola sa zamolbom da odobre provođenje istraživanja u kojem će sudjelovati učenici njihovih škola.

Istraživačica se, prije provođenja istraživanja i odabira sudionika, u svakoj od škola sastala s nekim od stručnih suradnika škole (pedagogom/psihologom) i uputila ih u osnovne aspekte istraživanja i kriterije za odabir sudionika. Potom su oni izvršili odabir sudionika a istraživačica je odabranim sudionicima podijelila obavijesti za roditelje o provođenju istraživanja (Prilog 2).

Istraživanje je provedeno u prostorima škole odabranim u suradnji sa stručnim suradnicima.

Prvu informaciju o provođenju istraživanja učenicima su dali stručni suradnici škole, a detaljnije informiranje je provela sama istraživačica u neposrednom kontaktu s njima, prije samog početka anketiranja.

Pojašnjeno im je da je cilj istraživanja objasniti obilježja slobodnog vremena i društvenih mreža i njihovu ulogu u kvaliteti života učenika te da se žele razumjeti njihova iskustva $\mathrm{i}$ viđenje povezanosti među navedenim pojmovima. Također su informirani o tome da će istraživanje imati znanstvenu i praktičnu svrhu. Rezultati istraživanja mogli bi biti korisni samim učenicima, stručnjacima koji rade u praksi s mladima, donositeljima odluka kreatorima politika i programa djelovanja za mlade, roditeljima i znanstvenoj javnosti. Korisnost istraživanja za same učenike očituje se u činjenici da sudjelovanjem u istraživanju mogu dati svoje viđenje uloge slobodnog vremena i društvenih mreža u kvaliteti života. Stručnjacima koji rade s mladima, profesorima i stručnim suradnicima u srednjim školama, rezultati će omogućiti dobivanje uvida u to kakvu ulogu imaju slobodno vrijeme i društvene mreže u kvaliteti života učenika te je opravdano očekivati da će utemeljenije planirati i provoditi svoj svakodnevni rad u smislu odabira ciljeva metoda i tehnika rada kao i veću usmjerenost stručnjaka na participativni rad s mladima. Znanstvena svrha je izrada doktorskog rada i produbljivanje spoznaja o slobodnom vremenu, društvenim mrežama i kvaliteti života učenika srednje škole. 
Učenici su obaviješteni da je istraživanje anonimno te da će podatci biti strogo povjerljivi i čuvani. Svi izvještaji nastali na temelju ovog istraživanja koristit će rezultate koji govore o grupi učenika, nigdje se neće navoditi rezultati pojedinačnog sudionika.

Također su upoznati s činjenicom da se istraživanje provodi putem upitnika i putem intervjua koji će uslijediti nakon anketiranja s manjim brojem ispitanika.

Nakon upoznavanja s predviđenim vremenom ispunjavanja upitnika, ukazano im je na njihovo pravo da u bilo kojem trenutku odustanu od sudjelovanja i zatražena usmena suglasnost učenika za sudjelovanje u istraživanju.

Ispitanici su dobili kontakt osobe (istraživačice) kojoj se mogu javiti nakon ispunjavanja upitnika s eventualnim pitanjima vezanima za njihovo sudjelovanje i ako žele informaciju o rezultatima istraživanja. Zatim su im podijeljeni upitnici. Istraživačica je bila prisutna tijekom njihova ispunjavanja i odgovarala na učenička pitanja.

Anketnim upitnikom je obuhvaćen cijeli uzorak, dok je dobrovoljnim pristankom učenika odabrano 23 sudionik (tri skupine, u tri škole) za intervjuiranje.

Nakon provedene ankete, ispitanici su zamoljeni da se dobrovoljno jave za sudjelovanje u nastavku istraživanja - intervjuu čije je predviđeno trajanje 20 minuta. U dogovoru s učenicima i stručnom službom škole određeni su termini i mjesta provođenja intervjua.

Prije početka intervjua ispitanici su upoznati s načinom provođenja grupnog intervjua, temama i sadržajem. Obaviješteni su da će se intervju snimati diktafonom, a potom će snimljeni materijal biti doslovno prepisan i analiziran. Ukoliko budu željeli, ispitanicima će se omogućiti uvid u transkripte. Svi izvještaji nastali na temelju ovog istraživanja koristit će rezultate koji govore o grupi učenika ove dobi općenito. Ponovljena im je mogućnost odustajanja od sudjelovanja u bilo kojem trenutku, bez navođenja razloga. Intervjui su se provodili sjedeći u krugu, a provodila ih je sama istraživačica.

Prije provođenja glavnog istraživanja provedeno je pilot-istraživanje, te se nakon analize rezultata prišlo daljnjem istraživanju.

Provedeno je empirijsko neeksperimentalno i transverzalno istraživanje u kojem su podatci prikupljeni mješovitim istraživačkim pristupom, primjenom triangulacije kvalitativnog i kvantitativnog pristupa, odnosno anketnim upitnikom i polustrukturiranim intervjuom. 


\section{5. 1. Mješoviti istraživački pristup}

Mješoviti istraživački pristup podrazumijeva miješanje kvantitativnog i kvalitativnog pristupa u jednom istraživanju (Este, Sitter i Maclaurin, 2009). Oba pristupa imaju cilj opisati, razumjeti, objasniti i interpretirati vrlo kompleksnu društvenu stvarnost. To su dva komplementarna pristupa, iako među njima postoje razlike u filozofskim korijenima i epistemiološkim izvorima.

Autori Symonds i Gorard (2008) smatraju da oba pristupa dijele neka zajednička obilježja jer binarna distinkcija između kvantitativnog i kvalitativnog pristupa nije održiva u praksi. Ističu da je subjektivnost prisutna i u kvantitativnim i u kvalitativnim istraživanjima, iako se često smatra da su statističke analize tehničke i objektivne, dok su ostale netehničke i subjektivne. Kvantitativni pristup je adekvatan za testiranje nekih teorija i odnosa, za identificiranje obrazaca podataka ili uspostavljanje uzročno-posljedičnih veza među pojavama. On se temelji se na primjeni metoda koje omogućuju kvantificiranje pojava i generaliziranje zaključaka o uzročnosti na cjelokupnu populaciju. Kao nedostatak kvantitativnog pristupa ističe se nemogućnost obuhvaćanja konteksta i nemogućnost dovoljno »dubokog« obuhvaćanja svega onog što je potrebno za potpuno razumijevanje socijalne interakcije, a rezultati su ograničeni varijablama uključenim u istraživanje jer je kvantitativno istraživanje deduktivno (Mejovšek, 2013).

Kvalitativni nacrt istraživanja je induktivan što omogućuje propitkivanje postojećih ideja, razvijanje novih teorija i otvorenost prema perspektivi sudionika istraživanja. To ovu metodu razlikuje od metode kvantitativnih istraživanja (Guba i Lincoln, 1994.). Osnovni nedostatak kvalitativnih istraživanja su pitanje vjerodostojnosti i dosljednosti podataka, objektivnost zaključaka te generalizacije rezultata istraživanja (Mejovšek, 2013).

Vidimo da i kvantitativni i kvalitativni pristup imaju svoje prednosti i nedostatke, bez obzira promatramo li ih kao dio kontinuuma ili odvojeno (Sekol i Maurović, 2017). Kod oba je pristupa ključno ulagati napore u izbjegavanju subjektivnosti i osiguravanju vjerodostojnosti i dosljednosti podataka (Tashakorri i Teddlie, 2003).

Istraživači sve češće kombiniraju kvalitativni i kvantitativni pristup kako bi iskoristiti njihove prednosti. Takvim se načinom koristi vjerodostojnost i dosljednost podataka i mogućnost generaliziranja rezultata koje omogućuju kvantitativne metode, kao i vjerodostojnost i autentičnost što omogućuju kvalitativne metode (Sekol i Maurović, 2017). Pri mješovitom pristupu istraživači mogu podatke dobivene jednom metodom koristiti za informiranje o 
podatcima dobivenim drugom metodom i tako doći do bogatijih i kompletnijih saznanja. U tom su slučaju dokazi potvrđeni s obje metode (Este, Sitter i Maclaurin, 2009).

Tri su osnovna nacrta mješovitog istraživačkog pristupa (Creswel, 2013) :

1. Konvergentno paralelni nacrt - vjerojatno najpoznatiji nacrt među mješovitim pristupima. U ovom pristupu istraživač prikuplja i kvantitativne i kvalitativne podatke, analizira ih zasebno, a zatim uspoređuje rezultate kako bi provjerio potvrđuju li se nalazi međusobno ili se ne potvrđuju.

2. Objašnjavajući uzastopni mješoviti nacrt - uključuje dvofazni projekt u kojem istraživač u prvoj fazi prikuplja kvantitativne podatke, analizira rezultate, a zatim rezultate koristi za planiranje (ili nadogradnju) druge, kvalitativne faze.

3. Istraživački uzastopni nacrt - nacrt u kojem istraživač najprije počinje istraživati i analizirati kvalitativne podatke, a zatim se dobivenim nalazima koristi u drugoj, kvantitativnoj fazi. Druga baza podataka se temelji na rezultatima početne baze podataka.

$\mathrm{U}$ ovome je istraživanju primijenjen konvergentno paralelni nacrt istraživanja u kojem oba pristupa (kvantitativni i kvalitativni) imaju jednaku važnost i odvijali su se u isto vrijeme. Miješaju se u vrijeme interpretacije podataka. Ovaj tip nacrta smatrao se korisnim za validaciju podataka (prilikom usporedbe rezultata jednog i drugog pristupa) i ilustriranje kvantitativnih rezultata kvalitativnim opisima, odnosno za sveobuhvatnije razumijevanje pojave koja se istražuje (Creswell i Plano Clark, 2007).

\section{5. 2. Varijable}

Nezavisne varijable kvantitativnog dijela istraživanja čine:

1. dob

2. spol

3. mjesto življenja

4. vrsta škole

5. opći uspjeh u prethodnom razredu

6. količina slobodnog vremena dnevno

7. posjedovanje, učestalost i način korištenja društvenih mreža

8. samoprocjena načina provođenja slobodnog vremena

9. stavovi o društvenim mrežama 
Zavisna varijabla: samoprocjena kvalitete života

U kvalitativnom dijelu (uz nezavisne varijable) istraživanja analizom utemeljene teorije dobivene su nove varijable (kategorije i koncepti). Ispitano je poimanje slobodnog vremena od strane učenika, načini provođenja slobodnog vremena, razlozi i načini korištenja društvenih mreža, razumijevanje pojma kvalitete života i samoprocjena kvalitete života.

\section{5. 3. Metode obrade podataka}

Podaci dobiveni anketnim upitnikom su uneseni u SPSS datoteku. Na osnovu SPSS datoteke izvedene su sve vrste statističkih analiza (programom SPSS Statistics for Windows, verzija 17.0).

Metrijske karakteristike instrumenata $u$ pilot te glavnom istraživanju provjerene su eksploratornom, a po potrebi i (kvazi) konfirmatornom faktorskom analizom te Cronbach Alpha testom. Obilježja uzorka i navedenih varijabli analizirani su deskriptivnim analizama. Prediktorski značaj demografskih obilježja učenika, njihovog načina provođenja slobodnog vremena, korištenje društvenih mreža i stavova o društvenim mrežama u objašnjavanju procjene kvalitete života ispitani su hijerarhijskom regresijskom analizom (s obzirom na teorijska uporišta, prediktori su u analizu umetani sljedećim redom: demografska obilježja, aktivnosti u slobodnom vremenu, korištenje društvenih mreža i stavovi o društvenim mrežama. Razlika u procjeni slobodnog vremena, stavova o društvenim mrežama te kvaliteti života $\mathrm{s}$ obzirom na spol analizirana je t-testom, tj. po potrebi njegovim neparametrijskim pandanom MannWhitney U testom, dok su razlike s obzirom na završni uspjeh i dob analizirane analizom varijance, tj. njegovim neparametrijskim pandanom - Kruskal Wallis $\mathrm{H}$ testom (normalnost distribucija je ispitana Kolmogorov-Smirnov testom kao jednim od uvjeta za upotrebu parametrijskih testova).

Intervju je sniman, a potom napravljen njegov transkript. Analiza podataka vođena je metodom utemeljene teorije (engl. grounded theory) (Glaser i Strauss, 1967; Strauss \& Corbin, 1989), tako da su podatci prvo inicijalno, osno i selektivno kodirani, zatim su na temelju kodova konstantnom komparativnom analizom formirane kategorije i koncepti, a u završnoj fazi je formiran model odnosa među formiranim konceptima. 


\section{5. 3. 1. Utemeljena teorija}

Utemeljena teorija (engl. grounded theory) je metodologija u društvenim znanostima koja se bazira na izgradnji teorija metodičkim prikupljanjem i analizom podataka (Martin i Turner, 1986; Strauss i Corbin, 1994). Ova teorija podrazumijeva induktivan pristup istraživanju i razlikuje se od tradicionalnog modela istraživanja po tome što istraživači ne odabiru postojeće teorijske okvire kako bi prikupljanjem podataka dokazali odnosi li se ta teorija na fenomen koji se istražuje, nego prikupljene kvalitativne podatke pregledavaju, te elemente koje se ponavljaju označavaju kodovima. Podatci se prikupljaju i revidiraju, kodovi se mogu grupirati u koncepte, a zatim u kategorije koje mogu postati temelj nove teorije (Allan, 2003).

Ova metoda omogućuje započinjanje istraživanja bez postavljenih hipoteza. Možemo reći da se hipoteze ne testiraju nego se stvaraju, razvijaju se tijekom istraživanja.

Metodu utemeljene teorije razvili su američki sociolozi Barney Glaser i Anselm Leonard Strauss sredinom šezdesetih godina prošlog stoljeća. Oni su je definirali kao teoriju koja je izvedena iz podataka istraživačkim procesom sustavnog prikupljanja i analize podataka (Strauss \& Corbin, 1990). Teorija je prvotno nazvana metodom stalne usporedbe (engl. constant comparative method), a nastala je dok su istraživali umiranje pacijenata u bolnicama (Jeđud, 2007). Temeljem tog istraživanja objavljeno je djelo Awareness of dying (Glaser i Strauss, 1965) koje se bazira na problematici umiranja i svijesti o tome. Koristili su stalni dinamički proces interakcije između prikupljanja i analize podataka metodom stalne usporedbe (Glaser i Strauss, 1967). Zbog tog stalnog procesa usporedbe i generiranja teorije iz podataka neki je autori nazivaju teorijom utemeljenom na podatcima (engl. data based theory)(Chicchi, 2000). Dvije godine kasnije objavljuju knjigu The discovery of grounded theory (Glaser i Strauss, 1967/2006) u kojoj iznose osnove same metode utemeljene teorije. U tome je djelu prvi put definirana, prikazana i objašnjena metoda utemeljene teorije (Topolovčan, 2017).

Tri su glavne svrhe objavljivanja otkrića utemeljene teorije:

1. ova teorija pomaže smanjivanju raskoraka između teorije i empirijskog istraživanja

2. pomaže pri logičnom utemeljenju teorija

3. ova je knjiga pomogla legitimizirati precizno kvalitativno istraživanje što se smatralo najvažnijim jer su do 1960-ih prevladavale kvantitativne istraživačke metode, dok kvalitativne metode nisu smatrane adekvatnima i provjerljivima (Strauss i Corbin, 1994). 
Strategija utemeljene teorije podrazumijeva proučavanje i tumačenje značenja društvenih interakcija (Glaser, 1992).

Prema Corbin i Straus (1990) utemeljena teorija ima specifične procedure za prikupljanje i analizu podataka, unutar kojih postoji određena fleksibilnost. Prikupljanje i analiza podataka su međusobno povezani procesi. U utemeljenoj teoriji, analiza počinje čim se prvi dio podataka prikupi i nužna je od samog početka jer se koristi za usmjeravanje sljedećeg intervjua i opažanja.

Analiza podataka primjenom utemeljene teorije uključuje sljedeće korake:

Kodiranje - proces definiranja o čemu se radi u prikupljenim podatcima. Postoje tri osnovna tipa kodiranja: otvoreno, aksijalno i selektivno kodiranje (Charmaz, 2006). Otvorenim kodiranjem raščlanjujemo podatke na manje dijelove. To je prva razina apstrakcije. U ovoj fazi tek dajemo oznake pojedinim dijelovima podataka. U daljnjoj fazi njihovim povezivanjem dobivamo koncepte. Koncepti su osnovne jedinice analize. Koncepti koji se odnose na istu pojavu mogu se grupirati u kategorije.

Kodovi mogu i sami predstavljati koncepte, a ponekad možemo odmah govoriti o kategorijama. Dakle, kodovi su oznake koje istraživač prepoznaje u sirovim podatcima (Jeđud, 2007). Zbirke kodova sličnog sadržaja omogućuju grupiranje podataka (Bernard i Ryan, 2010). U pristupu utemeljene teorije, kako se analiza nastavlja, kodovi i iz njih nastali koncepti postaju sve brojniji i apstraktniji. Tijekom vremena, kategorije se mogu međusobno povezati da bi formirale teoriju. Samo usporedbom i imenovanjem sličnih pojava istim pojmom istraživač može akumulirati osnovne jedinice za formiranje teorije.

$\mathrm{U}$ aksijalnom kodiranju, kategorije se odnose na njihove potkategorije, a odnosi se testiraju prema podatcima. Sve hipotetske veze predložene deduktivno tijekom aksijalnog kodiranja moraju se smatrati privremenim dok se ne potvrde više puta prema dolaznim podatcima. To je skup postupaka u kojima se nakon otvorenog kodiranja podatci ponovno povezuju na nove načine, uspostavljanjem veza između kategorija (Strauss \& Corbin, 1990).

Selektivno kodiranje je proces kojim se sve kategorije ujedinjuju oko osnovne, bazne kategorije, a kategorije koje trebaju daljnje objašnjenje popunjavaju se opisnim detaljima. Dobivene se kategorije i njihove potkategorije u ovoj fazi dovode u odnos, traži se objašnjenje veza među njima (Topolovčan, 2017). Ova vrsta kodiranja vjerojatno će se pojaviti u kasnijim fazama studije. Nakon odabira osnovne kategorije koja predstavlja središnji fenomen studije, istraživači selektivno kodiraju podatke prema njoj. Ona usmjerava njihovo kodiranje eliminirajući pojmove manje važnosti. Teorija se izgrađuje i testira do kraja projekta, u svim koracima (Bernard i Ryan, 2010). 
Uzorkovanje u utemeljenoj teoriji provodi se na teorijskim osnovama. Kada započne projekt, istraživač donosi neku ideju o fenomenu koji želi proučavati. Na temelju toga, mogu se odabrati skupine pojedinaca, organizacija ili zajednica koje predstavljaju taj fenomen. Teorijskim uzorkovanjem postiže se reprezentativnost i dosljednost. U utemeljenoj teoriji ključna je reprezentativnost pojmova, a ne osoba. Cilj je izgraditi teorijsko objašnjenje određivanjem fenomena u uvjetima koji ih tvore, a ne generaliziranje nalaza za širu populaciju (Khan, 2014).

Pri analizi se koriste stalne usporedbe. Usporedba pomaže istraživaču u zaštiti od pristranosti jer on tada povezuje koncepte sa svježim podacima, a pomaže i u postizanju veće preciznosti i dosljednosti. Mora se provjeriti pravilnost i eventualna nepravilnost podataka.

Pisanje teorijskih memorija je sastavni dio utemeljene teorije. Budući da analitičar ne može lako pratiti sve kategorije, svojstva, hipoteze i generativna pitanja koja proizlaze iz analitičkog procesa, mora postojati sustav za to. Korištenje podsjetnika predstavlja takav sustav. Zapisi su uključeni u formuliranje i reviziju teorije tijekom istraživačkog procesa.

Tijekom istraživačkog procesa trebaju se razvijati i provjeravati hipoteze o odnosima među kategorijama. Na utemeljenoj teoriji ne treba raditi sam istraživač. Za mnoge koji koriste pristup utemeljene teorije, važan dio istraživanja je testiranje koncepata i njihovih odnosa $\mathrm{s}$ kolegama koji imaju iskustva u istom suštinskom području. Istraživački projekti koje provode timovi istraživača povećavaju vjerodostojnost analize (Strauss, 1987). Bez obzira na to što su istraživanja mikroskopska, mora se analizirati širi kontekst. On može uključivati gospodarske uvjete, kulturne vrijednosti, političke trendove, društvene pokrete i sl. (Corbin i Strauss, 1988; Strauss i Corbin, 1989).

U ovom istraživanju korištena su dva osnovna principa metode utemeljene teorije:

- propitivanje umjesto mjerenja, što podrazumijeva da su sudionici istraživanja izvor znanja jer imaju direktno iskustvo s proučavanim fenomenima. Propituje se njihovo iskustvo i iz njihovih se odgovora stvaraju hipoteze.

- hipoteze se stvaraju procesom teorijskog kodiranja i utemeljene su na odgovorima sudionika (Auerbach i Silverstein, 2003)

Nakon provedenog grupnog intervjua, istraživačica je napisala kratak deskriptivni i analitički sažetak, te zabilježila opće dojmove istraživanja. Napravljen je transkript audio snimke.

Rezultati su interpretirani i diskutirani usporedbom i povezivanjem dobivenih podataka kvalitativnog i kvantitativnog dijela istraživanja te u odnosu na teorijska polazišta i rezultate 
postojećih istraživanja kako bi se formirali optimalni zaključci.

\section{5. 4. Pilot-istraživanje: inicijalna provjera metrijskih obilježja instrumenata}

Cilj provedbe pilot istraživanja je:

- utvrditi metrijska obilježja instrumenta,

- dobiti povratnu informaciju od učenika o pitanjima za polustrukturirani intervju (eng. feedback) kako bi se procijenila adekvatnost pitanja i napravile eventualno potrebne modifikacije. Feedback se odnosi na jasnoću postavljenih pitanja, formulaciju, potrebnost potpitanja i sl.

Pilot-istraživanje je provedeno na prigodnom uzorku učenika srednjih škola u Gradu Zagrebu. Ciljana skupina ispitanika bili su učenici višeg sekundarnog obrazovanja različitih školskih usmjerenja. Željelo se obuhvatiti i učenike gimnazija i učenike strukovnih škola. Imajući u vidu razlike u sredinama u kojima žive, smatralo se potrebnim usporediti mišljenja i stavove učenika iz urbanih i ruralnih sredina.

Uzorak učenika koji su sudjelovali u kvantitativnom dijelu istraživanja $(\mathrm{N}=150)$ činilo je 58 ispitanika muškog i 92 ispitanika ženskog spola (39\% i 61\%). Dob ispitanika je od 14 do 19 godina, najviše je anketirano petnaestgodišnjaka i sedamnaestogodišnjaka. Prosječna dob anketiranih učenika je $16.3 \pm 1.14$ godina, dok je medijan 16 .

Od ukupnog broja ispitanika u gradu ih živi 85 (57\%), dok njih 65 (43\%) živi u selu. Najviše ispitanih učenika pohađa gimnaziju (25\%), slijede polaznici Škole za modu i dizajn (23\%), ostala usmjerenja su hotelijersko-turistički tehničar (14\%), prodavač (14\%), kuhar, konobar, slastičar (11\%), ekonomska škola (10\%) te polaznici centra za obrazovanje (2\%).

Najčešća završna ocjena ispitivanih učenika u prethodnom razredu bila je vrlo dobar (kod 44\% učenika) koliko iznosi i medijan. Jedan učenik je imao nedovoljan opći uspjeh, tri su učenika s dovoljnim, 42 učenika s dobrim uspjehom, 66 s vrlo dobrim i 38 s odličnim. Prosječna je ocjena $3.9 \pm .82$.

U kvalitativnom dijelu istraživanja, grupnom polustrukturiranom intervjuu, sudjelovalo je 7 ispitanika, 4 ispitanika u dobi od 18 godina ( 2 muškog i 2 ženskog spola) i 3 ispitanika u 
dobi od 17 godina ( 2 dva ispitanika muškog i 1 ženskog spola), petero ih živi u gradu i dvoje u selu.

Nakon provedenog anketiranja metodom olovke i papira, odabrano je 7 učenika koji su se dobrovoljno javili za sudjelovanje u grupnom intervjuu.

Deskriptivna statistička analiza je pokazala da najviše učenika višeg sekundarnog obrazovanja ima po pet sati slobodnog vremena dnevno. Prosjek sati iznosi $4.55 \pm 2.59$ dok je medijan 4. Učenici su dosta heterogeni s obzirom na broj sati slobodnog vremena dnevno. Naime, taj broj sati varira od nula do 12 sati, te je koeficijent varijacije povišen, iznosi $57 \%$. Distribucija učenika s obzirom na broj sati slobodnog vremena nije slična normalnoj distribuciji kako to pokazuju rezultati Kolmogorov-Smirnovljevog testa $(\mathrm{z}=1.846 \mathrm{p}=.002)$.

Na pitanje koristi li društvene mreže potvrdno je odgovorilo 144 učenika (96\%), četiri učenika ih ne koristi, dok dva učenika nisu dala odgovor.

Pokazalo se da najveći broj ispitanika koristi dvije ili tri društvene mreže. Medijan je dva i prosjek od $2.4 \pm .98$, a dnevno koristeći društvene mreže provode u prosjeku 2,3 sata. Najveći se broj ispitanika izjasnio da koriste mreže tri i više sati dnevno (41\%), zatim dva sata (30\%), jedan sat (18\%), manje od jednog sata (8\%) i tri učenika ih uopće ne koriste.

Provedena je konfirmativna faktorska analize za svaku pojedinu skupinu varijabli:

- za 21 tvrdnju o aktivnostima u slobodno vrijeme,

- za 18 stavova o društvenim mrežama i

- za 19 tvrdnji o kvaliteti života.

Prethodno provedeni testovi, Kaiser-Meyer-Olkinova mjera adekvatnosti uzorka (KMO $=0,780)$ i Bartlettov test sfericiteta $(\mathrm{p}<.001)$ ukazuju da postoje preduvjeti za provedbu prve faktorske analize. Kaiser-Meyer-Olkinova mjera adekvatnosti uzorka $(\mathrm{KMO}=.781) \mathrm{i}$ Bartlettov test sfericiteta $(\mathrm{p}<.001)$, pokazuju da postoje preduvjeti za provedbu druge faktorske analize. Kaiser-Meyer-Olkinova mjera adekvatnosti uzorka $(\mathrm{KMO}=.908)$ i Bartlettov test sfericiteta $(\mathrm{p}<.001)$, također pokazuju da postoje preduvjeti za provedbu treće faktorske analize. 
Tablica 3

Rezultat provjere preduvjeta za provedbu faktorske analize za pojedine skupine varijabli $(N=150)$

\begin{tabular}{lccccc} 
skupine varijabli $(N=150)$ & \multicolumn{5}{c}{ Bartlettov test sfericiteta } \\
Skup manifestnih varijabli & KMO & $\chi^{2}$ & df & $\mathrm{p}$ \\
& & & & & \\
\hline 21 tvrdnja o aktivnostima u slob. vrijeme & .780 & 765.888 & 210 & $<.001$ \\
18 stavova o društvenim mrežama & .781 & 873.013 & 153 & $<.001$ \\
19 tvrdnji u vezi kvalitete života & .908 & 1596.350 & 171 & $<.001$ \\
\hline
\end{tabular}

Svaka od tri navedene faktorske analize je provedena tako što je izračunata matrica interkorelacija za skup tvrdnji iz upitnika, izvršena je ekstrakcija faktora metodom glavnih komponenti, varimax rotacija faktora i izračunati su faktorski bodovi (faktorska opterećenja) za sve ispitanike (150 učenika).

Tablica 4

Pregled rezultata faktorske analize za pojedine skupine varijabli $(N=150)$

\begin{tabular}{lcccccc}
\hline Skup manifestnih varijabli & $\begin{array}{c}\text { Broj } \\
\text { faktora }\end{array}$ & \multicolumn{2}{c}{$\begin{array}{l}\text { Svojstvene vrijednosti } \\
\text { ekstrahiranih faktora }\end{array}$} & $\begin{array}{c}\text { \% objašnjene } \\
\text { varijance }\end{array}$ \\
\hline 21 tvrdnja o aktivnostima u slob. vrijeme & 3 & 5.001 & 1.883 & 1.437 & 39.62 \\
18 stavova o društvenim mrežama & 4 & 4.483 & 2.732 & 1.501 & 1,329 & 55.81 \\
19 tvrdnji u vezi kvalitete života & 4 & 8.758 & 1.356 & 1.230 & 1.056 & 64.32 \\
\end{tabular}

Originalna faktorska struktura instrumenta Skala aktivnosti u slobodnom vremenu (Leisure time activity) (Deci i Ryan, 1989) pokazala je postojanje tri latentna faktora: Autonomija (sedam tvrdnji koje izražavaju samostalnost u odlučivanju o sadržajima slobodnog vremena), Kompetencija (šest tvrdnji koje se odnose na uspješnost u pojedinim aktivnostima u slobodnom vremenu) i Povezanost (osam tvrdnji kojima se izražavaju međusobni odnosi osoba koje zajedno provode svoje slobodno vrijeme).

Podaci iz ove analize podataka dobivenih pilot istraživanjem odstupaju od originalne faktorske strukture upitnika utoliko što je njome dobiveno šest faktora umjesto tri faktora koji su značajni prema Kaiser-Guttmanovom kriteriju određivanja značajnosti faktora (sve 
svojstvene vrijednosti veće od 1). Postotak objašnjene varijance s tri faktora iznosi $39.62 \%$, a sa šest faktora bi iznosio 53.34\%. Usporedbom faktorskih opterećenja s tri faktora utvrđeno je djelomično podudaranje s originalnom faktorskom strukturom upitnika. Naime, nisu sve manifestne varijable svrstane $\mathrm{u}$ one latentne faktore kako je to dobiveno prema originalnom upitniku već ih je preko polovinu drugačijeg rasporeda s obzirom na visinu faktorskih opterećenja.

\section{Tablica A4}

Faktorski bodovi (nakon Varimax rotacije) za pojedine tvrdnje Skale aktivnosti u slobodnom vremenu prema originalnom upitniku u odnosu na faktorske bodove dobivene u ovom istraživanju

\begin{tabular}{|c|c|c|c|c|}
\hline $\begin{array}{l}\text { Naziv } \\
\text { faktora }\end{array}$ & Manifestna varijabla & $\begin{array}{l}\text { Faktorski } \\
\text { bodovi } 1 . \\
\text { kompon. }\end{array}$ & $\begin{array}{l}\text { Faktorski } \\
\text { bodovi } 2 . \\
\text { kompon. }\end{array}$ & $\begin{array}{l}\text { Faktorski } \\
\text { bodovi } 3 . \\
\text { kompon. }\end{array}$ \\
\hline \multirow[t]{7}{*}{ autonomija } & $\begin{array}{l}\text { Sam/sama odabirem aktivnosti koje želim raditi } \\
\text { u slobodno vrijeme }\end{array}$ & .11 & .58 & -.24 \\
\hline & $\begin{array}{l}\text { Osjećam stres dok se bavim aktivnostima u } \\
\text { slobodnom vremenu. }\end{array}$ & -.01 & .61 & .07 \\
\hline & $\begin{array}{l}\text { Osjećam se slobodnim/slobodnom izraziti svoje } \\
\text { ideje i mišljenja za vrijeme aktivnosti u } \\
\text { slobodnom vremenu. }\end{array}$ & .43 & .29 & -.10 \\
\hline & $\begin{array}{l}\text { U svoje slobodno vrijeme moram raditi ono što } \\
\text { mi drugi kažu. }\end{array}$ & .08 & .46 & .22 \\
\hline & $\begin{array}{l}\text { Osobe s kojima obično provodim slobodno } \\
\text { vrijeme brinu o tome kako se osjećam. }\end{array}$ & .73 & .22 & .19 \\
\hline & U slobodno vrijeme se osjećam usamljeno. & -.04 & .39 & .69 \\
\hline & $\begin{array}{l}\text { Nemam često priliku reći što želim raditi u } \\
\text { slobodno vrijeme. }\end{array}$ & .21 & .53 & .19 \\
\hline \multirow[t]{6}{*}{ kompetencije } & $\begin{array}{l}\text { Mislim da nisam jako dobar/dobra u onome što } \\
\text { radim u slobod. vrijeme. }\end{array}$ & .35 & -.12 & .19 \\
\hline & $\begin{array}{l}\text { Osobe koje poznajem kažu da sam dobar/dobra u } \\
\text { onome što radim u slobodno vrijeme. }\end{array}$ & .55 & .06 & .20 \\
\hline & $\begin{array}{l}\text { Na aktivnostima kojima se bavim u slobodnom } \\
\text { vremenu naučim nove i zanimljive stvari. }\end{array}$ & .56 & .06 & -.14 \\
\hline & $\begin{array}{l}\text { Mislim da sam dobar/dobra u onome čime se } \\
\text { bavim u slobodno vrijeme. }\end{array}$ & .64 & 11 & .01 \\
\hline & $\begin{array}{l}\text { Nemam puno prilike pokazati koliko sam dobar } \\
\text { u onome čime se bavim u slobodno vrijeme. }\end{array}$ & -.04 & -.03 & .63 \\
\hline & $\begin{array}{l}\text { Često se ne osjećam dobro u aktivnostima u } \\
\text { slobodno vrijeme. }\end{array}$ & -.07 & .44 & .10 \\
\hline
\end{tabular}




\begin{tabular}{|c|c|c|c|c|}
\hline \multirow[t]{8}{*}{ povezanost } & $\begin{array}{l}\text { Volim ljude s kojima provodim slobodno } \\
\text { vrijeme. }\end{array}$ & .4 & .42 & .17 \\
\hline & $\begin{array}{l}\text { Slažem se s ljudima koje susrećem na } \\
\text { aktivnostima u slobodno vrijeme. }\end{array}$ & .62 & .15 & .16 \\
\hline & $\begin{array}{l}\text { Uglavnom sam/sama provodim slobodno } \\
\text { vrijeme. }\end{array}$ & .27 & .07 & .53 \\
\hline & $\begin{array}{l}\text { Ljude s kojima provodim slobodno vrijeme } \\
\text { smatram prijateljima. }\end{array}$ & .37 & .58 & .16 \\
\hline & $\begin{array}{l}\text { Ljudi s kojima provodim slobodno vrijeme brinu } \\
\text { o meni. }\end{array}$ & .66 & .04 & .05 \\
\hline & $\begin{array}{l}\text { Među ljudima s kojima provodim slobodno } \\
\text { vrijeme nema mnogo onih koje smatram dobrim } \\
\text { prijateljima. }\end{array}$ & .10 & .16 & .70 \\
\hline & $\begin{array}{l}\text { Ne sviđaju mi se ljudi s kojima provodim } \\
\text { slobodno vrijeme. }\end{array}$ & .27 & .49 & .42 \\
\hline & $\begin{array}{l}\text { Ljudi s kojima provodim slobodno vrijeme } \\
\text { uglavnom se prijateljski odnose prema meni. }\end{array}$ & .40 & .45 & -.02 \\
\hline
\end{tabular}

Napomena: u tablici su u svakom retku tamnije otisnuta najveća faktorska opterećenja

Originalna faktorska struktura Skale stavova o društvenim mrežama (Tsai, Lin i Tsai, 2001) pokazala je postojanje četiri latentna faktora: Korist (engl. Perceived Usefulness) (pet tvrdnji usmjerenih na praktičnu korisnost korištenja društvenih mreža), Afektivna procjena (engl. Affective) (odnosi se na pet tvrdnji koje izražavaju osjetilna stanja pri korištenju društvenih medija), Kontrola (engl. Perceived Control) (pet tvrdnji koje izražavaju samostalnost i vještinu pri korištenju društvenih medija) i Namjera korištenja (engl. Behavior) (tri tvrdnje koje izražavaju način i učestalost korištenja društvenih medija).

Podatci na uzorku 150 srednjoškolaca tek u manjem dijelu odstupaju od originalne faktorske strukture upitnika utoliko što je njome dobiveno pet faktora umjesto četiri faktora koji su značajni prema Kaiser-Guttmanovom kriteriju određivanja značajnosti faktora (sve svojstvene vrijednosti veće od 1). Postotak objašnjene varijance s četiri faktora iznosi $55.81 \%$ a s pet faktora bi iznosio $61.75 \%$. Samo tri manifestne varijable nisu svrstane u one latentne faktore kako je to dobiveno u originalnoj faktorskoj strukturi (tu je visoko podudaranje od 89\%). Pokazalo se da dobiveni faktori imaju zasićenja s većinom svojih originalnim manifestnih tvrdnji što ukazuje da se ovaj instrument zadovoljavajuće replicira na uzorku učenika višeg sekundarnog obrazovanja. 


\section{Tablica B4}

Faktorski bodovi (nakon varimax rotacije) za pojedine tvrdnje Skale stavova o društvenim mrežama prema originalnoj faktorskoj strukturi u odnosu na faktorske bodove dobivene u ovom istraživanju

\begin{tabular}{|c|c|c|c|c|c|}
\hline $\begin{array}{l}\text { Naziv } \\
\text { faktora }\end{array}$ & Manifestna varijabla & $\begin{array}{l}\text { Faktorski } \\
\text { bodovi } 1 . \\
\text { kompon. }\end{array}$ & $\begin{array}{l}\text { Faktorski } \\
\text { bodovi } 2 . \\
\text { kompon. }\end{array}$ & $\begin{array}{l}\text { Faktorski } \\
\text { bodovi } 3 . \\
\text { kompon. }\end{array}$ & $\begin{array}{l}\text { Faktorski } \\
\text { bodovi } 4 . \\
\text { kompon. }\end{array}$ \\
\hline \multirow[t]{5}{*}{ korist } & $\begin{array}{l}\text { Društvene mreže ono što radim } \\
\text { čine interesantnijim i maštovit. }\end{array}$ & .76 & -.15 & .10 & -.04 \\
\hline & $\begin{array}{l}\text { Društvene mreže šire moje } \\
\text { obzore. }\end{array}$ & .80 & -.01 & .20 & -.10 \\
\hline & $\begin{array}{l}\text { Društvene mreže čine veliki } \\
\text { doprinos ljudskom životu. }\end{array}$ & .85 & .02 & .03 & .14 \\
\hline & $\begin{array}{l}\text { Društvene mreže mi pomažu da } \\
\text { dobijem potrebne i važne } \\
\text { informacije. }\end{array}$ & .68 & -.06 & .13 & -.13 \\
\hline & $\begin{array}{l}\text { Društvene mreže čine društvo } \\
\text { naprednijim. }\end{array}$ & .77 & -.07 & .02 & .23 \\
\hline \multirow[t]{5}{*}{$\begin{array}{l}\text { afektivna } \\
\text { procjena }\end{array}$} & 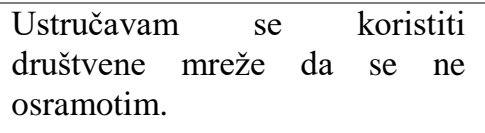 & .19 & .60 & -.19 & .31 \\
\hline & $\begin{array}{l}\text { Ako imam priliku koristiti } \\
\text { društvene mreže bojim se da ne } \\
\text { napravim neku štetu. }\end{array}$ & .01 & .67 & -.16 & .14 \\
\hline & $\begin{array}{l}\text { Društvene mreže mi izazivaju } \\
\text { nelagodu. }\end{array}$ & -.24 & .77 & .01 & -.06 \\
\hline & $\begin{array}{l}\text { Korištenje društvenih mreža mi } \\
\text { je dosadno. }\end{array}$ & -.44 & .64 & .29 & .02 \\
\hline & $\begin{array}{l}\text { Nisam baš sigurna/siguran u ono } \\
\text { što radim putem društv. Mreža }\end{array}$ & -.05 & .65 & -.09 & -.22 \\
\hline \multirow[t]{5}{*}{ kontrola } & $\begin{array}{l}\text { Vjerojatno mogu naučiti većinu } \\
\text { stvari koje trebam znati o } \\
\text { društvenim mrežama. }\end{array}$ & .37 & .18 & .47 & -.14 \\
\hline & $\begin{array}{l}\text { Trebam iskusnu osobu u blizini } \\
\text { kada koristim društvene mreže. }\end{array}$ & .04 & .66 & -.16 & .15 \\
\hline & $\begin{array}{l}\text { Kada naiđem na problem } \\
\text { koristeći društvene mreže, } \\
\text { obično to mogu nekako riješiti. }\end{array}$ & .04 & -.08 & .69 & -.04 \\
\hline & $\begin{array}{l}\text { Ne trebam nikoga da mi govori o } \\
\text { najboljim načinima korištenja } \\
\text { društvenih mreža. }\end{array}$ & .11 & -.10 & .60 & .18 \\
\hline & $\begin{array}{l}\text { Mogu koristiti društvene mreže } \\
\text { samostalno, bez ičije pomoći. }\end{array}$ & .06 & -.34 & .62 & -.09 \\
\hline $\begin{array}{l}\text { namjera } \\
\text { korištenja }\end{array}$ & $\begin{array}{l}\text { Koristim društv.mreže u školi } \\
\text { samo kada se to od mene traži. }\end{array}$ & .04 & .12 & .02 & .75 \\
\hline
\end{tabular}


Redovito koristim društvene mreže u školi.

Provodim puno vremena koristeći društvene mreže.

Napomena: u tablici su u svakom retku deblje otisnuta najveća faktorska opterećenja

Originalan faktorska struktura Skale kvalitete života (Wang i Kao, 2011) sadrži četiri latentna faktora: Fizički (engl. Physical) (četiri tvrdnje usmjerene na zadovoljstvo sobom, svojom radnom sposobnošću i međuljudskim odnosima), Psihološki (engl. Psychological) (sedam tvrdnji koje izražavaju smisao života, uživanje u životu, sposobnost koncentracije, životnu energiju i odmor), Društveni (engl. Social) (pet tvrdnji koje izražavaju prihvaćanje svoje vanjštine, informiranost i slobodno vrijeme) i Okolina (engl. Environmental) (odnosi se na tri tvrdnje koje izražavaju zadovoljstvo životnim uvjetima, javnim prijevozom i zdravstvenim nadzorom).

Analiza na ovom uzorku pokazuje odstupanja od navedene strukture. Njome je dobiveno četiri faktora kao u originalnoj faktorskoj strukturi upitnika. Međutim, usporedbom faktorskih opterećenja utvrđeno je veće nepodudaranje. Samo su tri manifestne varijable svrstane u one latentne faktore kako je to dobiveno pri razvijanju upitniku (tu postoji nisko podudaranje od samo $16 \%)$.

Tablica C4

Faktorski bodovi (nakon varimax rotacije) za pojedine tvrdnje Skale kvalitete života prema originalnoj faktorskoj strukturi u odnosu na faktorske bodove dobivene u ovom istraživanju

\begin{tabular}{|c|c|c|c|c|c|}
\hline $\begin{array}{l}\text { Naziv } \\
\text { faktora }\end{array}$ & Manifestna varijabla & $\begin{array}{l}\text { Faktorski } \\
\text { bodovi } 1 . \\
\text { kompon. }\end{array}$ & $\begin{array}{l}\text { Faktorski } \\
\text { bodovi } 2 . \\
\text { kompon. }\end{array}$ & $\begin{array}{l}\text { Faktorski } \\
\text { bodovi } 3 . \\
\text { kompon. }\end{array}$ & $\begin{array}{l}\text { Faktorski } \\
\text { bodovi } 4 . \\
\text { kompon. }\end{array}$ \\
\hline \multirow[t]{7}{*}{ psihološki } & Uživam u životu. & .19 & .86 & .18 & .10 \\
\hline & Moj život ima smisao. & .33 & .82 & .19 & .12 \\
\hline & Imam sposobnost koncentracije. & .63 & .28 & -.06 & .25 \\
\hline & $\begin{array}{l}\text { Osjećam se sigurno u } \\
\text { svakodnevnom životu. }\end{array}$ & .24 & .74 & .23 & .16 \\
\hline & Živim u zdravom okruženju. & .28 & .26 & .36 & .54 \\
\hline & Imam dovoljno energije za život. & .33 & .64 & .07 & .36 \\
\hline & $\begin{array}{l}\text { Zadovoljan/zadovoljna sam } \\
\text { svojim spavanjem. }\end{array}$ & .25 & .13 & -.01 & .77 \\
\hline
\end{tabular}




\begin{tabular}{|c|c|c|c|c|c|}
\hline \multirow[t]{5}{*}{ društveni } & $\begin{array}{l}\text { Mogu prihvatiti svoj vanjski } \\
\text { izgled. }\end{array}$ & .61 & .26 & .21 & .18 \\
\hline & Imam dovoljno novca. & .17 & .12 & .52 & .49 \\
\hline & $\begin{array}{l}\text { Lako dobivam dnevne } \\
\text { informacije. }\end{array}$ & .27 & .26 & .40 & .44 \\
\hline & Imam slobodnog vremena. & .09 & .10 & .08 & .74 \\
\hline & $\begin{array}{l}\text { Zadovoljan/zadovoljna sam } \\
\text { podrškom svojih prijatelja. }\end{array}$ & .45 & .30 & .34 & .21 \\
\hline \multirow[t]{4}{*}{ fizički } & $\begin{array}{l}\text { Zadovoljan/zadovoljna sam } \\
\text { svojom sposobnošću obavljanja } \\
\text { rutinskih dnevnih aktivnosti. }\end{array}$ & .70 & .20 & .16 & .37 \\
\hline & $\begin{array}{l}\text { Zadovoljan/zadovoljna sam } \\
\text { svojim radnim sposobnostima. }\end{array}$ & .81 & .13 & .20 & .16 \\
\hline & $\begin{array}{l}\text { Zadovoljan/zadovoljna sam } \\
\text { sobom. }\end{array}$ & .70 & .41 & .28 & .15 \\
\hline & $\begin{array}{l}\text { Zadovoljan/zadovoljna sam } \\
\text { svojim međuljudskim odnosima }\end{array}$ & .56 & .50 & .30 & .17 \\
\hline \multirow[t]{3}{*}{ okolina } & $\begin{array}{l}\text { Zadovoljan/zadovoljna sam } \\
\text { svojim životnim uvjetima }\end{array}$ & .10 & .20 & .87 & .01 \\
\hline & $\begin{array}{l}\text { Zadovoljan/zadovoljna sam } \\
\text { brigom za moje zdravlje }\end{array}$ & .33 & .18 & .67 & .18 \\
\hline & $\begin{array}{l}\text { Zadovoljan/zadovoljna sam } \\
\text { svojom mobilnošću }\end{array}$ & .59 & .23 & .45 & -.01 \\
\hline
\end{tabular}

Vizualna inspekcija scree-plota, koji pokazuje odnos broja ekstrahiranih komponenti (na apscisi) i veličine svojstvenih vrijednosti (eigenvalue) na ordinati, potvrđuje postojanje trofaktorske strukture kod prve skupine varijabli (Grafikon 1) odnosno postojanje četverofaktorske strukture kod druge i treće skupine varijabli (Grafikon 2 i Grafikon 3). 
Scree Plot

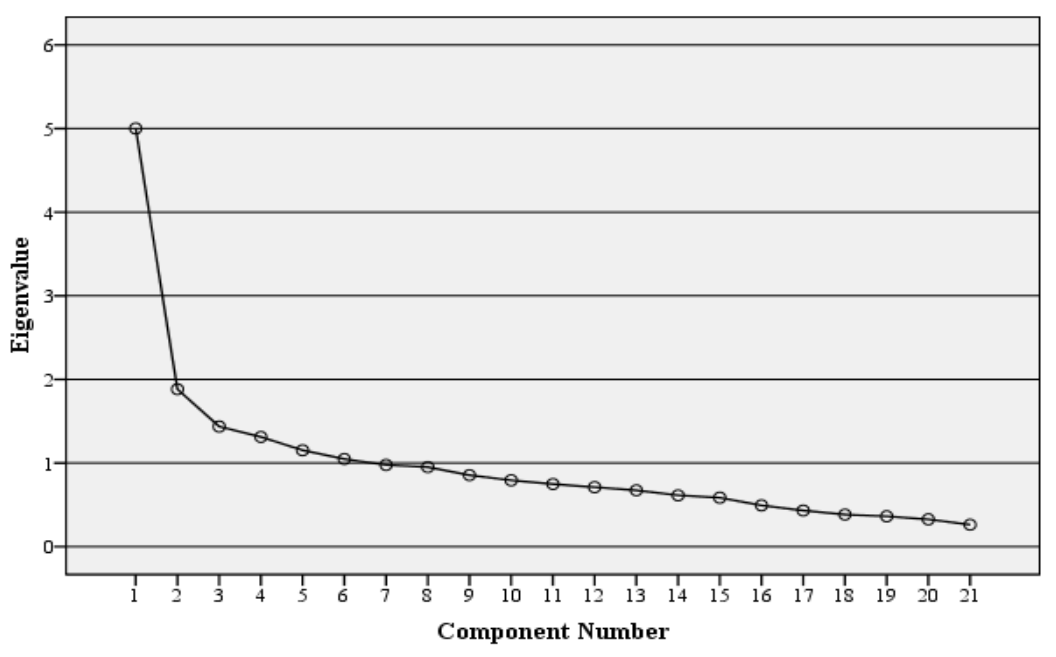

Grafikon 1. Svojstvene vrijednosti (eigenvalue) po pojedinim manifestnim varijablama Skale aktivnosti u slobodnom vremenu.

Scree Plot

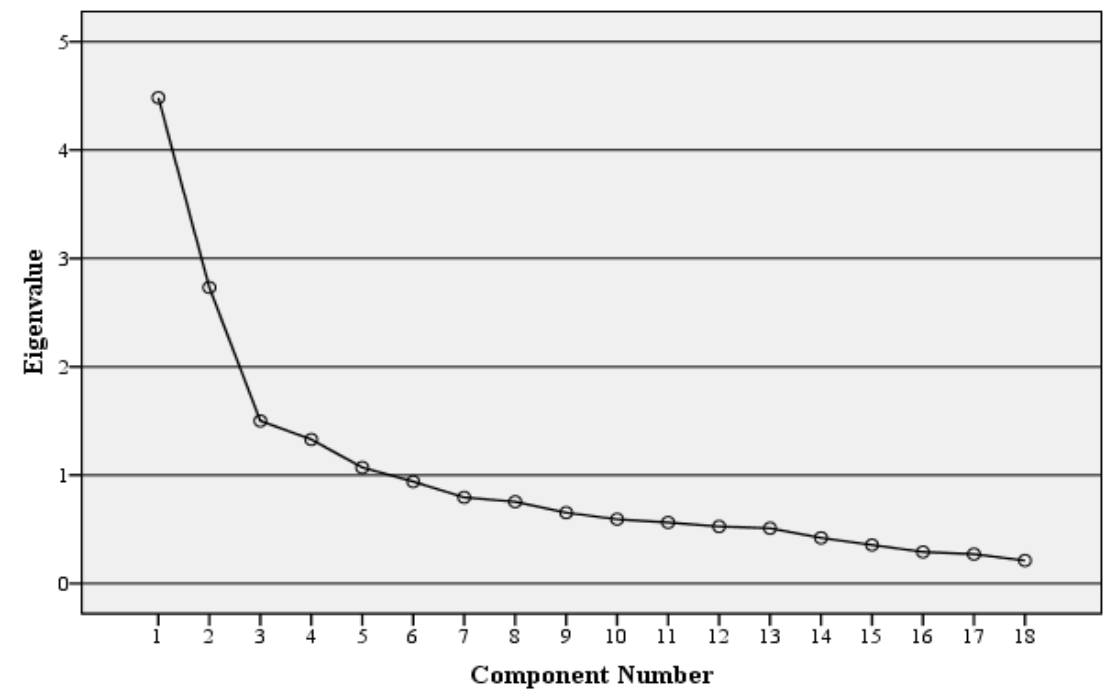

Grafikon 2. Svojstvene vrijednosti (eigenvalue) po pojedinim manifestnim varijablama Skale stavova o društvenim mrežama. 


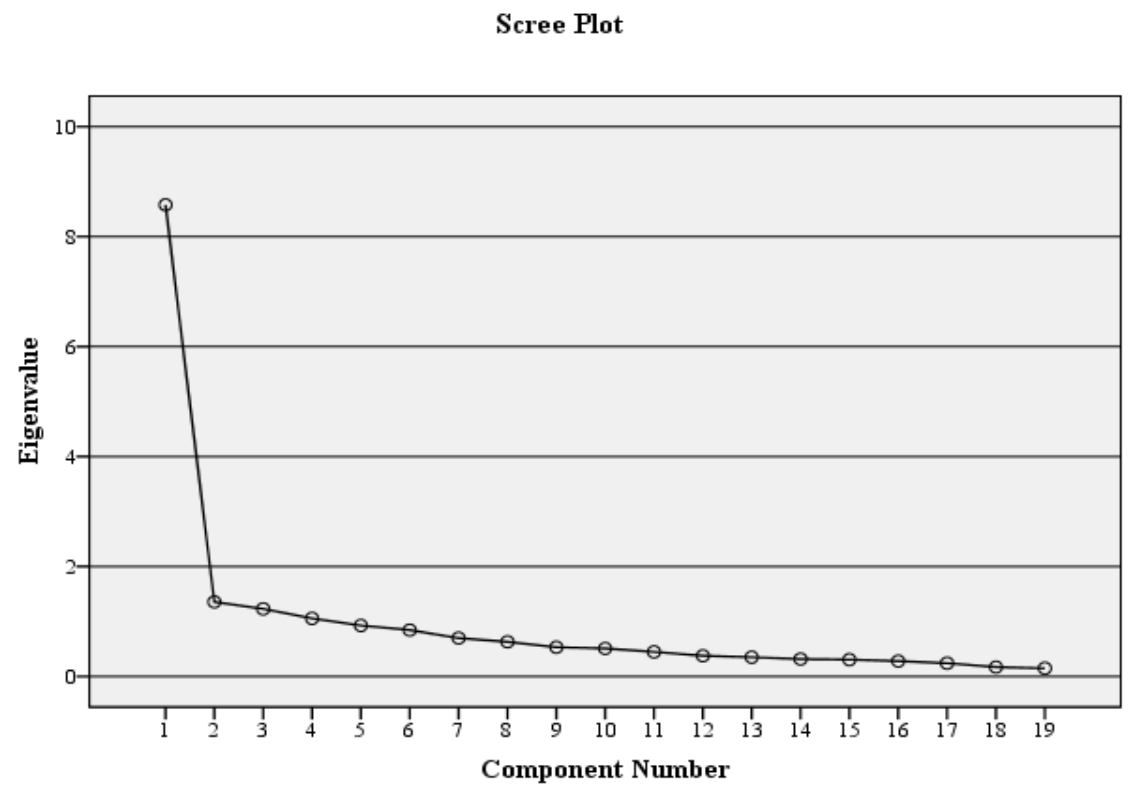

Grafikon 3. Svojstvene vrijednosti (eigenvalue) po pojedinim manifestnim varijablama Skale kvalitete života.

Za potrebe analize pouzdanosti osam varijabli iz skupine tvrdnji o aktivnostima $\mathrm{u}$ slobodnom vremenu je rekodirano budući da su te tvrdnje izrečene u negativnom obliku (tvrdnje 3, 4, 11, 16, 17, 18, 19 i 20). Nakon toga je izvedena analiza pouzdanosti (Reliability Analysis) triju skala s 21, 18 odnosno 19 čestica (items). Ta je analiza napravljena Cronbach alpha testom po pojedinim skupinama varijabli (Tablica 5).

Tablica 5

Rezultati analize pouzdanosti po skupinama varijabli

\begin{tabular}{|c|c|c|c|c|c|c|}
\hline $\begin{array}{l}\text { Red. } \\
\text { br. }\end{array}$ & Skupina varijabli & $\begin{array}{l}\text { Pripadajuće } \\
\text { varijable }\end{array}$ & $\mathrm{N}$ & $\begin{array}{l}\text { Koefic. } \\
\text { pouzd. } \\
\alpha\end{array}$ & $\begin{array}{l}\text { Najmanji koef. } \\
\text { korelacije među } \\
\text { varijablama }\end{array}$ & $\begin{array}{c}\text { Pouzda- } \\
\text { nost }\end{array}$ \\
\hline 1. & $\begin{array}{l}\text { Skala aktivnosti u } \\
\text { slobodnom vremenu }\end{array}$ & sv1 do sv21 & 150 & .815 & nema ispod .181 & dobra \\
\hline 2. & $\begin{array}{c}\text { Skala stavova o } \\
\text { društvenim mrežama }\end{array}$ & $\mathrm{dm} 1$ do $\mathrm{dm} 18$ & 150 & .643 & -.066 & $\begin{array}{l}\text { zadovo- } \\
\text { ljava }\end{array}$ \\
\hline 3. & Skala kvalitete života & kv1 do kv19 & 150 & .928 & nema ispod .394 & visoka \\
\hline
\end{tabular}


Prihvaćanje pojedinih tvrdnji međusobno je dobro usklađeno po pojedinim skalama.

Provjera normalnosti raspodjele triju numeričkih varijabli (skala) provedena je pomoću Kolmogorov-Smirnovljevog testa (Tablica 6). Ustanovljeno je da su sve tri distribucije slične normalnoj ( $p>.05)$ što znači da je kod primjene inferencijalne statističke analize moguće koristiti parametrijske testove.

Tablica 6

Rezultati provjere normalnosti raspodjele kod triju omjernih varijabli $(N=150)$

\begin{tabular}{llrrrr}
$\begin{array}{l}\text { Red. } \\
\text { br. }\end{array}$ & $\begin{array}{l}\text { Varijable za koje je provedeno testiranje } \\
\text { normalnosti raspodjele pomoću KS testa }\end{array}$ & $\mathrm{N}$ & $\mathrm{Z}$ & $\mathrm{p}$ & $\begin{array}{c}\text { Distribucija } \\
\text { je približno } \\
\text { normalna }\end{array}$ \\
\hline 1. & Aktivnosti u slobodno vrijeme (skala1) & 150 & .87 & .43 & $\mathrm{da}$ \\
\hline 2. & Stavovi o društvenim mrežama (skala2) & 150 & .98 & .30 & $\mathrm{da}$ \\
\hline 3. & Kvaliteta života (skala3) & 150 & 1.15 & .14 & da \\
\hline
\end{tabular}

Tablica 7

Rezultati deskriptivne statističke analize triju omjernih varijabli $(N=150)$

\begin{tabular}{clcc}
\hline Deskriptivni pokazatelj & $\begin{array}{l}\text { Skala 1 } \\
\text { (slobodno } \\
\text { vrijeme) }\end{array}$ & $\begin{array}{l}\text { Skala 2 } \\
\text { (društvene } \\
\text { mreže) }\end{array}$ & $\begin{array}{l}\text { Skala 3 } \\
\text { (kvaliteta } \\
\text { života) }\end{array}$ \\
\hline AS & 3.99 & 2.93 & 4.01 \\
Min & 4.00 & 2.94 & 4.03 \\
Max & 2.81 & 1.39 & 1.74 \\
SD & 4.95 & 4.50 & 5.00 \\
V & .48 & .46 & .72 \\
\hline
\end{tabular}


Obrada podataka kvalitativnog dijela istraživanja vođena je metodom utemeljene teorije (engl. grounded theory) (Glasser i Straus, 1967; Strauss i Corbin, 1989).

Nakon višestrukog iščitavanja transkripta, izdvojene su ključne riječi i izjave te definirani kodovi. Kodovi su povezani u koncepte i grupirani u analitičke kategorije:

1. Pojam slobodnog vremena

2. Dnevna količina slobodnog vremena

3. Način provođenja slobodnog vremena i

4. Odabir slobodnovremenskih aktivnosti

5. Organizirane slobodnovremenske aktivnosti

6. Korištenje društvenih mreža

7. Broj korištenih društvenih mreža

8. Vrste korištenih društvenih mreža

9. Razlozi korištenja društvenih mreža

10. Vrijeme korištenja društvenih mreža

11. Kompetentnost za korištenje društvenih mreža

12. Pojam kvalitete života

13. Utjecaji na kvalitetu života

14. Samoprocjena kvalitete života

\section{Prikaz rezultata}

\section{Pojam slobodnog vremena}

Učenici višeg sekundarnog obrazovanja pod pojmom slobodnog vremena podrazumijevaju ono vrijeme koje mogu provoditi kako oni žele, u kojem ne moraju ispunjavati neke zadane obaveze. U kojem se mogu baviti aktivnostima prema vlastitom izboru ili ne raditi ništa.

Odgovaraju da je slobodno vrijeme „, Vrijeme koje mogu provoditi na načine na koje želim, u kojem ne moram ispunjavati neke obaveze. “

„Da, bavimo se aktivnostima kojima mi želimo. “

„,Da, nemamo nikakvih obaveza što se tiče škole i slično. “ 


\section{Dnevna količina slobodnog vremena}

Većina učenika smatra da imaju dovoljno slobodnog vremena, u prosjeku četiri do pet $\mathrm{i}$ više sati dnevno.

Na pitanje imaju li dovoljno slobodnog vremena odgovaraju:

„Uglavnom imam dovoljno. “

„Kakokada.“

„Da, imam.“

„,Uglavnom imam dovoljno. “

Odgovori na pitanje koliko sati slobodnog vremena imaju dnevno:

„Nekoliko sati, 4,5.“

„Oko 4 sata“

\section{Način provođenja slobodnog vremena i odabir slobodnovremenskih aktivnosti}

Slobodno vrijeme provode baveći se sportom, ležanjem, odmaranjem, surfajući internetom, boraveći na društvenim mrežama.

Odgovori na pitanje kako provode svoje slobodno vrijeme:

„Sport, ležanje, odmaranje.“

„Čitanje. “

„Odmaranje od škole. “

„Surfanje internetom “

„, na face-u“"

„Instagram“

Aktivnosti odabiru prema količini vremena koje imaju na raspolaganju, prema svojim interesima i društvu s kojim žele biti.

„Pa, ovisi koliko vremena imam.“

„Ovisi s kim želim biti. “

„, Ovisi što želim raditi i što me zanima.“ 


\section{Organizirane slobodnovremenske aktivnosti}

Većina ispitanika je uključena u neke sportske aktivnosti (njih pet od sedam). Zadovoljni su ponudom aktivnosti u mjestu u kojem žive. Smatraju da u Zagrebu mogu pronaći i uključiti se u sve aktivnosti koje ih zanimaju.

„Pa dobro na to se ne možemo žaliti, Zagreb je ipak... “

\section{Korištenje društvenih mreža, broj i vrsta korištenih mreža}

Svi ispitanici u ovoj skupini koriste online društvene mreže. Imaju otvorene profile na nekoliko mreža.

Najviše koriste Instagram, Facebook, Snapchat, WhatsApp i Viber.

„, Instagram, Facebook, Snapchat, WhatsApp, Viber “

„Facebook, Messanger, Snapchat, Instagram“

„Snapchat, Viber“

\section{Razlozi i vrijeme korištenja društvenih mreža}

Kao razloge korištenja društvenih mreža navode komunikaciju s prijateljima i razmjenu informacija.

„Za komunikaciju, razmjenu nekih informacija, novosti, ... “

„Da, druženje s prijateljima, kad ne možemo biti s njima, da vidimo šta oni rade u životu $i$ tako, ...trošimo vrijeme. “

Koriste stalno, u slobodno vrijeme, u školi, pod odmorima, a često i pod nastavom.

„U školi, pod odmorima“

„, Kad mi je dosadno na nastavi.“

„, Samo za vrijeme nastave ne koristim, inače stalno." 


\section{Kompetentnost za korištenje društvenih mreža}

Smatraju se kompetentnima za svaki oblik korištenja online društvenih mreža i za rješavanje svih eventualno nastalih problema pri korištenju.

\section{Pojam kvalitete života}

Učenici pod kvalitetom života podrazumijevaju ravnotežu između obaveza, kvalitete obavljanja svojih dužnosti i obveza i bavljenja aktivnostima po vlastitom izboru, hobijima i razvijanje svojih sposobnosti i talenata. Smatraju da imaju jako puno školskih obveza pa im je teško uspostaviti tu ravnotežu.

„,Ja mislim da je kvaliteta života kad si dobar u svom poslu, ali imaš i slobodnog vremena za raditi ono što voliš. “”

„Zdravlje i te stvari. Da se brineš o tome.“

\section{Utjecaji na kvalitetu života}

Učenici ističu boravak u školi i način rada na nastavi kao važnu stavku u kvaliteti njihovog života.

„, Ako nam je dosadno u školi padamo u neku vrstu depresije, ne da nam se ići u školu, nismo sretni, htjeli bi promijeniti to a ne možemo i onda... nesretni smo. Zdravlje je najvažnije, ako smo bolesni, ne daj Bože... “

„,Zato što ipak provedemo pola dana tu onda još dođemo doma i učimo za tu školu, nerviramo se zbog ocjena u školi, tako da, sve je to povezano. “

Svojim odgovorima ističu da je slobodno vrijeme jako važno za kvalitetu života, za uspostavljanje već spomenute ravnoteže u životu i da nedostatak slobodnog vremena dovodi do stresa.

„Svakome treba slobodno vrijeme da ga provodi kako on želi, ako nema njega opet ..loše. “

„Ako nema slobodnog vremena opet stres, ako ne radimo stvari koje volimo u slobodno vrijeme i to dovodi do stresa" 
„Možda neko vrijeme se može tako izdržati neki visok tempo ali bez količine slobodnog vremena će izgorit svatko. “

Zdravlje smatraju jako važnim za kvalitetu života. Ističu potrebu češćeg odlaska na liječničke preglede, a smatraju da se o tome ne vodi dovoljna briga. Često se osjećaju umorni, nenaspavani jer moraju rano ustajati, a kasno odlaze na spavanje jer navečer uče, gledaju televiziju ili su na društvenim mrežama.

Iako neprestano komuniciraju putem društvenih mreža, smatraju da je za kvalitetu života izuzetno važan neposredni kontakt, druženje, povremeni izlasci s prijateljima.

„Pa osim društvenih medija, važno je da imate prijatelje, znači taj socijalni dio života. Ako je netko sam, uči non-stop sigurno da mu život nije baš lijep. “

„, To vam ništa ne vrijedi, mora biti kontakt ljudski tu, barem vikendom, neki izlasci... “

„, Ipak smo društvena bića, trebamo imati doticaja s drugim ljudima. “

\section{Samoprocjena kvalitete života}

Učenici iznose da su uglavnom zadovoljni kvalitetom svog života.

„Moglo bi biti i bolje, ali uglavnom da."

„Kakokada, većinom da. “

„Da, zadovoljan sam.“

Nakon provedenog grupnog intervjua učenici su se izjasnili da su im pitanja bila jasna i razumljiva, te da im je bilo ugodno i zanimljivo razgovarati o danim temama.

Primijećeno je da su se neki učenici ustručavali iznositi svoja mišljenja, te je bilo potrebno povremeno ih potaknuti na davanje odgovora. 


\section{5. 5. Glavno istraživanje}

Nakon provedenog pilot istraživanja i analize dobivenih rezultata pristupilo se glavnom istraživanju prema proceduri koja je detaljno opisana u na početku poglavlja.

\section{5. 5. 1. Provjera metrijskih obilježja instrumenata}

U svrhu provjere metrijskih obilježja instrumenata izvedene su konfirmatorne faktorske analize za svaku pojedinu skupinu varijabli:

- za 21 tvrdnju o aktivnostima u slobodno vrijeme,

- za 18 stavova o društvenim mrežama i

- $\quad$ za 19 tvrdnji o kvaliteti života.

Tablica 8

Pregled rezultata provjere preduvjeta za provedbu faktorske analize za pojedine skupine varijabli $(N=594)$

Bartlettov test sfericiteta

\begin{tabular}{|c|c|c|c|c|}
\hline Skup manifestnih varijabli & KMO & $\chi^{2}$ & df & $\mathrm{p}$ \\
\hline 21 tvrdnja o aktivnostima u sl. vrijeme & .866 & 2687.172 & 210 & $<.001$ \\
\hline 18 stavova o društvenim mrežama & .813 & 2796.877 & 153 & $<.001$ \\
\hline 19 tvrdnji u vezi kvalitete života & .937 & 5827.093 & 171 & $<.001$ \\
\hline
\end{tabular}

Prethodno provedeni testovi, Kaiser-Meyer-Olkinova mjera adekvatnosti uzorka (KMO $=.866)$ i Bartlettov test sfericiteta $(\mathrm{p}<.001)$ ukazuju da postoje preduvjeti za provedbu prve faktorske analize koja se odnosi na aktivnosti u slobodno vrijeme.

Prethodno provedeni testovi, Kaiser-Meyer-Olkinova mjera adekvatnosti uzorka $(\mathrm{KMO}=.813)$

i Bartlettov test sfericiteta $(\mathrm{p}<.001)$, pokazuju da postoje preduvjeti za provedbu druge faktorske analize koja se odnosi na stavove o društvenim mrežama. 
Prethodno provedeni testovi, Kaiser-Meyer-Olkinova mjera adekvatnosti uzorka $(\mathrm{KMO}=.937)$ i Bartlettov test sfericiteta $(\mathrm{p}<.001)$, također pokazuju da postoje preduvjeti za provedbu treće faktorske analize koja se odnosi na kvalitetu života srednjoškolaca.

Svaka od tri navedene faktorske analize provedena je izračunavanjem matrica interkorelacija za skup tvrdnji (varijabli) iz upitnika, izvršena je ekstrakcija faktora metodom glavnih komponenti, Varimax rotacija faktora i izračunati su faktorski bodovi (faktorska opterećenja) za sve ispitanike ( $\mathrm{N}=594)$.

Tablica 9

Pregled rezultata faktorske analize za pojedine skupine varijabli $(N=594)$

\begin{tabular}{|c|c|c|c|}
\hline Skup manifestnih varijabli & $\begin{array}{c}\text { Broj } \\
\text { faktora }\end{array}$ & $\begin{array}{l}\text { Svojstvene vrijednosti } \\
\text { ekstrahiranih faktora }\end{array}$ & $\begin{array}{c}\text { \% objašnjene } \\
\text { varijance }\end{array}$ \\
\hline 21 tvrdnja o aktivnostima u slobodno vrijeme & 3 & $\begin{array}{lll}5.12 & 1.79 & 1.35\end{array}$ & 39.36 \\
\hline 18 stavova o društvenim mrežama & 4 & $\begin{array}{llll}4.40 & 2.25 & 1.53 & 1.29\end{array}$ & 52.57 \\
\hline 19 tvrdnji u vezi kvalitete života & 4 & $\begin{array}{llll}8.62 & 1.18 & 1.13 & 0.94\end{array}$ & 62.40 \\
\hline
\end{tabular}

Faktorska analiza prve skupine varijabli koje se odnose na tvrdnje o aktivnostima u slobodno vrijeme (engl. Leisure time activity) prema originalnom upitniku Deci i Ryan iz 1989.g. pokazala je postojanje tri latentna faktora:
Autonomija $\rightarrow$ odnosi se na sedam tvrdnji koje izražavaju samostalnost $u$ odlučivanju o sadržajima slobodnog vremena
Kompetencija $\rightarrow$ odnosi se na šest tvrdnji i izražava uspješnost u pojedinim aktivnostima u slobodnom vremenu
Povezanost $\rightarrow$ odnosi se na osam tvrdnji i izražava međusobne odnose osoba koje zajedno provode svoje slobodno vrijeme

Podatci dobiveni ovim istraživanjem (594 ispitanika) odstupaju od navedenih rezultata originalnog upitnika. Analizom rezultata dobiveno je pet faktora umjesto tri faktora koji su značajni prema Kaiser-Guttmanovom kriteriju određivanja značajnosti faktora (sve svojstvene vrijednosti veće od 1). Postotak objašnjene varijance s tri faktora iznosi 39.36, a s pet faktora bi iznosio $50.38 \%$. Usporedbom faktorskih opterećenja s tri faktora utvrđeno je pretežno podudaranje sa s originalnim upitnikom. Naime, nisu sve manifestne varijable svrstane u one 
latentne faktore kako je to dobiveno prema originalnom upitniku već ih je trećina drugačijeg rasporeda s obzirom na visinu faktorskih opterećenja (Tablica 10), postoji 67\% podudarnosti.

Tablica 10

Faktorski bodovi (nakon varimax rotacije) za pojedine tvrdnje Skale aktivnosti u slobodnom vremenu prema originalnoj faktorskoj strukturi u odnosu na faktorske bodove dobivene u ovom istraživanju

\begin{tabular}{|c|c|c|c|c|}
\hline $\begin{array}{l}\text { Naziv } \\
\text { faktora }\end{array}$ & Manifestna varijabla & $\begin{array}{l}\text { Faktorski } \\
\text { bodovi } 1 . \\
\text { kompon. }\end{array}$ & $\begin{array}{l}\text { Faktorski } \\
\text { bodovi } 2 . \\
\text { kompon. }\end{array}$ & $\begin{array}{l}\text { Faktorski } \\
\text { bodovi } 3 . \\
\text { kompon. }\end{array}$ \\
\hline \multirow[t]{7}{*}{ autonomija } & $\begin{array}{l}\text { Sam/sama odabirem aktivnosti koje } \\
\text { želim raditi u slobodno vrijeme }\end{array}$ & .11 & .40 & .28 \\
\hline & $\begin{array}{l}\text { Osjećam stres dok se bavim } \\
\text { aktivnostima u slobodnom vremenu }\end{array}$ & -.01 & .58 & .08 \\
\hline & $\begin{array}{l}\text { Osjećam se slobodnim/slobodnom } \\
\text { izraziti svoje ideje i mišljenja za vrijeme } \\
\text { aktivnosti u slobodnom vremenu. }\end{array}$ & .25 & .15 & .48 \\
\hline & $\begin{array}{l}\text { U svoje slobodno vrijeme moram raditi } \\
\text { ono što mi drugi kažu. }\end{array}$ & -.07 & .58 & .25 \\
\hline & $\begin{array}{l}\text { Osobe s kojima obično provodim } \\
\text { slobodno vrijeme brinu o tome kako se } \\
\text { osjećam. }\end{array}$ & .68 & .03 & .29 \\
\hline & $\begin{array}{l}\text { U slobodno vrijeme se osjećam } \\
\text { usamljeno. }\end{array}$ & .27 & .63 & .03 \\
\hline & $\begin{array}{l}\text { Nemam često priliku reći što želim } \\
\text { raditi u slobodno vrijeme. }\end{array}$ & .21 & .64 & .16 \\
\hline \multirow[t]{6}{*}{ kompetencije } & $\begin{array}{l}\text { Mislim da nisam jako dobar/dobra u } \\
\text { onome što radim u slobod. vrijeme. }\end{array}$ & -.07 & .19 & .49 \\
\hline & $\begin{array}{l}\text { Osobe koje poznajem kažu da sam } \\
\text { dobar/dobra u onome što radim u } \\
\text { slobodno vrijeme. }\end{array}$ & .22 & .05 & .63 \\
\hline & $\begin{array}{l}\text { Na aktivnostima kojima se bavim u } \\
\text { slobodnom vremenu naučim nove i } \\
\text { zanimljive stvari. }\end{array}$ & .34 & .002 & .33 \\
\hline & $\begin{array}{l}\text { Mislim da sam dobar/dobra u onome } \\
\text { čime se bavim u slobodno vrijeme. }\end{array}$ & .21 & 17 & .69 \\
\hline & $\begin{array}{l}\text { Nemam puno prilike pokazati koliko } \\
\text { sam dobar u onome čime se bavim u } \\
\text { slobodno vrijeme. }\end{array}$ & .10 & .52 & .06 \\
\hline & $\begin{array}{l}\text { Često se ne osjećam dobro u } \\
\text { aktivnostima u slobodno vrijeme. }\end{array}$ & .06 & .55 & .19 \\
\hline povezanost & Volim ljude s kojima provodim & .56 & .26 & .06 \\
\hline
\end{tabular}




\begin{tabular}{|c|c|c|c|}
\hline slobodno vrijeme. & & & \\
\hline $\begin{array}{l}\text { Slažem se s ljudima koje susrećem na } \\
\text { aktivnostima u slobodno vrijeme. }\end{array}$ & .65 & .12 & .13 \\
\hline $\begin{array}{l}\text { Uglavnom sam/sama provodim } \\
\text { slobodno vrijeme. }\end{array}$ & .33 & .35 & -.16 \\
\hline $\begin{array}{l}\text { Ljude s kojima provodim slobodno } \\
\text { vrijeme smatram prijateljima. }\end{array}$ & .65 & .21 & .05 \\
\hline $\begin{array}{l}\text { Ljudi s kojima provodim slobodno } \\
\text { vrijeme brinu o meni. }\end{array}$ & .63 & -.09 & .28 \\
\hline $\begin{array}{l}\text { Među ljudima s kojima provodim } \\
\text { slobodno vrijeme nema mnogo onih } \\
\text { koje smatram dobrim prijateljima. }\end{array}$ & .46 & .39 & -.18 \\
\hline $\begin{array}{l}\text { Ne sviđaju mi se ljudi s kojima } \\
\text { provodim slobodno vrijeme. }\end{array}$ & .44 & .54 & .00 \\
\hline $\begin{array}{l}\text { Ljudi s kojima provodim slobodno } \\
\text { vrijeme uglavnom se prijateljski odnose } \\
\text { prema meni. }\end{array}$ & .56 & .13 & .25 \\
\hline
\end{tabular}

Napomena. U svakom su retku deblje otisnuta najveća faktorska opterećenja.

Faktorska analiza druge skupine varijabli koje se odnose na stavove o društvenim mrežama od Tsai, Lin i Tsai iz 2001.g. pokazala je postojanje četiri latentna faktora:

Korist (engl. Perceived Usefulness) $\rightarrow$ odnosi se na pet tvrdnji usmjerenih na praktičnu korisnost korištenja društvenih mreža;

Afektivna procjena (engl. Affective) $\rightarrow$ odnosi se na pet tvrdnji koje izražavaju osjetilna stanja pri korištenju društvenih medija;

Kontrola (engl. Perceived Control) $\rightarrow$ odnosi se na pet tvrdnji koje izražavaju samostalnost i vještinu pri korištenju društvenih medija;

Namjera korištenja (Behavior) $\rightarrow \quad$ odnosi se na tri tvrdnje koje izražavaju način i učestalost korištenja društvenih medija. 


\section{Tablica 11}

Faktorski bodovi (nakon varimax rotacije) za pojedine tvrdnje Skale stavova o društvenim mrežama prema originalnoj faktorskoj strukturi u odnosu na faktorske bodove dobivene u ovom istraživanju.

\begin{tabular}{|c|c|c|c|c|c|}
\hline $\begin{array}{l}\text { Naziv } \\
\text { faktora }\end{array}$ & Manifestna varijabla & $\begin{array}{l}\text { Faktorski } \\
\text { bodovi } 1 \\
\text { kompon. }\end{array}$ & $\begin{array}{l}\text { Faktorski } \\
\text { bodovi } 2 . \\
\text { kompon. }\end{array}$ & $\begin{array}{l}\text { Faktorski } \\
\text { bodovi } 3 . \\
\text { kompon. }\end{array}$ & $\begin{array}{l}\text { Faktorski } \\
\text { bodovi } 4 . \\
\text { kompon. }\end{array}$ \\
\hline \multirow[t]{5}{*}{ korist } & $\begin{array}{l}\text { Društvene mreže ono što radim } \\
\text { čine interesantnijim i } \\
\text { Maštovitijim }\end{array}$ & .72 & -.11 & .09 & .10 \\
\hline & $\begin{array}{l}\text { Društvene mreže šire moje } \\
\text { obzore. }\end{array}$ & .76 & -.08 & .23 & .08 \\
\hline & $\begin{array}{l}\text { Društvene mreže čine veliki } \\
\text { doprinos ljudskom životu. }\end{array}$ & .83 & -.04 & .01 & .00 \\
\hline & $\begin{array}{l}\text { Društv. mreže mi pomažu da } \\
\text { dobijem potrebne i važne } \\
\text { informacije }\end{array}$ & .69 & -.08 & .09 & .07 \\
\hline & $\begin{array}{l}\text { Društvene mreže čine društvo } \\
\text { naprednijim. }\end{array}$ & .73 & -.06 & .01 & .05 \\
\hline \multirow[t]{5}{*}{$\begin{array}{l}\text { afektivna } \\
\text { procjena }\end{array}$} & $\begin{array}{l}\text { Ustručavam se koristiti } \\
\text { društvene mreže da se ne } \\
\text { osramotim. }\end{array}$ & .07 & .67 & -.01 & -.08 \\
\hline & $\begin{array}{l}\text { Ako imam priliku koristiti } \\
\text { društvene mreže bojim se da ne } \\
\text { napravim neku štetu. }\end{array}$ & -.04 & .70 & -.04 & -.05 \\
\hline & $\begin{array}{l}\text { Društvene mreže mi izazivaju } \\
\text { nelagodu. }\end{array}$ & -.21 & .76 & -.05 & -.03 \\
\hline & $\begin{array}{l}\text { Korištenje društvenih mreža mi } \\
\text { je dosadno. }\end{array}$ & -.40 & .53 & .10 & -.21 \\
\hline & $\begin{array}{l}\text { Nisam baš sigurna/siguran u ono } \\
\text { što radim putem društvenih mreža. }\end{array}$ & -.12 & .64 & -.10 & -.03 \\
\hline \multirow[t]{5}{*}{ kontrola } & $\begin{array}{l}\text { Vjerojatno mogu naučiti većinu } \\
\text { stvari koje trebam znati o } \\
\text { društvenim mrežama. }\end{array}$ & .26 & .21 & .41 & -.02 \\
\hline & $\begin{array}{l}\text { Trebam iskusnu osobu u blizini } \\
\text { kada koristim društvene mreže. }\end{array}$ & .000 & .54 & -.34 & -.04 \\
\hline & $\begin{array}{l}\text { Kada naiđem na problem } \\
\text { koristeći društvene mreže, } \\
\text { obično to mogu nekako riješiti. }\end{array}$ & .14 & -.06 & .71 & .04 \\
\hline & $\begin{array}{l}\text { Ne trebam nikoga da mi govori o } \\
\text { najboljim načinima korištenja } \\
\text { društvenih mreža. }\end{array}$ & -.03 & -.09 & .68 & .10 \\
\hline & $\begin{array}{l}\text { Mogu koristiti društvene mreže } \\
\text { samostalno, bez ičije pomoći. }\end{array}$ & .08 & -.28 & .65 & -.04 \\
\hline
\end{tabular}




\begin{tabular}{|c|c|c|c|c|c|}
\hline \multirow[t]{3}{*}{$\begin{array}{l}\text { namjera } \\
\text { korištenja }\end{array}$} & $\begin{array}{l}\text { Koristim društvene mreže u } \\
\text { školi samo kada se to od mene } \\
\text { traži. }\end{array}$ & .08 & .10 & .03 & -.79 \\
\hline & $\begin{array}{l}\text { Redovito koristim društvene } \\
\text { mreže u školi. }\end{array}$ & .28 & -.08 & .09 & .80 \\
\hline & $\begin{array}{l}\text { Provodim puno vremena } \\
\text { koristeći društvene mreže. }\end{array}$ & .46 & -.11 & .12 & .48 \\
\hline
\end{tabular}

Napomena. U tablici su u svakom retku deblje otisnuta najveća faktorska opterećenja.

Podaci iz ove analize s podatcima dobivenim istraživanjem, na uzorku od 594 srednjoškolaca, tek u manjem dijelu odstupaju od navedenih rezultata standardnog upitnika utoliko što je njome dobiveno pet faktora umjesto četiri faktora koji su značajni prema KaiserGuttmanovom kriteriju određivanja značajnosti faktora (sve svojstvene vrijednosti veće od 1). Postotak objašnjene varijance s četiri faktora iznosi $52.57 \%$, a s pet faktora bi iznosio $58.44 \%$. Usporedbom faktorskih opterećenja s četiri faktora utvrđeno je veliko podudaranje sa standardiziranim upitnikom. Naime, samo jedna manifestna varijabla nije svrstane u one latentne faktore kako je to dobiveno prema standardiziranom upitniku, radi se o visokom podudaranju od $94 \%$ ).

Faktorska analiza treće skupine varijabli koje se odnose na tvrdnje o kvaliteti života prema standardiziranom upitniku od Wang i Kao (2011) pokazala je postojanje četiri faktora:

Fizički (engl. Physical) $\rightarrow$ sadrži četiri tvrdnje usmjerene na zadovoljstvo sobom, svojom radnom sposobnošću i međuljudskim odnosima

Psihološki (engl. Psychological) $\rightarrow$ sadrži sedam tvrdnji koje izražavaju smisao života, uživanje u životu, sposobnost koncentracije, životnu energiju i odmor

Društveni (engl. Social) $\rightarrow$ sadrži pet tvrdnji koje izražavaju prihvaćanje svoje vanjštine, informiranost i slobodno vrijeme

Okolina (engl. Environmental) $\rightarrow$ sadrži tri tvrdnje koje izražavaju zadovoljstvo životnim uvjetima, javnim prijevozom i zdravstvenim nadzorom

Podaci iz ove analize s podatcima dobivenim istraživanjem na uzorku od 594 srednjoškolaca, u većem dijelu odstupaju od navedenih rezultata originalnog upitnika. Njome je dobiveno tri faktora umjesto četiri kako je prikazano u originalnom upitniku. Usporedbom 
faktorskih opterećenja utvrđeno je pretežno nepodudaranje sa standardiziranim upitnikom. Ovdje postoji tek $37 \%$ podudaranja.

Tablica 12

Faktorski bodovi (nakon varimax rotacije) za pojedine tvrdnje Skale kvalitete života prema originalnoj faktorskoj strukturi u odnosu na faktorske bodove dobivene u ovom istraživanju.

\begin{tabular}{|c|c|c|c|c|c|}
\hline $\begin{array}{r}\text { Naziv } \\
\text { faktora }\end{array}$ & Manifestna varijabla & $\begin{array}{l}\text { Faktorski } \\
\text { bodovi } 1 . \\
\text { kompon. }\end{array}$ & $\begin{array}{l}\text { Faktorski } \\
\text { bodovi } 2 . \\
\text { kompon. }\end{array}$ & $\begin{array}{l}\text { Faktorski } \\
\text { bodovi } 3 . \\
\text { kompon. }\end{array}$ & $\begin{array}{l}\text { Faktorski } \\
\text { bodovi } 4 . \\
\text { kompon. }\end{array}$ \\
\hline \multirow[t]{7}{*}{ psihološki } & Uživam u životu. & .66 & .29 & .23 & .20 \\
\hline & Moj život ima smisao. & .71 & .31 & .20 & .15 \\
\hline & Imam sposobnost koncentracije. & .52 & .20 & .35 & .08 \\
\hline & $\begin{array}{l}\text { Osjećam se sigurno u } \\
\text { svakodnevnom životu. }\end{array}$ & .55 & .37 & .29 & .14 \\
\hline & Živim u zdravom okruženju. & .34 & .56 & .26 & .18 \\
\hline & Imam dovoljno energije za život. & .60 & .31 & .12 & .42 \\
\hline & $\begin{array}{l}\text { Zadovoljan/zadovoljna sam } \\
\text { svojim spavanjem. }\end{array}$ & .31 & .14 & -.01 & .80 \\
\hline \multirow[t]{5}{*}{ društveni } & $\begin{array}{l}\text { Mogu prihvatiti svoj vanjski } \\
\text { izgled. }\end{array}$ & .70 & .32 & .04 & .15 \\
\hline & Imam dovoljno novca. & .14 & .66 & .23 & .34 \\
\hline & $\begin{array}{l}\text { Lako dobivam dnevne } \\
\text { informacije. }\end{array}$ & .14 & .40 & .63 & .13 \\
\hline & Imam slobodnog vremena. & .05 & .13 & .35 & .78 \\
\hline & $\begin{array}{l}\text { Zadovoljan/zadovoljna sam } \\
\text { podrškom svojih prijatelja. }\end{array}$ & .24 & .26 & .71 & .15 \\
\hline \multirow[t]{4}{*}{ fizički } & $\begin{array}{l}\text { Zadovoljan/zadovoljna sam } \\
\text { svojom sposobnošću obavljanja } \\
\text { rutinskih dnevnih aktivnosti. }\end{array}$ & .51 & .05 & .62 & .19 \\
\hline & $\begin{array}{l}\text { Zadovoljan/zadovoljna sam } \\
\text { svojim radnim sposobnost. }\end{array}$ & .60 & .06 & .49 & .05 \\
\hline & $\begin{array}{l}\text { Zadovoljan/zadovoljna sam } \\
\text { sobom. }\end{array}$ & .81 & .25 & .15 & .12 \\
\hline & $\begin{array}{l}\text { Zadovoljan/zadovoljna sam } \\
\text { svojim međuljud. odnosima }\end{array}$ & .61 & .23 & .34 & .11 \\
\hline \multirow[t]{3}{*}{ okolina } & $\begin{array}{l}\text { Zadovoljan/zadovoljna sam } \\
\text { svojim životnim uvjetima. }\end{array}$ & .24 & .81 & .16 & .04 \\
\hline & $\begin{array}{l}\text { Zadovoljan/zadovoljna sam } \\
\text { brigom za moje zdravlje. }\end{array}$ & .37 & .67 & .06 & .15 \\
\hline & $\begin{array}{l}\text { Zadovoljan/zadovoljna sam } \\
\text { svojom mobilnošću. }\end{array}$ & .42 & .55 & .24 & -.07 \\
\hline
\end{tabular}

Napomena. U tablici su u svakom retku deblje otisnuta najveća faktorska opterećenja. 
Vizualna introspekcija tzv. scree-plota koji pokazuje odnos broja ekstrahiranih komponenti (na apscisi) i veličine svojstvenih vrijednosti (eigenvalue) na ordinati, pokazuje postojanje trofaktorske strukture odnosno postojanje četverofaktorske strukture.

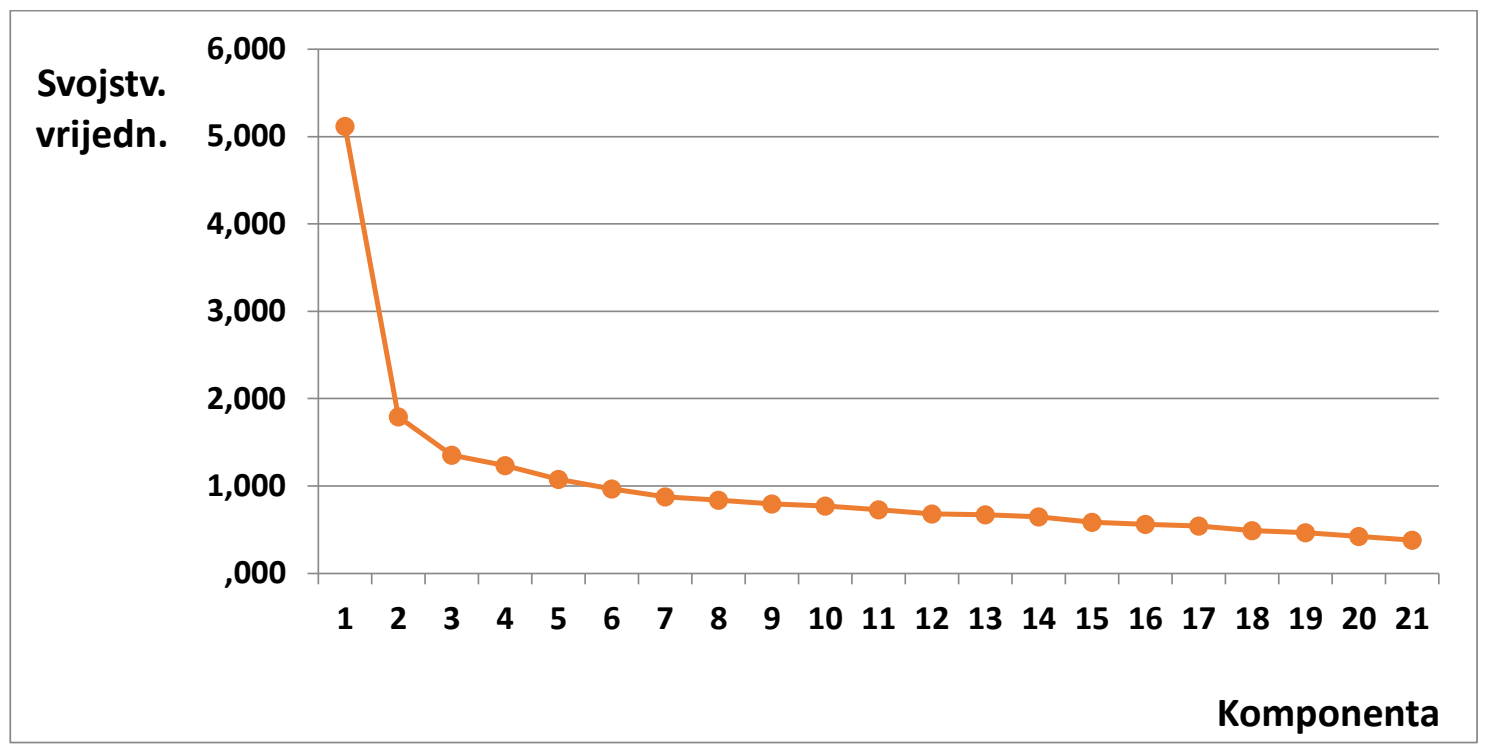

Grafikon 4. Svojstvene vrijednosti (eigenvalue) po pojedinim manifestnim varijablama Skale aktivnosti u slobodno vrijeme $(\mathrm{N}=594)$

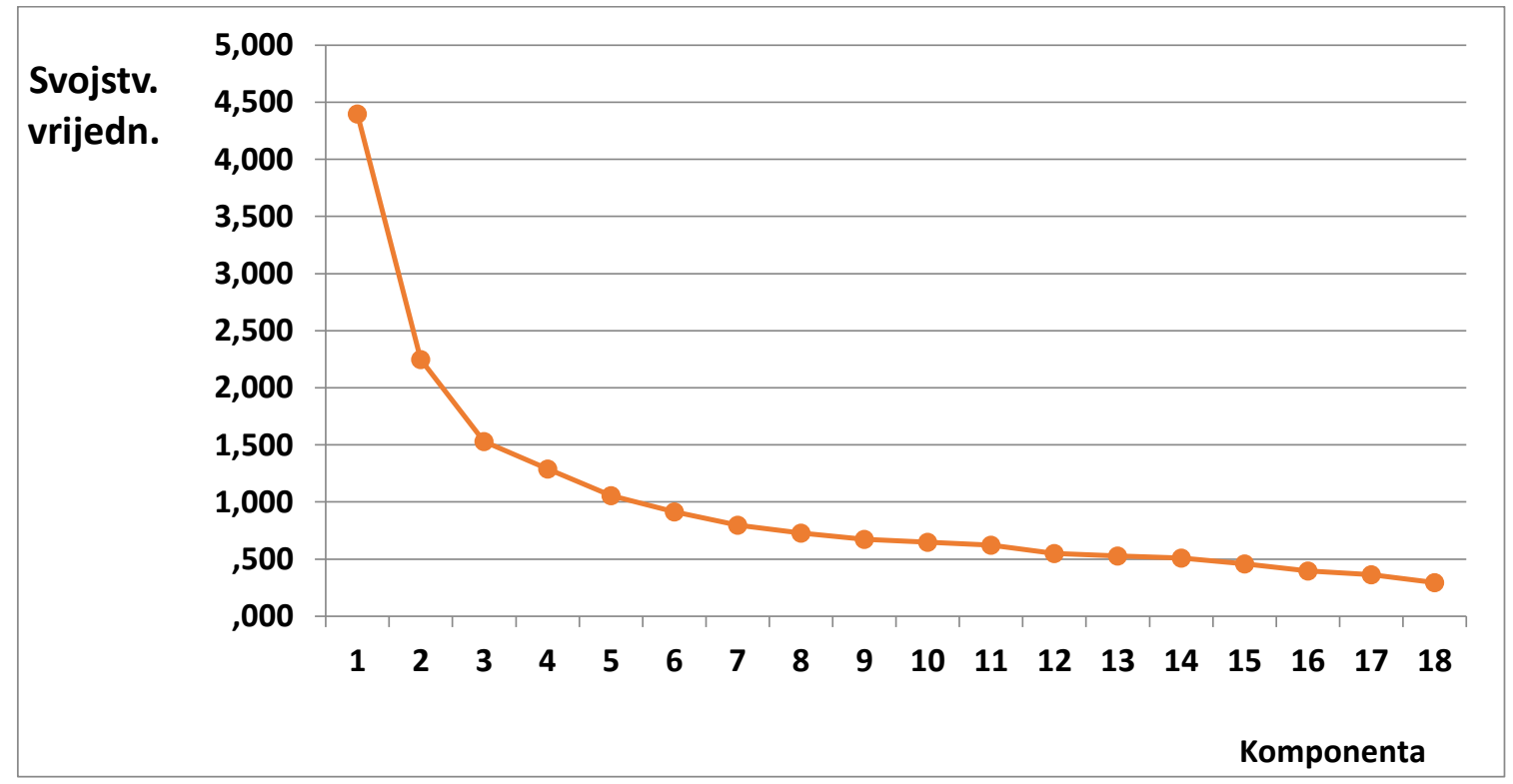

Grafikon 5. Svojstvene vrijednosti (eigenvalue) po pojedinim manifestnim varijablama Skale stavova o društvenim mrežama $(\mathrm{N}=594)$ 


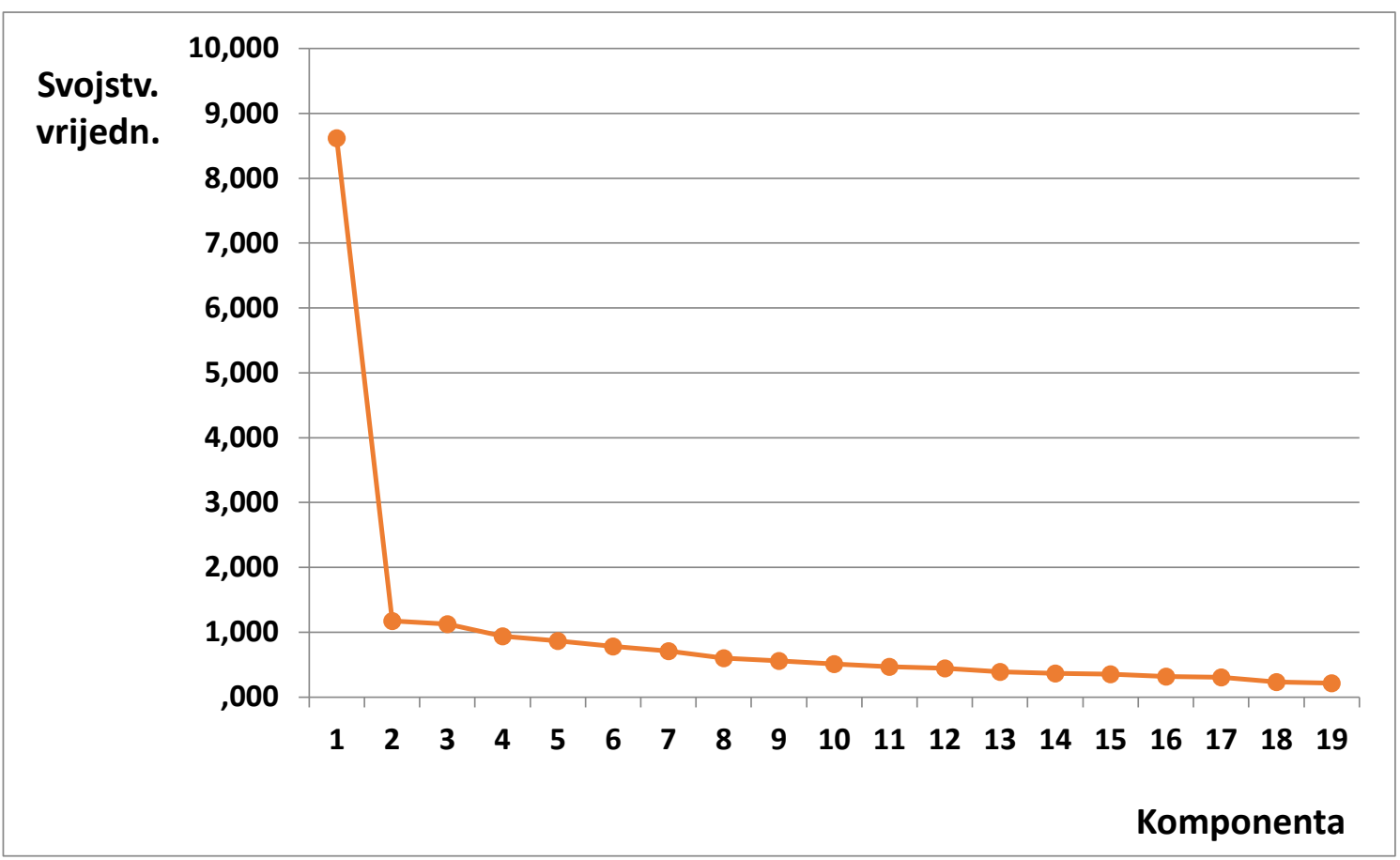

Grafikon 6. Svojstvene vrijednosti (eigenvalue) po pojedinim manifestnim varijablama Skale kvalitete života $(\mathrm{N}=594)$

Analiza pouzdanosti (Reliability Analysis) triju skupina varijabli (skale s 21, 18, odnosno 19 čestica) provedena je alfa modelom. Za potrebe analize pouzdanosti 10 varijabli (tvrdnji) iz skupine tvrdnji o aktivnostima u slobodno vrijeme je rekodirano budući da su te tvrdnje izrečene u negativnom obliku (tvrdnje 3, 4, 7, 11, 15, 16, 17, 18, 19 i 20).

Tablica 13

Rezultati analize pouzdanosti po skupinama varijabli

\begin{tabular}{lllllcl}
\hline $\begin{array}{l}\text { Red. } \\
\text { br. }\end{array}$ & Skupina varijabli & $\begin{array}{l}\text { Pripadajuće } \\
\text { varijable }\end{array}$ & $\mathrm{N}$ & $\begin{array}{l}\text { Koefic. } \\
\text { pouzd. } \\
\alpha\end{array}$ & $\begin{array}{l}\text { Najmanji koef. } \\
\text { korel. među } \\
\text { varijablama }\end{array}$ & $\begin{array}{l}\text { Pouzdanost } \\
\text { je }\end{array}$ \\
\hline 1. & $\begin{array}{l}\text { Tvrdnje o aktivnostima } \\
\text { u slobodno vrijeme }\end{array}$ & sv1 do sv21 & 594 & 0.83 & 0.22 & dobra \\
2. & $\begin{array}{l}\text { Tvrdnje (stavovi) o } \\
\text { društvenim mrežama }\end{array}$ & $\mathrm{dm} 1 \mathrm{do} \mathrm{dm18}$ & 594 & 0.69 & 0.16 & zadovoljava \\
3. & $\begin{array}{l}\text { Tvrdnje o kvaliteti života } \\
\text { kv1 do kv19 }\end{array}$ & 594 & 0.93 & 0.45 & visoka
\end{tabular}

Napomene. ${ }^{\text {1) }}$ Cronbach alpha manji od 0.6 smatra se nezadovoljavajućom pouzdanosti, veći od 0.7 znači zadovoljavajuću pouzdanost, veći od 0.8 znači dobru pouzdanost, a veći od 0.9 znači visoku pouzdanost (prema V.Turjačanin, 2006., strana 137)

Odgovori na pojedine tvrdnje dobro su usklađeni po skalama.

Provjera normalnosti raspodjele triju numeričkih varijabli provedena je pomoću Kolmogorov-Smirnovljevog testa. 
Tablica 14

Rezultati provjere normalnosti raspodjele kod triju omjernih varijabli $(N=594)$

\begin{tabular}{llllll}
\hline $\begin{array}{l}\text { Red. } \\
\text { br. }\end{array}$ & $\begin{array}{l}\text { Varijable za koje je provedeno testiranje } \\
\text { normalnosti raspodjele pomoću KS testa }\end{array}$ & $\mathrm{N}$ & $\mathrm{Z}$ & $\mathrm{p}$ & $\begin{array}{l}\text { Distribucija je } \\
\text { približno } \\
\text { normalna }\end{array}$ \\
\hline & & & & & \\
1. & Aktivnosti u slobodno vrijeme (skala1) & 594 & 1.718 & .005 & ne \\
2. & Stavovi o društvenim mrežama (skala2) & 594 & 1.682 & .007 & ne \\
3. & Kvaliteta života (skala3) & 594 & 2.093 & $<.001$ & ne \\
\hline
\end{tabular}

Kao što se iz rezultata KS testova vidi (Tablica 14) sve su p vrijednosti manje od .05 pa se na osnovu toga se zaključuje da ni jedna od tri distribucije nije slična normalnoj. Što upućuje na to da je kod primjene inferencijalne statističke analize moguće koristiti samo neparametrijske testove. 


\section{REZULTATI}

\section{1. Rezultati kvantitativnog dijela istraživanja}

Deskriptivna statistička analiza je pokazala je da anketirani učenici najčešće imaju po četiri sata slobodnog vremena dnevno. Prosjek sati iznosi $4.62 \pm 2.36$ dok je medijan 4 . Učenici su dosta heterogeni s obzirom na broj sati slobodnog dnevnog vremena. Broj sati varira od nula do nerealnih 12 sati, te je koeficijent varijacije povišen, iznosi 51\%. Distribucija učenika s obzirom na broj sati slobodnog vremena nije slična normalnoj distribuciji kako to pokazuju rezultati Kolmogorov-Smirnovljevog testa $(\mathrm{z}=3.57, \mathrm{p}<.001)$.

Na pitanje koristi li društvene mreže potvrdno je odgovorilo 588 učenika (99\%), dok ih šest učenika ne koristi. Stoga je u nekim tabelama iskazana suma frekvencija od 588, a ne 594.

Dnevno koristeći društvene mreže provode u prosjeku 2,4 sata. No, najveći se broj ispitanika izjasnilo da koriste mreže tri i više sati dnevno (44\%), zatim dva sata dnevno (32\%), jedan sat (17\%), manje od jednog sata (5\%) i 6 učenika ih uopće ne koristi.

Tablica 15

Društvene mreže koje koriste anketirani srednjoškolci $(N=594)$

\begin{tabular}{ccc}
\hline Društvena mreža & Br. uč. & \% uč. \\
\hline Instagram & 507 & 85.4 \\
Facebook & 444 & 74.7 \\
Snapchat & 232 & 39.1 \\
Twitter & 87 & 14.6 \\
WhatsApp & 66 & 11.1 \\
Viber & 27 & 4.5 \\
Messenger & 20 & 3.4 \\
Discord & 12 & 2.0 \\
YouTube & 19 & 3.2 \\
Reddit & 4 & .7 \\
ostale mreže & 7 & 1.2 \\
ne koristi nijednu & 6 & 1.0 \\
\hline
\end{tabular}


Iz Tablice 15 je vidljivo da učenici u najvećem postotku koriste društvenu mrežu Instagram. Iako je Facebook vodeća mreža prema broju korisnika u Hrvatskoj (www.arbona.hr).

Prema broju korištenih društvenih mreža pokazalo se da najveći broj ispitanika koristi dvije ili tri društvene mreže. Medijan i mod je dva i prosjek od $2.4 \pm .84$.

Pokazala se statistički značajna povezanost između spola i vremena dnevnog korištenja društvenih mreža $\left(\chi^{2}=41.91, \mathrm{~N}=588, \mathrm{df}=3, \mathrm{p}=.001\right)$. Djevojke značajno više koriste društvene mreže od mladića. Prosjek za mladiće iznosi približno 1.9 sati dnevno, a za djevojke približno 2.5 sati dnevno.

Kao najčešću svrhu korištenja društvenih mreža učenici navode kontakte s prijateljima putem chata ili poruka ( $42 \%$ slučajeva), te pregledavanje fotografija i video zapisa ( $26 \%$ slučajeva) što čini $2 / 3$ od svih navedenih načina korištenja. Slijedi igranje igrica i korištenje aplikacija (13\%), učenje (14\%), upoznavanje novih prijatelja $4 \%$ i ostale aktivnosti (1\%).

Tablica 16

Rezultati deskriptivne statističke analize triju omjernih varijabli $(N=594)$

\begin{tabular}{cccc}
\hline Deskriptivni pokazatelj & $\begin{array}{c}\text { Skala1 } \\
\text { (slob. } \\
\text { vrijeme) }\end{array}$ & $\begin{array}{c}\text { Skala2 } \\
\text { (društv. } \\
\text { mreže) }\end{array}$ & $\begin{array}{c}\text { Skala3 } \\
\text { (kvalit. } \\
\text { života) }\end{array}$ \\
\hline AS & 4.09 & 3.00 & 4.06 \\
M & 4.14 & 3.00 & 4.16 \\
Min & 2.33 & 1.39 & 1.00 \\
Max & 5.00 & 4.50 & 5.00 \\
SD & .46 & .37 & .69 \\
V & 11 & 12 & 17 \\
\hline
\end{tabular}

Rezultati deskriptivne statističke analize podataka o aktivnostima u slobodno vrijeme (N = 594) pokazuju ekstremno niske (1.52) kao i ekstremno visoke (4.63) vrijednosti aritmetičkih sredina po pojedinim tvrdnjama (Tablica 17). Od 21 tvrdnje deset je negativno formulirano: tvrdnje 3, 4, 7, 11 i 15 - 20 (označeno sa N). Stoga su njihove modalne vrijednosti 1 odnosno najniže (osim kod tvrdnje 7 i 15). Kod preostalih 11 koje su pozitivno formulirane najčešći je stupanj prihvaćanja 5 (u potpunosti se slažem), 3 (neutralan stav) ili 4 (uglavnom se slažem). Ispitanicima su najmanje prihvatljive (aritmetička sredina ispod 2.00) sljedeće tvrdnje: 
Ne sviđaju mi se ljudi s kojima provodim slobodno vrijeme (1.52),

Osjećam stres dok se bavim aktivnostima u slobodnom vremenu (1.75),

U slobodno vrijeme se osjećam usamljeno (1.78),

U svoje slobodno vrijeme moram raditi ono što mi drugi kažu (1.83),

Često se ne osjećam dobro u aktivnostima u slobodno vrijeme (1.83),

Nemam često priliku reći što želim raditi u slobodno vrijeme (1.98).

Kao što vidimo, najniže ocijenjene tvrdnje su negativno formulirane pa je stoga razumljiv niski prosjek i one idu u prilog najviše ocijenjenim tvrdnjama.

Najveću prihvatljivost (aritmetička sredina iznad 4.5) imaju sljedeće tri tvrdnje:

Ljude s kojima provodim slobodno vrijeme smatram prijateljima (4.53),

Sam/sama odabirem aktivnosti koje želim raditi u slobodno vrijeme (4.57) i

Volim ljude s kojima provodim slobodno vrijeme (4.63).

Prema ovim podatcima i uvidom u prikaz deskriptivnih pokazatelja pojedinih podskala Skale aktivnosti u slobodnom vremenu vidljivo je da učenici smatraju da imaju autonomiju u odabiru aktivnosti u slobodnom vremenu. Samostalno odlučuju kojim će se aktivnostima baviti.

Nadalje, smatraju da su dobri i uspješni u aktivnostima kojima se bave u slobodno vrijeme te ih okolina primjećuje i podržava njihov rad i uspjeh. Imaju priliku učiti nove i zanimljive stvari i izraziti svoje mišljenje koje okolina sluša i uvažava.

Slobodno vrijeme provode s osobama koje smatraju prijateljima, koje vole i koji se prema njima prijateljski i brižno odnose. U to se vrijeme osjećaju dobro i ugodno, bez stresa. Svojim odgovorima pokazuju da se u slobodno vrijeme osjećaju međusobno dobro i prijateljski povezani. 


$\begin{array}{cllll}\begin{array}{c}\text { Red. } \\ \text { br. }\end{array} & \text { Tvrdnja } & \text { N } & \text { AS } & \text { SD }\end{array}$

1. Sam/sama odabirem aktivnosti koje želim raditi u slobodno vrijeme

2. Volim ljude s kojima provodim slobodno vrijeme.

$\begin{array}{rrrr}594 & 4.57 & .68 & 15 \\ 594 & 4.63 & .70 & 15 \\ 594 & 2.30 & 1.23 & 53 \\ & & & \\ 594 & 1.75 & 1.05 & 60\end{array}$

4. Osjećam stres dok se bavim aktivnostima u slobodnom vremenu. N $\quad \begin{array}{llll}594 & 1.75 & 1.05 & 60\end{array}$

5. Osobe koje poznajem kažu da sam dobar/dobra u onome što radim $\quad \begin{array}{llll}594 & 3.92 & .91 & 23\end{array}$ u slobodno vrijeme.

6. Slažem se s ljudima koje susrećem na aktivnostima u slobodno vrijeme.

$\begin{array}{rrrr}594 & 4.20 & .86 & 20 \\ 594 & 2.64 & 1.18 & 45 \\ 594 & 4.22 & .90 & 21 \\ & & & \\ 594 & 4.53 & .76 & 17 \\ 594 & 3.95 & .97 & 25 \\ & & & \\ 594 & 1.83 & .95 & 52 \\ 594 & 3.89 & 1.01 & 26 \\ 594 & 4.14 & .81 & 20 \\ & & & \\ 594 & 3.97 & .92 & 23\end{array}$

7. Uglavnom sam/sama provodim slobodno vrijeme. $\mathrm{N}$
8. Osjećam se slobodnim/slobodnom izraziti svoje ideje i mišljenja za vrijeme aktivnosti u slobodnom vremenu.

9. Ljude s kojima provodim slobodno vrijeme smatram prijateljima.

10. Na aktivnostima kojima se bavim u slobodnom vremenu naučim nove i zanimljive stvari.

11. U svoje slobodno vrijeme moram raditi ono što mi drugi kažu. N

12. Ljudi s kojima provodim slobodno vrijeme brinu o meni.

13. Mislim da sam dobar/dobra u onome čime se bavim u slobodno vrijeme.

14. Osobe s kojima obično provodim slobodno vrijeme brinu o tome kako se osjećam.

15. Nemam puno prilike pokazati koliko sam dobar u onome čime se bavim u slobodno vrijeme. $\mathrm{N}$

16. Među ljudima s kojima provodim slobodno vrijeme nema mnogo onih koje smatram dobrim prijateljima. $\mathrm{N}$

17. U slobodno vrijeme se osjećam usamljeno. $\mathrm{N}$

$594 \quad 2.73 \quad 1.10 \quad 40$

18. Ne sviđaju mi se ljudi s kojima provodim slobodno vrijeme. N

$594 \quad 1.78 \quad 1.00 \quad 56$

19. Često se ne osjećam dobro u aktivnostima u slobodno vrijeme. N

$\begin{array}{llll}594 & 1.52 \quad .84 \quad 55\end{array}$

20. Nemam često priliku reći što želim raditi u slobodno vrijeme. N

$594 \quad 1.83 \quad 1.11 \quad 60$

21. Ljudi s kojima provodim slobodno vrijeme uglavnom se prijateljski

$594 \quad 1.98 \quad 1.13 \quad 57$ odnose prema meni. 
Tablica 18

Deskriptivni pokazatelji za pojedine podskale i cjelokupne skale varijable Aktivnosti u slobodnom vremenu $(N=594)$

\begin{tabular}{ccccc}
\hline \multirow{2}{*}{ Deskriptivni pokazatelj } & \multicolumn{3}{c}{ Podskala } & $\begin{array}{c}\text { Cijela } \\
\text { skala }\end{array}$ \\
\cline { 2 - 4 } as & 4.20 & 3.86 & 4.16 & 4.09 \\
M & 4.29 & 3.83 & 4.25 & 4.14 \\
Min & 2.29 & 1.83 & 1.52 & 2.33 \\
Max & 5.00 & 5.00 & 5.00 & 5.00 \\
SD & .55 & .57 & .55 & .46 \\
V & 13 & 15 & 13 & 11 \\
\hline
\end{tabular}

Kod tvrdnji o aktivnostima u slobodnom vremenu disperzija je niža ili osrednja (kod svih pozitivno formuliranih tvrdnji gdje je koeficijent varijacije između 15\% i 26\%) ili povećana (kod svih negativno formuliranih tvrdnji gdje je koeficijent varijacije između 40\% i 60\%).

Deskriptivni pokazatelji podataka o stavovima o društvenim mrežama (Tablica 19) pokazuju da su ispitanicima najmanje prihvatljive tvrdnje:

Trebam iskusnu osobu u blizini kada koristim društvene mreže (1.39),

Društvene mreže mi izazivaju nelagodu (1.64),

Nisam baš sigurna/siguran u ono što radim putem društvenih mreža (1.79),

Ustručavam se koristiti društvene mreže da se ne osramotim (1.84),

Korištenje društvenih mreža mi je dosadno (1.89) i

Ako imam priliku koristiti društvene mreže bojim se da ne napravim neku štetu (1.90). 
Tablica 19

Rezultati deskriptivne statističke analize stavova o društvenim mrežama $(N=594)$

\begin{tabular}{|c|c|c|c|c|c|}
\hline $\begin{array}{l}\text { Red. } \\
\text { br. }\end{array}$ & Tvrdnja & $\mathrm{N}$ & AS & SD & $\mathrm{V}$ \\
\hline 1. & Društvene mreže ono što radim čine interesantnijim i maštovitijim & 594 & 3.70 & 1.03 & 28 \\
\hline 2. & Društvene mreže šire moje obzore. & 594 & 3.72 & 1.04 & 28 \\
\hline 3. & Društvene mreže čine veliki doprinos ljudskom životu. & 594 & 3.34 & 1.10 & 33 \\
\hline 4. & Društv. mreže mi pomažu da dobijem potrebne i važne informacije & 594 & 4.04 & .95 & 23 \\
\hline 5. & Društvene mreže čine društvo naprednijim. & 594 & 3.34 & 1.16 & 35 \\
\hline 6. & Ustručavam se koristiti društvene mreže da se ne osramotim. & 594 & 1.84 & 1.11 & 61 \\
\hline 7. & $\begin{array}{l}\text { Ako imam priliku koristiti društvene mreže bojim se da ne napravim } \\
\text { neku štetu. }\end{array}$ & 594 & 1.90 & 1.11 & 58 \\
\hline 8. & Društvene mreže mi izazivaju nelagodu. & 594 & 1.64 & .94 & 57 \\
\hline 9. & Korištenje društvenih mreža mi je dosadno. & 594 & 1.89 & 1.10 & 58 \\
\hline 10. & Nisam baš sigurna/siguran u ono što radim putem društv. mreža & 594 & 1.79 & .98 & 55 \\
\hline 11. & $\begin{array}{l}\text { Vjerojatno mogu naučiti većinu stvari koje trebam znati o društvenim } \\
\text { mrežama. }\end{array}$ & 594 & 3.47 & 1.06 & 31 \\
\hline 12. & Trebam iskusnu osobu u blizini kada koristim društvene mreže. & 594 & 1.39 & .84 & 60 \\
\hline 13. & $\begin{array}{l}\text { Kada naiđem na problem koristeći društvene mreže, obično to mogu } \\
\text { nekako riješiti. }\end{array}$ & 594 & 3.98 & 1.03 & 26 \\
\hline 14. & $\begin{array}{l}\text { Ne trebam nikoga da mi govori o najboljim načinima korištenja } \\
\text { društvenih mreža. }\end{array}$ & 594 & 3.65 & 1.36 & 37 \\
\hline 15. & Mogu koristiti društvene mreže samostalno, bez ičije pomoći. & 594 & 4.49 & .91 & 20 \\
\hline 16. & Koristim društv.mreže u školi samo kada se to od mene traži. & 594 & 2.72 & 1.40 & 51 \\
\hline 17. & Redovito koristim društvene mreže u školi. & 594 & 3.38 & 1.39 & 41 \\
\hline 18. & Provodim puno vremena koristeći društvene mreže. & 594 & 3.72 & 1.21 & 33 \\
\hline
\end{tabular}

U najvećoj mjeri su prihvaćene tvrdnje:

Društvene mreže mi pomažu da dobijem potrebne i važne informacije (4.04) $i$

Mogu koristiti društvene mreže samostalno, bez ičije pomoći (4.49).

Prema ovim pokazateljima i rezultatima deskriptivnih pokazatelja za pojedinu podskalu Skale stavova o društvenim mrežama možemo zaključiti da mladi društvene mreže smatraju 
korisnima. One su za njih važno sredstvo informiranja. Smatraju da njihov život čine interesantnijim i maštovitijim, a društvo naprednijim.

Većina učenika se smatra kompetentnima za samostalno korištenje društvenih mreža, one im one ne izazivaju nelagodu i ne ustručavaju se koristiti ih. Osjećaju se sigurno i nemaju nikakvih bojazni pri njihovom korištenju.

Puno vremena provode koristeći društvene mreže i pri tome im ne treba kontrola niti bilo čija pomoć.

Što se tiče disperzije odgovora ispitanika ona je ili osrednja ili povećana (koeficijenti varijacije se kreću između 26\% i 67\%). Ispitanici su s obzirom na svoje stavove o društvenim mrežama relativno homogeni ili umjereno heterogeni.

Tablica 20

Deskriptivni pokazatelji za pojedine podskale i cjelokupnu skalu varijable Stavovi o društvenim mrežama $(N=594)$

\begin{tabular}{|c|c|c|c|c|c|}
\hline \multirow[b]{2}{*}{ Deskriptivni pokazatelj } & \multicolumn{4}{|c|}{ Podskala } & \multirow{2}{*}{$\begin{array}{l}\text { Cijela } \\
\text { skala }\end{array}$} \\
\hline & korist & $\begin{array}{l}\text { afektivna } \\
\text { procjena }\end{array}$ & kontrola & $\begin{array}{l}\text { namjera } \\
\text { korištenja }\end{array}$ & \\
\hline AS & 3.63 & 1.81 & 3.40 & 3.28 & 3.00 \\
\hline M & 3.60 & 1.60 & 3.40 & 3.33 & 3.00 \\
\hline Min & 1.00 & 1.00 & 1.00 & 1.00 & 1.39 \\
\hline $\operatorname{Max}$ & 5.00 & 5.00 & 5.00 & 5.00 & 4.50 \\
\hline SD & .81 & .728 & .544 & .752 & .37 \\
\hline V & 22 & 40 & 16 & 23 & 12 \\
\hline
\end{tabular}

Čak sedamnaest tvrdnji o kvaliteti života (Tablica 21) učenici su u većini slučajeva prihvatili s najvećim stupnjem prihvaćanja $(5=$ u potpunosti se slažem). Izuzetak su samo dvije tvrdnje, tvrdnja 3 i tvrdnja 13, kod kojih je najveća apsolutna frekvencija za jedan stupanj niža (4 = uglavnom se slažem).

Najniže aritmetičke sredine, iako su i one dosta visoko ocijenjene (ispod 4.00), su kod dviju tvrdnji: Zadovoljan/zadovoljna sam svojim spavanjem, Imam sposobnost koncentracije i Imam slobodnog vremena.

Najveće zadovoljstvo iskazali su kod dviju tvrdnji: Zadovoljan/zadovoljna sam brigom za moje zdravlje, Zadovoljan/zadovoljna sam svojim životnim uvjetima i Zadovoljan/zadovoljna sam svojim životnim uvjetima. 


\section{Tablica 21}

Rezultati deskriptivne statističke analize podataka o kvaliteti života $(N=594)$

\begin{tabular}{|c|c|c|c|c|c|}
\hline $\begin{array}{c}\text { Red. } \\
\text { br. }\end{array}$ & Tvrdnja & $\mathrm{N}$ & AS & SD & $\mathrm{V}$ \\
\hline 1. & Uživam u životu. & 594 & 4.15 & .98 & 24 \\
\hline 2. & Moj život ima smisao. & 594 & 4.14 & 1.09 & 26 \\
\hline 3. & Imam sposobnost koncentracije. & 594 & 3.84 & 1.04 & 27 \\
\hline 4. & Osjećam se sigurno u svakodnevnom životu. & 594 & 4.06 & 1.02 & 25 \\
\hline 5 . & Živim u zdravom okruženju. & 594 & 4.11 & 1.02 & 25 \\
\hline 6. & Imam dovoljno energije za život. & 594 & 4.05 & 1.08 & 27 \\
\hline 7. & Zadovoljan/zadovoljna sam svojim spavanjem. & 594 & 3.23 & 1.45 & 45 \\
\hline 8 . & Mogu prihvatiti svoj vanjski izgled. & 594 & 4.00 & 1.16 & 29 \\
\hline 9. & Imam dovoljno novca. & 594 & 4.05 & 1.03 & 25 \\
\hline 10. & Lako dobivam dnevne informacije. & 594 & 4.17 & .90 & 22 \\
\hline 11. & Imam slobodnog vremena. & 594 & 3.96 & 1.13 & 28 \\
\hline 12. & Zadovoljan/zadovoljna sam podrškom svojih prijatelja. & 594 & 4.24 & .94 & 22 \\
\hline & $\begin{array}{l}\text { Zadovoljan/zadovoljna sam svojom sposobnošću obavljanja } \\
\text { rutinskih dnevnih aktivnosti. }\end{array}$ & 594 & 4.01 & .97 & 24 \\
\hline 14. & Zadovoljan/zadovoljna sam svojim radnim sposobnost. & 594 & 4.00 & .98 & 24 \\
\hline & Zadovoljan/zadovoljna sam sobom. & 594 & 4.11 & 1.03 & 25 \\
\hline & Zadovoljan/zadovoljna sam svojim međuljud. odnosima & 594 & 4.05 & 1.00 & 25 \\
\hline & Zadovoljan/zadovoljna sam svojim životnim uvjetima. & 594 & 4.45 & .83 & 19 \\
\hline 18. & Zadovoljan/zadovoljna sam brigom za moje zdravlje. & 594 & 4.25 & .97 & 23 \\
\hline 19. & Zadovoljan/zadovoljna sam svojom mobilnošću. & 594 & 4.28 & .96 & 22 \\
\hline
\end{tabular}


Tablica 22

Deskriptivni pokazatelji za pojedine podskale i cjelokupnu skalu varijable Skale kvaliteta života $(N=594)$

\begin{tabular}{|c|c|c|c|c|c|}
\hline \multirow[b]{2}{*}{ Deskriptivni pokazatelj } & \multicolumn{4}{|c|}{ Podskala } & \multirow{2}{*}{$\begin{array}{l}\text { Cjelok. } \\
\text { skala }\end{array}$} \\
\hline & psihol. & društv. & fizički & okolina & \\
\hline AS & 3.94 & 4.08 & 4.04 & 4.33 & 4.06 \\
\hline M & 4.00 & 4.20 & 4.25 & 4.67 & 4.16 \\
\hline Min & 1.00 & 1.00 & 1.00 & 1.00 & 1.00 \\
\hline Max & 5.00 & 5.00 & 5.00 & 5.00 & 5.00 \\
\hline SD & .81 & .73 & .81 & .76 & .69 \\
\hline V & 20 & 18 & 20 & 18 & 17 \\
\hline
\end{tabular}

Kod svih podskala su vidljive vrlo visoke vrijednosti aritmetičkih sredina i medijana. Iz dobivenih rezultata možemo naslutiti da učenici ove dobi uživaju u životu, smatraju da njihov život ima smisao i osjećaju se sigurno u okruženju u kojem žive. Imaju dovoljno životne energije, no ipak im nedostaje sna. Iako se radi o vrlo malom smanjenju stupnja prihvaćanja, vidimo da uočavaju problem s koncentracijom.

Nadalje vidimo da su ispitani učenici dobro prihvaćaju svoj vanjski izgled, zadovoljni svojim materijalnim stanjem i smatraju se dovoljno informiranima. Iako se vidi nešto niža ocjena, još uvijek je dovoljno visoka da možemo zaključiti da su uglavnom zadovoljni količinom slobodnog vremena. Osjećaju podršku svojih prijatelja. Zadovoljni su sobom, svojim radnim sposobnostima i sposobnošću obavljanja svakodnevnih aktivnosti. Vrlo visoko ocjenjuju svoje međuljudske odnose i životne uvjete. Zadovoljni su mobilnošću i zdravstvenom skrbi.

Učenici su po ocjenama zadovoljstva kvalitetom života dosta homogeni (koeficijenti varijacije se kreću između 19\% i 45\%).

Razlike u procjeni aktivnosti u slobodnom vremenu, stavovima o društvenim mrežama i kvaliteti života s obzirom na spol utvrđene su pomoću Mann-Whitneyevog U-testa.

Razlike u procjeni aktivnosti u slobodnom vremenu, stavovima o društvenim mrežama i kvaliteti života s obzirom na završni uspjeh i s obzirom na dob (razred) provjerene su Kruskal-Wallisovim H-testom (Tablica 23). 
Tablica 23

Rezultati U-testova i H-testova usporedbe medijana $(N=594)^{4}$

\begin{tabular}{|c|c|c|c|c|c|c|c|}
\hline $\begin{array}{l}\text { Red. } \\
\text { br. }\end{array}$ & Varijabla & $\begin{array}{l}\text { Grupa } \\
\text { ispita- } \\
\text { nika }\end{array}$ & $\mathrm{N}$ & $\begin{array}{l}\text { Sredine } \\
\text { rang. }\end{array}$ & $\begin{array}{l}\text { U ili } \chi^{2} \\
\text { vrijedn. }\end{array}$ & $\mathrm{z}$ ili df & $\mathrm{p}$ \\
\hline \multirow[t]{2}{*}{1.} & $\begin{array}{l}\text { Aktivnosti u slob.vrijeme } \\
\text { (skala1) }\end{array}$ & muški & 224 & 290.22 & & & \\
\hline & & ženski & 370 & 301.91 & $\mathrm{U}=39808.5$ & $z=.805$ & .421 \\
\hline \multirow[t]{2}{*}{2.} & $\begin{array}{l}\text { Stavovi o } \\
\text { društv.mrežama (skala2) }\end{array}$ & muški & 224 & 285.24 & & & \\
\hline & & ženski & 370 & 304.92 & $\mathrm{U}=38693$ & $\mathrm{z}=1.357$ & .175 \\
\hline \multirow[t]{2}{*}{3.} & Kvaliteta života (skala3) & muški & 224 & 338.36 & & & \\
\hline & & ženski & 370 & 272.76 & $\mathrm{U}=32286.5$ & $\mathrm{z}=4.517$ & $<.001 * * *$ \\
\hline \multirow[t]{5}{*}{4.} & $\begin{array}{l}\text { Aktivnosti u slob.vrijeme } \\
\text { (skala1) }\end{array}$ & ocjena 1 & 3 & 256.67 & & & \\
\hline & & ocjena 2 & 3 & 273.00 & & & \\
\hline & & ocjena 3 & 131 & 300.24 & & & \\
\hline & & ocjena 4 & 292 & 290.95 & & & \\
\hline & & ocjena 5 & 165 & 308.10 & $\chi^{2}=1.321$ & $\mathrm{df}=4$ & .858 \\
\hline \multirow[t]{5}{*}{5.} & $\begin{array}{l}\text { Stavovi o } \\
\text { društv.mrežama (skala2) }\end{array}$ & ocjena 1 & 3 & 88.00 & & & \\
\hline & & ocjena 2 & 3 & 257.33 & & & \\
\hline & & ocjena 3 & 131 & 265.34 & & & \\
\hline & & ocjena 4 & 292 & 304.16 & & & \\
\hline & & ocjena 5 & 165 & 315.79 & $\chi^{2}=11.582$ & $\mathrm{df}=4$ & $.021 *$ \\
\hline \multirow[t]{5}{*}{6.} & Kvaliteta života (skala3) & ocjena 1 & 3 & 254.83 & & & \\
\hline & & ocjena 2 & 3 & 258.67 & & & \\
\hline & & ocjena 3 & 131 & 298.77 & & & \\
\hline & & ocjena 4 & 292 & 297.36 & & & \\
\hline & & ocjena 5 & 165 & 298.22 & $\chi^{2}=.350$ & $\mathrm{df}=4$ & .986 \\
\hline \multirow[t]{4}{*}{7.} & $\begin{array}{l}\text { Aktivnosti u slob.vrijeme } \\
\text { (skala1) }\end{array}$ & 15 god. & 154 & 317.20 & & & \\
\hline & & 16 god. & 124 & 282.46 & & & \\
\hline & & 17 god. & 208 & 290.69 & & & \\
\hline & & 18 god. & 92 & 298.52 & & & \\
\hline
\end{tabular}

Napomena. ${ }^{4}$ Iz analize pod 7, 8 i 9 isključena su tri učenika sa 14 godina. 


\begin{tabular}{|c|c|c|c|c|c|c|c|}
\hline & & 19 god. & 13 & 241.04 & $\chi^{2}=4.727$ & $\mathrm{df}=4$ & .316 \\
\hline \multirow[t]{5}{*}{8.} & $\begin{array}{l}\text { Stavovi o } \\
\text { društv.mrežama (skala2) }\end{array}$ & 15 god. & 154 & 286.69 & & & \\
\hline & & 16 god. & 124 & 282.51 & & & \\
\hline & & 17 god. & 208 & 295.19 & & & \\
\hline & & 18 god. & 92 & 328.42 & & & \\
\hline & & 19 god. & 13 & 318.42 & $\chi^{2}=4.792$ & $\mathrm{df}=4$ & .309 \\
\hline \multirow[t]{5}{*}{9.} & Kvaliteta života (skala3) & 15 god. & 154 & 329.16 & & & \\
\hline & & 16 god. & 124 & 271.61 & & & \\
\hline & & 17 god. & 208 & 297.98 & & & \\
\hline & & 18 god. & 92 & 285.71 & & & \\
\hline & & 19 god. & 13 & 176.88 & $\chi^{2}=15.037$ & $\mathrm{df}=4$ & $.005^{* * *}$ \\
\hline
\end{tabular}

Napomena. ${ }^{*} \mathrm{p}<.05, * * \mathrm{p}<.01, * * * \mathrm{p}<.001$

Rezultati pokazuju postojanje statistički značajnih razlika kod tri testa od devet koji su izvedeni:

1. Među muškim i ženskim ispitanicima, kao i među učenicima različitih općih uspjeha u prethodnom razredu i među učenicima različite dobi, ne postoji statistički značajna razlika $\mathrm{u}$ pogledu aktivnosti u slobodnom vremenu $(\mathrm{p}>.05)$ (Tablica 23, stavke pod rednim brojevima 1,4 i 7).

2. Među muškim i ženskim ispitanicima te među učenicima različite dobi ne postoji statistički značajna razlika u pogledu stavova o društvenim mrežama $(\mathrm{p}>$.05) (Tablica 23, redni broj 2 i 8$)$.

3. Među učenicima različitog općeg uspjeha u prethodnom razredu postoji statistički značajna razlika u pogledu stavova o društvenim mrežama $(\mathrm{p}=.02)$ (Tablica 23 , redni broj 5). Uočava se pravilnost da učenici s nižim ocjenama imaju niže prihvaćanje stavova o društvenim mrežama od učenika s višim ocjenama $(88.00<257.33<265.34<304.16<$ 315.79 ) budući da je 338.36 veći od 272.76 .

4. Među muškim i ženskim ispitanicima postoji statistički značajna razlika s obzirom na samoprocjenu kvalitete života $(p<.001)$. Muški ispitanici su zadovoljniji kvalitetom života od djevojaka (Tablica 23, redni broj 3).

5. Među učenicima različitog uspjeha u prethodnom razredu ne postoji statistički značajna razlika u samoprocjeni kvalitete života $(p=.99)$ (Tablica 23, redni broj 6). 
6. Među učenicima različite dobi postoji statistički značajna razlika u samoprocjeni kvalitete života $(\mathrm{p}=.005)($ Tablica 23 , redni broj 9). Usporedbom sredina rangova po pojedinim godinama života dolazimo do zaključka da je kod nižih godina života veće zadovoljstvo kvalitetom života, a da je kod viših godina života manje zadovoljstvo kvalitetom života.

Tablica 24

Rezultati usporedbe medijana pomoću Mann-Whitneyevog U-testa

\begin{tabular}{|c|c|c|c|c|c|c|c|}
\hline $\begin{array}{l}\text { Red. } \\
\text { br. }\end{array}$ & Varijabla & $\begin{array}{l}\text { Grupa } \\
\text { ispitanika }\end{array}$ & $\begin{array}{l}\mathrm{N}_{1} \\
\mathrm{~N}_{2}\end{array}$ & $\begin{array}{l}\text { Sredine } \\
\text { Rangova }\end{array}$ & $\mathrm{U}$ & $\mathrm{Z}$ & $\mathrm{p}$ \\
\hline \multirow[t]{2}{*}{1.} & Broj sati dnevnog korištenja & muški & 224 & 247.90 & & & \\
\hline & društvenıh mreża & ženski & 369 & 326.81 & 30329.5 & 5.84 & $<.001 * * *$ \\
\hline \multirow[t]{2}{*}{2.} & Kvaliteta života & selo & 164 & 294.79 & & & \\
\hline & & grad & 430 & 298.53 & 34815.5 & .24 & .812 \\
\hline \multirow[t]{2}{*}{3.} & Aktivnosti u slobodno vrijeme & selo & 164 & 287.03 & & & \\
\hline & & grad & 430 & 301.49 & 33543.0 & .92 & .358 \\
\hline \multirow[t]{2}{*}{4.} & Aktivnosti u slobodno vrijeme & gimnazija & 267 & 307.66 & & & \\
\hline & & struk.škola & 327 & 289.20 & 40940.5 & 1.31 & .192 \\
\hline \multirow[t]{2}{*}{5.} & Stavovi o društvenim mrežama & selo & 164 & 291.92 & & & \\
\hline & & grad & 430 & 299.63 & 34345.0 & .49 & .624 \\
\hline \multirow[t]{2}{*}{6.} & Stavovi o društvenim mrežama & gimnazija & 267 & 325.16 & & & \\
\hline & & struk.škola & 327 & 274.91 & 36268.5 & 3.56 & $<.001 * * *$ \\
\hline
\end{tabular}

Napomena. ${ }^{*} \mathrm{p}<.05, * * \mathrm{p}<.01, * * * \mathrm{p}<.001$

Na osnovu provedenih Mann-Whitneyevi U-testova (Tablica 24) vidimo da:

1. Između broja sati dnevnog korištenja društvenih mreža od strane ispitanika muškog spola i od strane ispitanika ženskog spola postoji statistički značajna razlika $(p<.001)$. Ispitanici muškog spola ih koriste značajno kraće u odnosu na djevojke $(247.90<326.81)$.

2. Ne postoji statistički značajna razlika u procjeni kvalitete života učenika s prebivalištem $\mathrm{u}$ selu u odnosu na one s prebivalištem u gradu $(\mathrm{p}=.812)$.

3. Ne postoji statistički značajna razlika u procjeni aktivnosti u slobodnom vremenu učenika $\mathrm{s}$ prebivalištem $\mathrm{u}$ selu $\mathrm{u}$ odnosu na one s prebivalištem $\mathrm{u}$ gradu $(\mathrm{p}=.358)$.

4. Ne postoji statistički značajna razlika u procjeni aktivnosti u slobodnom vremenu gimnazijalaca u odnosu na učenike strukovnih škola $(p=.19)$. 
5. Ne postoji statistički značajna razlika u stavovima o društvenim mrežama srednjoškolaca $\mathrm{s}$ prebivalištem u selu u odnosu na one s prebivalištem u gradu $(\mathrm{p}=.62)$.

6. Postoji statistički značajna razlika u stavovima o društvenim mrežama gimnazijalaca u odnosu na učenike strukovnih škola $(\mathrm{p}<.001)$. Gimnazijalci pokazuju viši stupanj prihvaćanja tvrdnji Skale stavova o društvenim mrežama $(325.16>274.91)$.

Neparametrijski koeficijenti korelacije među varijablama (Tablica 25) pokazuje da je za prva dva para varijabli (Broj korištenih društvenih mreža i Kvaliteta života te Broj sati korištenja društvenih mreža dnevno i Kvaliteta života) korelacija negativna i slaba ( $\mathrm{r}_{\mathrm{s}}$ je blizu nuli) i nije statistički značajna $(\mathrm{p}>.05)$. Korelacija između prosječnog broja sati slobodnog vremena dnevno i kvalitete života je statistički značajna $(p=.005)$, kao i između godina starosti i kvalitete života $(\mathrm{p}=.036)$ premda je i ona slaba.

Tablica 25

Rezultati korelacijske analize

\begin{tabular}{|c|c|c|c|c|}
\hline \multirow{2}{*}{$\begin{array}{l}\text { Red. } \\
\text { br. }\end{array}$} & \multirow[b]{2}{*}{ Varijable } & \multicolumn{3}{|c|}{ Spearmanov } \\
\hline & & $\mathrm{N}$ & $\begin{array}{c}\text { koef.korel. } \\
\mathrm{r}_{\mathrm{s}} \\
\end{array}$ & $\mathrm{p}$ \\
\hline \multirow[t]{2}{*}{1.} & Broj korištenih društvenih mreža & & & \\
\hline & Kvaliteta života (skala3) & 594 & -.07 & .115 \\
\hline \multirow[t]{2}{*}{2.} & Broj sati dnevnog korišt.društv.mreža & & & \\
\hline & Kvaliteta života (skala3) & 594 & -.06 & .120 \\
\hline \multirow[t]{2}{*}{3.} & Prosj.dnevni broj sati slobod.vremena & & & \\
\hline & Kvaliteta života (skala3) & 594 & .12 & $.005 *$ \\
\hline \multirow[t]{2}{*}{4.} & Godine starosti & & & \\
\hline & Kvaliteta života (skala3) & 594 & -.09 & $.036 *$ \\
\hline
\end{tabular}

Neparametrijskim testovima u kojima je kvaliteta života zavisna varijabla, a vrsta škole nezavisna kategorijalna varijabla (Prilog 6) utvrđeno je da učenici iz različitih škola imaju statistički značajno različitu samoprocjenu kvalitete života $(p=.09)$. Gimnazijalci procjenjuju svoju kvalitetu života nižom u odnosu na učenike strukovnih škola. Što pokazuje visina sredine 
rangova $(279.06<312.56)$, odnos aritmetičkih sredina $(4.00<4.11)$ kao i medijan $(4.11<$ 4.21).

Kako su se u dosadašnjim analizama kvalitete života spol i dob pokazale relevantne varijable, pomoću dvofaktorske analize varijance pokušalo se potvrditi takav nalaz. U ovom slučaju je zanemarena činjenica da kvaliteta života kao izvedena (kompozitna) varijabla nije normalno distribuirana. Dakle, u ovoj je analizi kvaliteta života kvantitativna zavisna varijabla, dok su spol i dob nezavisne varijable. U Tablici 26 navedene su aritmetičke sredine kvalitete života, dok je Tablica 27 ANOVA tablica pa sadrži standardne veličine.

Tablica 26

Prosječne vrijednosti kvalitete života anketiranih srednjoškolaca s obzirom na njihov spol i dob $(N=591)^{5}$

\begin{tabular}{|c|c|c|c|}
\hline \multirow[t]{2}{*}{ Godine } & \multicolumn{2}{|c|}{ Spol učenika } & \multirow[b]{2}{*}{ Ukupno } \\
\hline & muški & ženski & \\
\hline 15 & 4.39 & 4.01 & 4.17 \\
\hline 16 & 4.02 & 3.95 & 3.98 \\
\hline 17 & 4.19 & 4.00 & 4.07 \\
\hline 18 & 4.27 & 3.99 & 4.06 \\
\hline 19 & 4.28 & 3.19 & 3.45 \\
\hline Ukupno & 4.21 & 3.97 & 4.06 \\
\hline
\end{tabular}

\footnotetext{
${ }^{5}$ Iz ove su analize isključena tri učenika sa 14 godina života zbog premale frekvencije.
} 
Tablica 27

Rezultati analize varijance (ANOVA) za kvalitetu života kao zavisnu kvantitativnu varijablu $(N=591)^{6}$

\begin{tabular}{lccccc}
\hline $\begin{array}{l}\text { Kvalitativna } \\
\text { varijabla }\end{array}$ & $\begin{array}{c}\text { Suma } \\
\text { kvadrata }\end{array}$ & df & $\begin{array}{c}\text { Sredine } \\
\text { kvadrata }\end{array}$ & $\mathrm{F}$ & $\mathrm{p}$ \\
\hline spol & 6.98 & 1 & 6.98 & 15.52 & $<.001 * * *$ \\
dob & 4.41 & 4 & 1.10 & 2.45 & $.045^{*}$ \\
spol * dob & 3.30 & 4 & .83 & 1.84 & .120 \\
\hline Napomena. $* \mathrm{p}<.05 ; *$ * $<.01 ; * * * \mathrm{p}<.001$ & & &
\end{tabular}

Uočava da je samoprocjena kvalitete života veća kod ispitanika muškog spola u odnosu na ispitanike ženskog spola kod svih starosnih grupa (4.39>4.01 4.02>3.95 itd.). Rezultati navedeni u Tablici 26 upućuju na tri zaključka:

1. Postoji statistički značajan utjecaj spola na zadovoljstvo kvalitetom života (zanemarujući dob). Ispitanici muškog spola pokazuju veće zadovoljstvo kvalitetom života od ispitanika ženskog spola $(4.21>3.97)$ i ta je razlika statistički značajna $(p<.001)$.

2. Postoji statistički značajan utjecaj dobi na zadovoljstvo kvalitetom života (zanemarujući spol). Općenito, kod nižih dobnih grupa je veće zadovoljstvo kvalitetom života i obratno. Najniže je zadovoljstvo kvalitetom života kod učenika u dobi od 19 godina (3.45) dok je najveće zadovoljstvo kvalitetom života kod učenika u dobi od 15 godina $\mathrm{i}$ te su razlike statistički značajne $(\mathrm{p}=.05)$.

3. Ne postoji statistički značajna interakcija između spola i dobi na zadovoljstvo kvalitetom Života $(\mathrm{p}=.12)$.

U svrhu utvrđivanja odnosa kvalitete života (skala 3) i demografskih obilježja ispitanika (dob i spol), aktivnosti u slobodnom vremenu (skala 1) i stavova o društvenim mrežama (skala 2) primijenjena je hijerarhijska regresijska analiza.

U ovom modelu regresijske analize status i redoslijed uključivanja pojedinih varijabli te njihove aritmetičke sredine su sljedeće:

$\begin{array}{llr}\text { Zavisna varijabla } Y & \text { kvaliteta života (skala 3) } & 4.06 \\ \text { Nezavisna varijabla } X_{1} & \text { dob ispitanika } & 16.46 \\ \text { Nezavisna varijabla } X_{2} & \text { spol ispitanika } & 1.62\end{array}$

\footnotetext{
${ }^{6}$ Iz ove su analize isključena tri učenika sa 14 godina života zbog premale frekvencije.
} 
Nezavisna varijabla $\mathrm{X}_{3}$

Nezavisna varijabla $\mathrm{X}_{4}$ aktivnosti u slobodno vrijeme (skala1) stavovi o društvenim mrežama (skala2)

Prve dvije nezavisne varijable su uključene u blok 1 , dok su preostale dvije varijable uključene u blok 2 hijerarhijske (sekvencijalne) regresijske analize. Svi ispitanici u bazi podataka imali su podatke relevantne za ovu analizu $(\mathrm{N}=594)$. $\mathrm{U}$ ovom je modelu analize korištena Enter metoda. Provjerene su pretpostavke za analizu te je utvrđeno da je uzorak dovoljno velik, da ne postoji multikolinearnost i singularnost, da nema atipičnih vrijednosti (outliers), da se radi o trima varijablama koje nisu normalno distribuirane, da se radi o linearnoj povezanosti, homogenim varijancama te nezavisnim rezidualima.

Od rezultata koji nisu navedeni u Tablici 28 treba istaknuti da je u ANOVA analizi dobiveni rezultat $(\mathrm{F}=72.93, \mathrm{p}<.001)$ koji pokazuje značajnost koeficijenta multiple korelacije. Koeficijent korelacije (R) je .576 što znači da između kvalitete života kao zavisne varijable i četiri (naprijed navedenih) nezavisnih varijabli $\mathrm{X}_{1}, \mathrm{X}_{2}, \mathrm{X}_{3}$, i $\mathrm{X}_{4}$ postoji pozitivna i statistički značajna korelacija. Koeficijent determinacije $\left(\mathrm{R}^{2}\right) .33$ pokazuje da je vezom između promatrane zavisne varijable Y i nezavisnih varijabli objašnjeno 33.1\% odstupanja (varijacija) pa je po tome model multiple regresije slabije reprezentativnosti. Korigirani koeficijent determinacije (Adjusted $R$ Square) je .33.

S prve dvije nezavisne varijable postotak objašnjene varijance je 3.4\% dok je s preostale dvije nezavisne varijable on $29.7 \%$ što na kraju daje ukupni postotak objašnjene varijance u čitavom modelu 33.1\% (Tablica 28). Model je u cjelini statistički značajan kako je već naprijed navedeno.

Od četiri nezavisne varijable njih dvije su statistički značajne $(\mathrm{p}<.05)$ :

- dob kao nezavisna varijabla $X_{1}$ nije statistički značajna $(p=.49)$,

- spol kao nezavisna varijabla $\mathrm{X}_{2}$ je statistički značajna $(\mathrm{p}<.001)$,

- aktivnosti u slobodnom vremenu kao nezavisna varijabla $X_{3}$ je statistički značajna $(\mathrm{p}<.001)$, te

- stav o društvenim mrežama kao nezavisna varijabla $X_{4}$ nije se pokazao statistički značajnom varijablom $(\mathrm{p}=.82)$ pa je isključen iz jednadžbe multiple regresije.

Stoga jednadžba multiple regresije nema četiri nego dvije nezavisne varijable pa glasi: $\hat{\mathrm{Y}}=1.334-.256 \mathrm{X}_{2}+.817 \mathrm{X}_{3}$ 
Tablica 28

Pregled rezultata hijerarhijske regresijske analize $(N=594)$

\begin{tabular}{|c|c|c|c|c|c|}
\hline \multirow[t]{2}{*}{ Model i varijabla u modelu } & \multicolumn{2}{|c|}{$\begin{array}{l}\text { Nestandardizir. } \\
\text { koeficijenti }\end{array}$} & \multirow{2}{*}{$\begin{array}{l}\text { Standardiz. } \\
\text { koeficijent } \\
\text { beta }\end{array}$} & \multirow[b]{2}{*}{$\mathrm{t}$} & \multirow[b]{2}{*}{$\mathrm{p}^{1)}$} \\
\hline & $\mathrm{B}$ & $\begin{array}{l}\text { stand. } \\
\text { greška }\end{array}$ & & & \\
\hline \multirow{3}{*}{ godine starosti } & 5.10 & .41 & & 12.31 & $<.001 * * *$ \\
\hline & -.04 & .03 & -.07 & -1.59 & .113 \\
\hline & -.24 & .06 & -.17 & -4.06 & $<.001 * * *$ \\
\hline 2 konstanta & 1.33 & .45 & & 2.98 & $.003 * *$ \\
\hline godine starosti & -.02 & .02 & -.02 & -.69 & .488 \\
\hline spol & -.26 & .05 & -.18 & -5.32 & $<.001 * * *$ \\
\hline aktivn.u slob.vrijeme (skala1) & .82 & .05 & .55 & 16.17 & $<.001 * * *$ \\
\hline stav o društ.mrežama (skala2) & .01 & .06 & .01 & .22 & .821 \\
\hline
\end{tabular}

Veći relativni utjecaj na kvalitetu života imaju aktivnosti u slobodno vrijeme (nestadardizirani beta koeficijent od .82) dok spol ima manji utjecaj (nestandardizirani beta koeficijent je .26).

\section{1. 1. Zaključci prema postavljenim hipotezama na osnovu kvantitativnog istraživanja}

Rezultati hijerarhijske regresijske analize pokazuju:

a) da dob nije statistički značajan prediktor kvalitete života $(\mathrm{p}=.49)$.

b) da je spol statistički značajan prediktor kvalitete života $(p<.001)$.

c) da su aktivnosti u slobodnom vremenu statistički značajan prediktor kvalitete života ( $\mathrm{p}$ $<.001)$.

d) da stavovi o društvenim mrežama nisu statistički značajni prediktori kvalitete života ( $\mathrm{p}$ $=.82)$.

Pokazalo se da relativno veći utjecaj na kvalitetu života imaju aktivnosti u slobodnom vremenu dok manji utjecaj ima spol ispitanika. Ukupno razmatrajući hipotezu „Demografska obilježja, aktivnosti u slobodnom vremenu $i$ stavovi o društvenim mrežama su statistički značajni prediktori kvalitete života učenika višeg sekundarnog obrazovanja“, prema ukupnom 
koeficijentu značajnosti regresijske analize, hipoteza se prihvaća. S time da najveći značaj za varijancu kvalitete života objašnjavaju aktivnosti slobodnog vremena. Drugim riječima, kvaliteta života učenika višeg sekundarnog obrazovanja uvelike je određena aktivnostima njihova slobodnog vremena.

Radi provjere hipoteze „Ne postoji statistički značajna razlika u samoprocjeni kvalitete života s obzirom na sociodemografska obilježja ispitanika“, proveden je U-test te je utvrđeno da postoji statistički značajna razlika u procjeni kvalitete života ispitanika muškog spola u odnosu na ispitanike ženskog spola $(\mathrm{p}<.001)$.

H-testom je utvrđeno da postoji statistički značajna razlika u samoprocjeni kvalitete života učenika različite dobi $(\mathrm{p}=.005)$. Mlađi učenici procjenjuju kvalitetu života boljom nego stariji.

Dvofaktorska analiza varijance je pokazala da postoji statistički značajan utjecaj spola na zadovoljstvo kvalitetom života (zanemarujući pritom dob) $(\mathrm{p}<.001)$. Ista analiza je pokazala da postoji statistički značajan utjecaj dobi na zadovoljstvo kvalitetom života (zanemarujući pritom spol) budući da je $\mathrm{p}=.05$.

U-testom je utvrđeno:

a) da ne postoji statistički značajna razlika u samoprocjeni kvalitete života učenika koji žive u selu u odnosu na učenike koji žive u gradu $(\mathrm{p}=.81)$.

b) da postoji statistički značajna razlika u procjeni kvalitete života učenika koji pohađaju gimnaziju u odnosu na učenike koji pohađaju neku strukovnu školu $(\mathrm{p}=.02)$.

H-test pokazuje da ne postoji statistički značajna razlika u samoprocjeni kvalitete života učenika različitog općeg uspjeha u prethodnom razredu $(\mathrm{p}=.99)$. Pretpostavku da ne postoji statistički značajna razlika u samoprocjeni kvalitete života s obzirom na školski uspjeh učenika, možemo prihvatiti kao točnu.

Inferencijalnom statističkom analizom je provjerena hipoteza „Ne postoji statistički značajna razlika u aktivnostima slobodnog vremena s obzirom na sociodemografska obilježja ispitanika. “

Sociodemografska obilježja u ovom istraživanju su: dob, spol, mjesto življenja, vrsta škole i opći uspjeh u prethodnom razredu.

Dokazano je:

a) da između ispitanika muškog i ženskog spola ne postoji statistički značajna razlika u pogledu aktivnosti u slobodnom vremenu (Tablica 22), hipoteza da ne postoji statistički 
značajna razlika u aktivnostima u slobodnom vremenu s obzirom na spol učenika se prihvaća kao točna

b) da između učenika različite dobi ne postoji statistički značajna razlika u pogledu aktivnosti u slobodnom vremenu (Tablica 23), hipoteza da ne postoji statistički značajna razlika u aktivnostima u slobodnom vremenu s obzirom na dob učenika se prihvaća kao točna

c) da između učenika različitih općih uspjeha u prethodnom razredu ne postoji statistički značajna razlika u pogledu aktivnosti u slobodnom vremenu (Tablica 23), hipoteza da ne postoji statistički značajna razlika u aktivnostima u slobodnom vremenu s obzirom na školski uspjeh učenika se prihvaća kao točna

d) hipoteza da ne postoji statistički značajna razlika u aktivnostima u slobodnom vremenu s obzirom na mjesto življenja učenika se, prema podatcima u Tablici 24 , prihvaća kao točna

e) da ne postoji statistički značajna razlika u aktivnostima u slobodnom vremenu između gimnazijalaca i učenika strukovnih škola (Tablica 24), te se hipoteza prihvaća kao točna

f) na osnovu hi-kvadrat testa je utvrđeno da postoji statistički značajna povezanost između spola i vremena dnevnog korištenja društvenih mreža $(\mathrm{p}<.001)$, ispitanici ženskog spola više koriste društvene mreže od ispitanika muškog spola, hipoteza „Ne postoji statistički značajna razlika u učestalosti korištenja društvenih mreža s obzirom na spol učenika “ se odbacuje.

Provjera hipoteze „Ne postoji statistički značajna razlika u stavovima o društvenim mrežama s obzirom na sociodemografska obilježja ispitanika “ pokazuje da:

a) između ispitanika muškog i ženskog spola ne postoji statistički značajna razlika $u$ pogledu stavova o društvenim mrežama (Tablica 23), hipoteza da ne postoji statistički značajna razlika u stavovima o društvenim mrežama s obzirom na spol učenika se prihvaća kao točna

b) između učenika različite dobi ne postoji statistički značajna razlika u pogledu stavova o društvenim mrežama (Tablica 23), hipoteza da ne postoji statistički značajna razlika u stavovima o društvenim mrežama s obzirom na dob učenika se prihvaća kao točna

c) između anketiranih srednjoškolaca različitog uspjeha $u$ prethodnom razredu postoji statistički značajna razlika u pogledu stavova o društvenim mrežama $(\mathrm{p}=.02)$, hipoteza da ne postoji statistički značajna razlika u stavovima o društvenim mrežama s obzirom na školski uspjeh učenika se odbacuje. Uočena je pravilnost da učenici s nižim ocjenama imaju niže prihvaćanje stavova o društvenim mrežama od učenika s višim ocjenama $(88.00<257.33<$ 265.34 < 304.16 < 315.79 ) budući da je 338.36 veći od 272.76 (Tablica 22) . 
d) ne postoji statistički značajna razlika u stavovima o društvenim mrežama srednjoškolaca s prebivalištem na selu u odnosu na one s prebivalištem u gradu $(\mathrm{p}=.624)$ (Tablica 24), hipoteza da ne postoji statistički značajna razlika u stavovima o društvenim mrežama s obzirom na mjesto življenja se prihvaća kao točna.

e) postoji statistički značajna razlika u stavovima o društvenim mrežama gimnazijalaca $u$ odnosu na učenike strukovnih škola $(\mathrm{p}<.001)$. Gimnazijalci pokazuju veće prihvaćanje tvrdnji o društvenim mrežama $(325.16$ > 274.91) (Tablica 24), hipoteza da ne postoji statistički značajna razlika u stavovima o društvenim mrežama s obzirom na vrstu škole koju učenik pohađa se odbacuje. 


\section{2. Rezultati kvalitativnog dijela istraživanja}

Analiza podataka dobivenih grupnim intervjuima napravljena je unutar tri tematska područja:

1. Slobodno vrijeme

2. Društvene mreže

3. Kvaliteta života

Tematska područja se sastoje od po nekoliko tema koje su opisane kroz kategorije i izlučene kodiranjem podataka. Rezultati istraživanja obiluju doslovnim izjavama ispitanika, bez navodnika i originalnim rječnikom sudionika (pisano u kurzivu).

\section{Slobodno vrijeme}

Pojam slobodnog vremena. Učenici pod pojmom slobodnog vremena podrazumijevaju ono vrijeme koje mogu provoditi kako oni žele, u kojem ne moraju ispunjavati neke zadane obaveze, u kojem se mogu baviti aktivnostima prema vlastitom izboru ili ne raditi ništa.

Na pitanje: Što je slobodno vrijeme?, odgovaraju:

Vrijeme koje mogu provoditi na načine na koje želim, u kojem ne moram ispunjavati neke obaveze.(Ž) Da, bavimo se aktivnostima kojima mi želimo.(Ž)

Da, nemamo nikakvih obaveza što se tiče škole i slično.(M)

Da, znači možemo se baviti sportom, ležati, odmarati.(M)

Odmaranje.(M)

Ono nešto kad nemamo nikakvih obaveza.(Ž)

Opustiti se nakon teškog posla, nakon škole i ostalog.(Ž)

Vrijeme u kojem se možemo baviti isključivo onim što želimo.(Ž)

Vrijeme za naše hobije a ne za školske obaveze (M)

Vikend.(M)

Neko vrijeme u kojem se mogu odmoriti od škole i svih svojih obaveza i pogledati neki film, otić na mobitel i družit se s prijateljima vani.(M) 
Slobodno vrijeme smatraju jako važnim.

... čovjek koji nema slobodnog vremena pod stresom je i nervozan je i onda čak može doći i do oboljenja, recimo psihičkih nekih oboljenja. (Ž)

Pa da, važno je slobodno vrijeme. Da malo mozak opustimo od briga i da radimo nešto što nas

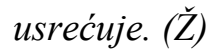

Da se odmorimo od svih svojih obaveza, da imamo malo vremena za sebe. (M)

Dnevna količina slobodnog vremena. Većina učenika je zadovoljna dnevnom količinom slobodnog vremena. U prosjeku imaju četiri do pet i više sati slobodnog vremena dnevno. Količina slobodnog vremena dnevno ovisi o količini školskih obaveza.

Na pitanje o količini slobodnog vremena odgovaraju:

Uglavnom imam dovoljno. (M)

Nekoliko sati, 4,5. (̌̌)

Oko 4 sata. $(M)$

Pa ovisi što imamo u školi, što nemamo... nekad 3, 4 sata, nekad više, nekad manje. (M)

Dosta 6,7 sati. (M)

Način provođenja slobodnog vremena i odabir slobodnovremenskih aktivnosti.

Učenici najčešće slobodno vrijeme provode baveći se nekim sportom, ležanjem, odmaranjem, surfajući internetom, boraveći na društvenim mrežama.

Odgovori na pitanje kako provode svoje slobodno vrijeme:

Stolni tenis. (允)

Odbojka. (M)

Vatrogasci. (M)

Ja sam u teretani. (Ž)

Nogomet. (M)

Plivanje. (M)

Sport, ležanje, odmaranje. (M)

Čitanje. (̌̌)

Odmaranje od škole. (M)

Surfanje internetom. (Ž)

Na face-u. (M)

Instagram. (̌̌) 
Spavanje. (M)

Dramska. (M)

A, ne bavim se ničim, a ono kad izađem s prijateljima do kafića i to, kad se družimo negdje,

kad idemo na nogomet. (M)

Kada gledamo seriju. (̌̌)

Aktivnosti odabiru prema količini vremena koje imaju na raspolaganju, prema svojim interesima i društvu s kojim žele biti.

Na pitanje o načinu odabira aktivnosti kojom će se baviti u slobodno vrijeme ogovaraju:

Pa, ovisi koliko vremena imam. (M)

Ovisi s kim želim biti. (Ž)

Ovisi što želim raditi $i$ što me zanima. (Ž)

Društvo jednostavno, dođete, vidite i svidi vam se, jednostavno, i dosta djece imaju jako puno talenata ali to još nisu razotkrili. (M)

Višak slobodnog vremena mogu iskoristiti za nešto drugo i bolje. (M)

Organizirane slobodnovremenske aktivnosti. Većina ispitanika je uključena u neke organizirane sportske aktivnosti. Učenici koji žive u gradu izražavaju zadovoljstvo ponudom različitih aktivnosti. Učenici koji žive u Zagrebu smatraju da u Zagrebu mogu pronaći i uključiti se u sve aktivnosti koje ih zanimaju. Nešto je drugačija situacija u manjim gradovima i selima. Tamo je ograničen broj aktivnosti kojima se mogu baviti.

$\mathrm{Na}$ upit o zadovoljstvu ponudom organiziranih slobodnovremenskih aktivnosti odgovaraju:

Jesmo. (svi)

Pa dobro na to se ne možemo žaliti, Zagreb je ipak... (M)

Sve nam je ponuđeno. (M)

Učenici koji žive u ruralnom područjima ističu i da im nedostaje mogućnost bavljenja plivanjem i nedostaje im klubova za mlade. No, postoje neki noćni klubovi u koje redovito vikendom zalaze.

Nedostaje više tih za mlade aktivnosti, događaja i tako (Ž) 
Rijetko se organizira neki koncert i neki kulturni događaj (Ž)

samo par puta godišnje (M)

\section{Društvene mreže}

Korištenje društvenih mreža, broj i vrsta korištenih mreža. Svi ispitanici koji su sudjelovali u grupnim intervjuima koriste online društvene mreže. Većina ih ima otvorene profile na nekoliko mreža, dvije, tri i više. Najviše koriste Instagram, Facebook, Snapchat, WhatsApp i Viber.

Odgovori učenika na pitanje koje društvene mreže koriste:

Ja imam tri profila otvoreno. (M)

$\operatorname{Na} \operatorname{tri}(\check{Z})$

Facebook više ne koristim. (M)

Instagram, Facebook, Snapchat, WhatsApp, Viber (M)

Facebook, Messanger, Snapchat, Instagram (Ž)

Snapchat, Viber (M)

Instagram, Viber (̌̌)

Instagram (M)

Snapchat, WhatsApp, sve (̌̌)

Ja sada imam samo Facebook (Ž)

Facebook i Instagram (M)

Snapchat (M)

Instagram, Snap Ž)

Facebook, Instagram, Snap (Ž)

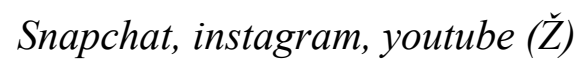

Meni je najbolji Twiter zato jer nitko ne koristi, koristim ga zato jer mi ni roditelji ne koriste ni nitko i ne mogu mi gledati i komentirati. Mogu pisati stvari da to samo drugi ljudi vide po svijetu i tako. (M)

Razlozi korištenja društvenih mreža. Kao razloge korištenja društvenih mreža navode komunikaciju s prijateljima i razmjenu informacija.

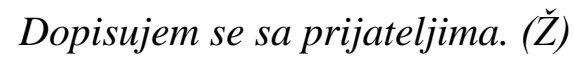

Pogledamo neke novost, slike i tak. (M) 


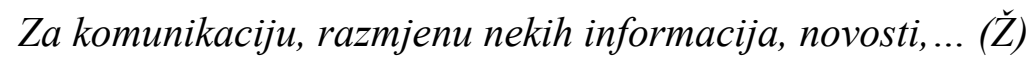

$D a$, druženje s prijateljima, kad ne možemo biti s njima, da vidimo šta oni rade u životu $i$ tako, ...trošimo vrijeme. (M)

Dopisujemo se, objavljujemo slike, gledamo šta ima i tako (̌̌)

Uređujem profil. (̌̌)

Ja koristim uglavnom samo za dopisivanje, lakše je preko društvenih mreža organizirati nekakvo okupljanje nego preko telefona $(M)$

Ponekad koriste društvene mreže i za potrebe nastave i učenja te komunikacije s profesorima. Smatraju da su društvene mreže korisne za nastavu.

Na primjer Kahoot (M)

Čujemo se s profesoricom iz engleskog jezikaj na WhatsApp-u. (̌̌)

Imamo grupu na Face-u pa si šaljemo ako nešto trebamo jedni drugima (Ž)

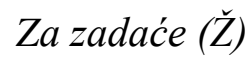

Ako radimo neki plakat, slike si šaljemo (Ž)

Ili ako ne znamo što će biti u ispitu (Ž)

Vrijeme korištenja društvenih mreža. Učenici društvene mreže koriste stalno, $u$ slobodno vrijeme, u školi, pod odmorima, a često i za vrijeme nastave. Ističu mogućnost ovisnosti o društvenim mrežama.

Stalno ih koristim. (M)

Uškoli, vani, pod odmorom, ... stalno (̌̌)

$U$ školi, pod odmorima (M)

Kad mi je dosadno na nastavi (M)

Samo za vrijeme nastave ne koristim, inače stalno (Ž)

Vremenom postajemo ovisni o društvenim mrežama. (Ž)

Mislim da ima puno ovisnosti o društvenim mrežama samo što to nije prepoznato u društvu kao druge ovisnosti. (̌̌)

Kompetentnost za korištenje društvenih mreža. Smatraju se kompetentnima za svaki oblik korištenja online društvenih mreža i za rješavanje svih eventualno nastalih problema pri korištenju. Smatraju da im nije potrebna ničija pomoć. 
Slobodno vrijeme i društvene mreže. Učenici smatraju da društvene mreže utječu na način provođenja slobodnog vremena. Zaokupljaju njihovu pozornost te često slobodno vrijeme provedu kod kuće družeći se online.

$\mathrm{Na}$ upit o utjecaju društvenih mreža na slobodno vrijeme odgovaraju:

Zaokupljaju nas. (̌̌)

Smanjujemo vanjske aktivnosti. (̌̌)

Često ostajem kod kuće družeći se preko društvenih mreža umjesto da izađemo van i nađemo se s prijateljima. (̌̌)

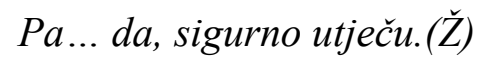

Često provedemo vrijeme surfajući. (M)

\section{Kvaliteta života}

Pojam kvalitete života. Učenici višeg sekundarnog obrazovanja pod kvalitetom života podrazumijevaju ravnotežu između obaveza, kvalitete obavljanja svojih dužnosti i obveza i bavljenja aktivnostima po vlastitom izboru, hobijima i razvijanje svojih sposobnosti i talenata. Smatraju da imaju jako puno školskih obveza pa im je teško uspostaviti tu ravnotežu.

To je kad imamo sve što nam treba uživotu. (M)

Ono, kad smo zadovoljni, sve imamo, zdravi i tako. (̌̌)

Ja mislim da je kvaliteta života kad imaš nekakvu ravnotežu u onome što radiš, znači obaveze, što bolje raditi ono što moraš, na primjer školovanje, ali da si uzmeš vremena za ono što voliš raditi, hobije i ono što te zanima $i$ da se razvijaš i na druge načine osim onoga što stvarno moraš. Normalno zdravlje i te stvari. Da se brineš o tome.(Ž)

To je kad nam je dobro u životu. (Ž)

Kad imamo sve što nam treba. (M)

Utjecaji na kvalitetu života. Učenici ističu boravak u školi i način rada na nastavi kao važnu stavku u kvaliteti njihovog života. Smatraju da okolina u kojoj se kreću i ljudi u njihovom okruženju, roditelji i prijatelji, utječu na kvalitetu života. Svjesni su i da kvaliteta života ovisi i o vlastitoj organizaciji života. Zdravlje ističu kao izuzetno važno. Važnim smatraju i materijalno blagostanje. 
Na pitanje o utjecajima na kvalitetu života odgovaraju:

Roditelji. (M)

Okolina i kako se mi osjećamo sami. (̌̌)

Novac utječe dosta $(M)$

Roditelji, prijatelji, novac, mjesto stanovanja, škola (M)

Škola dosta utječe. (M)

Ono što radimo u školi i u slobodno vrijeme (̌̌)

$\operatorname{Mi} \operatorname{sami}(\check{Z})$

Okolina u kojoj živimo, naša vlastita organizacija života. Znači u to spada i slobodno vrijeme

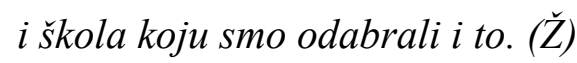

Blizina nekih mjesta gdje se možemo nečim baviti (Ž)

Zdravlje (M)

Što radimo, kako, na koji način (Ž)

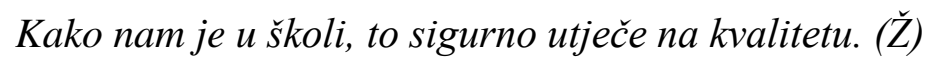

Ako nam je dosadno u školi padamo u neku vrstu depresije, ne da nam se ići u školu, nismo sretni, htjeli bi promijeniti to a ne možemo i onda ... nesretni smo. (M)

Zato što ipak provedemo pola dana tu onda još dođemo doma i učimo za tu školu, nerviramo se zbog ocjena u školi, tako da, sve je to povezano.(M)

Svojim odgovorima ističu da je slobodno vrijeme jako važno za kvalitetu života, za uspostavljanje već spomenute ravnoteže u životu. Nedostatak slobodnog vremena dovodi do stresa, a to utječe na kvalitetu života.

Čovjek koji je zauzet stalno je u stresu, stalno je u žurbi i onda nije zadovoljan. (Ž)

Svakome treba slobodno vrijeme da ga provodi kako on želi, ako nema njega opet ..loše. (M) „,Možda neko vrijeme se može tako izdržati neki visok tempo, ali bez količine slobodnog vremena će izgorit svatko. “

Različita su mišljenja o utjecaju društvenih mreža na kvalitetu života. Neki smatraju da društvene mreže uopće ne utječu na kvalitetu života, neki da pozitivno utječu, neki da negativno utječu dok postoji i mišljenje da utječu i pozitivno i negativno.

Ne utječu uopće.(M) 
Utječu ako previše vremena provodimo na društvenim mrežama a nismo sa svojim

prijateljima.(M)

Većinom negativno $(M)$

Sve više $i$ više nekako negativno.(M)

Osim ako netko nađe curu preko društvene mreže, onda utječe pozitivno jer smo onda sretni. $(M)$

Pa recimo, pozitivno je da se možemo lakše povezati s nekim, a negativno je da nas previše zaokupljaju. Postoji čak i nasilje na društvenim mrežama koje je češće možda nego fizičko.(Ž)

Zdravlje smatraju jako važnim za kvalitetu života. Ističu potrebu češćeg odlaska na liječničke preglede, a smatraju da se o tome ne vodi dovoljna briga. Često se osjećaju umorni, nenaspavani jer moraju rano ustajati, a kasno odlaze na spavanje jer navečer uče, gledaju televiziju ili su na društvenim mrežama.

Iako neprestano komuniciraju putem društvenih mreža, smatraju da je za kvalitetu života izuzetno važan neposredni kontakt, druženje, povremeni izlasci s prijateljima.

Zdravlje je najvažnije, ako smo bolesni, ne daj Bože...(M)

Pa osim društvenih medija, važno je da imate prijatelje, znači taj socijalni dio života. Ako je netko sam, uči non-stop sigurno da mu život nije baš lijep.(M)

To vam ništa ne vrijedi, mora biti kontakt ljudski tu, barem vikendom, neki izlasci...(M)

Ipak smo društvena bića, trebamo imati doticaja s drugim ljudima. E, sad to što se to svede na kraju na ljude koje viđamo u školi od prijatelja jer nekad nemamo vremena za vidit druge prijatelje izvan škole, to je malo šteta.(Ž)

Samoprocjena kvalitete života. Učenici iznose da su uglavnom zadovoljni kvalitetom svog života. Ocjenjuju je vrlo visokim ocjenama.

Zadovoljan. (M)

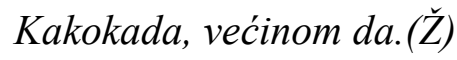

Da, zadovoljan sam.(M) 
Moglo bi biti i bolje, ali uglavnom da pet. (cijela grupa)

$4,8(\check{Z})$

4 i pol? (M)

3,5 (M)

$5(M)$ 


\section{RASPRAVA}

Rasprava je prezentirana u okviru tri tematska područja koja su formirana i pri analizi uzevši u obzir rezultate kvantitativnog i kvalitativnog dijela istraživanja.

\section{Slobodno vrijeme}

Učenici su u intervjuu ispitani o značenju pojma slobodnog vremena te su dobiveni odgovori pokazali da se značenja slobodnog vremena stvaraju iz načina na koji sudionici razumiju slobodno vrijeme i kako ga opisuju. Iz njihovih odgovora možemo izlučiti tri dimenzije značenja - vrijeme, aktivnost ili iskustvo. Takvo definiranje je vidljivo i u akademskim definicijama slobodnog vremena (Kelly, 1996). Definiraju slobodno vrijeme kao vrijeme koje im preostaje nakon svih školskih obveza i obveza u obitelji.

Prethodno postavljena hipoteza je glasila:

Ne postoji statistički značajna razlika u aktivnostima slobodnog vremena s obzirom na sociodemografska obilježja ispitanika.

Sociodemografska obilježja koja su relevantna u ovom istraživanju su: dob, spol, mjesto življenja, vrsta škole i opći uspjeh učenika u prethodnom razredu.

Kvantitativni dio istraživanja potvrđuje postavljenu hipotezu, pokazuje da ne postoji razlika u pogledu aktivnosti u slobodnom vremenu s obzirom na dob $(\mathrm{p}=.35)$, spol $(\mathrm{p}=.42)$, mjesto življenja $(\mathrm{p}=.36)$, vrsta škole $(\mathrm{p}=.19)$ i opći uspjeh učenika u prethodnom razredu ( $\mathrm{p}$ $=.86)$.

Rezultati dobiveni ovim istraživanjem pokazuju da učenici višeg sekundarnog obrazovanja imaju četiri i više sati slobodnog vremena dnevno. Broj sati anketiranih učenika varira od nula do dvanaest sati, no najčešći odgovor, koji je potvrđen i u intervju, je četiri sata dnevno. Taj je podatak u skladu s podatcima o broju sati slobodnog vremena dnevno u prethodnim istraživanjima (Hanžek, Holenko, Kojadin, Kolesarić i Morić, 2013; Ilišin, 2011; Mlinarević, 2006).

Učenici su uglavnom zadovoljni količinom slobodnog vremena. Količina slobodnog vremena dnevno ovisi o količini njihovih školskih obaveza. S obzirom na to da se radi o velikom broju sati u kojem su učenici prepušteni vlastitim izborima i različitim utjecajima okoline, to nas upućuje na potrebu ozbiljnog promišljanja o načinu provođenja slobodnog vremena mladih (Mlinarević, 2006). 
Slobodno vrijeme najčešće provode baveći se nekim sportom, ležanjem, odmaranjem, surfajući internetom, boraveći na društvenim mrežama. Iako su prethodna istraživanja (Venus, Brlas, Šeparac i Koić, 2007) pokazala da srednjoškolci slobodno vrijeme najradije provode družeći se s vršnjacima, većina sudionika grupnog intervjua se izjasnila da se u slobodno vrijeme bave organiziranim sportskim aktivnostima. Taj podatak ohrabruje jer fizička aktivnost u slobodno vrijeme izravno pridonosi boljem fizičkom zdravlju i dobrobiti (Iwasaki, Zuzanek i Mannell, 2001), a mnoga su istraživanja pokazala da se vrijeme provedeno u sportskim aktivnostima $u$ adolescenciji znatno smanjuje u odnosu na učenike osnovne škole (Steinberg, 1996; Timmer i sur.,1985. prema Brdar i Lončarić, 2004). Više ispitanika muškog spola se bavi sportskim aktivnostima, a ženskog nekim društvenim aktivnostima, što je u skladu s istraživanjem Opić i Đuranović (2014) koje potvrđuje stereotipe prema kojima su druženje i kulturne aktivnosti prikladnije ženama, a sportske aktivnosti muškarcima. Dosadašnja istraživanja su pokazala da djevojke više vremena provode s elektronskim medijima, $\mathrm{u}$ kulturnim aktivnostima, druženju, izlascima i opuštajućim aktivnosti, dok dječaci više slobodnog vremena provode baveći se sportskim aktivnostima (Brdar i Lončarić, 2003; Fahey, Delaney i Gannon, 2005; Opić i Đuranović, 2014).

Učenici koji žive u Zagrebu zadovoljni su načinom provođenja svog slobodnog vremena i ponudom organiziranih aktivnosti, smatraju da im grad pruža sve što trebaju što nije u skladu istraživanjem Hanžek i sur. (2013) koje je pokazalo da u Zagrebu niti jedan ispitanik nije potpuno zadovoljan provođenjem svog slobodnog vremena. Odgovori učenika koji žive u ruralnim područjima u skladu su s navedenim istraživanjem jer pokazuju nezadovoljstvo učenika ponuđenim sadržajima. Najviše im nedostaje različitih sportskih aktivnosti i kulturnih događanja. Ističu i da im nedostaje mogućnost bavljenja plivanjem i nedostaje im klubova za mlade. Takva se događanja obično organiziraju u gradovima, a njima je često problem mobilnost jer su u godinama kada ovise o javnom prijevozu ili roditeljima. Da mladi iz ruralnih sredina imaju poteškoće oko prijevoza do mjesta gdje se neke aktivnosti odvijaju pokazuje i istraživanje Byrne i sur. (2006).

Prema teoriji samoodređenja (Deci i Ryan 2000) odnos između sudjelovanja u slobodnim aktivnostima i zadovoljstva životom posreduje zadovoljavanje psiholoških potreba adolescenata. Psihološke potrebe su stanja koja su nužna za razvoj čovjeka. Za psihički razvoj adolescenta potrebna za autonomija, povezanost i kompetentnost. Otkriveno je da konteksti koji podržavaju svakodnevno zadovoljavanje potreba za autonomijom, povezanošću i kompetencijom utječu na zdravlje i opću dobrobit osobe i potiču veću internalizaciju i 
integraciju, dok nezadovoljavanje tih potreba povezujemo s lošim fizičkim i psihičkim stanjima (Sheldon i Elliot, 1999). Adolescenti potrebu za autonomijom zadovoljavaju samostalno donoseći odluke o svom ponašanju koje ovise o njihovim interesima, željama i vrijednostima. Povezanost se očituje u skladnim odnosima s okolinom, posebno s ljudima do kojih im je stalo. Potrebu za kompetencijom zadovoljavaju uspješnošću i samopouzdanjem pri bavljenju različitim aktivnostima. Zadovoljavanje osnovnih psiholoških potreba potiče osobu na aktivnost. Nužno je da svaki čovjek sam odlučuje o načinu ispunjavanja svojih potreba (Deci i Ryan, 2000).

Ovo je istraživanje pokazalo da učenici adolescentskog uzrasta imaju autonomiju pri odabiru aktivnosti u slobodnom vremenu. Samostalni su pri odlučivanju o načinima provođenja svog slobodnog vremena, nitko ne utječe na njih. Smatraju se kompetentnima i uspješnima u aktivnostima kojima se bave u slobodno vrijeme. Svojim odgovorima pokazuju da se u slobodno vrijeme osjećaju dobro i prijateljski povezani s osobama s kojima ga provode.

Učenici različitih školskih uspjeha i različite dobi jednako procjenjuju autonomiju, kompetenciju i povezanost tijekom svog slobodnog vremena. S obzirom na to da se radi o vrlo malom rasponu godina ispitanika i većina je učenika vrlo dobrog i odličnog uspjeha, ne začuđuje da nije utvrđena razlika u procjenama.

Unatoč činjenici da je učenicima u gradskim sredinama ponuđeno puno više sadržaja kojima se mogu baviti u slobodno vrijeme, čini se da učenici iz seoskih sredina uspijevaju pronaći sadržaje kojima će se baviti i u kojima zadovoljavaju svoje psiho-fizičke potrebe te se nije pokazala značajnom razlika $\mathrm{u}$ procjeni aktivnosti $\mathrm{u}$ slobodnom vremenu učenika $\mathrm{s}$ prebivalištem u selu u odnosu na one s prebivalištem u gradu.

Kako je kod učenika uočena autonomija u izboru aktivnosti u slobodnom vremenu, tako ne postoji razlika u procjeni aktivnosti u slobodnom vremenu gimnazijalaca u odnosu na učenike strukovnih škola jer svi biraju aktivnosti prema svojim željama, sposobnostima i potrebama koje žele zadovoljiti.

Aktivnosti u slobodno vrijeme pružaju mogućnosti za zadovoljavanje psiholoških potreba adolescenata. Primijećeno je da se razina zadovoljstva životom može objasniti kroz pozitivne procese zadovoljavanja potreba za kompetencijom i povezanošću. Što se adolescenti više uključuju u aktivnosti u slobodnom vremenu, to su veće mogućnosti za zadovoljenje osnovnih potreba, a to može imati veći pozitivan učinak na njihovo zadovoljstvo životom. Istraživanje (Leversen i sur., 2012) ukazuje na to da zadovoljstvo u kontekstu aktivnosti u slobodno vrijeme može biti važan izvor dobrobiti adolescenata. Djeca se od najranije dobi bave raznim vrstama 
aktivnosti u slobodno vrijeme, no u adolescentskoj dobi većina je već isprobala ponuđene aktivnosti i može birati sudjelovanje u onima koje će zadovoljiti njihove potrebe, a prema vlastitim interesima i talentu. Što se više bave tim aktivnostima to više zadovoljavaju svoje potrebe a time se povećava i njihovo zadovoljstvo životom (Leversen i sur., 2012).

Rezultati ovog istraživanja pokazali su da je zadovoljavanje psiholoških potreba u domeni slobodnih aktivnosti pozitivno povezano $\mathrm{s}$ povećanim zadovoljstvom životom kod adolescenata. Nadalje, zadovoljstvo potrebama u potpunosti je posredovalo povezanost između sudjelovanja u aktivnostima i zadovoljstva životom, što implicira da pozitivni procesi zadovoljavanja potreba utječu na opće životno zadovoljstvo adolescenata. Ovi rezultati pridonose prethodnim istraživanjima pozitivnog utjecaja zadovoljenja potreba u drugim važnim područjima u životu djece i adolescenata (Eccles i sur., 2003; Fredricks i Eccles, 2008; Gilman, 2001; Larson i sur., 2002).

\section{Društvene mrě̆e}

Današnji adolescenti su dobna skupina koja je rođena u doba digitalne revolucije i rastu okruženi digitalnim medijima te ne iznenađuje njihovo masovno korištenje svih mogućnosti koje ti mediji pružaju. Kako su u dobi kada vršnjačke interakcije predstavljaju važan socijalizacijski okvir (Livazović, 2011), komunikacija putem društvenih mreža je nezaobilazna pojava. U društvenom životu adolescenata preklapa se online i offline komunikacija i oni su u neprekidnom kontaktu.

Postavljena je hipoteza:

Ne postoji statistički značajna razlika u učestalosti korištenja društvenih mreža s obzirom na spol učenika.

$\mathrm{Na}$ osnovu $\chi^{2}$ - testa je utvrđeno da postoji statistički značajna povezanost između spola $\mathrm{i}$ vremena dnevnog korištenja društvenih mreža $(p<.001)$, ispitanici ženskog spola više koriste društvene mreže (2,5 sata) od ispitanika muškog spola (1,9 sati), što je dokazano i istraživanjem koje su proveli Kelly, Zilanawala, Booker i Sacker (2018) u Velikoj Britaniji. U istraživanju koje je analiziralo podatke o gotovo 11000 tinejdžera pokazalo se da dvije petine tinejdžera ženskog spola društvene medije koristi više od tri sata na dan, dok isto čini petina dječaka. Djevojke češće od momaka koriste internet za obrazovne i socijalne aktivnosti, uključujući chat, društvene mreže, e-mail i slušanje glazbe (Lenhart i Madden,2005; Lin i Tsai, 2008). 
Adolescenti su, neovisno o spolu i dobi, vjerni korisnici društvenih mreža. U ovom je sudjelovalo vrlo malo ispitanika koji ih ne koriste, postotak adolescenata koji koriste društvene mreže je $99 \%$ te je za pretpostaviti da su i njihovi stavovi o društvenim mrežama slični, kao što je i dokazano istraživanjem.

Istraživanje je pokazalo da vrlo veliki broj, najčešće imaju profile na dvije ili tri, a neki su izjavili da imaju profile na svim dostupnim mrežama. Iako je anketa pokazala da dnevno na društvenim mrežama provode 2,4 sata, intervjuirani učenici su se izjasnili da su neprestano online, da njihova komunikacija ne prestaje. Trenutno se pokazala najkorištenija mreža Instagram (85\%), zatim Facebook (75\%), Snapchat (39\%) i ostale što potvrđuje istraživanje među američkim tinejdžerima (Lenhart, 2015) o korištenju društvenih mreža. Iako je Facebook vodeća mreža prema broju korisnika u Hrvatskoj, broj korisnika Instagrama u velikom je porastu. U posljednje je tri godine broj korisnika se povećao pet puta (www.arbona.hr). To se svakako primjećuje i kod populacije učenika višeg sekundarnog obrazovanja.

Učenici društvene mreže koriste stalno, u slobodno vrijeme, u školi, pod odmorima, a često i za vrijeme nastave. Ističu mogućnost ovisnosti o društvenim mrežama. Iako društvene mreže pružaju brojne mogućnosti korištenja, najčešća svrha njihovog korištenja od strane adolescenata je razmjena informacija i komunikacija s prijateljima (42\%) i to s prijateljima s kojima komuniciraju i offline što je u skladu s podatcima istraživanja Ilišin, Bouillet, Gvozdanović i Potočnik (2013). Važno im je znati što se događa u životu njima najbližih osoba pa često pregledavaju njihove fotografije i video zapise (26\%). To potvrđuje činjenicu da mladi koriste društvene mreže da bi produžili susrete sa svojim prijateljima, da bi što više bili u kontaktu (Boyd, 2014).

Analiza podataka vezanih uz hipotezu Ne postoji statistički značajna razlika u stavovima o društvenim mrežama s obzirom na sociodemografska obilježja ispitanika, gdje su podaci analizirani u odnosu na dob, spol, mjesto življenja, vrstu škole i opći uspjeh učenika u prethodnom razredu, pokazuje da između ispitanika muškog i ženskog spola, između učenika različite dobi i ispitanika iz ruralnih i urbanih područja ne postoji statistički značajna razlika u pogledu stavova o društvenim mrežama $(\mathrm{p}>$.05). Između anketiranih srednjoškolaca različitog uspjeha $\mathrm{u}$ prethodnom razredu postoji statistički značajna razlika u pogledu stavova o društvenim mrežama $(p=.02)$. Uočena je pravilnost da učenici s nižim ocjenama imaju niže prihvaćanje stavova o društvenim mrežama od učenika s višim ocjenama $(88.00<257.33<$ $265.34<304.16<315.79$ ) budući da je 338.36 veći od 272.76. Vezu između školskog uspjeha i stavova o društvenim mrežama, tj. činjenicu da učenici s nižim školskim uspjehom pokazuju negativnije stavove o društvenim mrežama možemo tražiti u razini medijske pismenosti. 
Istraživanje koje su proveli Leung i Lee (2012) pokazuju da je veća vjerojatnost za ovisnost o internetu kod učenika s višom razinom internetske pismenosti. Otkriveno je da adolescenti koji su u mogućnosti locirati, pretraživati i pristupati različitim informacijama i koji imaju saznanja o kontekstu koji je u podlozi raznih informacija, postižu bolje rezultate na skali akademskih kompetencija i općenito imaju bolje ocjene. U skladu s tim možemo pretpostaviti da učenici višeg školskog uspjeha imaju i medijsku pismenost na višoj razini te više znanja o korištenju društvenih mreža što rezultira pozitivnijim stavovima o njima. $\mathrm{S}$ tim se može povezati $\mathrm{i}$ postojanje razlike u stavovima, između gimnazijalaca i učenika strukovnih škola. Postoji statistički značajna razlika u stavovima o društvenim mrežama gimnazijalaca u odnosu na učenike strukovnih škola $(\mathrm{p}<.001)$. Gimnazijalci pokazuju pozitivniji stav o društvenim mrežama $(325,16>274,91)$.

Adolescenti društvene mreže smatraju korisnima. Za njih su one najvažnije sredstvo informiranja. Smatraju da one u velikoj mjeri doprinose ljudskom životu, da čine društvo naprednijim, a njihov život interesantnijim i maštovitijim. Ponekad koriste društvene mreže i za potrebe nastave i učenja te komunikacije s profesorima. Smatraju da su društvene mreže korisne za nastavu.

Sebe smatraju vrlo kompetentnima za svaki oblik korištenja online društvenih mreža i za rješavanje svih eventualno nastalih problema pri korištenju. Sigurni su u ono što rade putem njih, nemaju nikakvih bojazni i ne osjećaju potrebu za bilo čijom pomoći, smatraju da pri korištenju društvenih mreža nema situacije u kojoj bi im mogla zatrebati nečija pomoć. Rado ih koriste, u svako doba dana (i noći), u svakoj situaciji, često i za vrijeme nastave. Ponekad se to od njih traži u svrhu nastave, a često i bez dozvole profesora.

Istraživanje je pokazalo da učenici uviđaju da društvene mreže utječu na način provođenja njihovog slobodnog vremena. Ističu mogućnost ovisnosti o njima. Puno vremena provode družeći se online pa se često događa da zanemaruju izlaske i druženje s prijateljima vani i neke druge aktivnosti koje smatraju važnima.

\section{Kvaliteta života}

Kvaliteta života kao multidimenzionalni koncept uključuje percepciju svakog pojedinca o različitim aspektima života (WHOQOL Group, 1998). Samoprocjena zadovoljstva životom pojedine osobe uključuje razmišljanje o važnosti i zadovoljstvu pojedinim životnim područjem. To je subjektivan pristup kvaliteti života koji podrazumijeva doživljaj zadovoljstva načinom i 
uvjetima života kao i mogućnostima i ograničenjima koje se nameću (Krizmanić, Kolesarić, 1989; Pastuović, 1993; Pastuović i sur., 1995).

Hipoteza glasi:

Ne postoji statistički značajna razlika u samoprocjeni kvalitete života s obzirom na demografska obilježja ispitanika.

Podatci su analizirani u odnosu na dob, spol, mjesto življenja, vrstu škole i opći uspjeh učenika u prethodnom razredu.

Sudionici ovog istraživanja kvalitetu života vide u ravnoteži između svih obaveza, rada i slobodnog vremena u kojem se mogu baviti svojim hobijima i odmarati. Smatraju da je jako važno naći tu ravnotežu u životu. Ističu da njihova mogućnost pronalaženja ravnoteže ne ovisi o njima nego o količini školskih obveza i dužnosti. Kvaliteta je za njih opća dobrobit, kada imaju sve što im je potrebno.

Utvrđeno je da postoji statistički značajna razlika u procjeni kvalitete života ispitanika muškog spola u odnosu na ispitanike ženskog spola $(\mathrm{p}<.001)$. Muški ispitanici pokazuju veće zadovoljstvo kvalitetom svog života od ispitanika ženskog spola. Što potvrđuje istraživanje Bezinović, Manestar i Ristić Dedić (2004) koje je također pokazalo da muški ispitanici značajno bolje procjenjuju kvalitetu svog života. Istraživanje kvalitete života (Vuletić i Ivanković, 2011) također pokazuje da postoji razlika u mjerenju i da ženski sudionici istraživanja imaju nižu vrijednost ukupne mjere osobne kvalitete života, no razlika se nije pokazala statistički značajnom kao u ovom istraživanju. Muški su ispitanici izvijestili o višim razinama kvalitete života, odnosno o fizičkoj i psihičkoj dobrobiti, roditeljskoj povezanosti i autonomiji i u istraživanjima Meade i Dowswell (2016) i Ravens-Sieberer i sur. (2007). Istraživanjem koje su proveli Gojčeta, Joković Oreb i Pinjatela (2008) nisu utvrđene razlike u procjeni kvalitete života prema spolu.

Postoji statistički značajna razlika u samoprocjeni kvalitete života učenika različite dobi $(\mathrm{p}=.005)$. Mlađi učenici procjenjuju kvalitetu života boljom nego stariji. Iako se, kako je već navedeno, radi o vrlo malom dobnom rasponu ispitanika, pokazalo se da mlađi ispitanici pokazuju veće zadovoljstvo kvalitetom života. Dosadašnja istraživanja kvalitete života su obuhvaćala ispitanike većeg raspona godina te su pokazala da mlađi ispitanici kvalitetu života procjenjuju višom nego stariji i da se samoprocjena kvalitete života smanjuje s dobi (Martinis, 2005; Vuletić, 1999). Učenici višeg sekundarnog obrazovanja većim dijelom žive u roditeljskoj sredini te nemaju financijskih i stambenih briga, zaštićeni su u svojim obiteljima pa je njihovo visoko procijenjeno zadovoljstvo životom očekivano. Tijekom pohađanja srednje škole događaju se intenzivne i brze promjene u psihosocijalnom razvoju te se i stavovi i uvjerenja 
mijenjaju zajedno s tim. Stoga ne iznenađuju ni razlike u njihovom samopoimanju vlastite kvalitete života.

Pokazalo se da postoji statistički značajan utjecaj spola na zadovoljstvo kvalitetom života (zanemarujući pritom dob) $(\mathrm{p}<.001)$ te da postoji statistički značajan utjecaj dobi na zadovoljstvo kvalitetom života (zanemarujući pritom spol) $(\mathrm{p}=.05)$. Također, postoji statistički značajna razlika u procjeni kvalitete života učenika koji pohađaju gimnaziju u odnosu na učenike koji pohađaju neku strukovnu školu $(\mathrm{p}=.02)$. U samoprocjeni kvalitete života učenika koji žive u selu u odnosu na učenike koji žive u gradu ne postoji statistički značajna razlika (p $=.81)$. Ne postoji statistički značajna razlika u samoprocjeni kvalitete života učenika različitog općeg uspjeha u prethodnom razredu $(\mathrm{p}=.99)$.

Istraživanje je obuhvatilo aspekte kvalitete života koje se odnose na opće zadovoljstvo sobom, svojom radnom sposobnošću, međuljudskim odnosima i vanjštinom. Ispitano je mišljenje adolescenata o smislu života, uživanju u životu, sposobnosti koncentracije, posjedovanja životne energije i mogućnosti odmora. Uključuje i njihovo zadovoljstvo informiranošću, slobodnim vremenom, životnim uvjetima, mobilnošću i zdravstvenom skrbi.

Pokazalo se da su učenici u velikoj mjeri zadovoljni svim navedenim aspektima kvalitete života što potvrđuje prethodna istraživanja (Ilišin, Bouillet, Gvozdanović i Potočnik, 2013; Ilišin i Spajić Vrkaš, 2015) čiji podatci također pokazuju da je dvije trećine mladih zadovoljno svojim životom. Brojne studije su otkrile koliko je to zadovoljstvo važno jer se pomoću individualnih razlika u samoprocjeni kvalitete života adolescenata mogu predvidjeti važni životni ishodi: problemi u ponašanju (Park, 2004; Suldo i Huebner, 2004), vršnjačko nasilje (Valois, Zullig, Huebner i Drane, 2001), samopouzdanje, socijabilnost (Diener i Ryan, 2009), stupanj socijalizacije (Shin i sur., 2011), usamljenost (Ozben, 2013) i dr. Zadovoljstvo životom može se promatrati kao važan doprinos postizanju adaptivnog razvoja adolescenata (Diener, 2012).

Učenici najveće zadovoljstvo pokazuju brigom za svoje zdravlje, informiranošću i svojim životnim uvjetima. Zdravlje smatraju jednim od najvažnijih faktora kvalitete života te $u$ intrevjuu ističu da bi briga za njihovo zdravlje mogla biti bolja i sustavnija što je u koliziji s kvantitativnim podatcima istraživanja.

Iako se radi o vrlo malom odstupanju, vidimo da učenici uočavaju problem $\mathrm{s}$ koncentracijom i nedostaje im sna. To je u skladu je s njihovom dobi. Adolescenti progresivno kasnije odlaze na spavanje te zbog škole i drugih obaveza nemaju dovoljno sna, a optimalna alertnost $\mathrm{u}$ adolescenciji zahtjeva u prosjeku devet sati sna svake noći (Carskadon i Acebo, 2002, prema Escribano, Diaz-Morales, Delgado i Collado, 2012). Posljedica nedovoljnog sna 
je umor koji može biti povezan s uočavanjem nedovoljne koncentracije, a jedan od problema u adolescenciji je depresija koja se manifestira na različite načine, jedan od pokazatelja je i gubitak koncentracije (Žitnik i Maglica, 2002) što, kako vidimo, adolescenti i sami uviđaju. Problem koncentracije, a i depresija povezuje se i s uporabom novih tehnologija, prvenstveno interneta čije korištenje direktno utječe na promjene u ljudskom mozgu. Ove generacije rastu uz internet te je neminovno da se na njima primjećuje utjecaj sveprisutne globalne mreže. Promjene koje se događaju u velikoj mjeri utječu na sposobnost održavanja pažnje i udubljivanja u pojedine sadržaje (Carr, 2011). I sami učenici kažu da su do kasnih noćnih sati na društvenim mrežama.

Osim dimenzija kvalitete života ispitanih anketnim upitnikom, učenici su u intervjuu istaknuli da na kvalitetu njihovog života utječe škola, roditelji, mjesto stanovanja i druženje s prijateljima. Smatraju da je utjecaj škole jako velik, posebno način rada na nastavi. Prema njihovom mišljenju škola uzrokuje stres, preopterećeni su te im je potrebno slobodno vrijeme da se opuste i odmore. Ta iskustva potvrđuju teze znanstvenih radova gdje se nalazi da učenici u školi mogu osjećati tjeskobu, biti frustrirani, depresivni, nositi se sa psihosomatskim tegobama. Pri tome često izostane razumijevanje i podrška okoline i mogućnost usvajanja znanja i vještina za uspješnije nošenje s izazovima i zahtjevima odrastanja. Iskustva koja učenici stječu u školi i način na koji doživljavaju školu u značajnoj mjeri određuju njihovu kvalitetu života (Dautbegović, Zvizdić i Marković Pavlović, 2015).

Emocionalno odvajanje od roditelja jedan je od najvažnijih zadataka adolescencije. Adolescenti se moraju odvojiti od roditelja da bi izgradili skladne i zrele odnose s njima. Taj proces odvajanja složen je i bolan za obje strane i često je praćen sukobima jer ga roditelji mogu poticati ili otežavati. Što ih roditelji više žele kontrolirati i provjeravati, to se javlja veći otpor kod adolescenata. U ovom razdoblju najizraženija je potreba za slobodom, neovisnošću, dokazivanjem i potvrđivanjem (Buljan Flander, 2010).

Učenici iz manjih sredina smatraju da je mjesto stanovanja važno za kvalitetu života jer, kao što su istakli, veća mjesta pružaju veće mogućnosti za razne aktivnosti. Nalaz potvrđuje istraživanje (Bouillet, 2006) u kojem se navodi da su mjestom življenja osobito nezadovoljni mladi iz sjedišta općina i sela. Njih u ovoj dobi zanimaju prvenstveno aktivnosti u kojima će provoditi vrijeme s vršnjacima, u druženju, a u manjima sredinama, prema iskazu sudionika istraživanja, manjka klubova za mlade i sličnih aktivnosti. Ipak, nema razlike u samoprocjeni kvalitete života učenika s prebivalištem u selu u odnosu na one s prebivalištem u gradu pa 
možemo pretpostaviti da ipak nalaze način da zadovolje svoje životne potrebe i uviđaju i neke prednosti života u selu.

Medije također smatraju važnima i potrebnima za kvalitetu života. Društvene mreže imaju jako veliku ulogu u njihovom životu. Ne razmišljaju puno o njihovom dobrom ili lošem utjecaju na život, jednostavno ih koriste. Mišljenja ispitanika o utjecaju društvenih mreža na kvalitetu njihovog života možemo podijeliti u tri smjera:

a) društvene mreže ne utječu na kvalitetu života

b) društvene mreže pozitivno utječu na kvalitetu života - pomažu u razmjeni informacija, u organizaciji druženja, omogućuju druženje s prijateljima

c) društvene mreže negativno utječu na kvalitetu života - oduzimaju slobodno vrijeme, smanjuju vrijeme provedeno u drugim aktivnostima i druženje s prijateljima vani, izvan škole

Provođenje vremena s prijateljima u aktivnostima izvan škole i doma, u direktnom kontaktu, učenici smatraju izuzetno važnim za kvalitetu života.

No, sumirajući sve navedene dimenzije, zadovoljni su kvalitetom svog života i vrlo je visoko ocjenjuju. To je u skladu s nalazom istraživanja zadovoljstva životom u funkciji dobi (Martinis, 2005) gdje srednjoškolci pokazuju najveće zadovoljstvo od svih dobnih skupina.

Prethodno postavljena hipoteza glasi:

Demografska obilježja, aktivnosti u slobodnom vremenu i stavovi o društvenim mrežama su statistički značajni prediktori kvalitete života učenika višeg sekundarnog obrazovanja.

Demografska obilježja u ovoj analizi su dob i spol.

Statistički je utvrđena povezanost zadanih varijabli i kvalitete života učenika, posebno se može istaknuti utjecaj aktivnosti u slobodnom vremenu.

Dob nije statistički značajan prediktor kvalitete života $(p=.49)$, kao ni stavovi o društvenim mrežama ( $\mathrm{p}=.82)$. U istraživanju koje su proveli stručnjaci sa Sveučilišta Oxford u Ujedinjenom Kraljevstvu u razdoblju od 2009. do 2017. godine također se pokazalo je da je povezanost između korištenja društvenih mreža i životnog zadovoljstva adolescenata neznatna, manja od 1\% (Domitrović, 2019).

Spol i aktivnosti u slobodnom vremenu pokazali statistički značajnim prediktorom kvalitete života $(\mathrm{p}<.001)$.

Pokazalo se da relativno veći utjecaj na kvalitetu života imaju aktivnosti u slobodnom vremenu dok manji utjecaj ima spol ispitanika. Prema ukupnom koeficijentu značajnosti regresijske analize, hipoteza se može prihvatiti. 
Kvaliteta života učenika višeg sekundarnog obrazovanja uvelike je određena aktivnostima u slobodnom vremenu. Kvalitativno istraživanje, također potvrđuje ovu hipotezu. Ispitanici ističu da je slobodno vrijeme jako važno za kvalitetu života, za uspostavljanje već spomenute, ravnoteže u životu. Nedostatak slobodnog vremena dovodi do stresa što utječe na kvalitetu života.

Dobiveni rezultati potvrđuju dosadašnje rezultate istraživanja (Larsen, McGraw i Cacioppo, 2001) koji navode da aktivnosti u slobodno vrijeme poboljšavaju individualnost rast i razvoj i predstavljaju važan dio života, posebno mladih. Prema Palen i sur. (2011), aktivnosti u kojima pojedinci sudjeluju tijekom svog slobodnog vremena mogu potencijalno pozitivno utjecati na njihov razvoj i zdravlje. Caldwell i sur. (2004) smatraju da angažiranje u slobodnim aktivnostima olakšava razvoj samopouzdanja među mladima, jer osigurava sigurno i opušteno okruženje za vrstu učenja koje utječe na životne odluke, čime pridonosi uspješnom odrastanju i odabirima koji uvjetuju kvalitetu života. 


\section{1. Ograničenja istraživanja}

Ovo se istraživanje temelji na podatcima dobivenim u presjeku, provedeno je u jednom trenutku i zanemareni su podatci o uzročnosti. Na osnovu istraživačkog modela korištenog u ovom radu, utvrđeno je da sudjelovanje u aktivnostima u slobodnom vremenu utječe na njihovo zadovoljstvo kvalitetom života, ali nije ispitano vrijedi li i obrnuta povezanost. Longitudinalno istraživanje bi omogućilo uvid u uzroke i posljedice istraživačkog problema.

Dosadašnja su istraživanja pokazala su da se iskustva sudjelovanja u aktivnostima mogu razlikovati s obzirom na vrstu aktivnosti (Hansen, Skorupski i Arrington, 2010; Larson, Hansen i Moneta, 2006; Tinsley i Eldredge, 1995), a neke aktivnosti čak mogu i onemogućiti zadovoljavanje potreba umjesto da ih zadovolje (Vallerand i Ratelle, 2002). Stoga je vjerojatno da ovo istraživanje nije potpuno relevantno za sve ispitanike jer se oni bave različitim aktivnostima. Međutim, demonstracija značajnih odnosa između demografskih osobina ispitanika, zadovoljavanja psiholoških potreba u slobodnom vremenu, stavova o društvenim mrežama i samoprocjene kvalitete života može doprinijeti jačanju pretpostavke da postoje elementi koji mogu povećati zadovoljstvo životom adolescenata.

Prilikom provođenja istraživanja došlo je do nekih organizacijskih ograničenja. Školski rasporedi su preopterećeni te je teško pronaći termine za provođenje istraživanja, stoga su se birali razredi ispitanika prema mogućnosti odabira termina i prostora te nije bilo moguće udovoljiti potpunom usklađivanju uzorka prema dobi i spolu. S obzirom na to da se istraživanje provodilo u travnju i svibnju, nastojalo se ne opterećivati učenike završnih razreda jer su u to vrijeme zauzeti pripremama za državnu maturu.

Primijećeno je da pojedini učenici anketni upitnik rješavanju bez udubljivanja, često nasumično zaokružujući odgovore, zato se vrlo korisnom pokazao odabir mješovitog istraživačkog pristupa. Provođenjem grupnog intervjua mogli su se preispitati stavovi i razmišljanja sudionika te se s većom sigurnošću može gledati na relevantnost ukupnih rezultata istraživanja. Intervju sudionicima omogućuje slobodno izražavanje mišljenja, bez ograničavanja unaprijed postavljenim kategorijama. To istraživačima omogućuje ne samo saznavanje činjenica, nego i značenja tih činjenica. Na uskraćivanje informacija i cenzuriranje odgovora ispitanika može utjecati sastav grupe. Grupe koje su intervjuirane ovim istraživanjem karakterizirala je dobra grupna dinamika te su vrlo otvoreno odgovarali na pitanja i sudjelovali u međusobnom razgovoru.

Rezultati istraživanja daju široku sliku o tome kako su zadovoljstvo aktivnostima u 
slobodnom vremenu, stavovima o društvenim mrežama i zadovoljstvo kvalitetom života učenika povezani što je bio i glavni cilj istraživanja. Istovremeno se otvaraju nova pitanja za buduća istraživanja ovoga područja. Na primer, bilo bi korisno istražiti koje konkretne aktivnosti pružaju okruženje u kojem učenici mogu zadovoljiti svoje potrebe za kompetencijom, povezanošću i autonomijom. Praktičarima bi to dalo važne informacije za planiranje i organizaciju aktivnosti za učenike koje bi ih poticale na sudjelovanje i smanjile broj odustajanja od bavljenja njima. 


\section{ZAKLJUČAK}

Ovim se radom željelo ispitati i objasniti obilježja i prediktorsku ulogu korištenja društvenih mreža i načina provođenja slobodnog vremena u kvaliteti života učenika višeg sekundarnog obrazovanja. Također se željelo razumjeti učenička iskustva i percepciju značaja upotrebe društvenih mreža u slobodnom vremenu kao jednog od pokazatelja kvalitete njihova života.

Pokazalo se da su demografska obilježja, aktivnosti u slobodnom vremenu i stavovi o društvenim mrežama statistički značajni prediktori kvalitete života učenika višeg sekundarnog obrazovanja. Drugim riječima, kvaliteta života učenika višeg sekundarnog obrazovanja uvelike je određena aktivnostima njihova slobodnog vremena.

Najveći utjecaj na kvalitetu života imaju aktivnosti u slobodnom vremenu, odnosno zadovoljavanje psiholoških potreba ispitanika pri sudjelovanju u tim aktivnostima. Iako kvantitativni dio istraživanja nije pokazao statistički značajnu povezanost između društvenih mreža i kvalitete života, kvalitativni dio pokazuje da učenici vrlo jasno povezuju društvene mreže s kvalitetom svog života. Oni društvene mreže koriste neprestano, u svim situacijama, najčešće u mjeri koja im svakodnevni život čini lakšim, vremenski i financijski ekonomičnijim i koja im omogućuje druženje s vršnjacima. Unatoč činjenici da su oni i njihovi mobilni telefoni nerazdvojni i da njihova komunikacija putem društvenih mreža, u virtualnom svijetu nikada ne prestaje, izražavaju žaljenje što se ne druže više s prijateljima u stvarnom okruženju. Uviđaju da im društvene mreže oduzimaju slobodno vrijeme koje im je vrlo važno pri samoprocjeni kvalitete života. Učenici u velikoj mjeri posjeduju profile na društvenim mrežama, na po nekoliko društvenih mreža. Oni rastu okruženi digitalnom tehnologijom i takav oblik komunikacije im je potpuno prirodan, smatraju se vrlo kompetentnima za njihovo korištenje. Puno ih koriste i uočavaju i njihove prednosti i nedostatke. Bilo je pretpostavljeno da ne postoji statistički značajna razlika u učestalosti korištenja društvenih mreža s obzirom na spol učenika, no rezultati istraživanja potvrđuju postojanje statistički značajne povezanosti između spola i vremena dnevnog korištenja društvenih mreža. Ispitanici ženskog spola značajno više vremena provode koristeći društvene mreže nego ispitanici muškog spola.

Usporedbom stavova o društvenim mrežama i demografskih karakteristika učenika možemo zaključiti da se stavovi ne razlikuju s obzirom na spol, dob, mjesto življenja i vrstu škole koju pohađaju, ali se razlikuju s obzirom na školski uspjeh učenika. Učenici nižeg uspjeha ne uviđaju veliku korist društvenih mreža, ne smatraju da one čine život boljim i društvo 
naprednijim, no istovremeno su njihovi vjerni korisnici i smatraju se vrlo kompetentnima za njihovo korištenje.

Općenito, učenici svoju kvalitetu života procjenjuju vrlo visokom u svakom aspektu. Visoko procjenjuju zadovoljavanje svojih psiholoških, društvenih i fizičkih potreba. U okolini u kojoj žive osjećaju se ugodno, sigurno, prihvaćeno i zaštićeno.

Demografske karakteristike ispitanika (spol, dob i vrsta škole koju pohađaju) značajno utječu na samoprocjenu kvalitete života. Ispitanici muškog spola svih ispitanih dobnih skupina svoju kvalitetu života procjenjuju značajno višom od ispitanika ženskog spola.

Istraživanje je obuhvatilo učenike od 14 do 19 godina starosti. Iako je raspon godina mali, pokazalo se da postoji statistički značajna razlika u samoprocjeni kvalitete života. Mlađi ispitanici svoju kvalitetu života procjenjuju boljom od starijih. Učenici koji pohađaju gimnazije kvalitetu svog života procjenjuju manjom u odnosu na učenike strukovnih škola što objašnjavaju opterećenošću obimom gradiva u gimnazijama i potrebom za dugotrajnim učenjem čime se smanjuje slobodno vrijeme učenika za koje je utvrđeno da ima značajnu ulogu u kvaliteti njihovog života. Mjesto življenja učenika i školski uspjeh nisu se pokazali značajnim varijablama u samoprocjeni kvalitete života učenika.

Pokazalo se da ne postoji razlika u zadovoljavanju psiholoških potreba učenika kroz aktivnosti u slobodnom vremenu s obzirom na njihove demografske karakteristike. Također, možemo zaključiti da je zadovoljstvo psihološkim potrebama u domeni slobodnih aktivnosti pozitivno povezano s povećanim zadovoljstvom životom adolescenata. Pozitivni procesi zadovoljavanja potreba utječu na opće zadovoljstvo životom učenika višeg sekundarnog obrazovanja.

Nalazi do kojih se došlo ovim istraživanjem daju nova i važna saznanja koja mogu biti smjernica za planiranje i organizaciju aktivnosti kojima će se promicati pozitivna klima i koje su u funkciji zadovoljavanja psiholoških potreba adolescenata. To su aktivnosti koje učenicima pružaju mogućnost za razvoj vještina, omogućuju im da se osjećaju dobro baveći se njima i pružaju im priliku za aktivno sudjelovanje. Istovremeno bi im trebale pružati priliku za razvoj društvenih odnosa i pozitivne interakcije među sudionicima, poticati njihov rast, razvoj i povećanu ulogu subjektivne dobrobiti (Leversen i sur., 2012).

Zadovoljavanje potreba u slobodnom vremenu važno je za nastavak bavljenja pojedinom aktivnošću. Ako se učenici bave aktivnostima u kojima ne zadovoljavaju svoje osnovne potrebe 
odustat će od bavljenja njima (Eccles, 2005). Budući da bavljenje aktivnostima u kojima se učenici osjećaju dobro ima pozitivne učinke na njihovu opću dobrobit, važno je promicati kontinuirano sudjelovanje u njima. S druge strane, prekomjerna kontrola, neoptimalni izazovi i nedostatak povezanosti, remete prirodne inherentne aktualizacijske i organizacijske tendencije pa takvi čimbenici rezultiraju, ne samo nedostatkom inicijative i odgovornosti, već psihopatologijama. Saznanja o tome što je učenicima potrebno za kvalitetu života, rezultira boljim i učinkovitijim djelovanjem roditelja i odgajatelja, a u konačnici ima vrlo širok značaj za čitavo društvo.

Uočena je povezanost između pozitivnih ishoda sudjelovanja adolescenata u slobodnim aktivnostima, percepcije uloge društvenih mreža i kvalitete života te je opravdano tvrditi da je samoprocjena kvalitete života učenika višeg sekundarnog obrazovanja određena zadovoljstvom u provođenju aktivnosti u slobodnom vremenu i uporabom društvenih mreža kao jednog od elemenata slobodnog vremena.

Dobivena su deskriptivna obilježja određenja kvalitete života i slobodnog vremena učenika višeg sekundarnog obrazovanja te objašnjeni prediktorski odnosi slobodnog vremena, društvenih mreža i individualnih obilježja učenika u kvaliteti njihovog života.

Rezultati pomažu u teorijskom (re)definiranje pojmova, definicija i klasifikacija u određenju kvalitete života, slobodnog vremena, uloge društvenih medija i individualnih obilježja učenika te predviđanju i kontroli svih istraživanih čimbenika.

Ovaj je rad važan doprinos potvrdi, produbljivanju i proširivanju dosadašnjih rezultata istraživanja $u$ ovom području, ali i otvara nove smjernice za daljnja istraživanja. Bolje razumijevanje istraživanih odnosa može može se koristiti kao osnova za razvoj pristupa u organiziranju aktivnosti za mlade u slobodnom vremenu i razvoju medijskih kompetencija kako bi se osiguralo da one doprinose razvoju i kvaliteti života mladih na najbolji mogući način. 


\section{POPIS LITERATURE}

Aaronson, N.K., Ahmendzai, S., Bergman, B., Bullinger, M., Cull, A., Duez, N.J., Filiberti, A., Fletchtner, H, Fleishman, S.B., De Haes, J.C.J.M., Kaasa, S., Klee, M., Osoba, D., Razavi, D., Rofe, P.B., Schraub, S., Sneeuw, K., Sullivan, M. i Takeda, F. (1993). The European Organization for Research and Treatment of Cancer QLQ-C30: A quality of life instrument for use in international clinical trials in oncology. Journal of the National Cancer Institute, 85, 365-376.

Acar, A. (2008). Antecedents and consequences of on line social networking behavior: The case of Facebook. Journal of Website Promotion, 3, 62 - 83.

Acquisti, A., \& Gross, R. (2006). Imagined communities: Awareness, information sharing, and privacy on the Facebook. In P. Golle \& G. Danezis (Eds.), Proceedings of 6th Workshop on Privacy Enhancing Technologies (pp. 36-58). Cambridge, UK: Robinson College.

Aitchison, C. C. (1995). Gender and Leisure: Social and cultural perspectives. London and New York: Routledge.

Ajduković, M. i Hudina, B. (1996). Značaj učinkovite komunikacije u radu pomagača. U Pregrad, J. (ur): Stres, trauma, oporavak. Društvo za psihološku pomoć, Zagreb, 7- 27.

Allan, G. (2003). "A critique of using grounded theory as a research method". Electronic Journal of Business Research Methods, vol. 2, no. 1, 1-10.

Allardt, E. (1976). Dimension of Welfareina Comparative Scandinavian Study. Acta Sociologica, Copenhagen, 19 (3), 227-239.

Amato P. (1989). Family processes and the competence of adolescents and primary school children. Journal of Youth \& Adolescence, 18, 39-53.

Andorka R. (1987). Gyermekszám a fejlett országokban. Gondolat, Budapest.

Anić, V. (2003). Veliki rječnik hrvatskoga jezika. Zagreb: Novi liber.

Arai, S. \& Pedlar, A. (2003). Moving beyond individualism in leisure theory: a critical analysis of concepts of community and social engagement. Leisure Studies 22, 185-202.

Aranđelović, M., Ilić, I. i Milić, I. (2010). Procena kvaliteta života -sadašnji pristupi. Acta Medica Medianae,4(49), 52 - 60.

Arbunić, A. (2002). Atruktura slobodnog vremena djece (učenika) osnovnoškolske dobi. (Neobjavljena doktorska disertacija). Filozofski fakultet, Zagreb.

Argyle, M. (1996). The Social Psychology of Leisure. Penguin Books, New York. 
Argyle, K. and Shields, R. (1996). Is there a Body on the Net? In Cultures of Internet: Virtual Spaces, Real Histories, Living Bodies. Rob Shields, ed. pp. 58-69. London: Sage.

Aristotel (1988). Politika. Zagreb: Liber.

Arnett, J.J. (1999). Adolescent storm and stress, reconsidered. Am Psychol, 54(5), 317-326.

Arnett, J. J. (2006). G. Stanley Hall's adolescence: brilliance and nonsense. American psychological association 9 (3), 186-197.

Artić, M. (2009). Prema novim iskustvima slobodnog vremena: slobodno vrijeme kao izvorište kritičke svijesti. Filozofska istraživanja, 114, god. 29, (281 - 295).

Assis A. D., Oliveira A. G. B. (2010). Vida Universitária e saúde mental: Atendimento às demências de saúde e saúde mental de estudantes de uma Universidade brasileira. Cadernos Brasileiros de Saúde Mental, 2 (4-5), 159-77.

Athenstaedt, U. \& Mikula, G. \& Bredt, C. (2009). Gender Role Self-Concept and Leisure Activities of Adolescents. Sex Roles, 60(5),399-409.

Auerbach, C.F. and Silverstein, L.B. (2003). Qualitative Data: An Introduction to Coding and Analysis. New York University, New York.

Aufenanger, S. (1999). Lernen mit den neuen Medien - Perspektiven für Erziehung und Unterricht. U Gogolin, Ingrid/Lenzen, Dieter(Ur.), Medien-Generation. Beiträge zum 16. Kongress der Deutschen Gesellschaft für Erziehungswissenschaft. (str. 61-75). Opladen. Auguštanec, V. (2008). Uloga sportskog marketinga u unapređenju kvalitete života. U M. Andrijaševiæ (Ur.), Zbornik radova međunarodne konferencije Kineziološka rekreacija $i$ kvaliteta života (str. 463-471). Zagreb, Kineziološki fakultet.

Baacke, D. (1997). Medienpädagogik. Tübingen: Max Niemeyer Verlag.

Baacke, D. (2007). Medienpädagogik. Tübingen, Max Niemeyer.

Bačkonja, K. (2014). Ulaze li danas djeca sve ranije u pubertet $i$ razdoblje adolescencije. [online] http://ordinacija.vecernji.hr/pretrazivanje/?query=. Pristupljeno 12. srpnja 2018. Bahney, A. (2006). High tech, under the skin. The New York Times, 2 February, p. 1, available at: http://nytimes.com/2006/02/02/fashion/thursdaystyles/02tags.html. Pristupljeno 30 . ožujka 2015.

Bakardijeva, M. (2005). Internet Society: The Internet in Everyday Life. London: Thousand Oaks.

Baldwin, C. K. \& Caldwell, L. L. (2003). Development of the free time motivation scale for adolescents. Journal of Leisure Research,35(2), 129-151. 
Barnes, G. M., Reifman, A. S., Farrell, M. P. \& Dintcheff, B. (2000). The effects of parenting on the development of adolescent alcohol misuse: A six-wave latent growth model. Journal of Marriage and the Family, 62, 175-186.

Bastašić, Z. (1995). Pubertet i adolescencija. Zagreb: Školska knjiga.

Baumeister, R. F, Leary, M. R. (1995). The need to belong: Desire for interpersonal attachments as a fundamental human motivation. Psychological Bulletin, 117(3), 497-529. doi: 10.1037/0033-2909.117.3.497.

Baym, N. K., Zhang, Y. B., Lin, M. C. (2004). Social interactions across media: Intrepersonal comunication on the Internet, telephone and face-to-face. New Media and Society 6(3), $299-318$.

Bean, R. A., Bush, K. R., McKenry, P. C. \&Wilson, S. M. (2003). The impact of parental support, behavioral control, and psychological control on the academic achievment and self-esteem of African American and European American adolescents. Journal of Adolescent Research, 18, 523-541.

Beck, A. T., Ward, C. H., Mendelson, M., Mock, J. i Erbaugh, J. (1961). An inventory for measuring depression. Archives of General Psychiatry, 4, 561-571.

Berk R. A. (2009). Teaching Strategies for Net Generation. Transformative Dialogues: Teaching \&Learning Journal, 3(2), 8-13.

Berk, L. E. (2015). Dječja razvojna psihologija. Jastrebarsko: Naklada Slap.

Berger, B., Motl, R. (2001). Physical activity and quality of life. Life Spain Development. U R. Singer, H., A., Hausenblas, C., M., Janelle (Eds.), Handbook of Sport Psychology (str. 636 - 671) Canada: J. Wiley \& Sons, Inc.

Bergner, M., Bobbitt, R., Carter, W. \& Gilson, B. (1981). The Sickness Impact Profile: Development and final revision of a health status measure. Med Care 19, 787-805.

Bernard, H. R., \& Ryan, G. W. (2010). Analyzing Qualitative Data: Systematic Approaches. California, CA: Sage Publication.

Best, C. J. i Cummins, R. A. (2000). The Quality of Rural and Metropolitan Life. Australian Journal of Psychology, 52(2), 69-74.

Bezinović, P., Manestar, K. i Ristić Dedić, Z. (2004). Obiteljska kohezivnost i zadovoljstvo životom djevojaka i mladića iz sela i grada. Sociologija sela, 42 (1/2), 157 - 172.

Biddle, S.J.H., Wang, C.K.J., Kavussanu, M., \& Spray, C.M. (2003). Correlates of achievement goal orientations in physical activity: A systematic review of research. European Journal of Sport Science, 3(5), 1-20. 
Bisegger, C., Cloetta, B., Rueden, U., Abel, T. (2005). Ravens-Sieberer, Europian kidscreen group Health-related quality of life: gender differences in childhood and adolescence. Soz.-Präventivmed, 50, 281-291. Basel: Birkhäuser Verlag.

Biškup, J. (1981). Osnove javnog komuniciranja. Zagreb : Školska knjiga.

Blane, D., Netuveli, G. (2008). Quality of life in older ages. British Medical Bulletin, 1 (85), $113-126$.

Bloom, B. (1956). Taxonomy of Educational Objectives: Handbook 1: Cognitive Domain. New York: Logmans, Green.

Bloom, B., Hastings, J., Madaus, G. (1971). Handbook on Formative and Summative Evaluation of Student Learning. New York: McGraw-Hill Book Company.

Blumer, H. (1937). Social Psychology. In Schmidt, E. P. (Ur.) Man and Society: A Substantive Introduction to the Social Sciences (str. 144-98). New York: Prentice-Hall.

Blumer, H. (1978). Society as symbolic interaction, in Manis, J.G. \& Meltzer, B.N. (Eds.), Symbolic interaction: A reader in social psychology. Boston: Allyn and Bacon, Inc.

Boneva, B. S., Quinn, A., Kraut, R. E., Kiesler, S., Shklovski, I. (2006). Teenage comunication in instant messaging era. U: Kraut, R. E., Brynin, N., Kiesler, S. (Ur.), Computer, Phones and the Internet: Domesticating Information Tehnology. Oxford: Oxford University Press, 201-218.

Borić, I., Ivelj, R., Leko, M., Bojanić, I., Roić, G. (2007). Radiološka dijagnostika prenaprezanja u djece i adolescenata. Paediatr. Croat, 51-55.

Bouillet, D. (2006). Kvaliteta života mladih: odgovornost zajednice i/ili obitelji. U V. Ilišin (Ur.) Mladi između želja i mogućnosti: Položaj, problemi i potrebe mladih Zagrebačke županije. (str. 27-92). Zagreb: Institut za društvena istraživanja.

Bowling, A. (1995). What things are important in people's lives? A survey of the public's Judgements to inform scales of health related quality of life. Social Science and Medicine, 41(10), 1447-1462.

Boyd, D. (2004). Friendster and publicly articulated social networks. Proceedings of ACM Conference on Human Factors in Computing Systems (pp. 1279-1282). New York: ACM Press.

Boyd, D. (2006a). Friends, Friendsters and MySpace Top 8: Writing community into being on social network sites. First Monday, 11(12). http://www.firstmonday.org/issues/issue11_12/boyd/. Pristupljeno 23. kolovoza 2016. 
Boyd, D. (2006b). Friendster lost steam. Is MySpace just a fad? Apophenia Blog. http://www.danah.org/papers/FriendsterMySpaceEssay.html. Pristupljeno 12.travnja 2015.

Boyd, D. (2007). "Why Youth (Heart) Social Network Sites: The Role of Networked Publics in Teenage Social Life." MacArthur Foundation Series on Digital Learning - Youth, Identity, and Digital Media (ed. David Buckingham). Cambridge, MA: MIT Press.

Boyd, D. (2008). Taken Out of Context: American Teen Sociality in Networked Publics. (PhD Dissertation). University of California-Berkeley.

Boyd, D. (2014). It's Complicated: The Social Lives of Networked Teens. New Haven: Yale University.

Boyd, D. i Ellison, N. B., (2007). Social network sites: definition, history and scholarship. Journal of Computer - mediacted, 13(1), 210 - 230.

Boyd, D.M. \& Ellison, N.B. (2008). Social network sites: Definition, history, and scholarship. Journal of Computer-Mediated Communication, 13, 210-230.

Božović, R. (1979). Iskušenja slobodnog vremena. Mladost, Beograd.

Bradburn, N. M.(1969). The structure of psychological well-being. Chicago: Aldine.

Brajković, L., Godan, A. i Godan, Lj. (2008). Quality of Life After Stroke in Old Age: Comparison of Persons Living in Nursing Home And Those Living in Their Own Home. Croatian Medical Journal, 50 (2), 182 - 188.

Brajković, L. i Vuletić, G. (2011). Teorije subjektivne kvalitete života. Osijek: Filozofski fakultet sveučilišta u Osijeku.

Brajša, P. (1994). Pedagoška komunikologija. Razgovor, problemi i konflikti u školi. Zagreb: Školske novine.

Brajša-Žganec, A., Kaliterna Lipovčan, Lj. (2006). Kvaliteta življenja, životno zadovoljstvo i sreća osoba koje profesionalno pomažu drugima. Društvena istraživanja, 4-5 (84 - 85), $713-728$.

Bramm, K.I., Dijk, E. M., Veening, M. A., Bierings, M. C., Merks, J. HM., Grootenhuis, M. A., Chinapaw, M. J. M., Sinnema, G., Takken, T., Huisman, J., Kaspera, G. J. L., Dulmenden Broeder, E. (2010). Design of the quality of Life in Motion (QLIM) study: a randomized controlled trial to evaluate the effectiveness and cost-effectiveness of a combined physical exercise and psychosocial training program to improve physical fi tness in children with cancer. BMC Cancer, 10, 624.

Brass, D. J., Butterfield, K. D., \& Skaggs, B. C. (1998). Relationships and unethical behavior: A social network perspective. The Academy of Management Review, 23(1), 14-31. 
Bratko, D., Sabol, J. (2006). Osobine liènosti i osnovne psihološke potrebe kao prediktori zadovoljstva životom: Rezultati on-line istraživanja. Društvena istraživanja, 15, 84- 85 (4-5), $693-711$.

Bratković, D. i Rozman, B. (2006). Čimbenici kvalitete življenja osoba s intelektualnim teškoćama. Hrvatska revija za rehabilitacijska istraživanja, 42(2), 101 - 112.

Brdar, I. \& Lončarić, D. (2004). Suočavanje s akademskim stresom i aktivnosti u slobodnom vremenu učenika. Društvena Istraživanja / Journal for General Social Issues (13), 967988.

Britton, B.K. \& Tesser, A. (1991). Effects of time management practices on college grades. Journal of Educational Psychology, 83(3), 405-410.

Brodie-Hall, G. (2018). The Sampo Generation: Why We Are Seeing the Lowest Fertility Rate of All Time? [online] https://www.theobserver-qiaa.org/the-sampo-generation-why-weare-seeing-the-lowest-fertility-rate-of-all-time. Pristupljeno_12. listopada 2019.]

Bromberg, H. (2001). Kulture interneta, identitet, pripadnost $i$ svijest u virtualnim svjetovima. Zagreb: Naklada Jesenski i Turk.

Brommick, R., Swallow, B. L., 2001: Parties, Lads, Friends, Love and Newcastle United: a study of young people values. Educational Studies 2 (27), 143-158.

Brown, B. B., Eicher, S. A., \& Petrie, S. (1986). The importance of peer group ("crowd") affiliation in adolescence. Journal of Adolescence, 9(1), 73-96.

http://dx.doi.org/10.1016/S0140-1971(86)80029-X. Pristupljeno 23. travnja 2017.

Browne, J. P., O’Boyle, C. A., McGee, H. M., Joyce, C. R. B., McDonald, N. J., O’Malley, K., Hiltbrunner, B. (1994). Individual quality of life in the healthy elderly. Quality of Life Research.2, 235-44.

Bubaš, G. i Kermek, D. (2000). Komparativna procjena Interneta u odnosu na tisak i televiziju, Medijska istraživanja, god. 6 (1), str. 109-123.

Bublitz, S., de Azevedo Guido, L., E de Oliveira Freitas, E. , Dias Lopes, L. F. (2012). Estresse em estudantes de enfermagem: uma revisão integrativa. Reufsm revista de enfermagem da ufsm, 2 (3). http://dx.doi.org/10.5902/217976923485

Buckingham, D. (2000a). After the Death of Childhood: Growing Up in the Age of Electronic. Media Cambridge, Polity.

Buljan Flander, G. (2010). Trebamo li brinuti?

https://www.poliklinika-djeca.hr/publikacije/trebamo-li-brinuti/. Pristupljeno 4.travnja 2019.

Buljan Flander, G. (2013). Adolescencija - izazovi odrastanja. 
http://www.poliklinika-djeca.hr/aktualno/teme/adolescencija-\%e2\%80\%93-izazovi-

odrastanjal. Pristupljeno 5. ožujka 2018.

Byrne, T., Nixon, E. Mayock, P. Whyte, J. (2006). Free-time and Leisure Needs of Young People Living in Disadvantaged Communities. Dublin. Combat Poverty Agency Working Paper Series 06/02.

Caldwell, L.L., \& Darling, N. (1999). Leisure context, parental control, and resistance to peer pressure as predictors of adolescent partying and substance use: An ecological perspective. Journal of Leisure Research, 31, 57-77.

Caldwell, L.L., Baldwin, C.K., Walls, T. \& Smith, E. (2004). Preliminary effects of a leisure education program to promote healthy use of free time among middle school adolescents. Journal of Leisure Research, 36(3), 310-335.

Canquilhem, G. (1987). Normalno in patološko. Ljubljana: Škuc.

Car, S. (2010). Online komunikacija i socijalni odnosi učenika. Pedagogijska istraživanja, 7(2), 281-290.

Car, S. (2013). Adolescencija 21. stoljeća: društvena uvjetovanost, temeljne karakteristike i pedagoški izazovi. Pedagogijska istraživanja, 10(2), 285-294.

Carr, N. (2010). The Web Shatters Focus, Rewires Brains.

http://aplangandcomp.blogs.rsu1.org/files/2010/06/the-shallows.pdf. Pristupljeno 24.lipnja 2016.]

Carr, N. (2011). Plitko - Što Internet čini našem mozgu. Zagreb: Jesenski i Turk.

Casas, F., Figuer, C., Gonzales, M., Malo, S. (2007). The Values Adolescents Aspire to, Their Well-being and the Values Parents Aspire to for Their Children. Social Indicators Research, 84, 271-290.

Casey, D. M., Ripke, M. N., Huston, A. C. (2005). Activity participation and the well-being of children and adolescents in the context of welfare reform. Mahwah, New Jersey: Lawrence Erlbaum Associates.

Castells, M. (2000). Uspon umreženog društva. Svezak 1. Informacijsko doba, Ekonomija, društvo i kultura. Zagreb: Golden marketing.

Castells, M. (2003). Internet galaksija. Zagreb: Naklada Jesenski i Turk

Cha, K.H. (2003). Subjective well-being among college students. Social Indicators Research 62(1), 455-477.

Chafkin, M. (2007). Hot to kill a great idea! Inc. Magazine. [online] http://www.inc.com/magazine/20070601/features-how-to-kill-a-great-idea.html. Pristupljeno 14. ožujka 2015. 
Charmaz, K. (2006). Constructing grounded theory: A practical guide through qualitative research. London: Sage.

Chatzitheochari, S. \& Arber, S. (2012). Class, gender and time poverty: A time-use analysis of British workers' free time resources. The British Journal of Sociology, 63(3), 451-471.

Cherquiari E. (2004). Saúde mental e qualidade de vida em estudantes universitários [tese]. Campinas (SP): Universidade Estadual de Campinas, Faculdade de Ciências Médicas.

Chicchi, F. (2000). Grounded Theory and Biographical Approach: an Attempt at an Integrated Heuristic Strategy, International Review of Sociology, 10 (1).

Chow, H. P. H. (2005). Life satisfaction among university students in a Canadian prairie city: Amultivariate analysis. Social Indicators Research 70(2), 139-150.

Christakis, N. A i Fowler, J. H. (2010). Povezani: iznenađujuća moć društvenih mreža i kako one utječu na naše živote. Zagreb: Algoritam.

Christofides, E. \& Muise, A. \& Desmarais, S. (2009). Information Disclosure and Control on Facebook: Are They Two Sides of the Same Coin or Two Different Processes?. Cyberpsychology \& behavior : the impact of the Internet, multimedia and virtual reality on behavior and society, 12, 341-5.

Claessens, B. J. C., Van Eerde, W., Rutte, C. G. \& Roe, R. A. (2005). A review of the time management literature. Personnel Review, 36(2), 255-276.

Colozzi, I. and Giovannini, G. (2003). Young People in Europe: Risk, Autonomy and Responsibilities. Italy: FrancoAngeli s.r.l.

Cogin, J. (2012). Are generational differences in work values fact or fiction? Multi-country evidence and implications. The International Journal of Human Resource Management, 23(11), 2268-2294.

Cohen, E., Clifton, R.A. \& Roberts, L.W. (2001). The cognitive domain of the quality of life of university students: A re-analysis of an instrument. Social Indicators Research 53(1), $63-$ 77.

Cohen, R. (2003). Livewire: Web sites try to make internet dating less creepy. Reuters. http://asia.reuters.com/newsArticle.jhtml?type=internetNews\&storyID=3041934.

Prisupljeno 17.prosinca 2014.

Conrad, C. \& Poole, M. S. (2005). Strategic Organizational Communication. Belmont, CA: Wadsworth.

Corbin, J. M, Strauss, A. (1988). Unending work and care: Managing chronic illness at home. San Francisco, CA. 
Crawford, D. W. i Godbey. G. (1987). Reconceptualizing barriers to family leisure. Leisure Sociences, 9, $119-127$.

Creswell, J. W. (2013). Research Design Qualitative, Quantitative, and Mixed Methods Approaches. SAGE Publications, Inc.

Creswell, J. W. \& Plano Clark, V. L. (2007). Designing and conducting mixed methods research. Thousand Oaks, CA: Sage Publication.

Crumlish, C. (2004). The power of many: How the living Web is transforming politics, business, and everyday life. San Francisco: Sybex.

Crumpacker, M. i Crumpacker, J. M. (2007). Succession Planning and Generational Stereotypes: Should HR Consider Age-Based Values and Attitudes a Relevant Factor or a Passing Fad?. Public Personnel Management, 36(4), 349 - 369.

Cufaude, J. B. (2000). Eager to attrack more young people into your association membership? Here's the rhetoric and the reality about generaional differences. Association Menagement, 52(1), 73-80.

Cummins, R. A. (1995). On the trail of the gold standard for subjective wellbeing. Social Indicators Research 35, 179-200.

Cummins, R. A. (1996). Bibliography on quality of life and cognate areas of study, 181. Secondedition. Melbourne: School of Psychology, Deakin University, (ISSN1326-2173).

Cummins, R. A. (1997). Assessing quality of life. In R. I. Brown (Ed.), Assessing Quality of life in people with disabilities: Models, research, and practices (str. 116-150). London: Stanley Thornes Publishers Ltd.

Cummins, R. A. (1998). The Second Approximation to an International Standard for Life Satisfaction. Social Indicators Research, 43 (1), 307-334.

Cummins, R. A.(2000). Personal income and subjective well -being: A review. Journal of Happiness Studies, 1, 133 - 158.

Cummins, R., Eckersley, R., Pallant, J., Vugt, J. \& Misajon, R. (2003). Developing a National Index of Subjective Wellbeing: The Australian Unity Wellbeing Index. Social Indicators Research. 64. 159-190. 10.1023/A:1024704320683.

Čudina-Obradović, M. i Obradović, J. (2006). Psihologija braka i obitelji. Zagreb: Golden marketing-Tehnička knjiga.

Čulig, B. Fanuko, N., Jerbić, V. (1982). Vrijednosti i vrijednosne orijentacijemladih. Zagreb, CDD SSOH. 
Daly, M. and Leonard, M. (2002). Against All Odds: Family Life on a Low Income in Ireland. Dublin: Combat Poverty Agency.

Darling, N., Steinberg, L. (1993). Parenting style as context: An integrative model. Psychological Bulletin, 113, 487-496.

Dautbegović, A., Zvizdić, S. i Marković Pavlović, M. (2015). Emocionalna prilagodba djece i adolescenata. U J. Zloković (Ur.) Unapređenje kvalitete života djece i mladih, Tematski zbornik I dio (str. 233-244). Edukacijsko-rehabilitacijski fakultet Univerziteta u Tuzli: udruženje za podršku i kreativni razvoj djece i mladih.

Deacon, D., Pickering, M., Golding, P., \& Murdock, G. (1999). Researching Communications: A Practical Guide to Methods in Media and Cultural Analysis. New York: Oxford University Press Inc.

Deci, E.L, Ryan, R.M. (1985). Intrinsic motivation and self-determination in human behavior. New York: Plenum Press.

Deci, E. L, Ryan, R. M (2000). Self-Determination Theory and the Facilitation of Intrinsic Motivation, Social Development, and Well-Being. University of Rochester.

De Grazia, S. (1962). Of Time, Work, and Leisure. New York: The Twentieth Century Fund.

De Haan, J. and Huysmans, F. (2004). IT/Media Use and Psychological development among Dutch Youth, IT and Society 2(1), 40 -53.

De Lisle, J, Smith, P. \& Jules, V. (2010). Evaluating the geography of gendered achievement using large-scale assessment data from the primary school system of the Republic of Trinidad and Tobago. International Journal of Educational Development. doi:10.1016/j.ijedudev

Delworth (2010). Dimensions of Leisure for Life: Individuals and Society Kinetics, Human Deportment of Statistics of Executive Yuan, Taiwan (2004). National Time Spending Survey. http://www.dabas.gov.tw/census-n/three/analysis89.htm. Pristupljeno 22. travnja 2015.

Despot, B. (1976). Plaidoyer za dokolicu. Beograd: Predsedništvo Konferencije Saveza socijalističke omladine Jugoslavije.

Dhamo, E., Kocollari, N. (2014). Older People Quality of Life Evaluation. Mediterranean Journal of Social Sciences, 5(13), 385-390.

Diener, E. (1984). Subjective well-being. Psychological Bulletin, 95 (3), 542-575.

Diener, E. (1996). Traits can be powerful, but are not enough: Lessons from subjective wellbeing. Journal of Research in Personality, 3, 389-399. 
Diener, E. (2006). Guidelines for national indicators of subjective well-being and ill-being. Applied Research in Quality of Life, 1(2), 151-157.

Diener, E. (2012). New findings and future directions for subjective well-being research. American Psychologist, 67, 590-597.

Diener, E. i Diener, C. (1996). Most people are happy. Psychological Science, 7(3), 181185.

Diener, E. \& Lucas, R. E. (2000). Explaining Differences in Societal Levels of Happiness: Relative Standards, Need Fulfilment, Culture, and Evaluation Theory. Journal of Happiness Studies, 1, 41-78. http://dx.doi.org/10.1023/A:1010076127199

Diener, E., Lucas, R. E., Oishi, S. (2002). Subjective well-being: The science of happiness and life satisfaction. In C.R. Snyder \& S.J. Lopez (eds), Handbook of positive psychology (str. 63-73). Oxford and New York: Oxford University Press.

Diener, E. i Ryan, K. (2009). Subjective well-being: A general overview. South African Journal of Psychology, 39(4), 391-406.

Dimanche, F. \& Samdahl, D. (1994). Leisure as symbolic consumption: A conceptualization and prospectus for future research. Leisure Sciences, 16, 119-129.

Dimbleby, R. i Burton, G. (1998). More than words an introduction to communication. Rouledge, London and New York.

Disch, W. B., Harlow, L. L., Campbell, J. F. and Dougan, T.R. (2000). Student functioning, concerns, and socio-personal well-being. Social Indicators Research 51(1), 41-74.

Doh, M. (2010). Leisure and Geography. Dimensions of Leisure for Life (289-314). USA, Champaign: Human Kinetics.

Domitrović, I. (2019). Vrijeme na društvenim mrežama minimalno utječe na tinejdžere. Djeca, Mediji i dječji razvoj. https://www.medijskapismenost.hr/vrijeme-na-drustvenim-mrezamaminimalno-utjece-na-tinejdzere/. Pristupljeno 4. listopada 2019.

Dowda, M., Dishman, R. K., Pfeiffer, K. A., Pate, R. R. (2007). Family support for physical activity in girls from 8th to 12th grade in South Carolina. Journal of Sport \& Exercise Psychology, 129, 677-678.

Dragun, A. (2012). Slobodno vrijeme i vrijednosti maturanata u Zadru. Crkva u svijetu, 47 (4), 487-513.

Driver, B. (1990). The North American Experience in Measuring the Benefits of Leisure, in E.Hamilton-Smith (Ed.), Proceedings, National Workshop on easurement of Recreation Benefits (str. 1-57). Australia: Phillip Institute of Technology, Bandoora. 
Driver, B.L \& Bruns, D.H. (1999). Concepts and Uses of the Benefits Approach to Leisure, in Edgar L. Jackson \& Thomas L. Burton, Leisure Studies (Ur.), Prospects for the TwentyFirst Century (str. 349-369). Venture Publishing, State College, PA.

Dumazedier, J. (1962). Vers une Civilisation du Loisir?. Paris: Du Seuil.

Dumazedier, J. (1967). Toward a Society of Leisure. Canada, Toronto: Collier-Macmillan.

Dumazedier, J. (1972). Rad i slobodno vrijeme, U: Friedmann, G., Naville, P. (Ur), Sociologija rada. Sarajevo: Veselin Masleša.

Eccles, J. S. (2005). Subjective Task Value and the Eccles et al. Model of Achievement-Related Choices. In A. J. Elliot, \& C. S. Dweck (Eds.), Handbook of Competence and Motivation (pp. 105-121). New York, NY: The Guilford Press.

Eccles J. S., Barber B. L., Stone M., Hunt J. (2003). Extracurricular activities and adolescent development. Journal of Social Issues, 59(4), 865-889. doi: 10.1046/j.00224537.2003.00095.x.

Eger, R. J., Maridal, J. H. (2015). A statistical meta-analysis of the wellbeing literature. Journal of Wellbeing, 5(2), 45-74.

Eisner, S. P. (2005). Managing generation Y. Safety for Advancement of Management. Advanced Management Journal, 70(4), 4-15.

Elkind, D. (1967). Egocentrism in adolescence. Child Development 38, 1025 - 34.

Ellison, N. B., Steinfield, C., \& Lampe, C. (2007). The benefits of Facebook „friends:” Social capital and college students' use of online social network sites. Journal of ComputerMediated Communication, 12(4), 1143-1168.

Elund, M. i Tancredi, L. R. (1987). Qualiti of Life: An Ideological Critique. Perspectives in Biology and Medicine, 28(4), 591 - 606.

Enciklopedijski rječnik pedagogije (1963). F. Dragutin, Z. Pregrad, P. Šimleša (Ur.). Zagreb: Matica hrvatska.

English, R. (2016). From tiger to free-range parents - what research says about pros and cons of popular parenting styles. http://theconversation.com/from-tiger-to-free-range-parentswhat-research-says-about-pros-and-cons-of-popular-parenting-styles-57986.

Pristupljeno 26. listopada 2016.

Epstein, J. L., McPartland, J. M. (1976). The concept and measurement of the quality of school life. American Educational Research Journal, 13, 15-30.

Erikson, E. H. (1950). Childhood and society. New York: Norton.

Escribano, C., Díaz-Morales, J. F., Delgado, P., \& Collado, M. J. (2012). Morningnesseveningness and school performance among Spanish ado-lescents: Further evidence. 
Learning and Individual Differences, 22, 409-413.

Este, D., Sitter, K. \& Maclaurin, B. (2009). Using mix methods to understand youth resilience. In: Liebenberg, L. \& Ungar, M. (eds.), Researching resilience. Toronto: University of Toronto Press, 201-224.

Esteve, R., San Martin, J. \& Lopez, A. E. (1999). Grasping the meaning of leisure: developing a self-report measurement tool. Leisure Studies, 18(2), 79-91.

DOI: $10.1080 / 026143699374961$

Etički kodeks istraživanja s djecom / <urednici Marina Ajduković, Vladimir Kolesarić>. Zagreb : Državni zavod za zaštitu obitelji, materinstva i mladeži : Vijeće za djecu Vlade Republike Hrvatske, 2003.

Fahey, T., Delaney, L. and Gannon, B. (2005). School Children and Sport in Ireland. Dublin: Economic and Research Institute.

Farkaš, H. (2014). Slobodno vrijeme kao resurs u postindustrijskome društvu. Amalgam, 6-7. (6-7), 37-56. Preuzeto s https://hrcak.srce.hr/134855

Fatović, I. (2009). Mladi i zadovoljstvo životom. Sveučilište u Zadru, odjel za pedagogiju.

Fayers, P.M. and Machin, D. (2000). Quality of life: Assessment, analysis and interpretation. Chichester: John Wiley \& Sons Ltd.

Feist, G. J., Bodner, T. E., Jacobs, J. F., Miles, M. i Tan,V. (1995). Integrating Top-Downand Bottom-UpStructural Models of Subjective Well-Being: A Longitudinal Investigation. Journal of Personality and Social Psychology, 68, 138-150.

Felce, D. (1996). Changing residential services: From institutions to ordinary living. In Mittler, P. and Sinason, V. (eds), Changing policy and practice for people with learning disability. London: Cassell.

Ferić, I. (2009): Vrijednosti i vrijednosni sustavi -psihologijski pristup, Zagreb. Alinea.

Ferlander, S. (2007). The importance of different forms of social capital for health. Acta Sociologica, 50, 115-128.

Ferrans, C. E., Johnson Zerwic, J. , Wilbur, J. E., Larson, J. L. (2005). Conceptual Model of Health-Related Quality of Life. Jurnal of Nursing Scholarship. https://doi.org/10.1111/j.1547-5069.2005.00058.x. Pristupljeno 20. srpnja 2018.

Festa, P. (2003). Investors snub Friendster in patent grab. CNet News. http://news.com.com/2100-1032_3-5106136.html. Pristupljeno 25. veljače 2015.

Filipczak, B. (1994). Its just a job: Generation X at work. Training, 31(4), 21-21. http://search.proquest.com/docview/203408323?accountid=1557. Pristupljeno 5.ožujka 2018. 
Fitzgerald, M., Joseph, A. P., Hayes, M., \& O’ Regan, M. (1995). Leisure activities of adolescent children. Journal of Adolescence, 18, 349-358.

Fletcher, A. C., Nickerson, P. \& Wright, K. L. (2003). Structured leisure activities in middle childhood: Links to well-being. Journal of Community Psychology,31(6), 641-659.

Fortman, J. (2003). Adolescent Language And Communication From An Intergroup Perspective. Journal of Language and Social Psychology, 22(1).

Fraser, N. (1992). Rethinking the Public Sphere: A Contribution to the Critique of Actually Existing Democracy. In Calhoun, C, (Eds.), Habermas and the Public Sphere Cambridge (str. 125). MA: MIT Press.

Fredricks, J. A, Alfeld-Liro, C. J, Hruda, L. Z, Eccles, J. S, Patrick, H., Ryan, A. M. (2002). A qualitative exploration of adolescents' commitment to athletics and the arts. Journal of Adolescent Research, 17(1), 68-97. doi: 10.1177/0743558402171004.

Fredericks, J. A., Eccles, J. (2005). Family socialization, Gender and Sport Motivation and Involvement. Journal of Sport \& Exercise Psychology, 27, 3-3.

Fredricks, J. A., Eccles, J. S. (2006). Is extracurricular participation associated with beneficial outcomes? Concurrent and longitudinal relations. Developmental Psychology, 42(4), 698-713. doi: 10.1037/0012-1649.42.4.698.

Fredricks, J. A., Eccles, J. S. (2008). Participation in extracurricular activities in the middle school years: Are there developmental benefits for African American and European American youth?. Journal of Youth and Adolescence, 37(9), 1029-1043. doi: 10.1007/s10964-008-9309-4.

Freeman, L., Trower ,C. A., Tan, R.J ., Terkla, D. G. (2009). Comparison of attitudes between Generation X and Baby Boomer veterinary faculty and residents. J Vet Med Educ, 36(1), $128-134$.

Friedman, G. (1959). Kuda ide ljudski rad. Beograd: Rad.

Friedmann, G. i Naville, P. (1972). Sociologija rada. Sarajevo: Veselin Masleša.

Fromme, J., Kommer, S., Mansel, J., Treumann, K. P. (1999). Selbstsozialisation, Kinderkultur und Mediennutzung. Opladen.

Fuchs, Ch. (2008). Internet and Society. Social Theory in the Information Age. Routledge Research in Information Technology and Society Ser. Number 8. New York: Routledge.

Furlong, A., Cartmel, F., Powney, J. and Hall, S. (1997). Evaluating Youth Work with Vulnerable Young People. Glasgow: The Scottish Council for Research in Education. 
Gaspar, T., Gaspar Matos. M., Pais, R., José, L., Leal, I. i Ferreira, A. (2009). Health-related quality of life in children and adolescents and associated factors. Journal of Cognitive and Behavioral Psychotherapies, 9(1), 33-48.

George, R.M. and Chaskin, R.J. (2004). What Ninth Grade Students in the Chicago Public Schools do in their Out of School Time. Chicago: Chapin Hall Centre for Research, University of Chicago.

Gibbs, J. L., Ellison, N. B. \& Heino, R. D. (2006). Self-presentation in online personals: The role of anticipated future interaction, self-disclosure, and perceived success in Internet dating. Communication Research, 33(2), 1-26.

Giddens, A. (1991). Modernity and Self-Identity: Self and Society in the Late Modern Age. Cambridge: Polity Press.

Gilman, R. (2001). The relationship between life satisfaction, social interest, and frequency of extracurricular activities among adolescent students. Journal of Youth and Adolescence, 30(6), 749-767. doi: 10.1023/A:1012285729701.

Glass, A. (2007). Understanding generational differences for competitive success. Industrial and Comercial Training, 39(2), 98-103.

Glaser, B. (1992). Basics of Grounded Theory Analysis. Mill Valley, CA: Sociology Press.

Glaser, B. \& Strauss, A. L. (1965). Awareness of dying. Chicago: Adline.

Glaser, B. \& Strauss, A. L. (1967/2006). The discovery of grounded theory. Chicago: Adline.

Glavaš, J. (2010). Djeca i slobodno vrijeme. Javno zdravstvo - časopis Nastavnog zavoda za javno zdravstvo splitsko-dalmatinske županije, 4(4).

Glover, T.D. \& Parry, D.C. (2005) Building Relationships, Accessing Resources: Mobilizing Social Capital in Community Garden Contexts. Journal of Leisure Research, 37(4), 450474.

Goby, V. (2003). Physical Space and Cyberspace: How do they interrelate: A Study of Offline and Online Social Interaction Choice in Singapore. Cyber Psyhology and Behavior, 6(6), $639-644$.

Godbey, G.G. (2003). Leisure in Your Life: An Exploration, (6th Ed.). Venture Publishing, Inc., State College, PA.

Godfrey, N., (2016). Cracking The Code On Gen Z: Do As I Say, Not As I Do. Forbes. Personal Finance.

https://www.forbes.com/sites/nealegodfrey/2016/11/06/cracking-the-code-on-gen-z- doas-i-say-not-as-i-do/2/. Prisupljeno 30. ožujka 2018.]

Goffman, E. (1959). The Presentation of Self ih Everyday life. New York: Doubleday. 
Gojčeta, M., Joković Oreb, I., Pinjetela, R.(2008). Neki aspekti kvalitete života adolescenata sa i bez cerebralne paralize. Hrvatska revija za rehabilitacijska istraživanja, 44, (1), 39 -47.

Gojčeta, M., Joković-Turalija, I., Mejovšek, M. (2005). Neke metrijske karakteristike upitnika za samoprocjenu kvalitete života adolescenata. Hrvatska revija za edukacijska istraživanja, 41(1), 17-25.

Goldberg, S. (2007). Analysis: Friendster is doing just fine. Digital Media Wire. http://www.dmwmedia.com/news/2007/05/14/analysis-friendster-is-doing-just-fine. Pristupljeno 30.ožujka 2016.

Goodin, R. E., Rice, J. M., Bittman, M. \& Saunders, P. (2005). The time-pressure illusion: discretionary time vs. free time. Social Indicators Research, 73(1), 43-70.

Gospodnetić, F. i Morić, D. (2014). Mladi i mediji u Hrvatskoj. Forum za slobodu odgoja. Zagreb.

Grabner-Kräuter S. \& Bitter, S. (2015) Trust in online social networks: A multifaceted perspective. Forum for Social Economics, 44(1), 48-68.

Graovac, M. (2010). Adolescent u obitelji. Medicina fluminensis, 46 (3), str. 261-266.

Grbavac, J. i Grbavac, V. (2014). Pojava društvenih mreža kao globalnog komunikacijskog fenomena. Media, culture and public relations, 5(2), 206-219.

Green, L., Heather, S., McKittrick, L., Naranjo, A. i Ward, C. (2013). “Understanding the Multiple Generations in the Workplace" https://www.saylor.org/site/wpcontent/uploads/2013/02/BUS209-6.4-enerationsintheWorkplace.pdf. Pristupljeno 12. siječnja 2018.

Groebel, J. (2001). Media violence in cross curtural perspective: Global study of children's media behavior and some educational implications. In D. G. Singer \& J. L. Singer (Eds.), Handbook of children and the media (255 - 268). Thousand Oaks, CA Sage.

Grossman L. (16. siječanj, 2005). Grow Up? Not So Fast.

http://content.time.com/time/magazine/article/0,9171,1018089,00.html. Pristupljeno 19. listopada 2019.

Guba, E. G. \& Lincoln, Y. S. (1994). Competing paradigms in qualitative research. In: Denzin, N. K. \& Lincoln, Y. S. (eds.), Handbook of qualitative research (str.105-117). Thousand Oaks, CA: Sage,

Haimer, S. i Rakovac, M. (2005.). Tjelesno vježbanje u zaštiti i unapređenju zdravlja-(javnozdravstvene osnove sportsko-rekreacijske medicine)., Hrvatski časopis za javno zdravstvo, 1(3). 
Hamer, M., Karageorghis, S. P. \& Vlachopoulos, S. P. (2002). Motives for exercise participation as predictors of exercise dependence among endurance athletes. Journal of Sport Medicine and Physical Fitness, 42(2), 233-239.

Hammill, G. (2005). Mixing and Managing Four Generations of Employees. FDU Magazine Online. http://www.fdu.edu/newspubs/magazine/05ws/generations.htm. Pristupljeno 5. ožujka 2018.

Han, J. (2007). Marketers Brace for Generation Z Customers. Korea Times.

Henderson, K. A. (2010). Leisure studies in the 21st century: The sky is falling?. Leisure science, 32(4), 391-400.

Hansen, D. M., Larson, R. W. (2007). Amplifiers of developmental and negative experiences in organized activities: Dosage, motivation, lead roles, and adult-youth ratios. Journal of Applied Developmental Psychology,28(4), 360-374. doi: 10.1016/j.appdev.2007.04.006.

Hansen, D. M., Skorupski, W. P. i Arrington, T. L. (2010). Differences in developmental experiences for commonly used categories of organized youth activities. Journal of Applied Developmental Psychology, 31(6), 413-421. doi: 10.1016/j.appdev.2010.07.001.

Hanžek, D, Holenko, J., Kojadin, J., Kolesarić, J. i Morić, D. (2013). Istraživanje potreba mladih - slobodno vrijeme mladih. U E. Bužinkić (Ur.) Znam, razmišljam, sudjelujem. 6. bilten studija i mladima i za mlade (str. 56-103). Zagreb: Mreža mladih Hrvatske.

Haralambos, M. i Heald, R. (1989). Uvod u sociologiju. Globus, Zagreb

Havighurst, R. J. (1972). To Live on this Earth: American Indian Education. New York: Doubleday.

Haythornthwaite, C. (2005). Social networks and Internet connectivity effects. Information, Communication, \& Society, 8(2), 125-147.

Healey, A. (1998). Figuring out generation X. Workspan, 41(2), 12-15. http://search.proquest.com/docview/194701649?accountid=1557. Pristupljeno 23. veljače 2018.

Heidemann, J., Klier, M., \& Probst, F. (2012). Online social networks: A survey of a global phenomenon. Computer Networks, 56(18), 3866-3878.

Heim, M. (1993). The Metaphisich of Virtual Reality. Oxford: Oxord Universiti Press.

Hendry, L. B. (1993). Young People's Leisure and Lifestyles. Routledge, London

Hendry, L. \& Kloep, M. (2003). Young people, unprotected time and overprotected contexts: Resources, challenges and risks?. 
https://www.researchgate.net/publication/278676293_Young_people_unprotected_time_and overprotected_contexts_Resources_challenges_and_risks. Pristupljeno 30. listopada 2019.

Hew, K. (2011). Review: Students' and teachers' use of Facebook. Computers in Human Behavior, 27.

Hilbrecht, M., Zuzanek, J., \& Mannell, R. C. (2008). Time use, time pressure and gendered behavior in early and late adolescence. Sex Roles: A Journal of Research, 58(5-6), 342357.

Hiltz, S. R. i Turoff, M. (1978). The network nation: Human comunication via computer. Reading MA: Addison - Wesley.

Hiltz, S. R. i Turoff, M. (1993). The network nation: Human comunication via computer, revised edition. Cambridge MA: MIT Press.

Hoffman, M. (2013). Life is too short for an undesirable satori. https://www.japantimes.co.jp/news/2013/03/31/national/media-national/life-is-tooshort-for-an-undesirable-satori/. Pristupljeno 16. listopada 2019.

Holjevac, I. A. (2006). Društvena odgovornost kao informac ijska dimenzija kvalitete života. Informatologia, 39(3), 153-158.

Horton, M. i Spafford, G. (1993). Rules for posting to Usernet. $\mathrm{http} / / \mathrm{rtfm}$.mit.edu,directory/pab/usernet/news.announce/newusers

House, J. S., Umberson, D. i Lendis, K. R. (1988). Structures and processes social support. Annual Review of Sociology, 14, 293 - 318.

Huebner, E. S, Valois, R. F, Paxton, R., Drane, W. J. (2005). Middle school students' perceptions of their quality of life. Journal of Happiness Studies, 6(1), 15-24. doi: 10.1007/s10902-004-1170-x.

Huntley, R. (2006). The World According to Y: Inside the new adult generation. Crows Nest, N.S.W.: Allen \& Unwin.

Ilišin, V. (2000). Promjene u slobodnom vremenu mladih. Napredak 141(4), 419-429.

Ilišin, V. (2003). Mediji u slobodnom vremenu djece i komunikacija o medijskim sadržajima. Medijska istraživanja 9(2), 9-34. Zagreb: Naklada medijska istraživanja.

Ilišin, V. (2007). Mladi: problem ili resurs. Zagreb: Institut za društvena istraživanja.

Ilišin, V. (2011). Vrijednosti mladih u Hrvatskoj. Politička misao, 48 (3), 82-122.

Ilišin, V., Bouillet, D., Gvozdanović, A., Potočnik, D. (2013). Mladi u vremenu krize. Zagreb, Freidrich Ebert Stiftung, IDIZ. 
Ilišin, V., Marinović-Bobinac, V., Radin, F. (2001). Djeca i mediji: Uloga medija u svakodnevnom životu djece. Zagreb: Državni zavod za zaštitu obitelji, materinstva i mladeži.

Ilišin, V. i Radin, F. (2002). Mladi uoči trećeg milenija. Zagreb: Institut za društvena istraživanja i Državni zavod za zaštitu obitelji, materinstva i mladeži.

Ilišin, V. i Radin, F. (2007). Slobodno vrijeme i interesi mladih. U Mladi: problem ili resurs. Znanost i društvo, 23, 13-37. Institut za društvena istraživanja, Zagreb.

Ilišin, V. i Spajić Vrkaš, V. (2015). Potrebe, problemi i potencijali mladih u Hrvatskoj. (istraživački izvještaj).

Inkpen, A.C. \& Tsang, E.W.K. (2005). Social Capital, Networks, And Knowledge Transfer. Academy of Management Review, 30(1).

Irby, I., Tolman, J. (2002). Rethinking Leisure Time: Expanding Opportunities for Young People and Communities. Washington, The Forum for Youth Investment.

Isić-Imamović, A. (2018). Motivi mladih za korištenje društvene mreže Facebook

http://www.usfm.hr/almira-isic-imamovic-motivi-mladih-za-koristenje-drustvene-mrezefacebook/. Pristupljeno 30. siječnja 2019.

Iso-Ahola, S. E. (1980). The Social Psychology of Leisure and Recreation. Wm C. Drown Company Publishers, Dubuque, IA.

Iso-Ahola, S. E. (1999). Motivational Foundations of Leisure. U L. J.Edgar and L.B. Thomas (Eds.) Leisure Studies: Prospects for the Twenty-First Century (str. 35-51). Venture Publishing, State College, PA, .

Ito, M., Baumer, S., Bittanti, M., boyd, d., Cody, R., Stephenson, B. H., Horst, H. A., Lange, P. G., Mahendran, D., Martínez, K. Z., Pascoe, C. J., Perkel, D., Robinson, L., Sims, Ch. and Tripp, L. ( 2013 ). Hanging Out, Messing Around, and Geeking Out. Kids Living and Learning with New Media. Cambridge, Massachusetts: The MET Press.

Iwasaki, Y., Zuzanek, J. i Mannell, R. C. (2001.). The effects of physically active leisure on stress-health relationship. Canadian Journal of Public Health, 92 (3), 214-218.

Izrael, B. A. (1982). Social networks and health status: Linking theory research and practice. Patient Counseling and Health Education, 4(2), 56-79.

Jakobs, G. (2004). Complicating contexts: Issues of metodology in researching the language and literacites of instant massaging. Reading Research Quarterly, 39(4), 394 - 406.

Janeković Römer, Z. (2004). Otium litteratum, utočište, ishodište. Kolo 4,103-114. 
Janković, V. (1973). Slobodno vrijeme u suvremenoj pedagoškoj teoriji i praksi. Zagreb: Pedagoško- književni zbor.

Jeđud, I. i Novak, T. (2006). Provođenje slobodnog vremena djece i mladih s poremećajima u ponašanju - kvalitativna metoda. Revija za sociologiju, 37(1-2), 77 - 90.

Jeđud, I. (2007). Alisa u zemlji čudesa - kvalitativna metodologija i metoda utemeljene teorije. Hrvatska revija za rehabilitacijska istraživanja, 43(2), 83-101.

Johnson, W. L., Johnson, A. M. (1993). Validity of the quality of school life scale: A primary and second-order factor analysis. Educational and Psychological Measurement, 53, 145153.

Jones, I. \& Symon, G. (2001). Lifelong Learning as serious leisure: policy, practice, and potential. Leisure Studies, 20, 269-283.

Jones, R. H., Hafner, C. A. (2012). Understanding Digital Literacies. New York: Routledge.

Jones, S. (2002). Virtual Culture: Identity and Communication in Cybersociety. SAGE Publications Ltd.

Jung, B. \& Moleda-Zdziech, M. (1998). Central and Eastern European cultural policies, media reform and development of media markets in the mid-nineties. Leisure Studies, 17(2), 6993. DOI: $10.1080 / 026143698375169$

Kaliterna Lipovčan, Lj., Prizmić-Larsen, Z. (2006) Kvaliteta življenja. životno zadovoljstvo $i$ osjećaj sreće u Hrvatskoj i europskim zemljama. U: (Katarina Ott, ur:) Pridruživanje Hrvatske EU: Izazovi sidjelovanja. Zagreb : Institut za javne financije i Friedrich Ebert Stiftung, Str. 181-197.

Kaplan, M. (1975). Leisure: Theory and Policy. New York: John Wiley.

Keaveney, S. M. \& Young, C. E, (1997). The Student Satisfaction and Retention Model (SSRM). (working paper). University of Colorado at Denver.

Kellner, D. (2003). Media Spectacle. New York: Routledge.

Kelly, J. R. (1987). Freedom to be: A new sociology of leisure. New York, NY: MacMillan Kelly, J.R. (1996). Leisure. Allyn and Bacon, Needham Heights, MA.

Kelly, J.R. (1999). Leisure and Society: A Dialectical Analysis, in Edgar L. Jackson and Thomas L. Burton, Leisure Studies: Prospects for the Twenty-First Century. Venture Publishing, State College, PA, 53-68.

Kelly, Y., Zilanawala, A., Booker, C. i Sacker, A. (2018). Social Media Use and Adolescent Mental Health: Findings From the UK Millennium Cohort Study. EClinicalMedicine, 6, $59-68$.

Kenton, W. (2018). Boomerang. https://www.investopedia.com/terms/b/boomerangs.asp. 
Pristupljeno 13.listopada 2019.

Khan, S. (2014). Qualitative Research Method: Grounded Theory. International Journal of Business and Management. 9. 10.5539/ijbm.v9n11p224.

Kindrick Patterson, C. (2007). The Impact of Generational Diversity in the Workplace. The Diversity Factor, 15(3), 17-22.

Kirin, A. (1991). Zaton Nietscheanske civilizacijske dogme. Ljubljana: Teorija i praksa.

Klarin, M. (2006). Razvoj djece u socijalnom kontekstu. Roditelji, vršnjaci, učitelji - kontekst razvoja djeteta. Jastrebarsko: Slap.

Klassen, A. F., Miller, A., Fine, S. (2004). Health-related quality of life in children and adolescents who have a diagnosis of attention-defi cit/hyperactivity disorder. Pediatrics, $114(5), 541-547$.

Klerk, D. i Bevan-Dye, D. (2014). Free-Time Management amongst Generation Y Students. Mediterranean Journal of Social Sciences, 5(21). MCSER Publishing, Rome-Italy.

Knežević, I. (2010). Upravljanje Generacijom Z. (Diplomski rad). Zagreb: Ekonomski fakultet.

Koković, D. (1977). Neki sociološki aspekti slobodnog vremena. Zbornik za društvene nauke Matice srpske.

Koković, D. (2007). Društvo i medijski izazovi. Novi Sad: Filozofski fakultet.

Komar, Z. (2009). Slobodno vrijeme kao vrijeme istinskog obrazovanja. Filozofska istraživanja, 29(2), 297-302.

Kooijman, D. (2002). A third revolution in retail? The Dutch approach to leisure and urban entertainment. Journal of Retail \& Leisure Property, 2(3), 214-229.

Kovčo-Vukadin, I. (2016). Kvaliteta života studenata u Republici Hrvatskoj. Zagreb: Edukacijsko-rehabilitacijski fakultet Sveučilišta u Zagrebu.

Kovčo-Vukadin, I. (2016). Zadovoljstvo životom: individualna i obiteljska perspektiva. Kriminologija i socijalna integracija, 24 (1).

Krämer, S. (2012). Carstvo medija [zbornik radova]. Ur. Katunarić, D. Zagreb: Litteris.

Krivokapić, N. (2007). Poimanje slobodnog vremena u savremenom društvu do 80-ih godina xx vijeka, Sociološka luča, I(2). Filozofski fakultet Nikšić.

Krizmanić, M. (1992). Mentalno zdravlje. U Petz, B. (ur.) Psihologijski rjenik. Zagreb, Prosvjeta.

Krizmanić M. i Kolesarić, V. (1989). Pokušaj konceptualizacije pojma kvalitete života. Primijenjena psihologija, 10, 179-184.

Krolo, K. (2015). Facebook prijatelji kao pokazatelj strukturnih dimenzija društvenog kapitala mladih u Hrvatskoj. Revija za sociologiju, 45 (2), 145 -170. 
Kron, F. W., Sofos, A. (2003). Mediendidaktik. Neue Medien in Lehr-und Lernprozessen. München / Basel: Rheinhart.

Kuss, F. R., Graefe, A. R i Vaske, J. J. (1990). Rekreation impact and carrying capacity: a review crowded in recreation settings. Leisure Sciences, 6, 1-4.

Kušić, S. (2010). Online društvene mreže i društveno umrežavanje kod učenika osnovne škole: navike facebook generacije. Život $i$ škola : časopis za teoriju $i$ praksu odgoja $i$ obrazovanja, 54(24), 103. - 125.

Kuzman, M. (2009). Adolescencija, adolescenti i zaštita zdravlja. Medicus, 18(2_Adolescencija), 155-172.

Labaš, D. (2011). Djeca u svijetu interneta: zatočenici virtualnoga svijeta. Pedagoški modeli i otvorena pitanja. U Ciboci, L., Kanižaj, I., Labaš, D. (ur.), Djeca medija. Od marginalizacije do senzacije (str. 35-64). Zagreb: Matica hrvatska.

Lacković-Grgin, K. (2006). Psihologija adolescencije. Jastrebarsko: Slap.

Lammiman, J. i Syrett, M. (2005). Cool generacija: Nova poslovna filozofija. Zagreb: Ljevak.

Lapinski, M. K. (2006). MySpace: The business of spam 2.0. ValleyWag.

http://valleywag.com/tech/myspace/myspace-the-business-of-spam-20-

exhaustiveedition-199924.php. Pristupljeno 12. svibnja 2016.

Larsen, M. C. (2007). Perspectives on Online Social Networking. Social Computing Magazine. www.socialcomputingmagazine.com

Larsen, J. T., McGraw, A. P. \& Cacioppo, J. T. (2001). Can people feel happy and sad at the same time?. Journal of Personality and Social Psychology, 81(4), 684-696.

Larson, R. (2000). Toward a psychology of positive youth development. American Psychologist, 55(1), 170-183.

Larson, R., \& Verma, S. (1999). How Children and Adolescents Spend Time across the World: Work, Play and Developmental Opportunities. Psychological Bulletin, 125, 701-736. http://dx.doi.org/10.1037/0033-2909.125.6.701. Pristupljeno 23. svibnja 2016.

Larson, R.W., Wilson, S., Bradford Brown, B., Furstenberg, F. F. Jr, Verma, S. (2002). Changes in adolescents' interpersonal experiences: Are they being prepared for adult relationships in the twenty-first century?. Journal of Research on Adolescence, 12(1), 31-68. doi: 10.1111/1532-7795.00024.

Larson, R. W., Hansen, D. M. i Moneta, G. (2006). Differing profiles of developmental experiences across types of organized youth activities. Developmental Psychology, 42(5), 849-863. doi: 10.1037/0012-1649.42.5.849. 
Lasheras, L., Aznar, S., Merino, B. i Lopez, E. G. (2001). Factors associated with physical activity among Spanish youth through the national health survey. Preventive Medicine, $32,455-464$.

Lauritano-Werner, B. (2006). „Reading My LiveJournal.” Youth Public Radio. http://youthradio.org/society/npr060628_onlinejournal.shtml. Pristupljeno 23. rujna 2016.

Lawton, M. P. (1991). A Multidimensional View of Quality of Life in Frail Elders. In Birren, J. E., Lubben, J., Rowe J., Deutchman, D. (eds)., The Concept and Measurement of Quality of Life. New York, Academic Press.

Lazarus, R. S. (1990). Stress, coping and illness. U: H. S. Friedman (ur.), Personality and Disease (97-120). New York: Wiley.

Lebedina-Manzoni, M., Lotar, M., Ricijaš, N. (2008). Podložnost vršnjačkom pritisku kod adolescenata - izazovi definiranja i mjerenja. Ljetopis socijalnog rada, god. 15(3), 401419.

Leburić, A., Quien, M., Lovrić, D. (2008). Stari i novi mediji : sociološka istraživanja medijskog stiliziranja života. Split: Redak.

Leburić, A. i Relja, R. (1999), Kultura i zabava mladih u slobodnom vremenu. Napredak 140(2), 175-183.

Lee, Y., McCormick, B. (2004). Subjective well-being of people with spinal cord injury - does leisure contribute?. Journal of Rehabilitation, 70, (3).

Lemos, A. (2001). Kulture interneta, Labirint Minitela. Zagreb: Naklada Jesenski i Turk. Lenhart, A. (2007). Cyberbullying and online teens. Pew Internet and American Life Project. http://www.pewinternet.org/files/oldmedia/Files/Reports/2003/PIP_College_Gaming_Reporta.pdf.pdf. Pristupljeno 27. travnja 2015.

Lenhart, A. (2015). Teens, Social Media \& Technology. Pew Internet and American Life Project Report.

https://www.pewresearch.org/internet/2015/04/09/teens-social-media-technology-2015/.

Pristupljeno 22. prosinca, 2018.

Lenhart, A. \& Madden, M. (2007). Teens, privacy, \& online social networks. Pew Internet and American Life Project Report.

http://www.pewinternet.org/pdfs/PIP_Teens_Privacy_SNS_Report_Final.pdf. Pristupljeno 30. travnja 2014. 
Leonard, C. (2002). Quality of school life and attendance in primary school. Newcastle: University of Newcastle, Australian Digital Thesis Program.

Lešnik, R. (1976). Srednjoškolci i slobodno vreme. Teorija in praksa, 1-2. University of Ljubljana Faculty of Social Sciences.

Leung, L., Lee, P. S. N. (2012). Impact of Internet Literacy, Internet Addiction, Symptoms, and Internet Activities on Academic Performance. Social Science Computer Review, 30 (4), 403-418.

Leutar, Z. i Lovreković, M. (2010). Kvaliteta života osoba u domovima za starije i nemoćne u Zagrebu. Socijalna ekologija, 1(19), 55-79.

Leversen, I., Danielsen, A. G. and Samdal, O. (2012): Basic Psychological need sastifaction in leisure activities and adolescents' life sastifaction. Yournal of Youth and Adolescence, 41(12), 1588-1599.

Levickaite, R. (2010). Generations X, Y, Z: How Social Networks Form the Concept of the World Without Borders (The Case of Lithuania), LIMES, 3(2), 170-183.

Levinson, D. J. (1986). A conception of adult development. American Psychologist, 4, 3-13. doi: 10.1037/0003-066X.41.1.3.

Lewin, K. (1939). Field theory and experiment in social psychology. Concepts and methods. American Journal of Sociology, 44, 868 - 896.

Lewis, C., Fabos, B. (2005). Instant messaging literacies, and sicial identities. Reading research Quaterly, 40(4), 470 - 501.

Liddle, M. J. (1997). Recreation ecology: the ecological impact of out-door recreation and ecotourism. London, UK: Chapman and Hall.

Lin, H-M., Tsai, C-C. (2008). Conceptions of Learning Management among Undergraduate Students in Taiwan. https://doi.org/10.1177/1350507608096041. Pristupljeno 23. svibnja 2016.

Ling, R. (2000). „We will be reached“: The use of mobile telephoney among Norwegian youth. Information tehnology and people, 13(2), 102- 120.

Linnakylä, P., Brunell,V . (1996.). Quality of school life in the Finnish and Swedish-speaking schools in Finland. U M. Binkley, K. Rust, T . Williams (ur.), Reading literacy in an international perspective (str.203-217), Washington: U.S.Department of Education, Office of Educational Research and Improvement.

Livazović, G. (2010). Dimenzije odnosa medijske i socijalne kompetencije. Pedagogijska istraživanja, 7 (2), 255-265. 
Livazović, G. (2011). Utjecaj medija na poremećaje u ponašanju adolescenata. (Neobjavljena doktorska disertacija). Filozofski fakultet Sveučilišta u Zagrebu.

Livingstone, S. M. (2005). Adult media literacy: a review of the research literature. London: Media@LSE.

Lorger, M. i Barić, R. (2012). Metrijske karakteristike hrvatske verzije Upitnika kvalitete života za djecu i adolescente The Kidscreen-52. Napredak, 153(3 - 4). 373 - 397.

Lovink, G. (2011). Network without a cause. Cambridge: Polity press.

Lučev, I. (2007.). Povezanost subjektivne kvalitete života s nekim objektivnim mjerama kvaliete života te demografskim i psihološkim varijablama. (Magistarski rad). Zagreb: Sveučilište u Zagrebu, Filozofski fakultet.

Lučev, I. i Tadinac, M. (2008). Kvaliteta života u Hrvatskoj -povezanost subjektivnih i objektivnih indikatora te temperamenta i demografskih varijabli s osvrtom na manjinski status. Migracijske i etničke teme, 1(2), 67-89.

MacCann, C., Fogarty, G.J. \& Roberts, R.D. (2012). Strategies for success in education: Time management is more important for parttime than full-time community college students. Learning and Individual Differences, 22(5), 618-623.

Madhavan, N. (2007). India gets more Net Cool. Hindustan Times. http://www.hindustantimes.com/StoryPage/StoryPage.aspx?id=f2565bb8-663e-48c194ee-d99567577bdd. Pristupljeno 22.rujna 2016.

Maggino F. and Shifini D'Andrea S. (2003). Different scales for different survey methods: validation in measuring the quality of university life. In Sirgy, M. J., Rahtz, D. and Samli, A. C. (eds) Advances in Quality-of-life Theory and Research (pp 233-256).

Mahoney, J.L. \& Stattin, H.K. (2000). Leisure activities and adolescent antisocial behaviour: the role of structure and social context. Journal of Adolescence, 23(2), 113-127.

Mayock, P. (2000). Choosers or Losers? Influences on Young People's Choices about Drugs in Inner-City Dublin. Dublin: The Children's Research Centre, Trinity College.

Mayock, P. and Byrne, T. (2004). A Study of Sexual Health Issues, Attitudes and Behaviours: The Views of Early School Leavers. Dublin: Crisis Pregnancy Agency.

Makinen, J. A. and Pychyl, T. A. (2001). The differential effects of project stress on life satisfaction. Social Indicators Research 53(1), 1-16.

Maleš, D., Kušević, B. (2011). Nova paradigma obiteljskoga odgoja, U: D. Maleš (Ur.), Nove paradigme ranoga odgoja (str. 44-66). Zagreb: Filozofski fakultet Sveučilišta u Zagrebu, Zavod za pedagogiju.

Malić, J. i Mužić, V. (1986). Pedagogija. Zagreb: Školska knjiga. 
Manago, A. M. (2015). „Identity Development in the Digital Age: Casa of Social Networking Sites“. In K. C. McLean, M. Syed (eds.) The Oxford Handbook of Identity Development (str. 508 - 524). Abingdon: Routledge.

Mannell, R. C. and Reid, D. G. (1999). Work and leisure. In Jackson, E. L. and Burton, T. L. (Ur.) Leisure studies at the millennium, 151-165. State College, PA: Venture.

Mannheim, K. (1952). „The Problem of Generations“. U P. Kecskemeti (ed.) Essays on the Sociology of Knowledge. Collected Works, 5, 276-322. New York: Routledge.

Marcuse, H. (1965). Eros i civilizacija. Zagreb: Naprijed.

Markert, J. (2004). Demographics of age: Generational and cohort confusion. Journal of Current Issues and Research in Advertising, 26(2), 11-25.

Markić, I. (2010). Socijalna komunikacija među učenicima. Pedagogijska istraživanja, 7(2), 307-315.

Marsh, H. W., Kleitman, S. (2002). Extracurricular school activities: The good, the bad, and the nonlinear. Harvard Educational Review, 72, 464-514.

Martinić, T. (1977). Slobodno vrijeme i suvremeno društvo. Zagreb: Izdavačka kuća Informator.

Martin, P. Y. \& Turner, B. A. (1986). "Grounded Theory and Organizational Research," The Journal of Applied Behavioural Science, vol. 22, no. 2, 141.

Martinis, T. (2005). Percepcija kvalitete života u funkciji dobi. Zagreb: Sveučilište u Zagrebu.

Marx, K. (1975). Kapital : kritika političke ekonomije : izbor. Zagreb : Školska knjiga

Maslow, A. H. (1954). The Instinctoid Nature of Basic Needs. Journal of Personality. https://doi.org/10.1111/j.1467-6494.1954.tb01136.x. Pristupljeno 22. srpnja 2018.

Maslow, A. H. (1968). Toward a Psihology of being. New York: Van Nostrand

Matthews, H. \& Taylor, M. \& Percy-Smith, B. \& Limb, M. (2000). The Unacceptable FlaneurThe Shopping Mall as a Teenage Hangout. Childhood-a Global Journal of Child Research-CHILDHOOD, 7, 279-294. 10.1177/0907568200007003003.

McCaughey, M. i Ayers, M. D. (2003). Cyberactivism: Online Activism ih Theory and Practice. New York: Routledge.

McCready, V. (2011). Generational Issues in Supervision and Administration. ASHA Leader, $16(5), 12-15$.

McVey, G. L, Pepler, D., Davis, R., Flett, G. L. \& Abdolell, M. (2002). Risk and protective factors associated with disordered eating during early adolescence. Journal of Early Adolescence, 22, 75-95. 
Meade, T., \& Dowswell, E. (2016). Adolescents' health-related quality of life (HRQoL) changes over time: A three-year longitudinal study. Health and Quality of Life Outcomes, 14, 14. https ://doi.org/10.1186/s12955-016-0415-9

Meenan, R. F., Gertman, P. M. i Mason, J. H. (1980). Measuring health status in arthritis: The Arthritis Impact Measurement Scales. Arthritis and Rheumatism, 23, 146-152.

Mehdizadeh, S. (2010). Self - Presentation 2.0: Narcissism and Self- Esteem on Facebook. Cyberpsychology, Behavior, And Social Networking, 13(4), 357-364.

Meister, J. C., Willyerd, K. (2010.). 2020 Workplace. New York, Harper Business.

Mejovšek, M. (2013). Metode znanstvenog istraživanja u društvenim i humanističkim znanostima. Jastrebarsko: Naknada Slap.

Mesch, G. S. (2009). Parental mediation, online activities, and cyberbullying. CyberPsychology \& Behavior, 12, 387393. http://doi.org/10.1089/cpb.2009.0068. Pristupljeno 23. travnja 2015.

Mihovilović, M. A. (2000). Izabrani radovi. Zagreb: Hrvatsko sociološko društvo.

Miliša, Z. (2006). Manipuliranje potrebama mladih. Zagreb: MaRkom.

Miliša, Z. i Tolić, M. (2009). Uloga simboličkog interakcionizma u analizama medijske manipulacije. Pedagogijska istraživanja, 6(1-2), 57-70.

Miliša, Z., Tolić, M., Vertovšek, N. (2009). Mediji i mladi. Zagreb: Sveučilišna knjižara.

Milutinović, I. (2011). Izmedju utopije i moralne panike: o društvenoj vrednosti Interneta. Časopis za upravljanje komuniciranjem, 6(18), 39. Fakultet političkih nauka Univerziteta u Beogradu.

Milyavskaya, M., Gingras, I., Mageau, G. A., Koestner, R., Gagnon, H., Fang, J. Q., et al. (2009). Balance across contexts: Importance of balanced need satisfaction across various life domains. Personality and Social Psychology Bulletin, 35(8), 1031-1045. doi: $10.1177 / 0146167209337036$.

Mlinarević, V., Miliša, Z. i Proroković, A. (2007) Slobodno vrijeme mladih u procesima modernizacije - usporedba slavonskih gradova i Zadra. Pedagogijska istraživanja, 4(1), $81-99$.

Mlinarević, V. (2006). Slobodno vrijeme kao prediktor poremaćaja u ponašanju učenika. (Doktorska disertacija). Zagreb: Filozofski fakultet.

Mlinarević, V. i Gajger, V. (2010). Slobodno vrijeme mladih - prostor kreativnog djelovanja. [online] http://bib.irb.hr/datoteka/505378.Slobodno_vrijeme_mladih.pdf

Montana, P. J., Petit, F. (2008.), Motivating Generation X and Y on the Job and Preparing Z. Global Journal of Business Research, 2(2), 139-148. 
Mooney, C. (2015). Online Privacy and Social Media. San Diego: ReferencePoint Press.

Morrow, V. (2001). Young people's explanations and experiences of social exclusion: retrieving Bourdieu's concept of social capital. International Journal of Sociology and Social Policy, 21 (4/5/6), 37-63. https://doi.org/10.1108/01443330110789439

Motion, J., Heath, R. L., Leitch, S. (2016). Social Media and Public Relations. New York: Routledge.

Mujkić, A. i Vuletić, G. (2002). Što čini osobnu kvalitetu života: Studija na uzorku Hrvatske gradske populacije. Liječnički Vjesnik, 2(124), 64-70.

Myerson, J. (2001). IDEO. Masters of Innovation. London: Laurence King Publishing.

Nach, J.B. (1960). Psychology of recreation and leisure. Dubuque Iowa.

Nadinloyi, K.B., Hajloo, N., Garamaleki, N.S. \& Sadeghi, H. (2013). The study efficacy of time management training on increase academic time management of students. Procedia Social and Behavioural Sciences, 84, 134-138.

Nelson, J.G., Butler, R.W. and Wall, G. (1993). Tourism and Sustainable Development: Monitoring, Planning, Managing. Waterloo. Ontario: Universityof Waterloo

Neulinger, J. (1974). The Psychology of Leisure. Springfield, IL: Charles C. Thomas.

Neumeyer, M., \& Neumeyer, E. (1958). Leisure and Recreation. New York: Ronald Press.

$\mathrm{Ng}$, S. L. (2005). Subjective residential environment and its implications for quality of life among university students in Hong Kong. Social Indicators Research 71(1), 467-48

Nimac, D. (2010) (Ne)mogućnosti tradicijske obitelji u suvremenom društvu. Obnovljeni život, 65(1), 23-35.

Ninčević, M. (2009). Izgradnja adolescentskog identiteta u današnje vrijeme. Odgojne znanosti, god. 11 (1), str. 119-141.

Norris, R., Douglas, C. i Cochrane, R. (1992.), The effects of physical activity and exercise on psychological stress and well-being in an adolescent population. Journal of Psychosomatic Research, 36 (1), 55-65.

O'Boyle, C.A. (1994). The Schedule for the Evaluation of Individual Quality of Life (SEIQoL). International Journal of Mental Health, 23,3-23.

Oliveira N. R. C., Padovani, R. C. (2014). Saúde do estudante universitário: uma questão para reflexão. Ciênc. saúde colet, 19(3), 995-6.

Olweny, C.L.M. (1992). Quality of life in developing countries. Journal of Palliative Care, 8, 25-30.

Opić, S. i Đuranović, M. (2014). Leisure Time of Young Due to Some Socio- demographic Characteristics. Procedia - Social and Behavioral Sciences, 159, 546-551. 
Orešković, S. (1994). Koncepti kvalitete života. Socijalna ekologija : časopis za ekološku misao i sociologijska istraživanja okoline, 3, 3-4.

Osit, M. M. (2008). Generation Text: Raising WellAdjusted Kids in an Age of Instant Everything. New York: AMACOM.

O'Sullivan, T., Dutton, B., Rayner, P. (1994). Studying the Media: An Introduction. London, New York: Arnold.

Ozben, S. (2013). Social skills, life satisfaction and loneliness in Turkish university students. Social Behavior and Personality: An International Journal, 41(2), 203-213.

Paige, A. (2017). 11 Characteristics of Generation Z. Popsugar. Living. https://www.popsugar.com/career/What-Generation-Z-40064775. Pristupljeno 23. lipnja 2017.

Pajić, B., (2012). Društveni mediji kao marketinški alat. [e-book] Dostupno na http://www.scribd.com/doc/142487824/Drustveni-Mediji-Kao-Marketinski-Alat.

Pristupljeno 23. travnja 2018.

Palen, L.A., Caldwell, L.L., Smith, E.A., Gleeson, S.L. \& Patrick, M.E. (2011). A mixedmethod analysis of free-time involvement and motivation among adolescents in Cape Town, South Africa. Leisure/Loisir, 35(3), 227-252.

Pang, N. S. (1999). Students' quality of school life in band 5 schools. Asian Journal of Counseling, 6, 79-10.

Pantić, D. (1980). Interesovanja mladih, I deo - Priroda interesovanja. Istraživačkoizdavački centar SSo Srbije u saradnji sa Institutom društvenih nauka - OOUR Centar za politikološka istraživanja i javno mnjenje, Beograd.

Park, N. (2004). The role of subjective well-being in positive youth development. The ANNALS of the American Academy of Political and Social Science, 591(1), 25-39.

Park, N., Kee, K. F. i Valenzuela, S. (2009). Being immersed in social outcomes. Cyber Psyhology i Behavior, 12(6).

Parks, M. R., Floyd, K. (1996). Making Friends in Cyberspace. Journal of Communication, 46 (1), 80-97.

Parker, S. (1985.). Leisure and Work. London: George Allen.

Parsi, M. R., Cantelmi T., Orlando F. (2009). L'immaginario prigioniero. Come educare $i$ nostri figli a un uso creativo e responsabile delle nuove tecnologie. Milano: Mondadori.

Pastuović, N. (1993). Kvaliteta života kao kriterij održivosti razvoja-psihologijski pristup, Socijalna ekologija: časopis za ekološku misao i sociologijska istraživanja okoline, 2(3), 471-479. 
Pastuović, N. (2006.). Kako do društva koje uči. Odgojne znanosti, 8(2), 421 -441.

Pastuović, N., Kolesarić, V., Krizmanić, M. (1995). Psychological variables as predictors of quality of life. Review of Psychology, 2(1-2), 49-61.

Pawelko, K. A., Magafas, A. H. (1997). Leisure Well Being among Adolescent Groups: Time, Choices and Self-Determination. Research Update. Parks and Recreation, 32(7), 28-39.

Pavot, W. i Diener, E. (1993). The affective and cognitive context of self-reported measures of subjective well-being. Social Indicator Research, 28, 1-20.

Pavot, W. i Diener, E. (2003). Well-being (including life satisfaction). U Encyclopedia of psychological assessment (Vol. 2, str. 1097-1101). Thousand Oaks, CA: Sage Publications, Inc.

Pavot, W. i Diener, E. (2013). Happiness experienced: The science of subjective well-being. U S. David, I. Boniwell i A.C. Ayers (Ur.) The Oxford handbook of happiness (str. 134151). Oxford, UK: Oxford University Press.

Pavot, W., Diener E., Colvin, C. R, Sandvik, E. (2001). Further validation of the satisfaction with life scale: Evidence for the cross-method convergence of well-being measures. Journal of Personality Assessment, 57(1), 149-161. doi: 10.1207/s15327752jpa5701_17.

Peck, D. S. (2008). Hanging Out and Growing Up With Social Media. Media Psihology Review, l(1).

Pedersen, S. \& Seidman, E. (2005). Contexts and correlates of out-of-school activity participation among low-income urban adolescents. Organized Activities as Contexts of Development: Extracurricular Activities. After-school and Community Programs, 85109.

Pehlić, I. (2014). Slobodno vrijeme mladih: socijalnopedagoške refleksije. Sarajevo: Centar za napredne studije.

Penezić, Z. (1996). Zadovoljstvo životom - provjera konstrukta. (Neobjavljeni diplomski rad). Filozofski fakultet u Zadru.

Penezić, Z. (1999). Zadovoljstvo životom: Relacije sa životnom dobi i nekim osobnim značajkama. (Magistarski rad). Zagreb: Filozofski fakultet.

Penezić, Z. (2006). Zadovoljstvo životom u adolescentnoj i odrasloj dobi. Društvena istraživanja, 15(4-5), 643-669.

Pepe, K. \& Bozkurt, I. (2010). Free time spending ways of university students, and the benefits they gained through these activities. Series Physical Education and Sport/Science, movement and health,10(2), 253-262. 
Perasović, B. (2000): Slobodno vrijeme i subkulturni identitet. Napredak, 141(4) 411-418. Zagreb.

Perasović, B. i Bartoluci, S. (2008). Slobodno vrijeme i kvaliteta života mladih. U M. Andrijašević (ur.), Zbornik radova međunarodne znanstveno-stručne konferencije Kineziološka rekreacija i kvaliteta života (str.15-24). Zagreb : Kineziološki fakultet.

Petrić, D. (2007). Homo zappiens: Generacija koja se rodila s daljinskim, mobitelom i webom. http://www.jutarnji.hr/homo-zappiens--generacija-koja-se-rodila-s-daljinskim-mobitelom-i-webom/215658/ . Pristupljeno 26. travnja 2015.

Petz, B. (2005). Psihologijski rječnik. Jastrebarsko: Naklada Slap

Pieper, J. (1963). Leisure: The basis of culture. New York: Random House.

Pigram J.J. (1993). Planning for tourism in rural areas. Briding the policy implementation gap in tourism research. In Pearce D. and Butter W. (Ed.) Critiques and challenges, 156-174.

Pilcher, J. J. (1998). Affective and daily events predictors of life satisfaction in college students. Social Indicators Research 43 (3), 291-306.

Plenković, J. (1998). »Slobodno vrijeme u okruženju novog poretka«. Povijest hrvatskog športa, 29, 5-11.

Plenković, J. (2000). Slobodno vrijeme mladeži. Sveučilište u Rijeci.

Podgorelec, S. (2003). Mark Rapley: Quality of Life Research-a Critical Introduction. Migracijske i etničke teme, 19 (4), 454-457.

Pointdexter, P. M., \& Lasora, D. L. (1999). Generation X: Is it meaning understood? Newspaper Research Journal, 20 (4), 28 -36.

Polić, R. (2003). Odgoj i dokolica. Metodički ogledi, 10(2), 25 - 37.

Poredoš, D. (2002). Utjecaj gubitaka u starijoj životnoj dobi na doživljaj kvalitete života. (Magistarski rad). Medicinski fakultet sveučilišta u Zagrebu.

Postman, N. (1982). Disappearance childhooh. New York: Delacorte Press.

Potkonjak, N. i Šimleša, P. (1989). Pedagoška enciklopedija. Beograd: Zavod za udžbenike i nastavna sredstva, Zagreb: Školska knjiga, Sarajevo: Svjetlost.

Pöttinger, I., Schill, W., Thiele, G. (2004). Medienbildung im Dopelpack-Wie Schule und Jugendhilfe einander ergänzen können. Bielefeld: GMK.

Powell, W. and Smith-Doerr, L. (1994). Networks and economic life. In N. Smelser and R. Swedburg (ed), Handbook of economic sociology (str. 368-402). Princeton, NJ: Princeton University Press.

Pregrad, Z. (1961). Pedagogija slobodnog vremena. Pedagoški rad : časopis za pedagoška i kulturno-prosvjetna pitanja , 16(5-6), 165-169. Zagreb : Pedagoško-književni zbor. 
Prensky, M. (2001). Digital Natives, Digital Immigrant. On the Horizon, 9(5). MCB University Press.

Previšić, V. (2000). Slobodno vrijeme između pedagogijske teorije i odgojne prakse. Napredak, 141(4), 403 - 409. Zagreb: Hrvatski pedagoško-književni zbor.

Previšić, V. (2007). Pedagogija: Prema cjeloživotnom obrazovanju i društvu znanja. U Previšić, V., Šoljan, N., Hrvatić, N. (ur.) Pedagogija: Prema cjeloživotnom obrazovanju i društvu znanja, Svezak 1. Zagreb: Hrvatsko pedagogijsko društvo.

Putnam, R. \& Gross, K. (2002). Introduction. In R. Putnam (Ed.), Democracies in Flux: The Evolution of Social Capital in Contemporary Society (str. 3-21). New York: Oxford Press. Putnam, R. D. (1993). The Prosperous Community. The American prospect, 24, 35-42.

Putnam, R. D. (2000). Bowling Alone: The collapse and revival of american community. New York: Simon \& Schuster.

Quinn, K., Papacharissi, Z. (2014). The Place Where Our Social Networks Reside: Social Media and Sociality. U Oliver, M. B., Raney A. A. (ur.), Media and Social Life. New York: Routledge.

Radin, F. (2002). Vrijednosne hijerarhije i strukture. U Ilišin, V, i Radin, F. (ur), Mladi uoči trećeg milenija (str. 47-78). Zagreb: Institut za društvena istraživanja i Državni zavod za zaštitu obitelji, materinstva i mladeži.

Ragheb, M. G. and Tate, R .L. (1993). A behavioural model of leisure participation, based on leisure attitude, motivation and satisfaction. Leisure Studies, 12, 61-70.

Rajmil, L., Palacio-Viera, J. A., Herdman, M., Lopez-Aguila, S., Villalonga-Olives, E., Valderas, J. M., Espallargues, M., Alonso, J. (2009.). Effect on health-related Quality of Life of changes in mental health in children and adolescents. Health and Quality of Life Outcomes, 7(103).

Rattinger, M. (2017). Aktivnosti i društvene mreže u slobodnom vremenu mlađih tinejdžera. Školski vjesnik, 66(2), 222-237.

Ravens-Sieberer, U., Schmidt, S., Gosch, A., Erhart, M., Petersen, C. i Bullinger, M. (2007). Measuring subjective health in children and adolescents: Results of the European KIDSCREEN/DISABKIDS Project. GMS Psycho-Social Medicine, 4.

Regan Shade, L. (2002). Gender and Community in the Social Construction on the Internet. New York, Peter Lang.

Relja, R. i Božić, T. (2012). Socio-ekonomski aspekti korištenja mobitela među mladima. Media, culture and public relations, 3 (2), 138-149. Preuzeto s https://hrcak.srce.hr/87766 Ravens-Sieberer, U., Schmidt, S., Gosch, A., Erhart, M., Petersen, C., Bullinger, M. (2007). 
Easuring subjective health in children and adolescents: result of the European KIDSCREEN/DISABKIDS Project. GMS Psycho-Social-Medicine, 4,1 - 13.

Rhodes, J., Spencer, R. (2005). Someone to watch over me: Mentoring programs in the afterschool lives of children and adolescents. Mahwah, New Jersey: Lawrence Erlbaum Associates.

Ridge, T. (2002). Childhood poverty and social exclusion: From a child's perspective. Bristol: Policy Press.

Riera, M. (2004). Uncommon sense for parents with teenagers. Berkley, CA: Celestial Arts.

Riesman, D. Glazer, N. \& Revel, D. (1950). The Lonely Crowd. A Study of Changing American Character. New Haven, CT: Yale University Press.

Rijavec, M. (2007.). Životni ciljevi mladih i psihološka dobrobit. Dijete i društvo, 9(2), 355 365.

Rijavec, M., Miljković, D. i Brdar, I. (2008). Pozitivna psihologija. Zagreb: IEP-D2.

Ristić, D. (2011). Internet u svakodnevnom životu: sociološki aspekti onlajn komunikacije. Medijska istraživanja: Zbornik radova III, 69-82. Novi Sad: Filozofski fakultet.

Rivoltella, P. C. (2008). Digital literacy: Tools and methodologies for information society. London: IGI Publications.

Roberts, K. (1997). Same activities, different meanings: British youth cultures in the 1990s. Leisure Studies, 16, 1-15.

Roberts, K. i Parsell, G. ( 1994). Youth cultures in Britain: the middle class takeover. Leisure Studies, 13, $33-48$.

Roberts, L. and R. Clifton, R (1992). Measuring the affective quality of life of university

Robinson, J. P. (1977). How Americans Use Time. New York: N. Y. Praeger.

Rojek, Ch. (1995). Decentring Leisure: Rethinking Leisure Theory. London: Sage Publications.

Rojek, Ch. (2010). Leisure and emotional intelligence. World Leisure Journal, 52 (4), 240-252. DOI: $10.1080 / 04419057.2010 .9674646$

Rolim, M., K., Thiago, S., M., Segato, L.,Andrade, A. (2007). Selfefficacy of actives and nonactives adolescents. Journal of Sport\&Exercise Psychology, 29, 198 - 199.

Rosandić, H. (2018). http://www.zenasamja.me/porodica/2592/egocentrizam-najcesci-uzroksukoba-tinejdzera-sa-roditeljima. Pristupljeno 1. ožujka 2018.

Rosen, C. (2007). Virtual Friendship and The New Narcissim. U Bauerlein, M. (ur.) The Digital Divide. New York: Penguin Group.

Rosić, V. (1998). Obiteljska pedagogija. Rijeka:Sveučilište u Rijeci. 
Rosić, V. (2005). Slobodno vrijeme - slobodne aktivnosti: priručnik za uspješno organiziranje i vođenje. Rijeka : Žagar.

Rot, N. (1983). Psihologija grupa. Beograd, Zavod za udžbenike i nastavna sredstva.

Rothberg, D. (2006). Generation y for dummies, E Week. http://www.eweek.com/c/a/ITManagement/Generation-y-for-dummies/. Pristupljeno 5. ožujka 2018.

Royal, M. A. \& Rossi, R. J. (1993). A comparative approach to assessing the quality of life of intercollegiate athletes. Social Indicators Research 29(3), 317-330.

Rudan, V. (2004). Normalan adolescentni razvoj. Medix, 10(52), 36-39.

Russell, R. V. (2002). Pastimes: The Context of Contemporary Leisure. (2nd Ed.). Champagne, IL: Sagamore Publishing.

Ružić, N. (2008). Zakonska ograničenja ili sloboda izražavanja na internetu?. MediAnali, 2(4), 101-111.

Ryan, R. M. i Deci, E. L. (2000). Self-determination theory and the facilitation of intrinsic motivation, social development, and well-being. American Psychologist, 55(1), 68-78. doi: 10.1037/0003-066X.55.1.68.

Säfvenbom, R. \& Samdahl, D. M. (1998). Involvement in and perception of the free-time context for adolescents in youth protection institutions. Leisure Studies, 17(3), 207-226.

Savage, S., Collins-Mayo, S., Mayo, B., Cray, G. (2006). Making sense of Generation y: the world view of 15-25-year-olds. London: Church House Publishing.

Schalock, R. L. (2004). The concept of quality of life: what we know and do not know. $J$ Intellect Disabil Res, 48(3), 203-216.

Schalock, R. L., Brown, I., Brown, R., Cummins, R. A., Felce, D., Matikka, L., Keith, K.D., \& Parmenter, T. (2002). Conceptualization, measurement, and application of quality of life for persons with intellectual disabilities: Results of an international panel of experts. Mental Retardation, 40, 457-470.

Schawbel, D. (2014). Gen Z Employees: The 5 Attributes You Need to Know. Entrepreneur. https://www.entrepreneur.com/article/236560. Pristupljeno 26. srpnja 2017.

Scheerder, J., Vanreusel, B., Taks, M., (2005). Stratification Patterns of Active Sport Involvement Among Adults. Social Change and Persistence. Volume: 40 (2), 139-162.

Schiano, D.J., Elliott, A. \& Bellotti, V. (2007). A look at Tokyo youth at leisure: Towards the design of new media to support leisure outings. Computer Supported Cooperative Work, 16(1-2), 45-73.

Schorb, B. (1995). Medienaltag und Handeln. Medienpadagogik in Geschichte, Forschung und Praxis. Opladen: Leske und Budrich. 
Schorer, W. J. (2004). Generations $\mathrm{x}, \mathrm{y}, \mathrm{z}$ and the Others. The Social Librarian. http://socialmarketing.org/archives/generations-xy-z-and-the-others/. Pristupljeno 5. ožujka 2018.

Schwartz, S. H. \& Huismans, S. (1995). Value priorities and religiosity and four Western nations. Social Psychology Qarterly, 58, 88 - 107.

Schwartz, S. H., \& Rubel, T. (2005). Sex differences in value priorities: Cross-cultural and multimethod studies. Journal of Personality and Social Psychology, 89(6), 1010-1028.

Scraton, S. and Bramham, P. (1995). Leisure and postmodernity, in Developments in Sociology. M. Haralambos (Edt.). Ormskirk, Causeway Press.

Seargeant, P. i Tagg, C. (2014). The Language of Social Media. London: Palgrave Macmillan.

Segran, E. (2016, 16. kolovoza). Your Guide to Generation Z: The Frugal, Brand-Wary Determined Anti-Millenials. Fast Company. Dostupno na https://www.fastcompany.com/3062475/your-guide-to-generation-z-the-frugal-brandwary-determined-anti-millen. Pristupljeno 14. srpnja 2017.

Sekol, I. i Maurović, I. (2017). Miješanje kvantitativnog i kvalitativnog istraživačkog pristupa u društvenim znanostima - miješanje metoda ili metodologija? Ljetopis socijalnog rada, 24 (1), 7-32. https://doi.org/10.3935/ljsr.v24i1.147.

Shafie, L.A., Nayanb, S., Osmanc, N. (2012). Constructing Identity through Facebook Profiles: Online Identity and Visual Impression Management of University Students in Malaysia. Procedia - Social and Behavioral Sciences, 65, 134-140.

Schalock, R. L. (2004). The concept of quality of life: what we know and do not know. Journal of Intellectual Disability Research, 48(3), 203-216.

Schorb, B. (1995). Medienalltag und Handeln. Medienpädagogik im Spiegel von Geschichte. Forschung und Praxis, Opladen.

Shaw, S. i Fairhurst, D. (2008). Engaging a new generation of graduates. Education + Training, 50 (5), 366-378. https://doi.org/10.1108/00400910810889057

Shaw, S. M., Caldwell, L. K. i Kleiber, D. A. (1996). Boredom, stress and social control in daily activities of adolescents. Journal of Leisure Research, 28 (4), 274-292.

Sheldon, P. (2008). The relationship between unwillingness to communicate and students Facebook use. Journal of Media Psyhology, 20(2), 67 -75.

Sheldon, K. M., Abad, N., Omoile, J. (2009). Testing self-determination theory via Nigerian and Indian adolescents. International Journal of Behavioral Development, 33(5), 451459. doi: 10.1177/0165025409340095 
Sheldon, K. M. i Elliot, A. J. (1999). Goal striving, need satisfaction, and longitudinal wellbeing: The self-concordance model. Journal of Personality and Social Psychology, $76(3), 482-497$.

Shepard, C., Giles, H., Le Poire, B. (2001). Communication accommodation theory. U Robinson, W. P., Giles, H. (ur.), The new handbook of language and social psychology (str. 35-56). Chichester, UK: Wiley.

Shields, R. (2001). Kulture Interneta-Virtualni prostori, stvarne povijesti i živuća tijela. Zagreb: Naklada Jesenski i Turk.

Shin, N., Vaughn, B. E., Akers, V., Kim, M., Stevens, S., Krzysik, L. i Korth, B. (2011). Are happy children socially successful? Testing a central premise of positive psychology in a sample of preschool children. Journal of Positive Psychology, 6, 355-367.

Shipp, D. (1993). Loving them to death? Sustainable tourism in Europe's nature and national parks, Federation of Nature and National Parks of Europe. Grafenau, Germany.

Shirky, C. (2003). Social software: A new generation of tools. Release 1.0, 21(5). http://cachefly.oreilly.com/radar/r1/05-03.pdf. Pristupljeno 24. travnja 2016.

Silver, K. (2018). Adolescence now lasts from 10 to 24'. Health reporter, BBC News. https://www.bbc.com/news/health-42732442. Pristupljeno 18. listopada, 2019.

Slavuj, L. (2012). Objektivni i subjektivni pokazatelji u istraživanju koncepta kvalitete života. Geoadria, 17(1), 73-92. https://doi.org/10.15291/geoadria.238. Pristupljeno 23. lipnja 2017.

Sloterdijk, P. (2005). „Slike nasilja - nasilje slika”. Europski glasnik, 10, 548. Zagreb.

Smith, A. (2000). Researching quality of life of older people: concepts, measures and findings. Keele: Keele University.

Smith, J. H.,. Briers, G. E and Smith, C. W. (2004). Correlates of quality of life of agricultural scholarship recipients. Social Indicators Research 69(1), 51-66.

Soares, A.B., Del Prette, Z.A.P. (2015). Habilidades sociais e adaptação à universidade: convergências e divergências dos construtos. Análise Psicológica, 33(2), 139-51.

Steinberg, L. (1996). Beyond the classroom: Why school reform has failed and what parents need to do. New York, New York: Simon \& Schuster.

Stevens, R. H. (2010). Managing Human Capital: How to Use Knowledge Management to Transfer Knowledge in Today's Multi-Generational Workforce. International Business Research, 3(3), 77-83.

Strauss, A. L. (1987). Qualitative Analysis for Social Scientists. Cambridge University Press, New York. http://dx.doi.org/10.1017/CBO9780511557842 
Strauss, A. \& Corbin, J. (1990). Grounded Theory Research: Procedures, Canons, and Evaluative Criteria. Qualitative Sociology, 13 (1).

Strauss, A. L., Corbin, J. (1989). Basics of qualitative research: techniques and procedures for developing grounded theory. (2nd ed.) Thousand Oaks, CA: Sage.

Strauss, A. \& Corbin, J. (1994). Grounded Theory Methodology: An Overview. In N. Denzin \& Y. Lincoln Handbook of Qualitative Research. 1st ed., 273-284.

Subrahmanyam, K. \& Greenfield, P. (2008). Online Communication and Adolescent Relationships. The Future of children / Center for the Future of Children, the David and Lucile Packard Foundation, 18, 119-46.

Suldo, S. M. i Huebner, E. S. (2004). Does life satisfaction moderate the effects of stressful life events on psychopathological behavior during adolescence? School Psychology Quarterly, 19(2), 93-105.

Sundén, J. (2003). Material Virtualities. New York: Peter Lang Publishing.

Supek, R. (1996). Modernizam i postmodernizam. Zagreb: Antibarbarus.

Süss, D. (2004). Mediensozialisation von Heranwachsenden. Dimensionen-KonstantenWandel. Wiesbaden: VS-Verlag für Sozialwissenschaften.

Symonds, J. \& Gorard, S. (2009). The Death of Mixed Methods: Research Labels and their Casualties.ResearchGate.

https://www.researchgate.net/publication/252477890_The_Death_of_Mixed_Methods

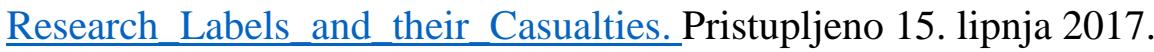

Szabo, S. (1996). Chap 36: The World Health Organization Quality of Life (WHOQOL) assessment instrument. In B. Spiker (ed.), Qualify of Life and Pharmacoeconomics in Clinical Triols (pp. 355-362). Philadelphia: Lippincott-Raven.

Šmakić, K. (2016). Društvene mreže i mladi: utjecaj opcije „like“ na kreativno ponašanje mladih. Izlaganje sa znanstvenog skupa. Univeztet u Beogradu - Poljoprivredni fakultet.

Taprial, V., Kanwar, P. (2012). Understanding Social Media. Ventus Publishing ApS.

Tapscott, D. (2008). Grown Up Digital: How the Net Generation Is Changing Your World. New York: McGraw-Hill.

Tashakkori, A. \& Teddlie, C. (2003). Handbook of mixed methods in social and behavioral research. Thousand Oaks, CA: Sage Publications.

The Quality of Life Model (1997) http://sites.utoronto.ca/qol/qol_model.htm. Pristupljeno 22. listopada 2018.]

Theofilou, P. (2013). Quality of Life: Definition and Measurement. Europe's Journal of Psychology, 9, 150-162. 10.5964/ejop.v9i1.337. 
The WHOQOL Group (1995). The World Health Organization Quality of Life assessment (WHOQOL): position paper from the World Health Organization. Social Science and Medicine, 41 (10), 1403-1409.

The WHOQOL Group (1998). The World Heolth Organization Quality of Life assessment (WHOQOL): development and general psychometric properties. Social Science and Medicine, 46 (121), 1569-1585.

The WHOQOL Group (1998b). Development of the World Health Organization WHOQOLBREF quality of life assessment. Psychological Medicine, 28. 551 -558.

The World Health Organization Quality of Life Group (1996). The World Health Organization Quality of Life Assessment (WHOQOL-BREF): Introduction, administration, scoring and generic version of the assessment. Field trial version. Geneva: Programme on mental health.

Thomas, A. (2007). Youth online: Identity and Literacy in the digital age. New York: Peter Lang Publishers.

Thomson, R., Holland, J. (2002). Young People, Social Change and the Negotiation of Moral Authority. Children Society, 16, 103-115.

Tinsley, H. E. A., Eldredge, B. D. (1995). Psychological benefits of leisure participation: A taxonomy of leisure activities based on their need-gratifying properties. Journal of Counseling Psychology, 42(2):123-132. doi: 10.1037/0022-0167.42.2.123.

Tolić, M. (2009). Temeljni pojmovi suvremene medijske pedagogije. Život i škola, 22, 7-103. Tomić, Z. (2007). Odnosi s javnošću i novinarstvo. Komunikacijske znanosti (zbornik radova). Zagreb, Hrvatski studiji.

Topolovčan, T. (2017). Utemeljena teorija u istraživanjima odgoja i obrazovanja. Učiteljski akultet Sveučilišta u Zagrebu.

Trujillo, L. (2007). Leisure meanings, experiences and benefits: a cross-cultural analysis of young adults.

http://citeseerx.ist.psu.edu/viewdoc/download?doi=10.1.1.454.1757\&rep=rep1\&type=pdf. Pristupljeno 24. lipnja 2015.

Tsai, C.C., Lin, S.S.J. \& Tsai, M.J. (2001). Developing an Internet Attitude Scale for high school students. Computers \& Education, 37(1), 41-51.

Tulgan, B. (2000). Managing Generation X. New York, NY: W.W.Norton \&Company, Inc.

Tufekci, Z. (2008). Grooming, Gossip, Facebook And Myspace. Information, Communication \& Society, 11(4), 544-564. doi: 10.1080/13691180801999050

Turkle, S. (1999). Cyberspace and Identity. Contemporary Sociology, 28(6), 643-648. 
Turkle, S. (2012). Alone Together: Why We Expect More from Technology and Less from Each. New York: Basic Books.

Uchida, Y. \& Norasakkunkit, V. (2015). The NEET and Hikikomori spectrum: Assessing the risks and consequences of becoming culturally marginalized. Frontiers in psychology, 6, 1117. doi:10.3389/fpsyg.2015.01117

Uldrijan, I. (2011) Zašto odgajati za medije? Mediji kao "odgojitelji" u doba odgojne krize. U Labaš, D. (ur.), Komunikacija i mediji u krizi (str. 173-192). Zagreb, Hrvatski studij.

Urberg, K.A., Luo, Q., Pilgrim, C., Degirmencioglu, S. M. (2003). A two-stage model of peer influence in adolescent substance use: individual and relationship-specific differences in susceptibility to influence. Addictive Behaviors. 28, 1243-1256.

Urquia, N. (2005). The re-branding of salsa in London's dance clubs: How an ethnicised form of cultural capital was institutionalized. Leisure Studies, 24(4), 385-397.

Vaez, M., Kristenson, M. and Laflamme, L. (2004). Perceived quality of life and self-rated health among first-year university students. Social Indicators Research 68(2), 221-234.

Valkenburg, P. \& Peter, J. (2008). Adolescents' Identity Experiments on the Internet Consequences for Social Competence and Self-Concept Unity. Communication Research, 35, 208-231.

Vallerand, R. J. i Ratelle, C. F. (2002). Intrinsic and extrinsic motivation: A hierarchical model. NY: University of Rochester Press.

Valjan Vukić, V. (2013). Slobodno vrijeme kao "prostor" razvijanja vrijednosti u učenika. Magistra Iadertina, 8 (1.), 59-73.

Valois, R.F., Zullig, K.J., Huebner, E.S. i Drane, J.W. (2001). Relationship between life satisfaction and violent behaviors among adolescents. American Journal of Health Behavior, 25(4), 353-366.

Vasić, M. (2010). Uticaj društvenih mreža Interneta na društvo. (Magistarski rad). Filološki fakultet u Beogradu.

Vasta, R., Haith, M. i Miller, S. A. (1998). Dječja psihologija. Slap, Jastrebarsko.

Veblen, T. (1966). Teorija dokoličarske klase. Beograd: Kultura.

Veenhoven, R. (1993). Happiness in nations: subjective appreciation of life in 56 nations 19461992. Rotterdam, Netherlands: RISBO, Erasmus University of Rotterdam.

Veenhoven, R. (1996). The study of life satisfaction. In W. E. Saris, R. Veenhoven, A. C. Scherpenzeel, \& B. Bunting (Eds.), A comparative study of satisfaction with life in Europe (11-48). Budapest: EOtvOs University Press. 
Venus, M., Brlas, S., Šeparac, V. i Koić, E. (2005 -2007). Slobodno vrijeme i problem zlouporabe sredstava ovisnosti među djecom i mladima. (Istraživanje među mladima Virovotičko-podravske županije). http://centar.zzjzvpz.hr. Pristupljeno 23. siječnja 2019.

Verdugo, M. A., Schalock, R. L., Keith, K. D. i Stancliffe, R. J. (2005). Quality of Life and Its Measurement: Important Principles and Guidelines, Journal of Intellectual Disability Research, 49(10), 707-717.

Vranjesevic, J., Trikić, Z., Koruga, D., Vidović S. i. Dejanović, V. (2003). Vršnjačka medijacija - priručnik za voditelje radionica iz oblasti obrazovanja za veštine medijacije. Beograd: Kinderberg and GTZ.

Veronneau, M. H., Koestner, R. F. , Abela, J. R. Z. (2005). Intrinsic need satisfaction and wellbeing in children and adolescents: An application of the self-determination theory. Journal of Social and Clinical Psychology, 24(2), 280-292. doi: 10.1521/jscp.24.2.280.62277.

Vidulin-Orbanić, 2008. Fenomen slobodnog vremena u postmodernom društvu. Metodički obzori 3(2).

Vukasović, A. (2000). Sve veća važnost odgoja u slobodnom vremenu. Napredak, 141(4), 448457.

Vuletić, G. (1999). Sociopsihološki čimbenici osobne kvalitete života. (Magistarski rad). Medicinski fakultet, Zagreb.

Vuletić, G. (2004). Generacijski i transgeneracijski imbenici kvalitete života vezane za zdravlje studentske populacije. (Doktorska disertacija). Medicinski fakultet Sveučilišta u Zagrebu.

Vuletić, G. (2013). Samoprocijenjeno zdravlje i kvaliteta života u Bjelovarsko bilogorskoj županiji: regionalne razlike i specifičnosti. Radovi Zavoda za znanstvenoistraživački $i$ umjetnički rad u Bjelovaru, 5 (7), 213-222.

Vuletić, G. i Ivanković , D. (2011). Što čini osobnu kvalitetu života: studija na uzorku hrvatske gradske populacije. U G. Vuletić (Ur.), Kvaliteta života i zdravlje (str. 32 - 40). Filozofski fakultet Sveučilišta u Osijeku.

Vuletić, G i Misajon, R. (2011). Subjektivna kvaliteta života. U G. Vuletić (Ur.), Kvaliteta života i zdravlje (str. 8 -16). Filozofski fakultet Sveučilišta u Osijeku.

Wallander, J. L. i Koot, H. M. (2016). Quality of life in children: A critical examination of concepts, approaches, issues, and future directions. Clin Psychol Rev., 45,131-143. doi: 10.1016/j.cpr.2015.11.007. 
Walker S, J. i Clurman, A. (2007). Generation Ageless: How Baby Boomers Are Changing the Way We Live Today...And They're Just Getting Started (Hardcover). New York City: HarperBusiness.

Wang, W. C. \& Kao, C. H. (2006). An exploration of the relationships between free time management and the quality of life of wageearners in Taiwan. World Leisure Journal, 48(1), 24-33.

Wang, W. C., Wu, C. C, Wu, C. Y \& Huan, T. C. (2012). Exploring the relationships between free-time management and boredom in leisure. Psychological Reports, 110(2), 416-426.

Ware, J. E. (1993). SF-36 Health Survey: Manual \& interpretation guide. Boston, MA: The Health Institute, New England Medical Center.

Warn, S. (1999). Recreation and Tourism. Stanley Thornes (Publishers) Ltd.

Waserman, S. i Faust, K. (1994). Social network analysis. Methods and aplications. Cambridge, UK: Cambridge university Press.

Watson, J. (2003). Media Communication: An Introduction to Theory and Process. Hampshire, NewYork: Palgrave MacMillan.

Wei, R., Venhwei, L. (2003). Staying Connected while on the Move: Cell Phone Use and Social Connectedness. New Media \& Society, 6(5), 53- 72.

West, C. \& Zimmerman, D. H. ( 1987). Doing gender. Gender and Society, 1(2), 125-151.

Westerman, J. W. \& Yamamura, J. H. (2006). Generational preferences for work environment fit: Effects on employee outcomes. Career Development International, 12(2), 150-161.

White, R. W. (1959). Motivation reconsidered: The concept of competence. Psychological Review, 66(5), 297-333. doi: 10.1037/h0040934.

Whitbeck, L. B., Conger, R. D. i Kao, M. Y. (1993). The influence of parental support, depressed affect, and peers on the sexual behaviors of adolescent girls. Journal of Family Issues, 14, 261-278.

WHO-EURO (1993). Healt for all Strategies - Eight Evaluation. Geneva.

Williams, T., Roey, S. (1996). Consistencies in the quality of school life. U M. Binkley, K. Rust, T. Williams (ur.), Reading literacy in an international perspective (str. 193-202). Washington, U.S. Department of Education, Office of Educational Research and Improvement.

Wilson, W., (1967). Correlates of avowed happiness. Psychological Bulletin, 67, 294 - 306.

Witmer, J. M. and Sweeney, T. J. (1992). A Holistic Model for Wellness and Prevention Over the Life Span. Journal of Counseling and Development 71, 140-148.

Wittel, A. (2001). Toward a Network Sociality. Theory, Culture \& Society, 18(6), 51-76. 
Woodruffe, C. (2009). Still in the making. Training Journal, 13(7), 35.

Wyn, J. i White, R. (1997). Rethinking Youth. SAGE Publications.

Zaglia, M. E. (2013). Brand communities embedded in social networks. Journal of Business Research, 66(2), 216-223.

Zakon o Hrvatskom kvalifikacijskom okviru, pročišćeni tekst zakona. NN 22/13, 41/16, 64/18. na snazi od 26.07.2018.

Zamarovsky, V. (1978). Grčko čudo. Zagreb : Školska knjiga.

Zarotis, G.F., Katsagolis, A. \& Mitrotasios, M. (2007). Free time and its alteration tendencies. Studies in Physical Culture and Tourism, 14(2), 179-183.

Zeijl, E., DuBois-Reymond, M. and Te Poel, Y. (2001). Young adolescents' leisure patterns. Society and Leisure, 2, 379-402.

Zemke, R., Raines, C., Filipczak, B. (2000). Generations at Work: Managing the Clash of Veterans, Boomers, Xers and Nexterst in Your Workplace. New York: AMACOM.

Žepić, M. (1961). Latinsko-hrvatskosrpski rječnik. Zagreb: Školska knjiga.

Žganec, N., Rusac, S. i Laklija, M. (2007). Trendovi skrbi za osobe starije životne dobi u Republici Hrvatskoj i u zemljama Europske unije. Revija socijalne politike. 15, 171-188.

Žitnik, E. i Maglica, T. (2002). Bol i nada; Priručnik za prevenciju suicida kod mladih. Udruga $\mathrm{Mi}$-centar za prevenciju suicida.

\section{Izvori s interneta:}

Arbona - specijalizirana digialna agencija. https://www.arbona.hr/ . Pristupljeno 22. kolovoza 2018.

Encyclopedia Britannica. https://www.britannica.com/. Pristupljeno 6. veljače 2018.

Extended adolescence: What UK and international research exists on extended adolescence? " "About Families Evidence Bank" Edinburgh (UK). (2012).

https://aboutfamilies.files.wordpress.com/2012/07/erb-evidence-response_extendedadolescence1.pdf. $\quad$ Pristupljeno 24. srpnja 2018.

Grail Research (2011). Consumers of Tomorrow - Insights and Observations About Generation $\mathrm{Z}$.

http://www.grailresearch.com/pdf/ContenPodsPdf/Consumers_of_Tomorrow_Insights and_Observations_About_Generation_Z.pdf. Pristupljeno 25. travnja 2017.

Hrvatska enciklopedija. http://www.enciklopedija.hr/natuknica.aspx?id=34866. Pristupljeno 23. lipnja 2018.

International Standard Classification of Education ISCED 2011. Montreal: UNESCO Institute 
for Statistics (2012).

http://www.uis.unesco.org/Education/Documents/UNESCO_GC_36C-

19_ISCED_EN.pdf). Pristupljeno na 26. veljače 2019.

Metodologija nacionalne standardne klasifikacije obrazovanja (28.11.2001). »Narodne novine« broj 52/94. https://narodne-novine.nn.hr/clanci/sluzbeni/2001_11_105_1734.html.

Pristupljeno 26. lipnja 2018.

Obrazovanje: metodološka objašnjenja. Statistički ljetopis 2005. Republika Hrvatska: Državni zavod za statistiku. https://www.dzs.hr/Hrv_Eng/ljetopis/2005/26-met.pdf.

Pristupljeno 26. lipnja 2018.

Roper Organization (1990). The environment: Public attitude and individual behavior. https://www.worldcat.org/title/environment-public-attitudes-and-individualbehavior/oclc/22431438. Pristupljeno 22. travnja 2018.

Royal College of Psychiatrists (2003). The mental health of students in higher education. London: Council Report CR112.

http://www.healthyuniversities.ac.uk/uploads/files/rcp_mental_healthreport2003.pdf. Pristupljeno 26. svibnja 2018.

Statistički ljetopis (2005). https://www.dzs.hr/Hrv_Eng/ljetopis/2005/00-sadrzaj.pdf. Pristupljeno 25. srpnja 2018.

The Boomerang Generation (15. ožujka, 2012).

https://www.pewsocialtrends.org/2012/03/15/the-boomerang-generation/. Pristupljeno 18. lipnja 2017.

The Quality of Life Model._http://sites.utoronto.ca/qol/qol_model.htm. Pristupljeno 23. siječnja 2019.

Urban dictionary. https://www.urbandictionary.com/. Pristupljeno 16. prosinca 2018.

Volonterski centar Dubrovnik-projekt inVOLONTIRAMse! Moje slobodno vrijeme istraţivanje o volonterskom djelovanju kao naĉinu korištenja slobodnog vremena među dubrovačkim srednjoškolcima. (2014).

http://www.udrugabonsai.hr/newbonsai/wp-content/uploads/2014/02/Moje-slobodnovrijeme-istra\%C5\%BEivanje.pdf. Pristupljeno 3. ožujka 2019.

Zephoria Digital Marketing. https://zephoria.com/top-15-valuable-facebook-statistics/. Pristupljeno 15. studenog 2019. 


\section{PRILOZI}

Prilog 1

\section{U P IT N I K}

Poštovani,

pred Vama je anketni upitnik koji služi za izradu doktorskog rada na Filozofskom fakultetu. Svrha mu je prikupljanje informacija o ulozi slobodnog vremena, nastavnih aktivnosti i društvenih mreža u kvaliteti života učenika višeg sekundarnog obrazovanja.

Upitnik je anoniman i dobrovoljan, te u bilo kojem trenutku možete odustati od ispunjavanja, stoga molimo da na pitanja odgovorite objektivno i iskreno, uvažavajući prvenstveno vlastitu prosudbu.

Unaprijed zahvaljujem na suradnji!

1. Koliko imaš godina?

2. Spol (zaokruži): $\mathbf{M} \quad \check{z}$

3. Gdje živiš? a) selo $\quad$ b) grad

4. Koju školu pohađaš?

$\begin{array}{lllllll}\text { 5. Kakav je bio tvoj školski uspjeh u prethodnom razredu? } & \mathbf{1} & \mathbf{2} & \mathbf{3} & \mathbf{4} & \mathbf{5}\end{array}$

6. Koliko u prosjeku dnevno imaš slobodnog vremena (onog vremena u kojem se posvećuješ aktivnostima po vlastitom izboru)?

7. Koristiš li društvene mreže? DA NE

8. Koje društvene mreže koristiš? (zaokruži ili dopuni)
a) Facebook
b) Twitter
c) Instagram
d)
e)

8. Koliko vremena dnevno provedeš koristeći društvene mreže?
a) manje od jednog sata tjedno
c) dva sata dnevno
b) jedan sat dnevno
d) tri i više sati dnevno

9. Za što najčešće koristiš društvene mreže?
a)Kontakt s prijateljima putem chata ili poruka
b)Pregledavanje fotografija i video zapisa
c)Igranje igrica i korištenje aplikacija
d)Upoznavanje novih prijatelja
e)Učenje
f) 


\begin{tabular}{|c|c|c|c|c|c|}
\hline $\begin{array}{l}\text { 10. Slijedi popis tvrdnji o vama i vašim aktivnostima u } \\
\text { slobodno vrijeme. Pažljivo ih pročitaj i zaokruži broj } \\
\text { ispod stupnja slaganja s pojedinom tvrdnjom. }\end{array}$ & $\begin{array}{l}\text { Uopće } \\
\text { se ne } \\
\text { slažem }\end{array}$ & $\begin{array}{l}\text { U glav- } \\
\text { nom se } \\
\text { ne sla- } \\
\text { žem }\end{array}$ & $\begin{array}{l}\text { Niti se } \\
\text { slažem } \\
\text { niti se } \\
\text { ne } \\
\text { slažem }\end{array}$ & $\begin{array}{l}\text { Uglav- } \\
\text { nom } \\
\text { se } \\
\text { slažem }\end{array}$ & $\begin{array}{l}\text { U } \\
\text { potpu- } \\
\text { nosti } \\
\text { se } \\
\text { slažem }\end{array}$ \\
\hline $\begin{array}{l}\text { Sam/sama odabirem aktivnosti koje želim raditi u slobodno } \\
\text { vrijeme. }\end{array}$ & 1 & 2 & 3 & 4 & 5 \\
\hline Volim ljude s kojima provodim slobodno vrijeme. & 1 & 2 & 3 & 4 & 5 \\
\hline $\begin{array}{l}\text { Mislim da nisam jako dobar/dobra u onome što radim u } \\
\text { slobodno vrijeme. }\end{array}$ & 1 & 2 & 3 & 4 & 5 \\
\hline $\begin{array}{l}\text { Osjećam stres dok se bavim aktivnostima u slobodnom } \\
\text { vremenu. }\end{array}$ & 1 & 2 & 3 & 4 & 5 \\
\hline $\begin{array}{l}\text { Osobe koje poznajem kažu da sam dobar/dobra u onome što } \\
\text { radim u slobodno vrijeme. }\end{array}$ & 1 & 2 & 3 & 4 & 5 \\
\hline $\begin{array}{l}\text { Slažem se s ljudima koje susrećem na aktivnostima u } \\
\text { slobodno vrijeme. }\end{array}$ & 1 & 2 & 3 & 4 & 5 \\
\hline Uglavnom sam/sama provodim slobodno vrijeme. & 1 & 2 & 3 & 4 & 5 \\
\hline $\begin{array}{l}\text { Osjećam se slobodnim/slobodnom izraziti svoje ideje i } \\
\text { mišljenja za vrijeme aktivnosti u slobodnom vremenu. }\end{array}$ & 1 & 2 & 3 & 4 & 5 \\
\hline $\begin{array}{l}\text { Ljude s kojima provodim slobodno vrijeme smatram } \\
\text { prijateljima. }\end{array}$ & 1 & 2 & 3 & 4 & 5 \\
\hline $\begin{array}{l}\text { Na aktivnostima kojima se bavim u slobodnom vremenu } \\
\text { naučim nove i zanimljive stvari. }\end{array}$ & 1 & 2 & 3 & 4 & 5 \\
\hline U svoje slobodno vrijeme moram raditi ono što mi drugi kažu. & 1 & 2 & 3 & 4 & 5 \\
\hline Ljudi s kojima provodim slobodno vrijeme brinu o meni. & 1 & 2 & 3 & 4 & 5 \\
\hline $\begin{array}{l}\text { Mislim da sam dobar/dobra u onome čime se bavim u } \\
\text { slobodno vrijeme. }\end{array}$ & 1 & 2 & 3 & 4 & 5 \\
\hline $\begin{array}{l}\text { Osobe s kojima obično provodim slobodno vrijeme brinu o } \\
\text { tome kako se osjećam. }\end{array}$ & 1 & 2 & 3 & 4 & 5 \\
\hline $\begin{array}{l}\text { Nemam puno prilike pokazati koliko sam dobar u onome čime } \\
\text { se bavim u slobodno vrijeme. }\end{array}$ & 1 & 2 & 3 & 4 & 5 \\
\hline $\begin{array}{l}\text { Među ljudima s kojima provodim slobodno vrijeme nema } \\
\text { mnogo onih koje smatram dobrim prijateljima. }\end{array}$ & 1 & 2 & 3 & 4 & 5 \\
\hline U slobodno vrijeme se osjećam usamljeno. & 1 & 2 & 3 & 4 & 5 \\
\hline Ne sviđaju mi se ljudi s kojima provodim slobodno vrijeme. & 1 & 2 & 3 & 4 & 5 \\
\hline Često se ne osjećam dobro u aktivnostima u slobodno vrijeme. & 1 & 2 & 3 & 4 & 5 \\
\hline Nemam često priliku reći što želim raditi u slobodno vrijeme. & 1 & 2 & 3 & 4 & 5 \\
\hline
\end{tabular}




\begin{tabular}{|c|c|c|c|c|c|}
\hline $\begin{array}{l}\text { judi s kojima provodim slobodno vrijeme uglavnom se } \\
\text { prijateljski odnose prema meni. }\end{array}$ & 1 & 2 & 3 & 4 & 5 \\
\hline $\begin{array}{l}\text { 11. Kakvi su tvoji stavovi o društvenim mrežama? (u } \\
\text { svakom redu zaokruži broj koji odgovara tvom } \\
\text { mišljenju) }\end{array}$ & $\begin{array}{l}\text { Uopće } \\
\text { se ne } \\
\text { odnosi } \\
\text { na mene }\end{array}$ & $\begin{array}{l}\text { Uglav- } \\
\text { nom se } \\
\text { ne od- } \\
\text { nosi na } \\
\text { mene }\end{array}$ & 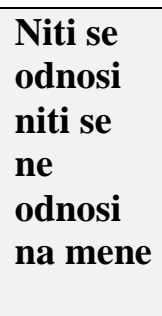 & $\begin{array}{l}\text { Uglav- } \\
\text { nom } \\
\text { se } \\
\text { odnosi } \\
\text { na } \\
\text { mene }\end{array}$ & $\begin{array}{l}\text { U } \\
\text { potpu- } \\
\text { nosti } \\
\text { se } \\
\text { odnosi } \\
\text { na } \\
\text { mene }\end{array}$ \\
\hline $\begin{array}{l}\text { Društvene mreže ono što radim čine interesantnijim i } \\
\text { maštovitijim. }\end{array}$ & 1 & 2 & 3 & 4 & 5 \\
\hline Društvene mreže šire moje obzore. & 1 & 2 & 3 & 4 & 5 \\
\hline Društvene mreže čine veliki doprinos ljudskom životu. & 1 & 2 & 3 & 4 & 5 \\
\hline $\begin{array}{l}\text { Društvene mreže mi pomažu da dobijem potrebne i važne } \\
\text { informacije. }\end{array}$ & 1 & 2 & 3 & 4 & 5 \\
\hline Društvene mreže čine društvo naprednijim. & 1 & 2 & 3 & 4 & 5 \\
\hline Ustručavam se koristiti društvene mreže da se ne osramotim. & 1 & 2 & 3 & 4 & 5 \\
\hline $\begin{array}{l}\text { Ako imam priliku koristiti društvene mreže bojim se da ne } \\
\text { napravim neku štetu. }\end{array}$ & 1 & 2 & 3 & 4 & 5 \\
\hline Društvene mreže mi izazivaju nelagodu. & 1 & 2 & 3 & 4 & 5 \\
\hline Korištenje društvenih mreža mi je dosadno. & 1 & 2 & 3 & 4 & 5 \\
\hline $\begin{array}{l}\text { Nisam baš sigurna/siguran u ono što radim putem društvenih } \\
\text { mreža. }\end{array}$ & 1 & 2 & 3 & 4 & 5 \\
\hline $\begin{array}{l}\text { Vjerojatno mogu naučiti većinu stvari koje trebam znati o } \\
\text { društvenim mrežama. }\end{array}$ & 1 & 2 & 3 & 4 & 5 \\
\hline $\begin{array}{l}\text { Trebam iskusnu osobu u blizini kada koristim društvene } \\
\text { mreže. }\end{array}$ & 1 & 2 & 3 & 4 & 5 \\
\hline $\begin{array}{l}\text { Kada naiđem na problem koristeći društvene mreže, obično to } \\
\text { mogu nekako riješiti. }\end{array}$ & 1 & 2 & 3 & 4 & 5 \\
\hline $\begin{array}{l}\text { Ne trebam nikoga da mi govori o najboljim načinima } \\
\text { korištenja društvenih mreža. }\end{array}$ & 1 & 2 & 3 & 4 & 5 \\
\hline Mogu koristiti društvene mreže samostalno, bez ičije pomoći. & 1 & 2 & 3 & 4 & 5 \\
\hline $\begin{array}{l}\text { Koristim društvene mreže u školi samo kada se to od mene } \\
\text { traži. }\end{array}$ & 1 & 2 & 3 & 4 & 5 \\
\hline Redovito koristim društvene mreže u školi. & 1 & 2 & 3 & 4 & 5 \\
\hline Provodim puno vremena koristeći društvene mreže. & 1 & 2 & 3 & 4 & 5 \\
\hline
\end{tabular}




\begin{tabular}{|c|c|c|c|c|c|}
\hline $\begin{array}{l}\text { 12. Zaokruživanjem brojeva od jedan do pet u svakom } \\
\text { redu izrazite svoj stupanj slaganja s pojedinom } \\
\text { tvrdnjom o kvaliteti života. }\end{array}$ & $\begin{array}{l}\text { Uopće } \\
\text { se ne } \\
\text { slažem }\end{array}$ & $\begin{array}{l}\text { Uglav- } \\
\text { nom se } \\
\text { ne sla- } \\
\text { žem }\end{array}$ & $\begin{array}{l}\text { Niti se } \\
\text { slažem } \\
\text { niti se ne } \\
\text { slažem }\end{array}$ & $\begin{array}{l}\text { Uglav- } \\
\text { nom se } \\
\text { slažem }\end{array}$ & $\begin{array}{l}\text { U potpu- } \\
\text { nosti se } \\
\text { slažem }\end{array}$ \\
\hline Uživam u životu. & 1 & 2 & 3 & 4 & 5 \\
\hline Moj život ima smisao. & 1 & 2 & 3 & 4 & 5 \\
\hline Imam sposobnost koncentracije. & 1 & 2 & 3 & 4 & 5 \\
\hline Osjećam se sigurno u svakodnevnom životu. & 1 & 2 & 3 & 4 & 5 \\
\hline Živim u zdravom okruženju. & 1 & 2 & 3 & 4 & 5 \\
\hline Imam dovoljno energije za život. & 1 & 2 & 3 & 4 & 5 \\
\hline Zadovoljan/zadovoljna sam svojim spavanjem. & 1 & 2 & 3 & 4 & 5 \\
\hline Mogu prihvatiti svoj vanjski izgled. & 1 & 2 & 3 & 4 & 5 \\
\hline Imam dovoljno novca. & 1 & 2 & 3 & 4 & 5 \\
\hline Lako dobivam dnevne informacije. & 1 & 2 & 3 & 4 & 5 \\
\hline Imam slobodnog vremena. & 1 & 2 & 3 & 4 & 5 \\
\hline Zadovoljan/zadovoljna sam podrškom svojih prijatelja. & 1 & 2 & 3 & 4 & 5 \\
\hline $\begin{array}{l}\text { Zadovoljan/zadovoljna sam svojom sposobnošću } \\
\text { obavljanja rutinskih dnevnih aktivnosti. }\end{array}$ & 1 & 2 & 3 & 4 & 5 \\
\hline Zadovoljan/zadovoljna sam svojim radnim sposobnostima. & 1 & 2 & 3 & 4 & 5 \\
\hline Zadovoljan/zadovoljna sam sobom. & 1 & 2 & 3 & 4 & 5 \\
\hline $\begin{array}{l}\text { Zadovoljan/zadovoljna sam svojim međuljudskim } \\
\text { odnosima. }\end{array}$ & 1 & 2 & 3 & 4 & 5 \\
\hline Zadovoljan/zadovoljna sam svojim životnim uvjetima. & 1 & 2 & 3 & 4 & 5 \\
\hline Zadovoljan/zadovoljna sam brigom za moje zdravlje. & 1 & 2 & 3 & 4 & 5 \\
\hline Zadovoljan/zadovoljna sam svojom mobilnošću. & 1 & 2 & 3 & 4 & 5 \\
\hline
\end{tabular}

Hvala na suradnji! 


\section{Prilog 2}

Poštovani roditelji!

Za potrebe doktorskog rada provodi se istraživanje o ulozi slobodnog vremena i društvenih mreža u kvaliteti života učenika višeg sekundarnog obrazovanja.

Cilj ovog istraživanja je ispitati i objasniti obilježja i prediktorsku ulogu slobodnog vremena i društvenih mreža u kvaliteti života učenika višeg sekundarnog obrazovanja, te razumjeti pojedinačna učenička iskustva i percepciju međupovezanosti istraživanih koncepata.

Podatci dobiveni u ovom istraživanju bit će strogo povjerljivi i čuvani. Svi izvještaji nastali na temelju ovog istraživanja koristit će rezultate koji govore o grupi djece ove dobi općenito (nigdje se neće navoditi rezultati pojedinačnog sudionika).

Vašoj djeci će također biti pobliže objašnjena svrha ispitivanja, te će biti zamoljeni za pristanak na sudjelovanje u istraživanju. Ispitivanje će se obaviti samo sa onim učenicima koji su pristali sudjelovati.

Dozvolu za ispitivanje dobili smo od ravnatelja škole, a u skladu s Etičkim kodeksom, prije ispitivanja željeli smo Vas kao roditelje obavijestiti o istraživanju.

Aktivnosti predviđene planom istraživanja odobrilo je Etičko povjerenstvo Odsjeka za pedagogiju Filozofskog fakulteta u Zagrebu, Ministarstvo znanosti i obrazovanja i Agencija za odgoj i obrazovanje.

Srdačno,

mr. sc. Marija Rattinger

doktorandica Filozofskog fakulteta Sveučilišta u Zagrebu 


\section{Prilog 3}

Tablica: Učestalost ocjena prihvatljivosti pojedinih tvrdnji u vezi aktivnosti u

slobodno vrijeme $(\mathrm{N}=594)$

\begin{tabular}{|c|c|c|c|c|c|c|c|}
\hline $\begin{array}{l}\text { Red. } \\
\text { br. }\end{array}$ & Tvrdnja & 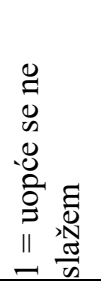 & 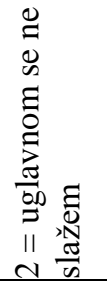 & 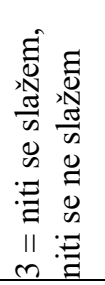 & 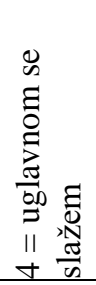 & $\begin{array}{l}0 \\
\infty \\
: \\
0 \\
0 \\
\vdots \\
0 \\
0 \\
0 \\
0 \\
= \\
\| \\
\text { II } \\
\text { n } \frac{\pi}{n}\end{array}$ & 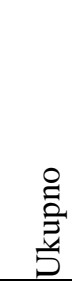 \\
\hline 1. & $\begin{array}{l}\text { Sam/sama odabirem aktivnosti koje želim raditi u slobodno } \\
\text { vrijeme }\end{array}$ & 2 & 10 & 22 & 171 & 389 & 594 \\
\hline 2. & Volim ljude s kojima provodim slobodno vrijeme. & 7 & 4 & 20 & 141 & 422 & 594 \\
\hline 3. & $\begin{array}{l}\text { Mislim da nisam jako dobar/dobra u onome što radim u } \\
\text { slobodno vrijeme. }\end{array}$ & 198 & 171 & 114 & 73 & 38 & 594 \\
\hline 4. & $\begin{array}{l}\text { Osjećam stres dok se bavim aktivnostima u slobodnom } \\
\text { vremenu. }\end{array}$ & 341 & 124 & 80 & 35 & 14 & 594 \\
\hline 5. & $\begin{array}{l}\text { Osobe koje poznajem kažu da sam dobar/dobra u onome } \\
\text { što radim u slobodno vrijeme. }\end{array}$ & 11 & 14 & 164 & 230 & 175 & 594 \\
\hline 6. & $\begin{array}{l}\text { Slažem se s ljudima koje susrećem na aktivnostima u } \\
\text { slobodno vrijeme. }\end{array}$ & 9 & 12 & 80 & 244 & 249 & 594 \\
\hline 7. & Uglavnom sam/sama provodim slobodno vrijeme. $\quad \mathrm{N}$ & 111 & 172 & 182 & 77 & 52 & 594 \\
\hline 8. & $\begin{array}{l}\text { Osjećam se slobodnim/slobodnom izraziti svoje ideje i } \\
\text { mišljenja za vrijeme aktivnosti u slobodnom vremenu. }\end{array}$ & 7 & 23 & 80 & 205 & 278 & 594 \\
\hline 9. & $\begin{array}{l}\text { Ljude s kojima provodim slobodno vrijeme smatram } \\
\text { prijateljima. }\end{array}$ & 4 & 16 & 26 & 162 & 386 & 594 \\
\hline 10 & $\begin{array}{l}\text { Na aktivnostima kojima se bavim u slobodnom vremenu } \\
\text { naučim nove i zanimljive stvari. }\end{array}$ & 15 & 26 & 129 & 229 & 195 & 594 \\
\hline 11 & $\begin{array}{l}\text { U svoje slobodno vrijeme moram raditi ono što mi drugi } \\
\text { kažu. }\end{array}$ & 279 & 178 & 103 & 27 & 7 & 594 \\
\hline 12 & Ljudi s kojima provodim slobodno vrijeme brinu o meni. & 15 & 36 & 137 & 216 & 190 & 594 \\
\hline 13 & $\begin{array}{l}\text { Mislim da sam dobar/dobra u onome čime se bavim u } \\
\text { slobodno vrijeme. }\end{array}$ & 1 & 17 & 101 & 253 & 222 & 594 \\
\hline 14 & $\begin{array}{l}\text { Osobe s kojima obično provodim slobodno vrijeme brinu } \\
\text { o tome kako se osjećam. }\end{array}$ & 11 & 20 & 133 & 241 & 189 & 594 \\
\hline 15 & $\begin{array}{l}\text { Nemam puno prilike pokazati koliko sam dobar u onome } \\
\text { čime se bavim u slobodno vrijeme. }\end{array}$ & 89 & 151 & 222 & 94 & 38 & 594 \\
\hline 16 & $\begin{array}{l}\text { Među ljudima s kojima provodim slobodno vrijeme nema } \\
\text { mnogo onih koje smatram dobrim prijateljima. }\end{array}$ & 211 & 201 & 94 & 55 & 33 & 594 \\
\hline 17 & U slobodno vrijeme se osjećam usamljeno. & 314 & 149 & 88 & 33 & 10 & 594 \\
\hline 18 & $\begin{array}{l}\text { Ne sviđaju mi se ljudi s kojima provodim slobodno } \\
\text { vrijeme. }\end{array}$ & 388 & 130 & 58 & 11 & 7 & 594 \\
\hline 19 & $\begin{array}{l}\text { Često se ne osjećam dobro u aktivnostima u slobodno } \\
\text { vrijeme. }\end{array}$ & 318 & 143 & 72 & 38 & 22 & 594 \\
\hline 20 & $\begin{array}{l}\text { Nemam često priliku reći što želim raditi u slobodno } \\
\text { vrijeme. }\end{array}$ & 274 & 140 & 120 & 35 & 25 & 594 \\
\hline 21 & $\begin{array}{l}\text { Ljudi s kojima provodim slobodno vrijeme uglavnom se } \\
\text { prijateljski odnose prema meni. }\end{array}$ & 10 & 13 & 45 & 240 & 286 & 594 \\
\hline
\end{tabular}

Napomena: U tabeli su u svakom retku deblje otisnute najveće frekvencije; $\mathrm{N}=$ negativno formulirana tvrdnja 


\section{Prilog 4}

Tablica: Učestalost ocjena prihvatljivosti pojedinih tvrdnji u vezi društvenih mreža $(N=594)$

\begin{tabular}{|c|c|c|c|c|c|c|c|}
\hline $\begin{array}{l}\text { Red. } \\
\text { br. }\end{array}$ & Tvrdnja & 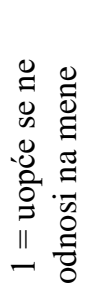 & 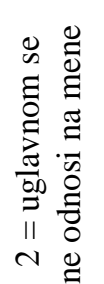 & 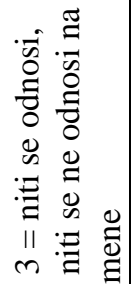 & 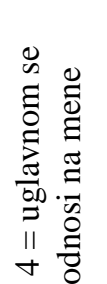 & 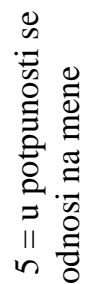 & 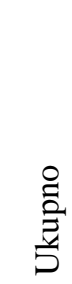 \\
\hline 1. & $\begin{array}{l}\text { Društvene mreže ono što radim čine interesantnijim i } \\
\text { maštovit. }\end{array}$ & 25 & 33 & 178 & 216 & 142 & 594 \\
\hline 2. & Društvene mreže šire moje obzore. & 24 & 46 & 149 & 231 & 144 & 594 \\
\hline 3. & Društvene mreže čine veliki doprinos ljudskom životu. & 39 & 73 & 232 & 147 & 103 & 594 \\
\hline 4. & $\begin{array}{l}\text { Društv. mreže mi pomažu da dobijem potrebne i važne } \\
\text { informac. }\end{array}$ & 9 & 33 & 102 & 232 & 218 & 594 \\
\hline 5. & Društvene mreže čine društvo naprednijim. & 47 & 80 & 203 & 154 & 110 & 594 \\
\hline 6. & $\begin{array}{l}\text { Ustručavam se koristiti društvene mreže da se ne } \\
\text { osramotim. }\end{array}$ & 326 & 117 & 97 & 31 & 23 & 594 \\
\hline 7. & $\begin{array}{l}\text { Ako imam priliku koristiti društvene mreže bojim se da } \\
\text { ne napravim neku štetu. }\end{array}$ & 298 & 133 & 104 & 40 & 19 & 594 \\
\hline 8. & Društvene mreže mi izazivaju nelagodu. & 362 & 121 & 84 & 18 & 9 & 594 \\
\hline 9. & Korištenje društvenih mreža mi je dosadno. & 304 & 129 & 102 & 41 & 18 & 594 \\
\hline 10 & $\begin{array}{l}\text { Nisam baš sigurna/siguran u ono što radim putem društv. } \\
\text { mreža }\end{array}$ & 311 & 143 & 104 & 28 & 8 & 594 \\
\hline 11 & $\begin{array}{l}\text { Vjerojatno mogu naučiti većinu stvari koje trebam znati } \\
\text { o društvenim mrežama. }\end{array}$ & 36 & 47 & 217 & 188 & 106 & 594 \\
\hline 12 & $\begin{array}{l}\text { Trebam iskusnu osobu u blizini kada koristim društvene } \\
\text { mreže. }\end{array}$ & 462 & 69 & 36 & 20 & 7 & 594 \\
\hline 13 & $\begin{array}{l}\text { Kada naiđem na problem koristeći društvene mreže, } \\
\text { obično to mogu nekako riješiti. }\end{array}$ & 21 & 33 & 93 & 236 & 211 & 594 \\
\hline 14 & $\begin{array}{l}\text { Ne trebam nikoga da mi govori o najboljim načinima } \\
\text { korištenja društvenih mreža. }\end{array}$ & 65 & 61 & 112 & 134 & 222 & 594 \\
\hline 15 & $\begin{array}{l}\text { Mogu koristiti društvene mreže samostalno, bez ičije } \\
\text { pomoći. }\end{array}$ & 14 & 15 & 40 & 122 & 403 & 594 \\
\hline 16 & $\begin{array}{l}\text { Koristim društv.mreže u školi samo kada se to od mene } \\
\text { traži. }\end{array}$ & 155 & 121 & 147 & 75 & 96 & 594 \\
\hline 17 & Redovito koristim društvene mreže u školi. & 86 & 77 & 121 & 143 & 167 & 594 \\
\hline 18 & Provodim puno vremena koristeći društvene mreže. & 38 & 64 & 124 & 169 & 199 & 594 \\
\hline
\end{tabular}

Napomena: U tabeli su u svakom retku deblje otisnute najveće frekvencije. 


\section{Prilog 5}

Tablica: Učestalost ocjena prihvatljivosti pojedinih tvrdnji u vezi kvalitete života $(N=594)$

\begin{tabular}{|c|c|c|c|c|c|c|c|}
\hline $\begin{array}{l}\text { Red. } \\
\text { br. }\end{array}$ & Tvrdnja & 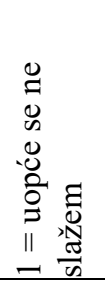 & 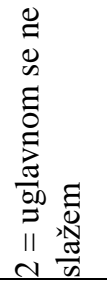 & 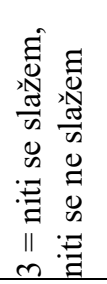 & 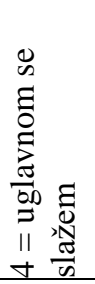 & 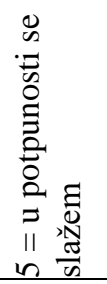 & 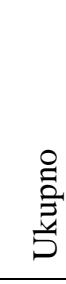 \\
\hline 1. & Uživam u životu. & 14 & 30 & 72 & 216 & 262 & 594 \\
\hline 2. & Moj život ima smisao. & 26 & 29 & 77 & 168 & 294 & 594 \\
\hline 3. & Imam sposobnost koncentracije. & 20 & 47 & 112 & 244 & 171 & 594 \\
\hline 4. & Osjećam se sigurno u svakodnevnom životu. & 20 & 26 & 95 & 208 & 245 & 594 \\
\hline 5. & Živim u zdravom okruženju. & 18 & 22 & 105 & 179 & 270 & 594 \\
\hline 6. & Imam dovoljno energije za život. & 19 & 40 & 99 & 173 & 263 & 594 \\
\hline 7. & Zadovoljan/zadovoljna sam svojim spavanjem. & 103 & 103 & 103 & 125 & 160 & 594 \\
\hline 8. & Mogu prihvatiti svoj vanjski izgled. & 32 & 39 & 93 & 164 & 266 & 594 \\
\hline 9. & Imam dovoljno novca. & 20 & 22 & 116 & 188 & 248 & 594 \\
\hline 10 & Lako dobivam dnevne informacije. & 11 & 11 & 100 & 218 & 254 & 594 \\
\hline 11 & Imam slobodnog vremena. & 22 & 48 & 112 & 159 & 253 & 594 \\
\hline 12 & $\begin{array}{l}\text { Zadovoljan/zadovoljna sam podrškom svojih } \\
\text { prijatelja }\end{array}$ & 11 & 23 & 73 & 194 & 293 & 594 \\
\hline 13 & $\begin{array}{l}\text { Zadovoljan/zadovoljna sam svojom sposobnošću } \\
\text { obavljanja rutinskih dnevnih aktivnosti. }\end{array}$ & 12 & 29 & 119 & 218 & 216 & 594 \\
\hline 14 & Zadovoljan/zadovolj.sam svojim radnim sposobn. & 12 & 30 & 122 & 213 & 217 & 594 \\
\hline 15 & Zadovoljan/zadovoljna sam sobom. & 17 & 30 & 92 & 186 & 269 & 594 \\
\hline 16 & Zadovoljan/zadovolj.sam svojim međuljud.odnos. & 14 & 30 & 111 & 197 & 242 & 594 \\
\hline 17 & $\begin{array}{l}\text { Zadovoljan/zadovolj.sam svojim životnim } \\
\text { uvjetima }\end{array}$ & 6 & 12 & 59 & 147 & 370 & 594 \\
\hline 18 & $\begin{array}{l}\text { Zadovoljan/zadovolj.sam brigom za moje } \\
\text { zdravlje }\end{array}$ & 12 & 24 & 79 & 165 & 314 & 594 \\
\hline 19 & Zadovoljan/zadovoljna sam svojom mobilnošću & 13 & 21 & 71 & 170 & 319 & 594 \\
\hline
\end{tabular}

Napomena: U tablici su u svakom retku deblje otisnute najveće frekvencije. 


\section{Prilog 6}

Tablica: Rezultati usporedbe kvalitete života po grupama škola i po vrstama škola pomoću Mann-Whitneyevog U testa odnosno pomoću Kruskal-Wallisovog H-testa $(N=594)$

\begin{tabular}{|l|l|l|r|r|r|r|c|}
\hline $\begin{array}{l}\text { Red. } \\
\text { br. }\end{array}$ & Varijabla & Škola & $\begin{array}{c}\text { Broj } \\
\text { učen. }\end{array}$ & \multicolumn{1}{c|}{$\begin{array}{c}\text { Sredine } \\
\text { rangova }\end{array}$} & z ili $\chi^{2}$ & U ili df & p \\
\hline 1. & $\begin{array}{l}\text { Kvaliteta života } \\
\text { (skala3) }\end{array}$ & gimnazije & 267 & 279,06 & & & \\
\hline & & strukovne škole & 327 & 312,56 & $\mathrm{z}=2,368$ & $\mathrm{U}=38730,5$ & $\mathbf{, 0 1 8}$ \\
\hline 2. & $\begin{array}{l}\text { Kvaliteta života } \\
\text { (skala3) }\end{array}$ & gimnazija & 267 & 279,06 & & & \\
\hline & & HTT & 22 & 373,93 & & & \\
\hline & & ekonomska & 114 & 326,00 & & & \\
\hline & & prodavač & 21 & 325,29 & & & \\
\hline & & kuh.,kon.,slast. & 17 & 297,15 & & & \\
\hline & & šk.za mid & 77 & 254,32 & & & \\
\hline & & centar za obraz. & 3 & 265,00 & & & \\
\hline & & automehaničar & 2 & 279,00 & & & \\
\hline & & bravar & 4 & 328,88 & & & \\
\hline & & CNC operater & 11 & 293,77 & & & \\
\hline & & komercijalist & 10 & 284,45 & & & \\
\hline & & polj.teh. & 12 & 356,63 & & & \\
\hline & & računalni tehn. & 11 & 343,82 & & & \\
\hline
\end{tabular}




\section{ŽIVOTOPIS}

Marija Rattinger rođena je 3. veljače, 1970. godine u Rakitovici, općina Donji Miholjac Diplomirala 1991. g. na Pedagoškom fakultetu u Osijeku i stekla stručni naziv nastavnice razredne nastave. 1996. g. stekla stručni naziv višeg knjižničara u Zagrebu. 1999.g. diplomirala na Pedagoškom fakultetu u Osijeku, Sveučilište Josipa Jurja Strossmayera i stekla visoku stručnu spremu i stručni naziv diplomirane učiteljice razredne nastave. Od 1992. godine radi na mjestu učiteljice razredne nastave, 2017. g. stekla stručni naziv učitelja mentora. Magistrirala 2010.g. s temom Socijalni aspekti kurikuluma cjelodnevne škole na Odsjeku za pedagogiju Filozofskog fakulteta Sveučilišta u Zagrebu, pod vodstvom mentora prof. dr. sc. Nevena Hrvatića. Doktorski studij je upisala 2014. godine na Odsjeku za pedagogiju Filozofskog fakulteta Sveučilišta u Zagrebu.

Tijekom doktorskog studija sudjelovala je na Doktorskim konferencijama DOKON 2015 i DOKON 2017 u Rijeci i objavila studijem propisane znanstvene radove.

\section{Radovi:}

Rattinger, Marija. Cjelodnevna škola i razvoj socijalnih vještina i kompetencija // Doktorska konferencija za studente, voditelje i suradnike poslijediplomskih doktorskih studija pedagogije i obrazovnih znanosti DOKON 2015 ; KNJIGA SAŽETAKA (e-izdanje) / Kovač, Vesna ; Ledić, Jasminka ; Kušić, Siniša (ur.). Rijeka : Filozofski fakultet, 2015. 23-24 (sažetak,znanstveni).

Rattinger, Marija. Aktivnosti i društvene mreže u slobodnom vremenu mlađih tinejdžera. // Školski vjesnik : časopis za pedagoška i školska pitanja. 66 (2017) , 2; 222-238 (članak, znanstveni).

Rattinger, Marija. Aktivnosti i društvene mreže u slobodnom vremenu mlađih tinejdžera // Doktorska konferencija za studente, voditelje i suradnike poslijediplomskih doktorskih studija pedagogije i obrazovnih znanosti DOKON 2017 ; KNJIGA SAŽETAKA (e-izdanje) / Kovač, Vesna ; Ledić, Jasminka ; Kušić, Siniša (ur.). Rijeka : Filozofski fakultet, 2017. 8-9 (sažetak,znanstveni).

Rattinger, Marija. Odnos slobodnog vremena i kvalitete života srednjoškolaca. // Život i škola : časopis za teoriju i praksu odgoja i obrazovanja. LXIV (2018) , 1; 43-58 (članak, znanstveni) 